Fall 1969

\title{
1969 Miracle Yearbook
}

Cedarville College

Follow this and additional works at: https://digitalcommons.cedarville.edu/yearbooks

Part of the Higher Education Commons, Organizational Communication Commons, and the Public Relations and Advertising Commons

\section{Recommended Citation}

Cedarville College, "1969 Miracle Yearbook" (1969). Yearbooks. 48.

https://digitalcommons.cedarville.edu/yearbooks/48

This Book is brought to you for free and open access by DigitalCommons@Cedarville, a service of the Centennial Library. It has been accepted for inclusion in Yearbooks by an authorized administrator of DigitalCommons@Cedarville. For more information, please contact digitalcommons@cedarville.edu. 

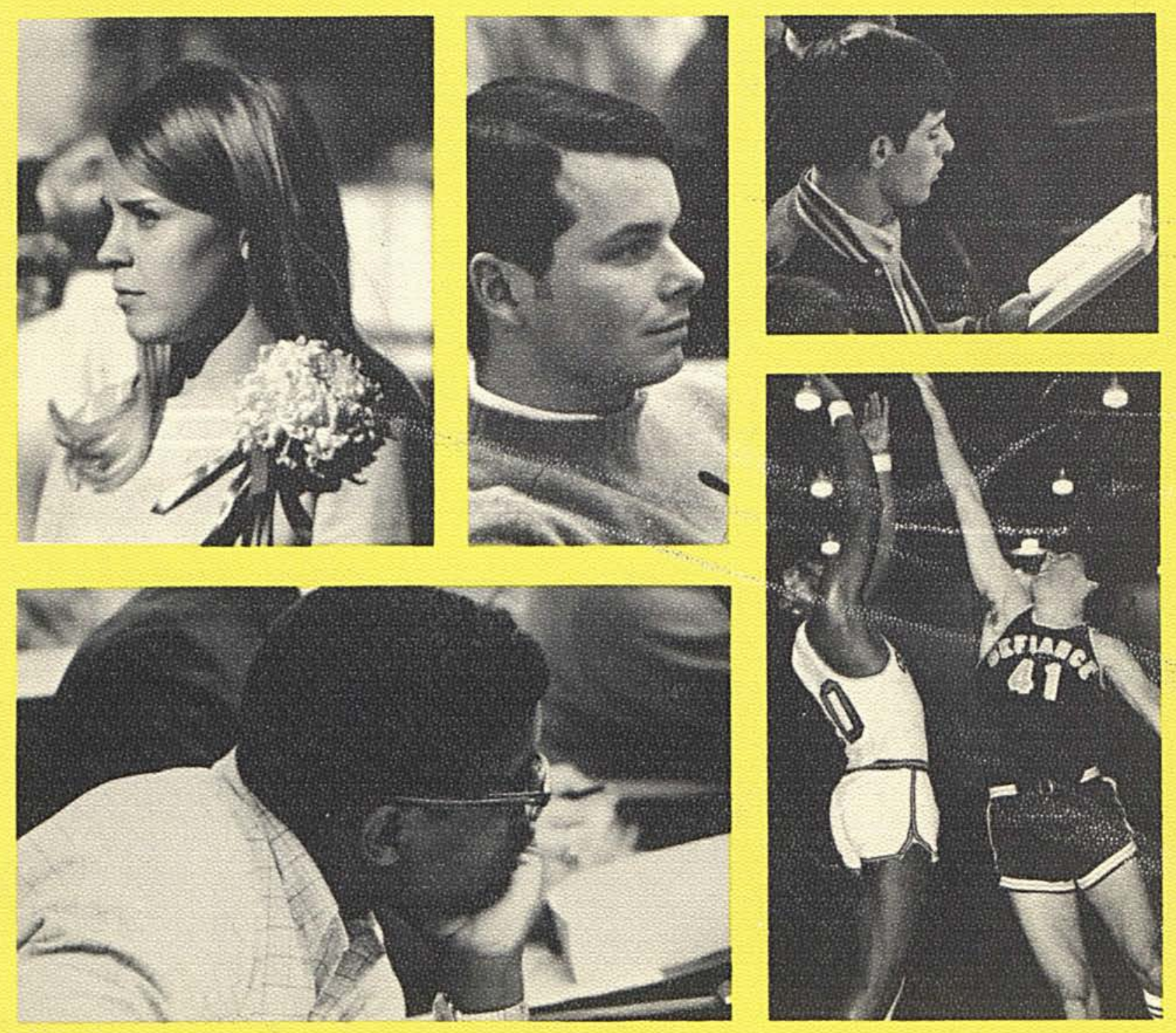

\section{MIRACLE}





\section{PEOPLE \\ ARE \\ $\mathrm{OF}$ \\ GOD}

To feel, to think, to strive, to do, to be this is life... and yet how shallow is this

without purposewithout direction.

For some, that purpose is wealth, fame for some

it is education, knowledge for some it is freedom, peace for some

it is social justice, religion. But how very few find life through a Person. A Person who died that we might live, who went to hell that we might go to heaven, who suffered doubt, hatred, anger, revenge, greed, that we might enjoy love, joy, gentleness, faith, and peace.

Oh that we might live for Him that others, too, may find true purpose in life...

In small recognition of what $\mathrm{He}$ has done for each of us, we dedicate this 1969 Miracle, as well as our lives, to Jesus Christ. 


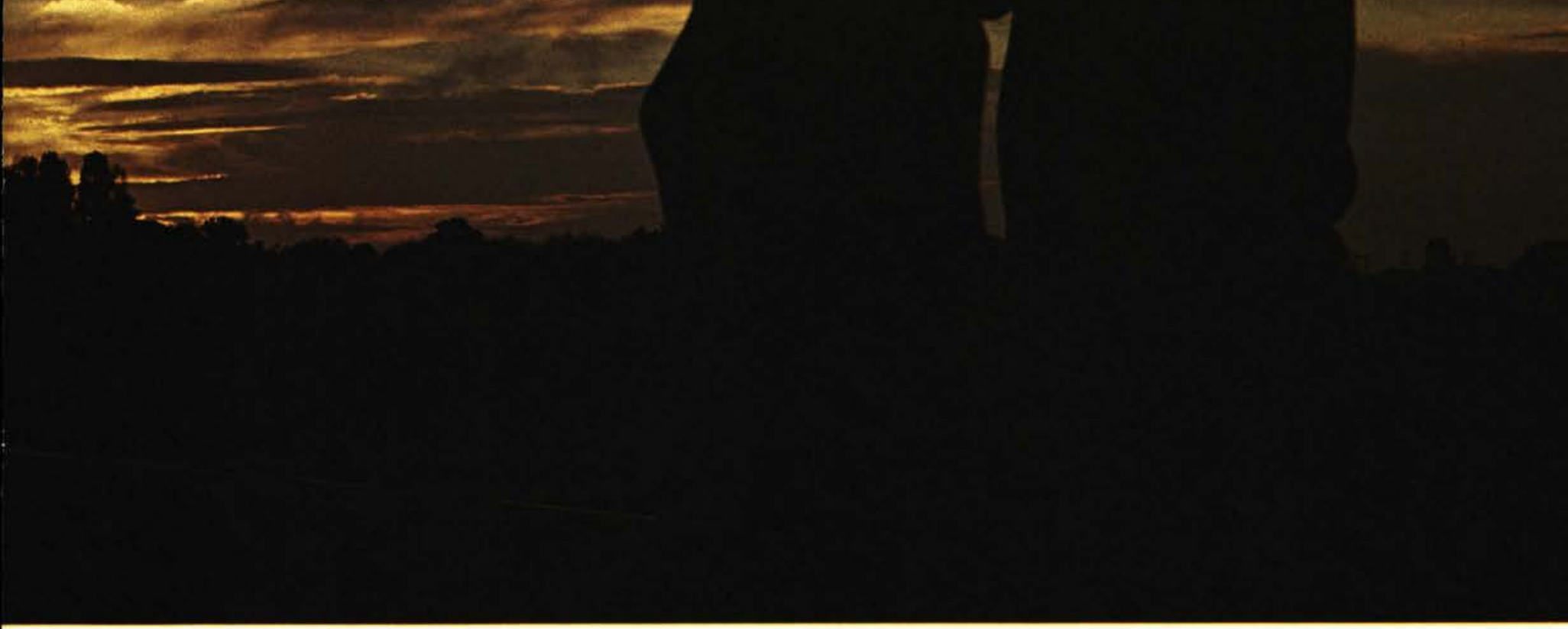


College life is more

than the experiences we have.

It seems to thrive

on the people we meet. . . the scholar, the clown,

the politician, the adviser, the lover, the friend.

Each shares

a moment

of our life

and for that moment

discloses some fragment

of himself-

his moods

his thoughts

his spirit

his action

his vision

At Cedarville College,

this sharing of ourselves

becomes something

extra special.

the joy of a full mailbox the embarrassment of a spilled lunch the water fights and demerits

the wonder of a sunny day the laughter of a friend. . .

these are our moods.

leaving for quarter break Mr. Murdoch's blue books an unannounced quiz no class the sleepy eyelids .. these are our thoughts.

the smile of a homecoming beauty training meals and early hours a basketball championship, almost

laryngitis and red hands the thrill of being at $C C$.

this is our spirit.

the pinching of pennies the rivalry of elubs leaving Student Council at 9:00 P.M. the burning of midnight oil the excitement of belonging ....this is our action.

sharing with someone the love of Christ praying with your roommate apologizing to a friend an all-night hymn sing . striving to be like Christ ...this is our vision. 
MOODS ... pg. 40

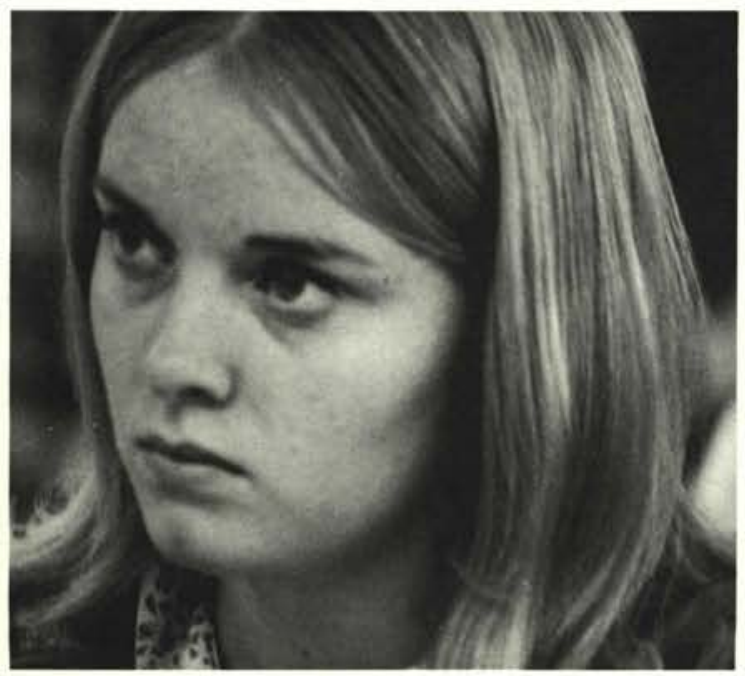

SPIRIT ... pg. 128
THOUGHTS ... pg. 98

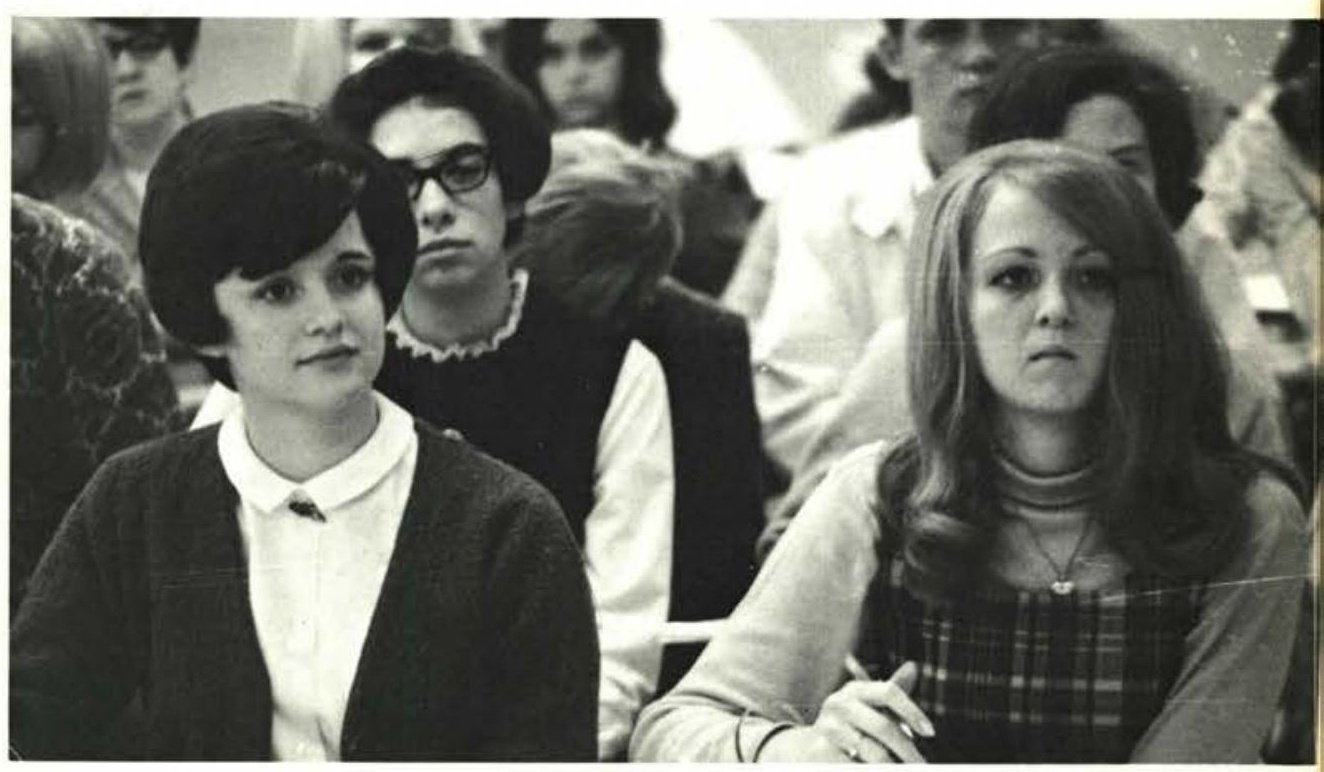

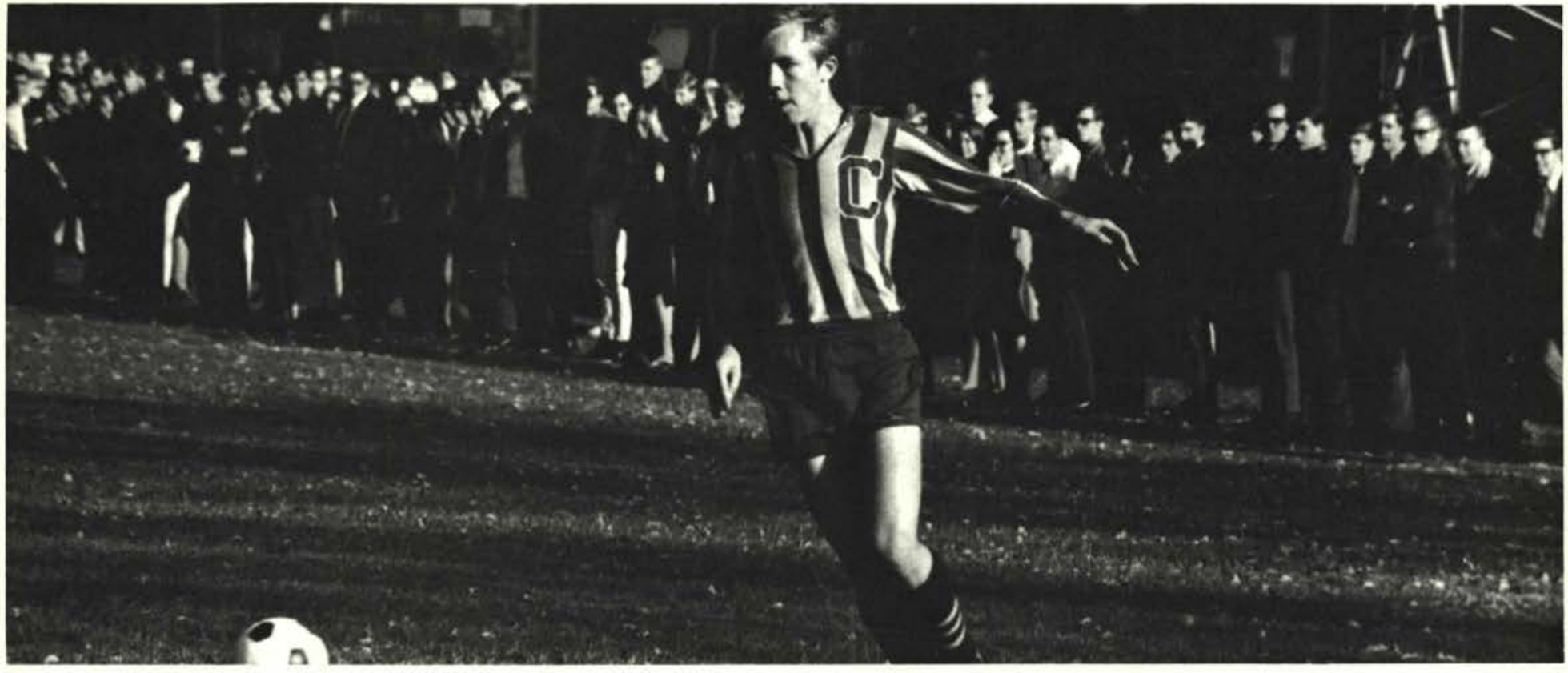

\section{ACTION ...pg. 146}

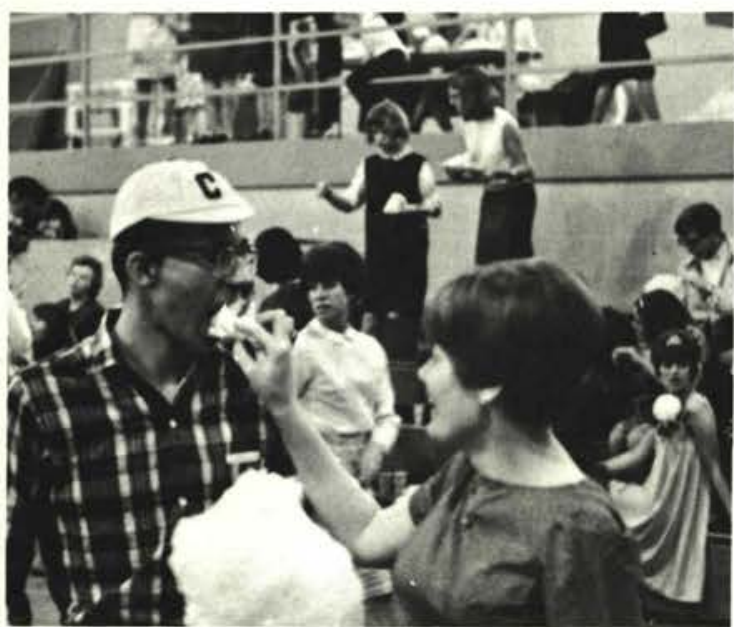

VISION ... pg. 168

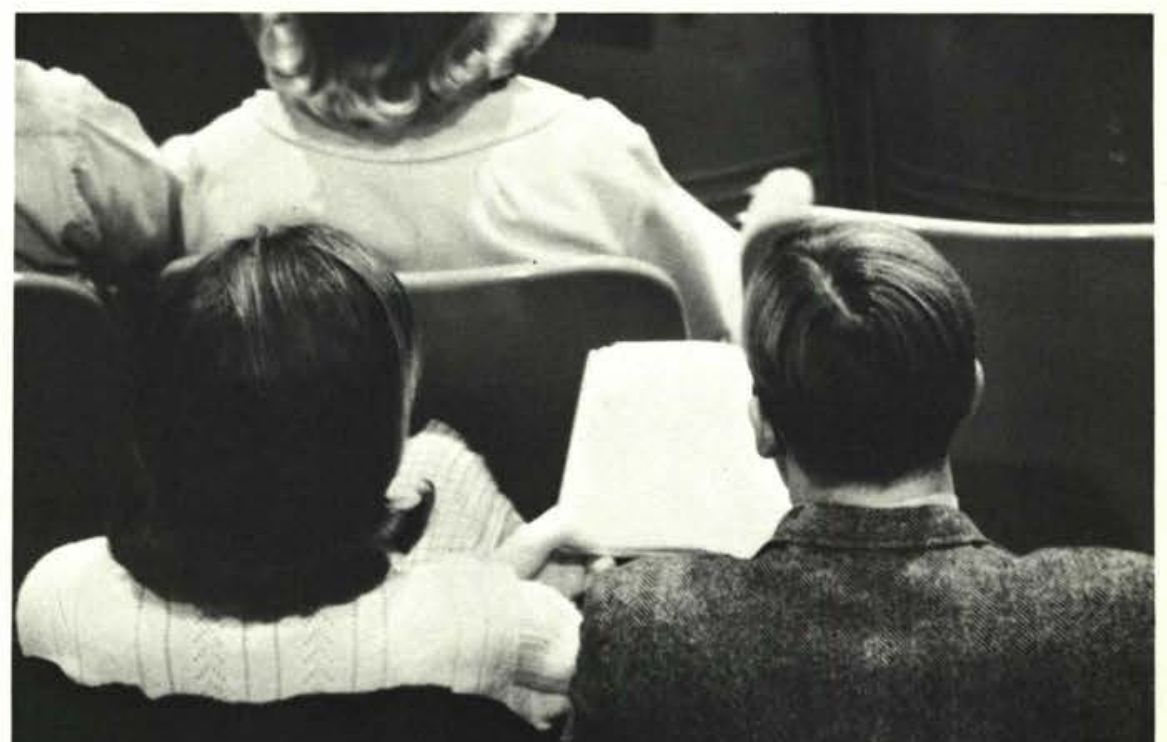




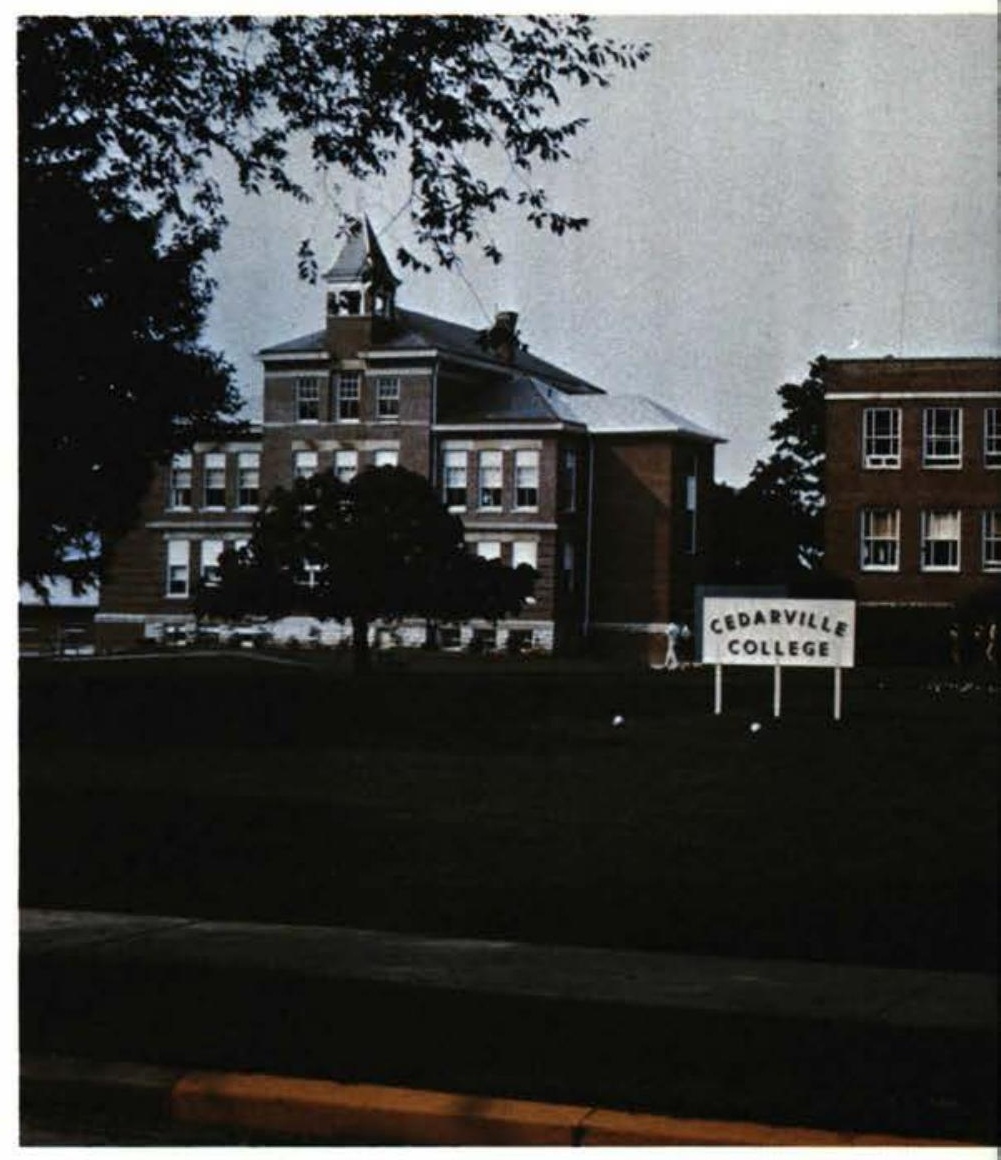

\section{THESE ARE OUR MOODS}
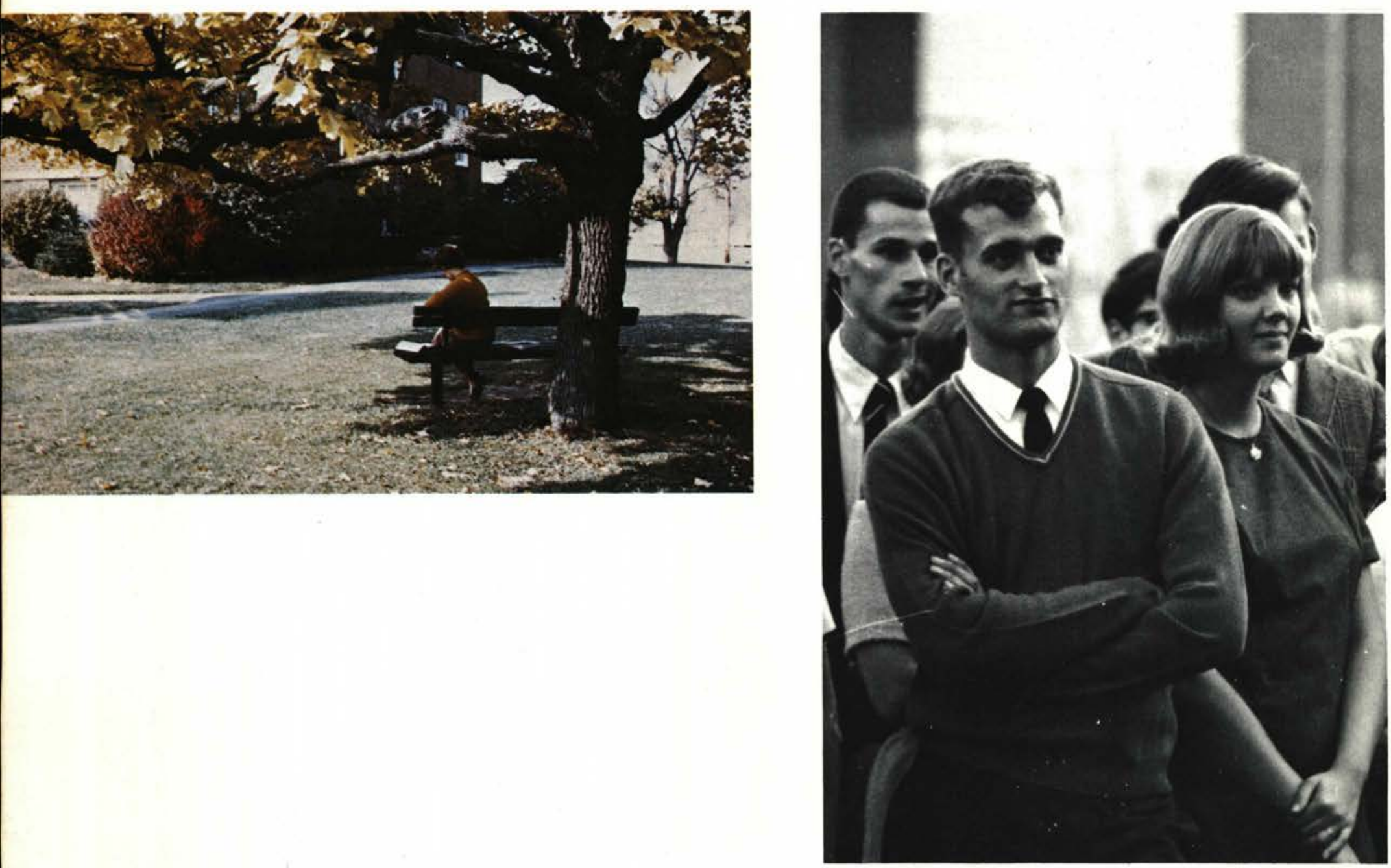

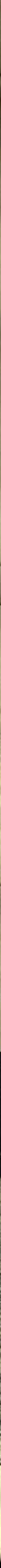


\section{THESE ARE OUR THOUGHTS}
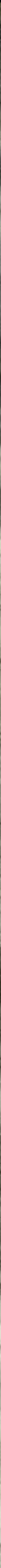


\section{THIS IS OUR SPIRIT}
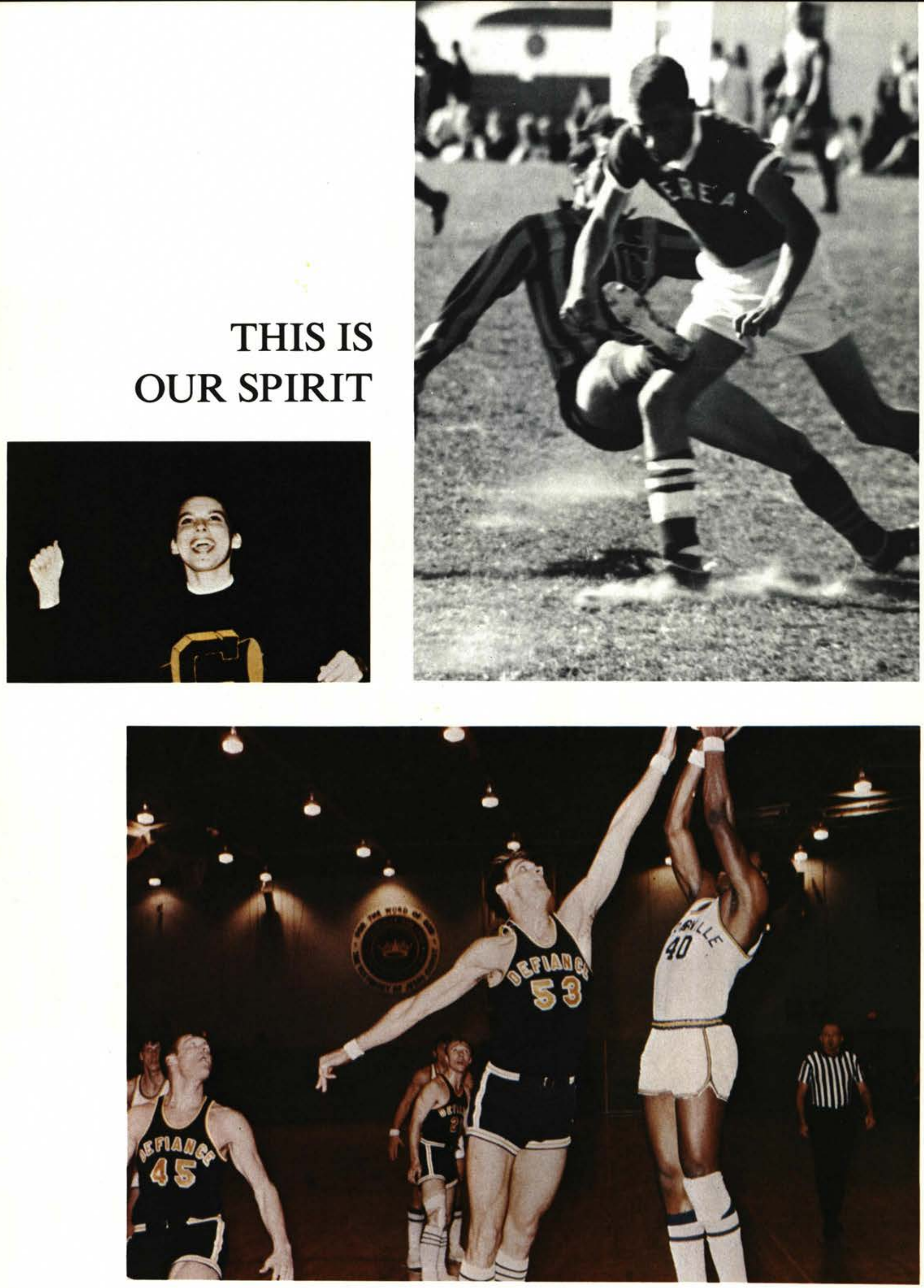

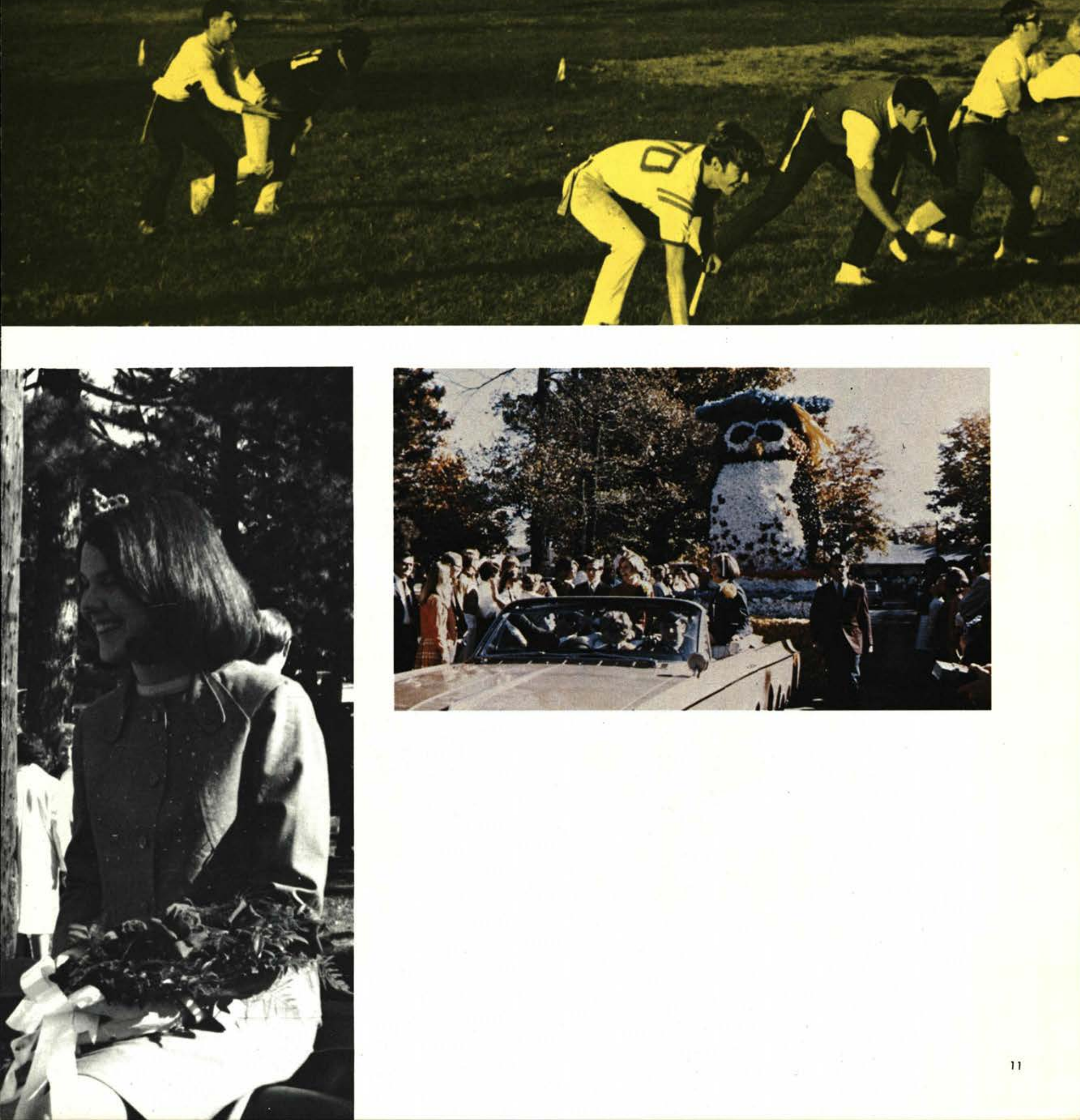


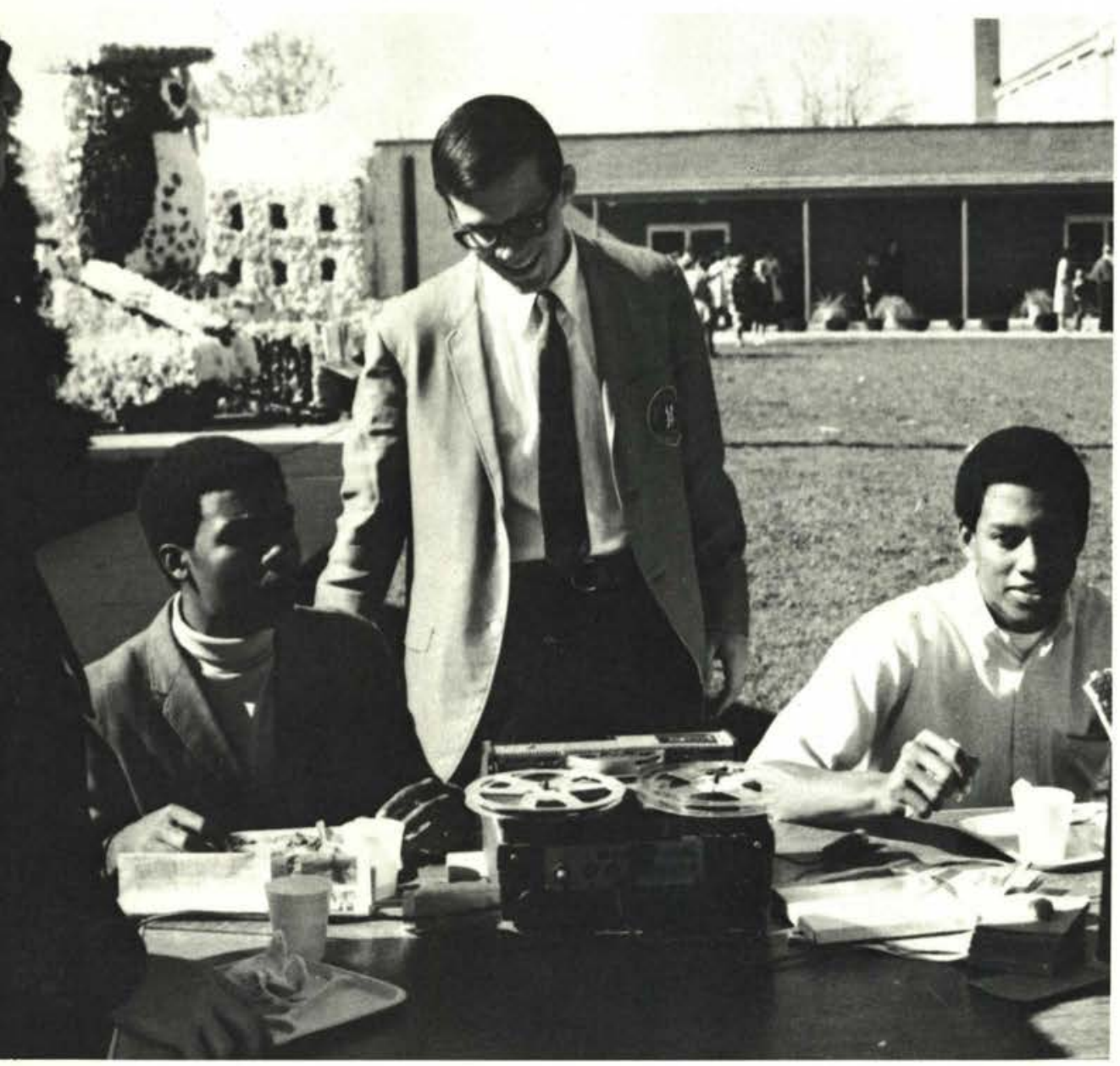

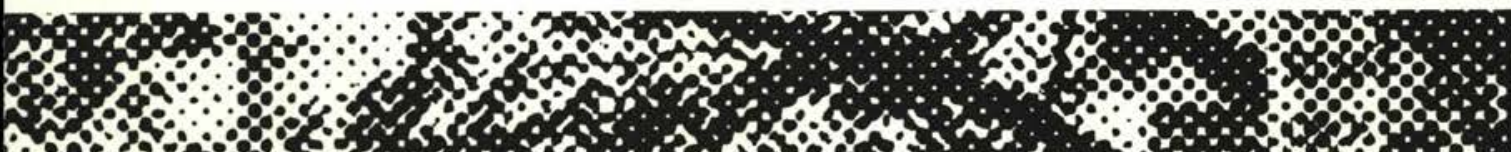

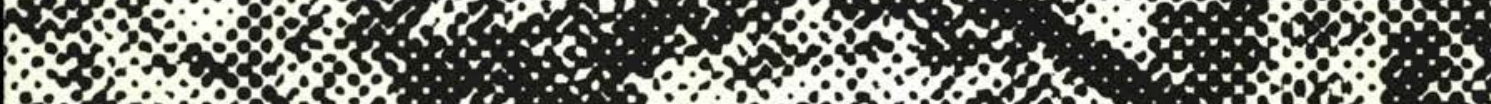
a

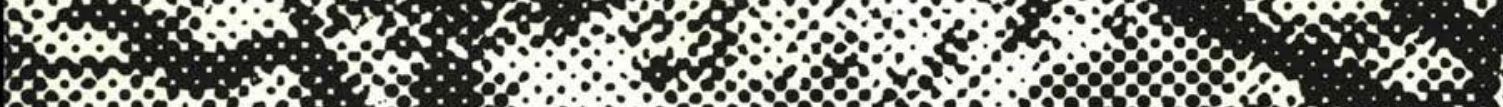

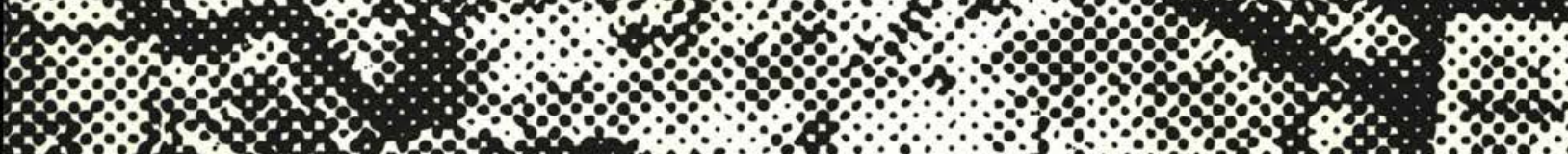
.

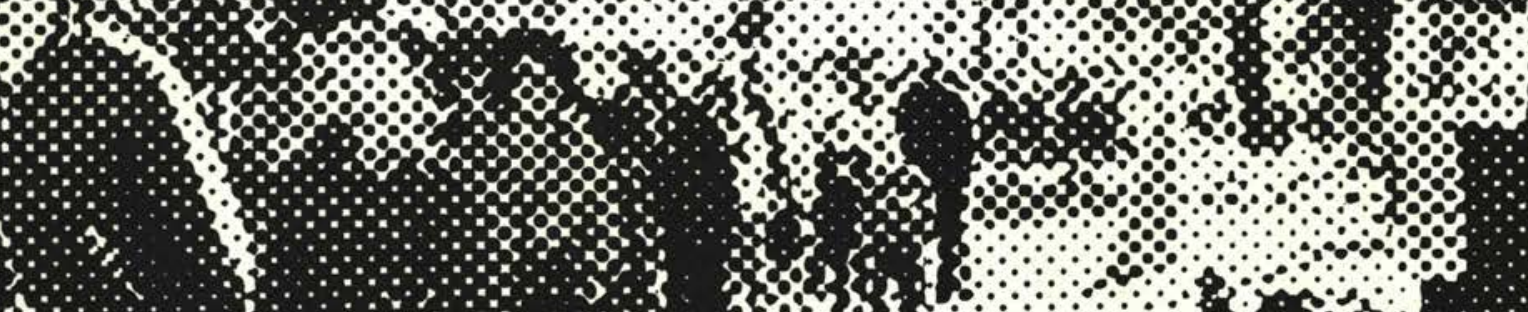

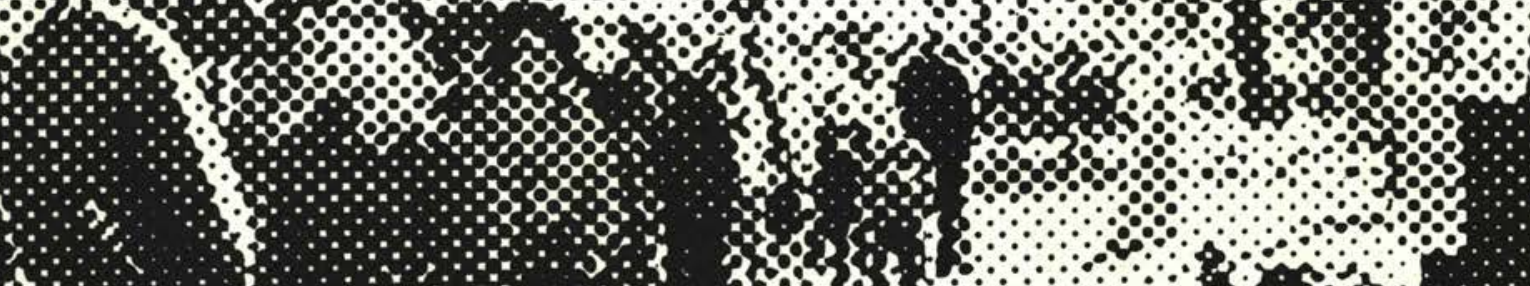

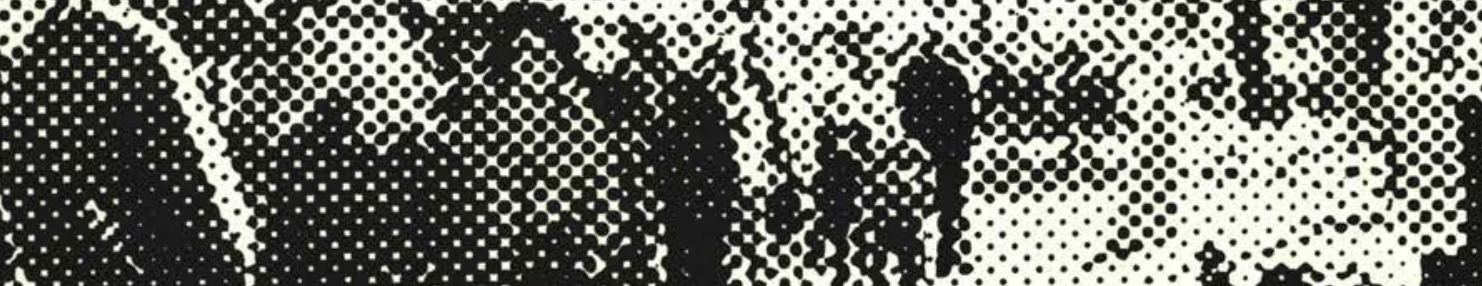

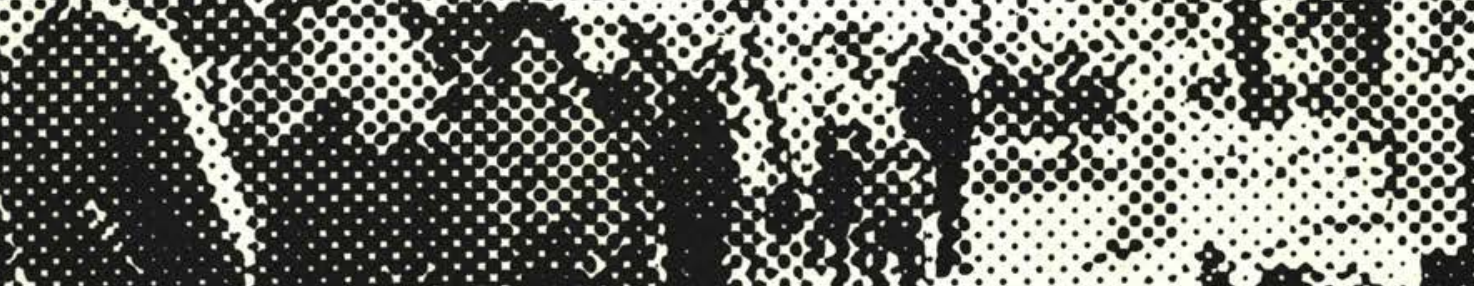
(2)

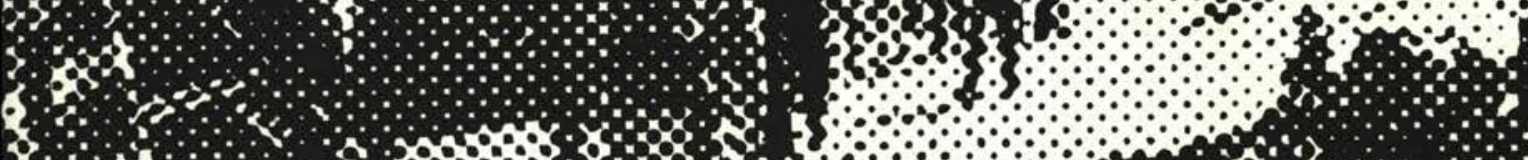
$3:$ $\therefore$

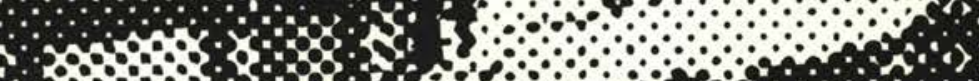
(a)

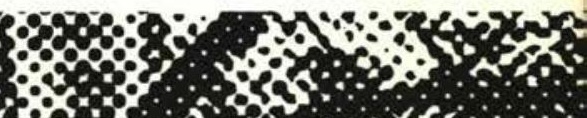
3. S (2) 

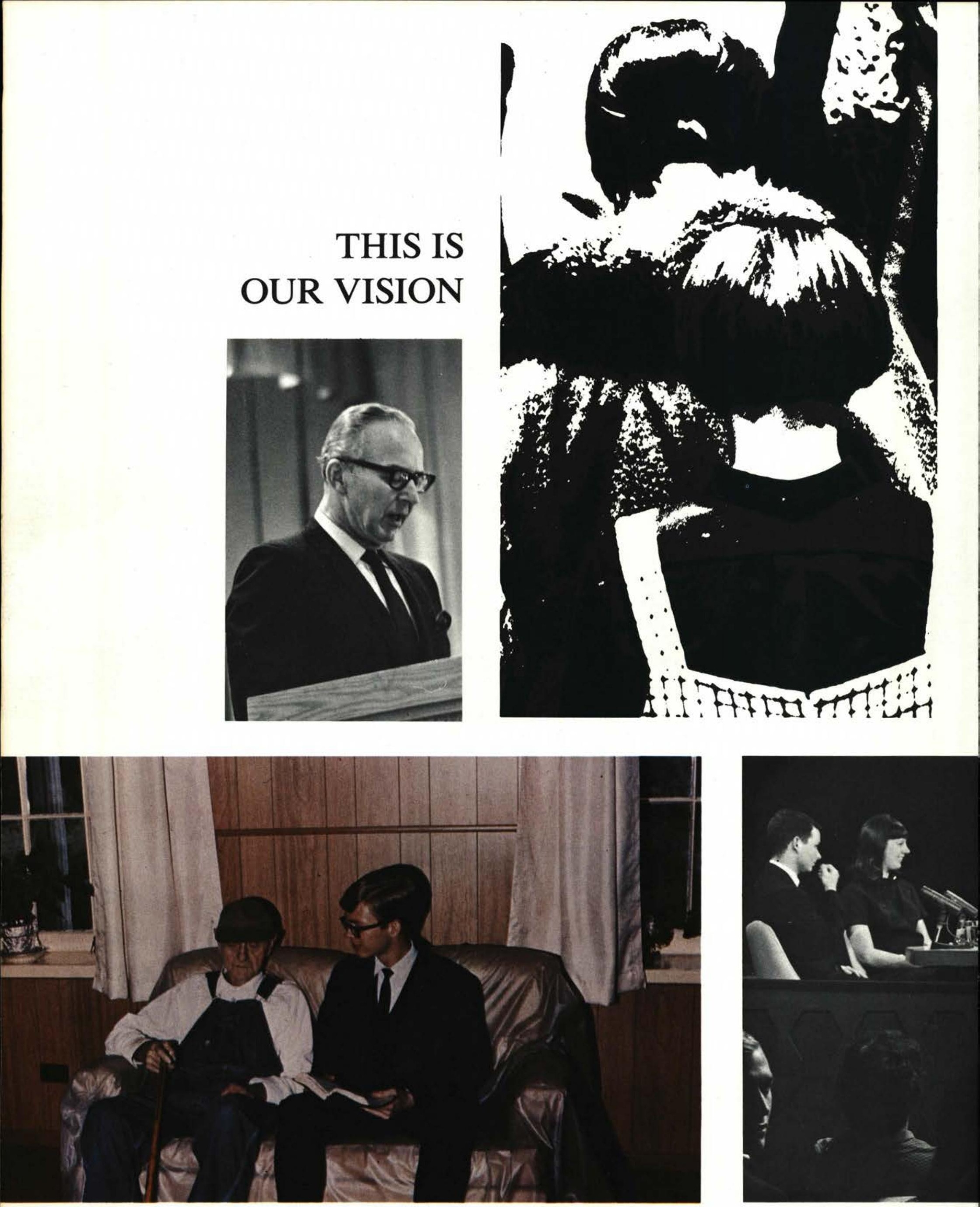

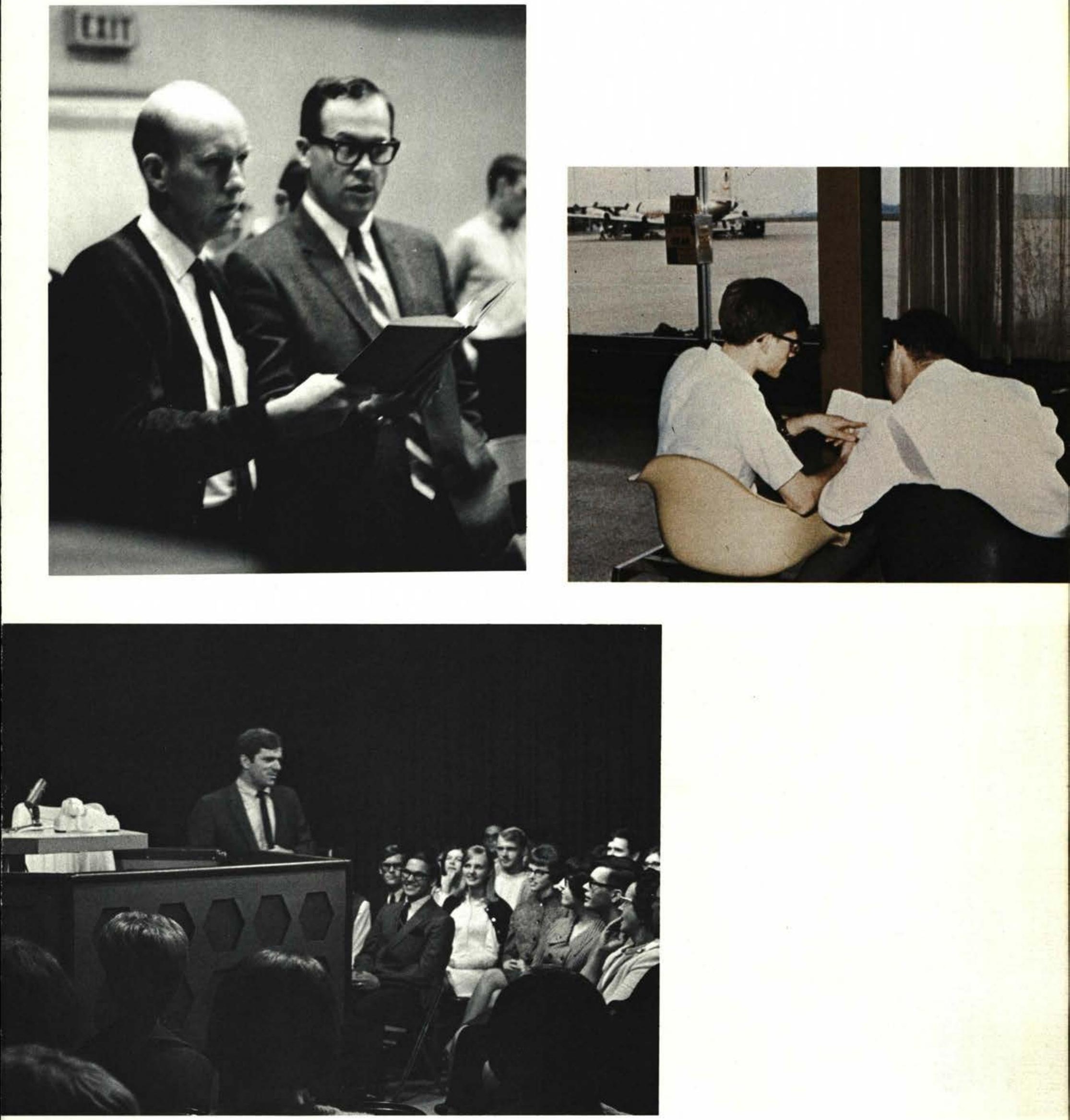

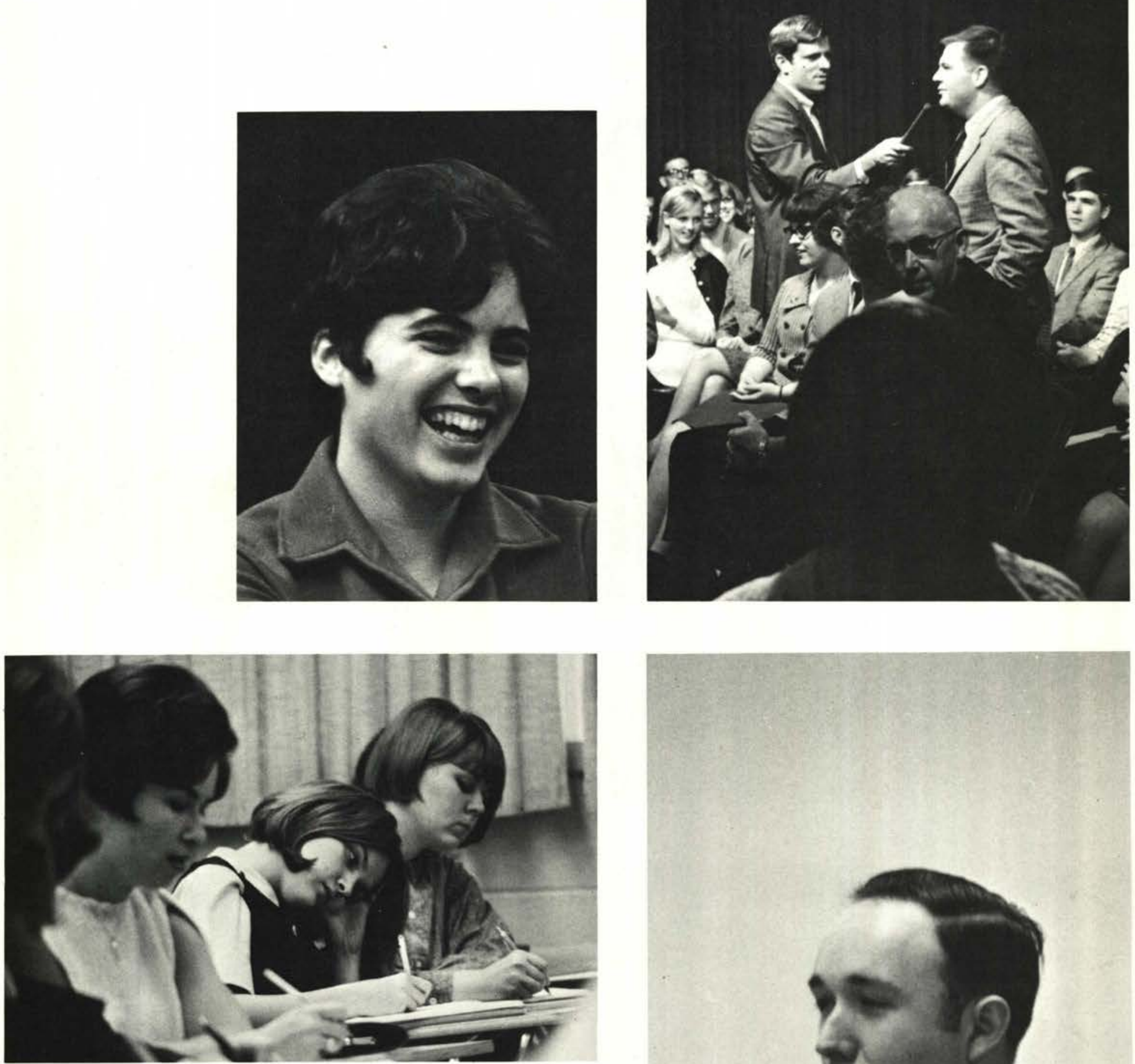

THE FIRST FEW DAYS . . .

a friendly laugh, the Phil Donahue show, the second day of classes, a history lecture

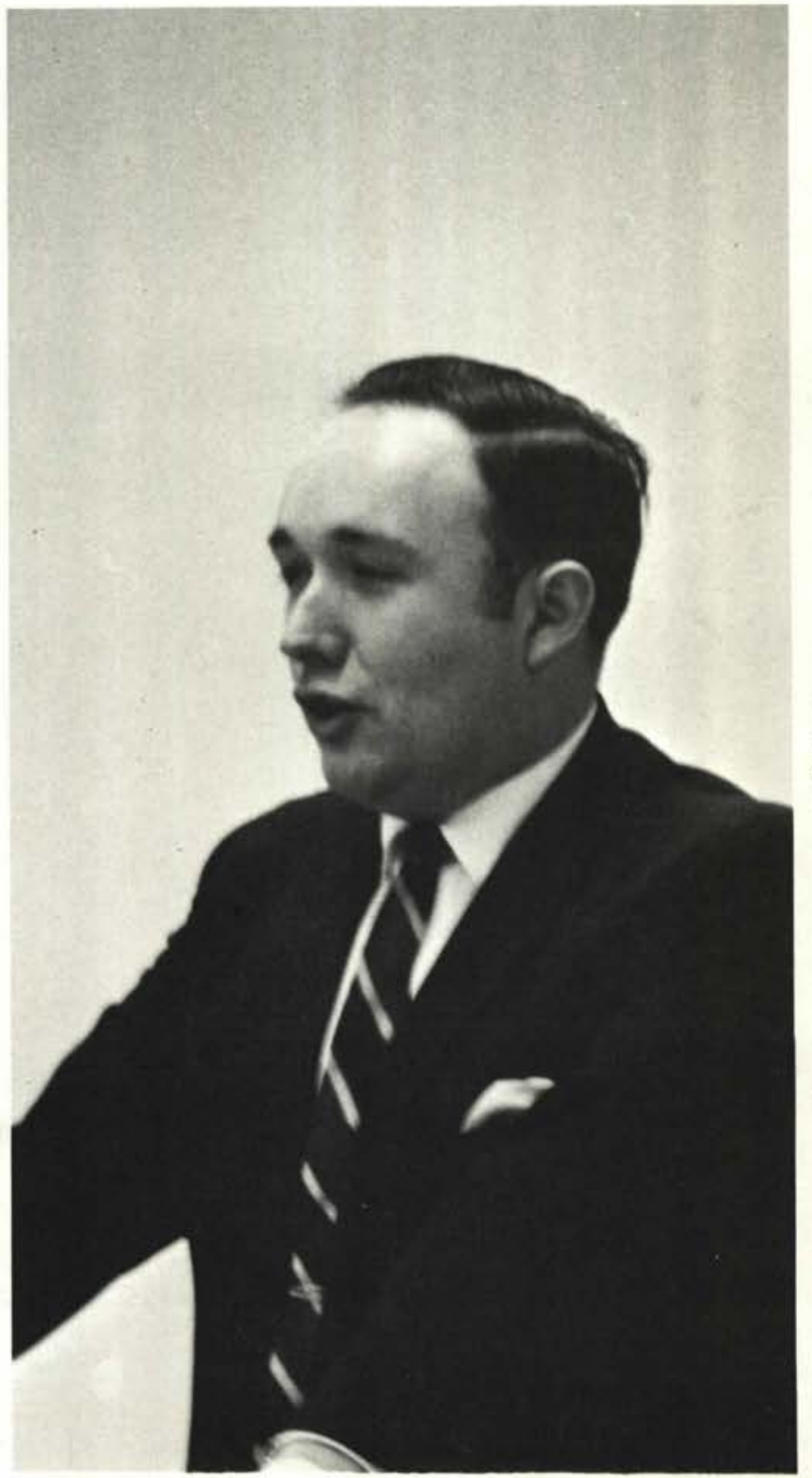


THE FIRST FEW WEEKS . . .

the action of a soccer game,

a fighting goalie,

a disgusting moment,

the horror of

Varsity C Initiation,

Cedarville weather
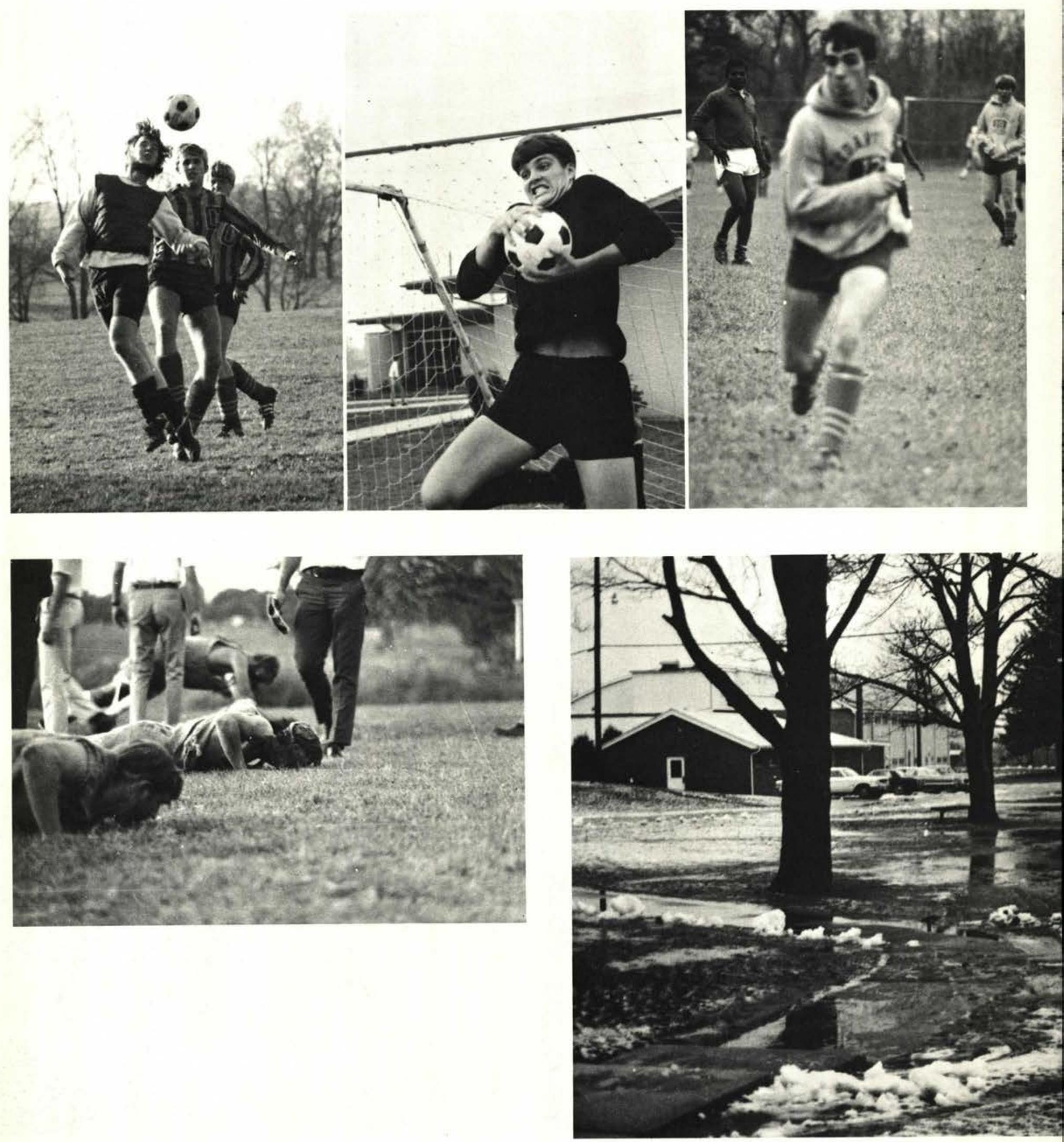


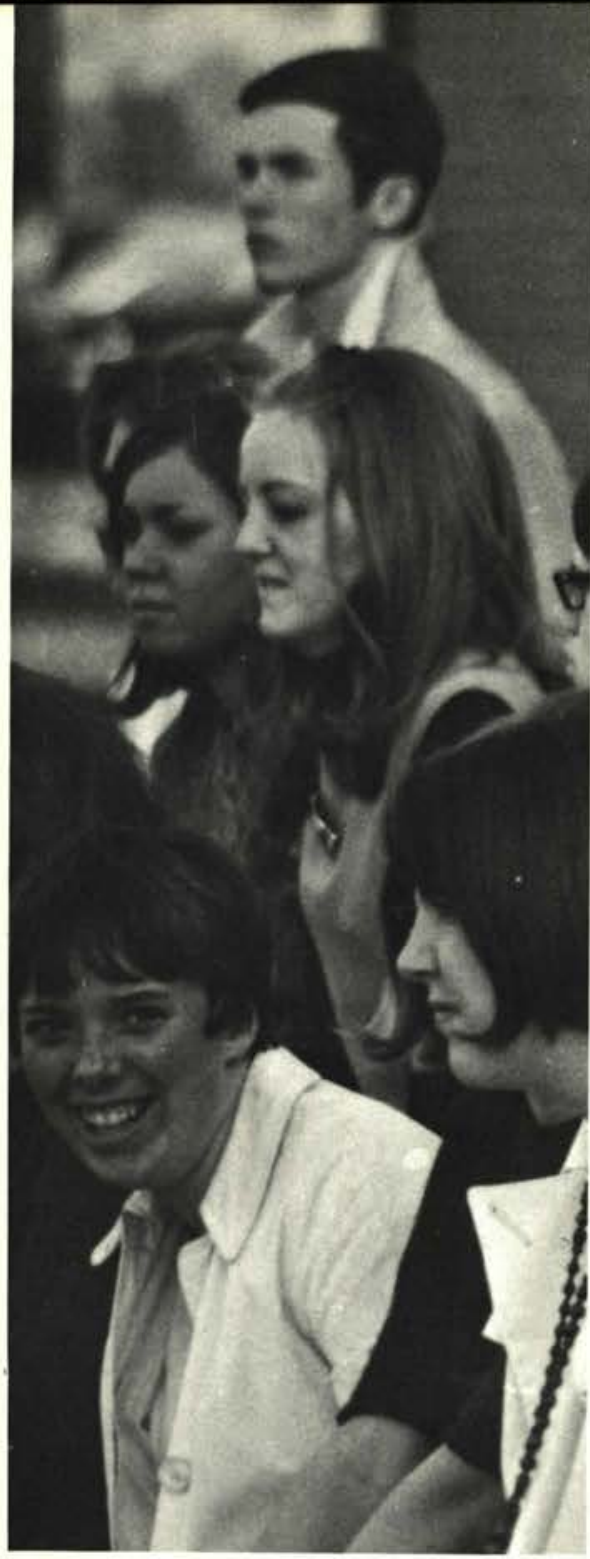

crowded bleachers,

the first goal,

the smell of onions and

the itch of burlap
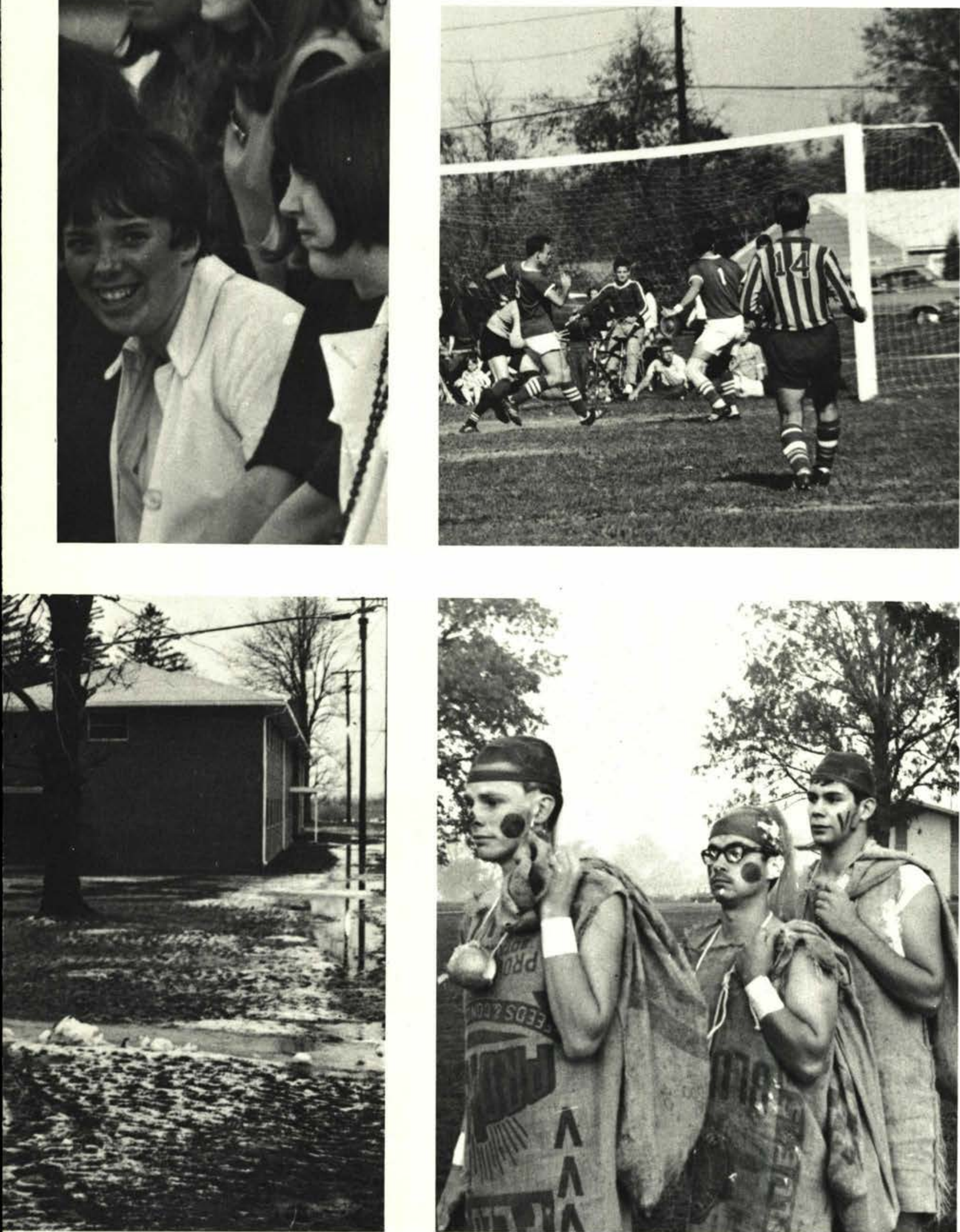
before the banquet,

crammed Alford,

daydreaming,

an ice cream social, the "brief" study break
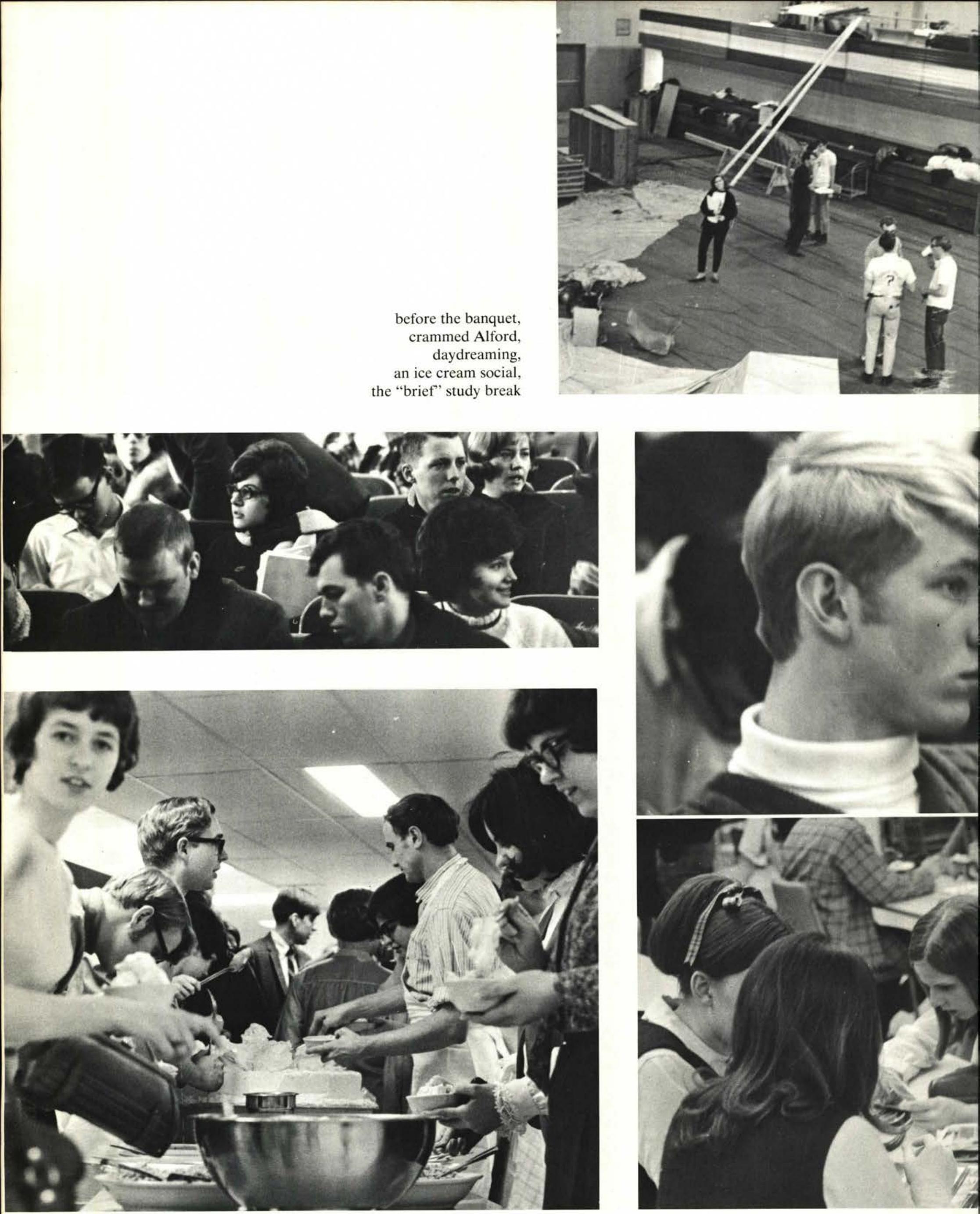

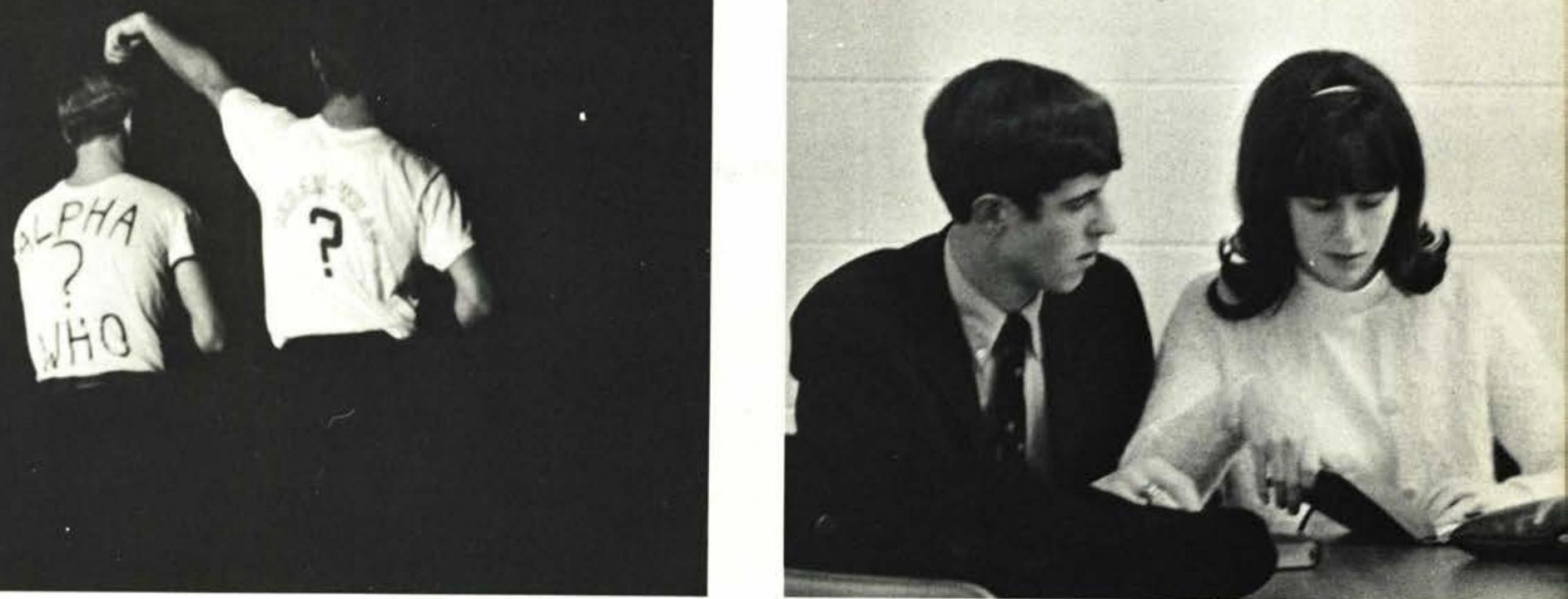

Alpha Who?

Cedar What?

quiet devotions,

another test,

the new library,

the old studies

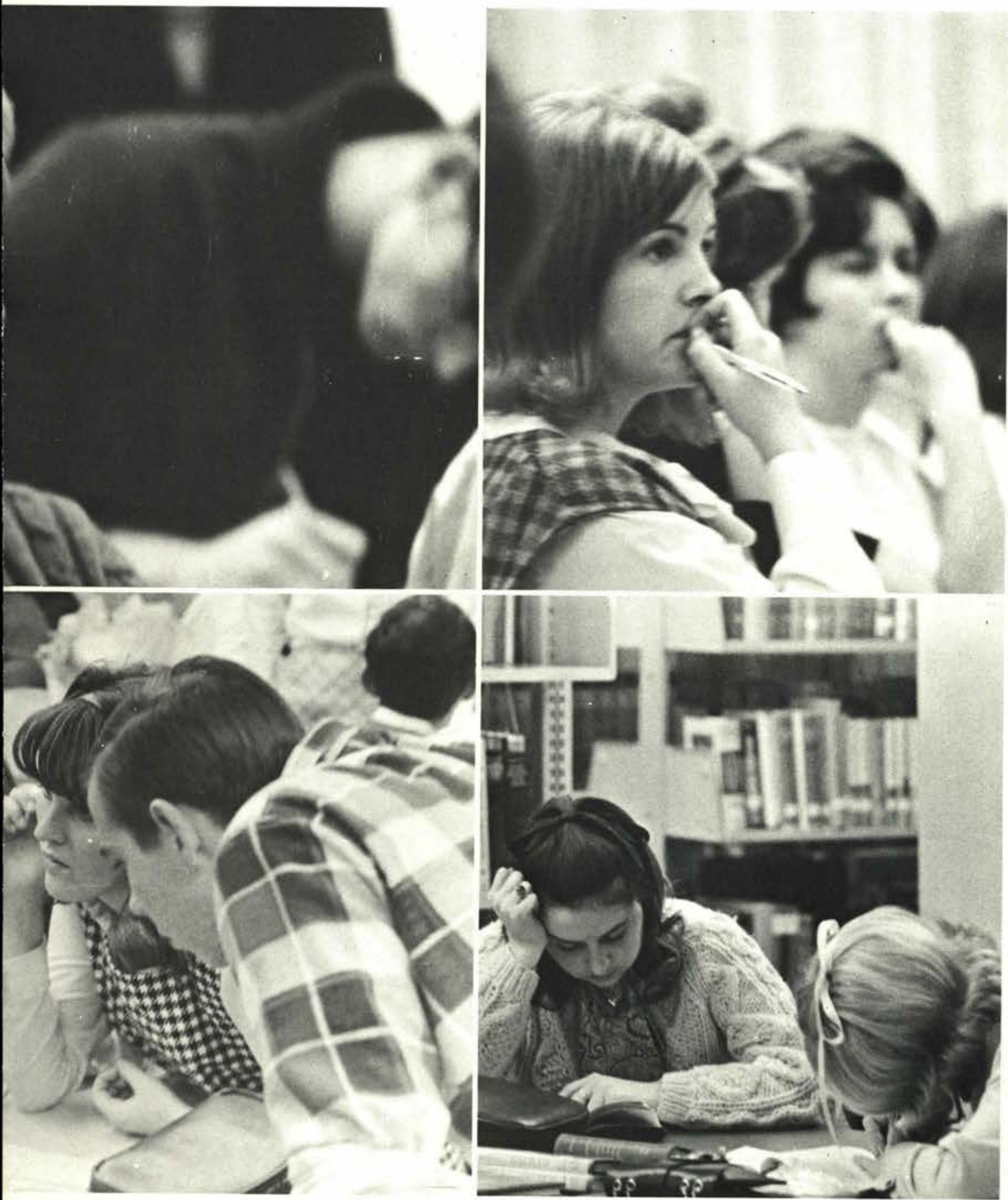



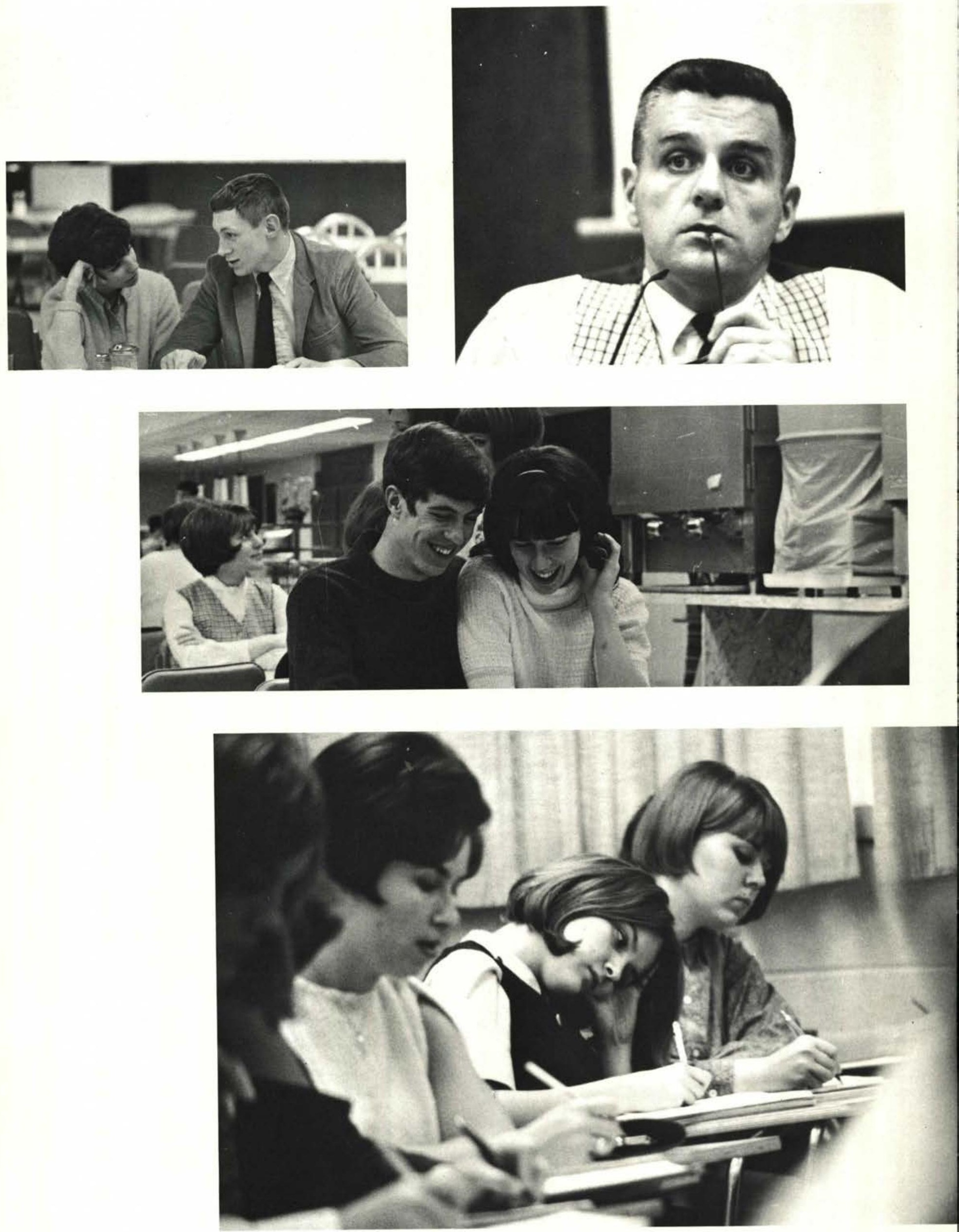

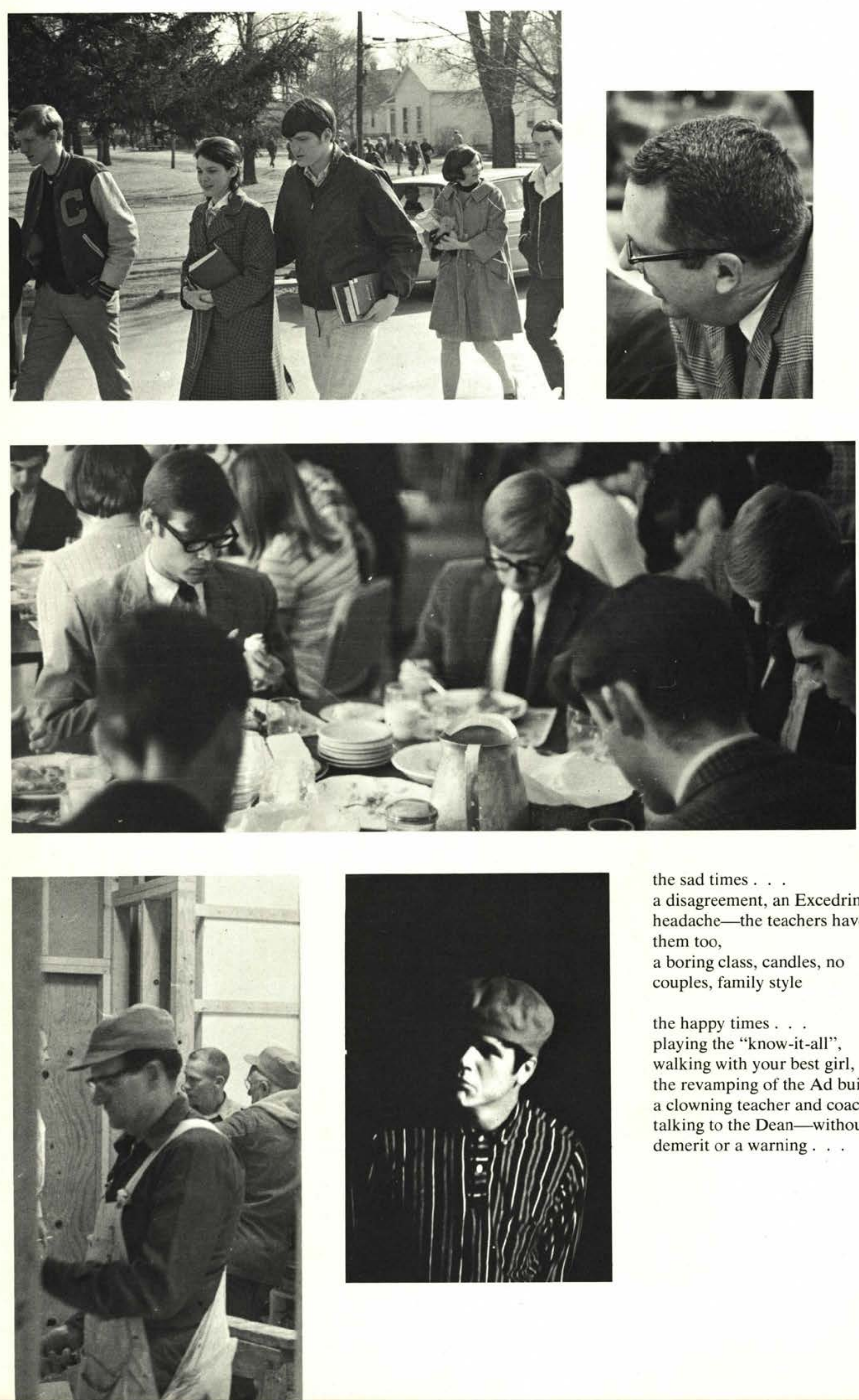

the sad times ... .

a disagreement, an Excedrin headache - the teachers have them too,

a boring class, candles, no couples, family style

the happy times . . .

playing the "know-it-all", walking with your best girl, the revamping of the Ad building, a clowning teacher and coach, talking to the Dean-without a demerit or a warning. . . 
THE FIRST FEW MONTHS . . .

the banquet feasts,

a "talented" clown,

vespers
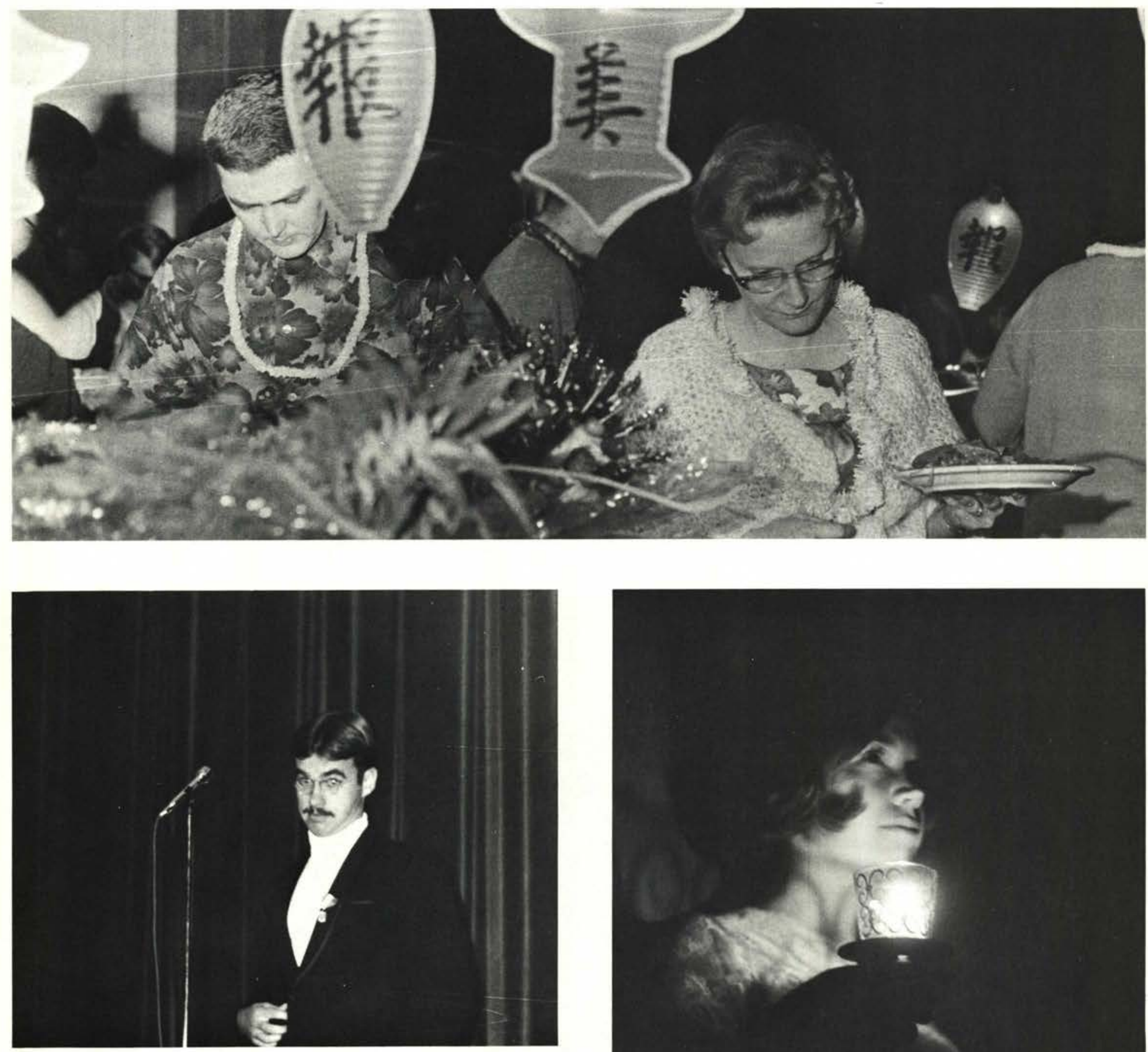


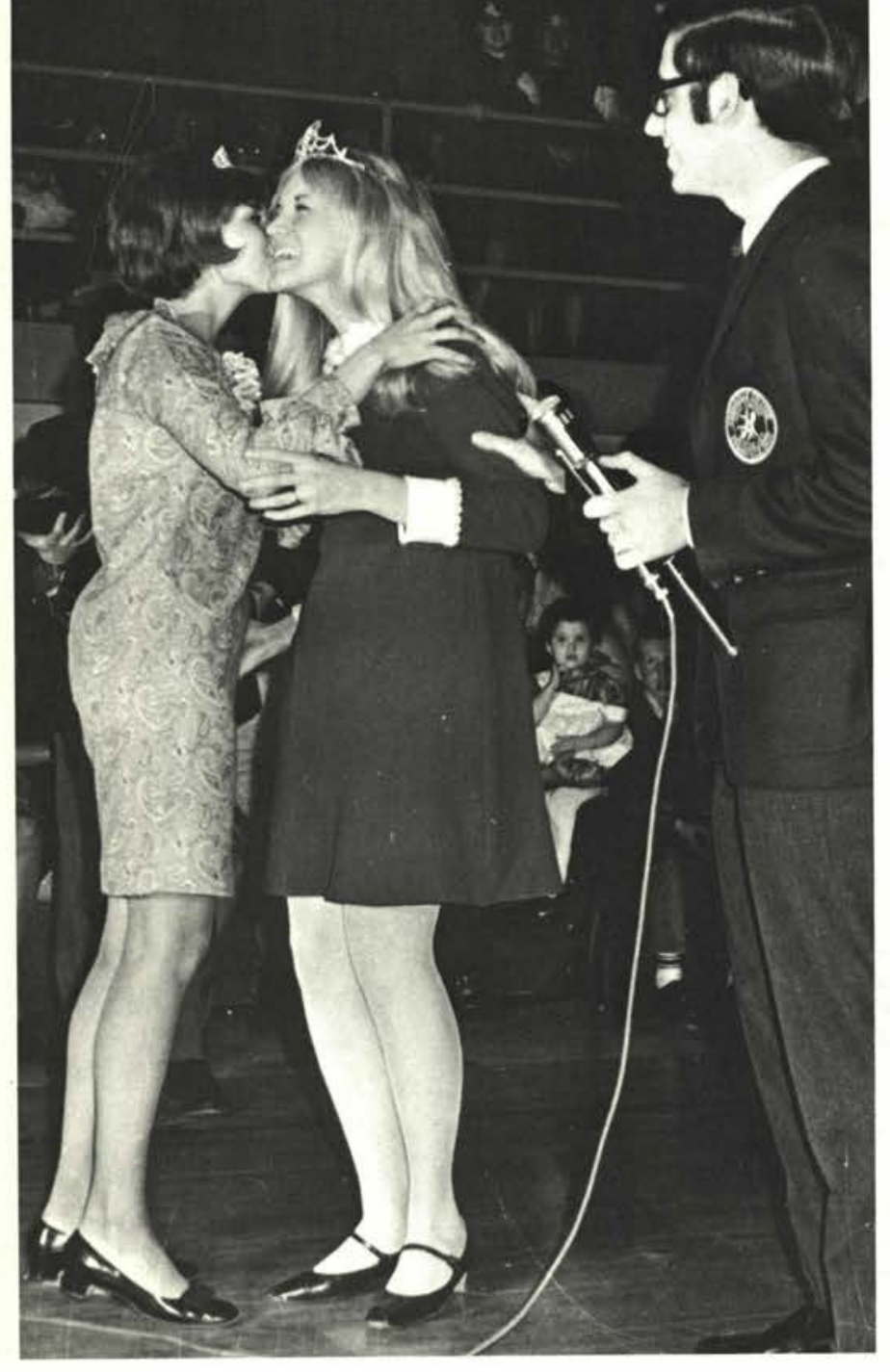

the crowning of a sweetheart,

family style dinner,

the gaiety of a luau
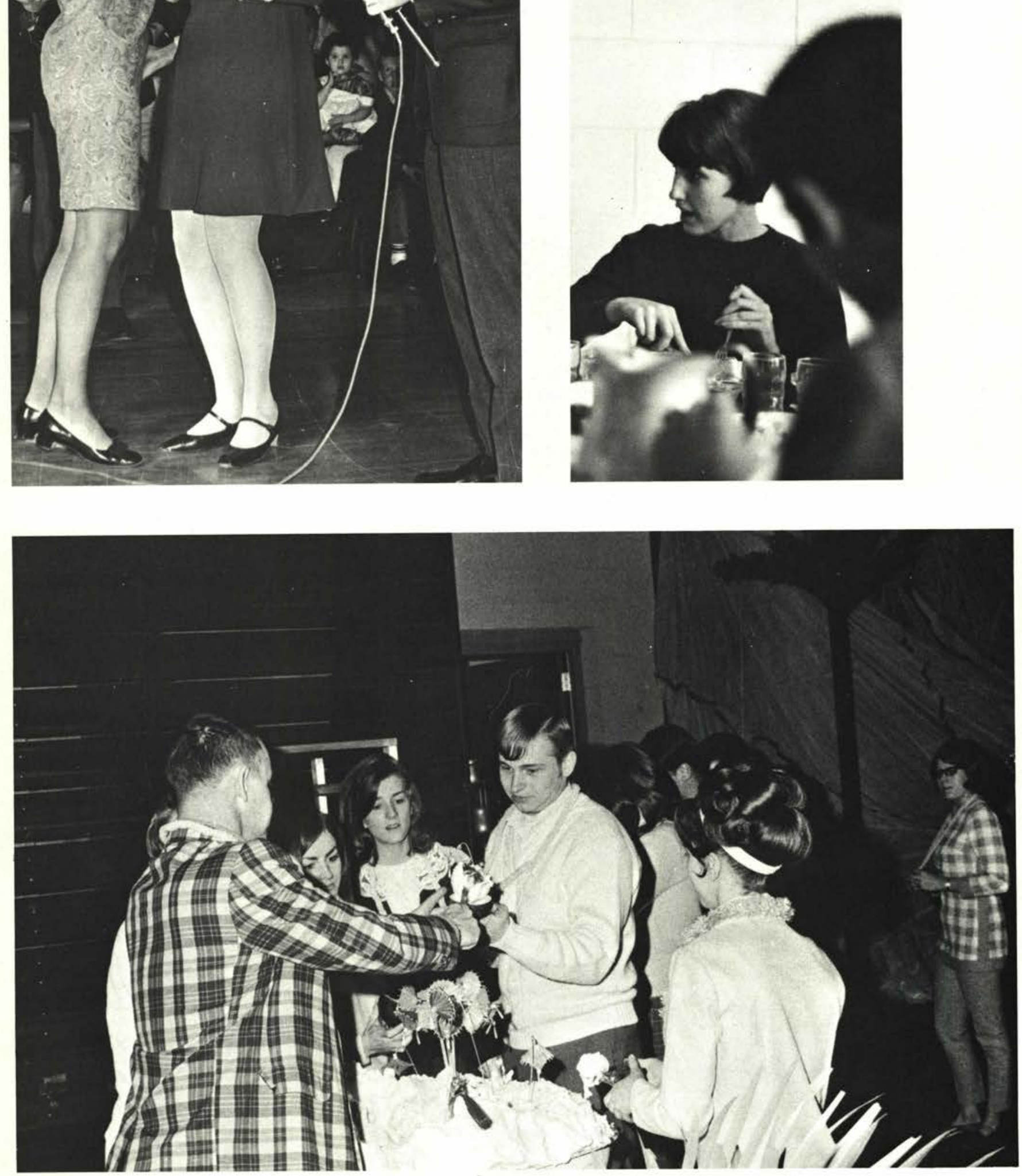
the faculty basketball team?

beating Defiance,

the fast play,

man-to-man defense
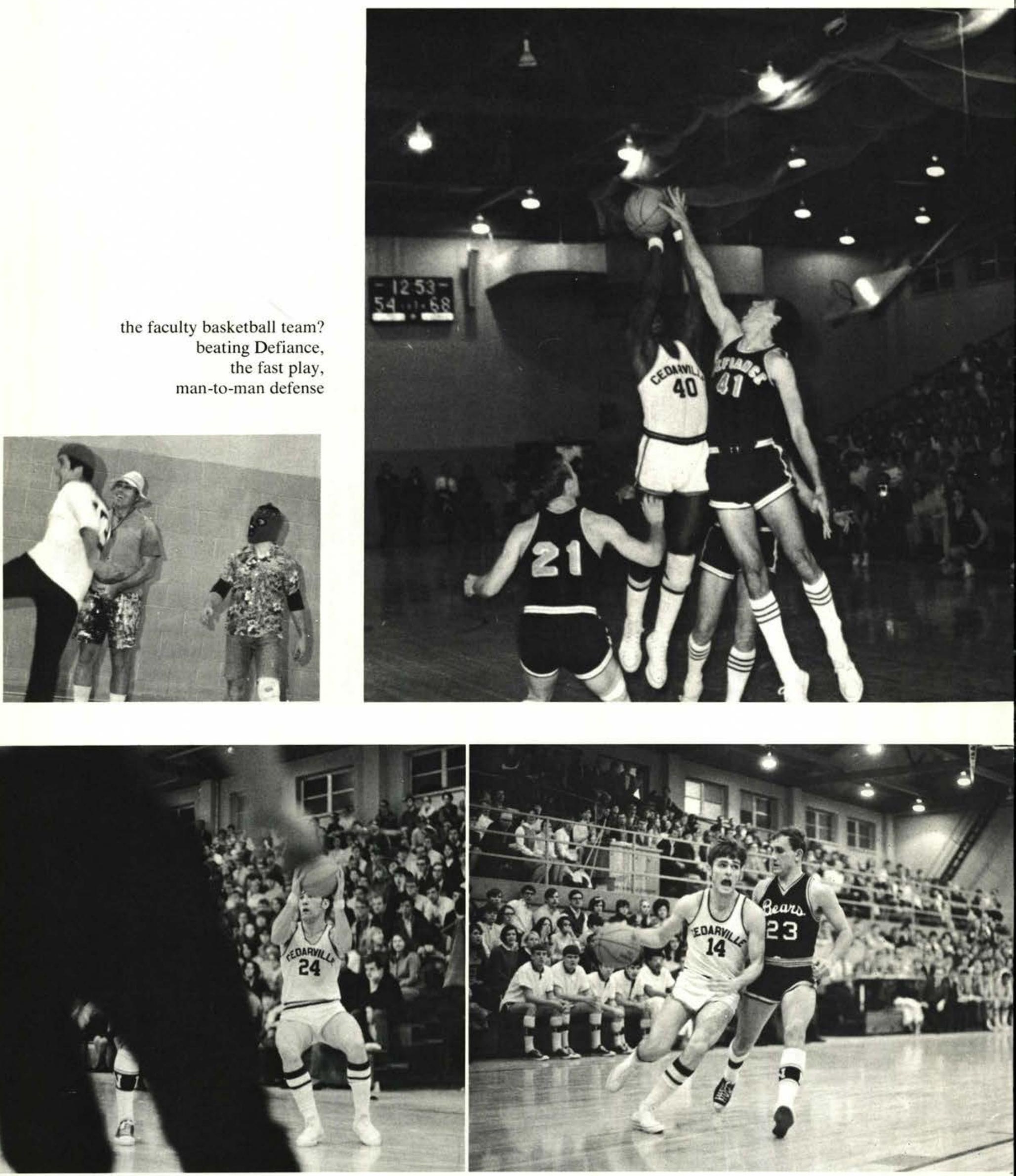

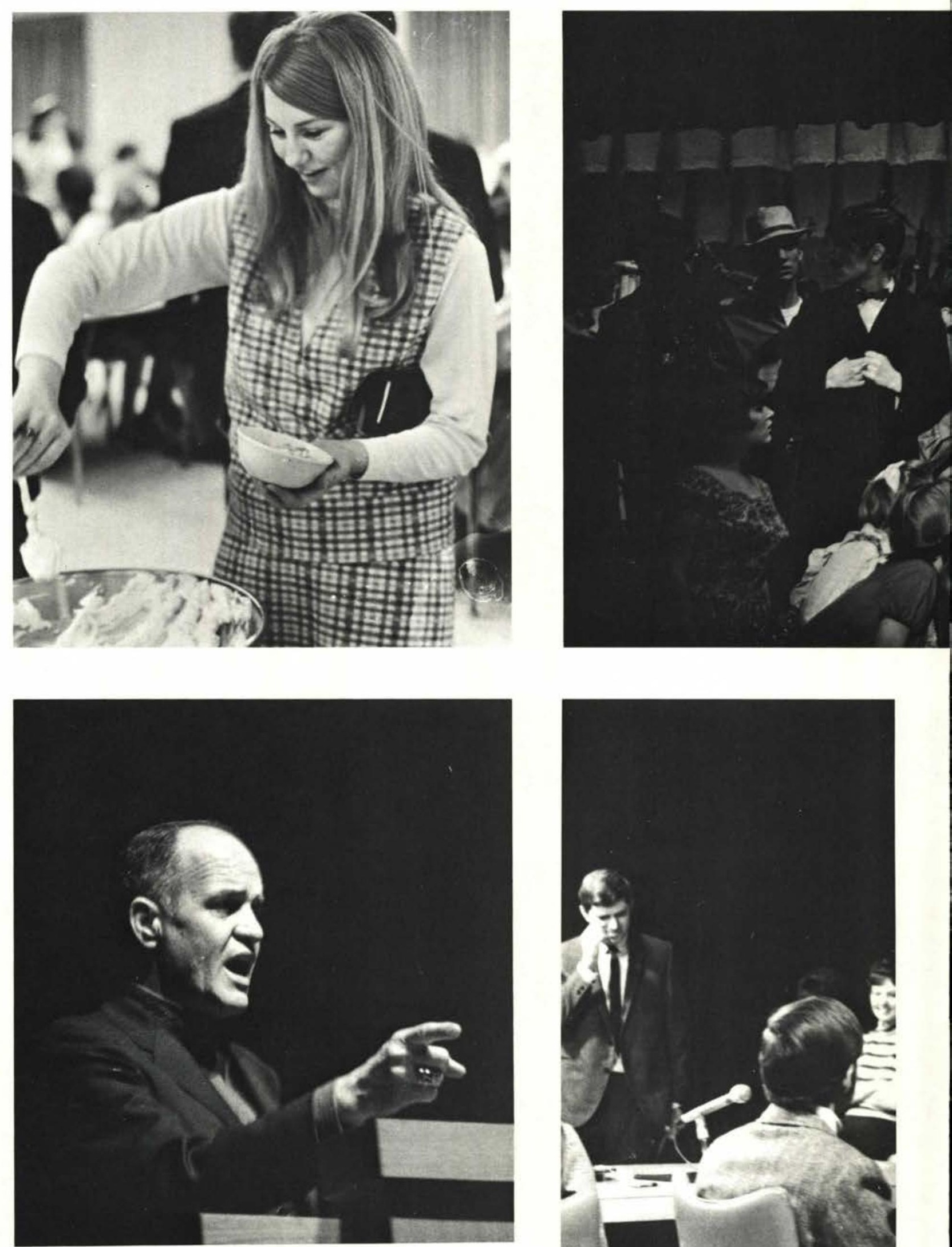

THE FIRST FEW QUARTERS . . .

forgetting the diet, being Irish for one night, hearing of Mr. Sand's love and dedication, the T.V. presents Cedarville College and Antioch College

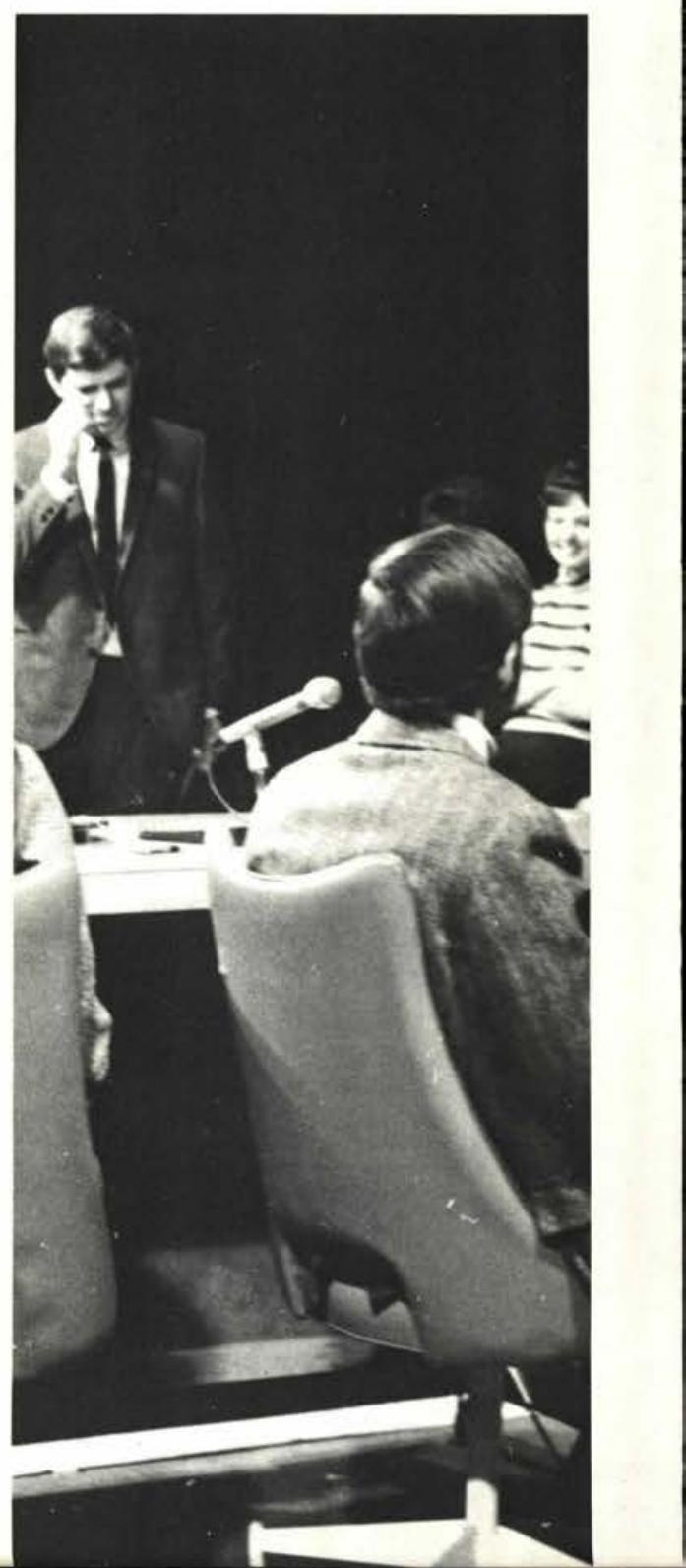



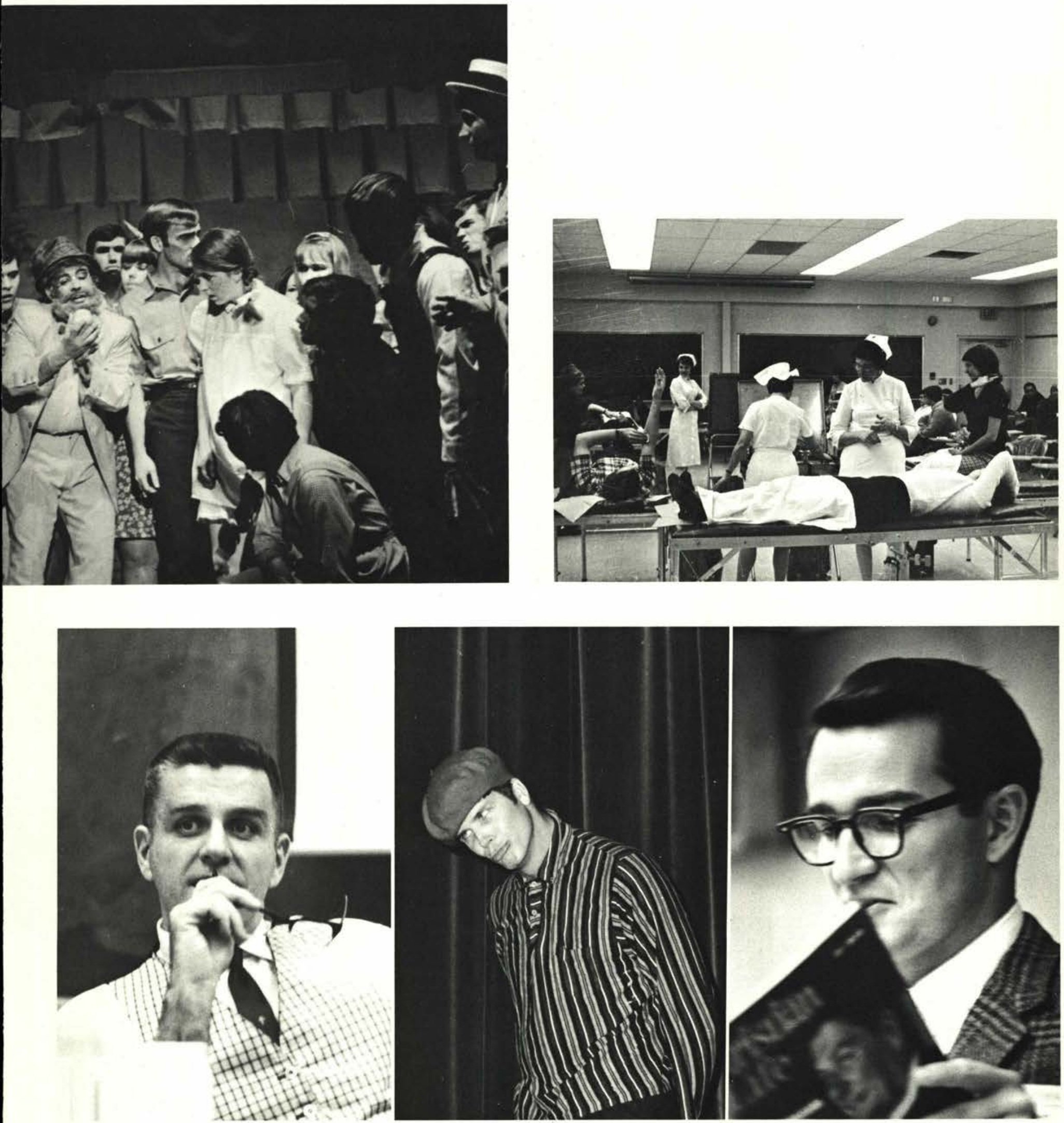

the fright of giving blood, the thoughtful mind,

the "free" mind,

the inquiring mind 
the final cram, the missionarya real person, Miss Malmstrom, the millionth report, the joy of fellowship, the teaching experience, the professors
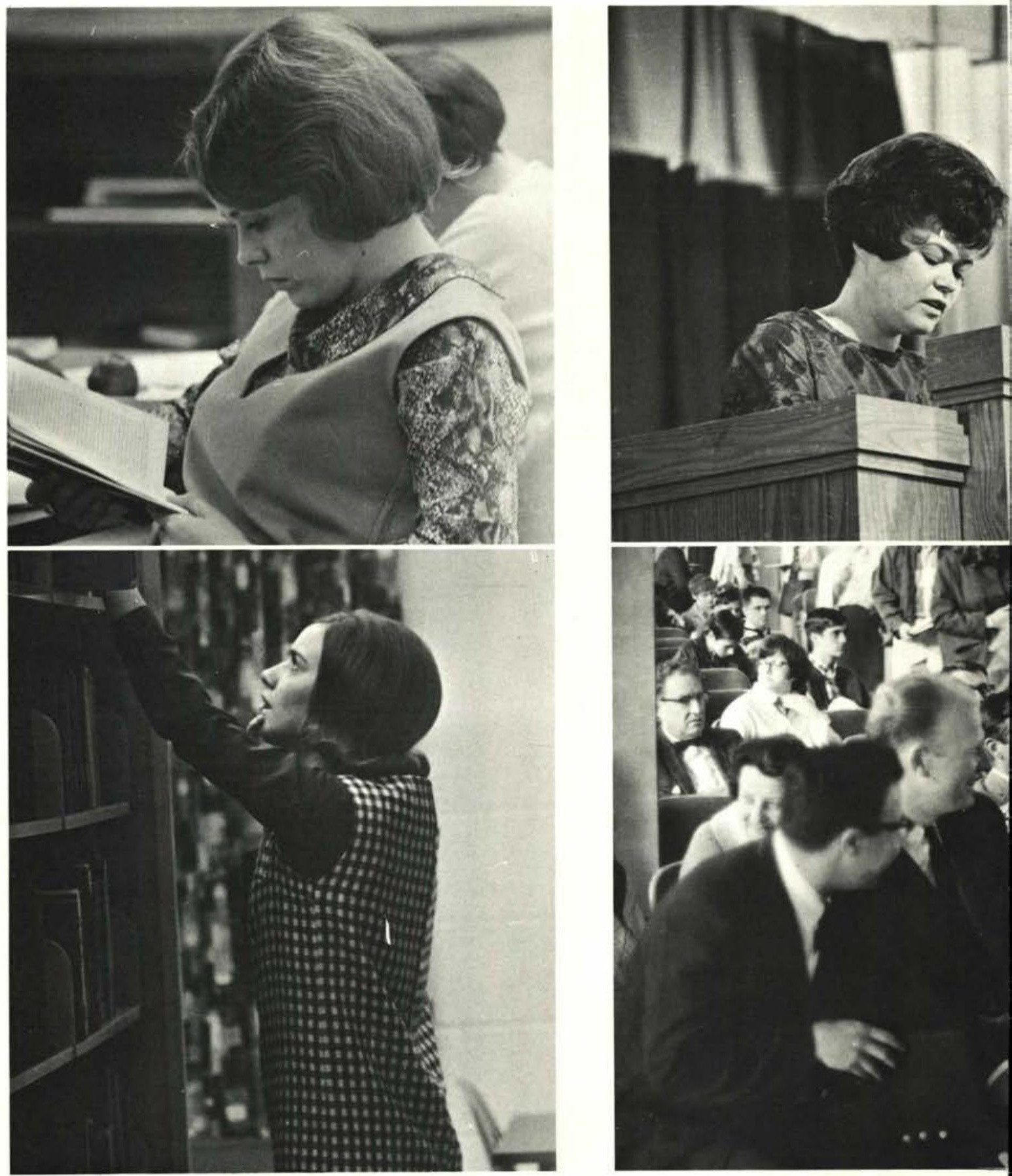

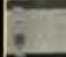

$$
3
$$




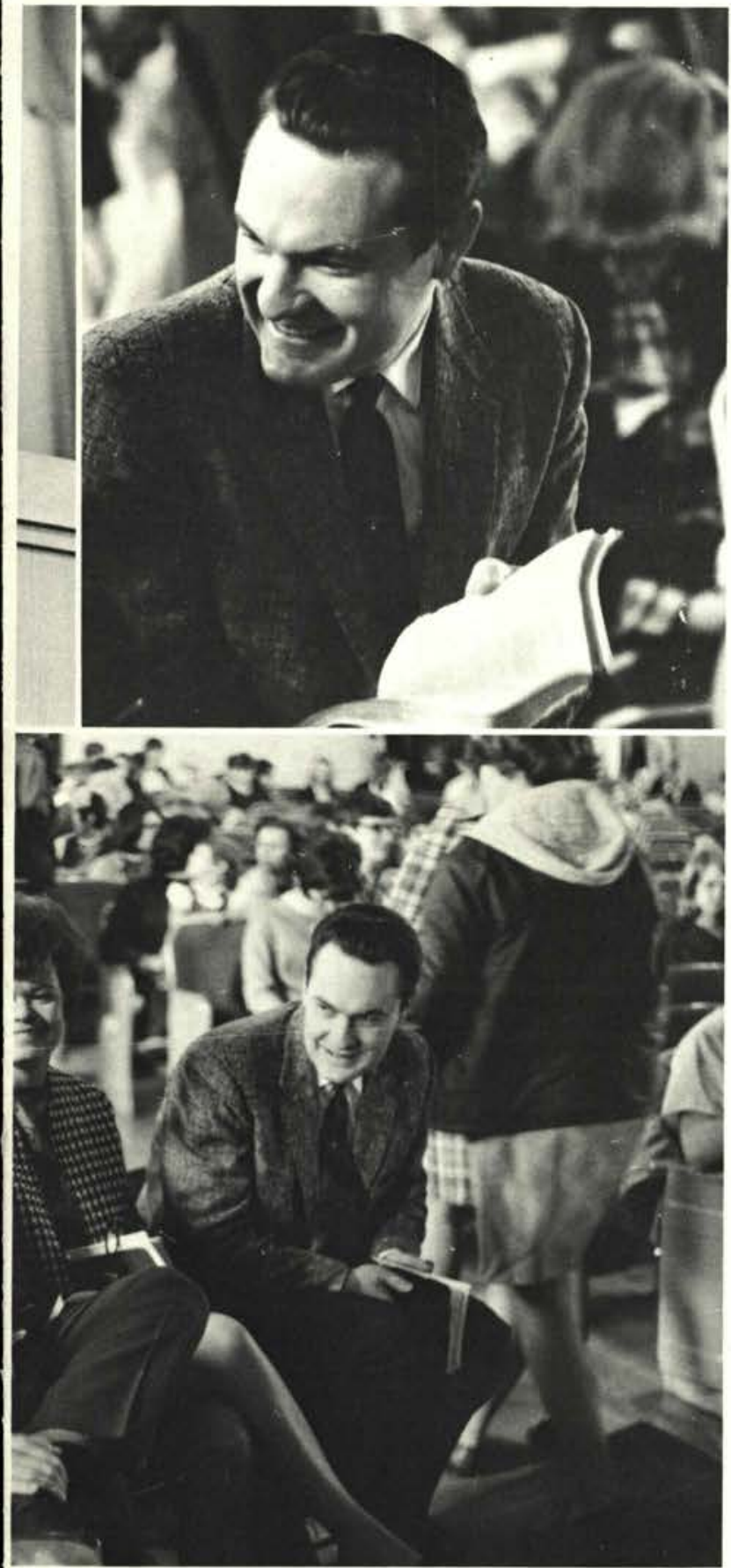

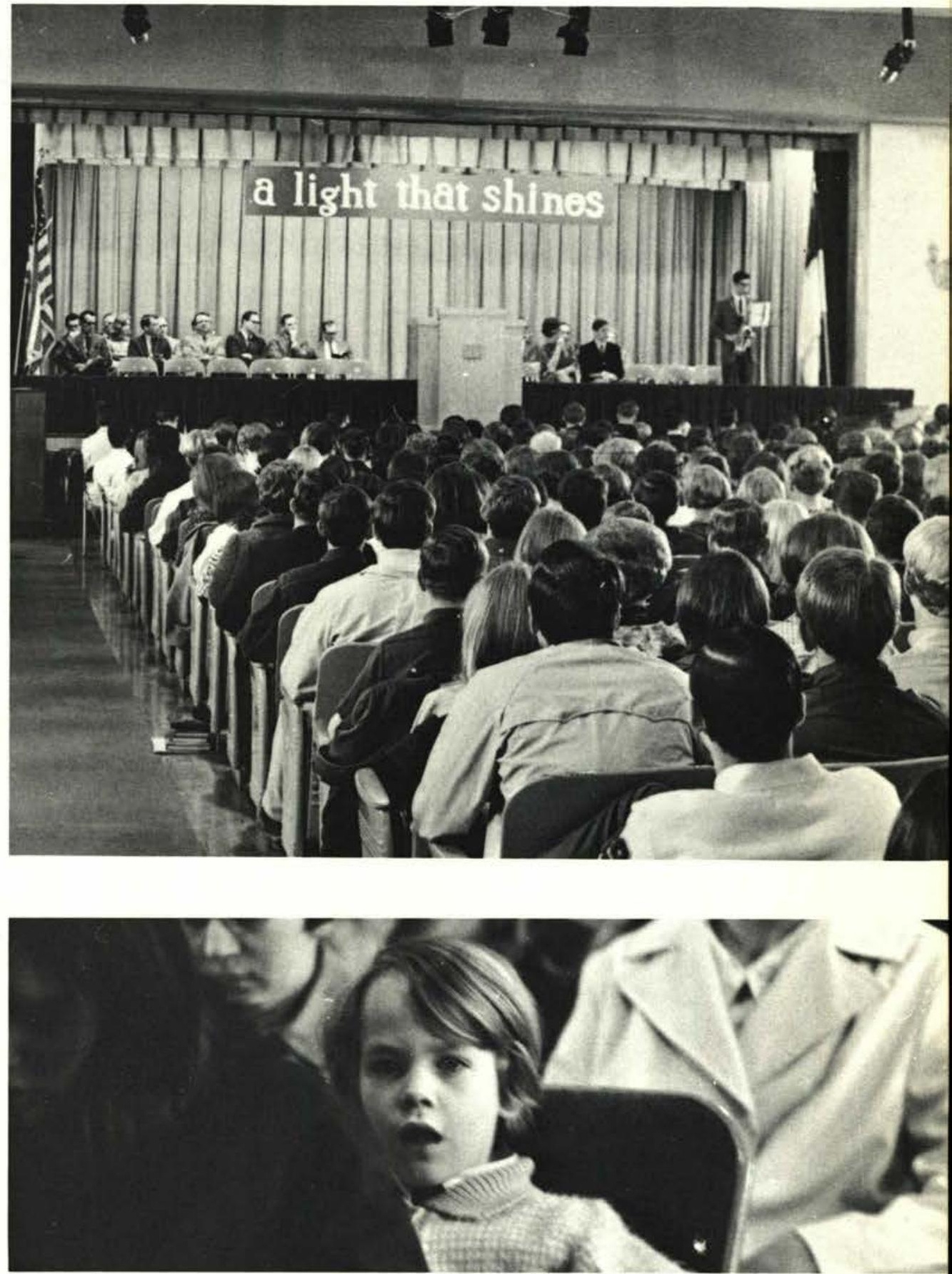

the wonder of the Bible's truth,

Mr. Crotts,

the missionary conference,

the light that shines,

dreaming of past days,

the heart that sings 

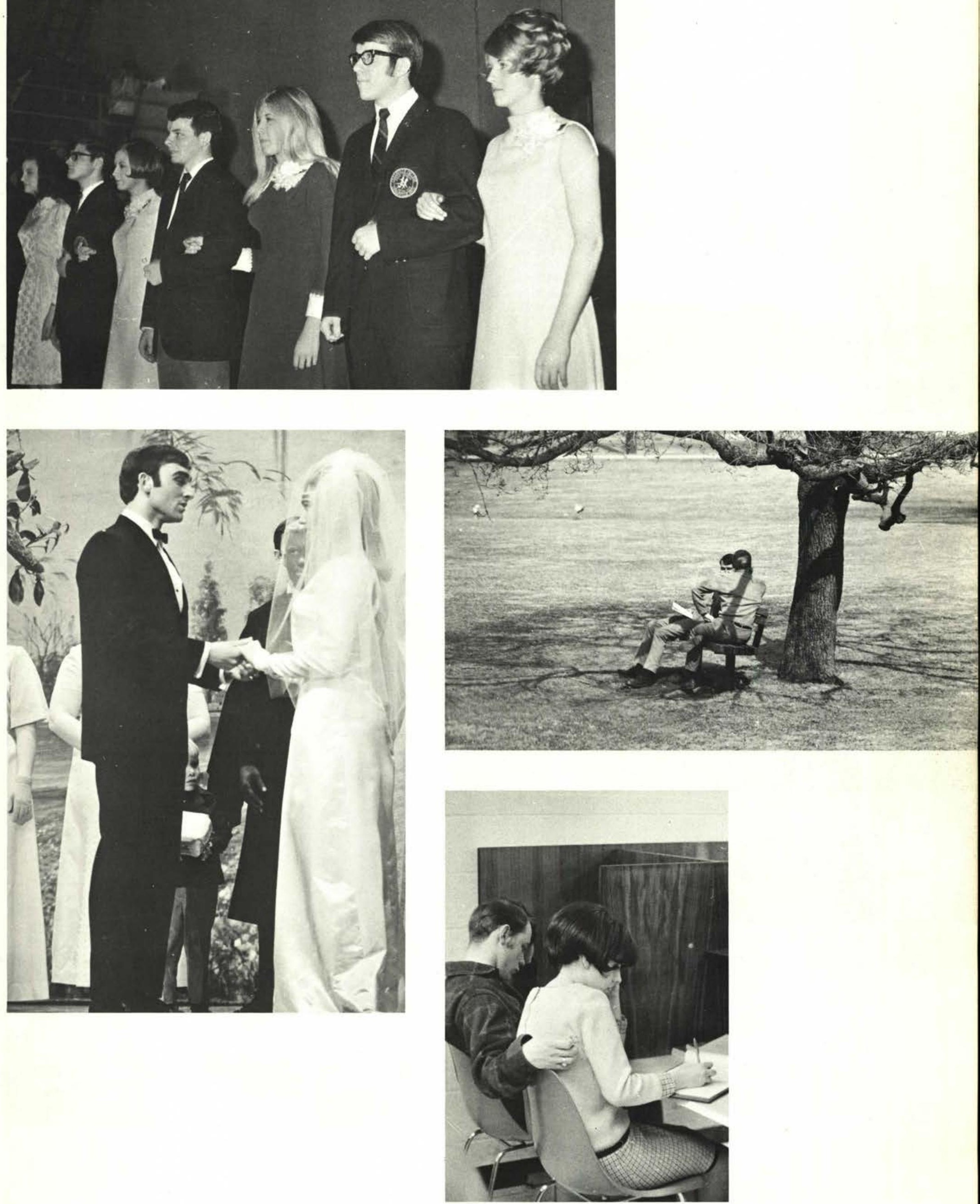

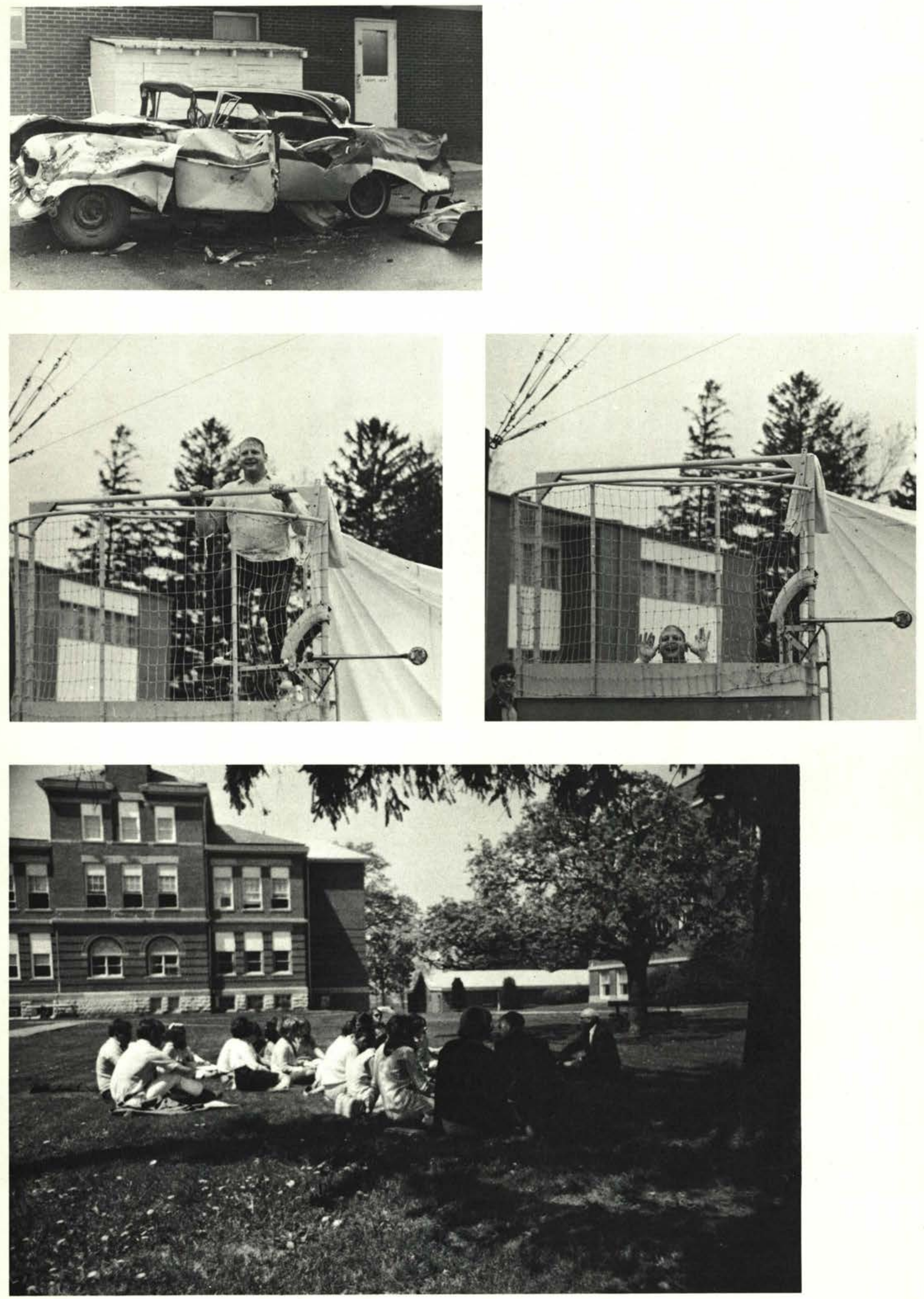

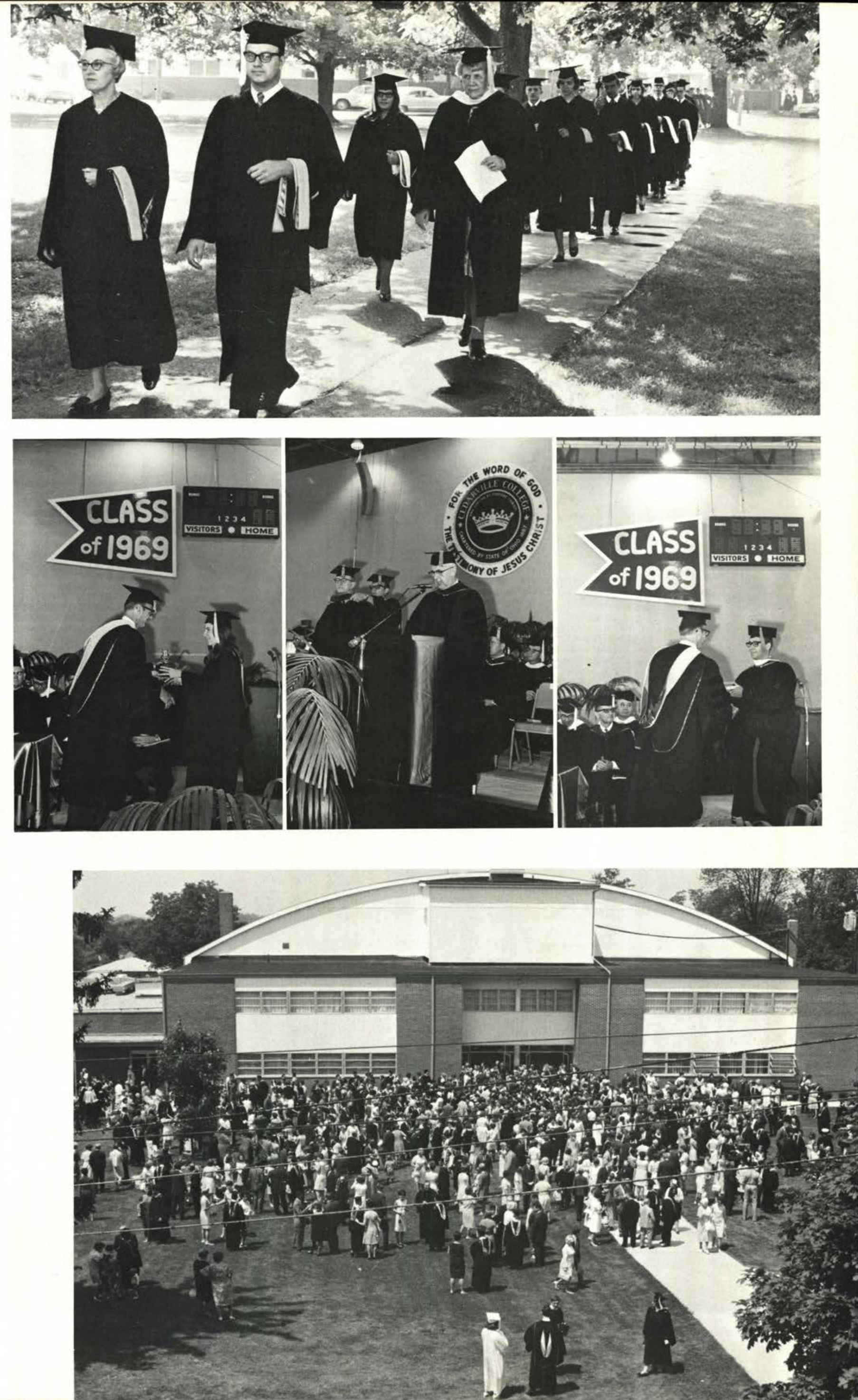


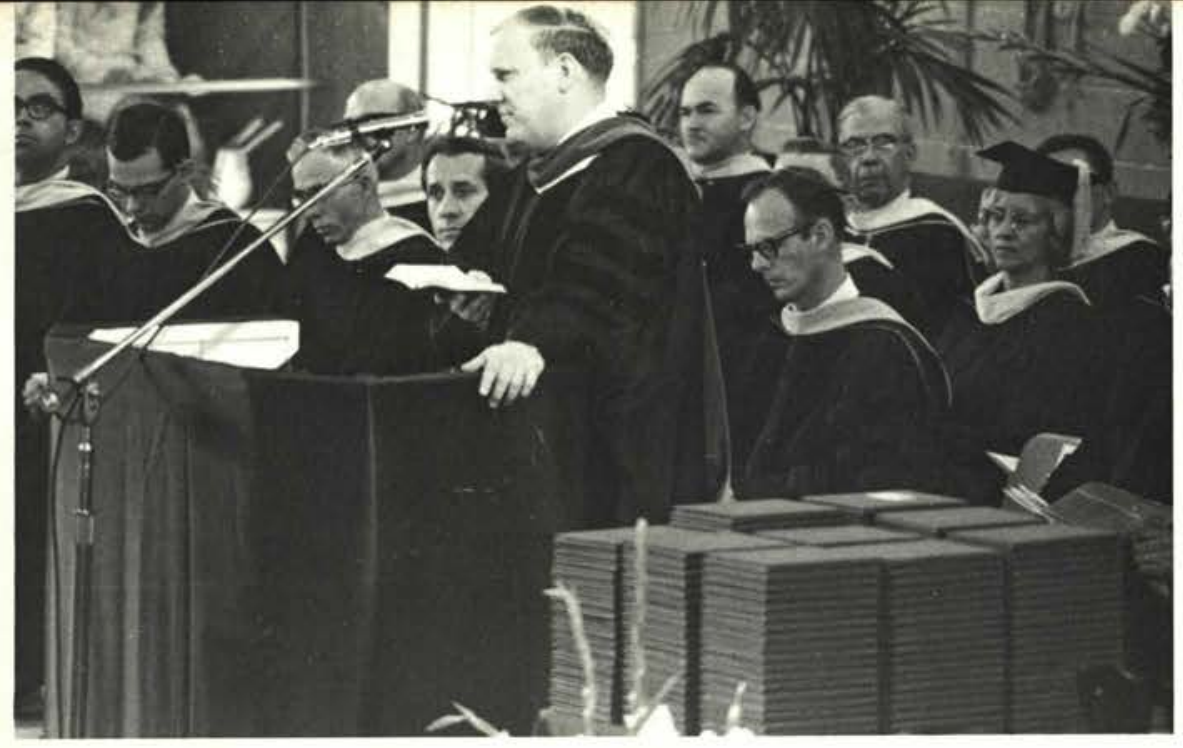

the last days . . the junior-senior banquet, the late hours, water fights, the search for knowledge culminates in graduation. The 1969 graduating class found June 17 a day of joy, tears, honors, prayers, congratulations, speeches, friends, packing, best wishes, goodbyes, and unknown beginnings.

Pictured at far left is Colonel William Goldie receiving an honorary degree; at left, the graduation speaker, Pastor Warren Wiersbe.
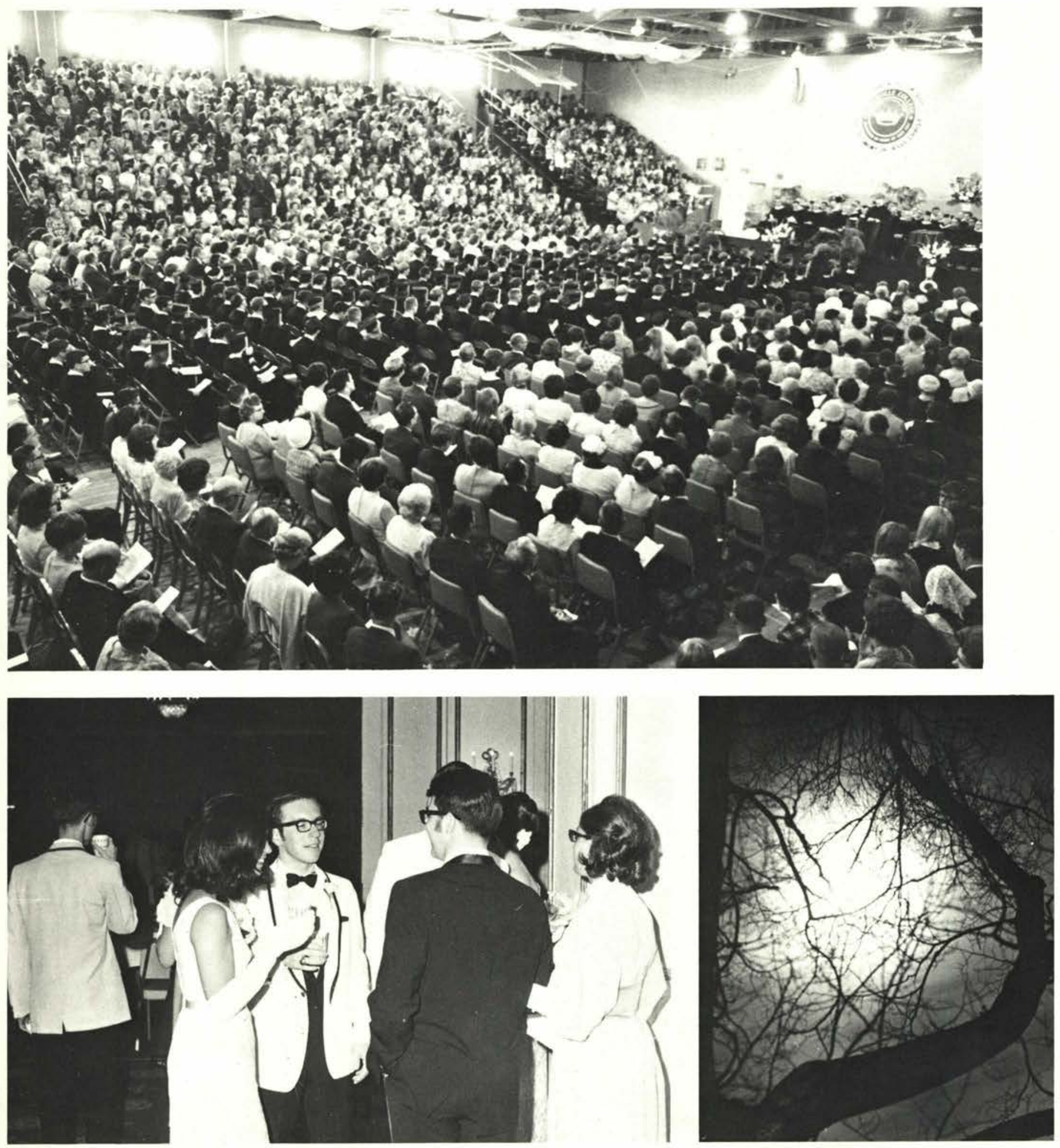


\section{MOODS ...}
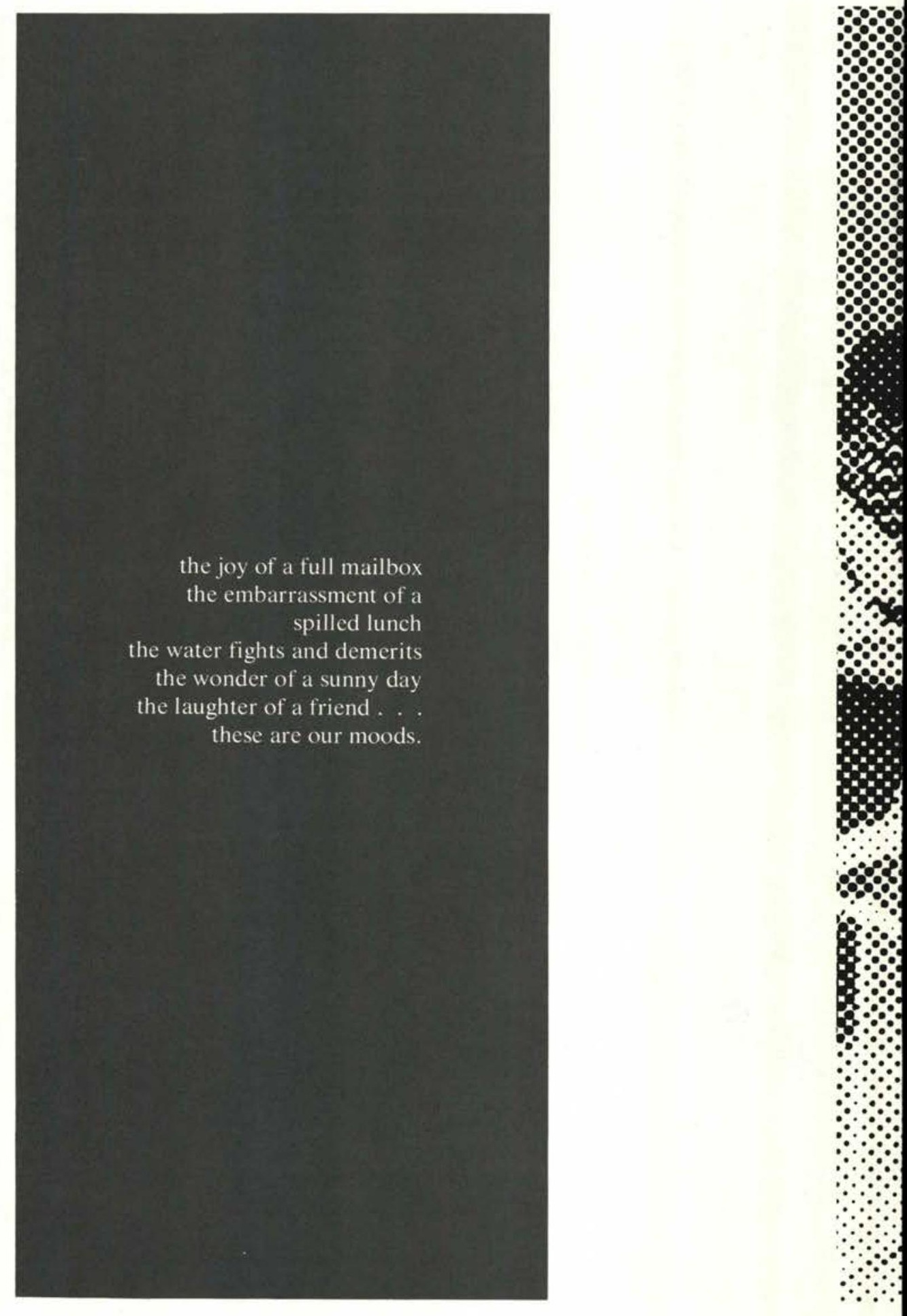


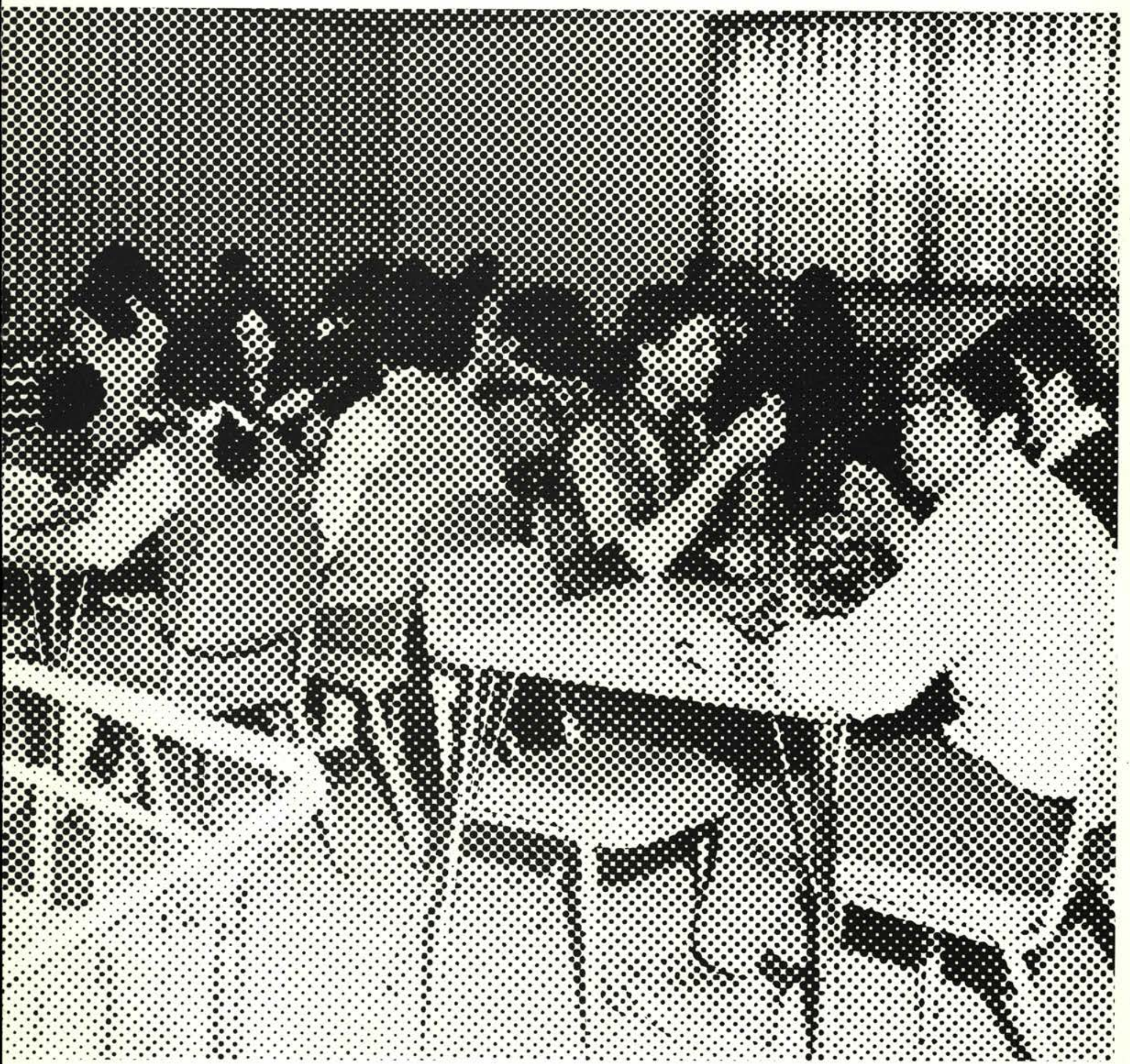




\section{FRESHMEN}

The Freshman Life Is

\section{One of Discipline.}

Pictured below are the freshman class officers: Denise Walters, St. Council Rep.; Mike Wilhite, Chaplain; Chip McDaniel, Pres.; Tim Kline, St. Council Rep.; Mr. Green- wood, Adviser; Ralph Perkins, V.-Pres.; Dianne Kemp, Secretary. The treasurer, Bill Hoffman, is not pictured.

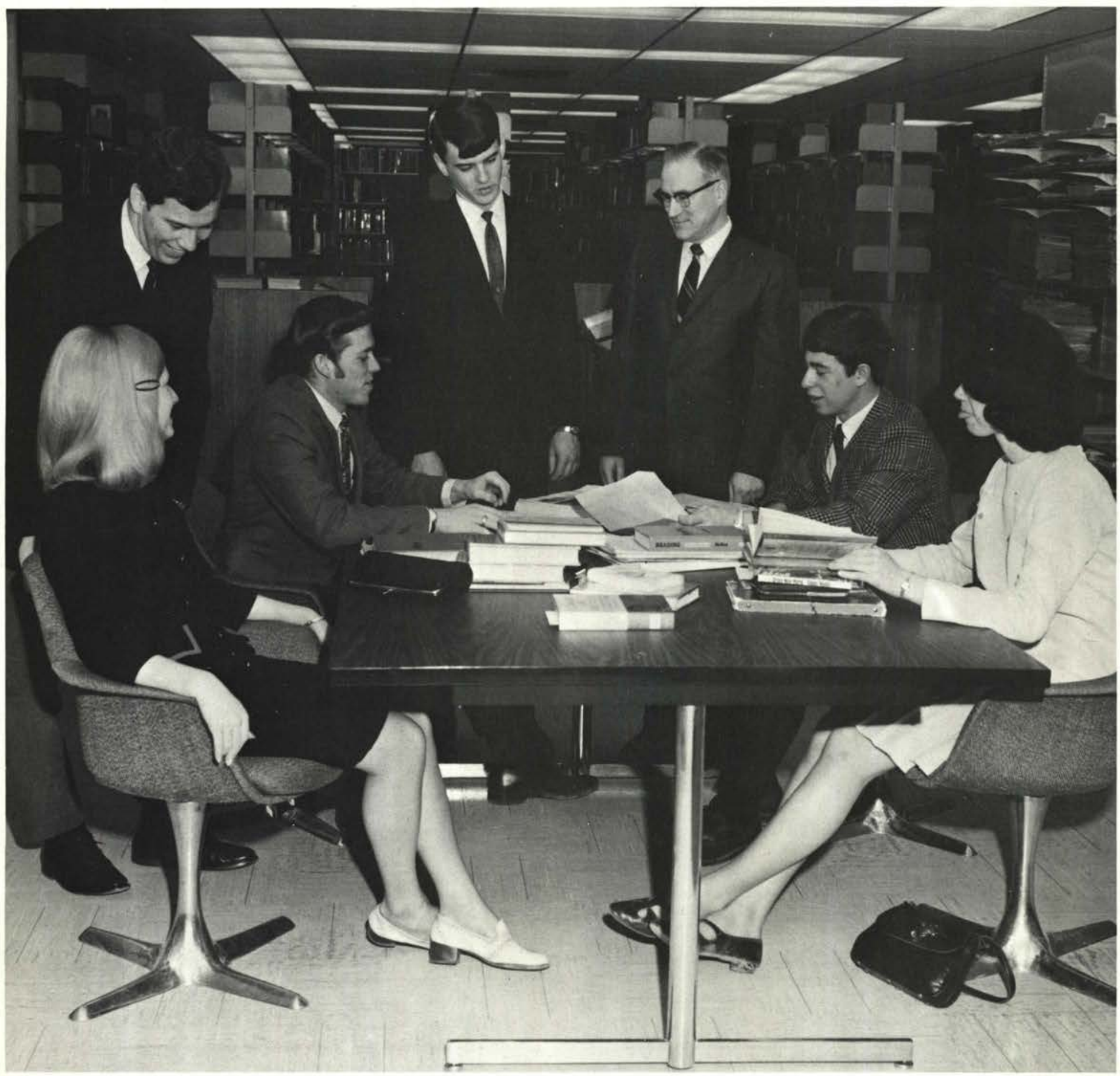


Jo Anna Adams

Dayton, O.

Nancy Addleman

Hillsdale, Mich.

Kathy Aldrich

Ithaca, N.Y.

David Argo

Vliets, Kansas

Kathy Aumack

Haddon Hghts., N.J.
Robert Austin

New Milford, N.J.

Judith Baker

Schenectady, N.Y.

Rodney Baker

Cardington, $\mathrm{O}$.

Michael Balyo

Cleveland Hghts., $\mathrm{O}$.

Basil Bates

Cedarville, $\mathrm{O}$.
Margaret Beck

Oswego, N.Y.

Phyllis Beckley

Hamburg, N.Y.

Mary Beitz

Cheektowaga, N.Y.

Karen Bernath

Stryker, O.

Randy Berry

Pontiac, Mich.
Linda Betts

Wellington, $\mathrm{O}$.

Pamela Betts

Dorsey, Ill.

Rebecca Bittner

Tacoma, Wash.

Richard Black

Algona, Iowa

Linda Blum

Kalamazoo, Mich.
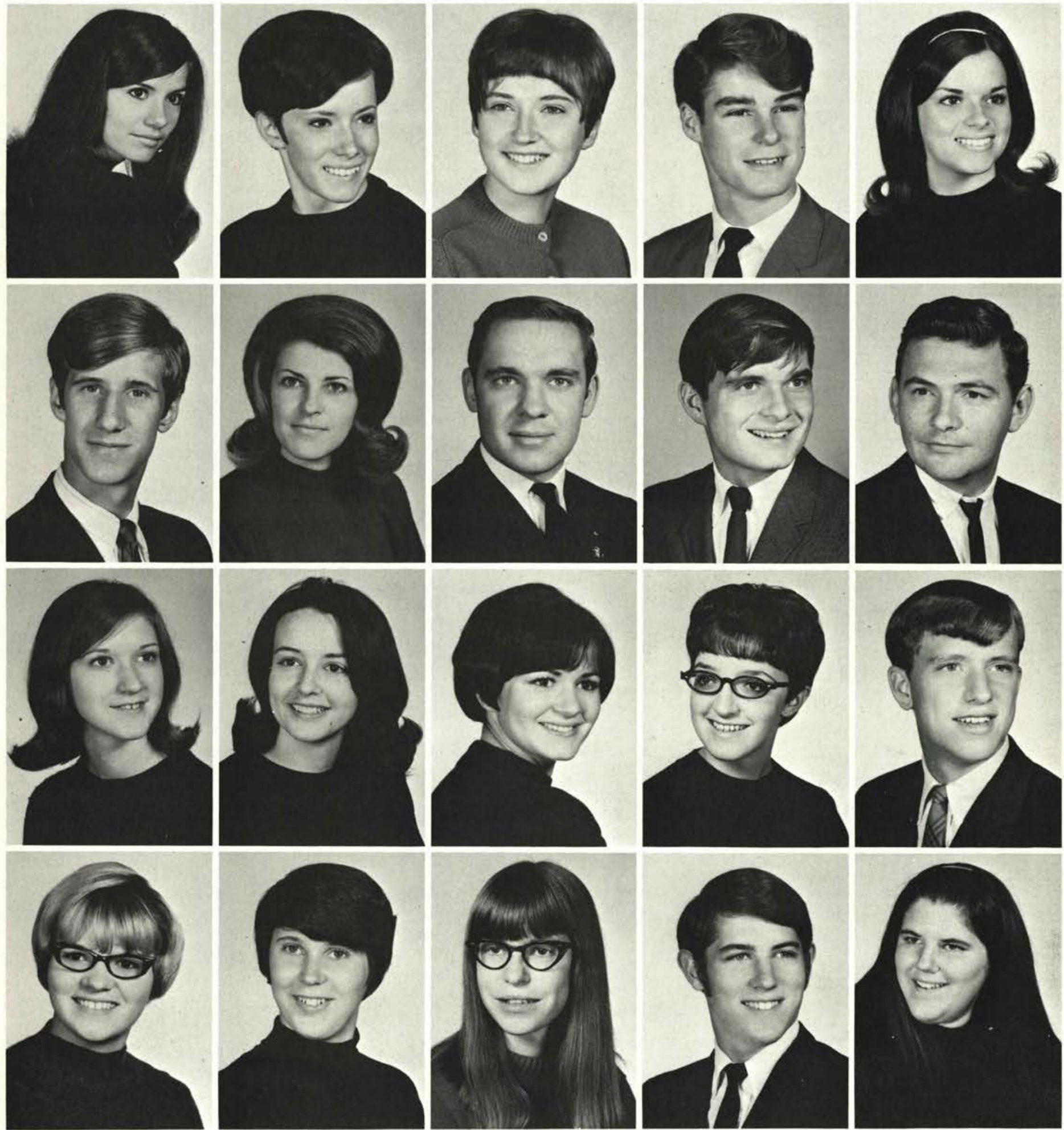
Thayne Bodenmiller Homerville, O.

Carl Bondorff Maywood, N.J.

Kenneth Boothe Tallmadge, $\mathrm{O}$.

Donald Bosh Cedarville, $\mathrm{O}$.

David Bradford Coshoston, O.

Pamela Branning Binghamton, N.Y.

Martha Brooker Sebrima, Fla.

Beverly Brown Hornell, N.Y.

Linda Brown Milton, Ind.

Marjorie Brown Boothwyn, $\mathrm{Pa}$.

Janet Butler Richmondville, N.Y.

Beverly Byer Kimmell, Ind.

\section{Roy Calvin}

Salem, O.

Gail Carsey

Grand Blanc, Mich.

Helen Carter

North Royalton, O.
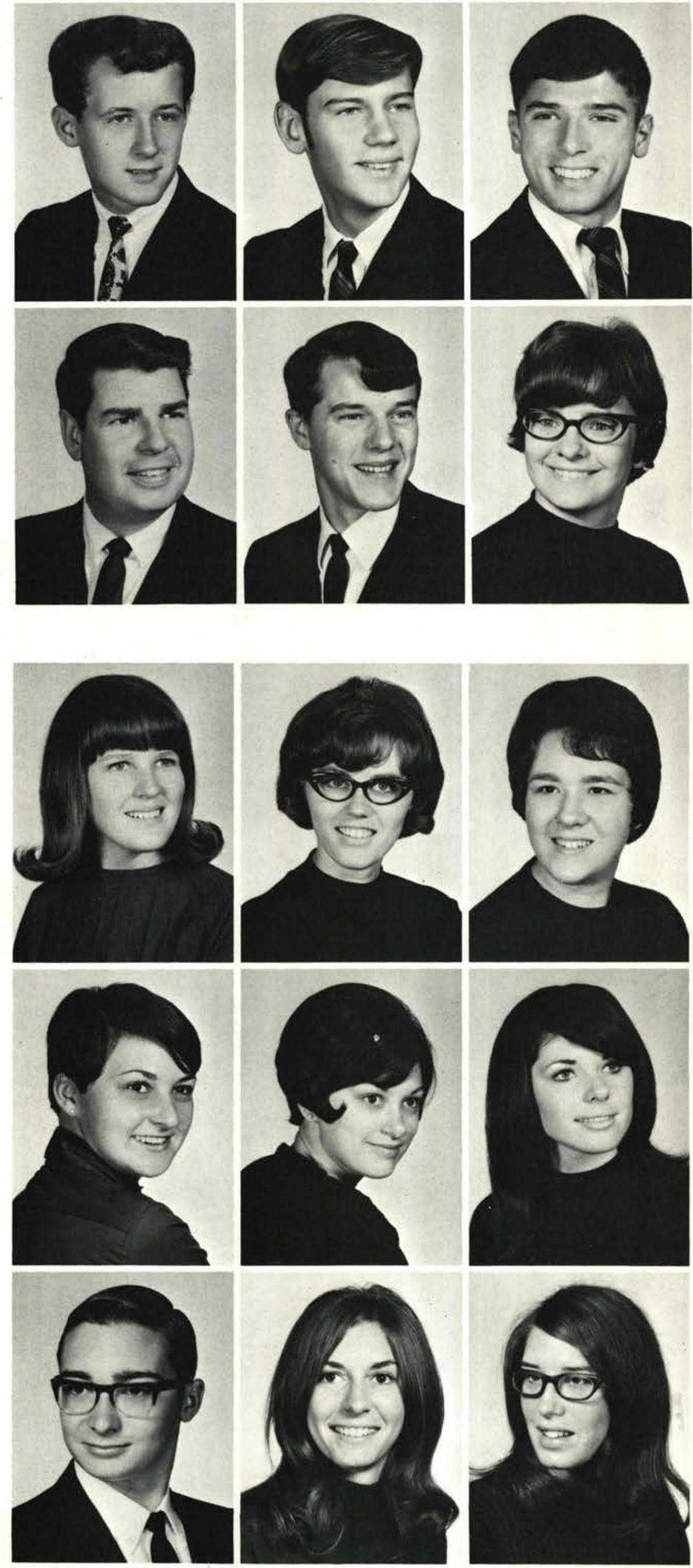

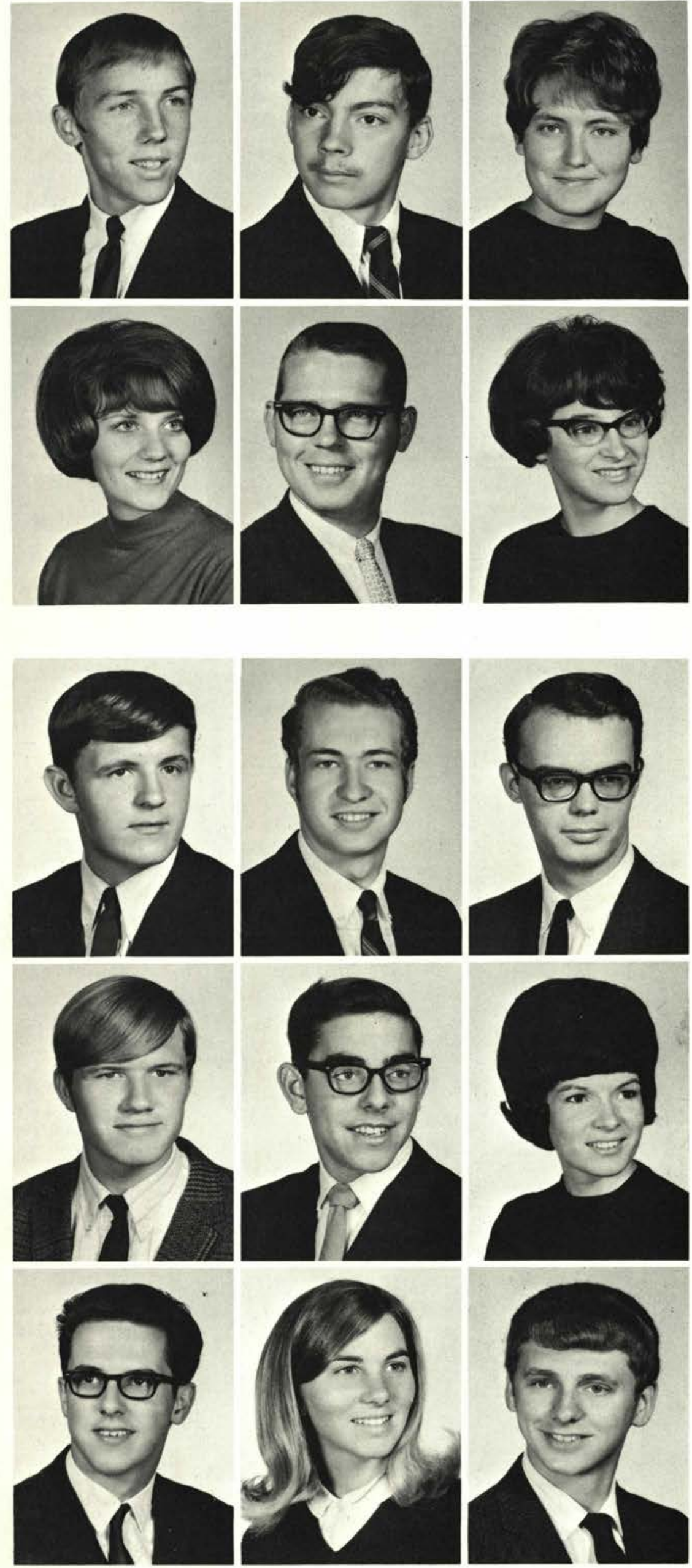
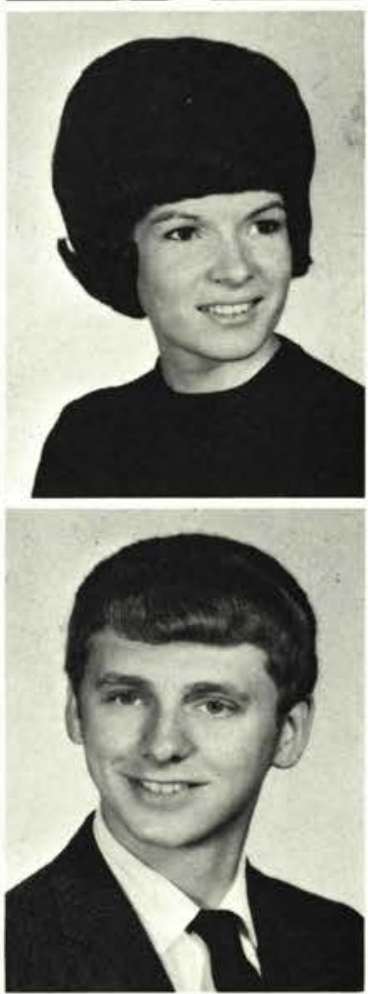

James Cavey

Sao Paulo, Brazil

Ervin Chaney

Batavia, O.

Linda Christiansen

Des Moines, Iowa

Connie Clark

Spokane, Washington

Roger Clay

Cedarville, $\mathrm{O}$.

Pamela Closson

Berea, $\mathrm{O}$.

John Colyer

New Richmond, O.

John Conant

Hackensack, N.J.

James Crabtree

Quincy, III.

Mark Cunningham Wyoming, Mich.

Roger Curtis

Newark, O.

Edith Dalton

Wakeman, O.

Terry Daniel

Milford, O.

Anne Darst

Lake Worth, Fla.

Jeffrey Davis

Dayton, $\mathrm{O}$. 
Bruce Dawley Rochester, Mich.

Michael Dersham Lorain, $\mathrm{O}$.

Elizabeth Devor Maywood, N.J.

Elaine Dixon Spokane, Washington

Silas Doctor Ellsworth, Mich.

Brenda Duell Galeton, $\mathrm{Pa}$.

Mary Dunkin Fairless Hills, $\mathrm{Pa}$.

Pamela Earnhart Waynesville, $\mathrm{O}$.

Meda Edelblute Gallipolis, O.

Marsha Edwards Albion, Iowa

Clinton Eichelberger Kuns, Idaho

James Elsner Dayton, O.

Patricia Emerson Richmond Heights, O.

Richard Emerson

Cedar Falls, Iowa

Sharon Estes Endicott, N.Y.

Brenda Falci Hornell, N.Y.

Thomas Falknor Arcanum, $\mathrm{O}$.

Beverly Fallo Dayton, $\mathrm{O}$.

Barbara Fiest Elyria, O.

Roger Fissel West Liberty, O.
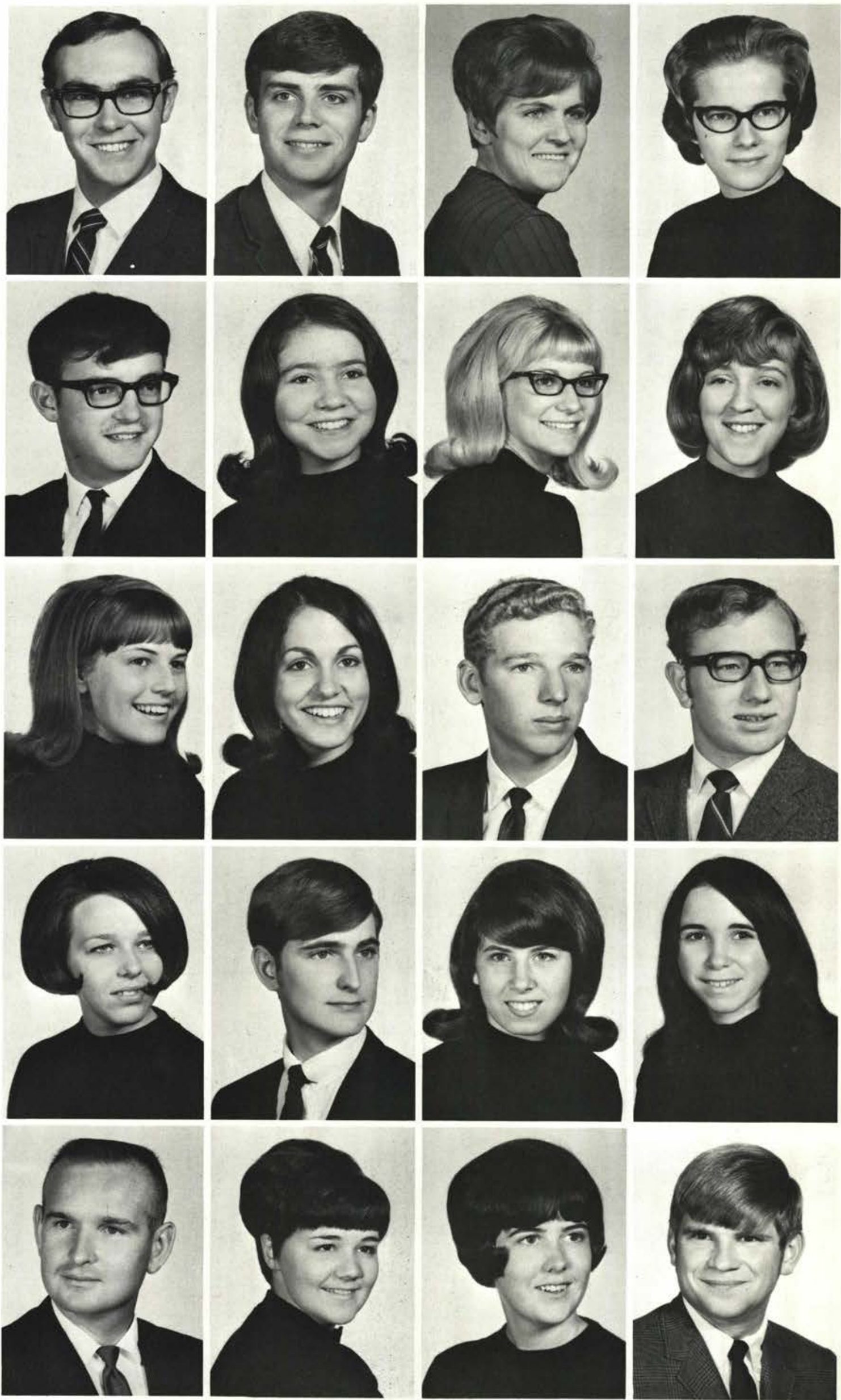


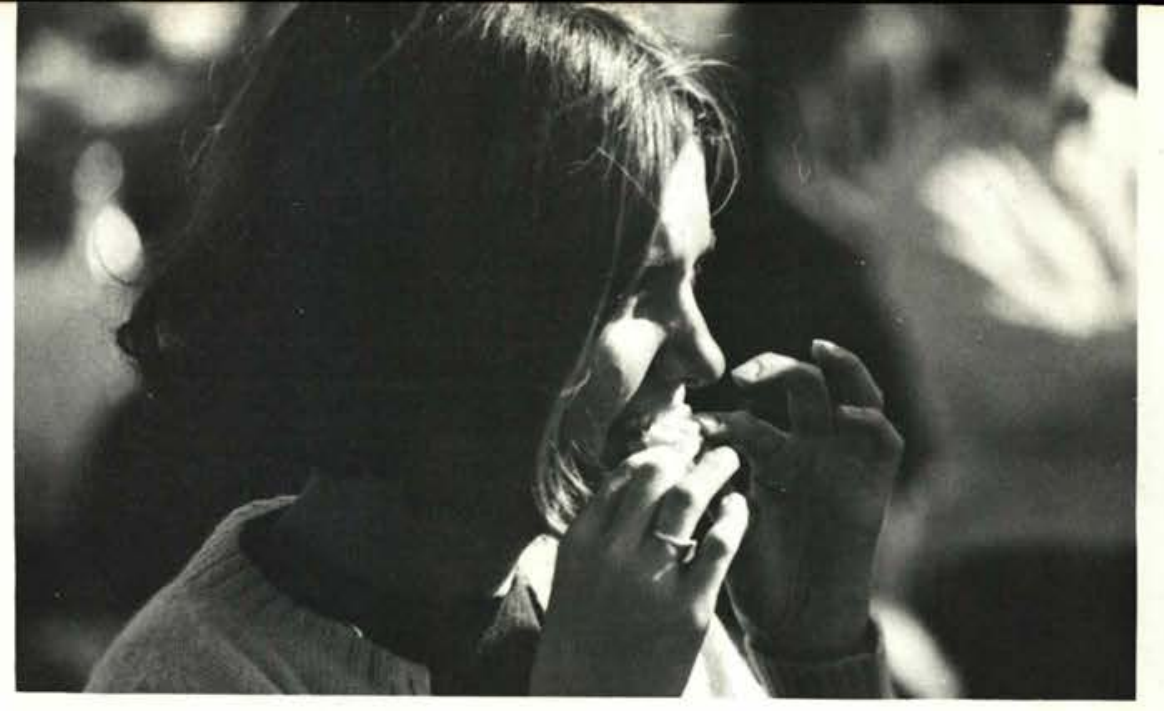

Deborah Good New Castle, Del.

Sherry Gossett Clinton, Ind.

Laura Lee Grable Wheaton, Maryland

David Grant New Hyde Park, N.Y.

Christine Graves Saginaw, Mich.

Jerry Grayson Prescott, Ariz.

James Greening Johnson City, N.Y.

Rebecca Hanthorn Lima, O.

Beverly Hare Cedarville, $\mathrm{O}$.

Susan Harold Huntington, W. Va.

John Harrison New Richmond, O.

Barbara Hart Des Moines, Iowa
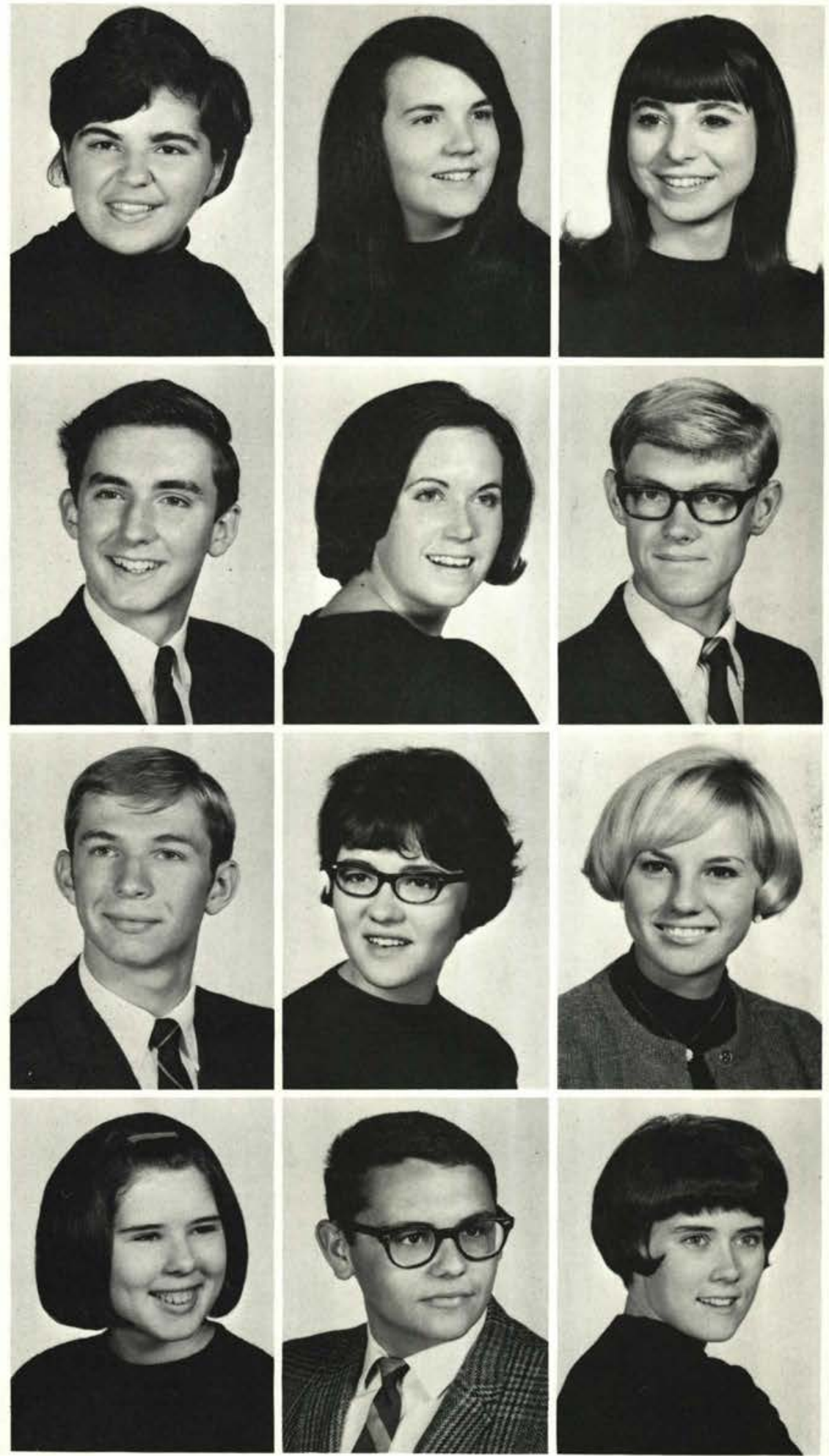
Barbara Healey

Brunswick, O.

William Henry

Painesville, $\mathrm{O}$.

Carol Herriman

Nat'l. City, Mich.

Susan Hesler

Cedarville, O.

Alan Hill

Lombard, IIl.
David Hitchman

Butler, O.

William Hoffman

Oaklyn, N.J.

Kevin Holden

Endicott, N.Y.

Teresa Holderby

Springfield, O.

Sharon Hon

Wood River, Ill.
Carla Hopkins

Hubbard, O.

Wilma Hopkins

Corry, $\mathrm{Pa}$.

Bonita Hostetler

Smithville, O.

Andrea Houchin

Kansas City, Kan.

Joan Hovingh

Allendale, Mich.
William Howdyshell

Pickerington, $\mathrm{O}$.

Rebecca Hull

Ithaca, N.Y.

Gary Hunter

Decatur, III.

Rebecca Hunter

Warsaw, Ind.

Patricia Hussey

Cleveland, O.
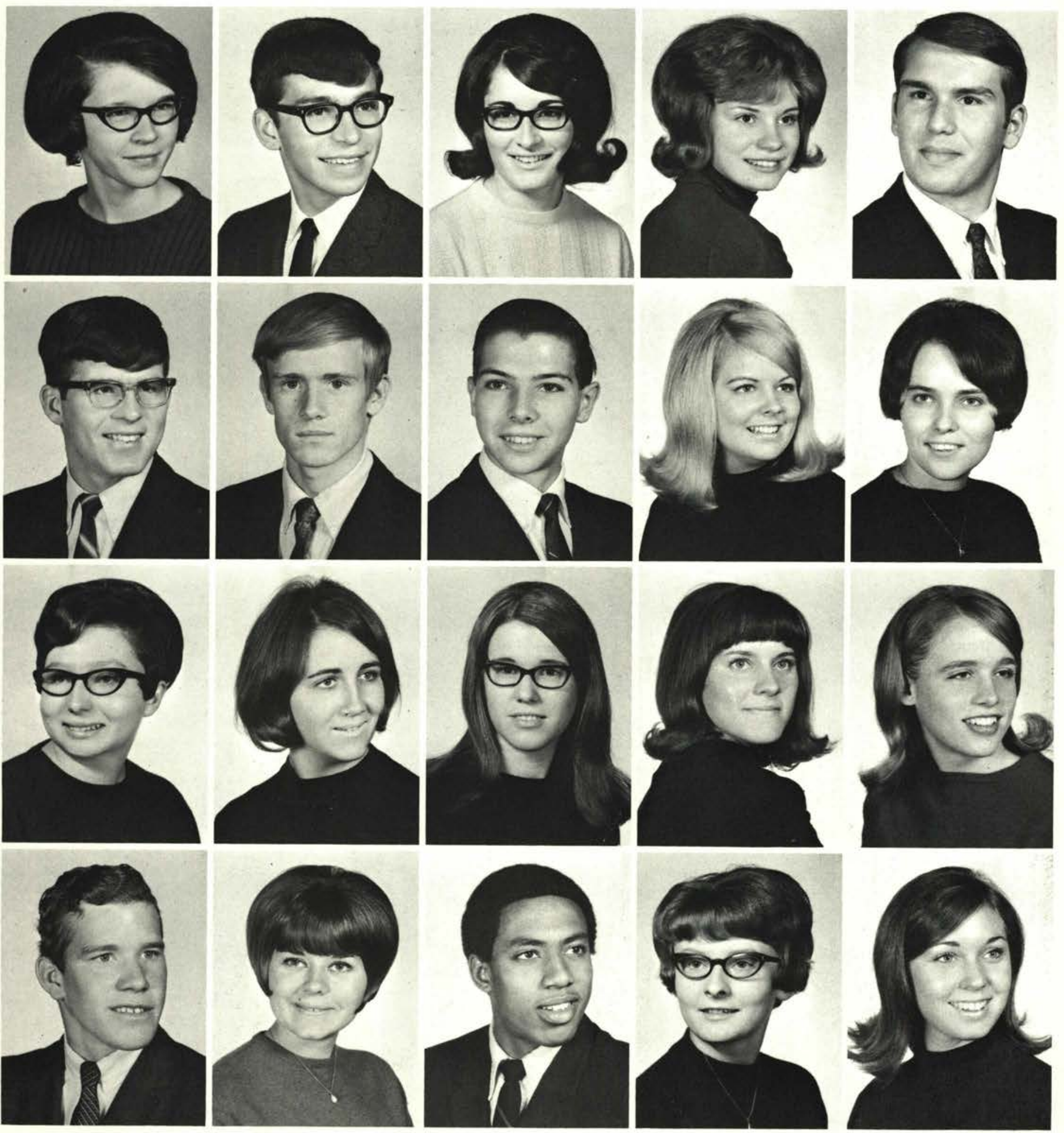
Dan Inghram Morningsun, lowa

Warren Jenkins McLean, Va.

Clifton Jensen Caro, Mich.

David Jewell Elyria, O.

Laura Jones Uniontown, $\mathrm{O}$.

Stephen Journell Kettering, $\mathrm{O}$.

Donna Kahler Leawood, Kansas

Dianne Kemp Coal Valley, Ill.

Pamela Kendrick Xenia, O.

Sherian Kinniburgh Marion, Montana
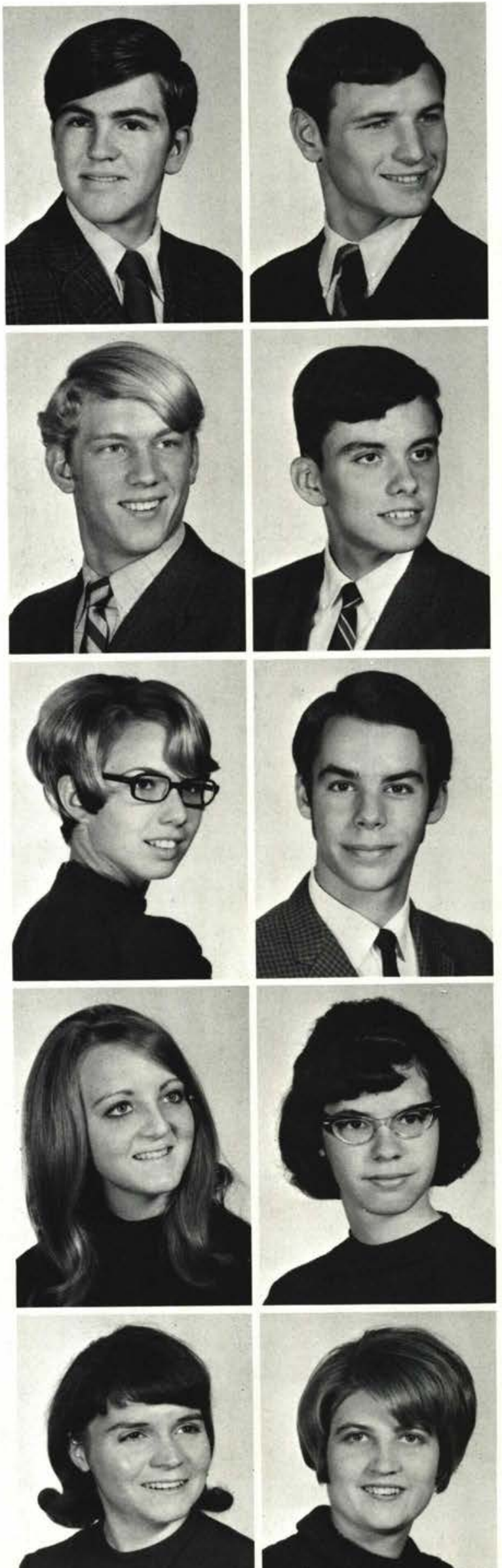

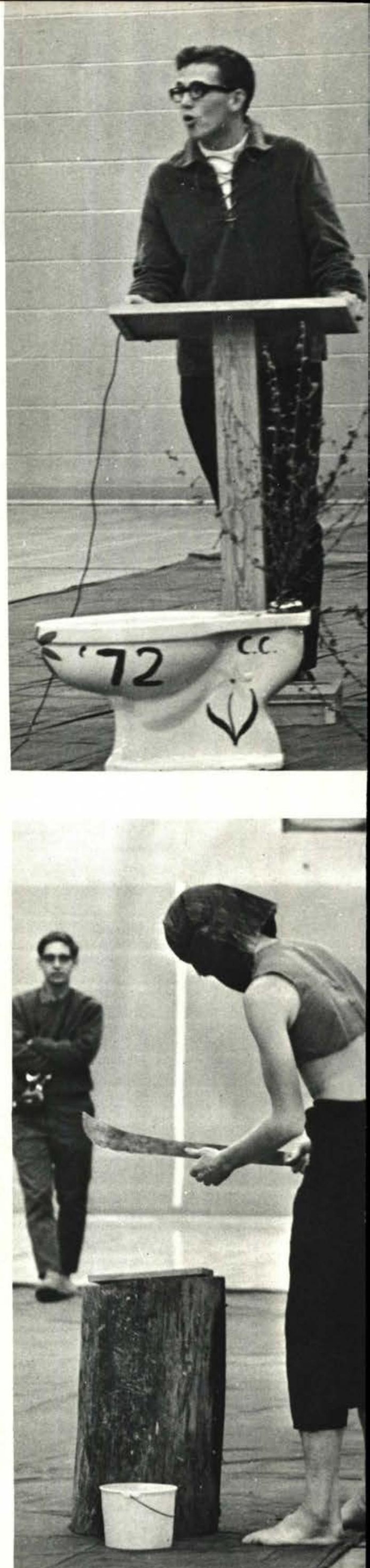



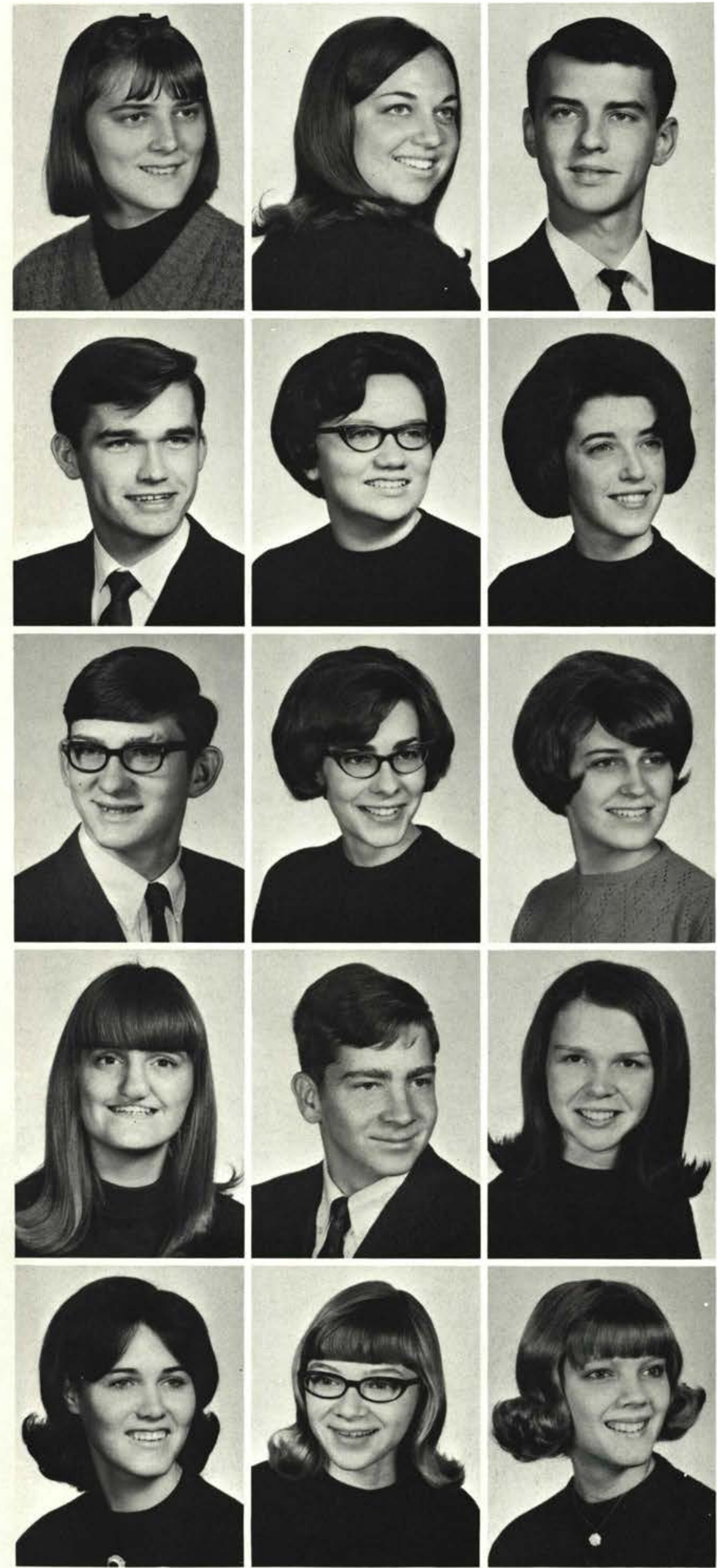

Ruth Kircher

Haddon Heights, N.J.

Julie Kleymeer

Grand Rapids, Mich.

Tim Kline

Greene, Iowa

Victor Lakes

Dayton, $\mathrm{O}$.

Carolyn Lambert Rittman, O.

Dawn Lantz

Broomall, $\mathrm{Pa}$.

Curtis Larson

Allegan, Mich.

Susan Lathrop

Downers Grove, Ill.

Linda LeFever

Rochester, Mich.

Susanne Leonard Des Moines, Iowa

Frank Leslie

Meshoppen, Pa.

Linda Linger

Northfield, $\mathrm{O}$.

Sharon Lixey

Romulus, Mich.

Sharon Loomis

Niles, O.

Joyce Love

Huntington, W. Va. 
Larry Lovins

Blanchester, $\mathrm{O}$.

Catherine Marlowe

Oxford, Mich.

Daniel Martin

Crawfordsville, Ind.

Sue Marvel

South Bend, Ind.

Michael Mays

Chillicothe, O.

Roger McCrum Clubb, Mo.

Ferris McDaniel Mancelona, Mich.

Rita McDowell Hobart, Ind.

Mary McMurtry Pittsburgh, $\mathrm{Pa}$.

Daniel Mead South Bend, Ind.

Judith Meyer Willoughby, $\mathrm{O}$.

Roger Miller Allegan, Mich.
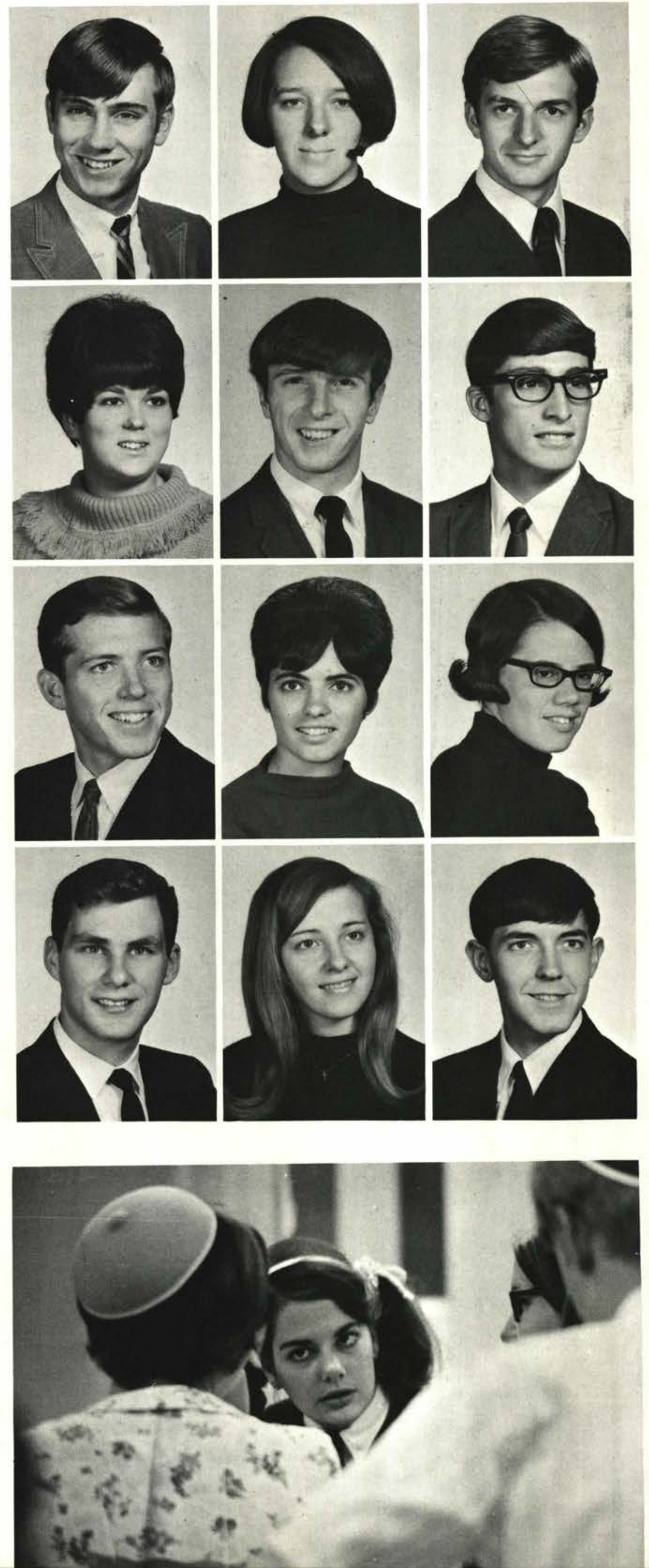

Susan Perryman Indianapolis, Ind

Cheryl Persing Medina, $\mathrm{O}$

David Peters Troy, $\mathrm{O}$.

Karyn Peterson Colona, Ill.

Linda Phelps Lorain, $\mathrm{O}$

Kathryn Phenix Cedar Falls, Iowa

Pamela Porter Worthington, $\mathrm{O}$.

James Powell Silvis, Ill.

Sharon Pribble Royal Oak, Mich.

Daryl Prindle Dowagiac, Mich.

John Pruden Prudenville, Mich.

Paul Radcliff Caldwell, $\mathrm{O}$.

David Railsback Olmsted Falls, O.

Ruth Ransbottom Pittsburgh, $\mathrm{Pa}$.

Mary Ravas Vestal, N.Y.
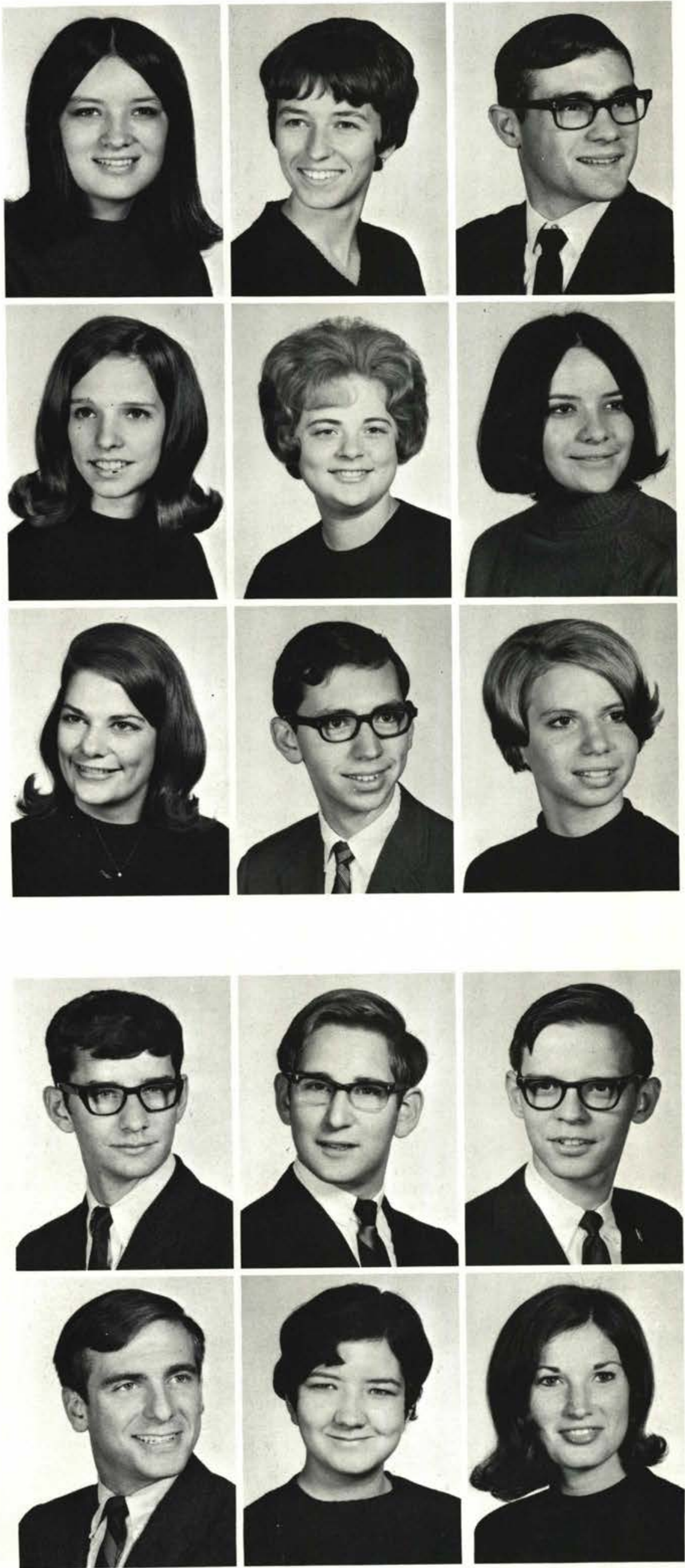



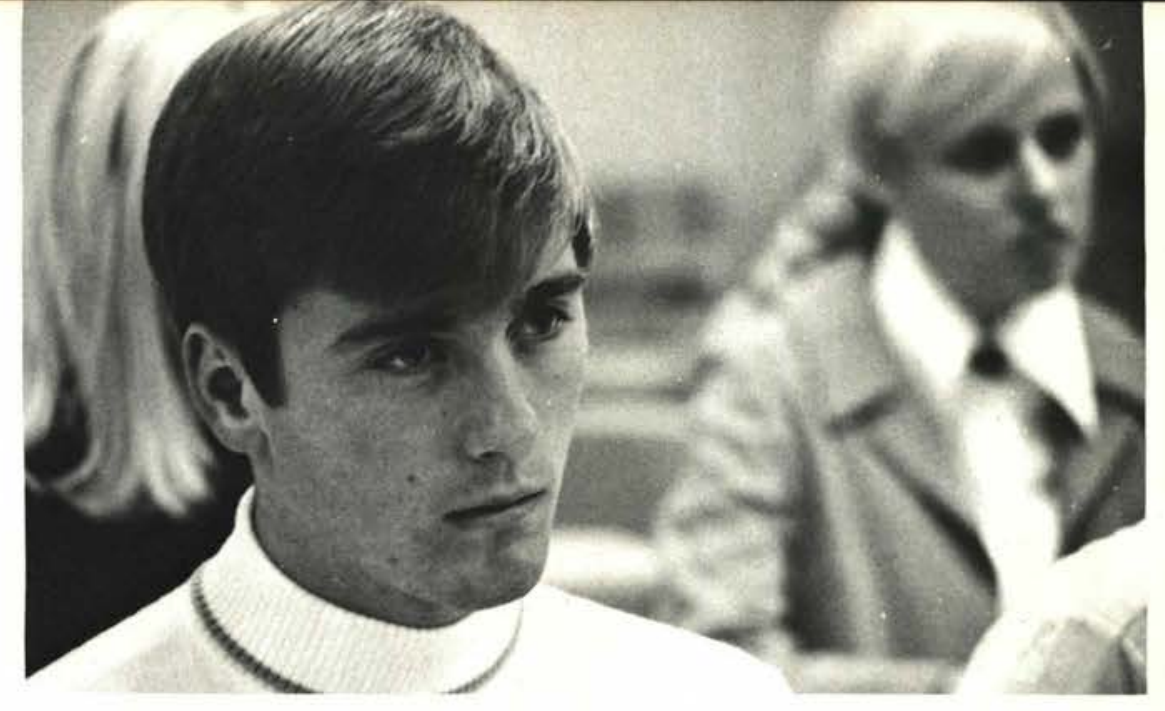

Suzanne Saulter Coudersport, $\mathrm{Pa}$.

Cynthia Schaechterle Norwalk, O.

Dale Schwanbeck Norwalk, O.

Susan Scott Ft. Sam Houston, Texas

Thomas Seidler

Cincinnati, O.

Robert Senseney Linwood, N.J.

Lona Shafer Troy, O.

Cathy Shaw Xenia, O.

Melanie Shelley Indianapolis, Ind.

Gloria Shriver Ursa, Ill.

Charlene Sickels Barberton, O.

Linda Skelton Wabash, Ind.
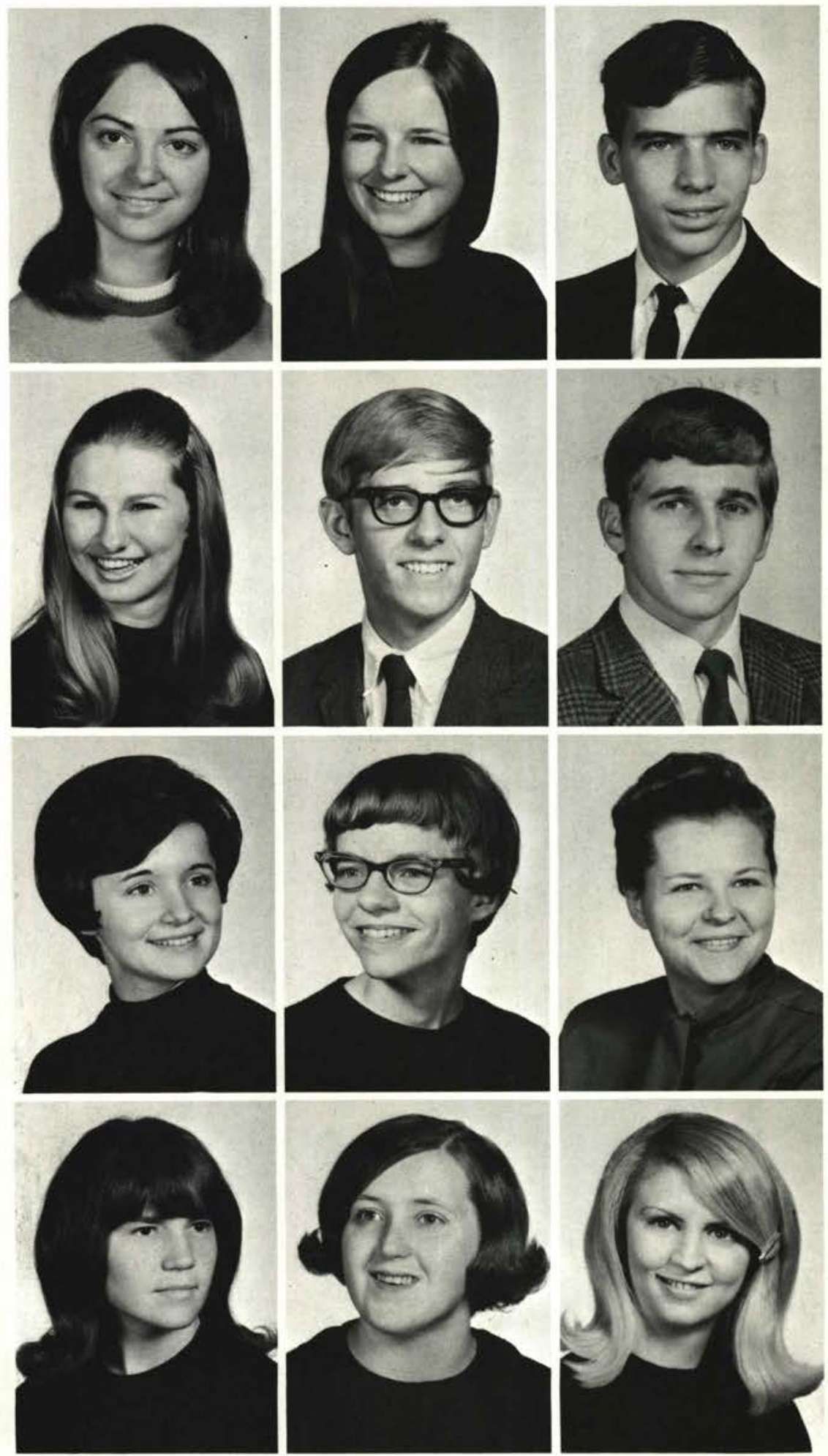
Suzanne Slater

Glen Aubrey, N.Y.

Deborah Slavens

Crawfordsville, Ind.

Donna Smith

Detroit, Mich.

Nancy Smith

Sinclairville, N.Y.

Robert Snyder

Ft. Wayne, Ind.
William Sopher

Wabash, Ind.

David Soule

Rochester, Mich.

Carol Spencer

Collins, N.Y.

Thomas Sperry

Ferndale, Mich.

Robert Stewart

Warren, O.
Cheryl Stock

Lansing, Mich.

Beth Stoner

Cambridge, $\mathrm{O}$.

Tom Strong

Painesville, $\mathrm{O}$.

Chuck Strychalski

Lebanon, Ind.

Carolyn Stubrich

Hubbard, O.
Karol Taylor

Steambt. Rock, Iowa

Louis Tewis

Cedarville, $\mathrm{O}$.

Janice Timpe

Godfrey, III.

Vicki Tobias

Port Allegany, Pa.

Connie Tompkins

Sherman, N.Y.
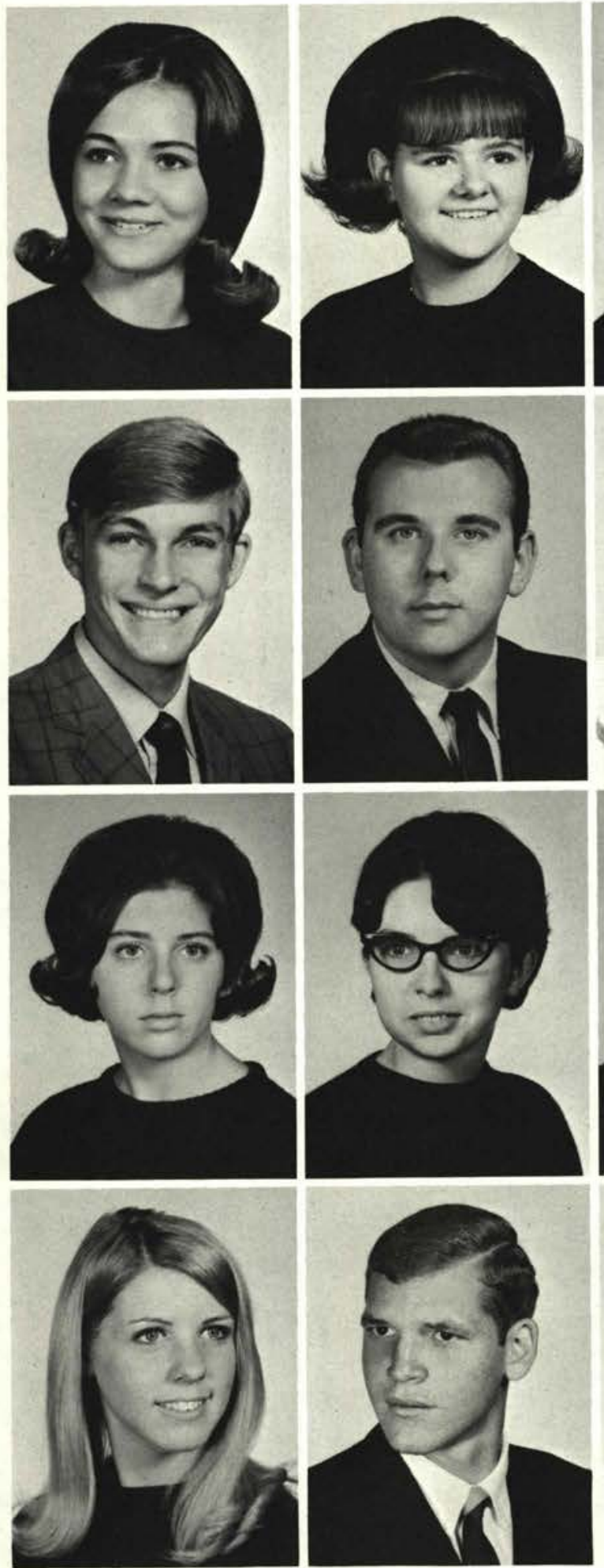
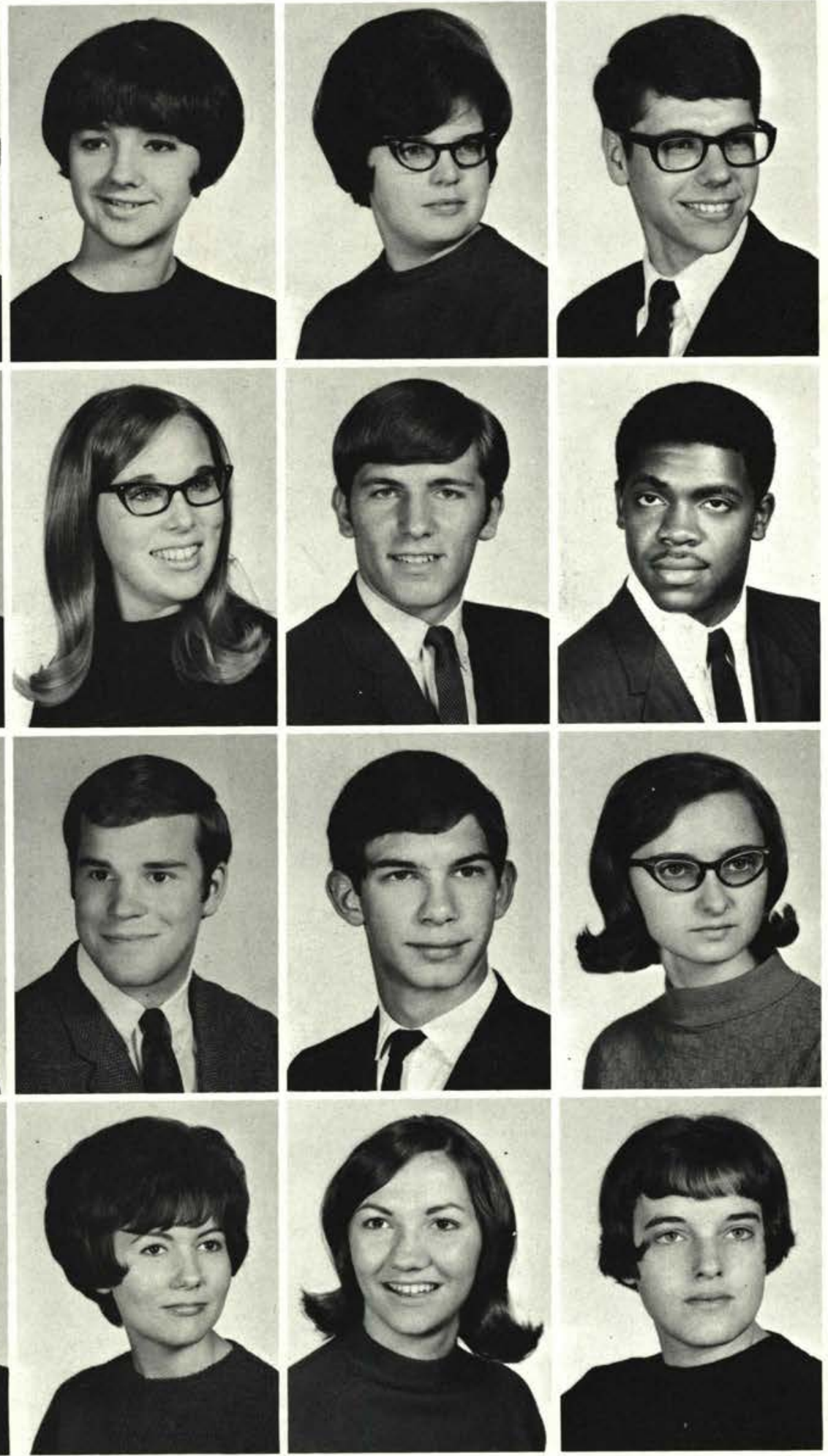
Anton VanderMeer Pontiac, Mich.

Patricia Waggoner Coatesville, Ind.

Corinne Waldron Haveland, $\mathrm{O}$.

Connie Walker Kirtland, O.

Carl Wallner Jacksonville, Fla.

Denise Walters Northfield, O.

Art Warburton Lawrenceburg, Ind.

John Warren Indianapolis, Ind.
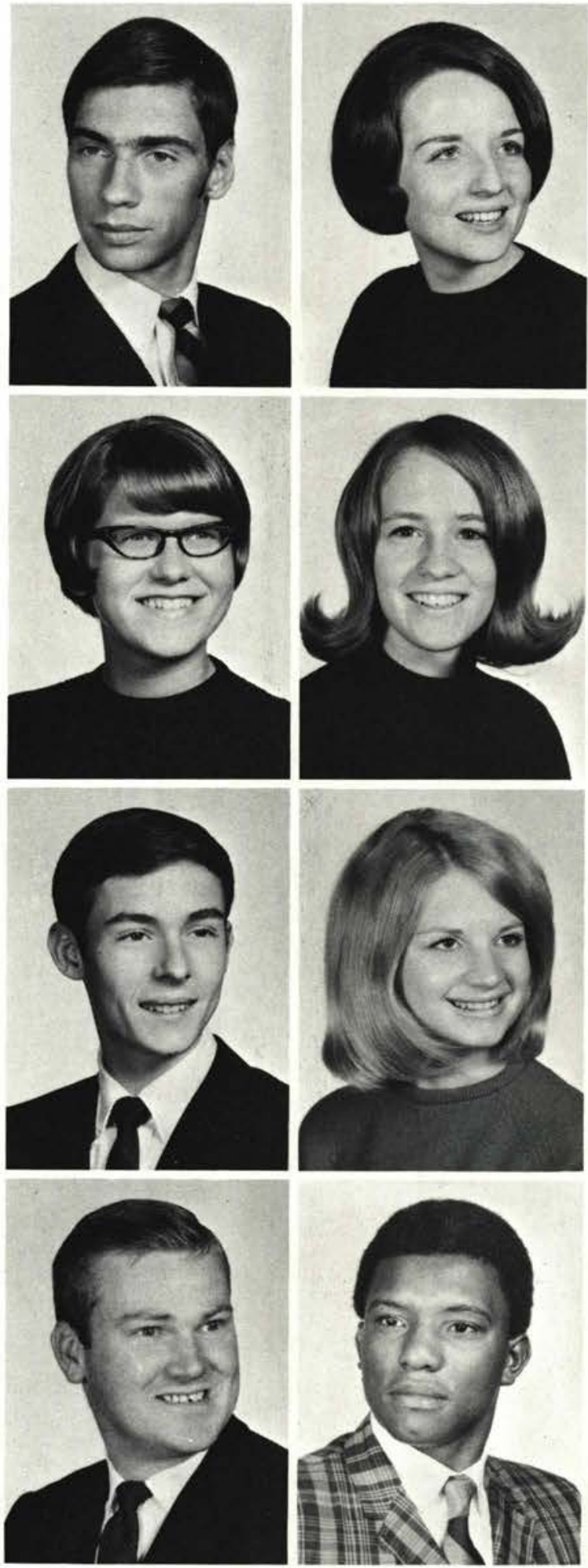

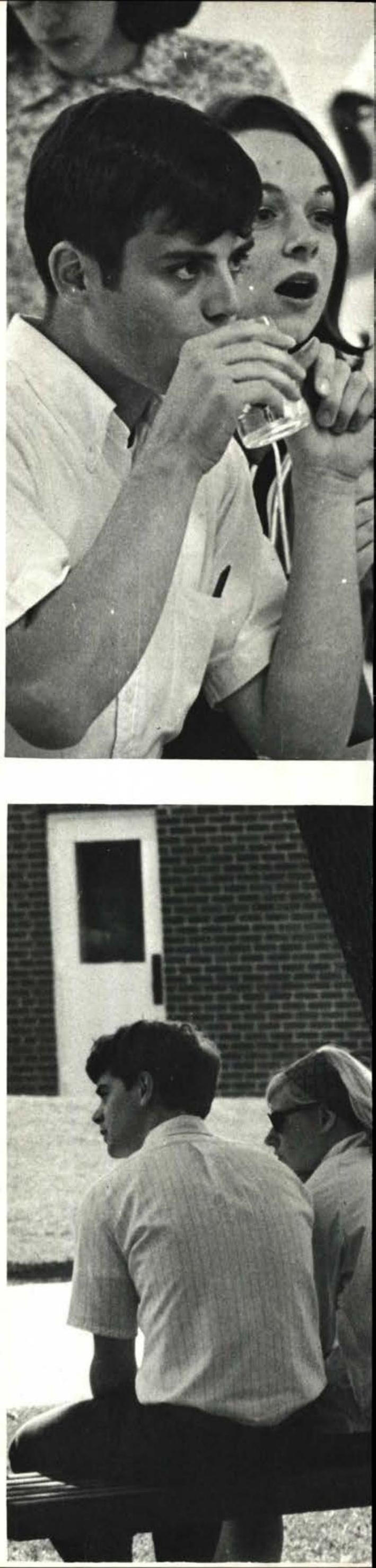



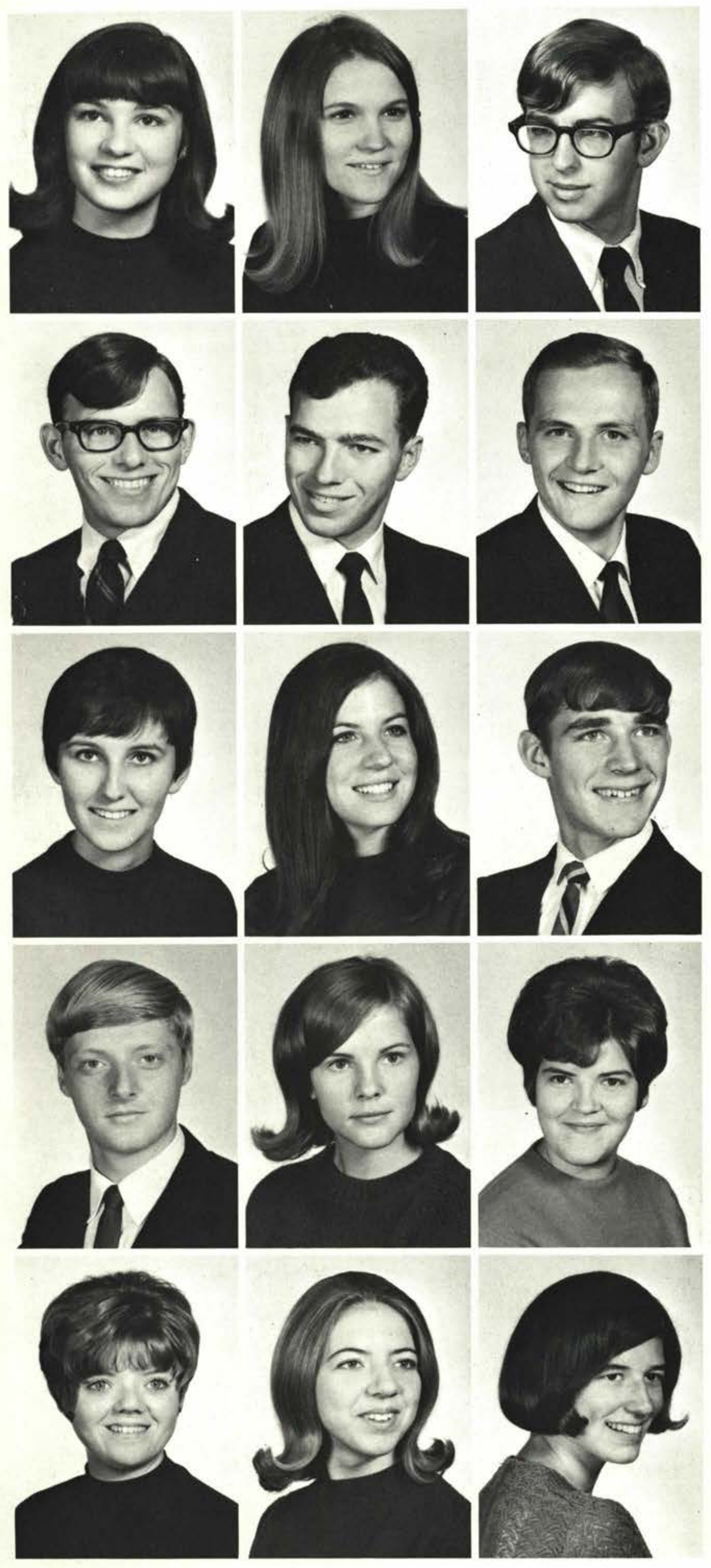

Jeanette Weaver

Rushford, N.Y.

Judith Weaver

Columbus, O.

Jeffrey Webb

Indianapolis, Ind.

Ronald Wheatley Harvey, Ill.

Michael Wilhite

Clayton, Ind.

Charles Williams

Nebraska City, Neb.

Diane Williamson

Chicopee Falls, Mass.

Charlotte Willis

Rochester, Mich.

David Wood

Clarkston, Wash.

Jeffrey Woodcock

Jamestown, N.Y.

Barbara Work

Coudersport, Pa.

Rebecca Wright

Grafton, O.

Ellen Young

St. Paris, O.

Mabel Young

Mt. Pleasant, Mich.

Monica Zimmerman

Date-Bun Fukushima Sen, Japan 


\section{SOPHOMORES}

As One Year Is Completed, The Sophomore Matures Socially.

Pictured below are the sophomore class officers: Dennis Bunting, V.-Pres.; Timothy Northy, Chaplain; Dan Man- ross, Pres.; John Frye, Treasurer; and Janet Gabriel, Secretary. Not pictured is adviser, Dr. Ager.

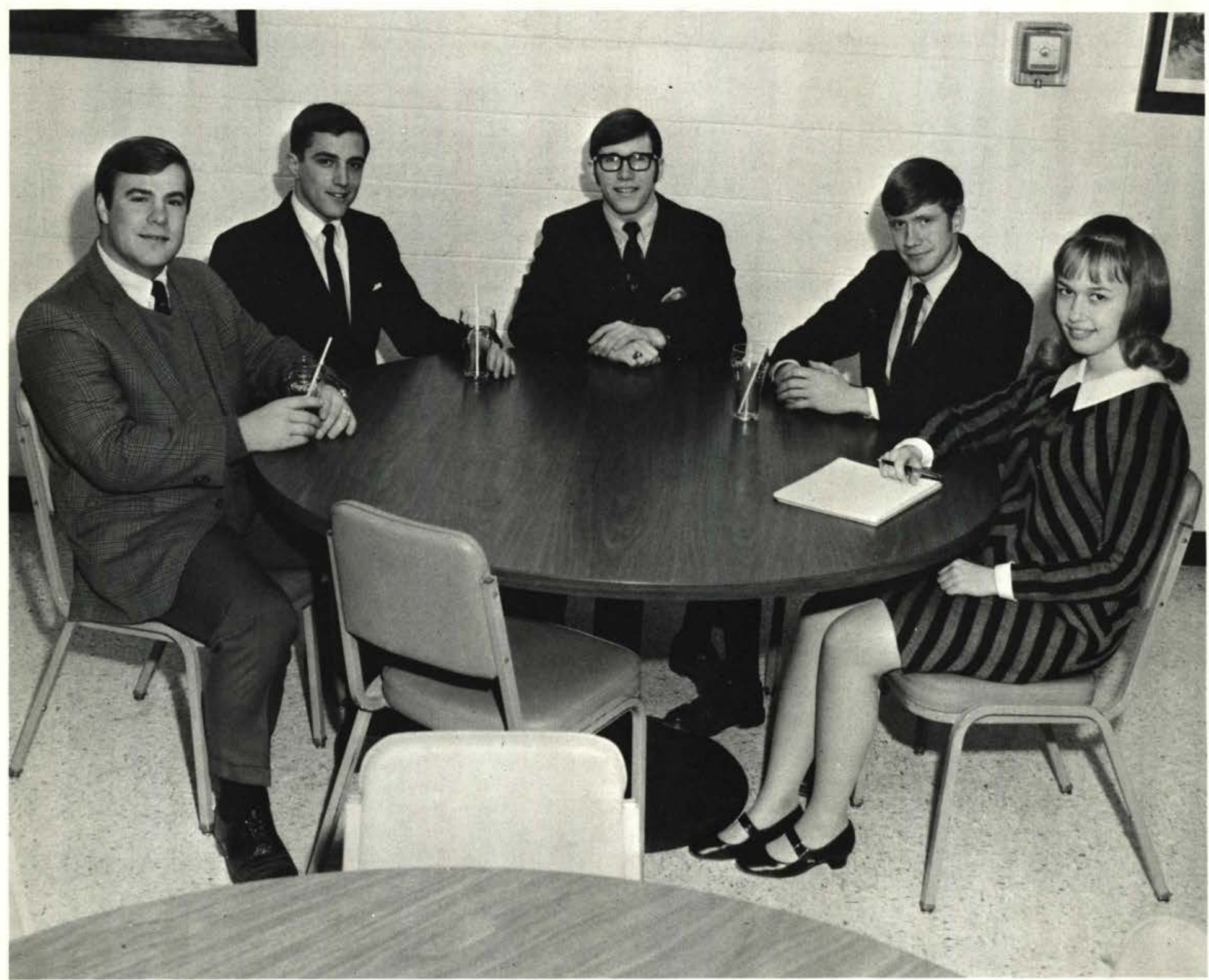


Daniel Acton

Mentone, Ind.

John Afolabi

West Nigeria

William Amstutz

Cherry Hill, N.J.

Donald Atherton

Vandalia, $\mathrm{O}$.

Constance Averitt

Richmond, Ind.
Marsha Bair

Flint, Mich.

Mary Bartlett

Schiller Park, Ill.

David Beck

Harvey, Ill.

Janet Beesley

Monroe, Iowa

Mareanne Beitler

Medina, $\mathrm{O}$.
Ken Bell

Colfax, Iowa

Bill Berkheiser

Cedarville, O.

Barbara Biddison

Grand Blanc, Mich.

Regina Bigley

Dunbar, $\mathrm{Pa}$.

Hilda Boothroyd

Chicago, Ill.
Timothy Bosworth

Columbus, $\mathrm{O}$.

Michael Boyce

Euclid, O.

Joan Boyd

Millersburg, $\mathrm{O}$.

Sylvia Braswell

Sebring, Fla.

Joyce Brookhart

Lima, O.
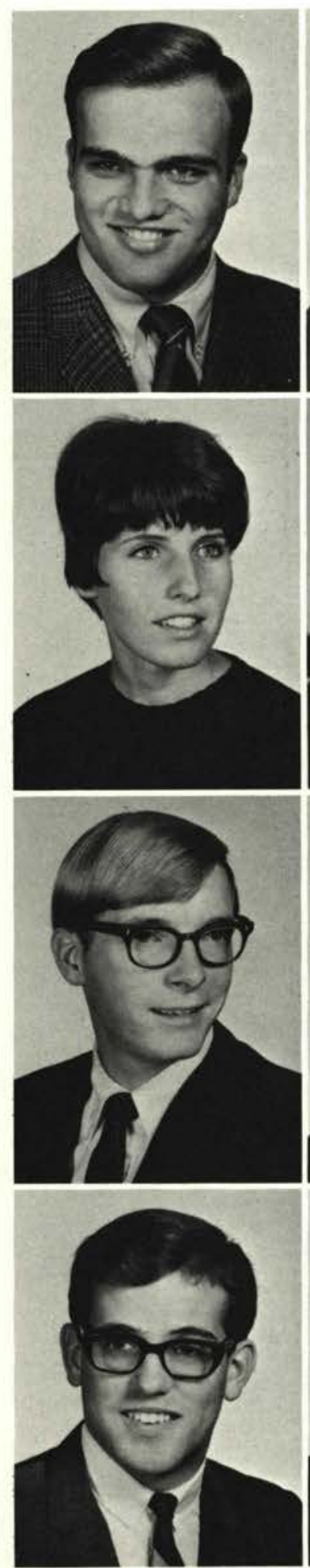
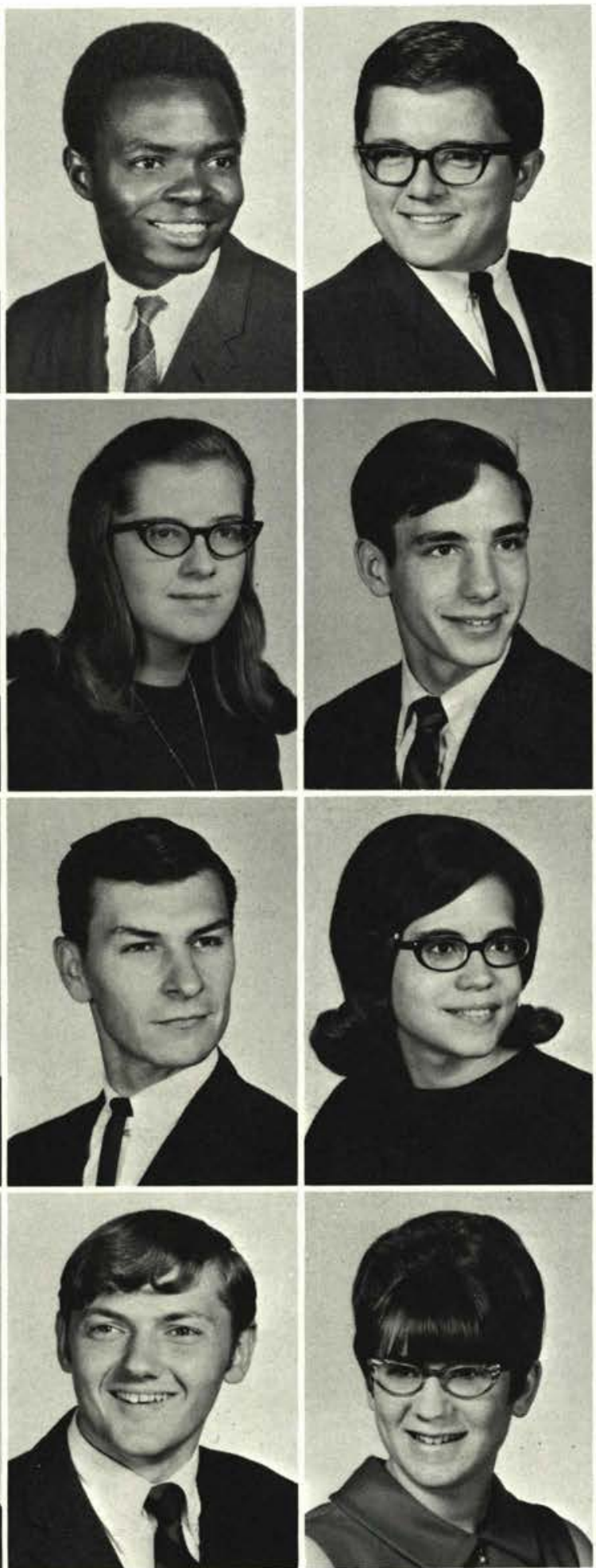
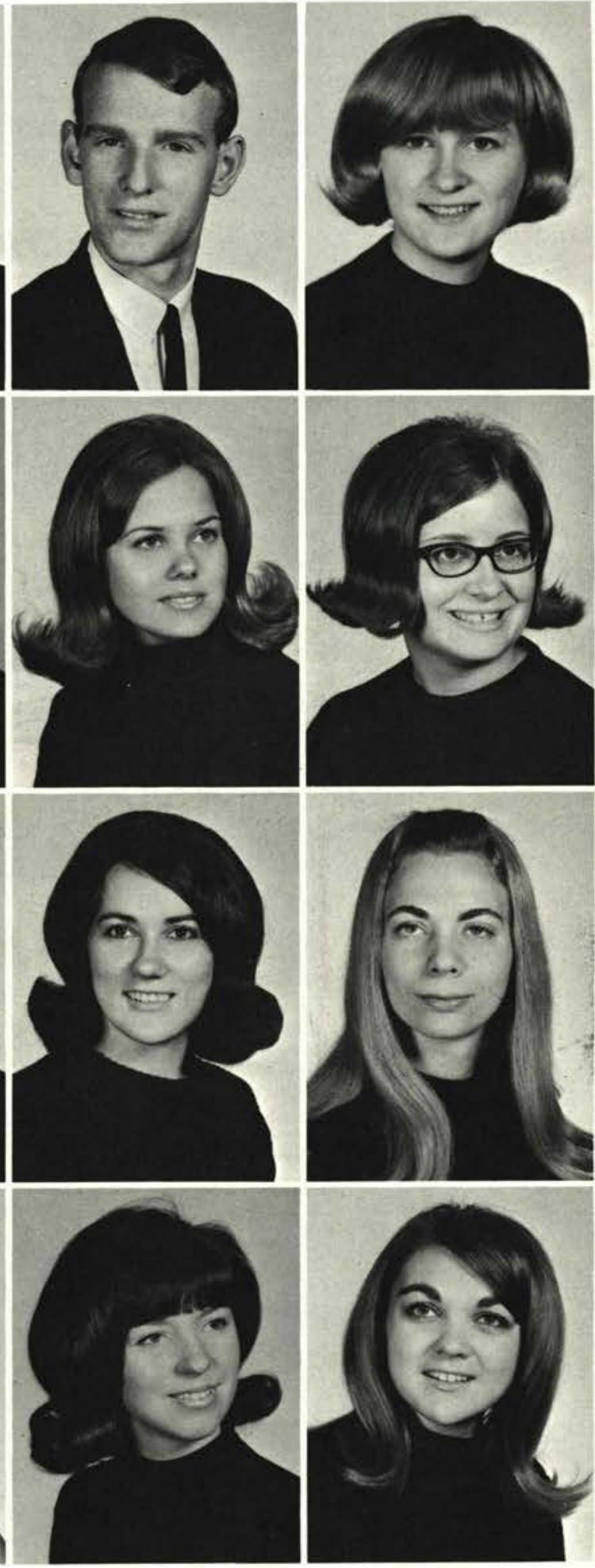

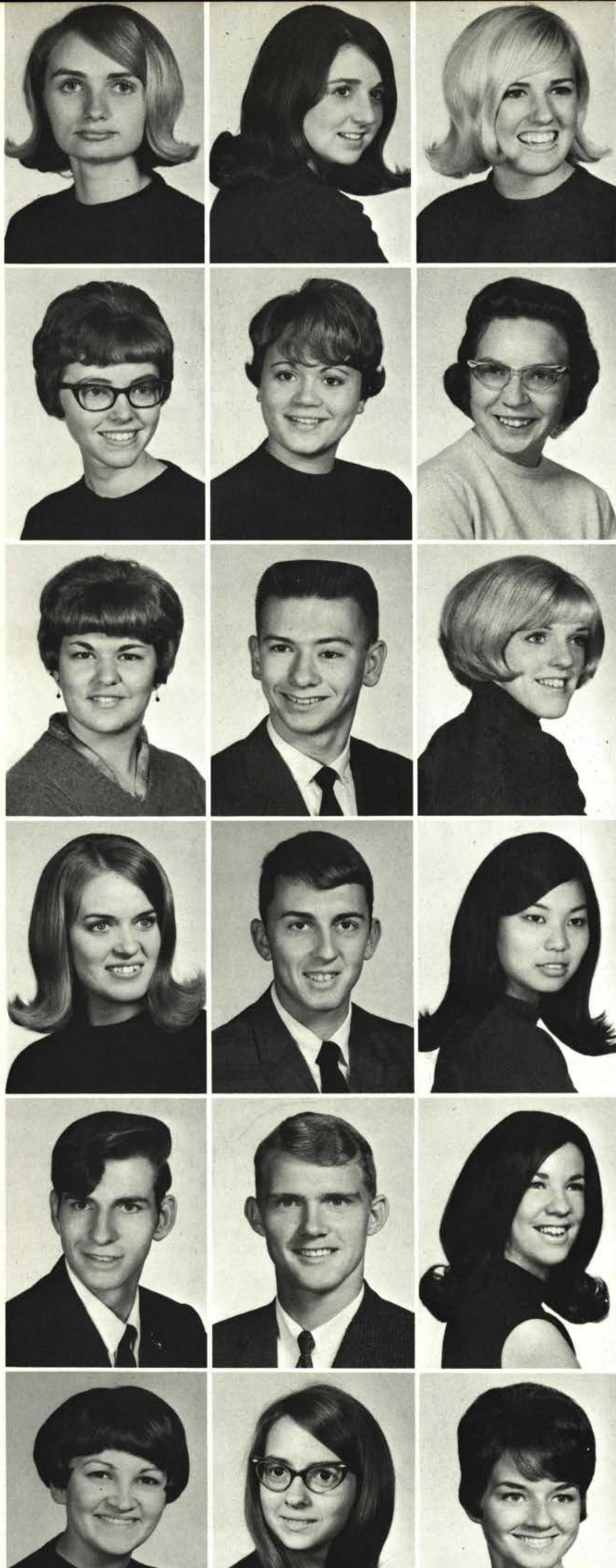

Elaine Jacoby

Lima, O.

Patricia Jenkin

Cleveland, $\mathrm{O}$.

Dorena Johnson

Paulding, $\mathrm{O}$.

Faye Johnson

Eastlake, O.

Joan Kaufman

Roanoke, Ind.

Carol Kies

New Philadelphia, O.

Jean King

Olmstead Falls, O.

Harvey Klamm

Union City, Pa.

Deborah Koehn

Cleveland, O.

Florence Krikke Greenwich, O.

Thomas Kukasky Wheaton, Ill.

Ann Kusumoto

Seabrook, N.J.

Robert Lapp

Valley City, O.

Paul Large

Iquitos, Peru

Judith Leach

East North Port, N.Y.

Patricia Lear

Derry, Pa.

Darlene Lewis

Maine, N.Y.

Judy Lewis

Kokomo, Ind. 


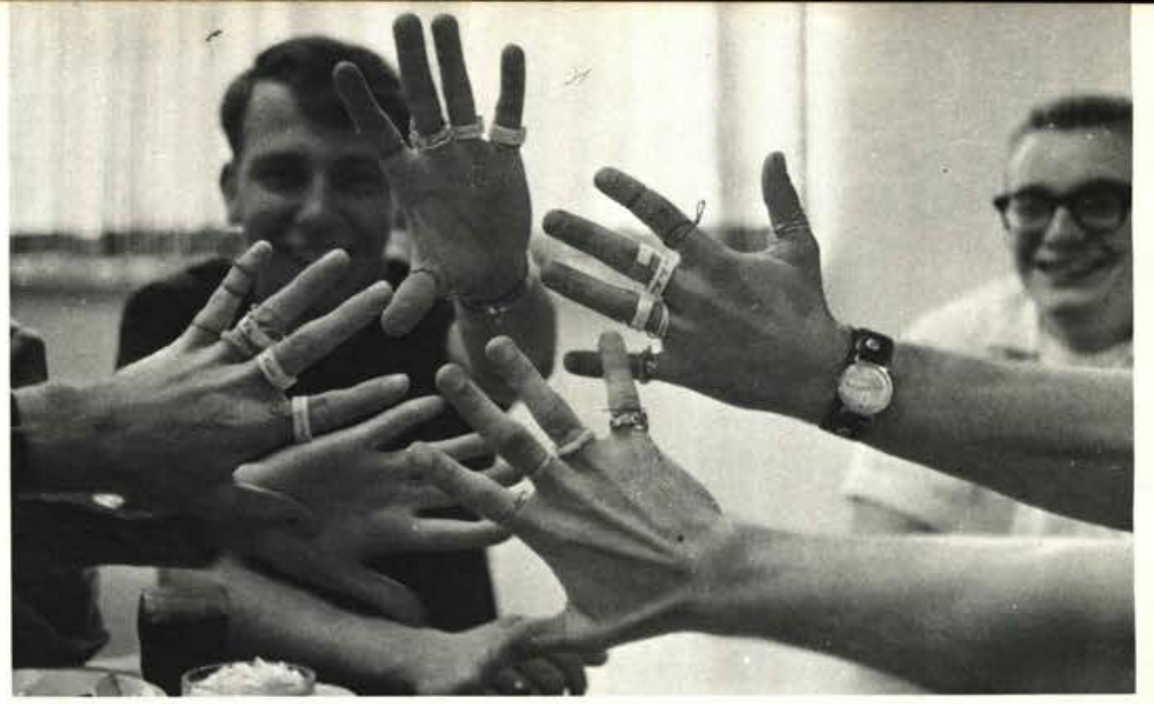

Barbara Lewright Eagle Grove, Iowa

Iris Lima St. Thomas, Virgin Islands

Margarita Lima St. Thomas, Virgin Islands

Donald Long Worthington, $\mathrm{Pa}$.

Robert Lunney Port Huron, Mich.

Beverly Maidment Toledo, O.

Darlene Mann Eldora, Iowa

Dan Manross Akron, $\mathrm{O}$.

Beverlee Mason Toledo, $\mathrm{O}$.

Dee Mays Chillicothe, O.

Rodney McComber Marysville, Mich.

James McCulloch Willoughby, O.
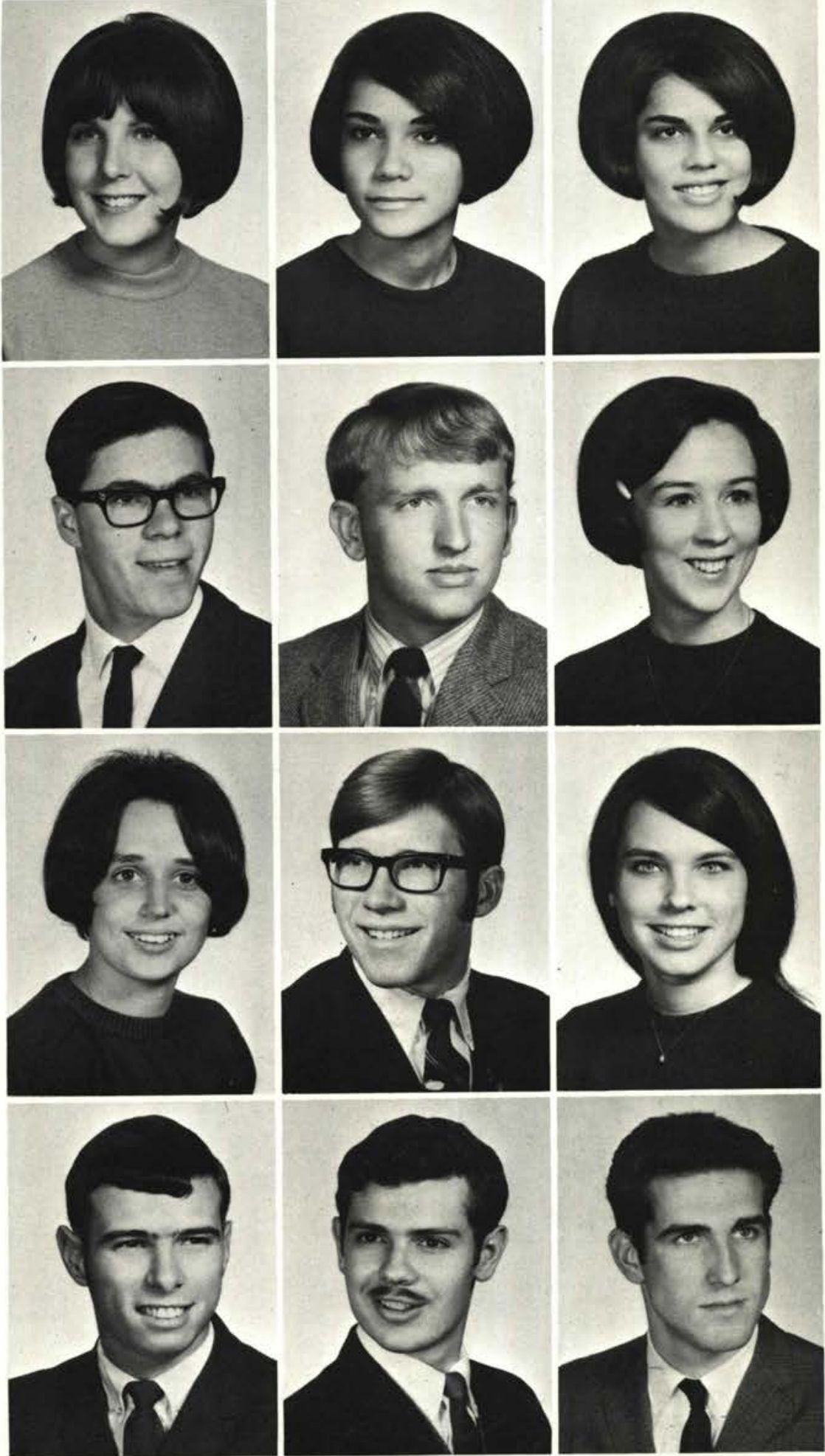
Tanis McDaniel

Mancelona, Mich.

Rebecca McDonald

Cedarville, $\mathrm{O}$.

Tom McGehee

Harvey, III.

Samuel McMillen

Xenia, O.

Melinda McNiece

Valparaiso, Ind.
Ronald Meyers

E. Moline, III

Darryl Miller

Xenia, O.

Joan Miller

Allegan, Mich.

Dale Mills

Columbus, $\mathrm{O}$.

Beverly Mix

Meadville, $\mathrm{Pa}$.
David Mohler

Litchfield, O.

Philip Mohler

Litchfield, O.

Jerry Mooney

New Castle, Pa.

Coletta Morrow

Kenton, O.

Carol Morse

Flint, Mich.
Janice Mossman

Jamestown, O.

Joyce Motts

Northfield, $\mathrm{O}$.

Steven Moulder

Sharpsville, Ind.

Dawn Myers

Chicago, Ill.

Linda Myers

Mattoon, Ill.
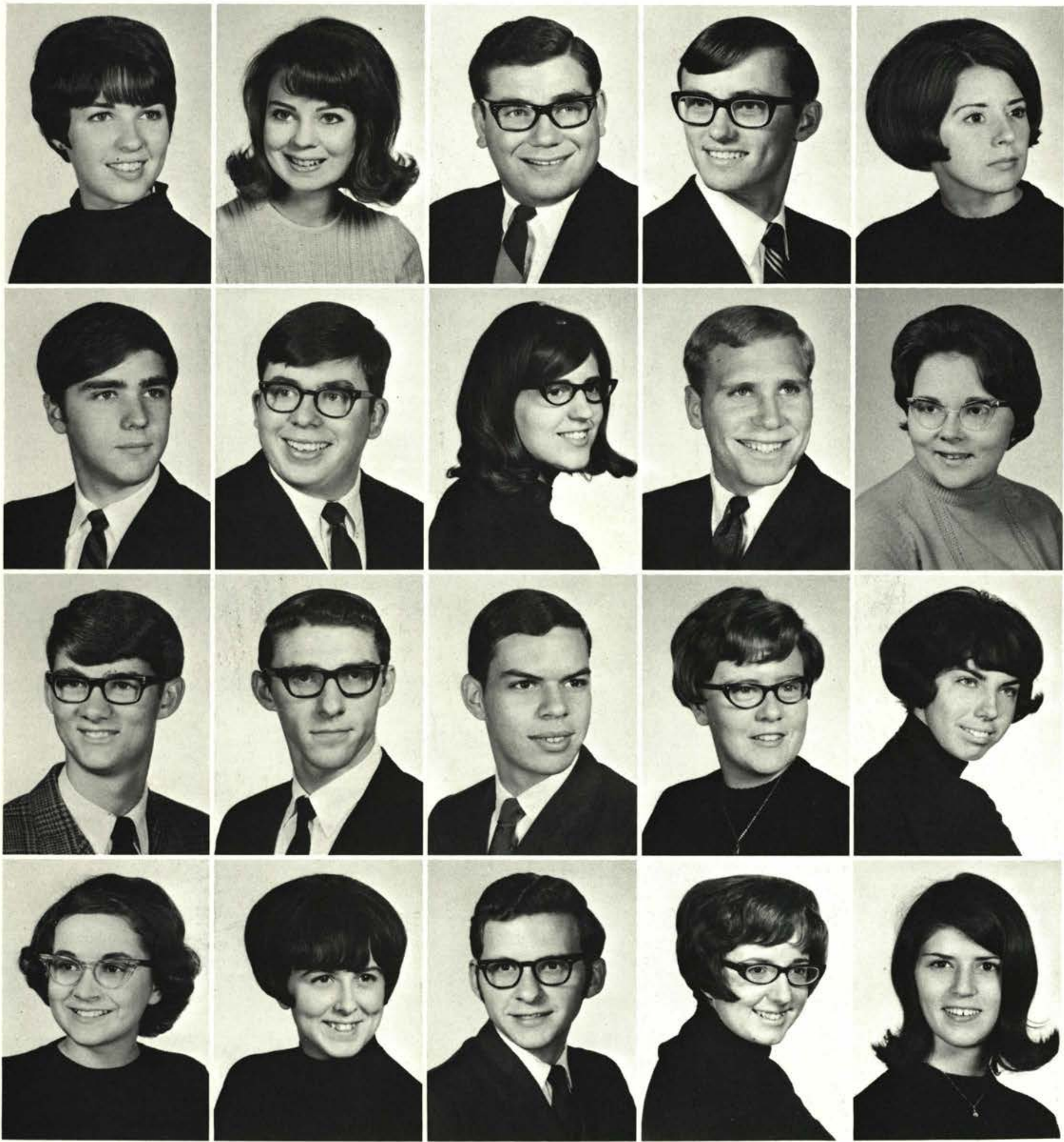


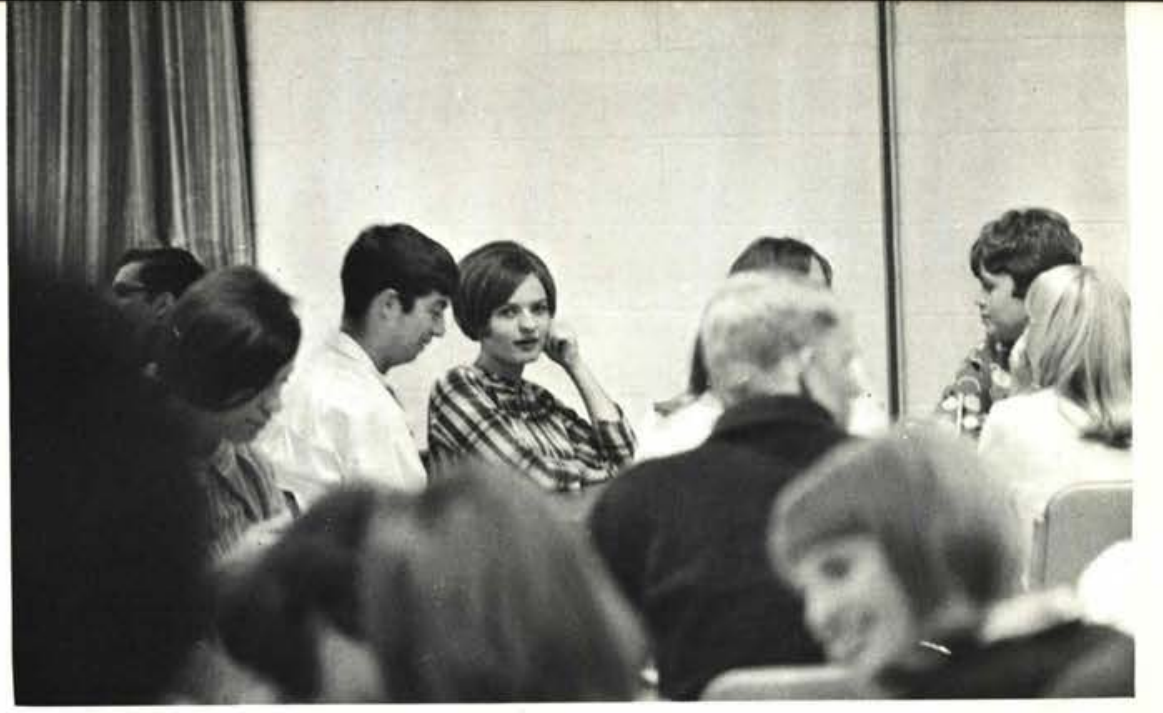

Brenda Nelson Shawnee, Kan.

Linda Nelson Nalaybalay, Bukidnon, R.I.

Tim Northey Medina, O.

Dan Norton Columbus, $\mathrm{O}$.

Carolyn O'Keefe Wesleyville, $\mathrm{Pa}$.

Marsha Osman Jamestown, O

Lynn Paige Hicksville, N.Y.

Milton Palmer Cortland, N.Y.

Vicki Palmer Allegan, Mich.

George Parcher Pittsburgh, $\mathrm{Pa}$.

Randy Patten Caldwell, $\mathrm{O}$

Nancy Paugh Oakland, Maryland
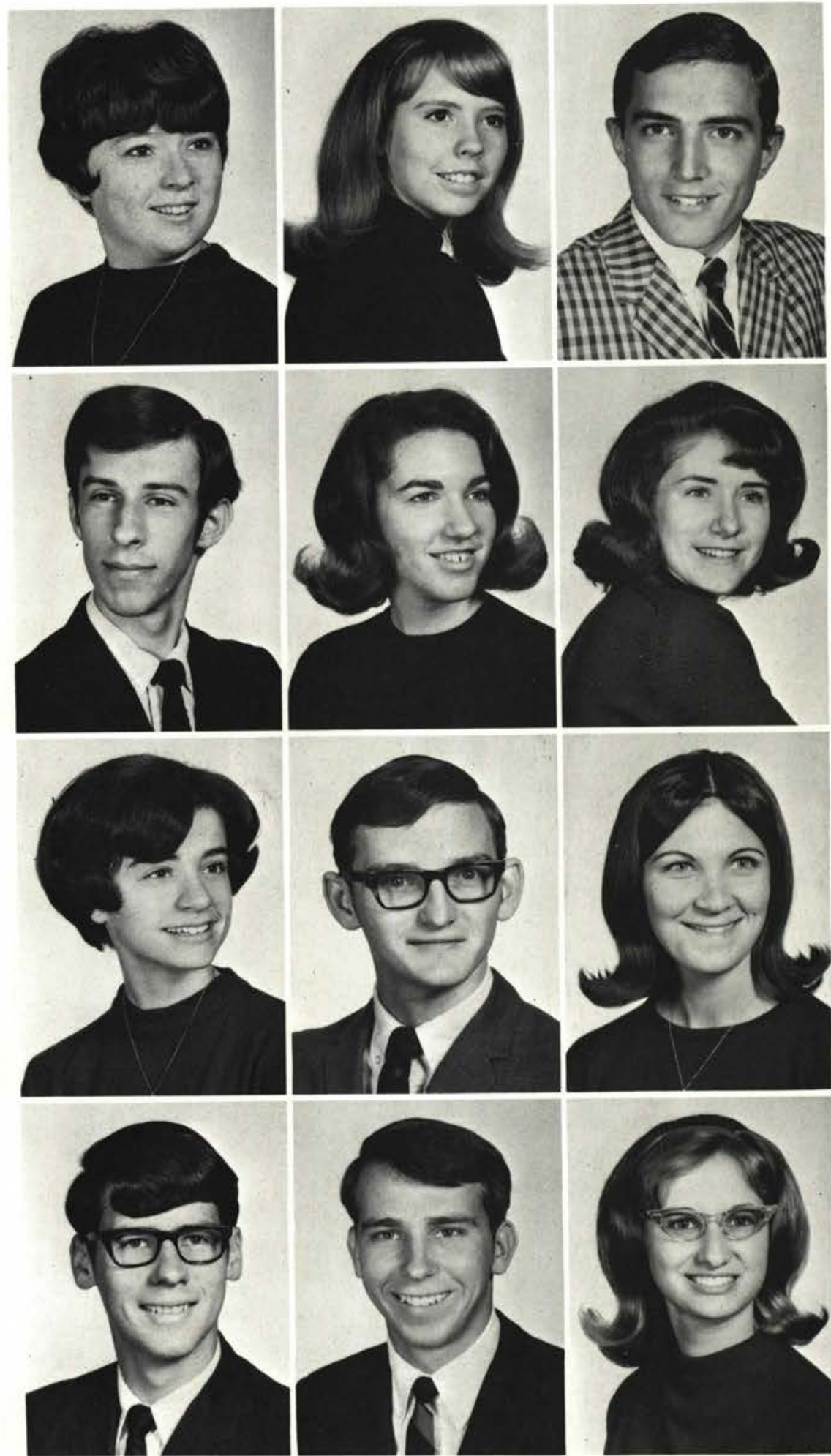
Carol Pears

Volant, $\mathrm{Pa}$.

Peggy Porterfield

Austin, Minn.

Sandra Prather

Kettering, O.

Connie Price

Decatur, III.

Judith Price

Haddon Hghts., N.J.
Barbara Reed

Seven Hills, O.

Lee Reno

Wheaton, III.

Craig Roberts

W. Des Moines, Iowa

Dane Rohm

Audubon, N.J.

Charles Rowe

DeRuyter, N.Y.
Melbourne Sattler

W. Chicago, Ill.

Dale Schilling

Novelty, $\mathrm{O}$.

Marikay Schneider

Hammond, Ind.

Norma Schwarm

Barberton, O.

Jeff Seeley

Oberlin, O.
Cheryl Shafer

Hagerstown, Ind.

Patricia Sherrill

South Bend, Ind.

David Shreve

Meadville, $\mathrm{Pa}$.

Renee Silverthorn

Centerline, Mich.

James Simmons

Perry, O.
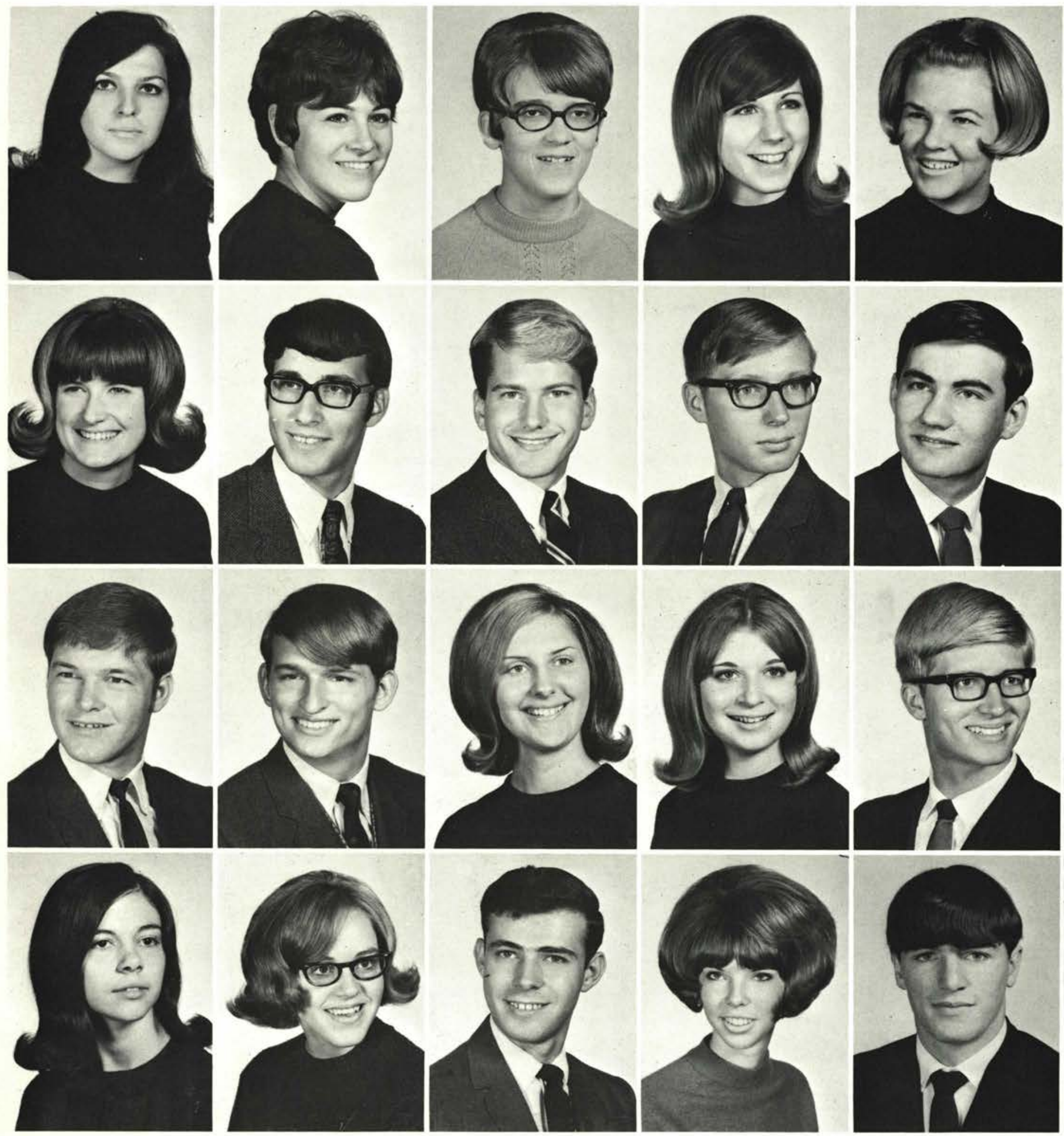
Linda Slates St. Louis, Mich.

Bonnie Smith Indianapolis, Ind.

Melba Smith Bellevue, Mich.

Nancy Snider Barberton, O.

James Spaulding Indianapolis, Ind.

Ronald Spieth East Gary, Ind. Linda Stephens
Cedarville, O.

Mary Storey Erie, $\mathrm{Pa}$.

Hannah Stowell Hackensack, N.J.

\section{Gary Stutzman} Berlin, O.
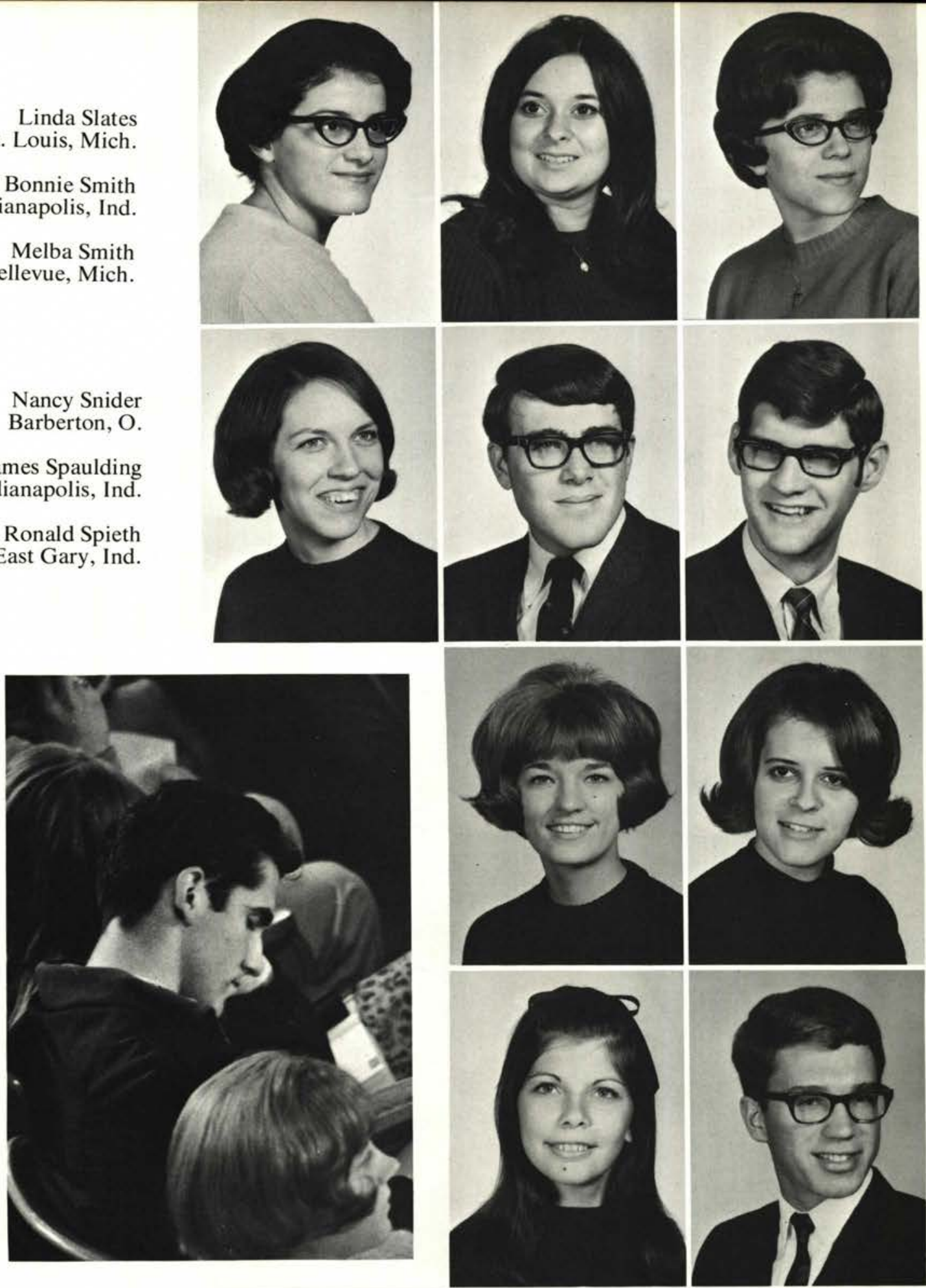

Rita Sumner Indianapolis, Ind.

Terry Suter Arlington, $\mathrm{O}$.

Verna Tallmon Creston, Iowa

Stephen Taylor Philadelphia, $\mathrm{Pa}$.

Mercy Tennant Bay City, Mich.

Billie Thomas

Columbus, $\mathrm{O}$.
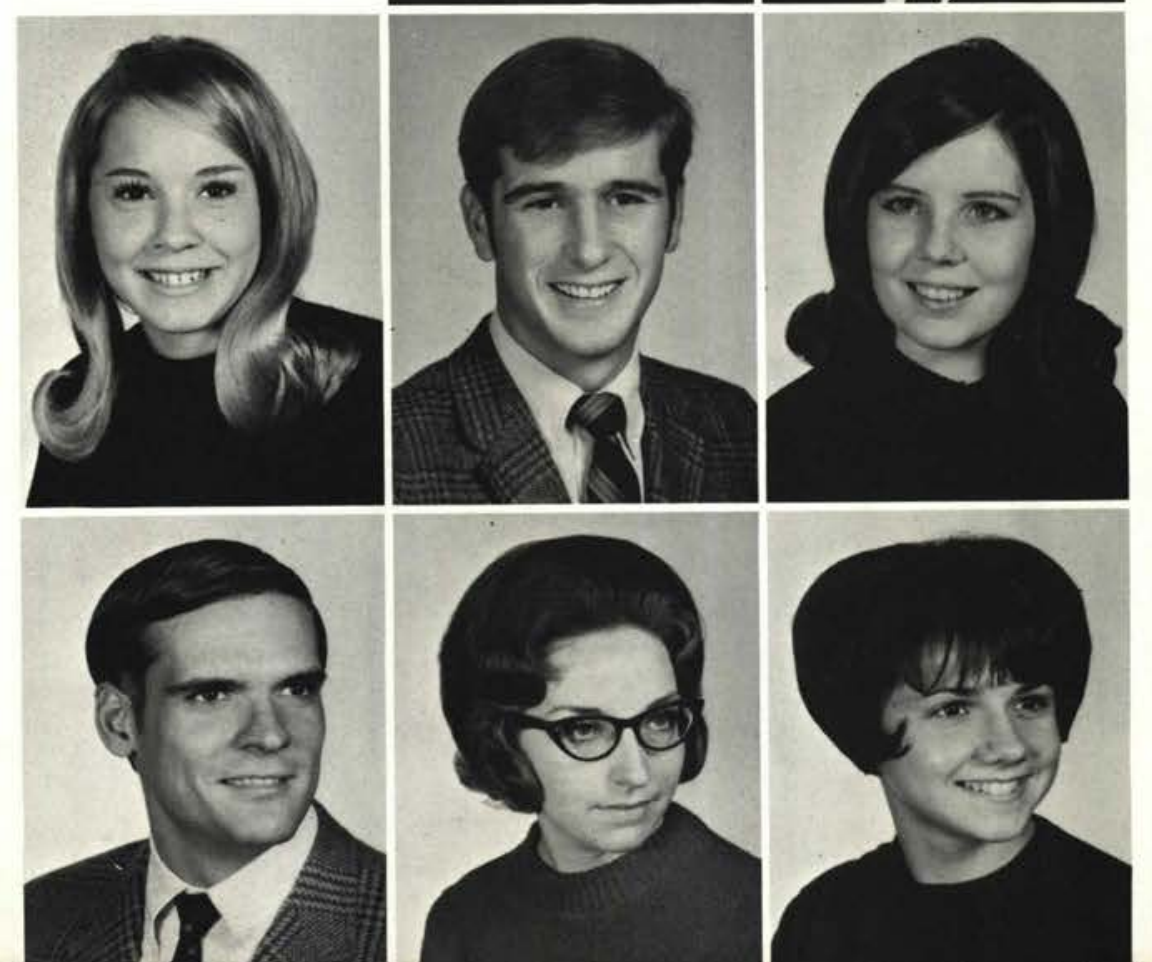


\section{JUNIORS}

The Junior Year Is

Characterized by Service.

Pictured below are the junior class officers: Kirk Heldreth, Chaplain; Paul Jones, Treasurer; Joyce Young, St. Council Rep.; Ken Hammonds, Pres.; Beth Bennett, Secretary; Dan
Leichty, V.-Pres.; Dr. Reed, Adviser; and Richard Mitchell, St. Council Rep.

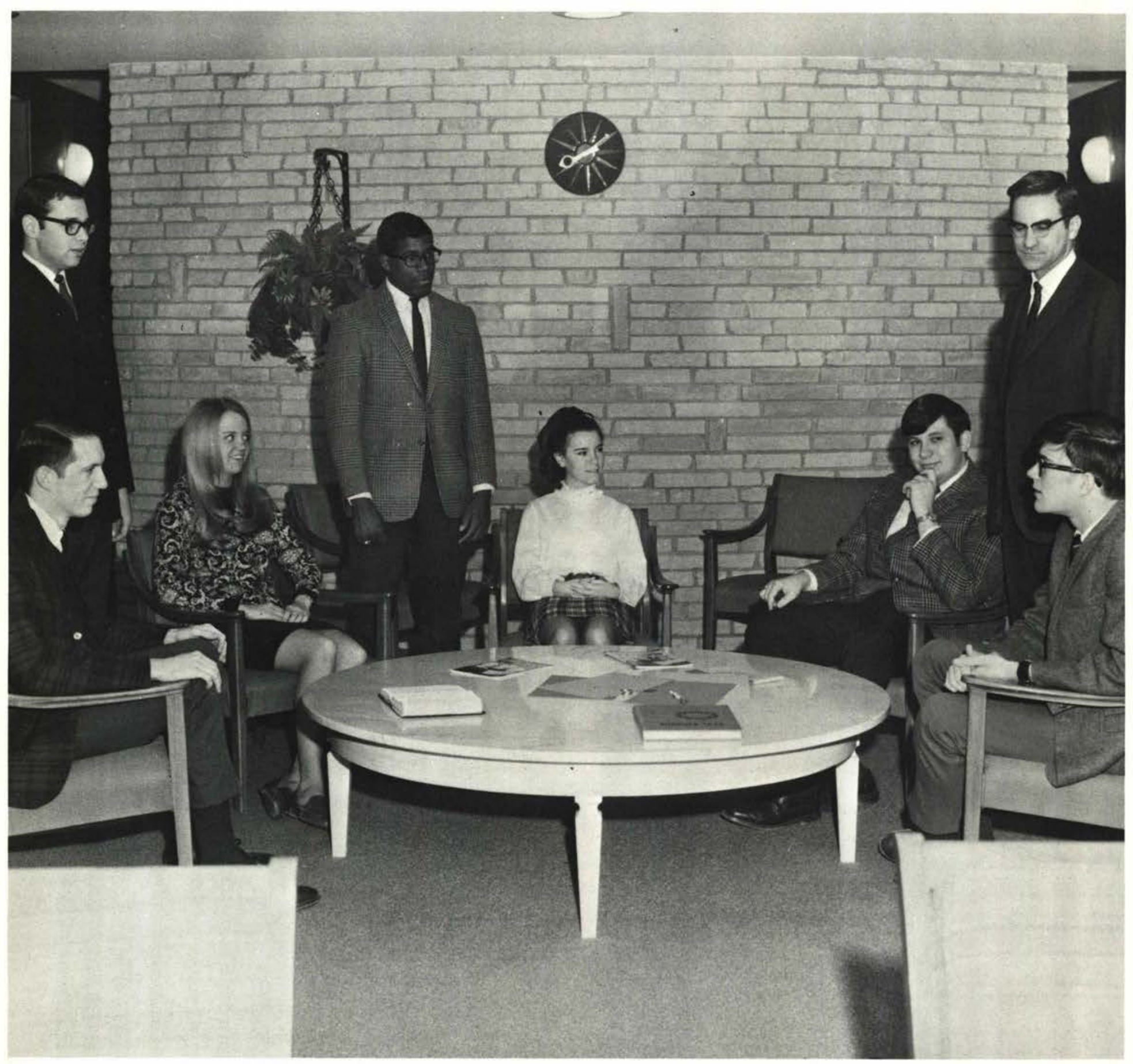


Betty Abernathy

Newfield, N.J.

Dorothy Abrams

Skaneateles, N.Y.

Kathryn Albright

Washington, Iowa

Robert Allen

Harlock, Maryland

Lyle Anderson

Des Moines, Iowa
Ronald Artrip

Creston, O.

Janet Ashley

Avon Lake, O.

Jane Austin

Bridgeton, N.J.

Kathleen Austin

New Milford, N.J.

Nancy Bailey

Traverse City, Mich.
Donita Baker

Cardington, $\mathrm{O}$.

Allen Beltle

Manasquan, N.J.

Beth Bennett

Lyndhurst, O.

David Bodden

Oley, $\mathrm{Pa}$.

Darwin Boertje

Lima, O.
Karen Borger

New Castle, Pa.

Bernice Bowersox

Xenia, O.

Donna Bratka

West Liberty, O.

Dale Braun

Wheaton, Ill.

Janice Brock

Columbus, $\mathrm{O}$.
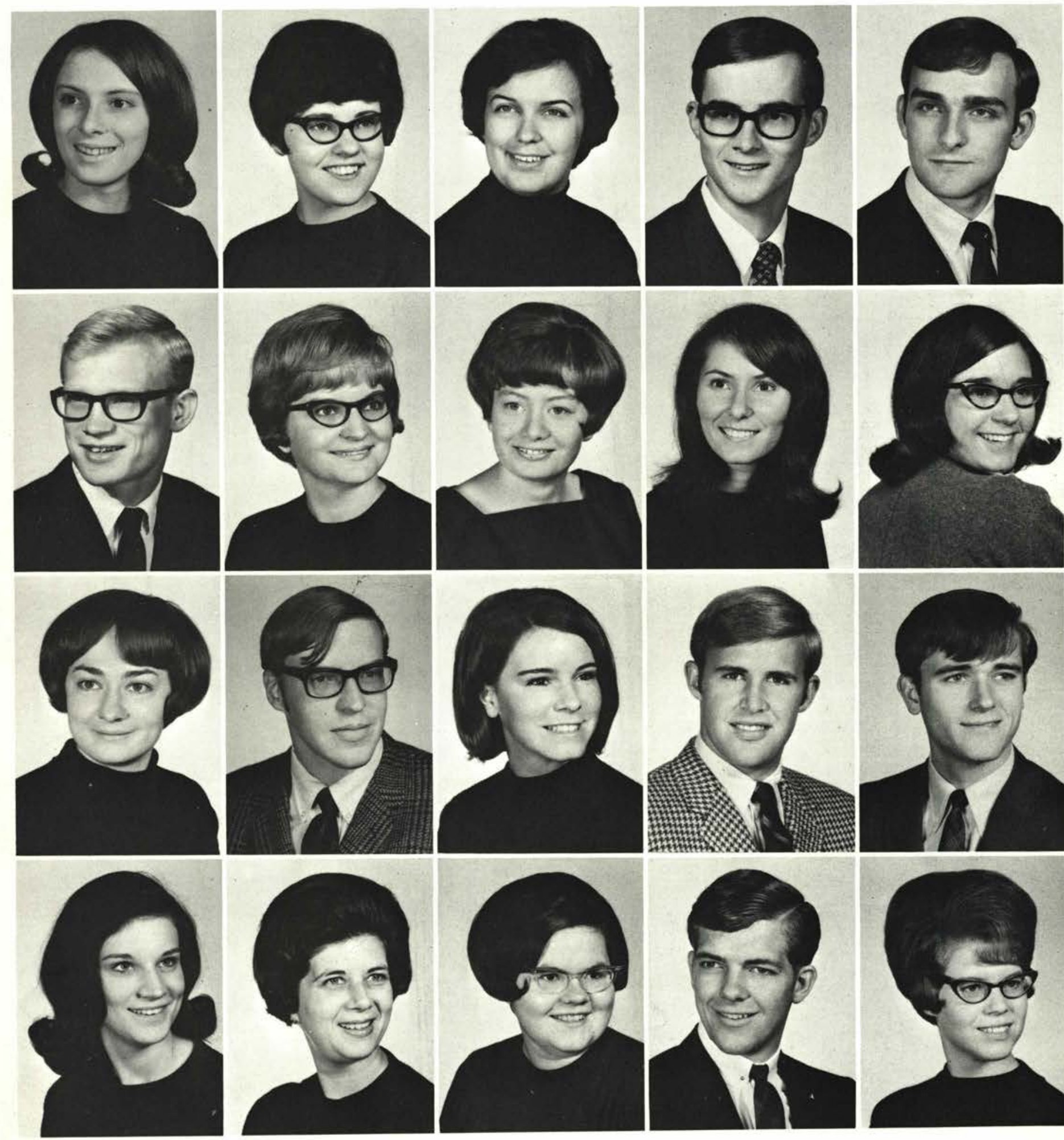
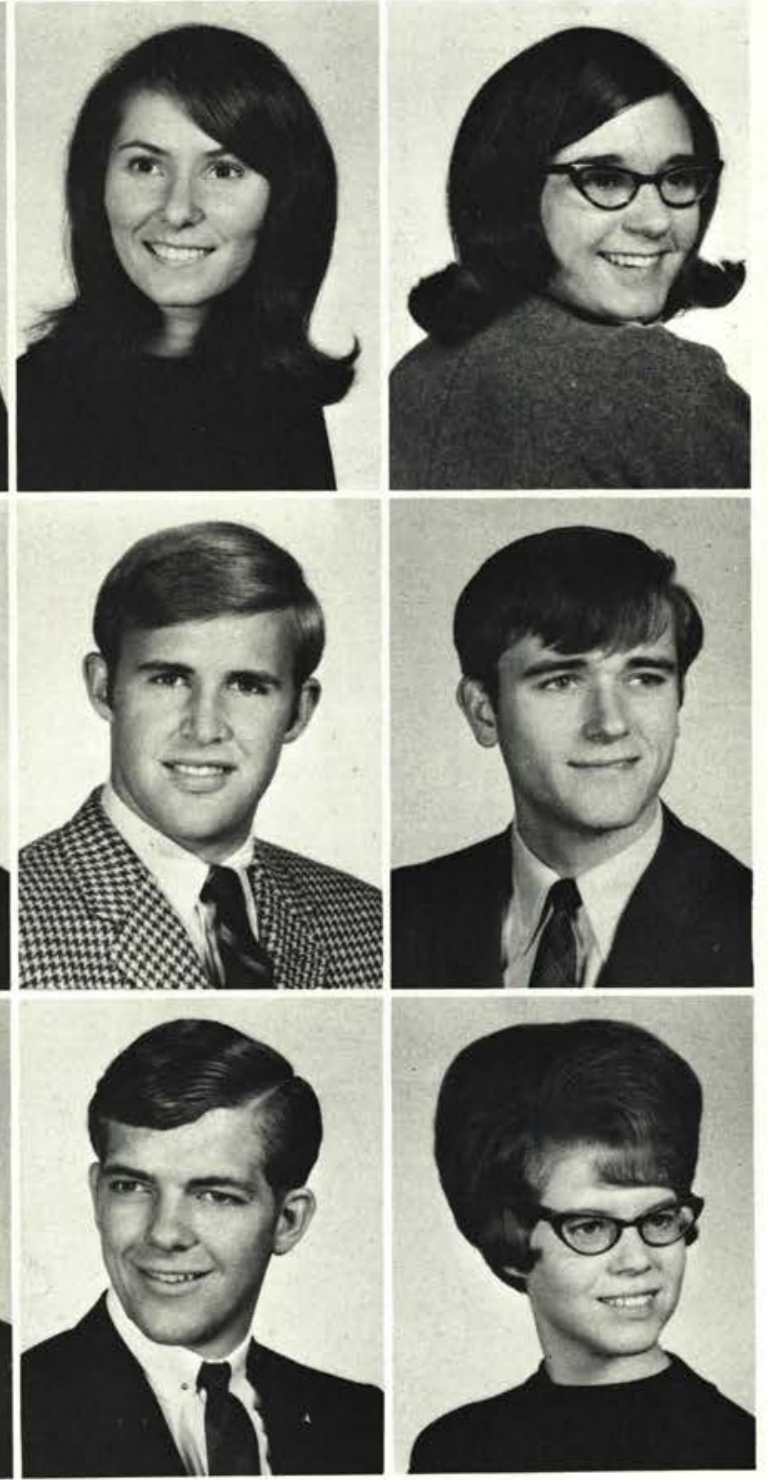
Preston Butcher Alexandria, Va.

Valerie Butler Hop Bottom, Pa.

Alan Call

Boise, Idaho

Robert Carmean

Dayton, O.

Cindy Cartner Markham, Ill.

Mark Causey

Morton, Ill.

Carolyn Clark

Clarion, Iowa

Kenneth Cole Gallipolis, O.

Janice Cooley Prescott, Ariz.

Martha Cox Elkhart, Ind.

Charles Curcio Sciotoville, O.

Joan Dautel Harvey, Ill.

Becky Decker Hinckley, O.

Richard Dewalk Hubbard, $\mathrm{O}$.

David Draxler Berea, O.
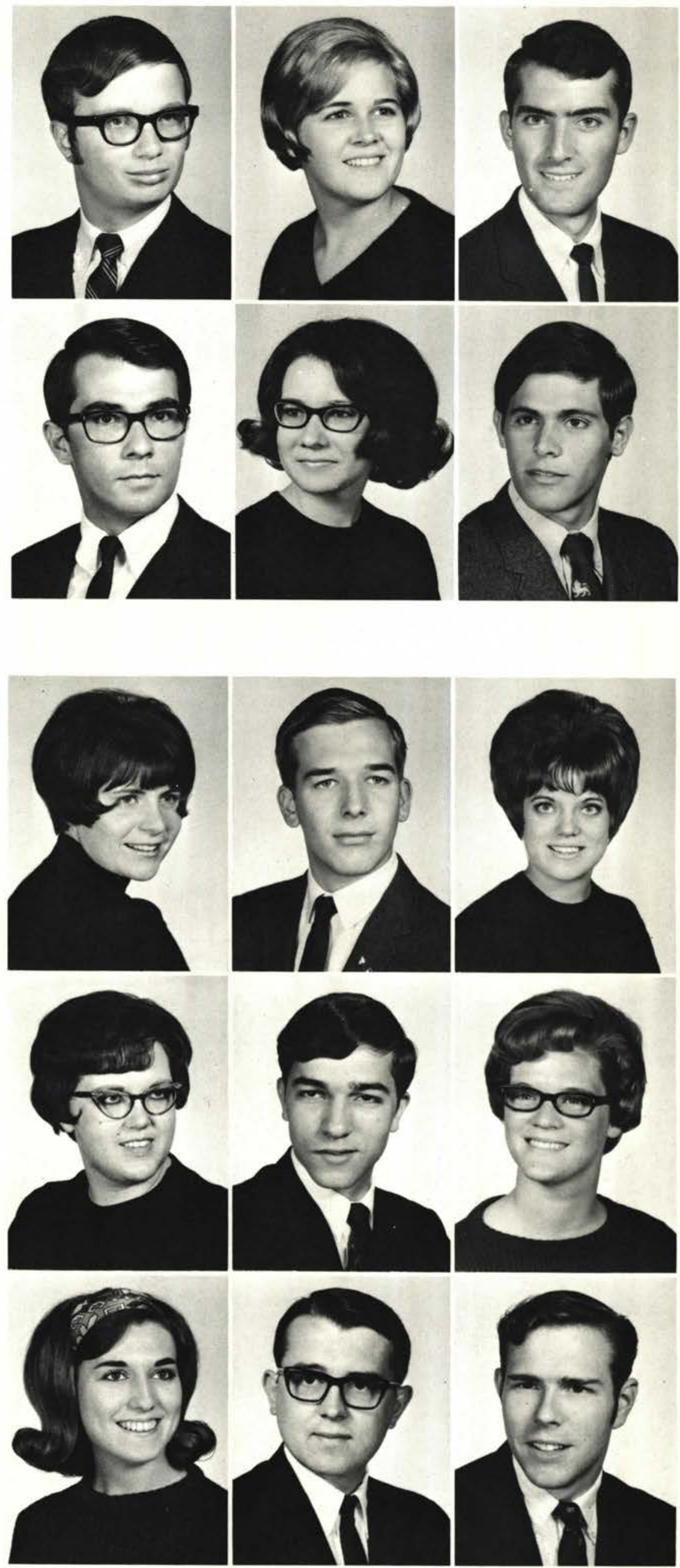

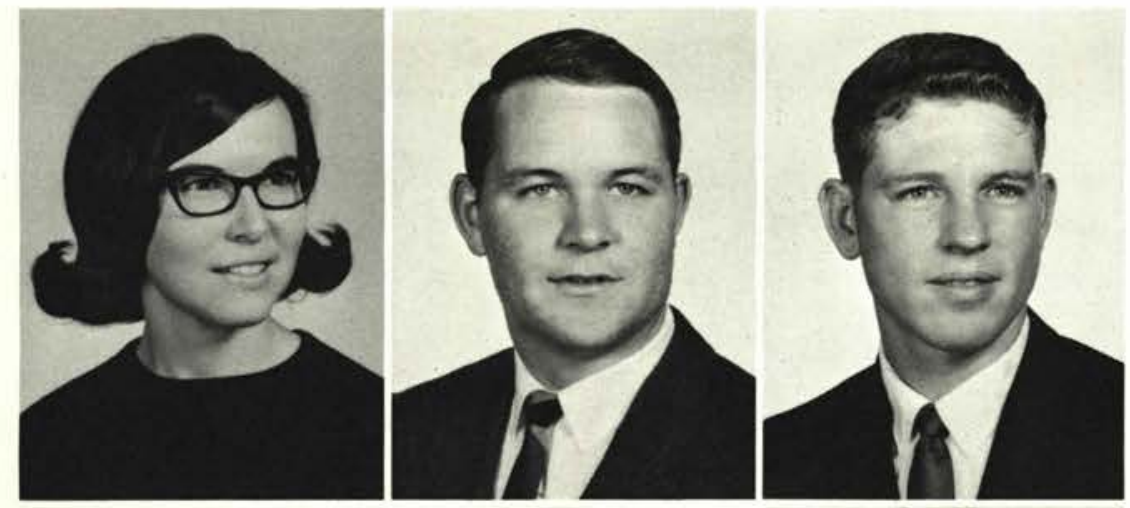

Cynthia Eckart

Belmont, W. Va.

Ronald Edwards

Kipton, O.

Leland Eichelberger

Kana, Idaho
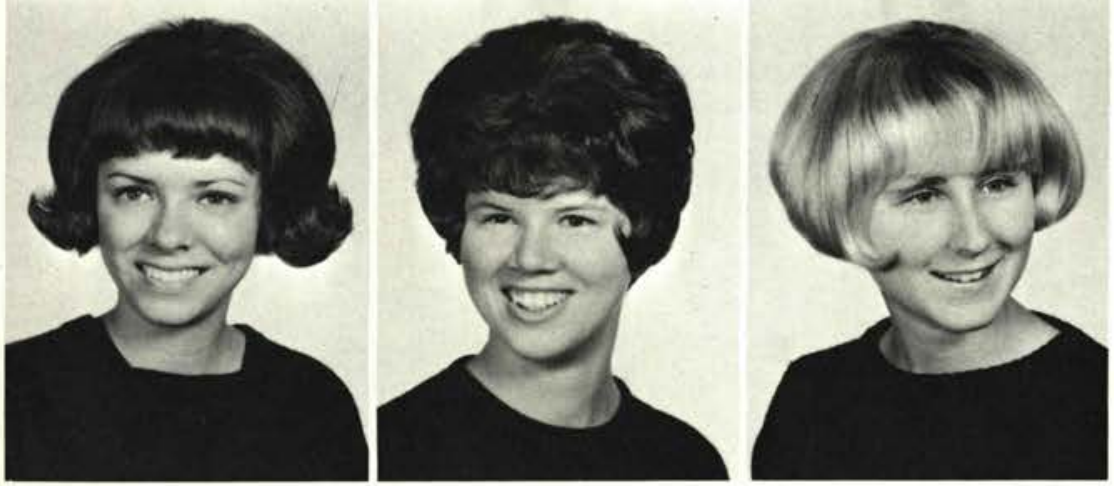

Elaine Eldridge

Francesville, Ind.

Connie Endicott

Springfield, $\mathrm{O}$.

Patricia France

Bedford, O.
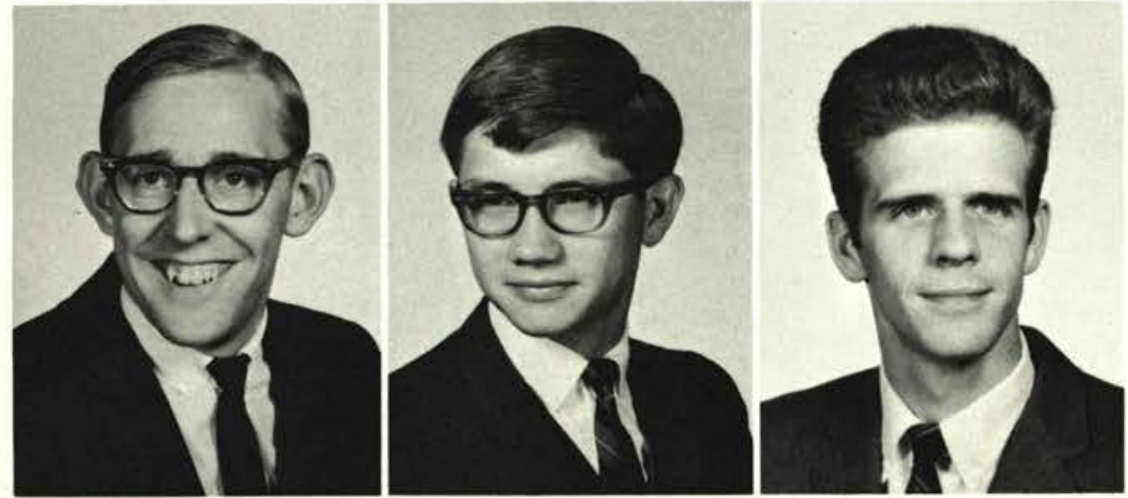

Paul Francisco

Delevan, N.Y.

Andrew Gathany

Montague, Mich.

Thomas Gelo

Cedarville, O.
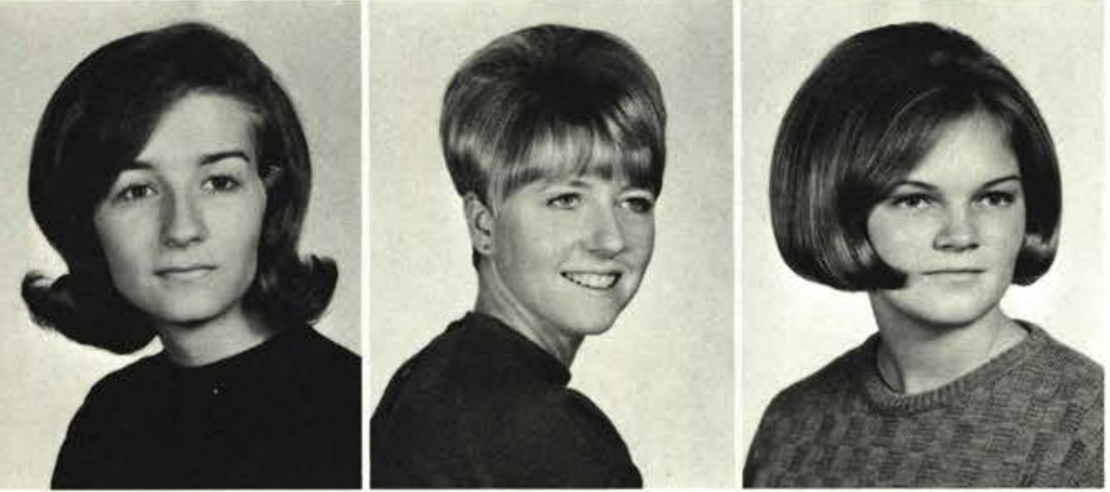

Susan Gift

Jackson, Mich.

Glenda Gillenwater

Dayton, $\mathrm{O}$.

Sharon Graham

Aurora, O.

Faith Hammond

Laceyville, $\mathrm{Pa}$.

Kenneth Hammonds

Wilmington, Del.

Evelyn Hare

Cedarville, O. 
Rebecca Harman Connellsville, $\mathrm{Pa}$.

Kirk Heldreth Brunswick, O.

Sherrill Hesler Cedarville, $\mathrm{O}$.

Sarah Hickam Moline, Ill.

Robert J. Hoffman Oaklyn, N.J.

Jack Holliday Richard, W. Va.

Donna Hopkins Corry, $\mathrm{Pa}$.

Barbara Hoyer Cortland, N.Y.

Dennis Huddleston Dayton, $\mathrm{O}$.

David Hull Cortland, $\mathrm{O}$.
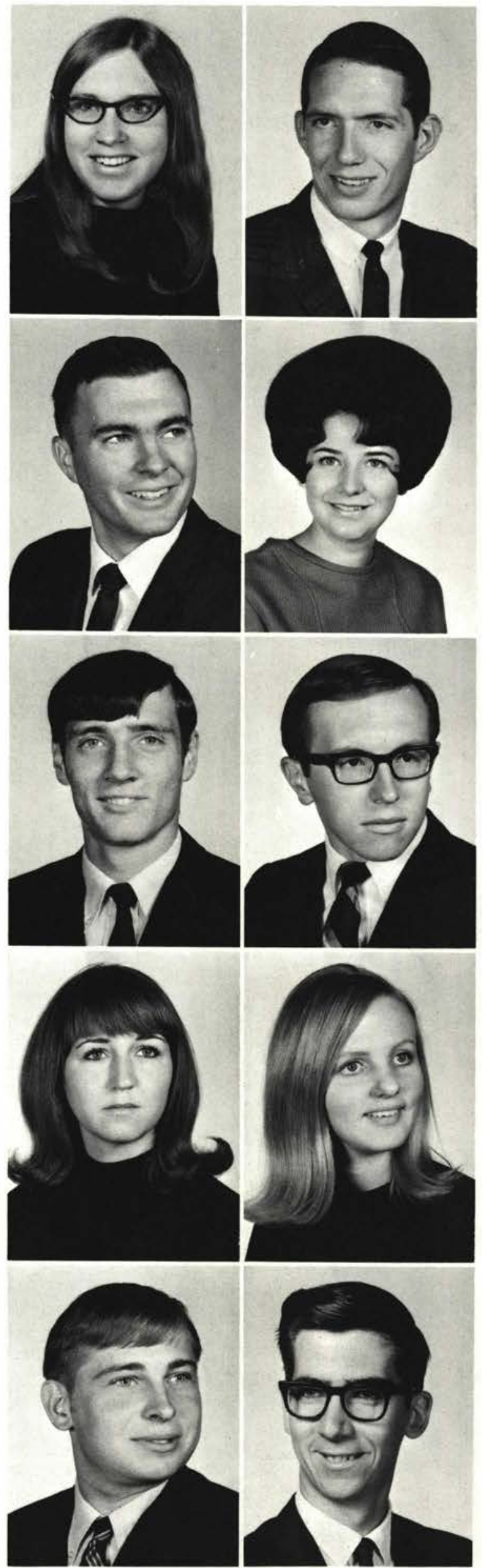
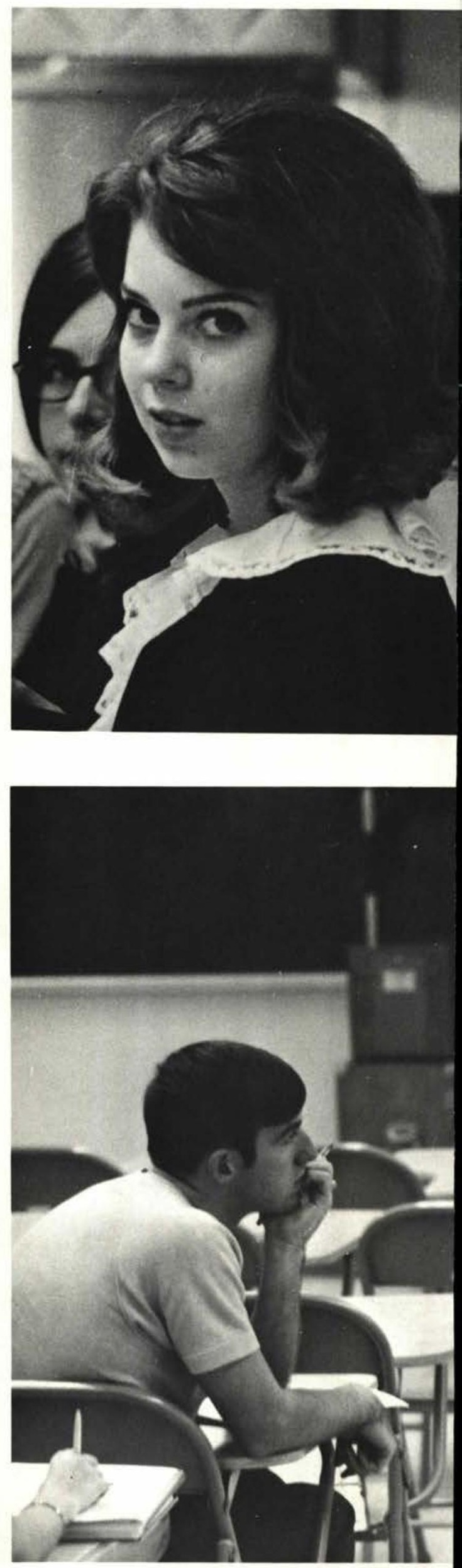

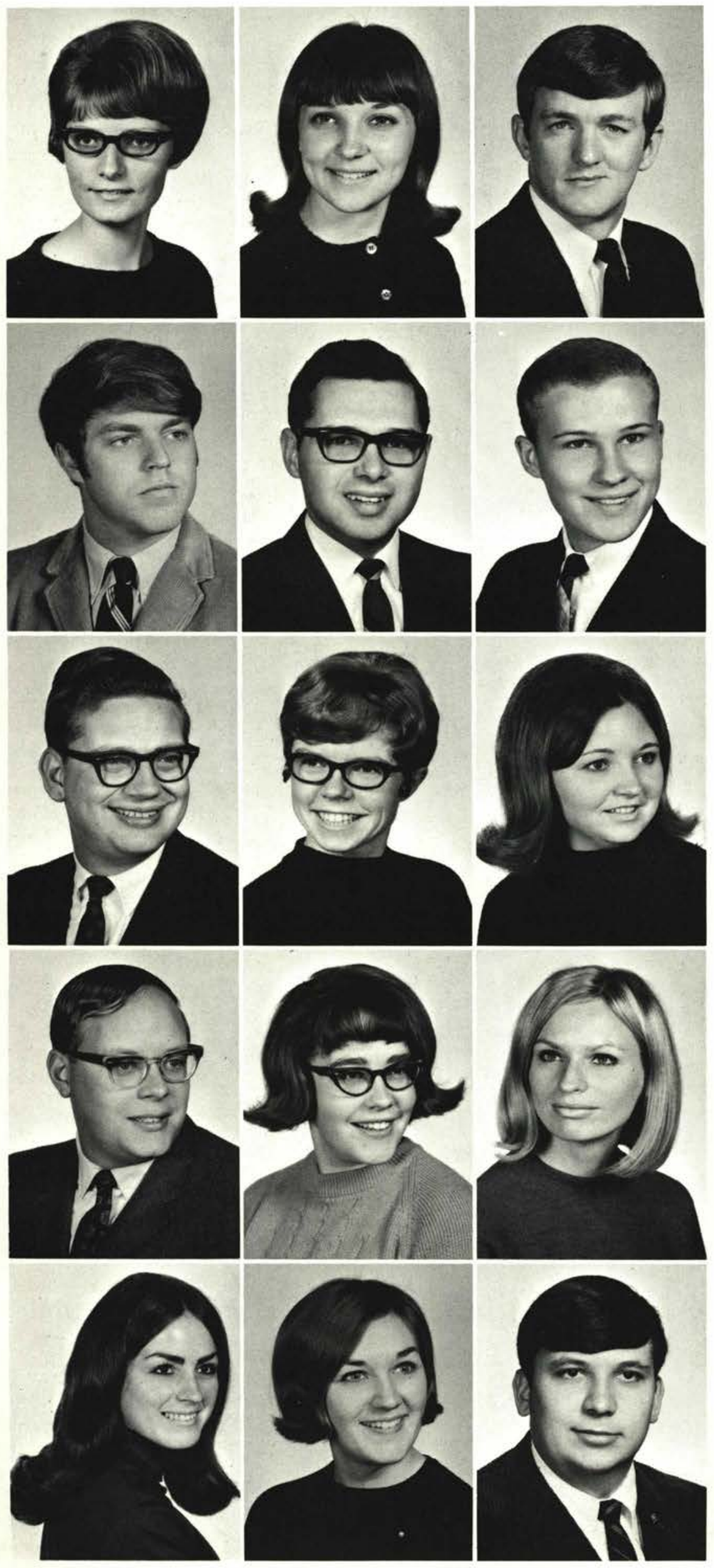

Dianna Hutchison

Columbus, $\mathrm{O}$.

Linda Jefferies

Bridgeport, W. Va.

James Jeremiah

Cedarville, $\mathrm{O}$.

Philip Johnson

Decatur, Ill.

Paul Jones

Piqua, O.

David Kearney

Elyria, O.

Robert King

Springfield, $\mathrm{O}$.

Deanna Kishpaugh Sand Creek, Mich.

JoAnne Kishpaugh Sand Creek, Mich.

George Klein

Oakland, N.J.

Sandra Lathrop

Downers Grove, Ill.

Pat Lawhead

Coshocton, O.

Nancy Leapline Dunbar, Pa.

Barbara Lepine Buffalo, N.Y.

Daniel Liechty

Hobart, Ind. 


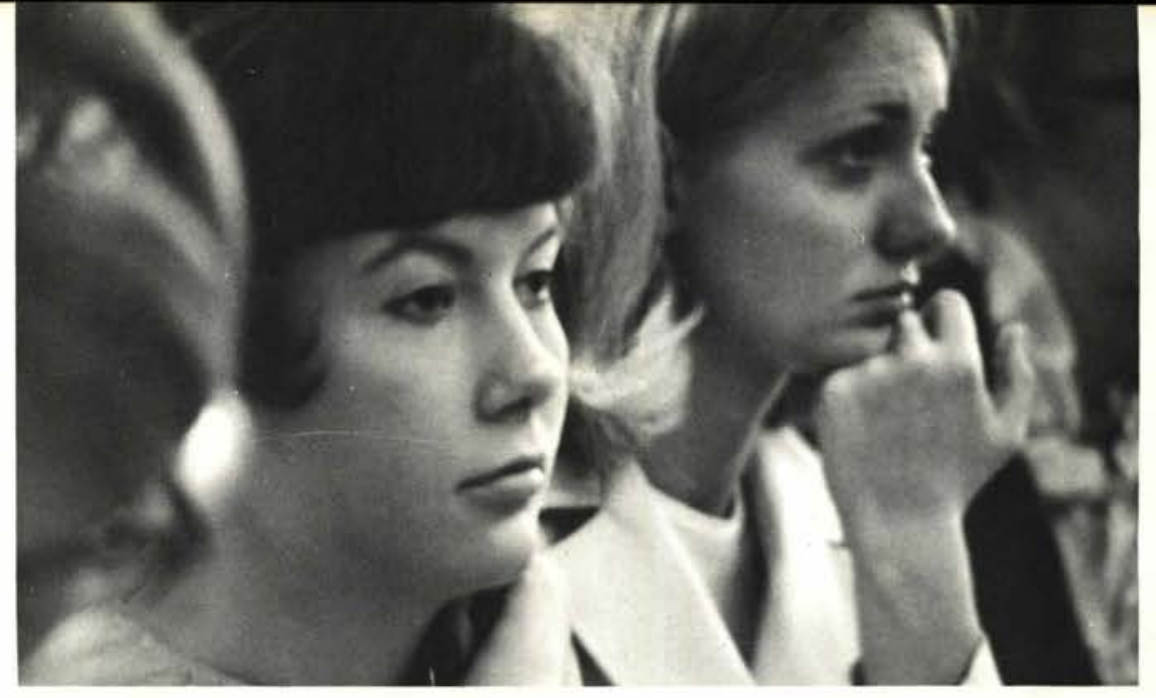

Janis Martin Crawfordsville, Ind.

Judy McCann Quincy, Mich.

Max McCullough

Coshocton, O.

Gary McDowell Hobart, Ind.

Viann Meyer Waterloo, Iowa

Alice Miller Columbus, $\mathrm{O}$.

Joyce Miller Williamston, Mich.

Richard Mitchell

Malaga, N.J.

Alice Moorman Xenia, O.

Carol Morrell Indianapolis, Ind.

Shirley Mott Angelica, N.Y.

Jerome Motter Genoa, O.
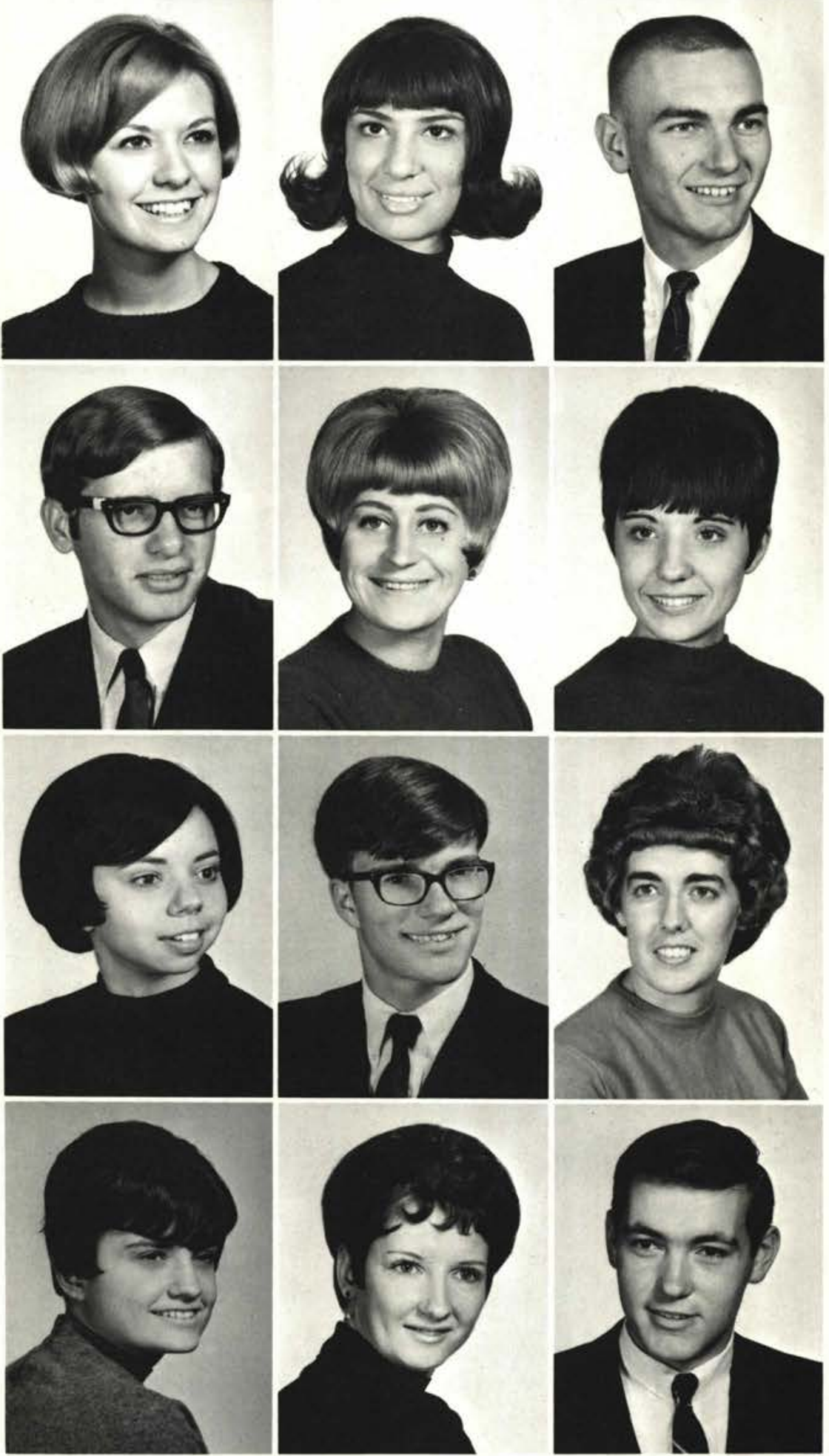
Margaret Muirhead Fulton, Ill.

Penny Nichols

Crawfordsville, Inc.

William Norton

Whitehall, Mich.

Peter Oehmcke

Wauwatosa, Wis.

Beth O'Keefe

Parma, O.
James O'Keefe

Wesleyville, $\mathrm{Pa}$.

Sam Olsen

Lima, Peru

Susan Pauling

Allenwood, Pa.

Warren Pettitt

Florence, N.J.

Janet Phenix

Cedar Falls, Iowa
Edith Phillips

Plainfield, Ind.

Patricia Phipps

Portsmouth, O.

Terry Phipps

Concord, Calif.

Alberta Plate

Otley, Iowa

Larry Radcliff

Caldwell, O.
Diana Radcliffe

Wakeman, O.

Susan Ray

Decatur, Ill.

Donald Reams

Springfield, O.

Betty Reese

Lock Haven, $\mathrm{Pa}$.

Robert Rehkopf

Petoskey, Mich.
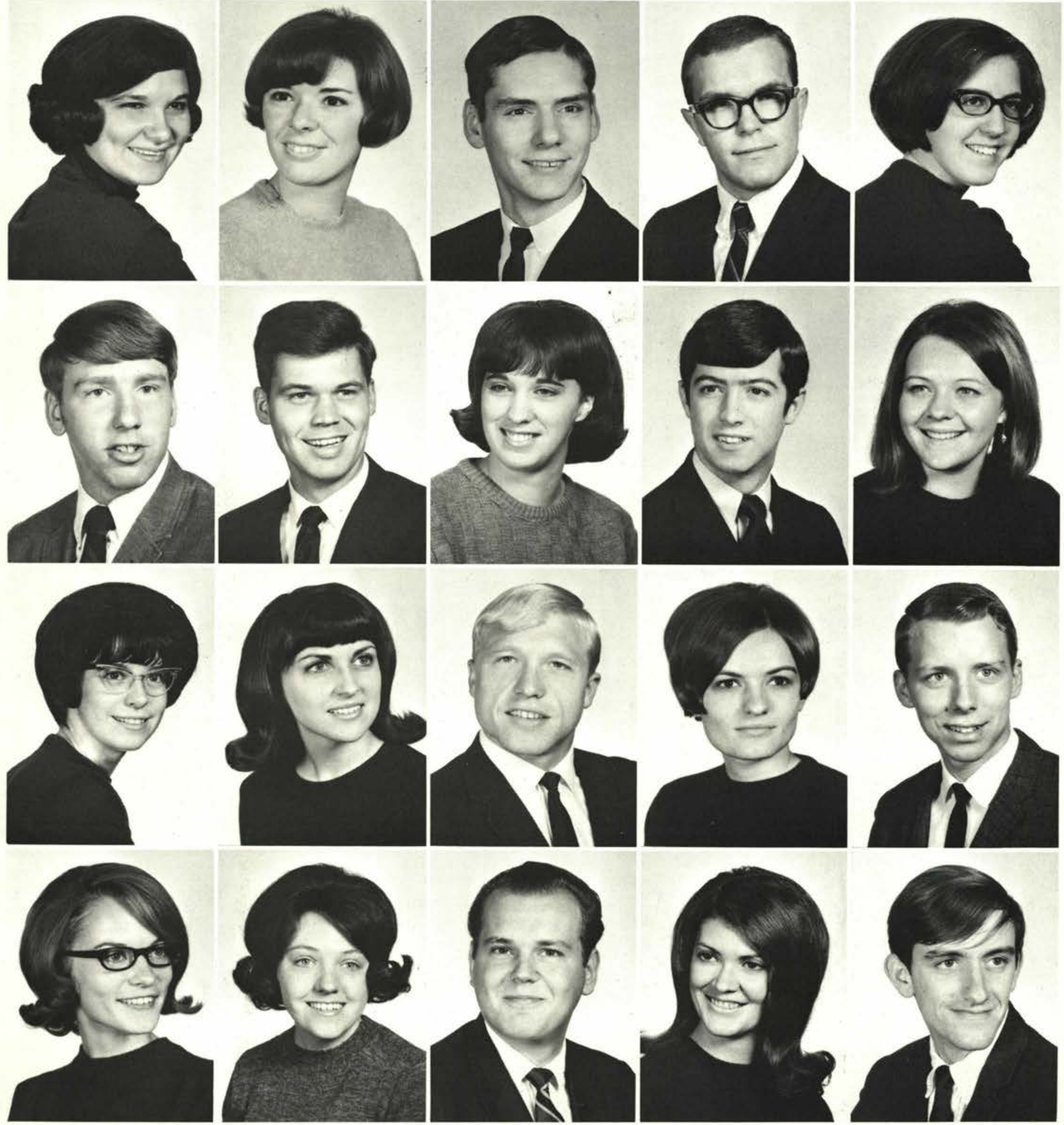
Loren Reno
Wheaton, Ill.

Rebekah Rochelle

Atlanta, Ga.

Ruth Rodriguez

Greenlawn, N.Y.

Rebecca Rudig

Waterloo, Iowa

Dan Ruffin

Grandview, Wash.
Lois Rumage

Hallstead, Pa.

Sandy Russell

Cleveland, O.

Joyce Saemenes

Phoenix, Ariz.

John Schneider

Hammond, Ind.

Gail Sears

Grinnell, Iowa
Philip Senseney

Linwood, N.J.

Rebecca Sharp

Columbus, $\mathrm{O}$.

Arthur Shuter Carroll, O.

Dan Smith Boise, Ind.

William Smith Milford, Ill.
Philip Sommerfield San Diego, Calif.

David Southwell Mancelona, Mich.

Judith Stamatis Glen Cove, N.Y.

Cheryl Steenburg Elba, N.Y.

Dennis Stora Allegan, Mich.
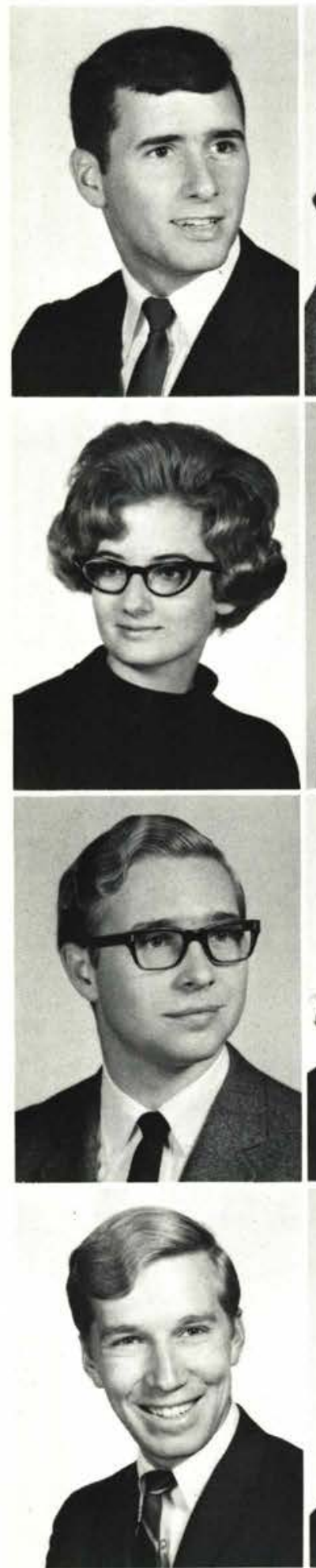
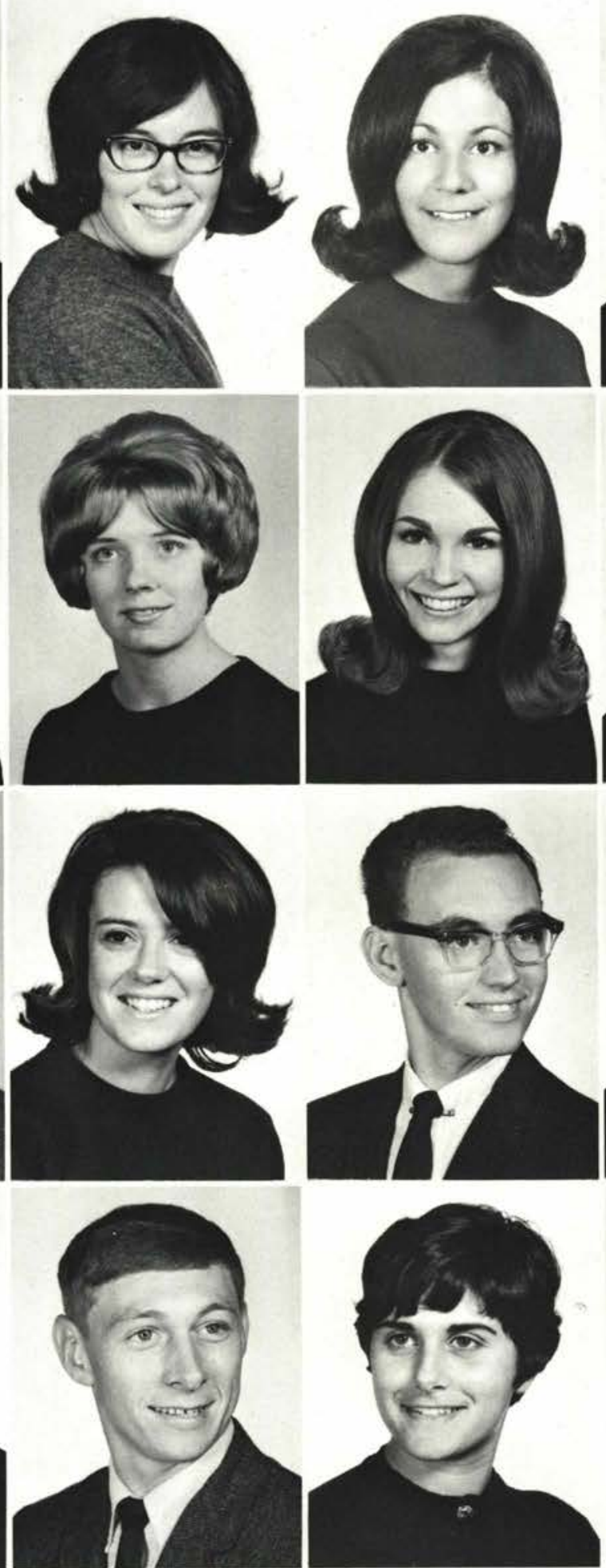
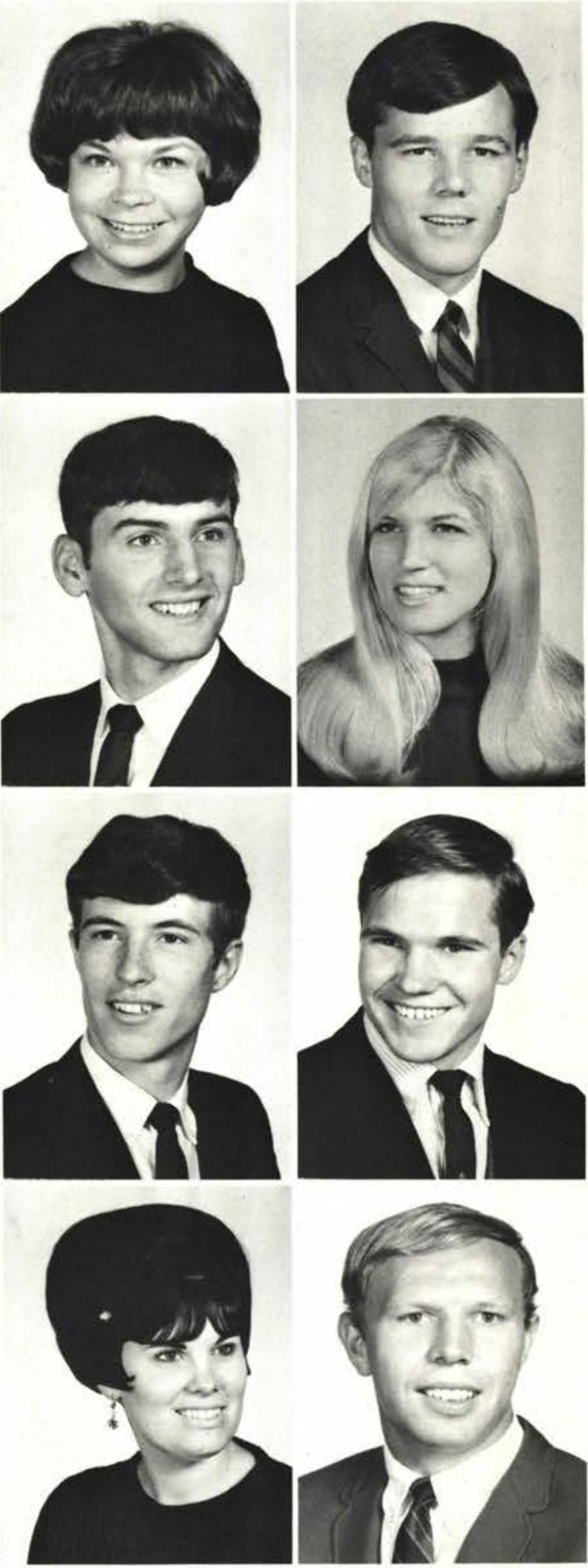


\section{SENIORS}

The Senior's Hard Work

And Fun and Service,

Turn into Lasting

Memories.

Pictured below are:

Dave Handyside, Chaplain;

Bruce McDonald, Vice-Pres.;

Dan Caraway, President;

Mr. Riter, Advisor; Nancy

Towle, Secretary; and

Linda Garlock, Treas.
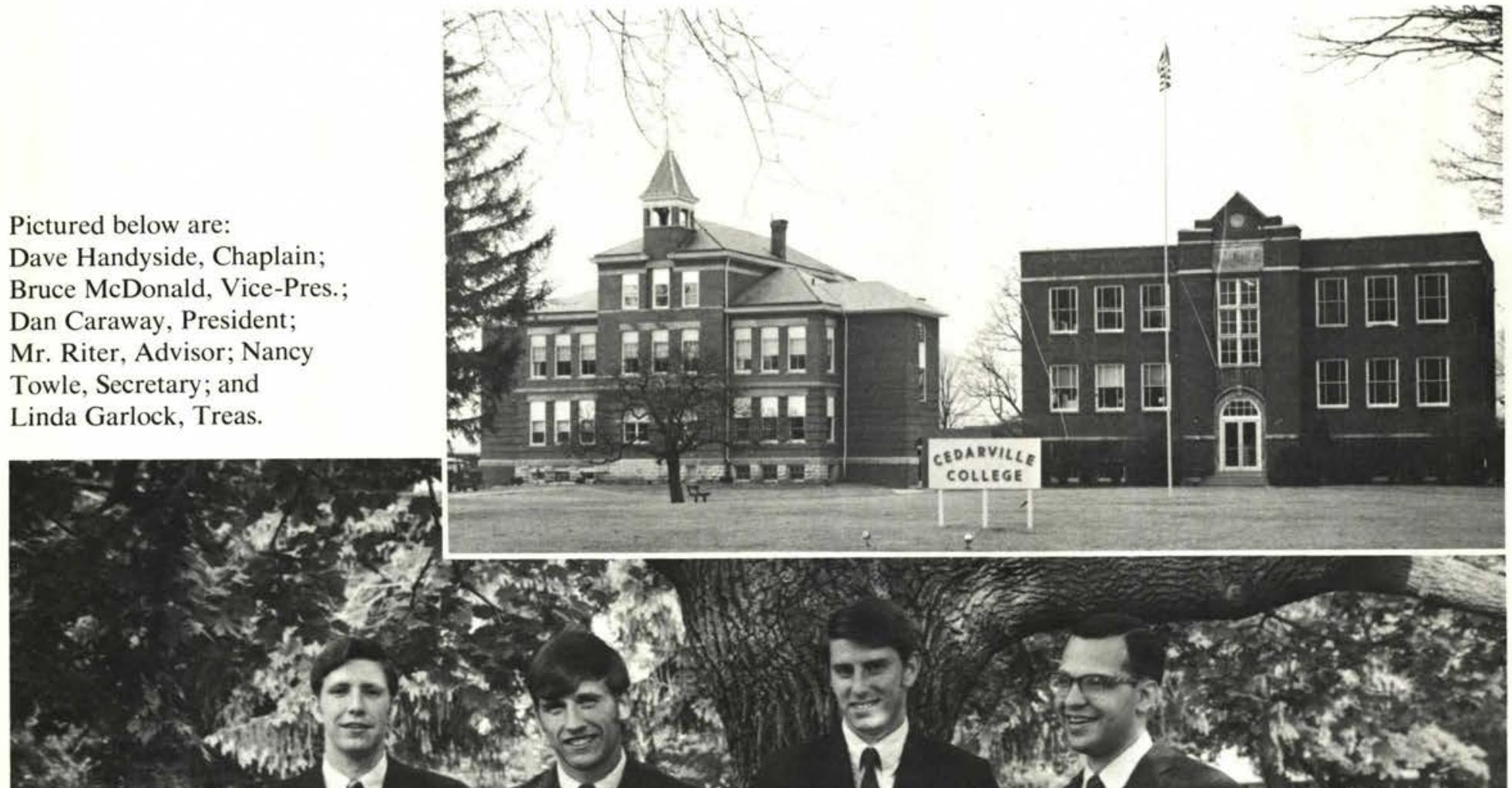

2 .

$\cos ^{2}$

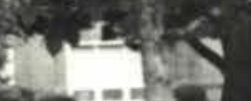

$\lim _{n=5}=1$
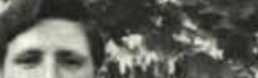

$\cos ^{2}=$
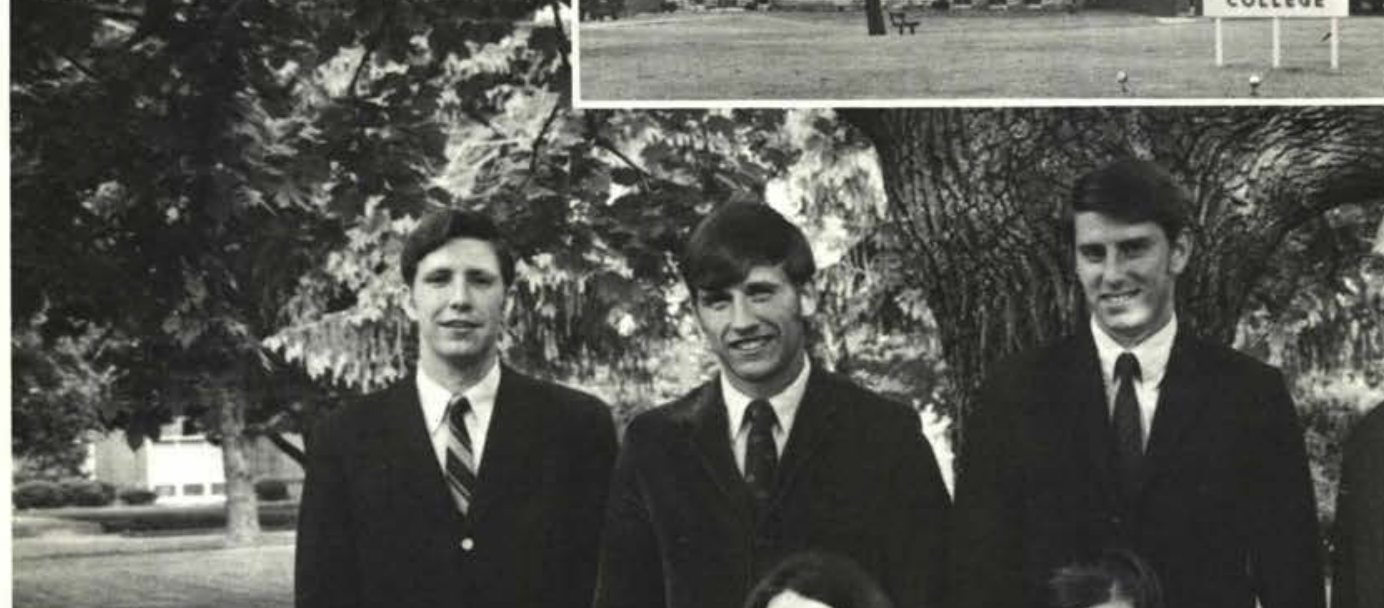

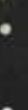

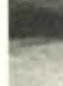

$x+\frac{1}{2}$
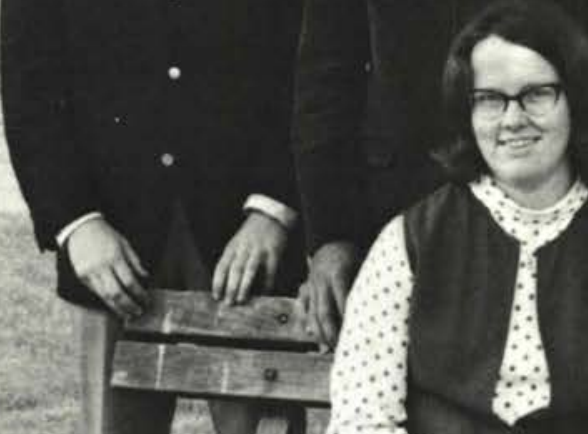

a

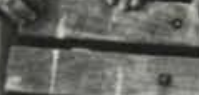

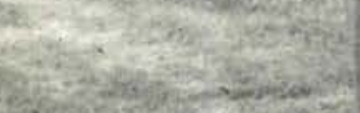

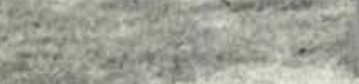

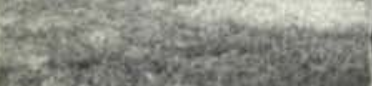

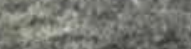

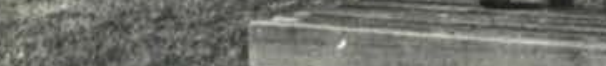
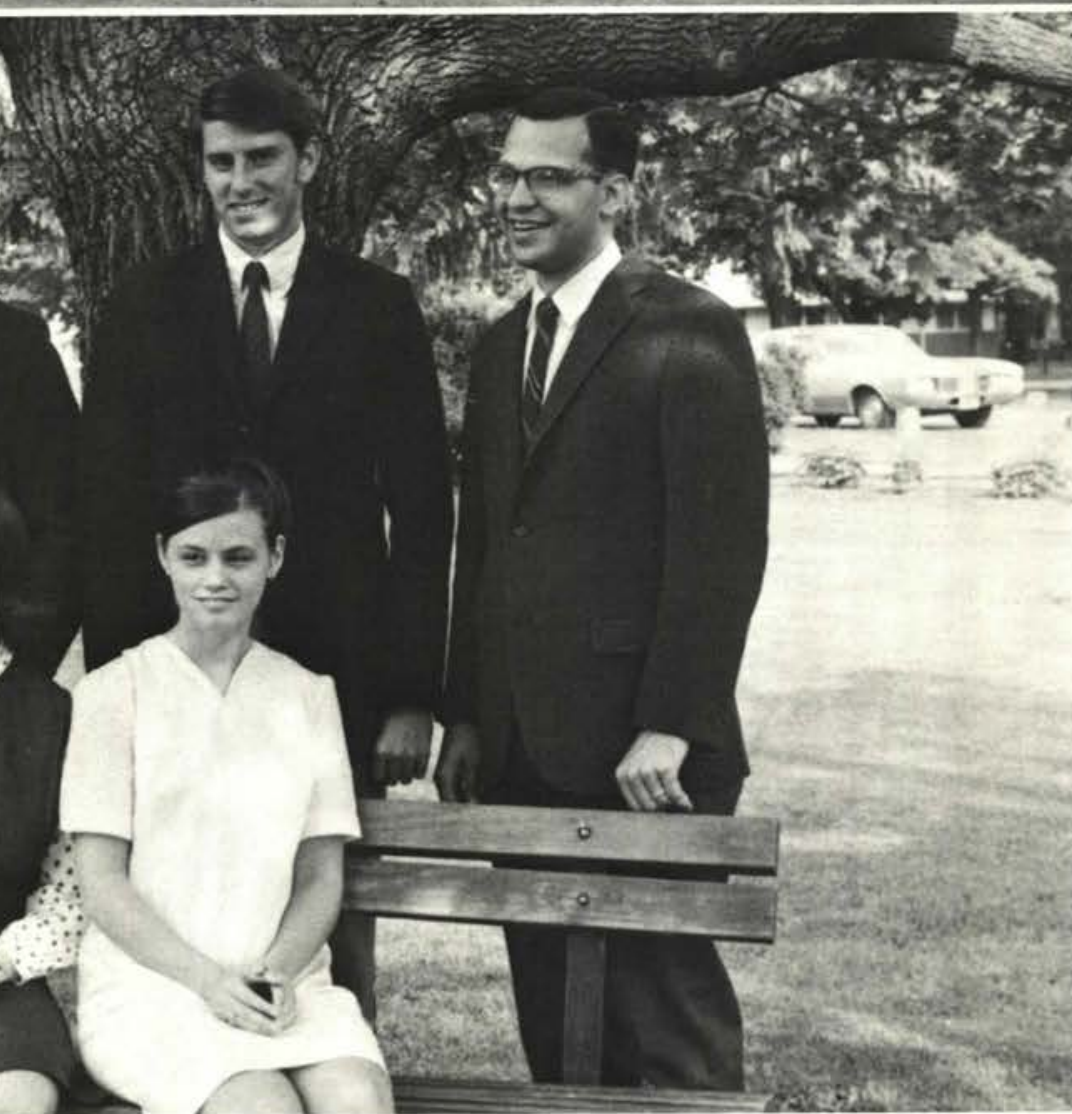

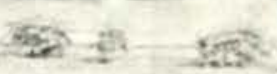

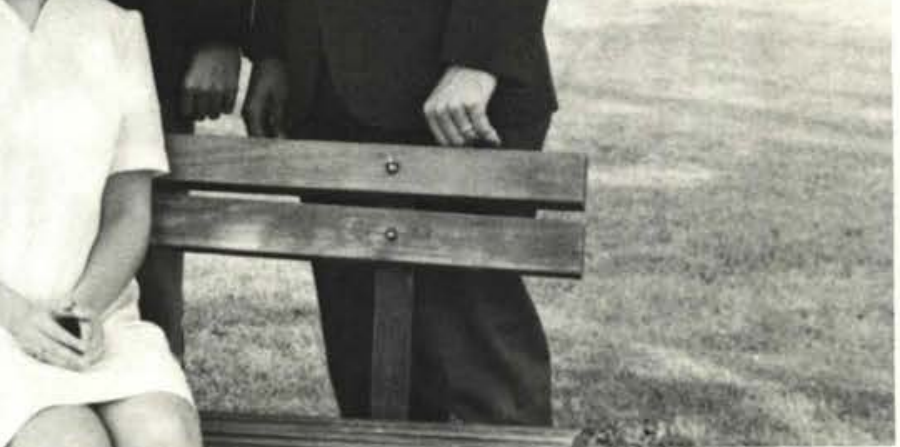


Donald Acker

Randolph, N.Y.

Richard Adams

New Milford, Conn.

Douglas Ambroza

Lima, O.

Margaret Anderson

Maroa, Ill.
Olivia Anderson

Berea, O.

Thomas Andrews

Cedarville, $\mathrm{O}$.

Maxine Augsburger

Bani, Dominican Republic

Ruth Augspurger

Middletown, O.
Carol Baker

Schenectady, N.Y.

Ronald Baker

Schenectady, N.Y.

Joanna Barcus

Kansas City, Mo.

Karen Barnhart

DuBois, $\mathrm{Pa}$.
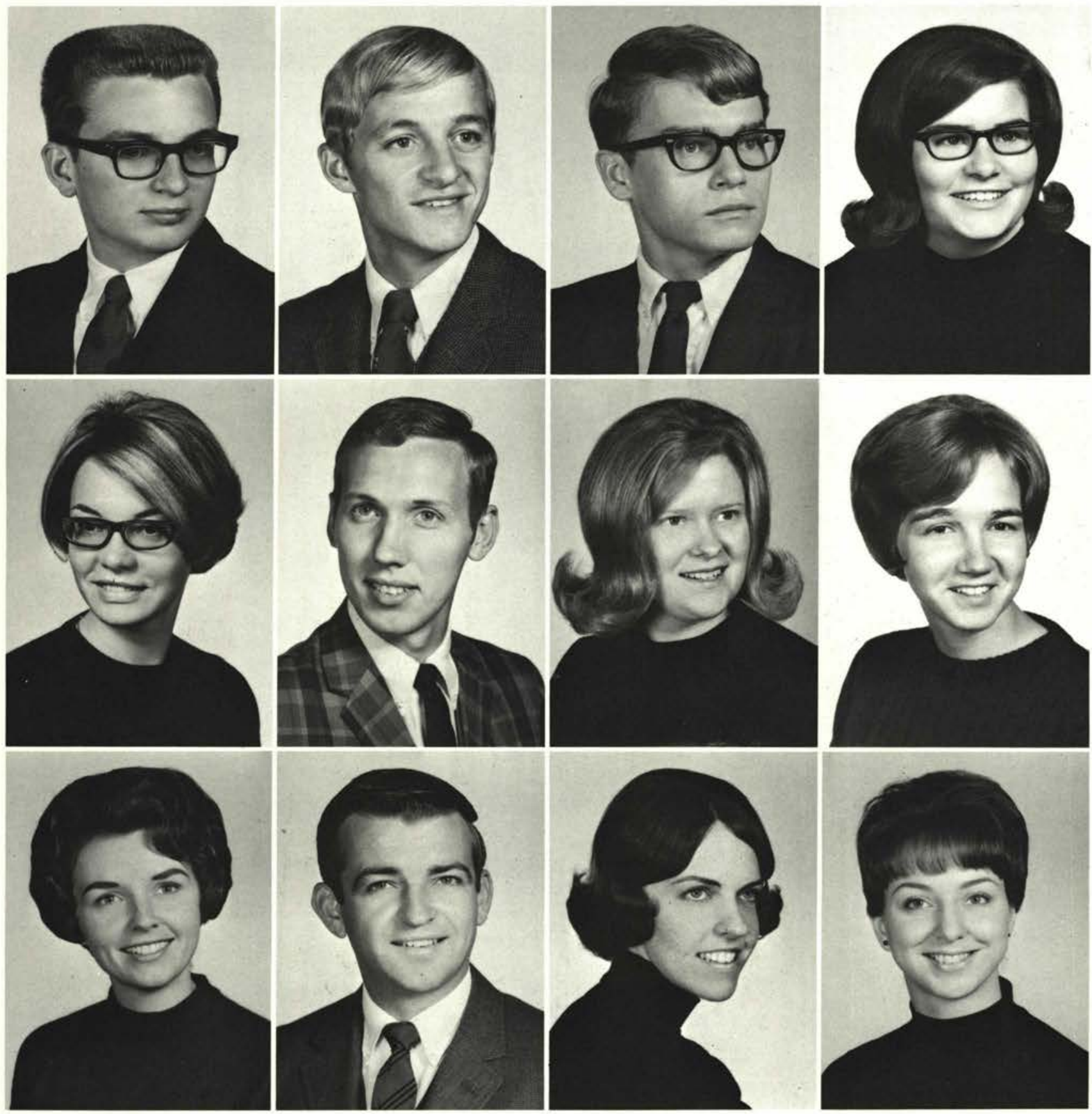
Carol Beerer

Elkhart, Ind.

Marilyn Beitler

Medina, O.

James Berry

Medina, O.

Robert Bixel

Bellefonte, $\mathrm{Pa}$.

Patricia Black

Coal Port, Pa.

Diane Blake

Lexington, $\mathrm{Ky}$.

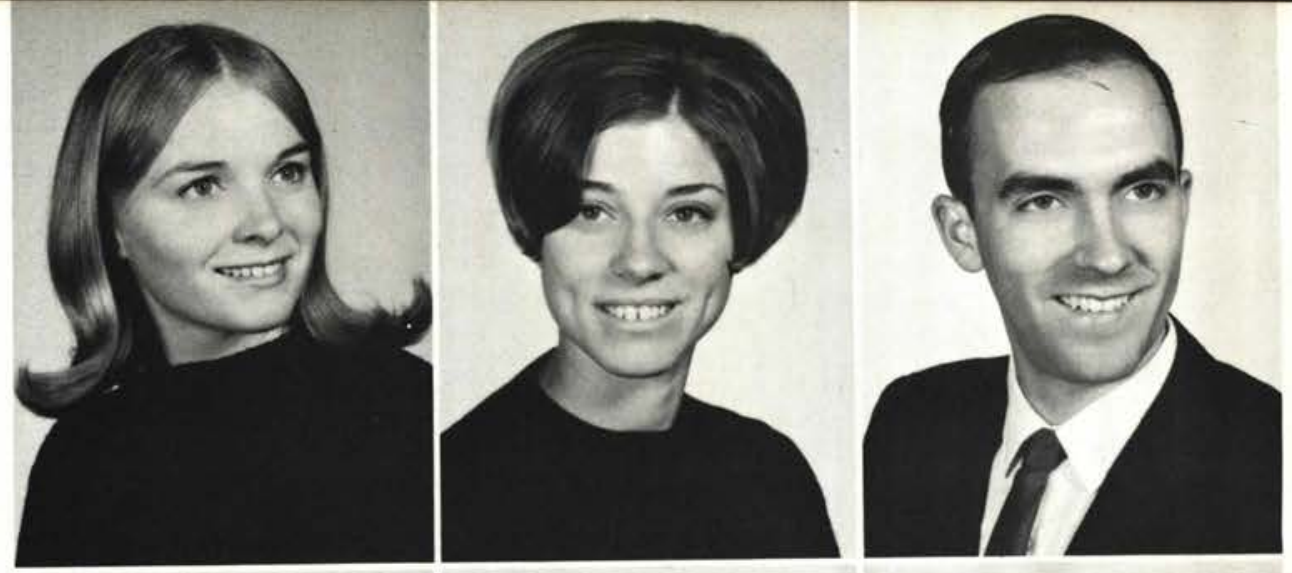

Betsy Bodenmiller Homerville, $\mathrm{O}$.

Paula Bolen New Carlisle, O.

Stephen Booghier Springfield, $\mathrm{O}$

Carolyn Brown Cedarville, $\mathrm{O}$.

Stanley Brown Kasson, Minn.

Carol Burroughs Otego, N.Y.

Roxanne Butler Bemidji, Minn.

Daniel Caraway Covington, $\mathrm{Ky}$.

Annie Carlson Bessemer, Ala.
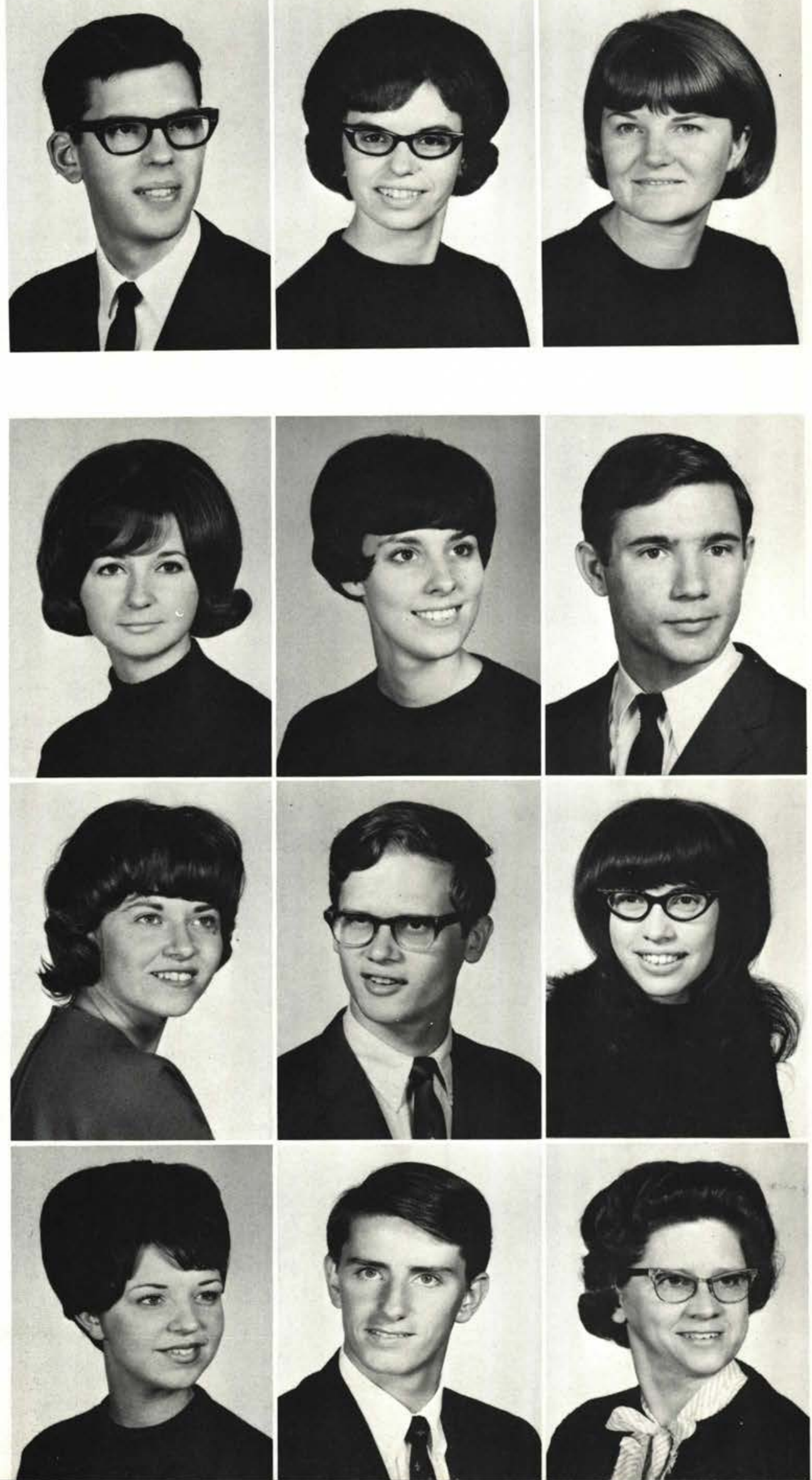
Gary Darrow Westwood, N.J.

Larry Davis Homer City, Pa.

Barbara Dewar Audubon, N.J.

Joseph Dillard Springfield, O.

Rose Dillard Lancaster, $\mathrm{O}$.

Karen Donaldson Continental, O.

John Donley Bellbrook, O.

Leonard DuBois East Detroit, Mich.

Michael Eberhart Troy, O.

Sara Empet Kingsley, $\mathrm{Pa}$.

Paul Entner Cedarville, $\mathrm{O}$.

Tom Evans Columbus, $\mathrm{O}$.

Dave Fidler Cedarville, $\mathrm{O}$.

Darlene Fitch Jamesville, N.Y.

Glenda Foster Springfield, $\mathrm{O}$.
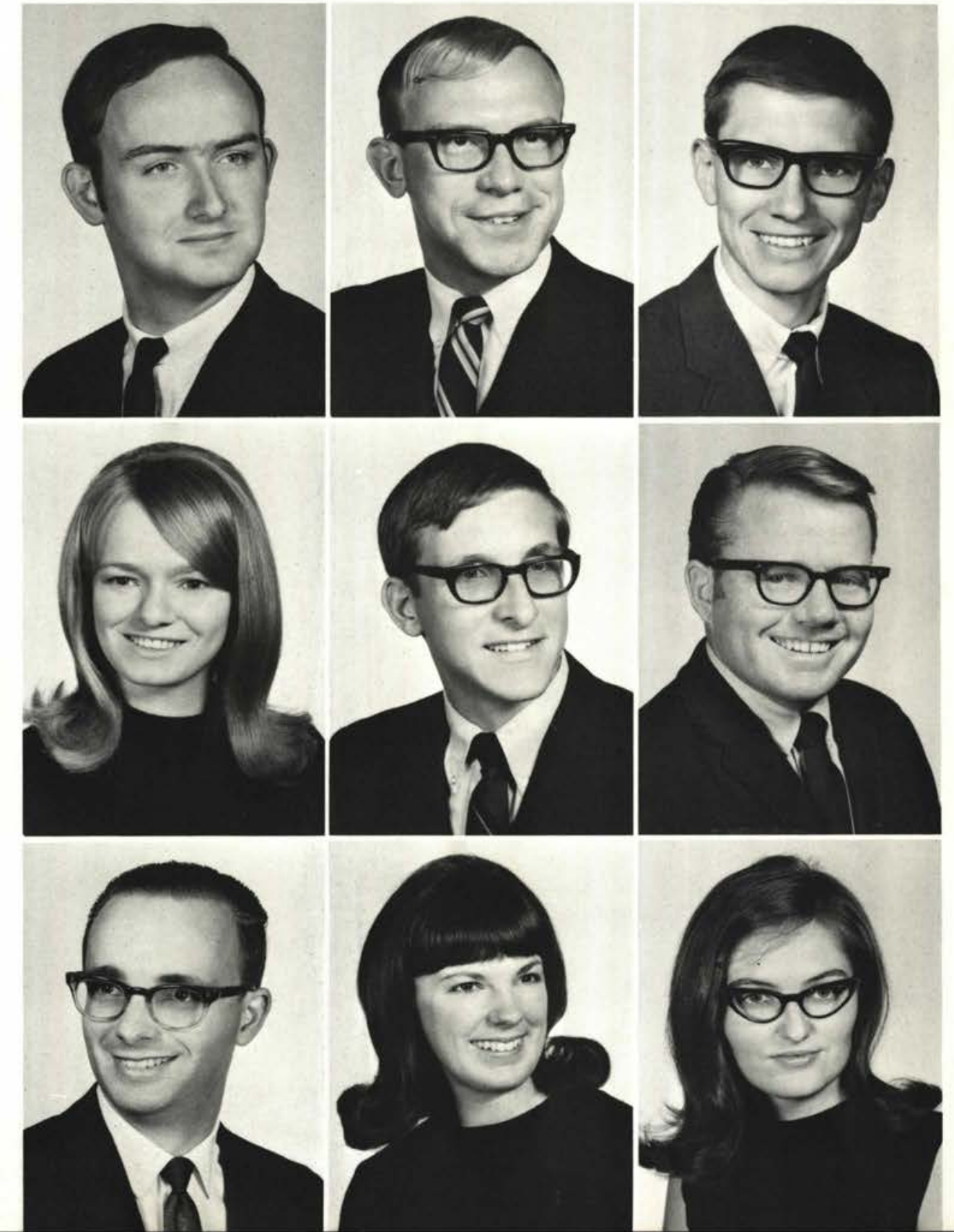

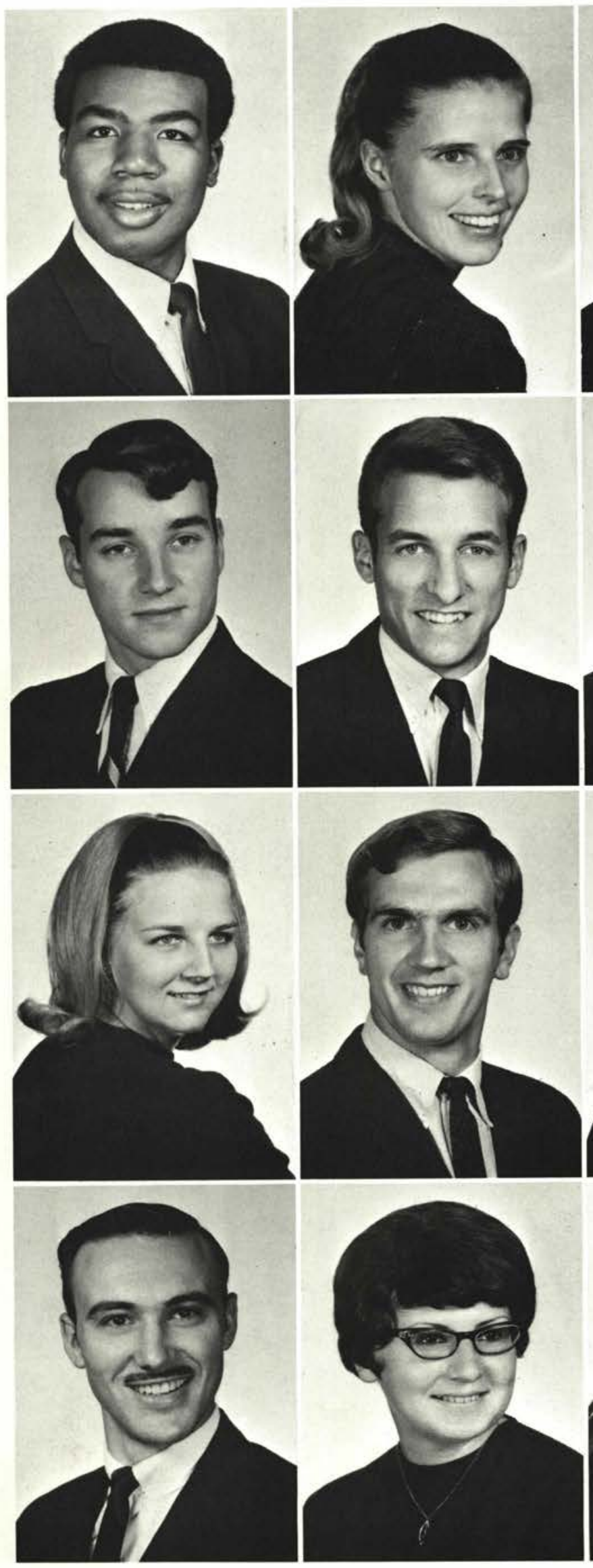
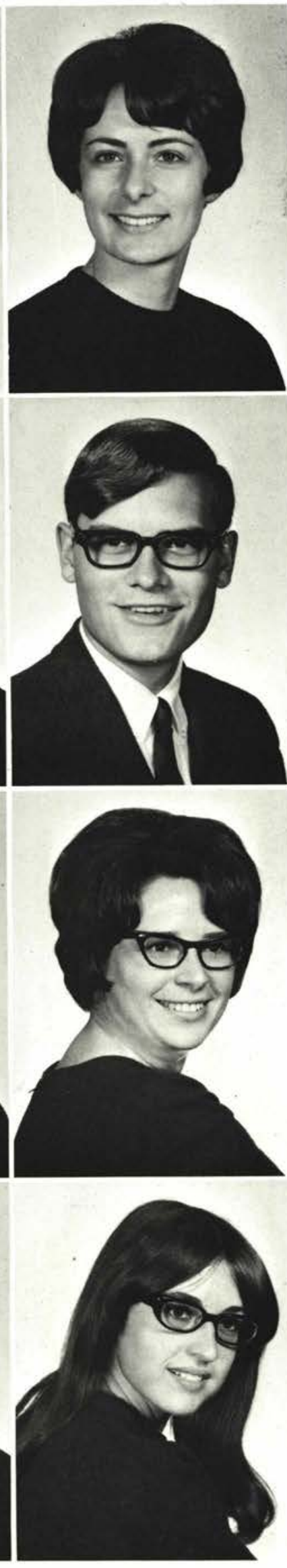

Robert Hunter

Decatur, Ill.

Julene Ivins

Des Moines, Iowa

Barbara Jefferies

Cedarville, $\mathrm{O}$.

William Jefferies

Cedarville, $\mathrm{O}$.

Val Jensen

Williamsville, N.Y.

Ronald Jezowski

Midland, Mich.

Elaine Johnson

Summerville, S.C.

Francis Johnson

Lock Haven, Pa.

Barbara Jordan

Bellefontaine, $\mathrm{O}$.

Samuel Kelley

Fairborne, O.

Barbara Kensil

Decatur, Ill.

Janet Kever

Macedonia, O. 
Donna Kincannon

Lagrange, $\mathrm{O}$.

Maureen King

Dayton, $\mathrm{O}$.

Daniel Kinniburgh

Marion, Montana

Michael Kintz

Colfax, Iowa

Paul Kinvig

Summerland, Canada

Helen Kirby

Cedarville, O.

David Kirchner

Chicago, Ill.

Joy Kleymeer

Grand Rapids, Mich.

Ruth Klomparens Grand Rapids, Mich.

Harry Lake Atlantic City, N.J.

Larry Lavender Troy, O.

Cliff Layner Little Hocking, O.

Roger Leach Camp Point, Ill.

Lynnette Marsh

Corry, Pa.

Mike McCullough Michigan City, Ind.
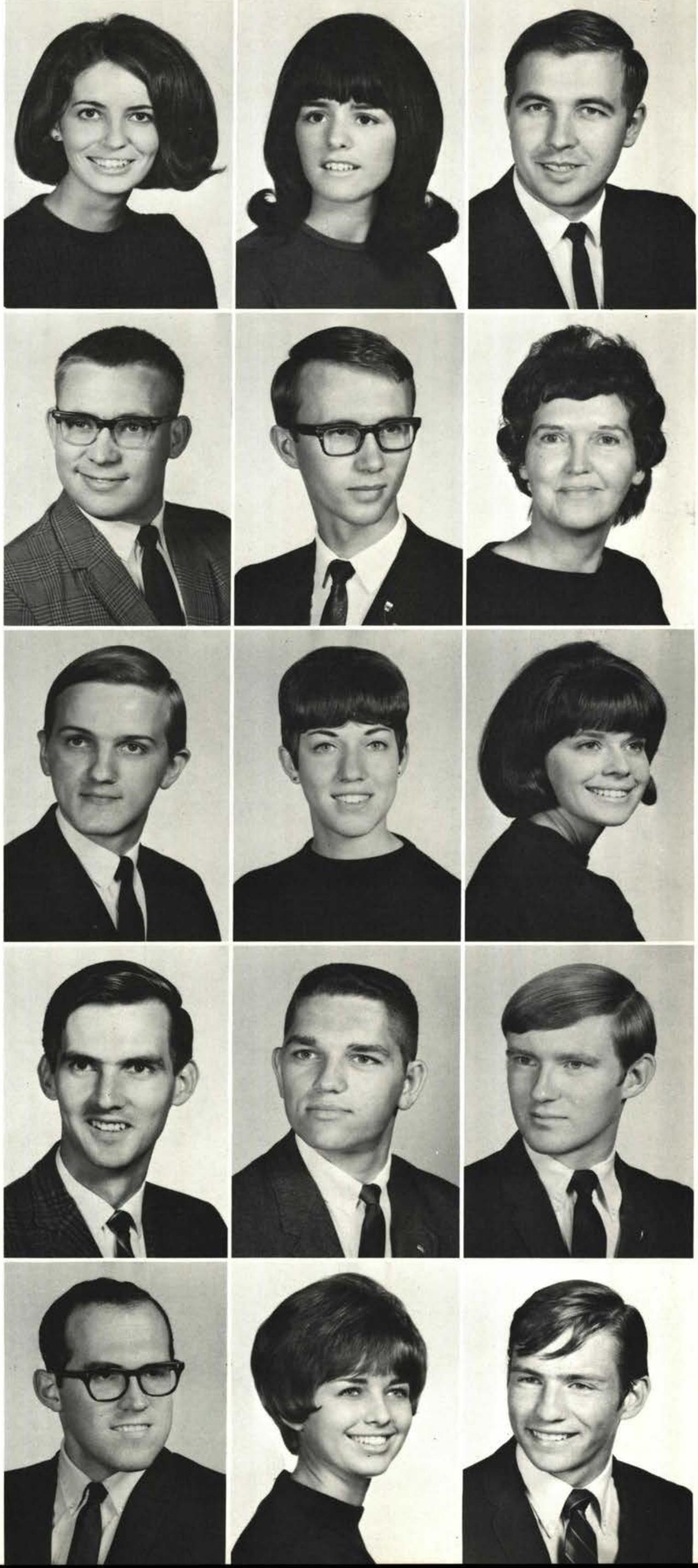



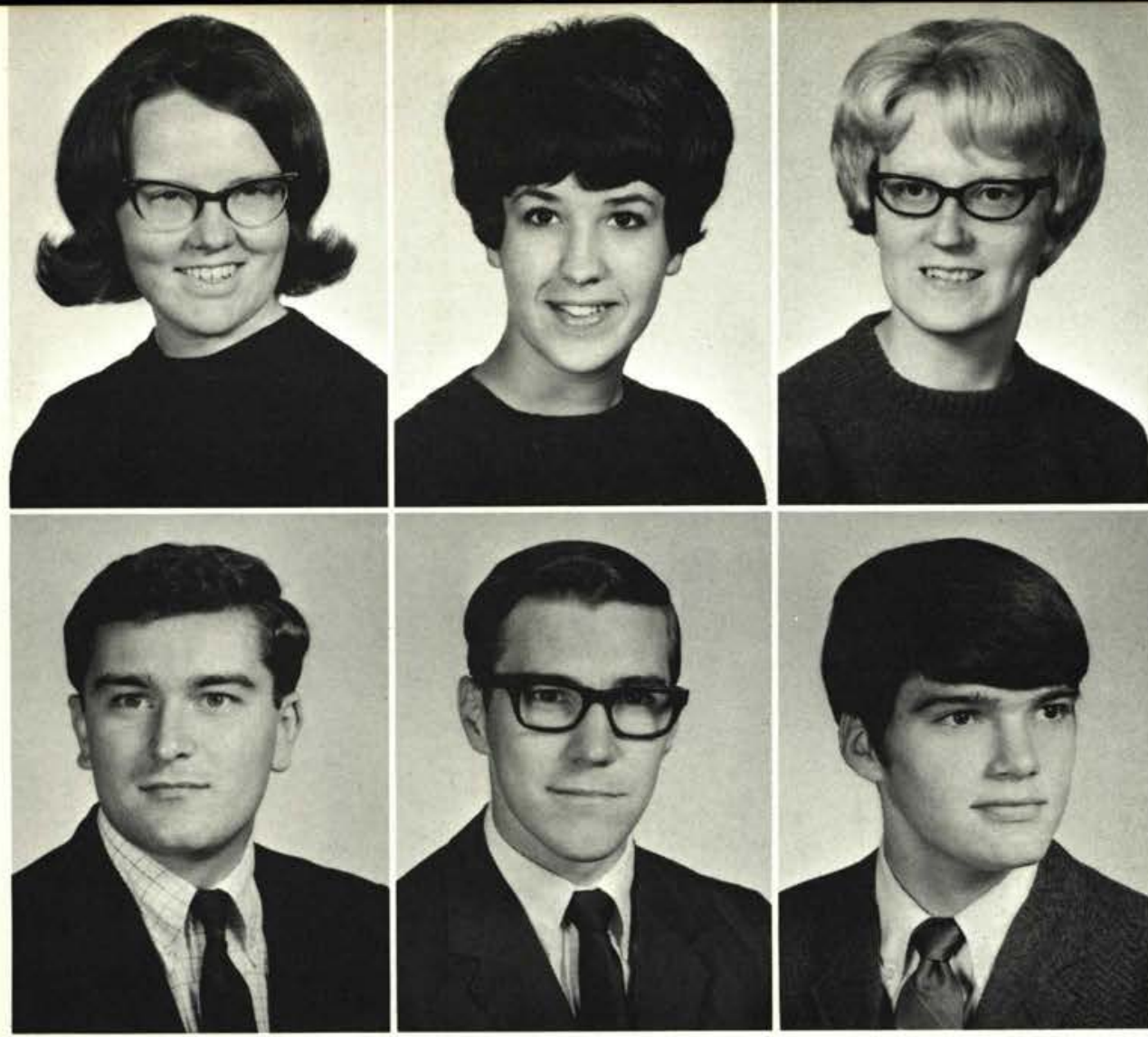

Nancy Towle

Pataskala, O.

Cheryl Trumbull

Cedarville, $\mathrm{O}$.

Ruth Vincent

Cedarville, O.

Daniel Walborn

Wauseon, O.

Nelson Wallis

Thurston, $\mathrm{O}$.

Timothy Warren

Allegan, Mich.
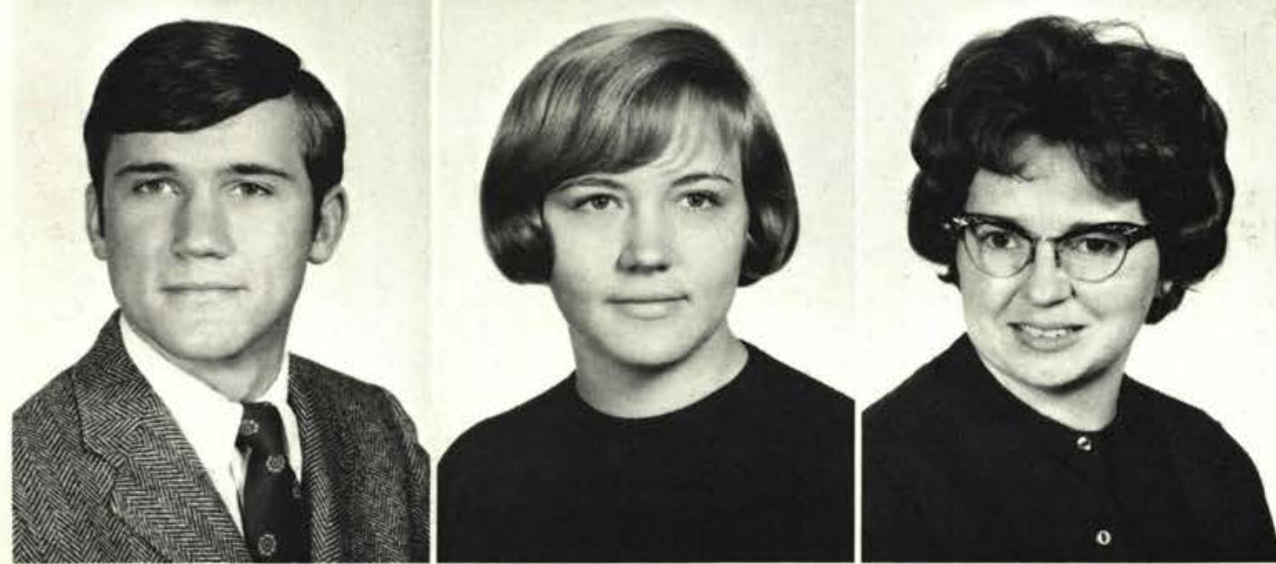

Robert Whattoff

Ames, Iowa

Ellen Whipple

Laceyville, $\mathrm{Pa}$.

Leah Whitney

Coudersport, $\mathrm{Pa}$.
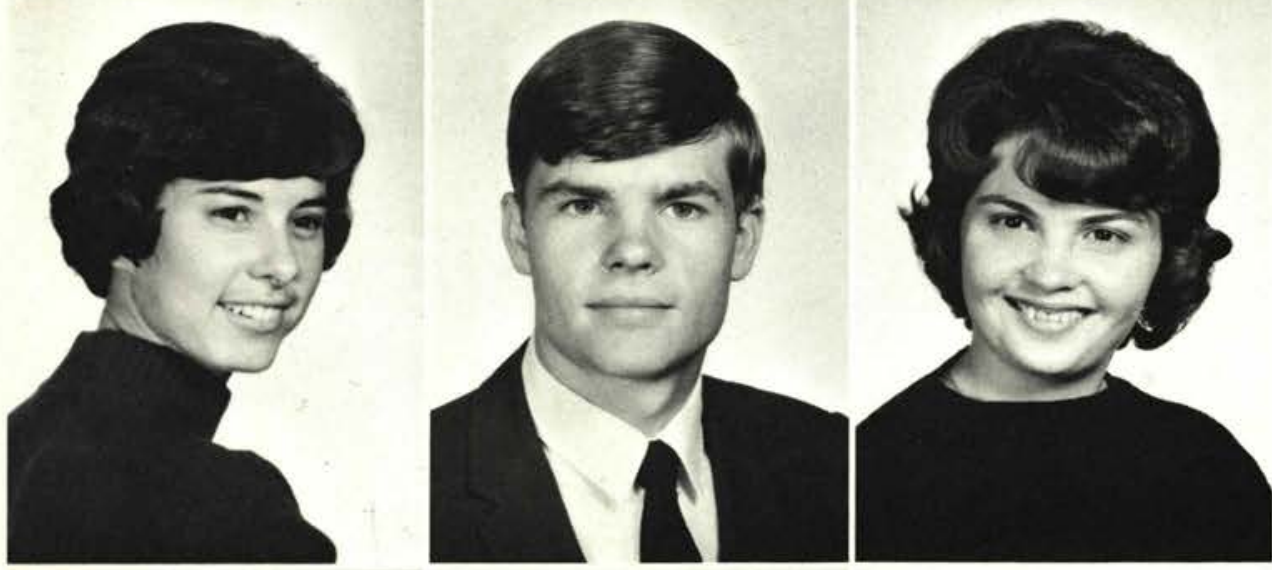

Irene Wilson

Arrada, Colorado

Dale Work

Coudersport, Pa.

Sharon Yeater

Wampum, Pa.

Charlotte Yoder

Hobart, Ind.

Douglas Yoder

West Liberty, O.

\section{Jeff Young}

Lorain, $\mathrm{O}$. 


\section{THOUGHTS . . .}

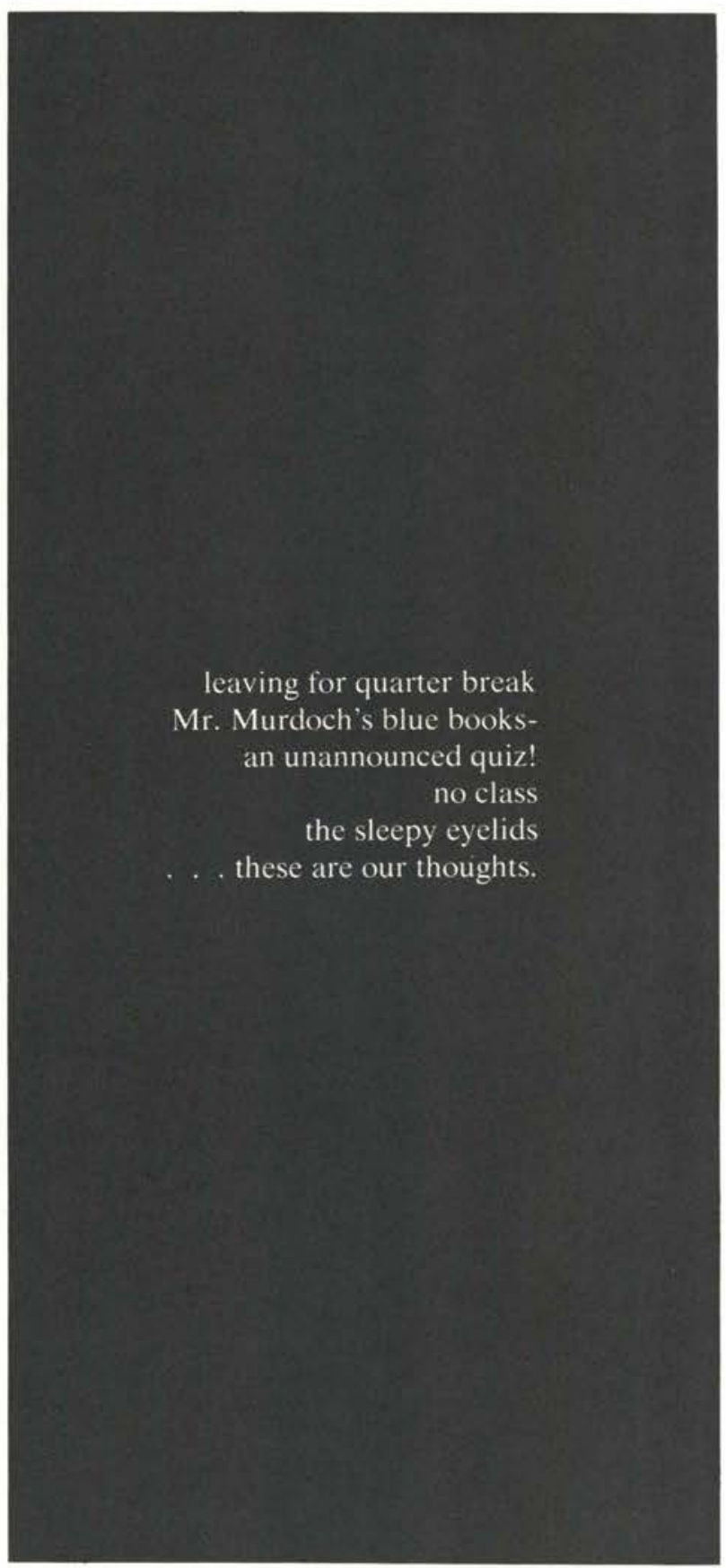



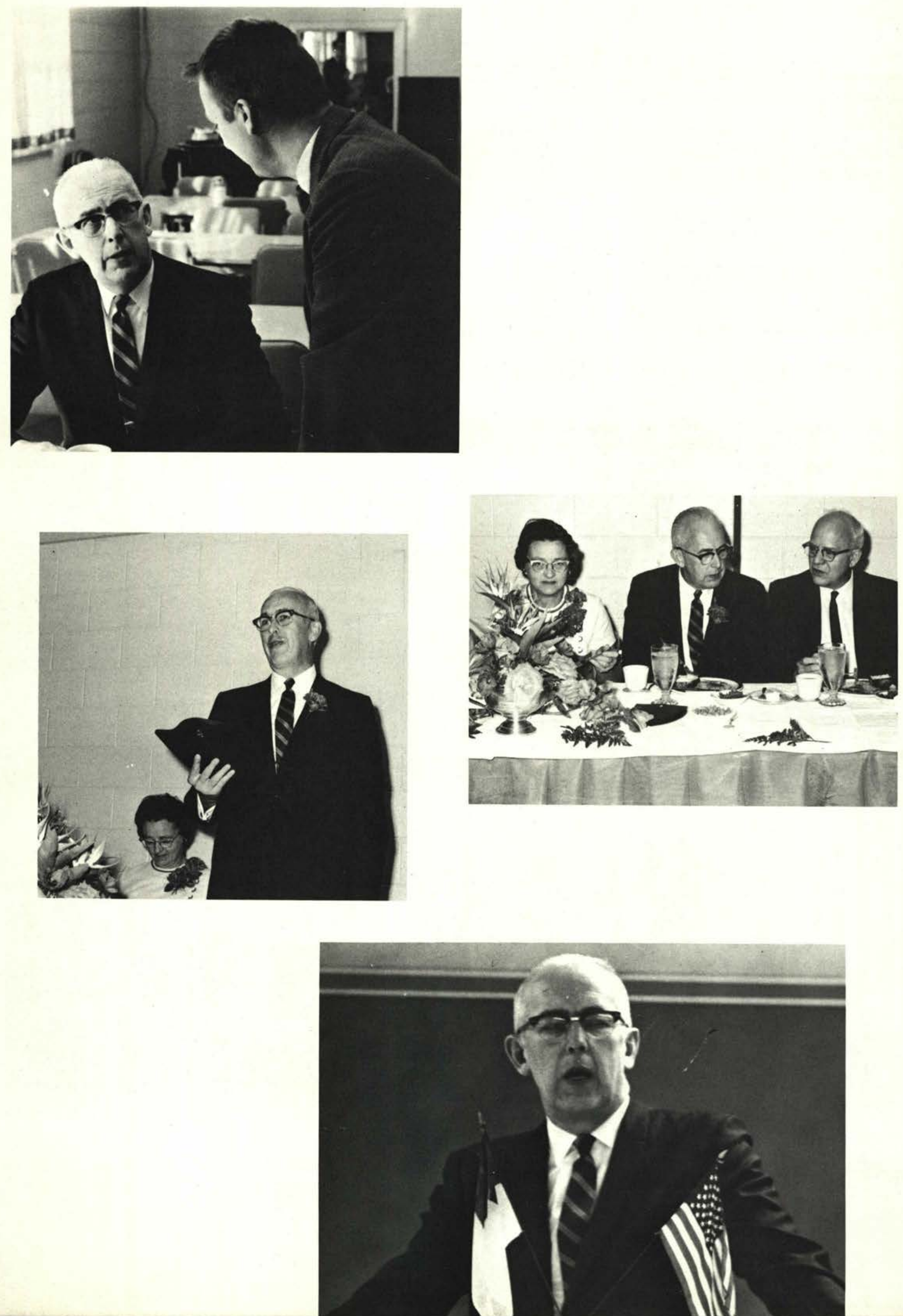
Clifford Johnson, B. Ed., M. Ed., D. Ed.

Academic Dean

C. B. Hurst, B.E., M.A.

Registrar and Director of Admissions
Richard McIntosh, B.A., B.D., Th.M. Dean of Students

Student

Personnel,

Instruction,

Development
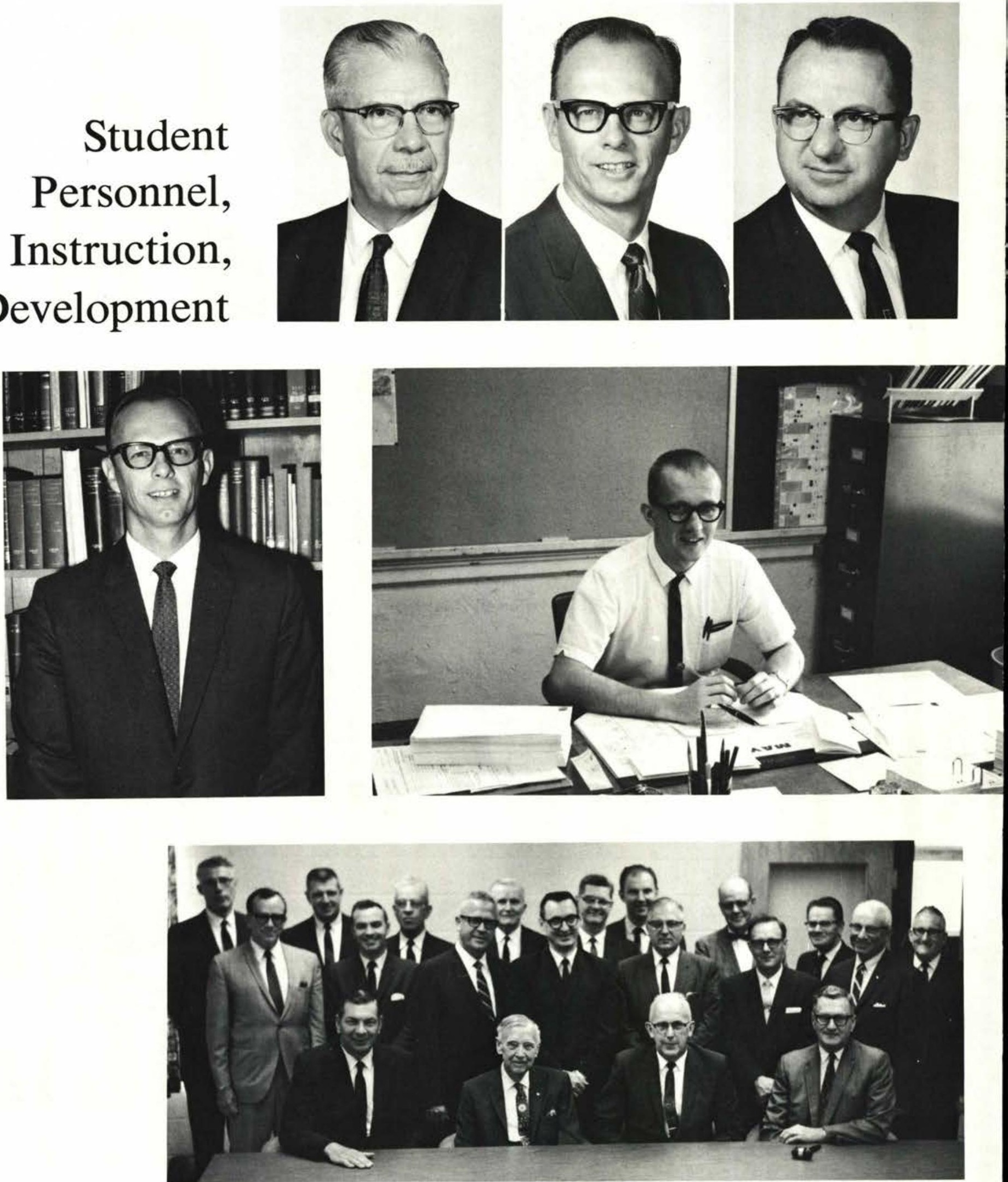
Joyce Moore, Dean of Women

Lee Turner, B.A., B.D.

Director of Development
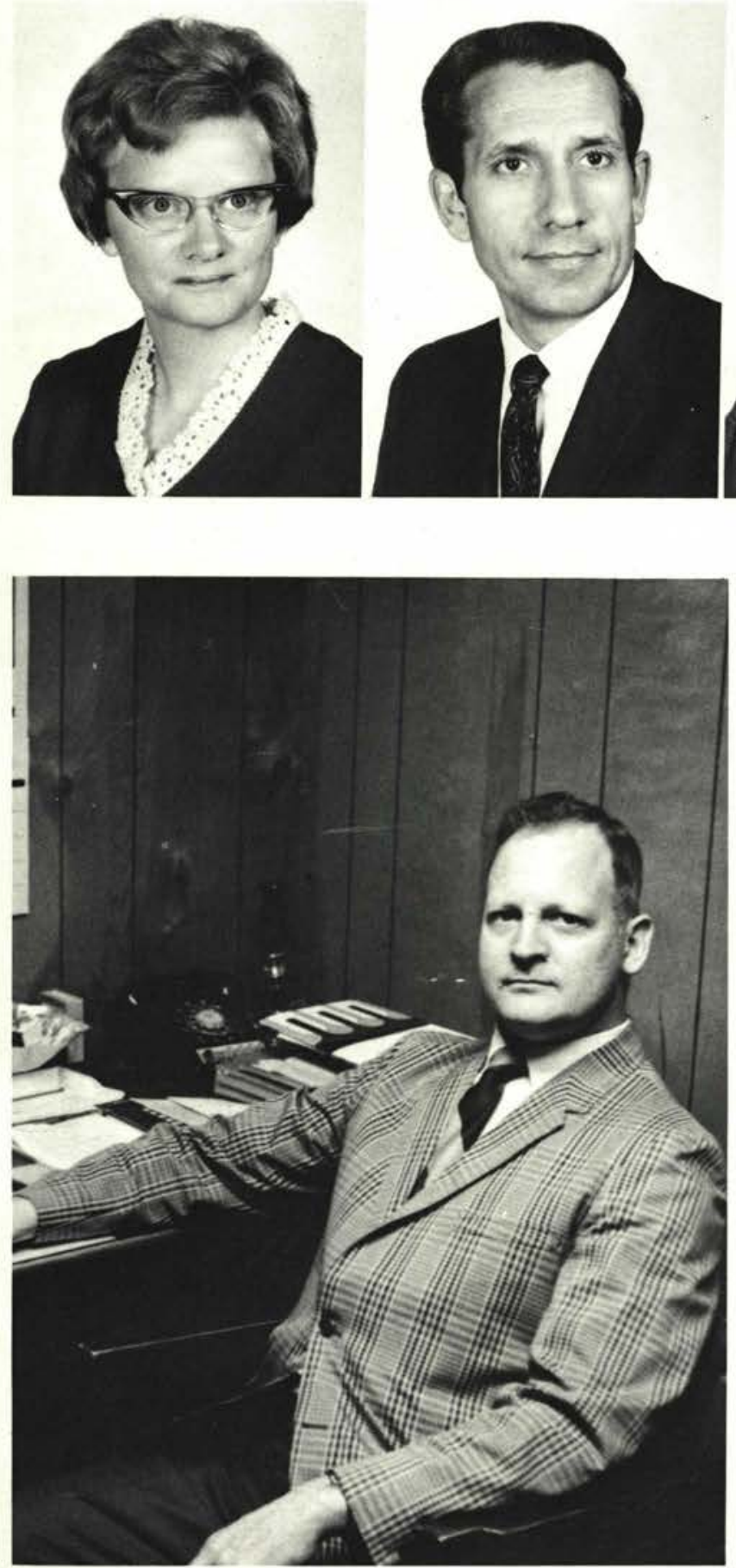

Thomas Loper, B.E., M.A. Dean of Men
Henry Phillips, B.A.

Development Officer

Ralph Yarnell, Jr., B.A.

Alumni Relations
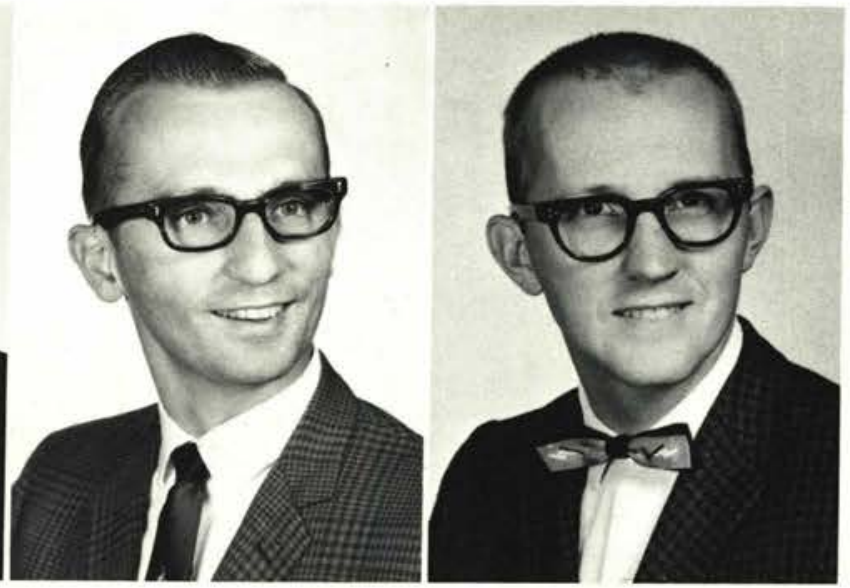

Do good to thy Friend to keep him, to thy Enemy to gain him.

Benjamin Franklin

Counseling with students, planning the growth of the school, and distributing grades are a vital part of the college administration. The traveling, lecturing, and appointments must be squeezed in and yet most of the time of these administrators is allotted to the students - their problems, plans, and friendships.

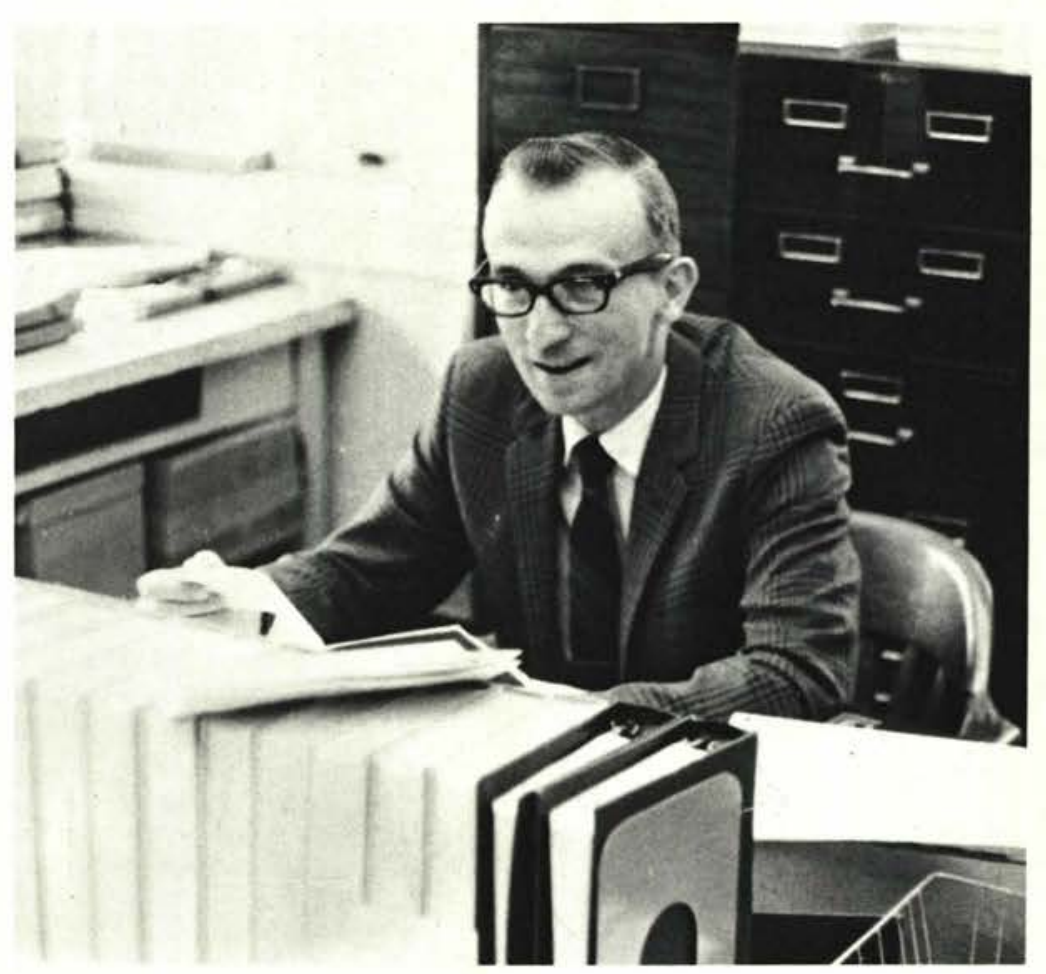




\section{Administrative Secretaries}

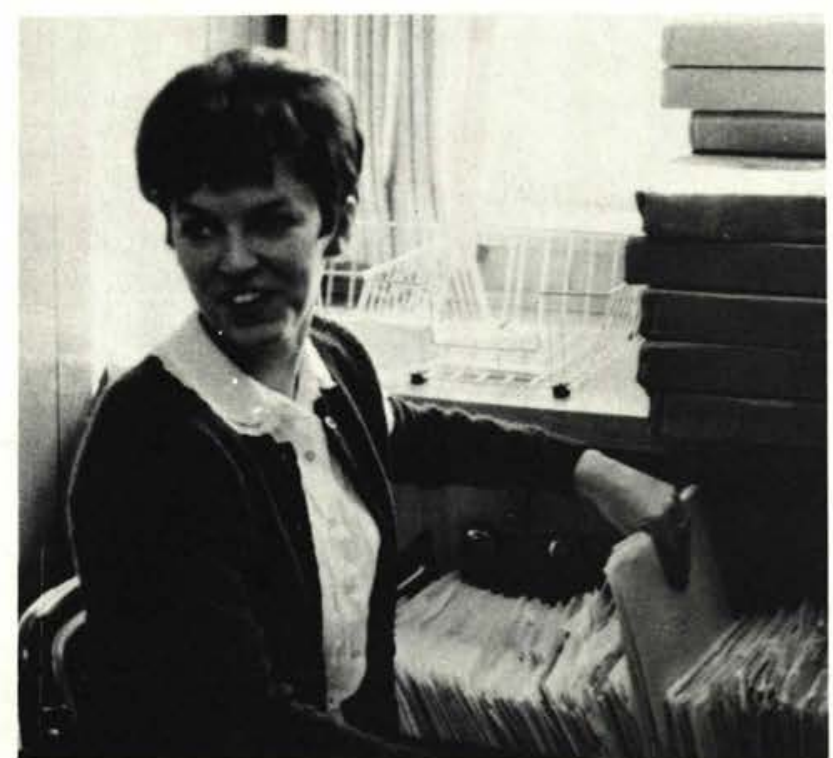

Cheryl Rochwell

Secretary to Director of Development
Diligence is the mother of good luck.

Benjamin Franklin Behind e ver y executive is a harder working secretary. She is the one who types, files, phones, and records, and though seldom praised, she is recognized as the backbone of the institution.
Maribeth Elmore

Secretary to

Business Manager

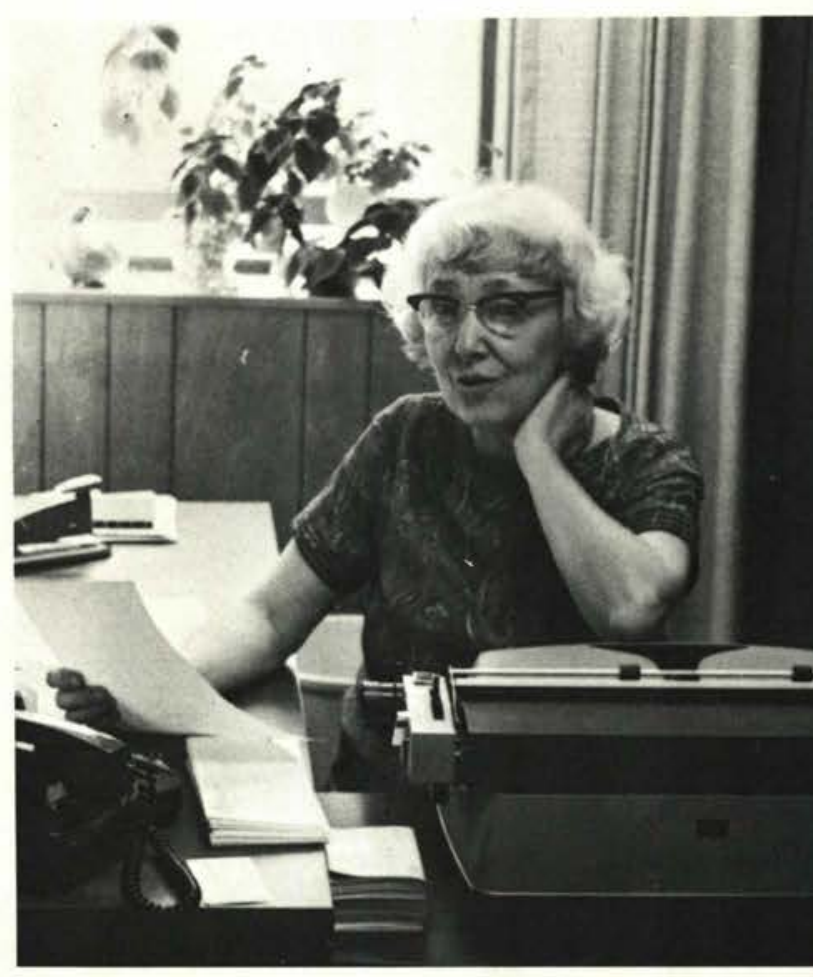

Beryl Brown

Secretary to the President

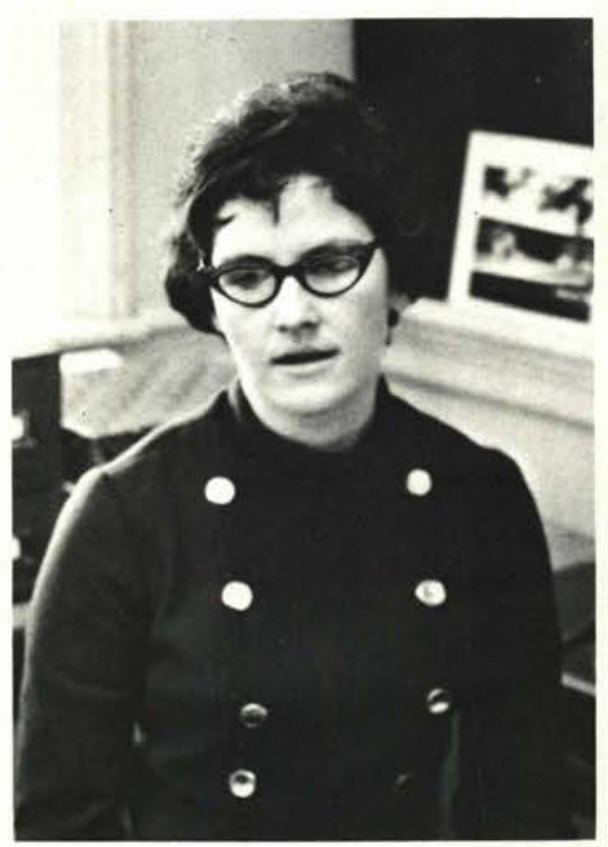

Phyllis Wetzel Secretary of Alumni and Deferred Giving 


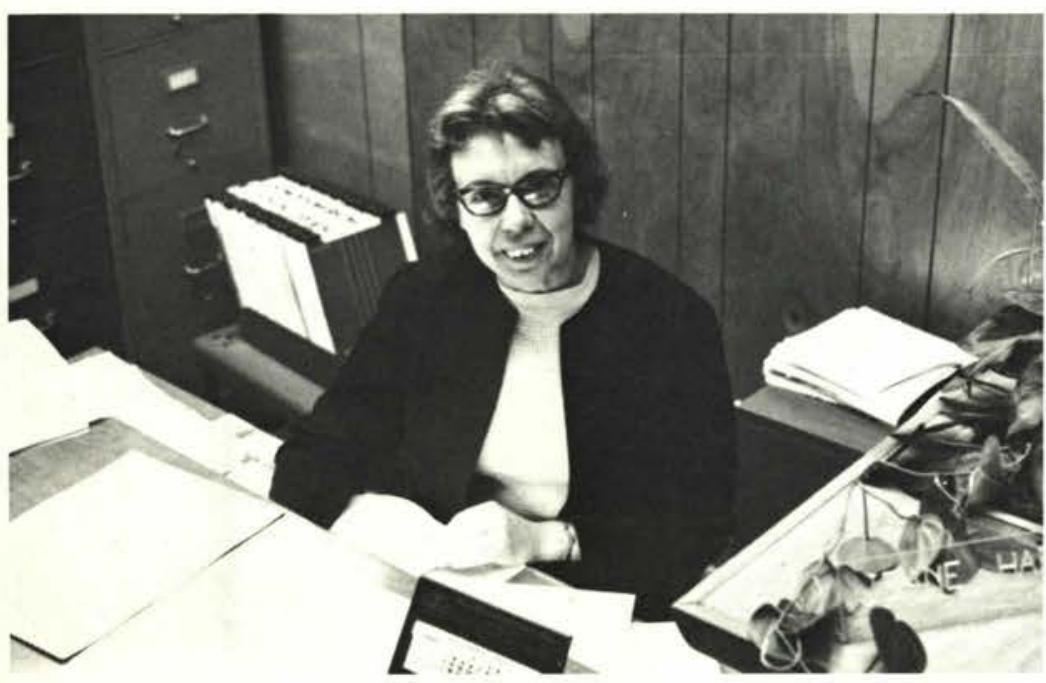

Jeane Hartsell

Secretary to Dean of Students

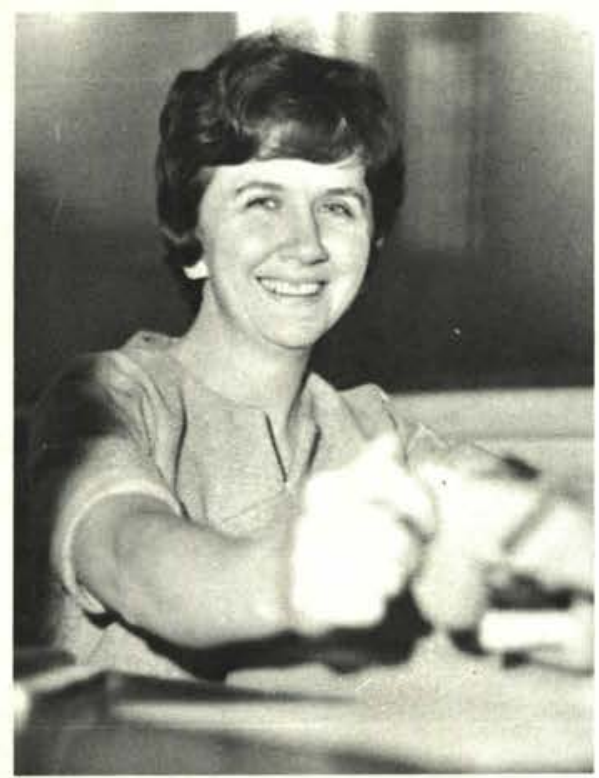

Nancy McPheeters

Secretary to Registrar

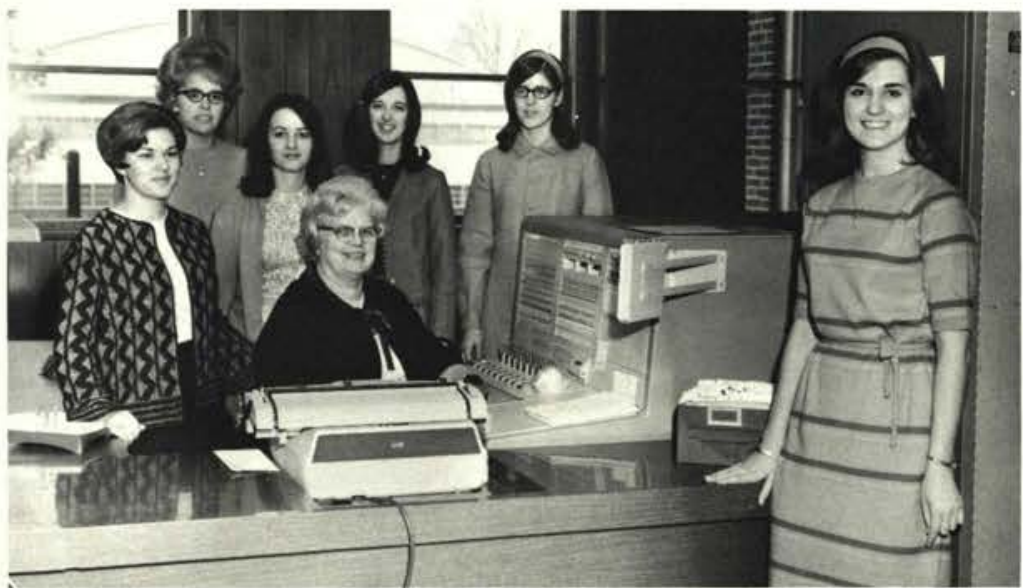

The switchboard operators are Jean King, Darlyne Wuest, Phyllis Beckley, Mrs. Elmore, Jackie Barlow, Joan Miller, and Becky Decker.

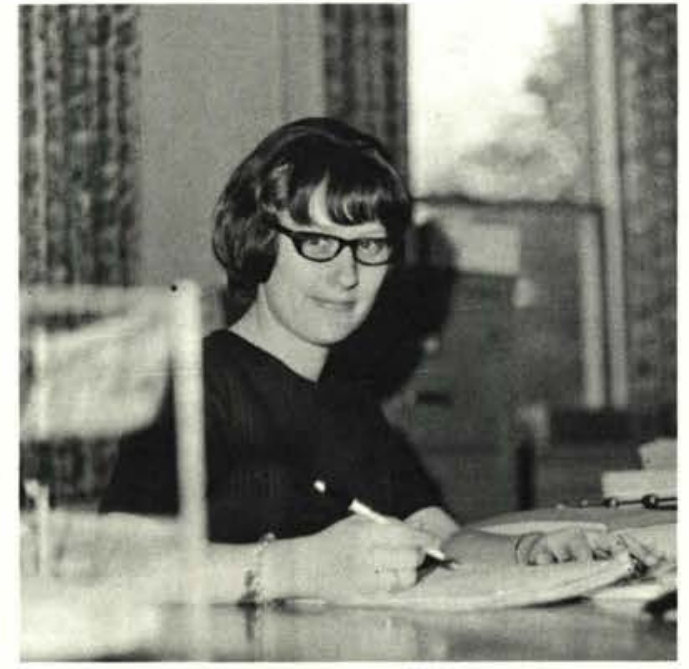

Rebecca Wilhite

Secretary of Admissions and Testing

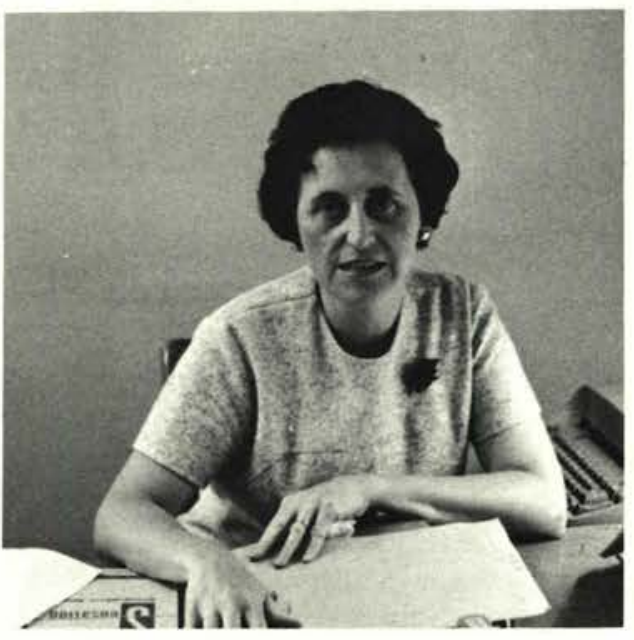

May Greenwood

Secretary to Academic Dean 


\section{Business Office}

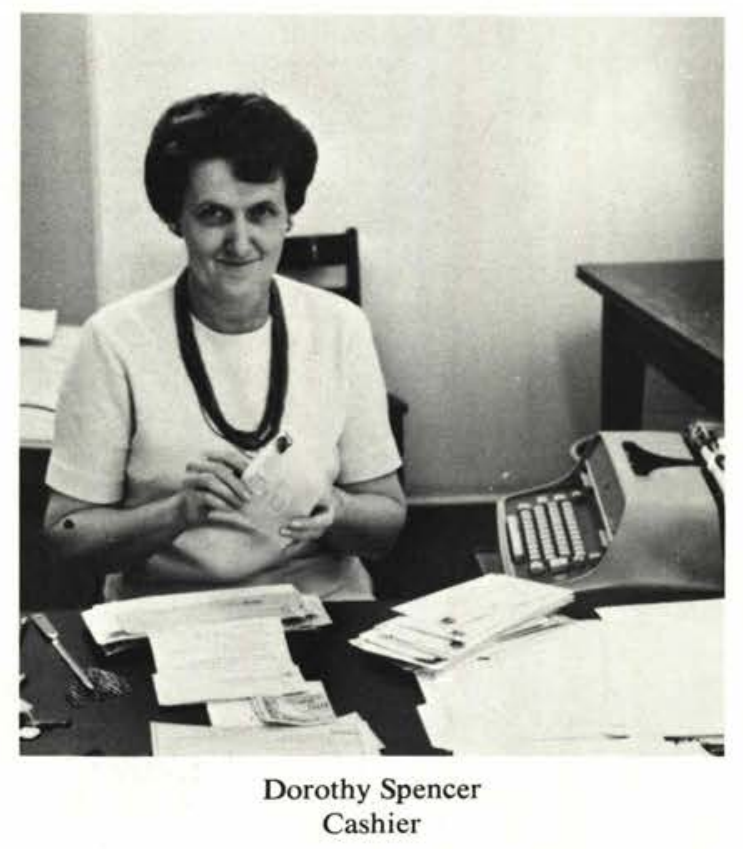

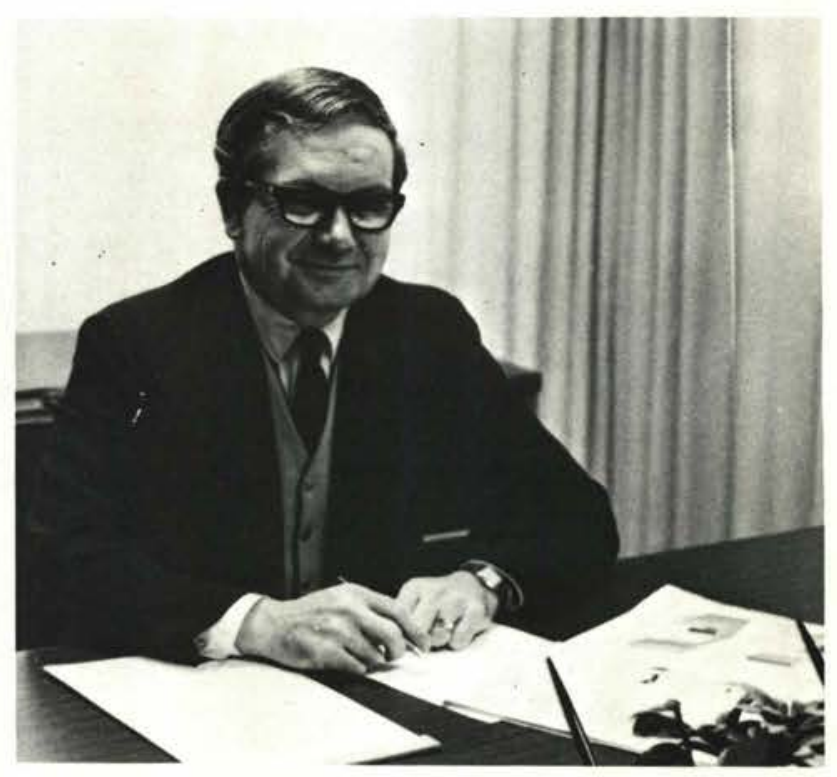

Kenneth H. St. Clair

Business Manager

He that hath a Trade, hath an Estate. Benjamin Franklin

The handling of finances is a job of much work and great import. And to handle it effectively, we have a wellqualified staff. Through their efforts, the college can operate efficiently.

Patricia Thornton

Secretary to Director of Physical Plant

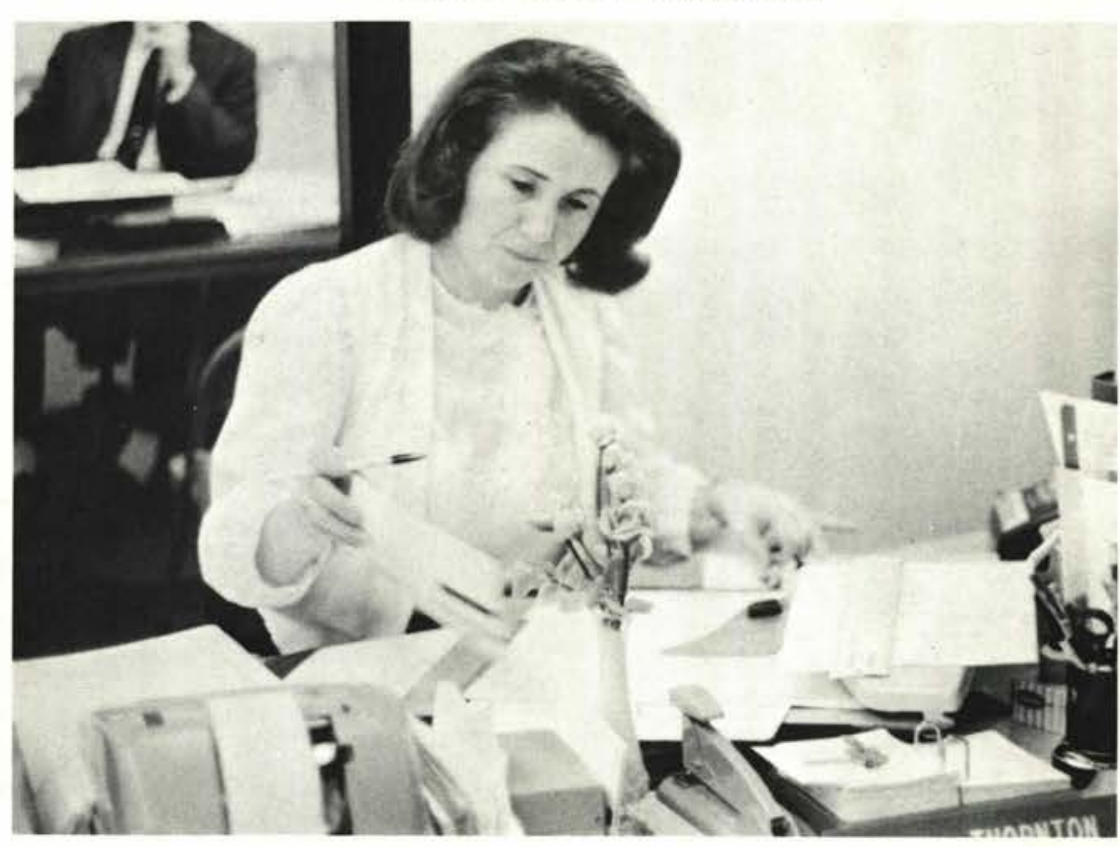




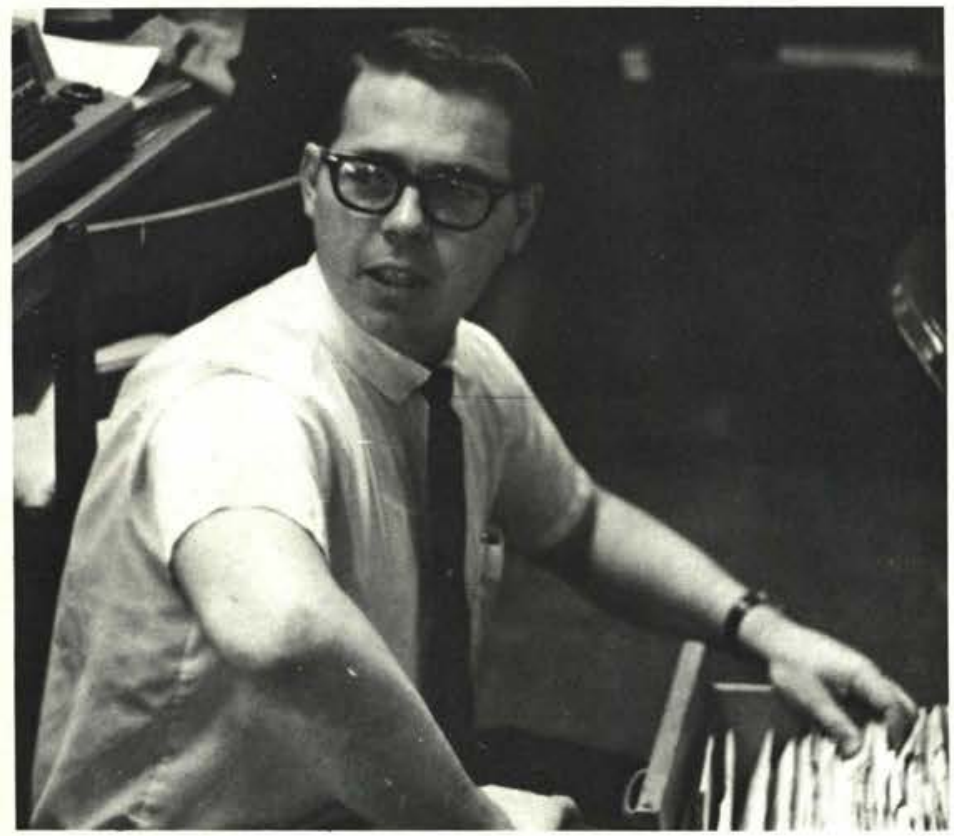

Roger Clay

Manager of Print Shop

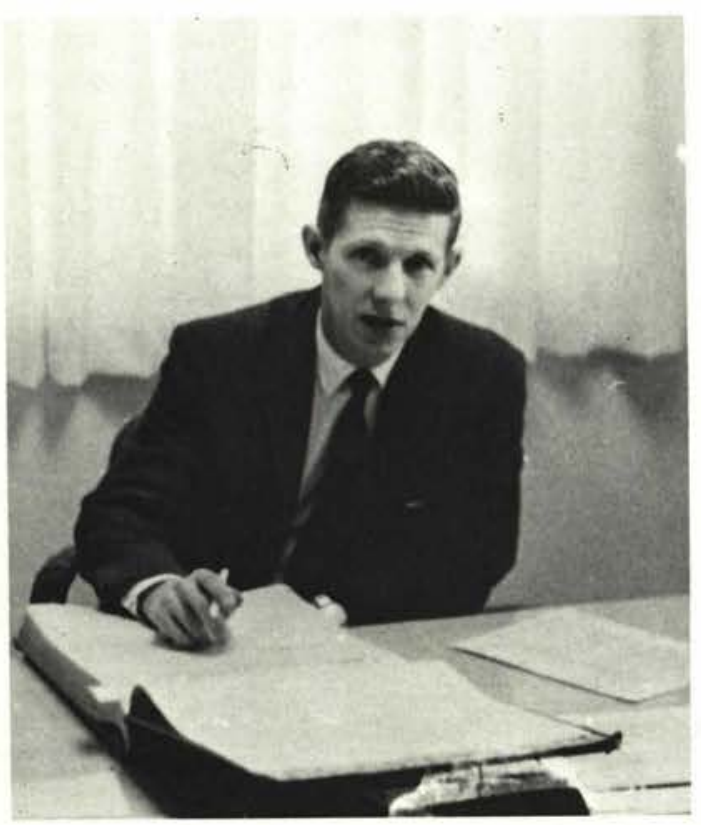

David Gidley

Accountant

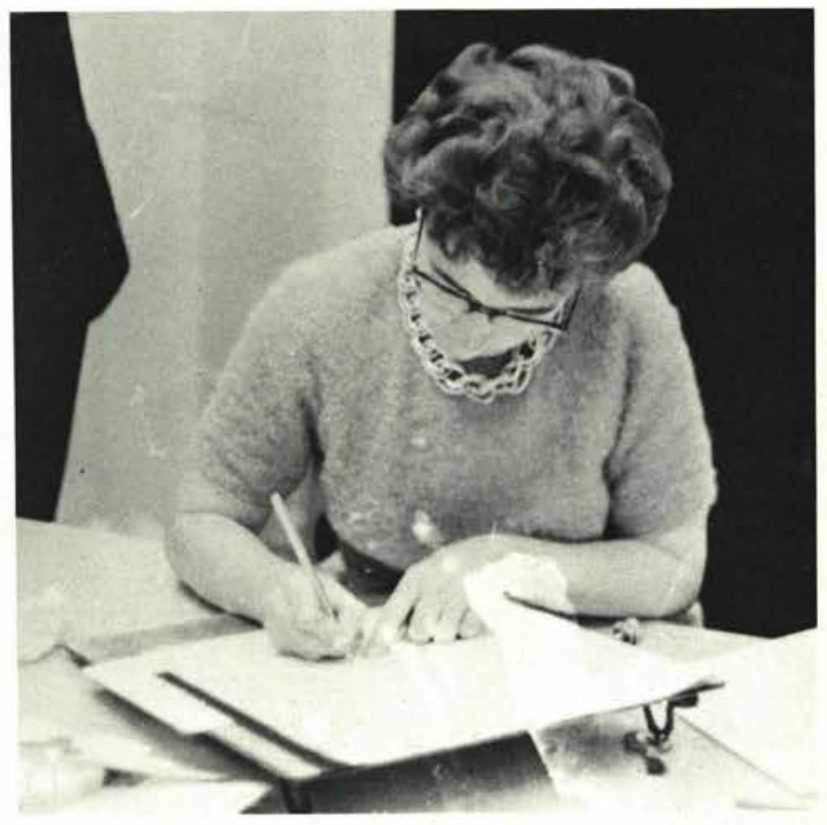

Verna Carter

Accounts Payable

Tyronne Bryant

Alumni and Deferred Giving

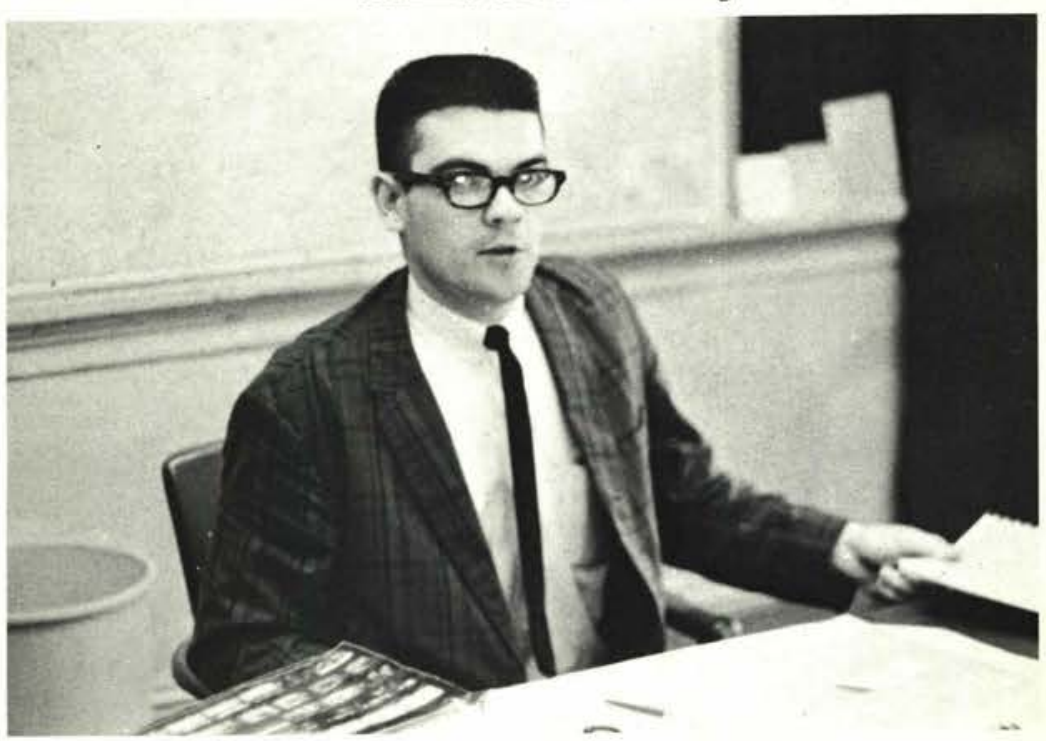


Mead Armstrong, M. Litt.

Jean Fisher, M.A.

George Lawlor, Th.D.

Not pictured

\section{Biblical Education}

Many a Man thinks he is buying pleasure when he is really selling himself a Slave to it.

Benjamin Franklin

Instruction in spiritual guidelines for living, delving into the historical setting, and applying practical principles of soulwinning are basic activities of the Biblical Education department. And yet through all the teaching, that of greatest value is their sincerity in providing a college experience of spiritual growth.
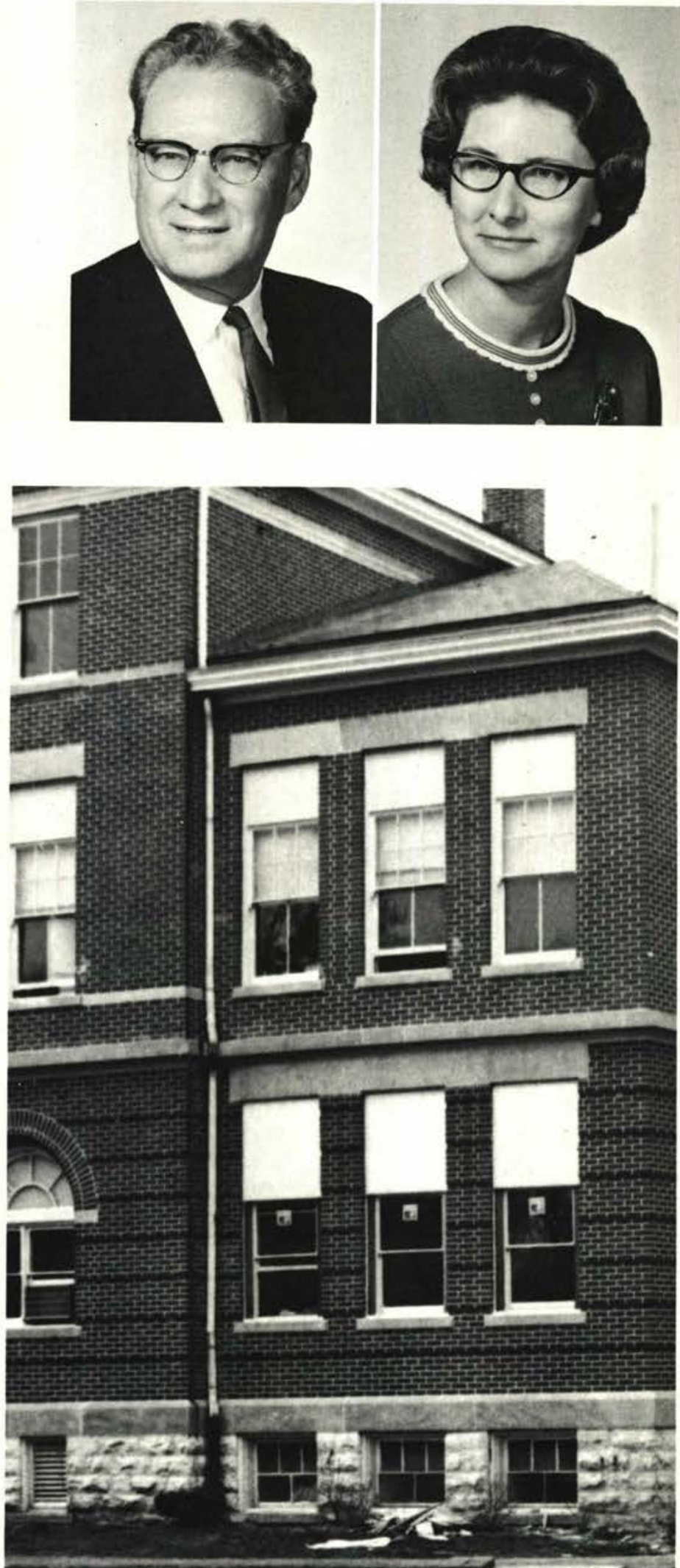


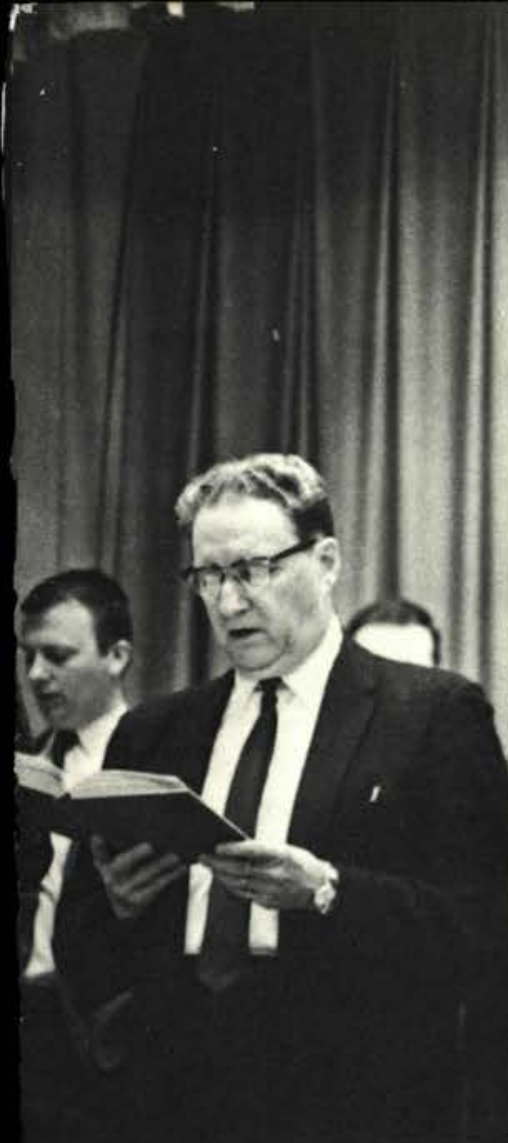

Robert Gromacki, Th.D.

Joy Mackay, M.A.

Jack R. Riggs, Th.D.
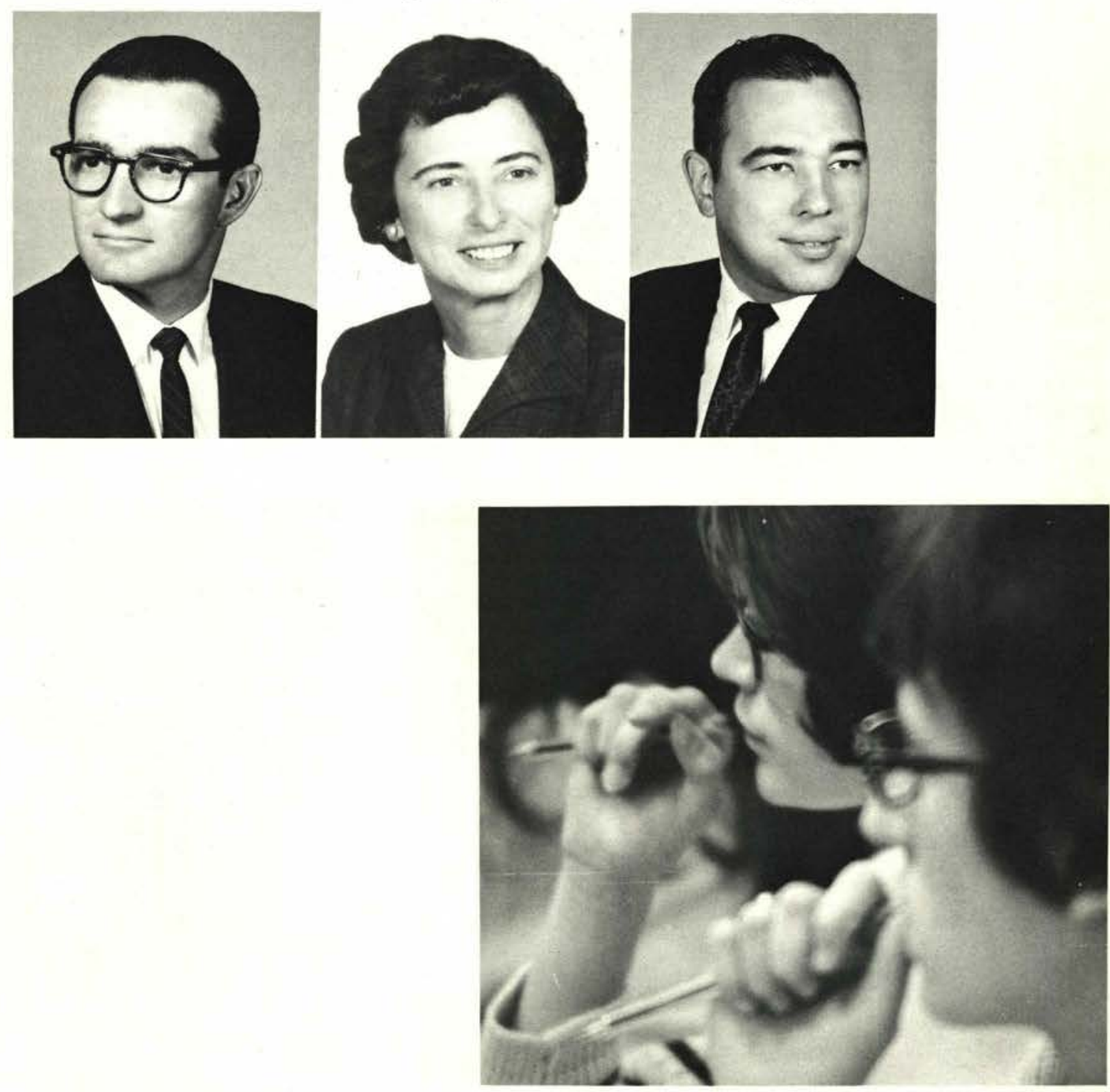


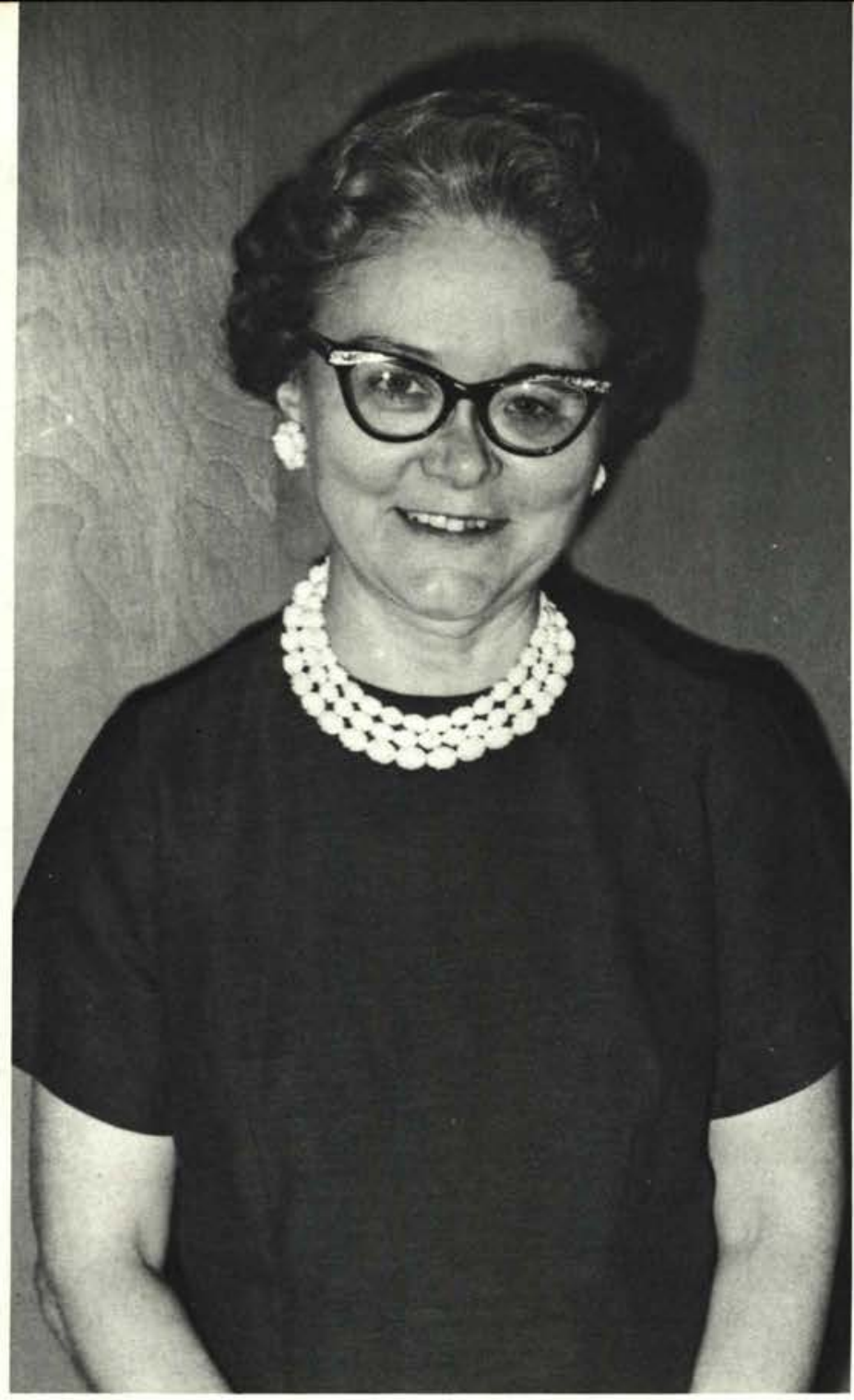

Learn of the skillful: He that teaches himself, hath a fool for his master.

Benjamin Franklin

The task of motivating the prospective teacher, the social worker, the modern adult has been placed in the hands of capable, skillful personnel. And as we are taught of new techniques and methods, of new ideas and philosophies, we are getting the experience we need to someday share our learning with others — the learning of the skillful.
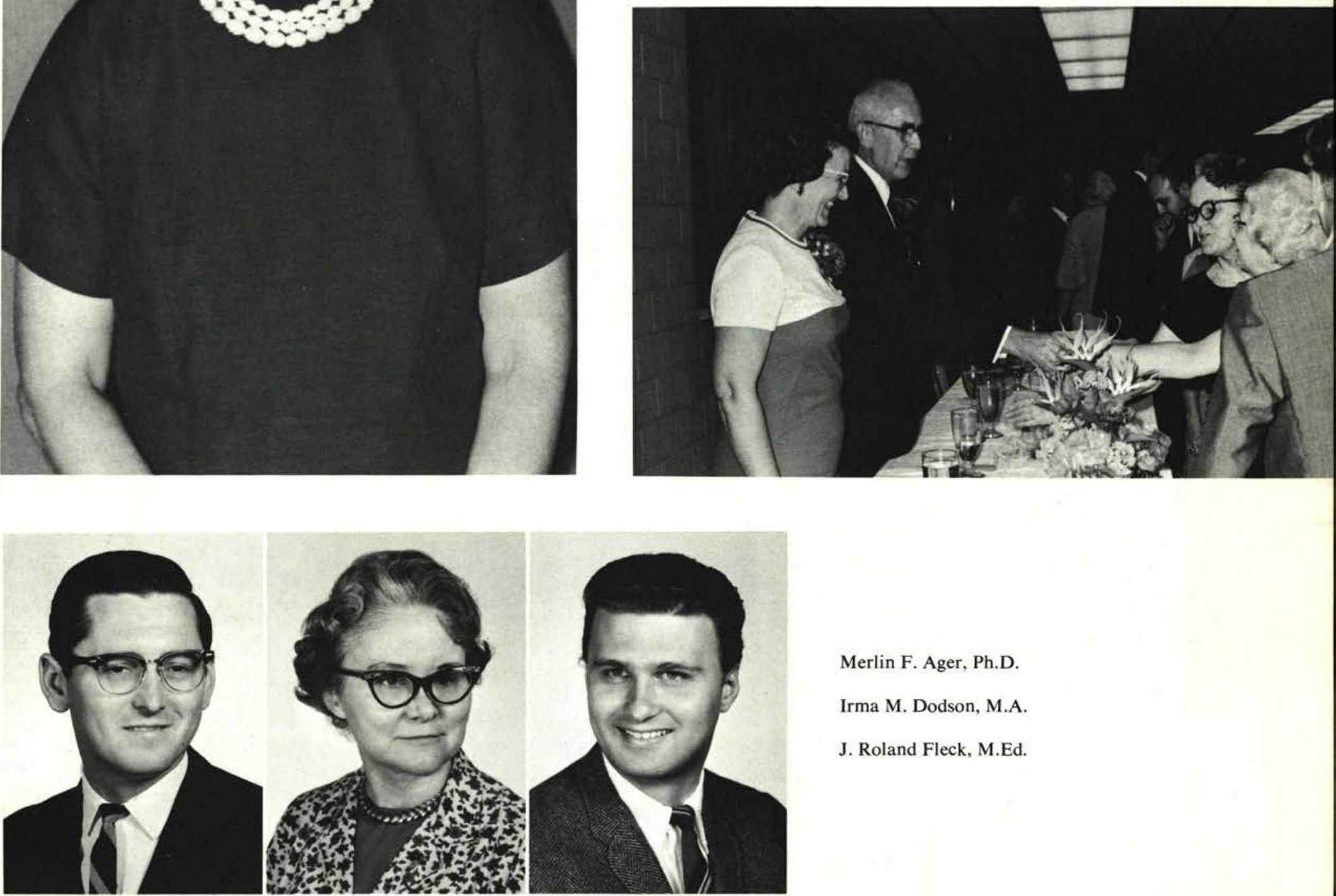

Merlin F. Ager, Ph.D.

Irma M. Dodson, M.A.

J. Roland Fleck, M.Ed.
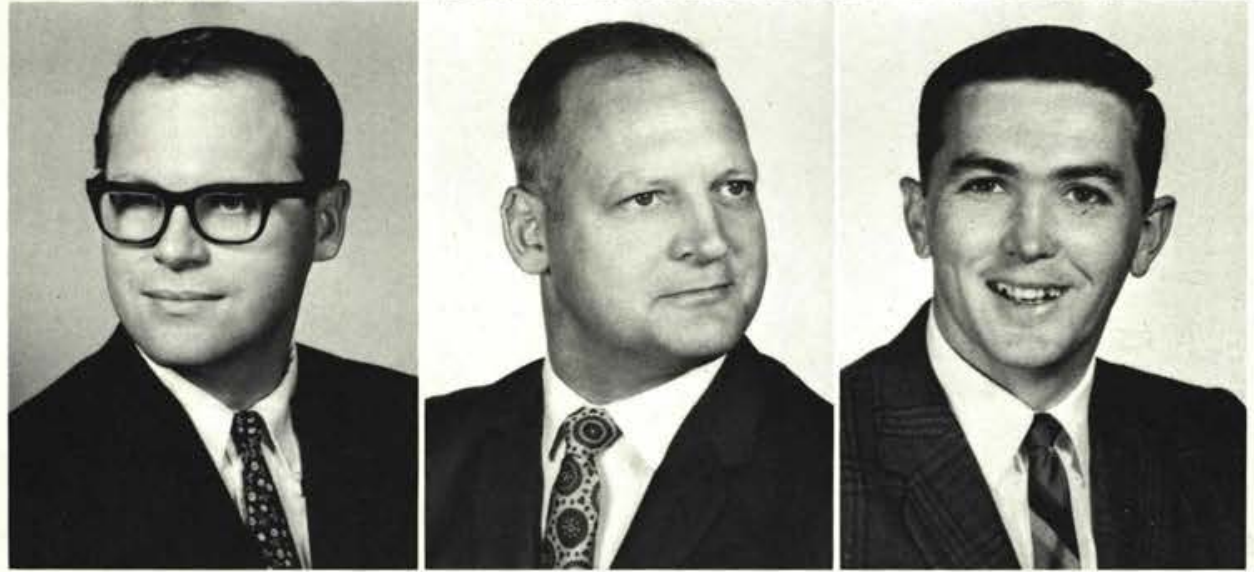

Dwayne Frank, M.S.

Thomas E. Loper, M.A.

Brad Moore, M.A.

Stanley N. Ballard, M.S.

Not pictured 


\section{Language and Literature}

Harmon Bergen, M.A.

Sharon Boylan, B.A.

Paul Gathany, B.A.

Edward L. Greenwood, M.A.

Ronald Grosh, M.A.T.

Miriam Maddox, B.A.
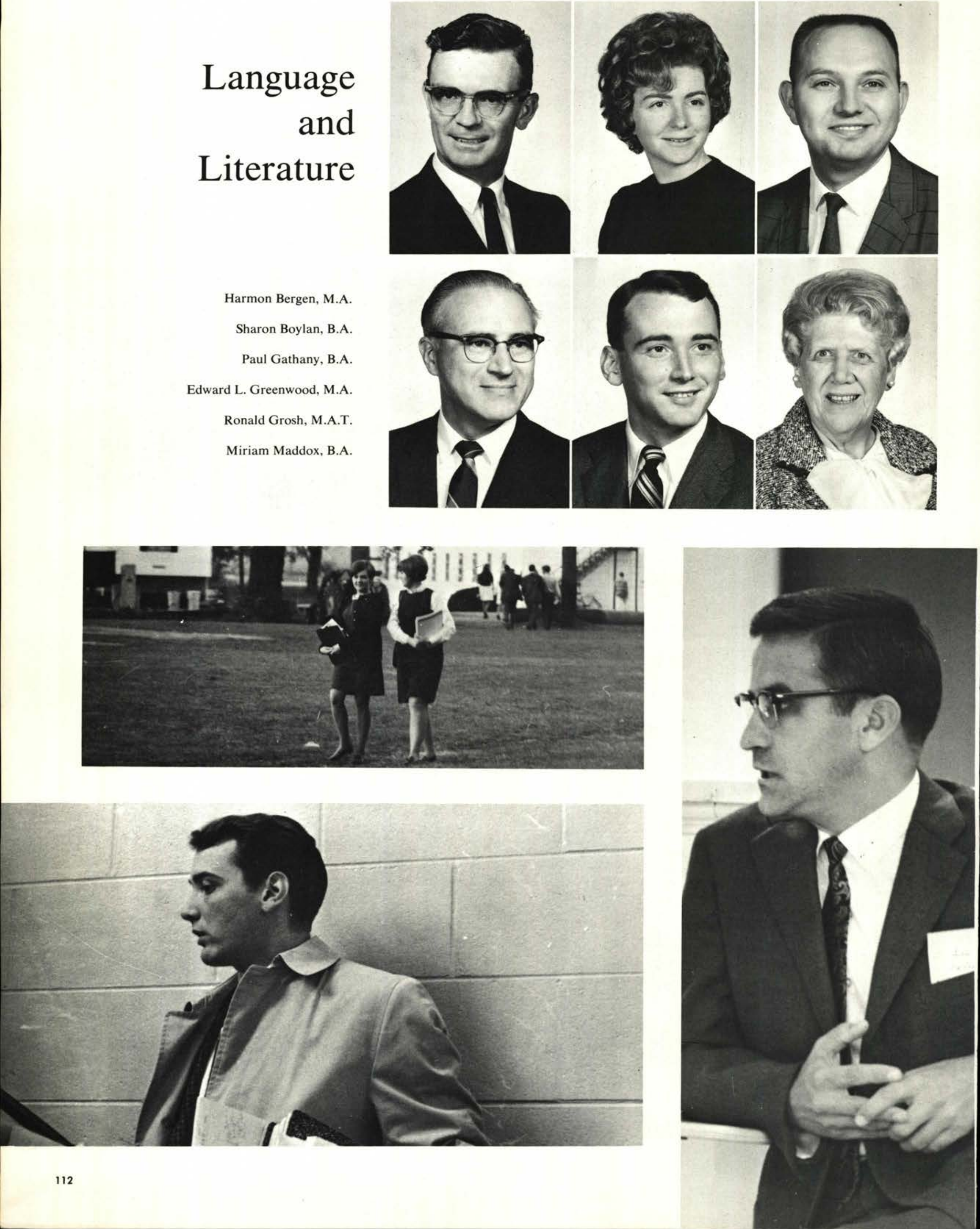


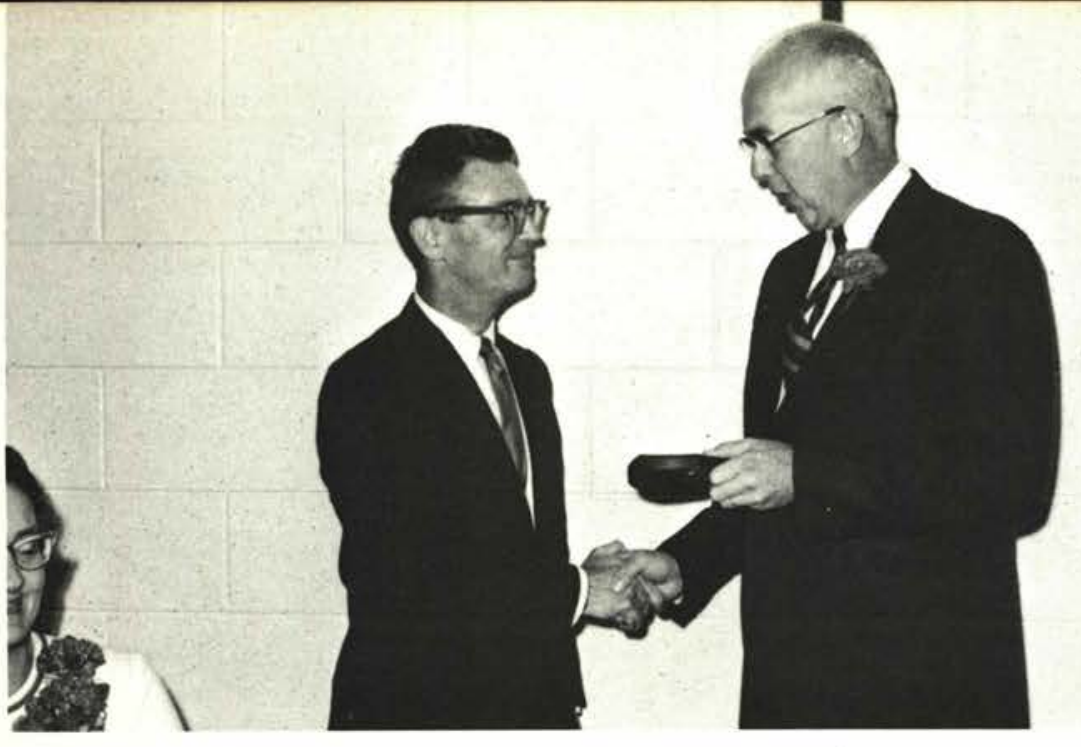

Reading makes a full man-Meditation a profound man-Discourse a clear man.

Benjamin Franklin

And to stimulate our thinking into better means of reading, meditation, and discourse, are the professors of language and literature. The discovery of writings, the thrill of a debate, the vividness of a foreign word, and the fluency of an announcer are the unforgettable learning experiences of these classes.
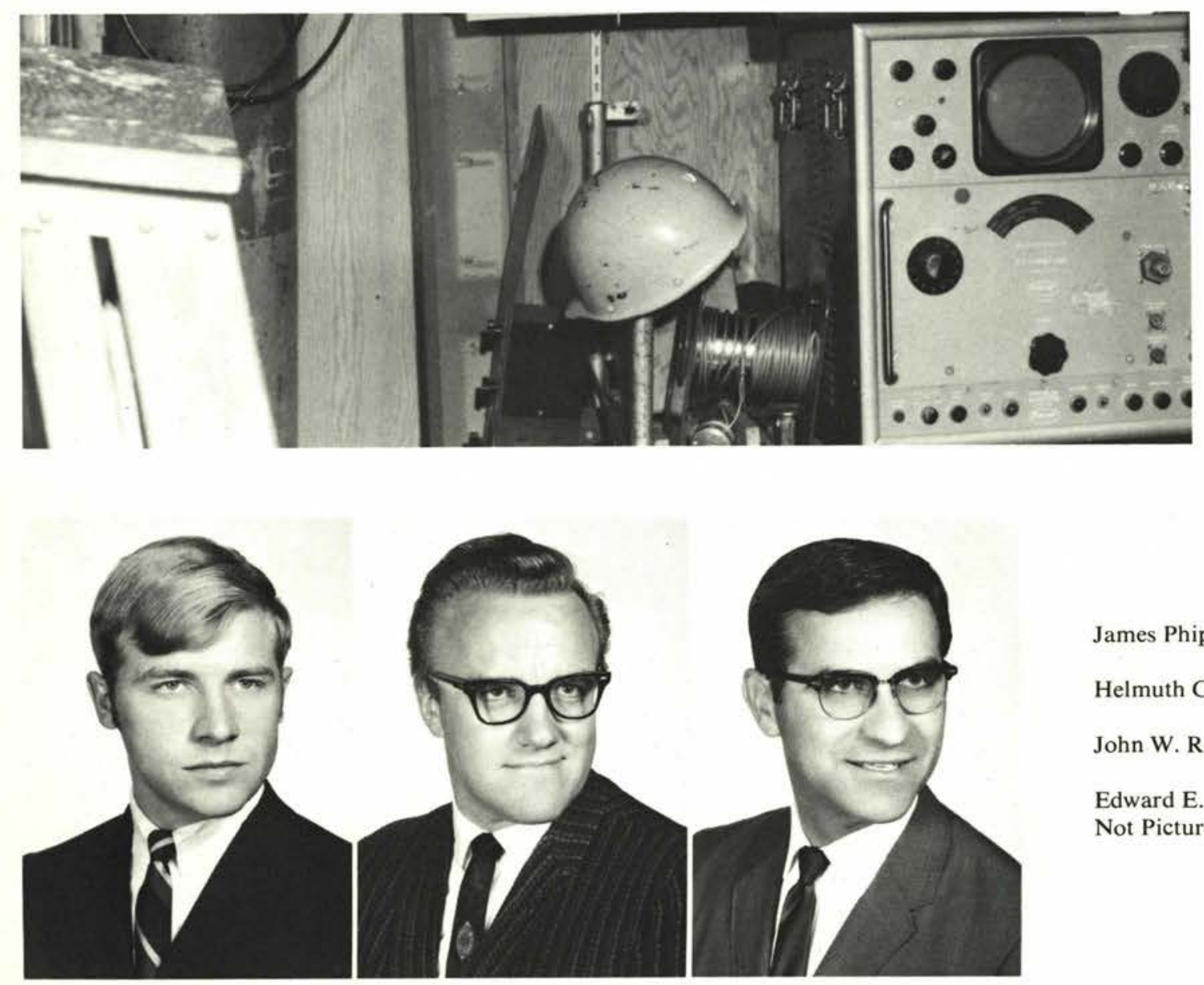

James Phipps, B.A.

Helmuth C. Poggenmiller, M.A.

John W. Reed, Ph.D.

Edward E. Spencer, M.A

Not Pictured
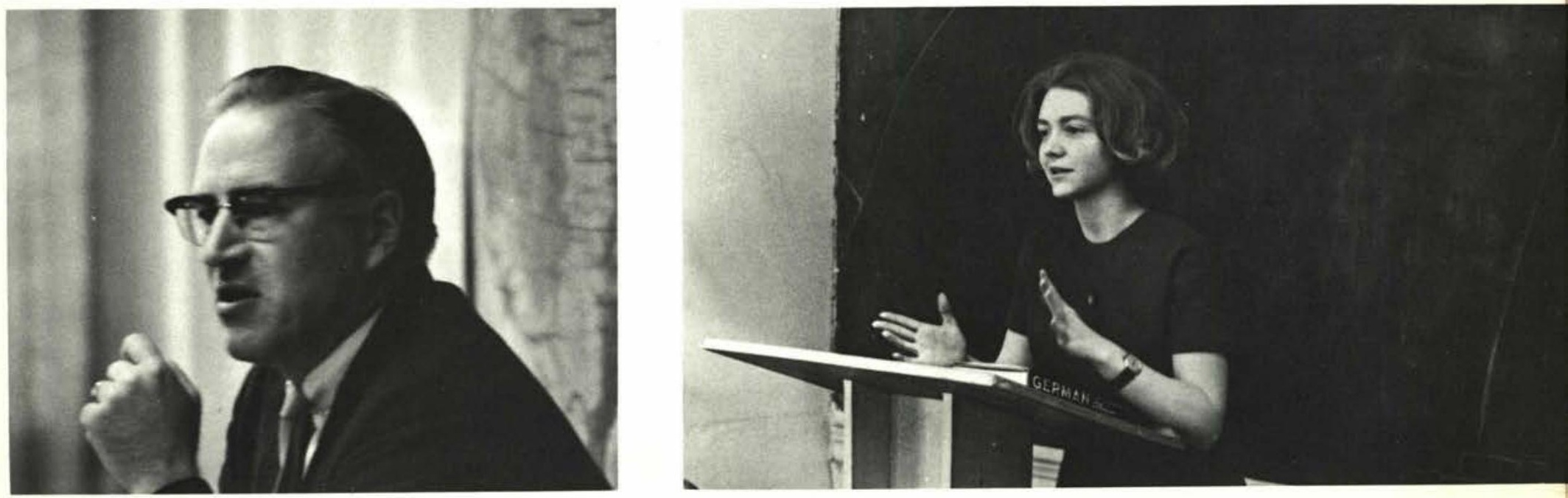

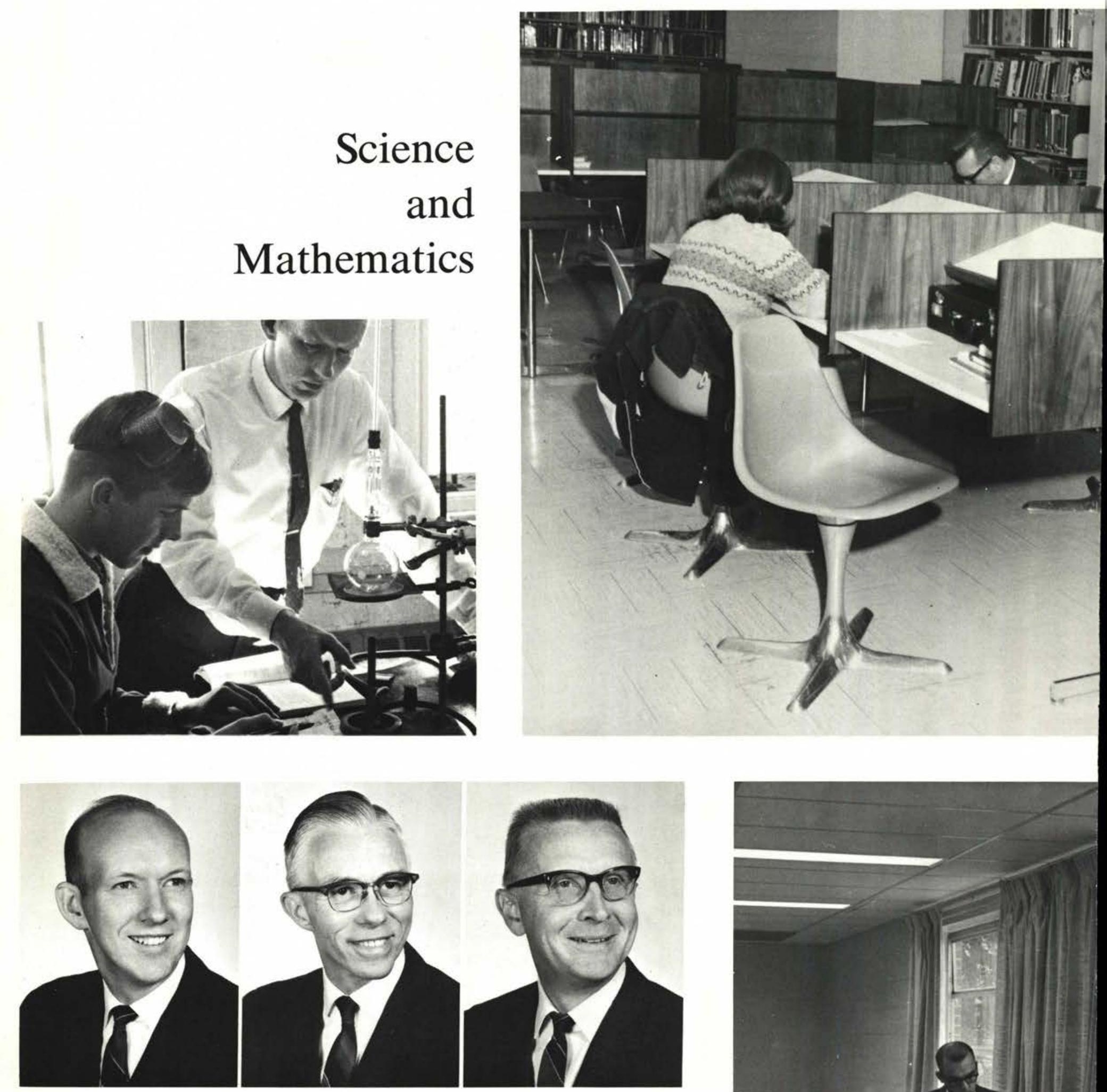

Donald P. Baumann, Ph.D.

Austin D. Elmore, M.A.T.

L. Bert Frye, M.A.T. 
Ralph B. Gale, M.A.

Cleveland McDonald, Ph. D.

Allen L. Monroe, M.A.

Murray Murdoch, M.A

Ardeth Webber, M.A

Donald T. Wilcoxon, M.A.

William R. Riter, B.S., C.P.A Not pictured
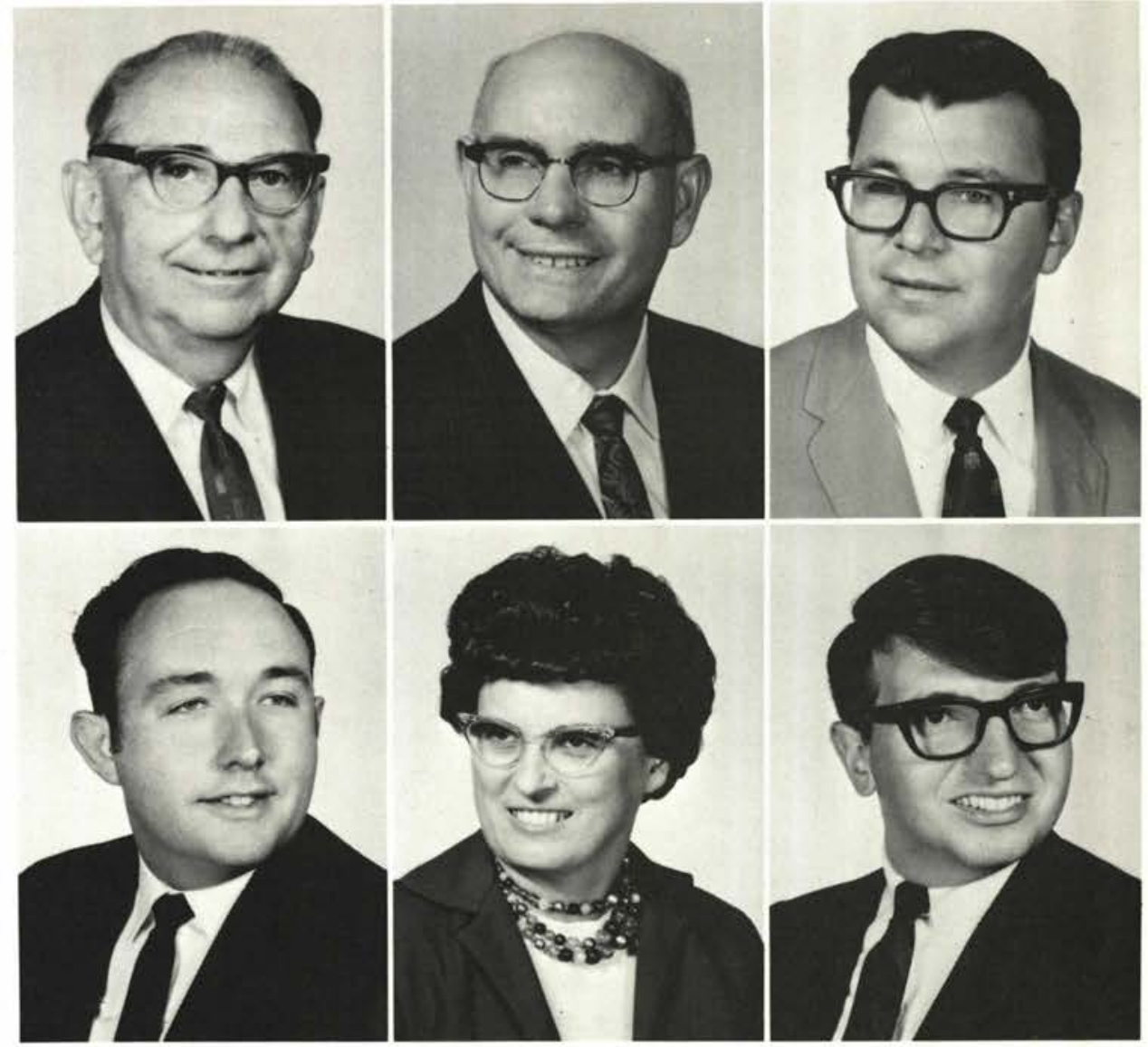
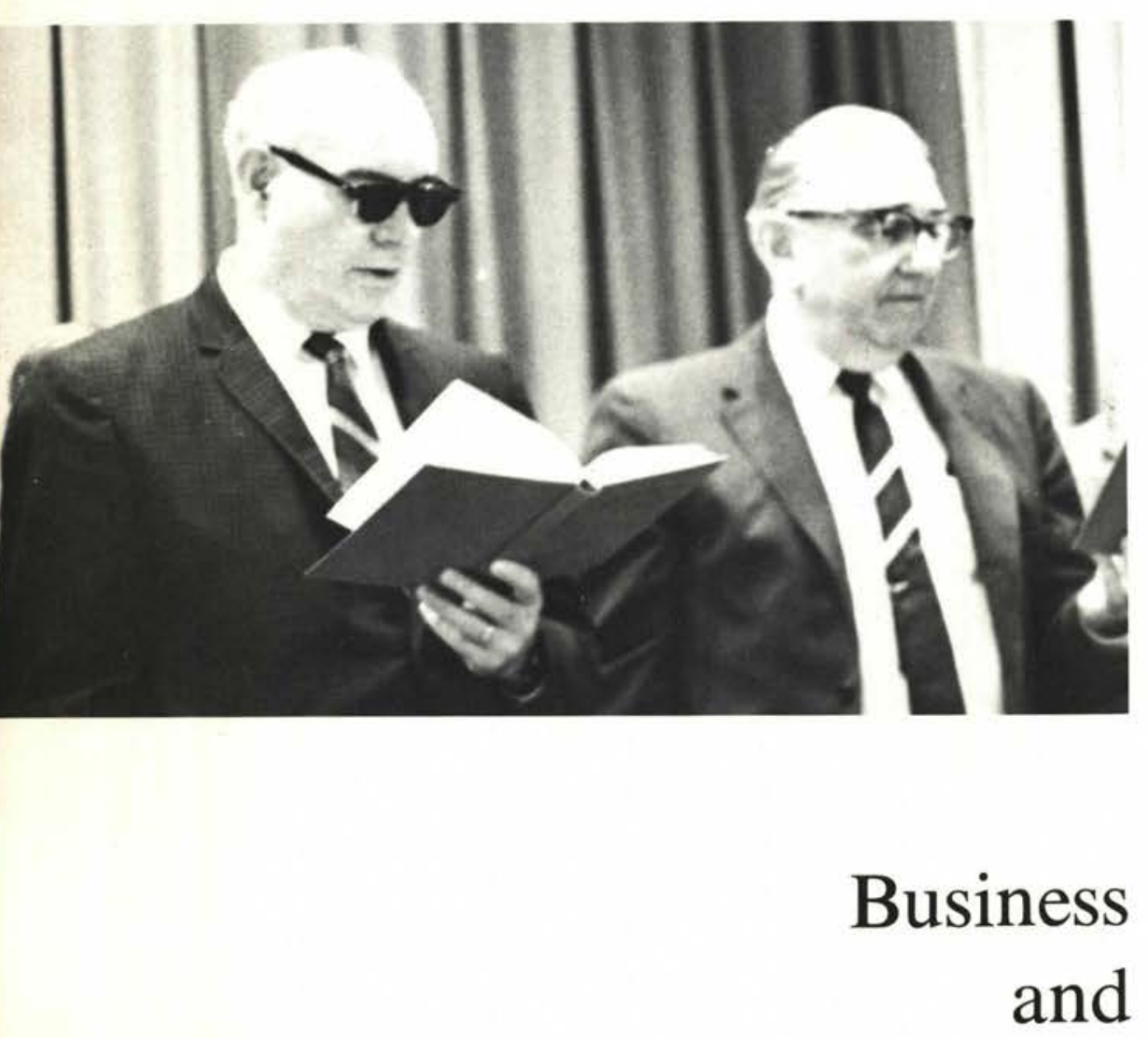

Social Science

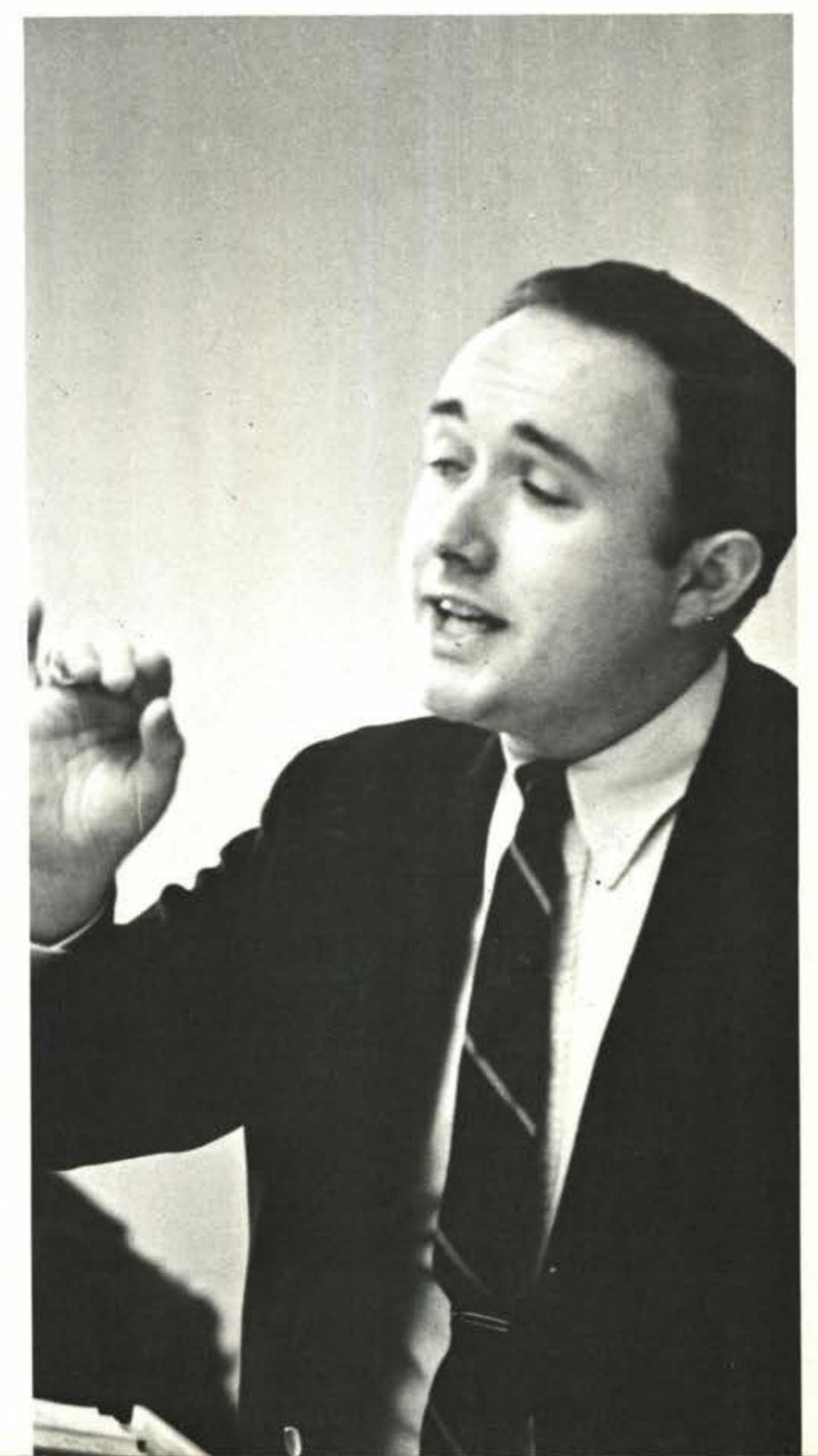



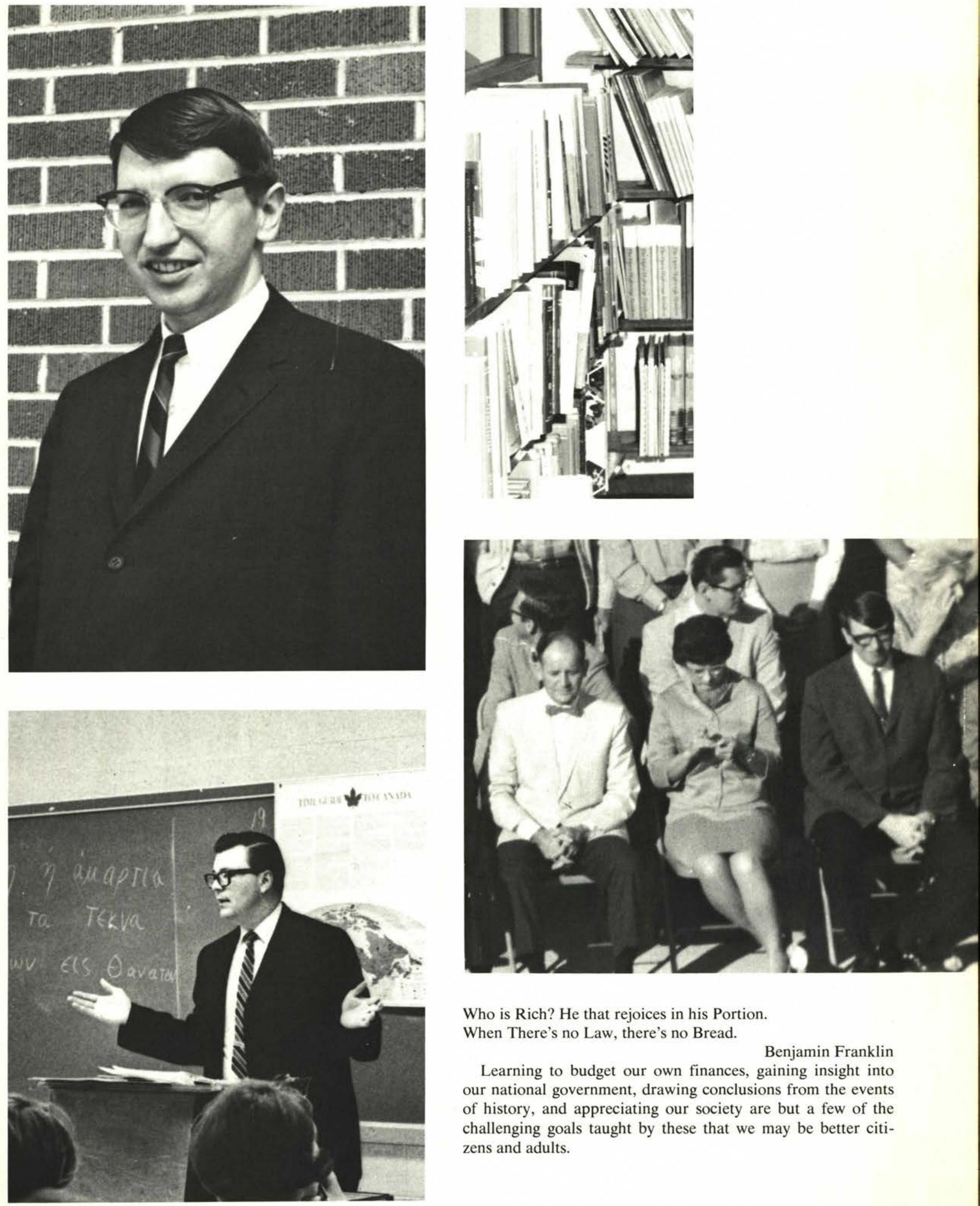

Who is Rich? He that rejoices in his Portion.

When There's no Law, there's no Bread.

Benjamin Franklin

Learning to budget our own finances, gaining insight into our national government, drawing conclusions from the events of history, and appreciating our society are but a few of the challenging goals taught by these that we may be better citizens and adults. 
Paintings and fightings are best seen at a distance. A pair of good ears will drink dry a hundred Tongues.

\section{Arts}

The skill of painting, the performing with an instrument, and even the art of listening are of the greatest value in life, for these activities are everywhere, all around us. They are seen in the beauty of God's nature, the symphony of the birds, and the quietness of a concerned friend. And even these simple things are a part of the more complicated and deeper meaning of the teaching of the fine arts.

Shirley Byrd, B.A.

David L. Matson, M.A.

Ardeth J. Riter, A.B.
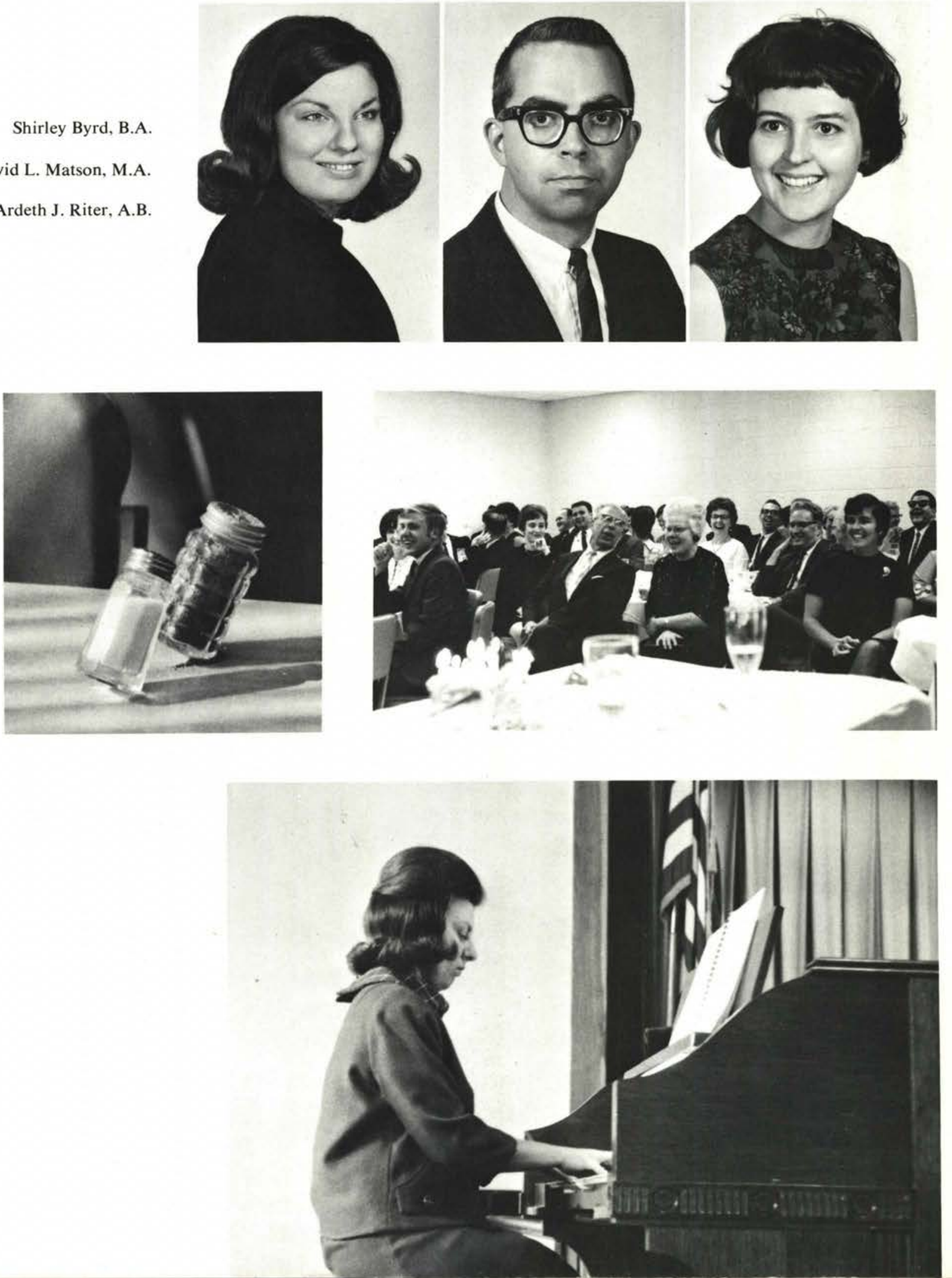

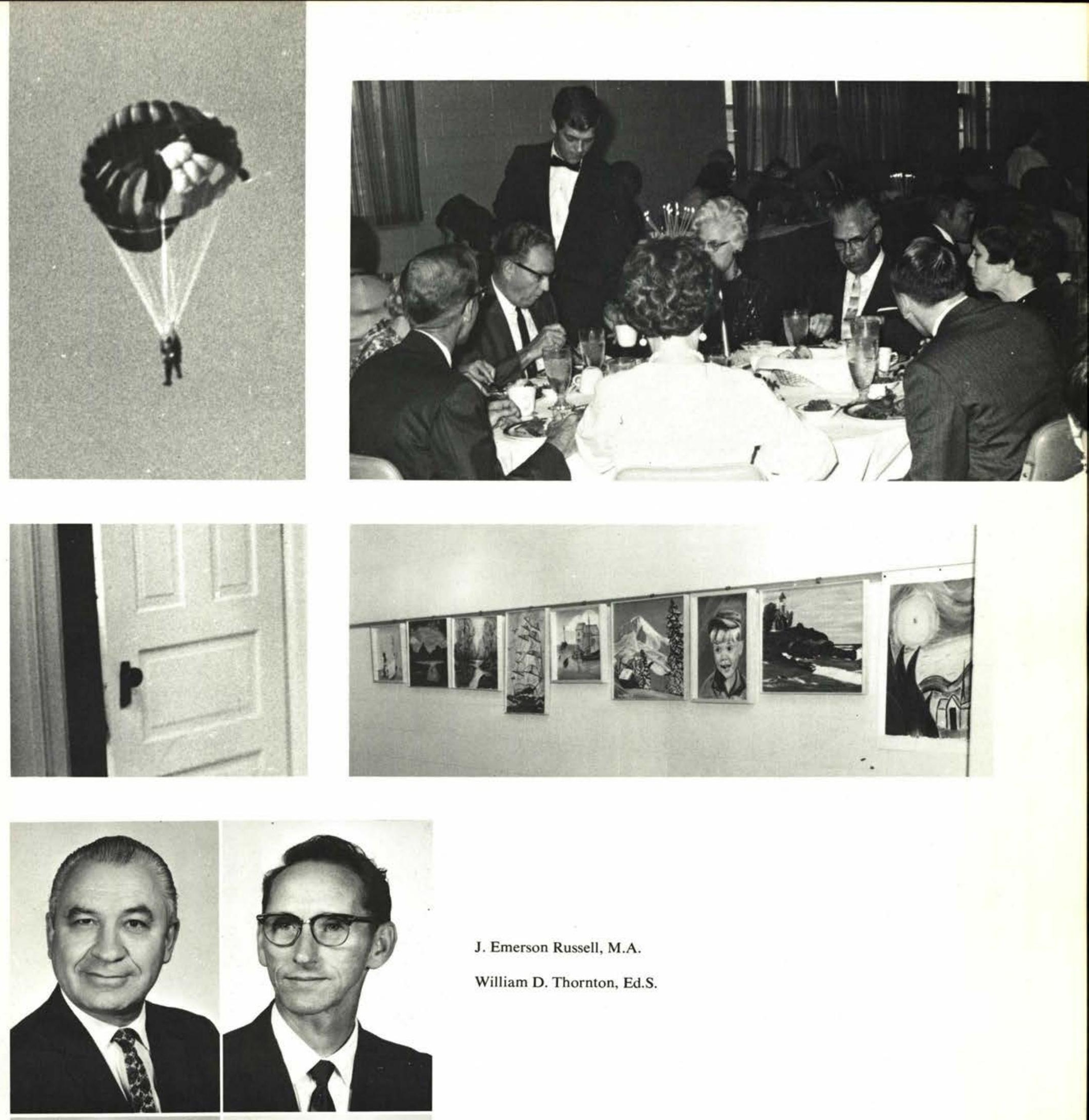

J. Emerson Russell, M.A.

William D. Thornton, Ed.S.
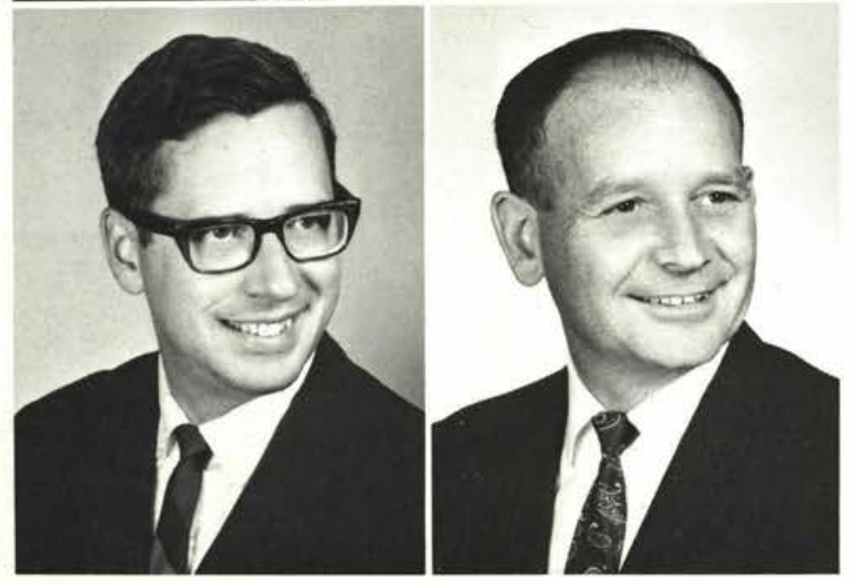

Paul A. Vanderkoy, M.M.

Warren L. Webber, Ph.D. 

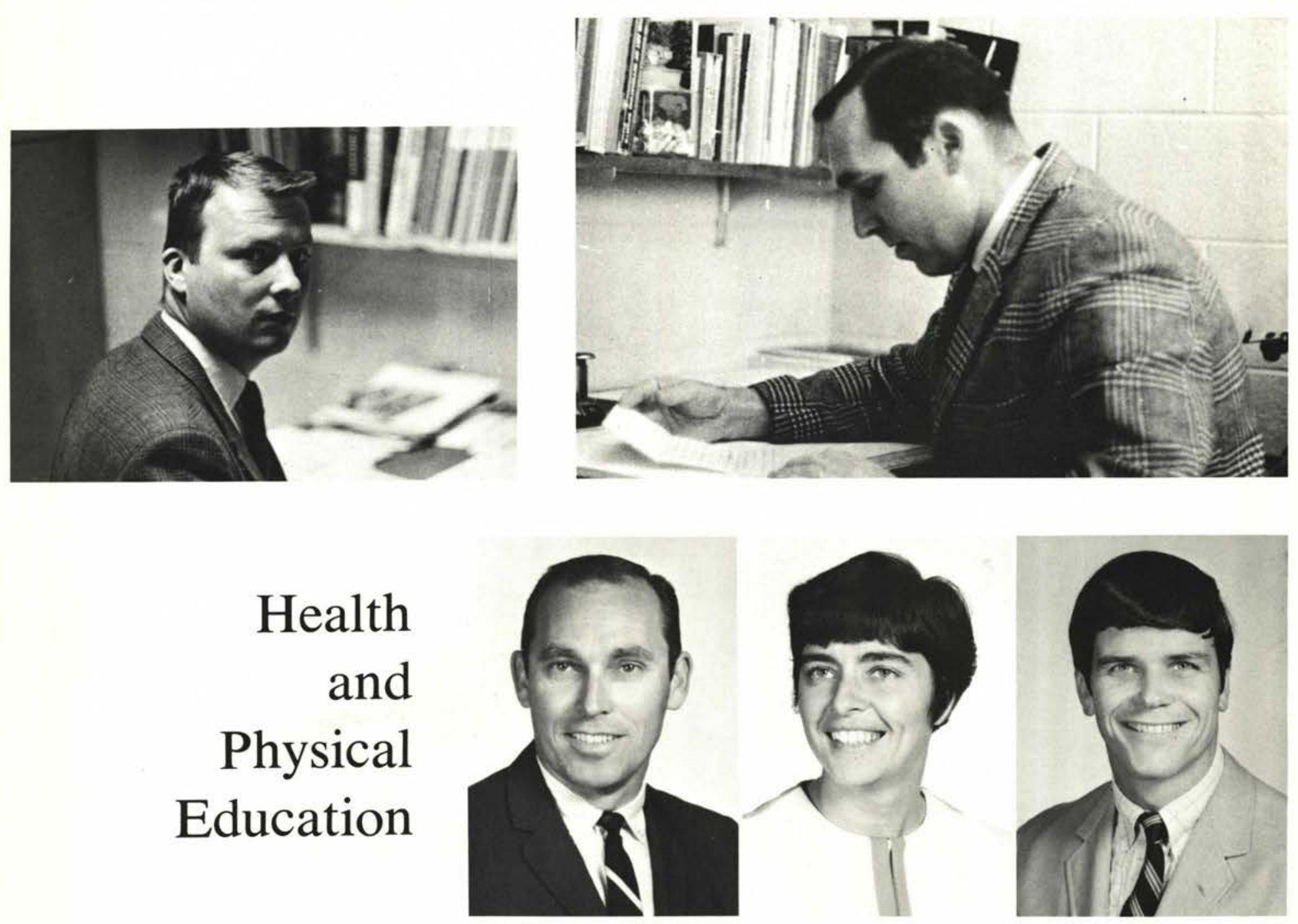

Don Callan, Ph.D.

He that can compose himself is wiser than he that composes books.

Benjamin Franklin

The complexity of man not only proves the miracle of creation, but also the necessity for exercise and good health. And these can be provided now and enhanced in the future by the teaching of these teachers.

June Kearney, M.Ed.

Randall A. Ross, B.A.

Not Pictured are: Dennis A. Olson, M.S. Judith Stamatis Patricia Wissinger

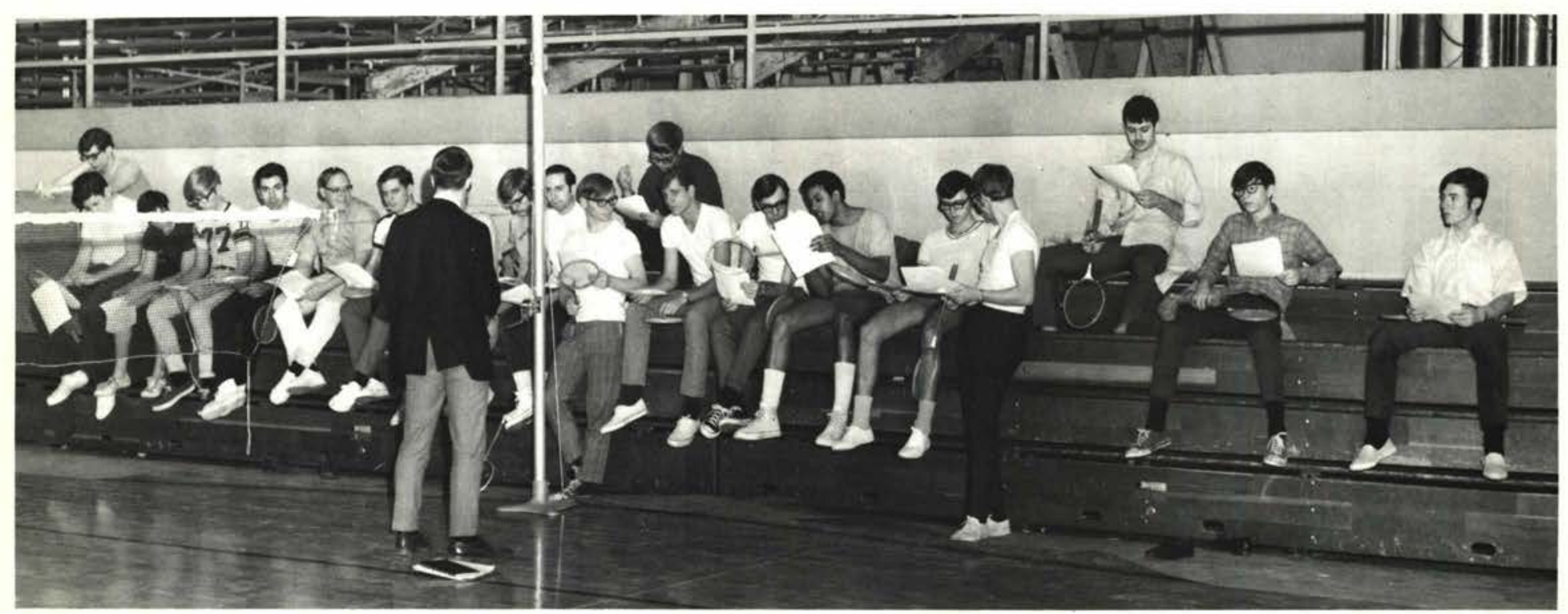




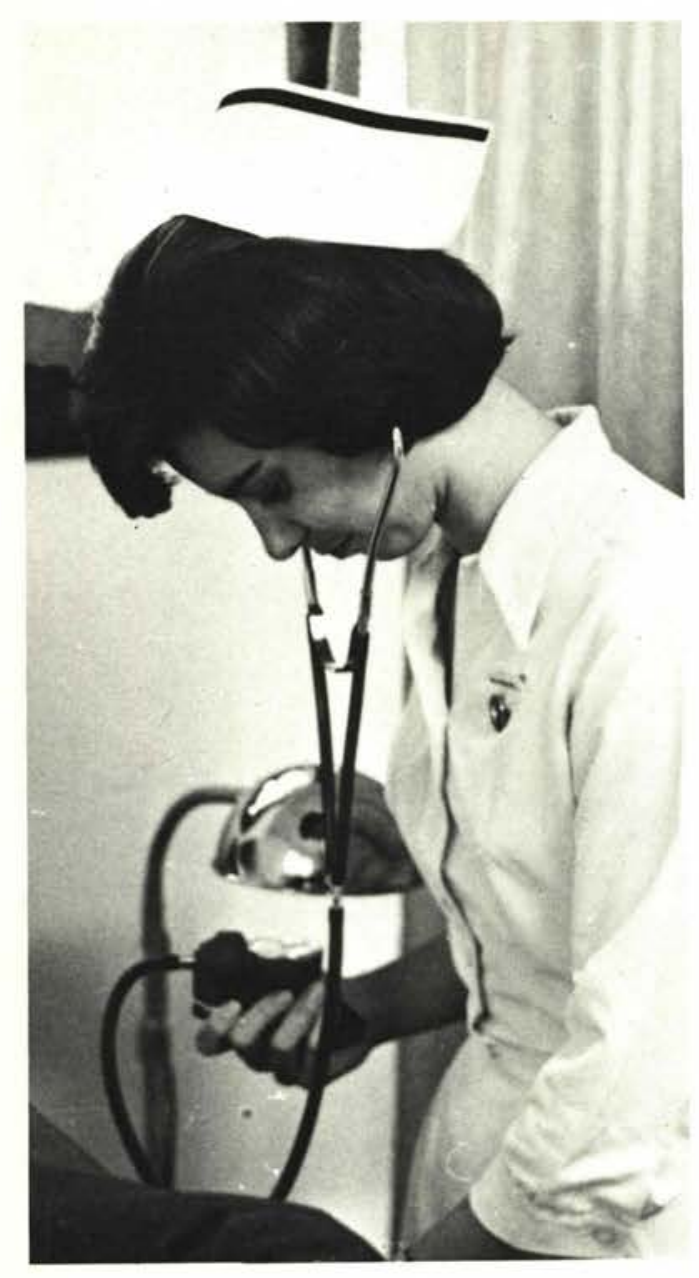

\section{Health Service}

The sniffles, broken legs, and viruses dare not go unnoticed by the college nurses. Their concern and service provide for the aches, pains, and discomfort, and along with God's healing and a bit of rest, keep our campus family in the best of health.

Pictured at the left is Irene Wilson. Below: Joan Corbin; and left bottom, Betty Bertschinger.
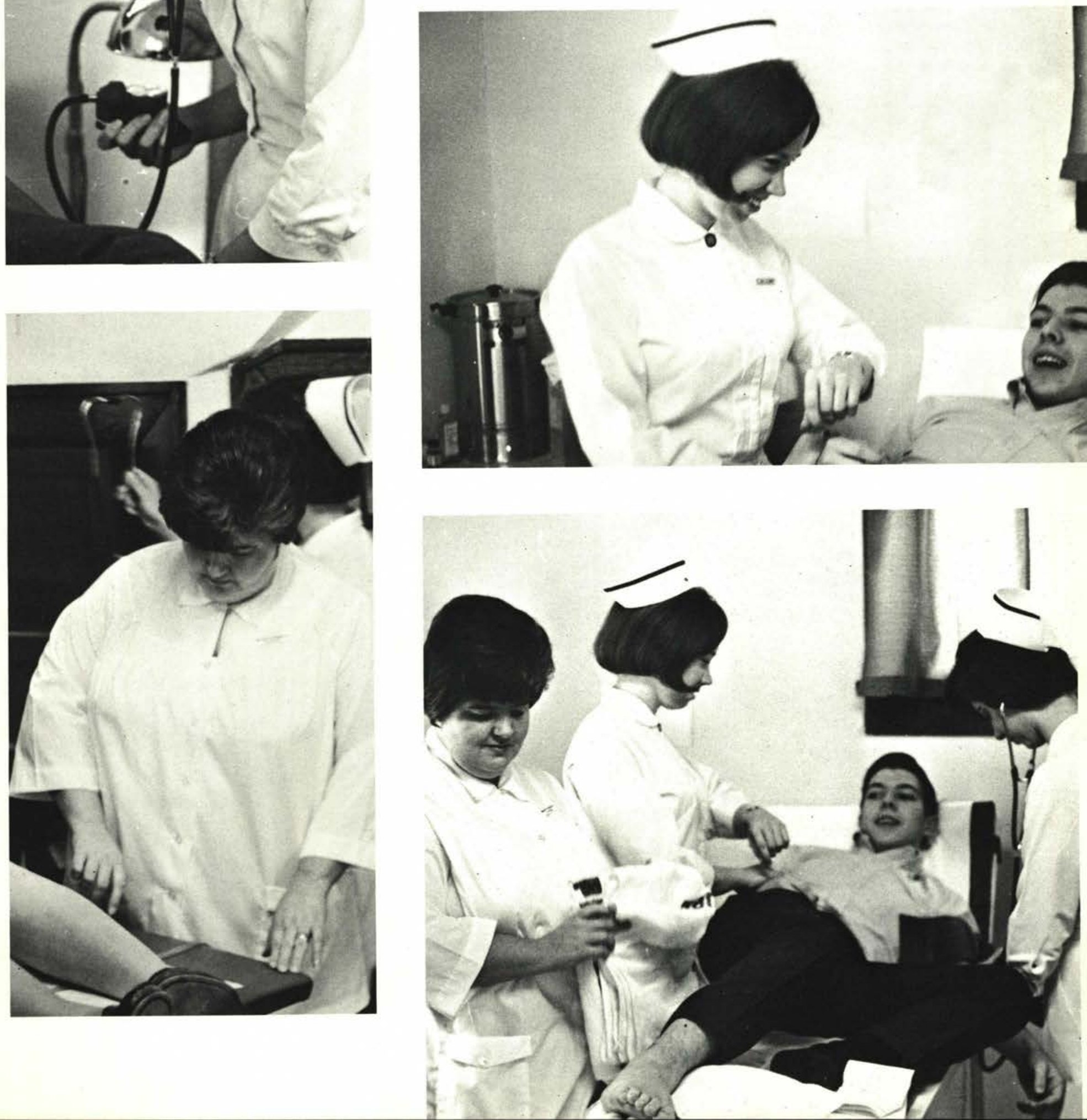

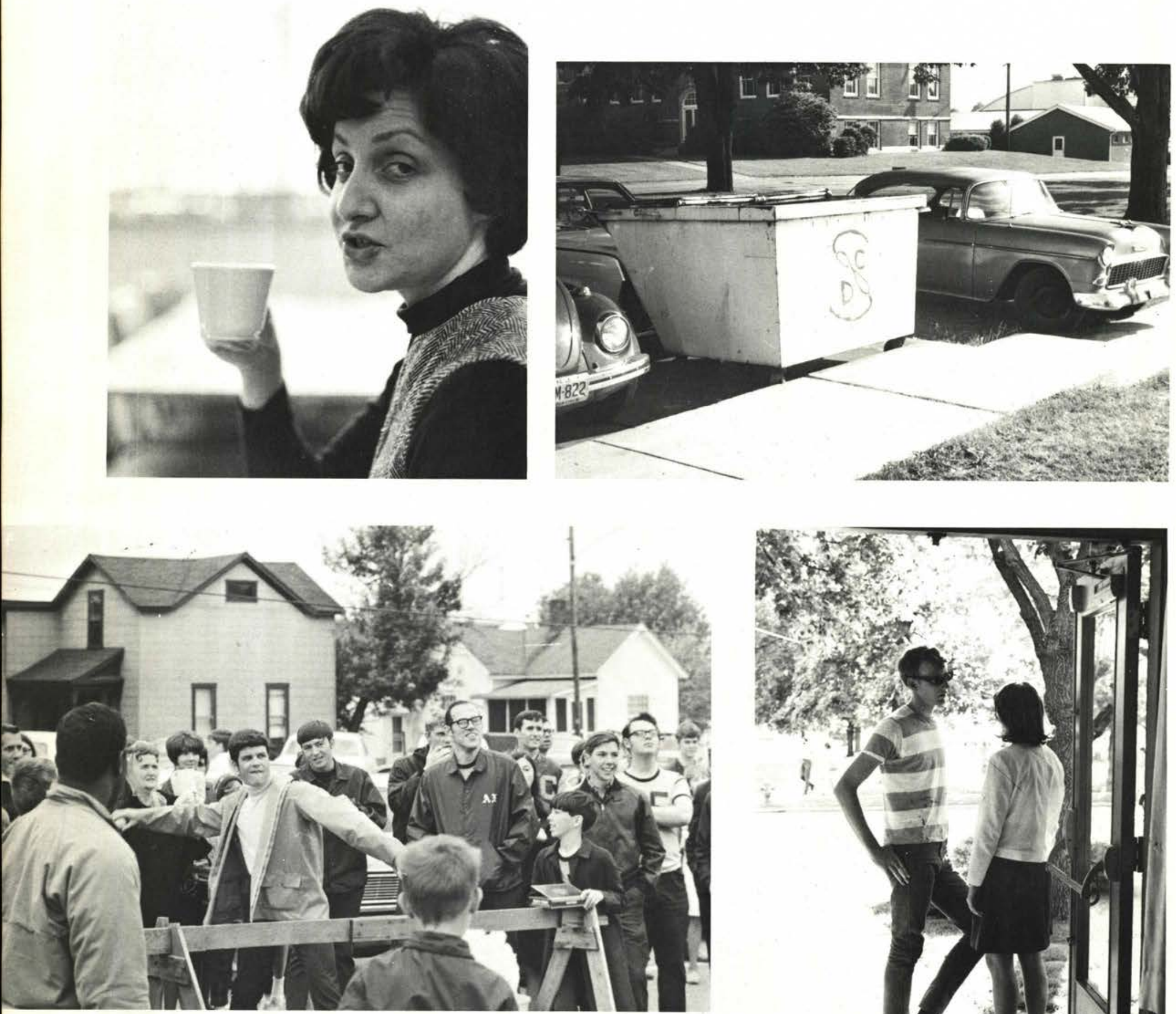

To act as friend, counselor, and advisor, the dormitory parents serve the students, the college, and God. Not pictured are Mr. and Mrs. Bresson.

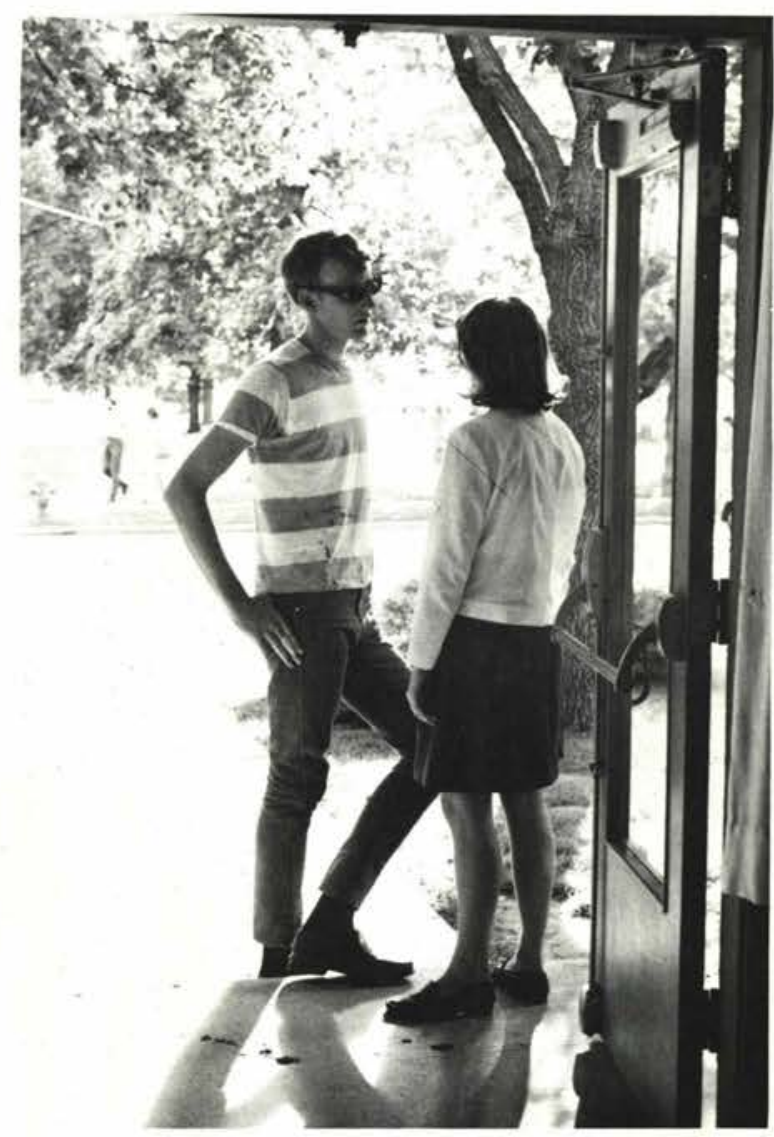




\section{Library Bookstore Post Office}
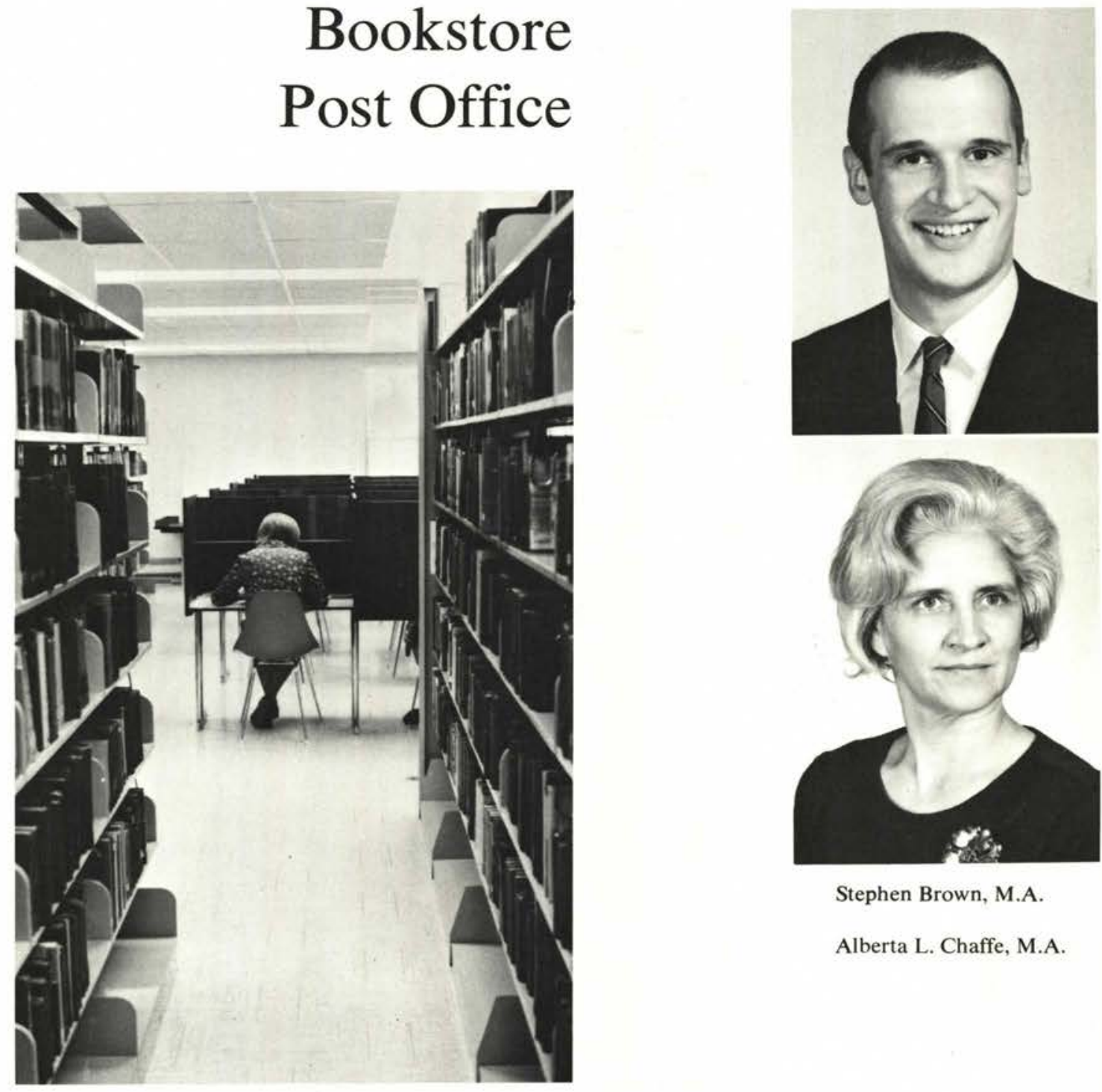

Stephen Brown, M.A.

Alberta L. Chaffe, M.A.

Virginia Russell, Shirley King, Becky Harman, Stanley Brown, Bev Maidment, Beverly Curtis, Richard Taylor, Nancy Towle, Esther Ruder, and June Carr.

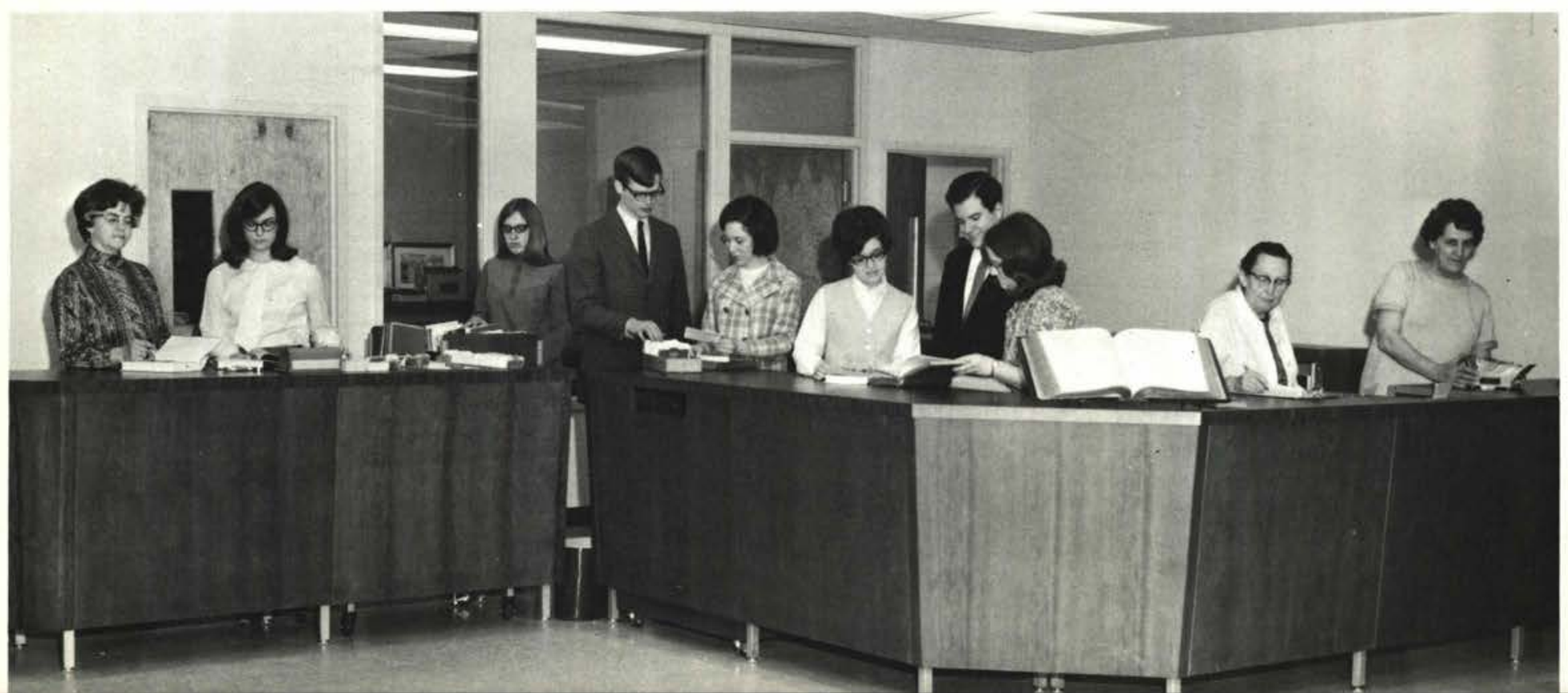




\section{Scholarship, Service Honored}

Last year the Student Council presented the first faculty award to the most deserving, dedicated, conscientious professor. This year the award honored Dr. George Lawlor, professor of Greek and Bible. His surprise and gratitude were rewarded by minutes of boisterous applause by faculty and students as Student Council President, Dan Stevens, presented the honored award.

Dedicated teachers as Dr. Lawlor are the impetus for students of action and service. Each year a national committee selects outstanding collegiennes who have demonstrated exceptional scholarship and service and award them the position of "Who's Who in American Colleges." This year Cedarville's "Who's Who" included Ruth Hardy, Nancy Norton, Patti France, Jane Hess, Judy Hirschy, Ron Baker, Dean Seigneur, Paul Entner, Ken Cole, Bruce McDonald, Lyle Anderson, Dan Stevens, and Judy Wren.
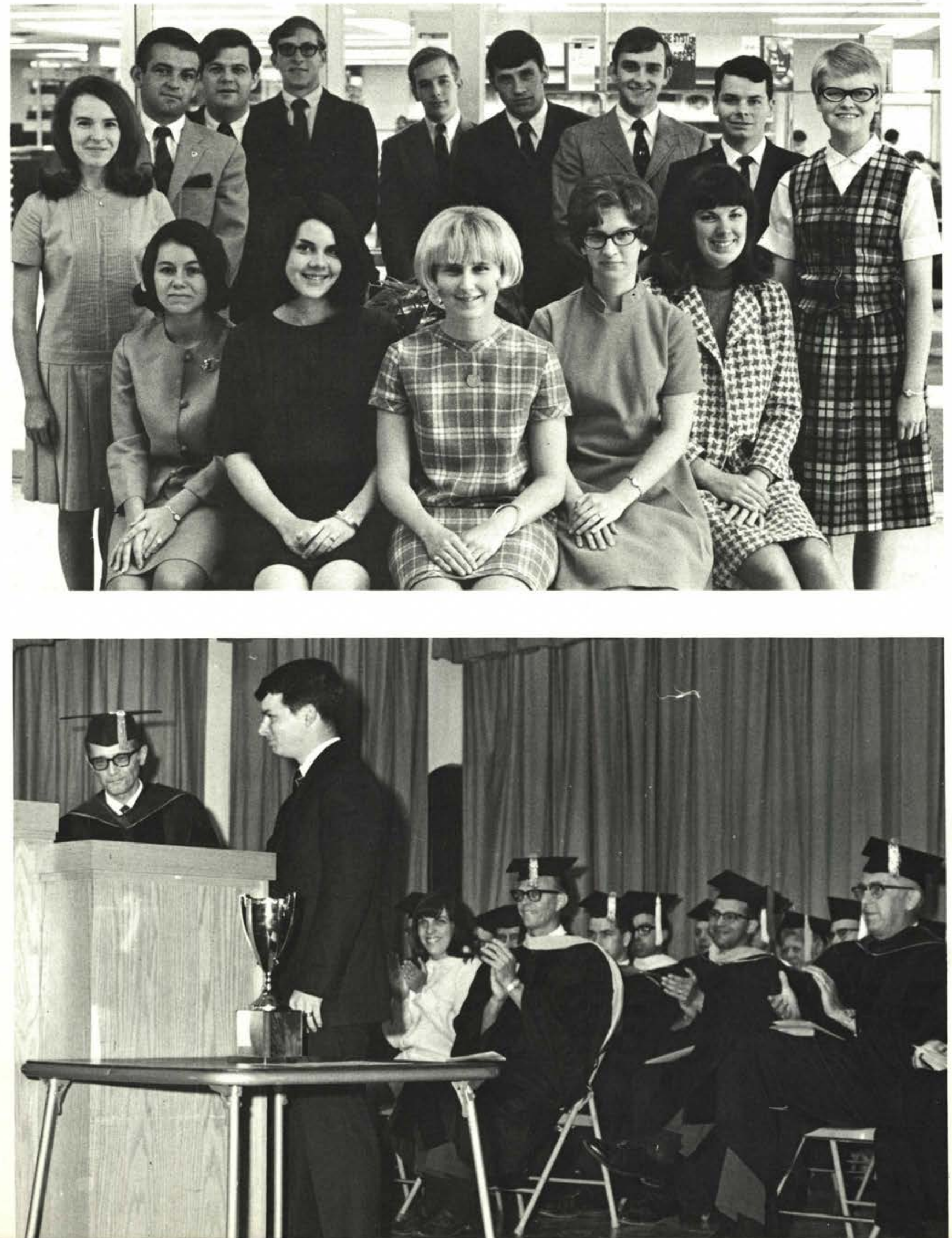


\section{Maintenance and Cafeteria}

Sloth (like Rust) Consumes faster than labor wears: the used Key is always bright.

Benjamin Franklin

These people are so busy feeding and repairing for 850 students that they have no time for sloth.
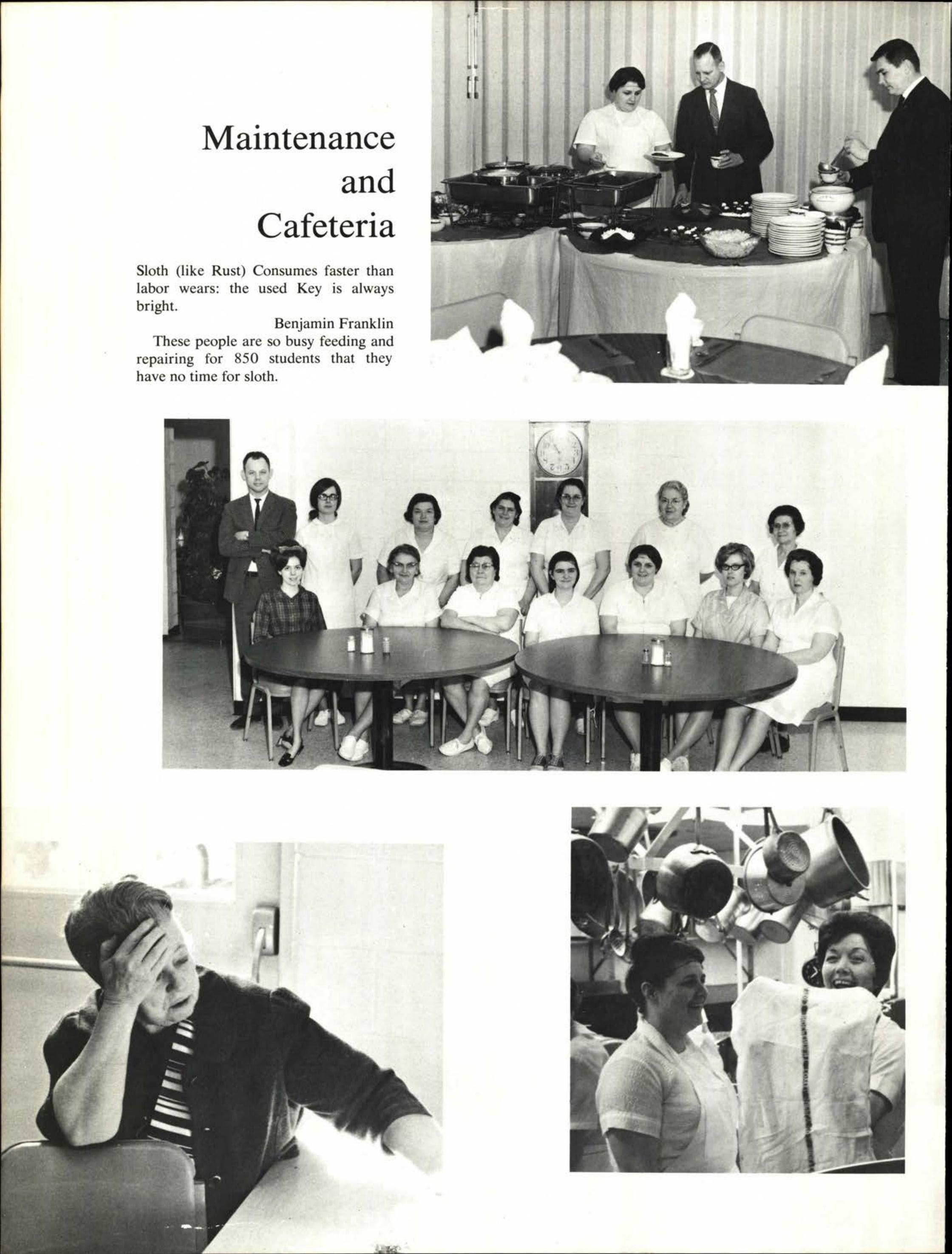
Cedarville's cafeteria workers include Barbara Behrend, Bonnie Bingamon, Vivian Cline, Barbara Conkion, Janice Conkion, Wynona Davis, Grace Horner, Betty Hawes, Alberta Isaac, Virginia Kearns, Mary McPhearson, Phyllis Miller, Edna Monroe, Mary Piach, Sarah Shope, Doris Racnick, Sally Ullrich, Julia Wilson, Joyce Jefferies, and Kate Smith.
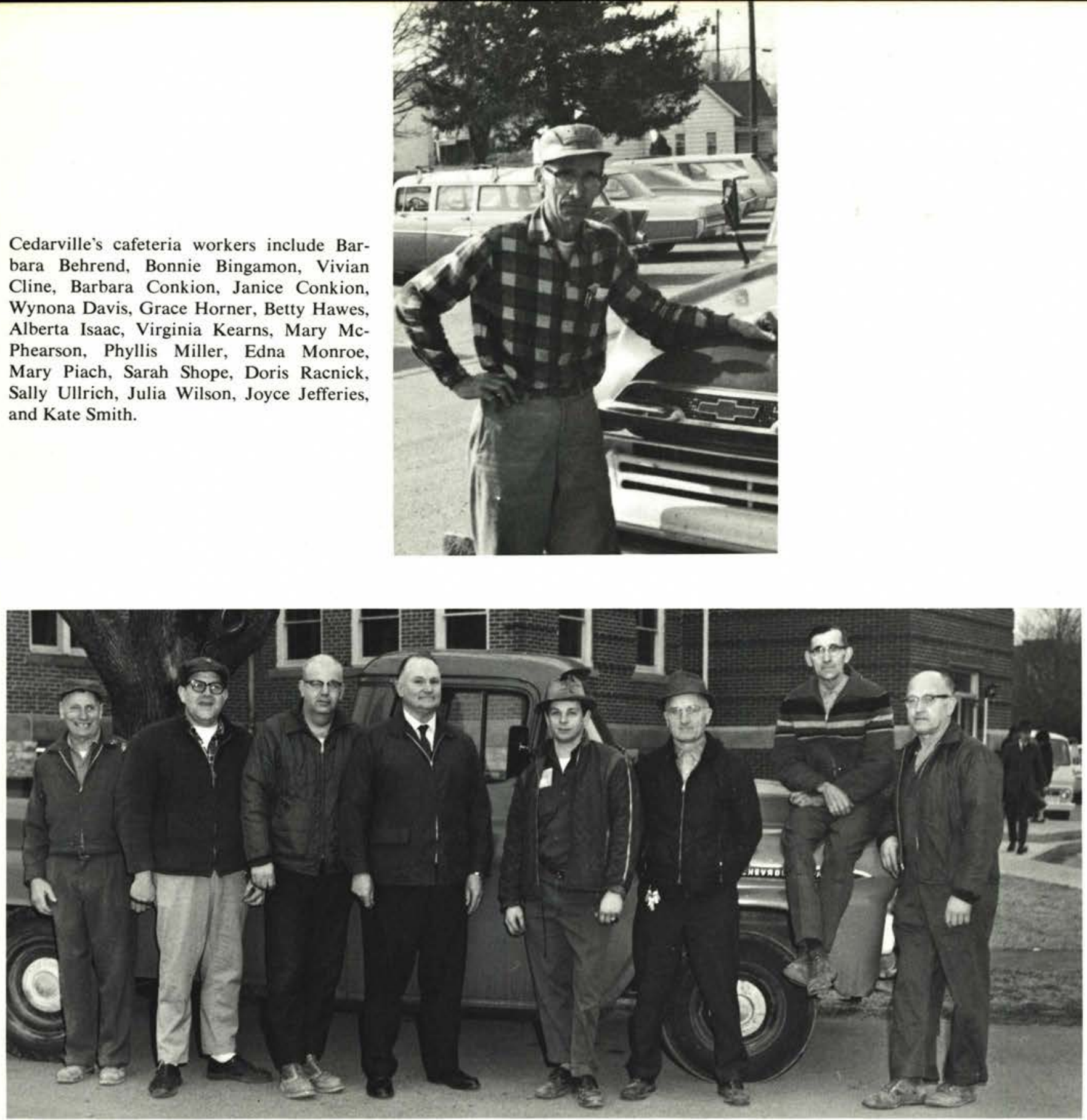

Maintenance crew in cludes Henry Bresson, Charlie Tarter, Ralph Steiger, Merle Slabaugh, Roger Rochelle, Robert Dillon, "Pop" Marshall, and Hugh Carr.
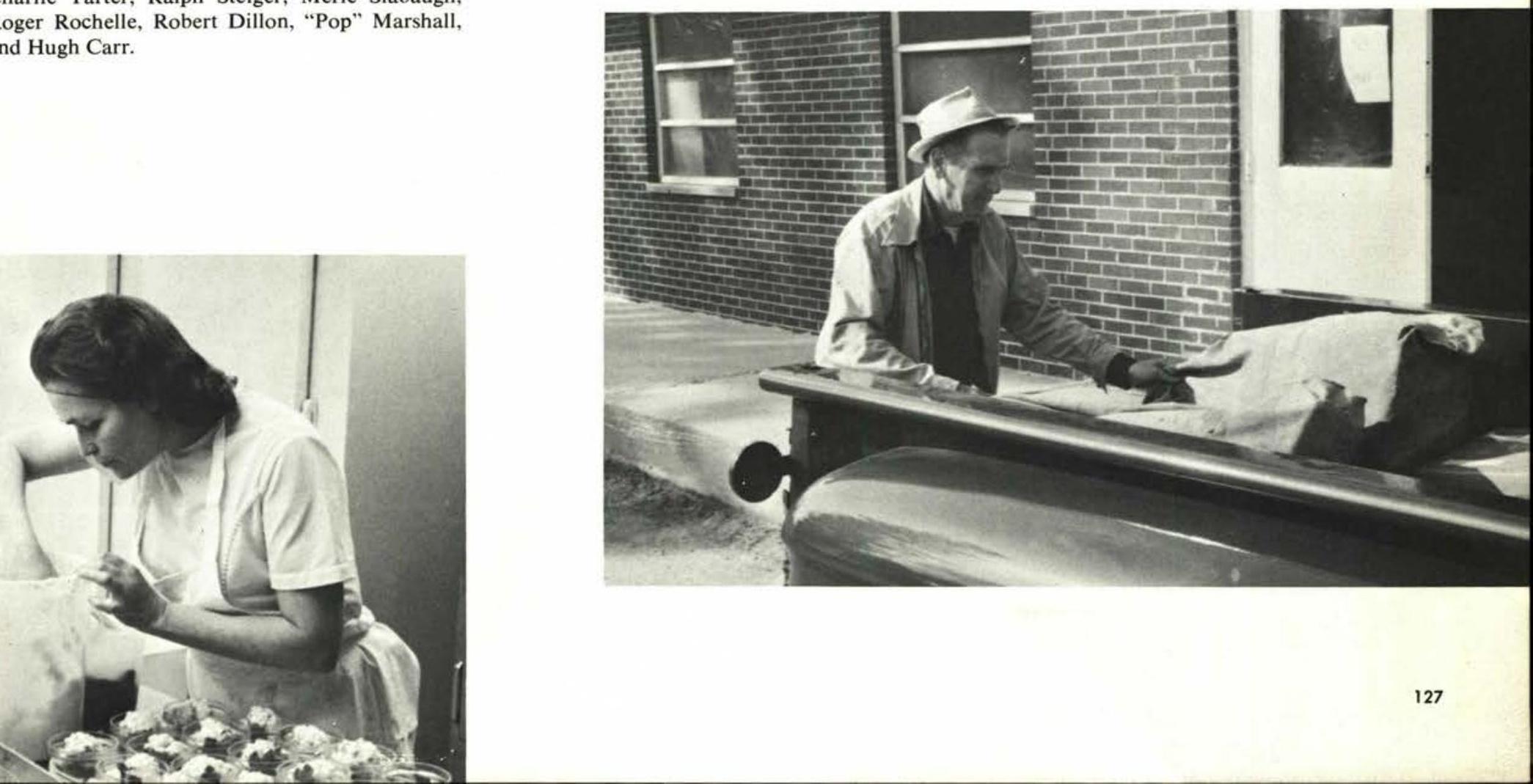


\section{SPIRIT . .}
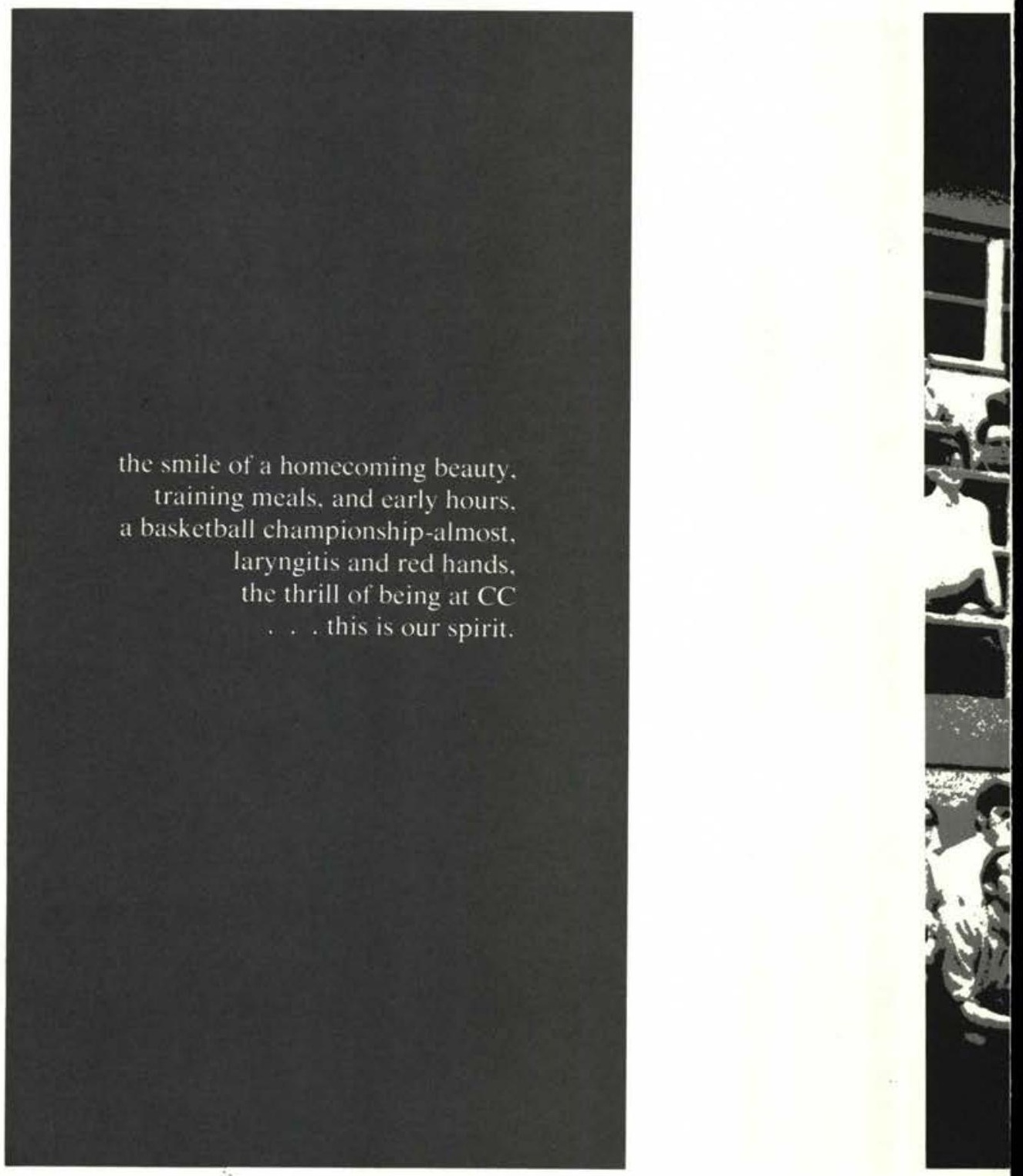


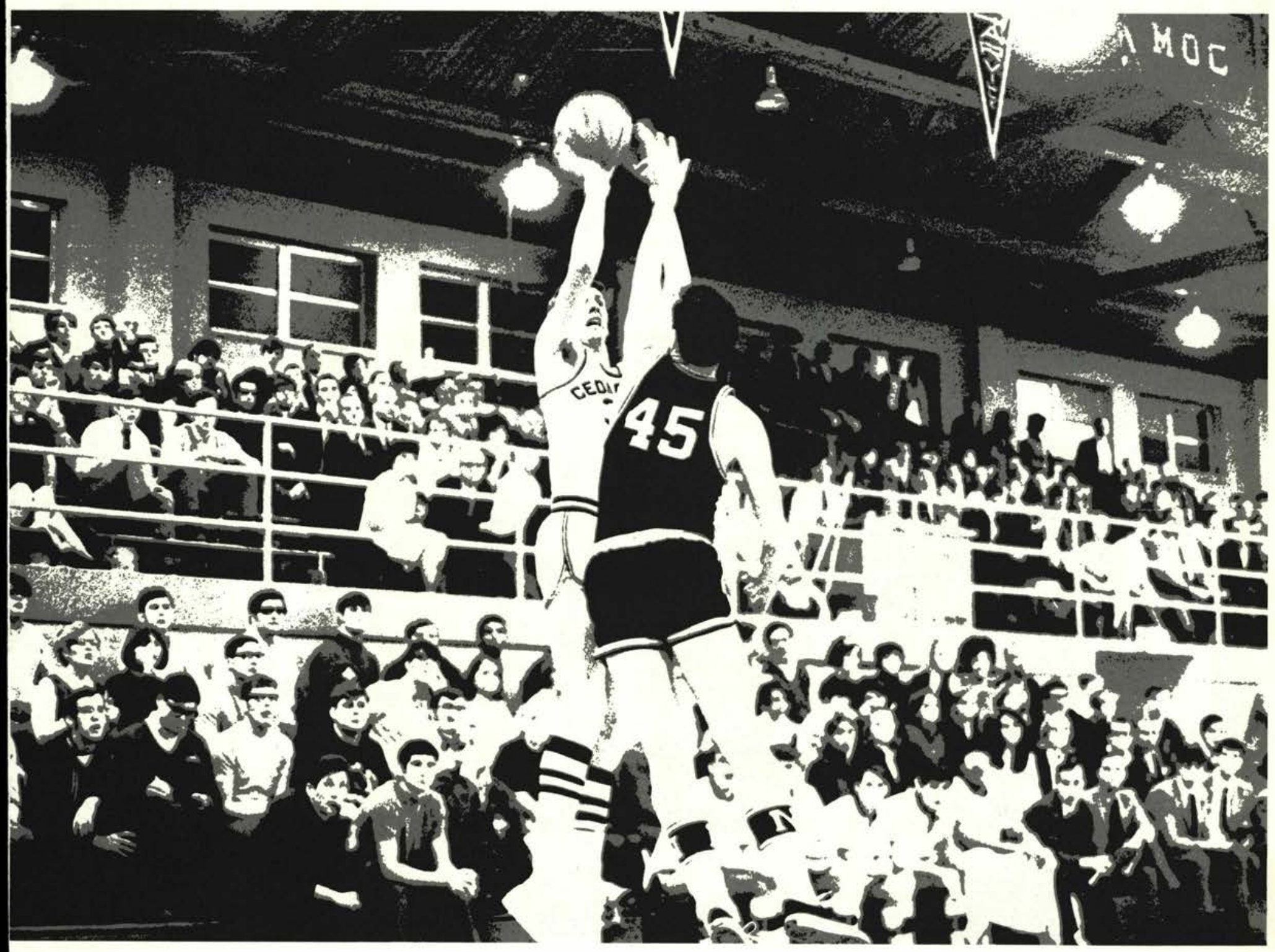




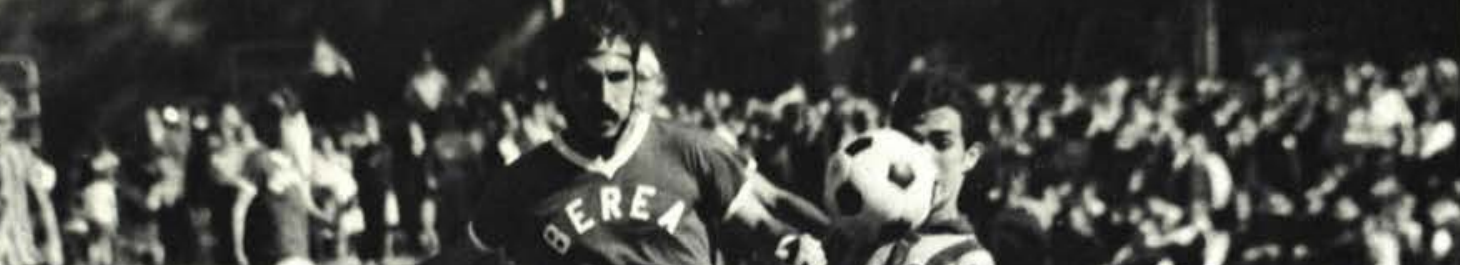

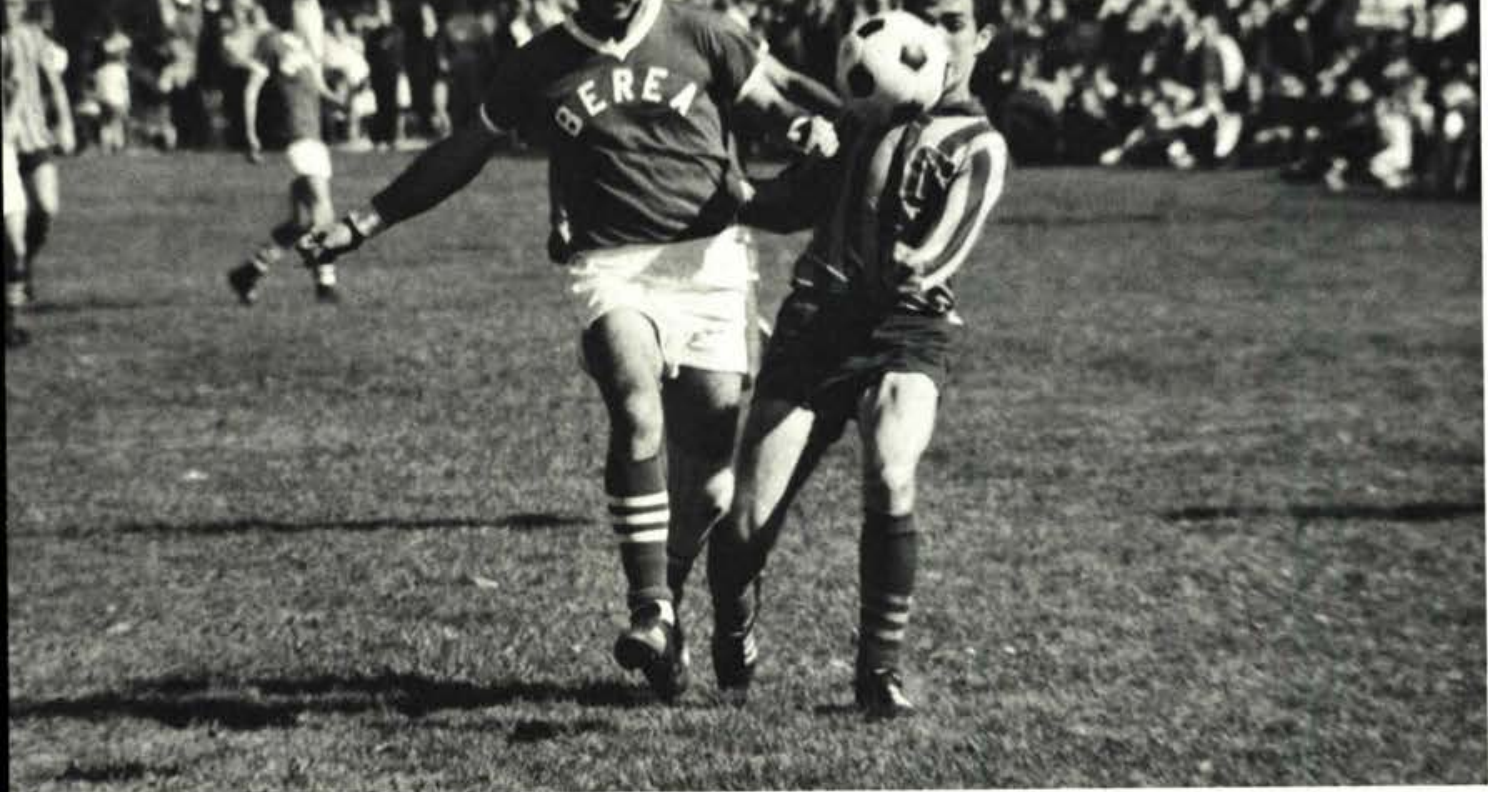
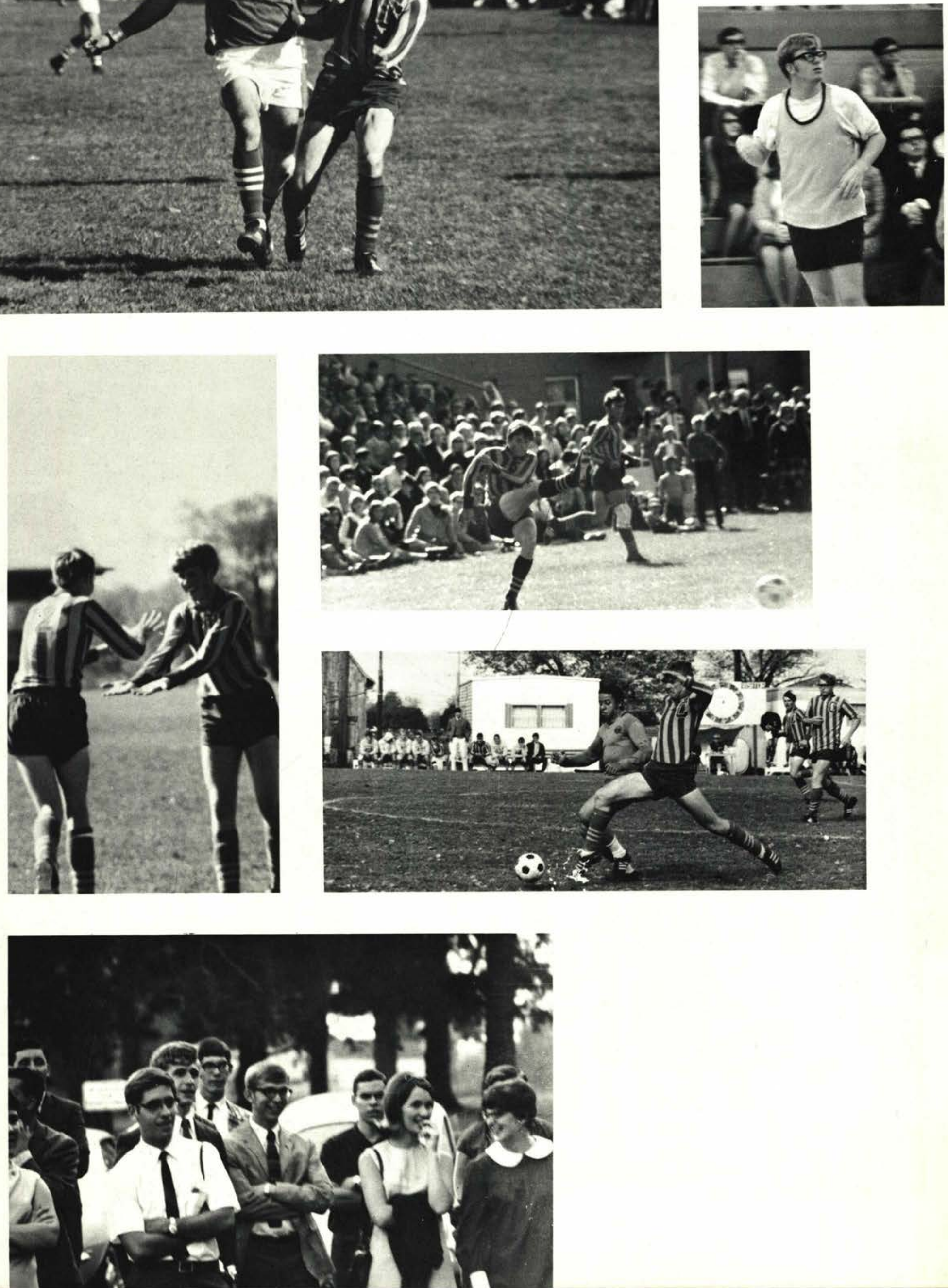
Varsity C Club is composed of men who have earned varsity letters in collegiate sports. The members sell refreshments at the basketball games, but the highlight is the annual VC initiation.

The officers are Dave Haffey, Pres.; Ken Curcio, V.-Pres.; Dave Wright, Sec.; Richard Adams, Treas.; Gary Darrow, St. Council Rep.

The Women's Recreation Association is an organization which seeks to promote Christian fellowship among the college women through such activities as overnights, campouts, and sports.

The officers are JoA n n Strychalski, Pres.; Marilyn Beitler, V.-Pres.; Sandy Lathrop, Sec.; Gail Sears, Treas.; Mareanne B e i t l e r, Publicity, Judy Stamatis, Intramural Chrman; Mary Lynne Grable, St. Council Rep.

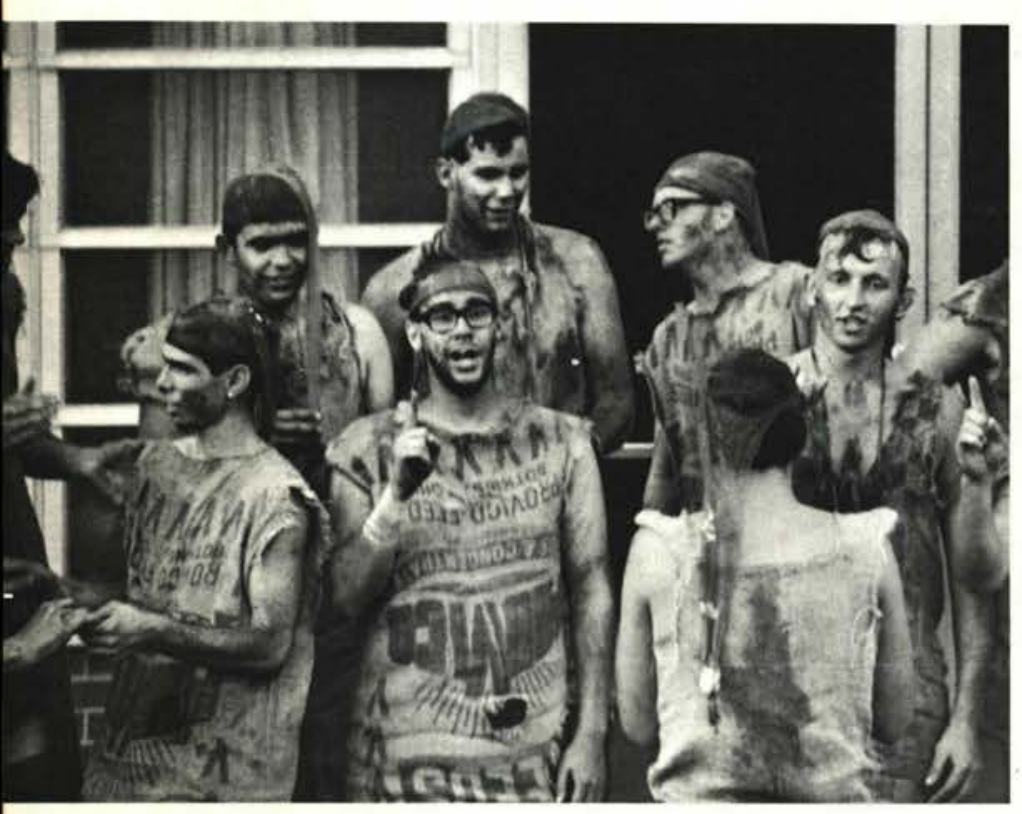

\section{Varsity $\mathrm{C}$ and WRA}

VARSITY C-Row 1: S. Walker, D. Mays, R. Inghram, R. Coriell. Row 2: M. Causey, B. Lunney, B. Schultz, D. Caraway, K. Muck, D. Handyside. Row 3: B. McDonald, D. Gregory, L. Reno, D. Atherton, M. Wolford. Row 4: B. Trefzger, S. Taylor, W. Pettit, K. Evans. Row 5: R. Adams, K. Curcio, D. Haffey, G. Darrow, D. Wright.

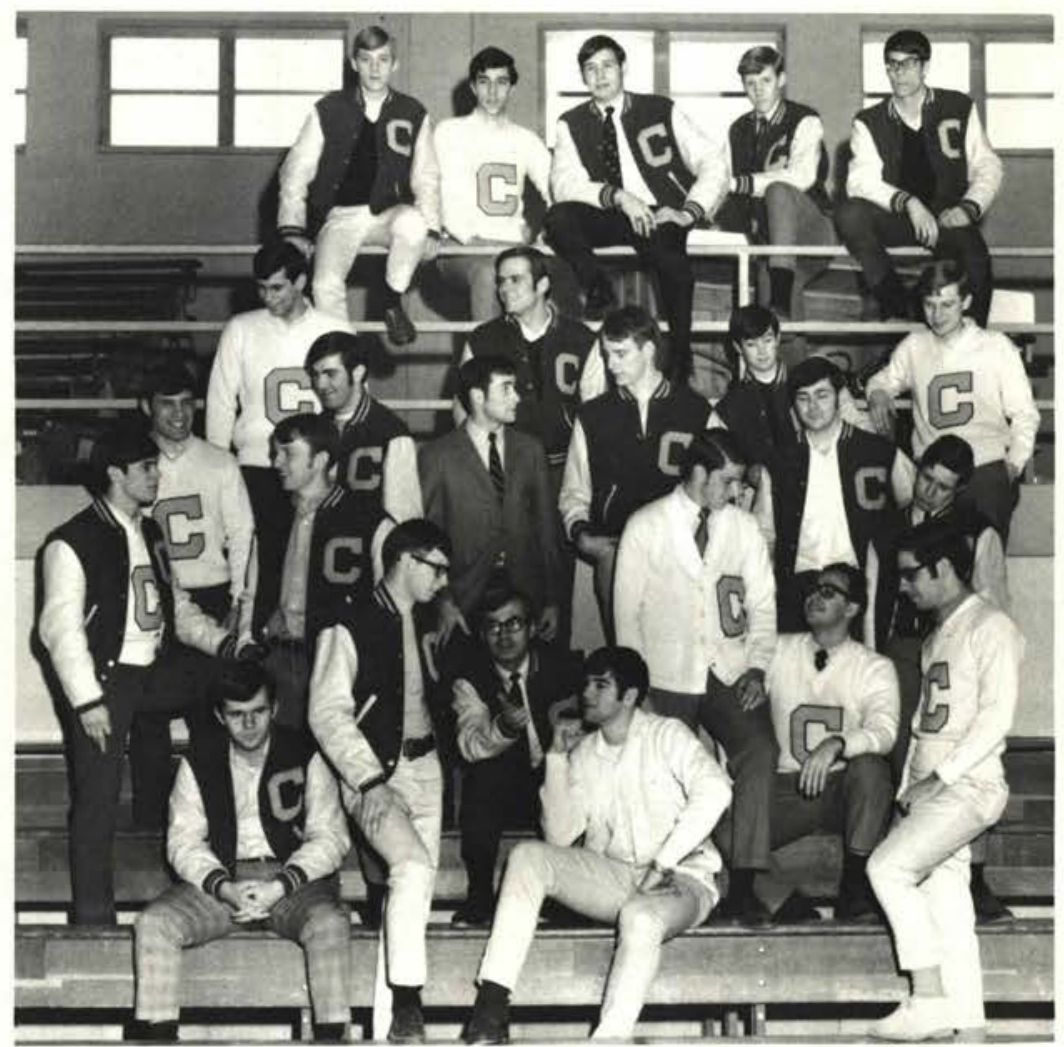

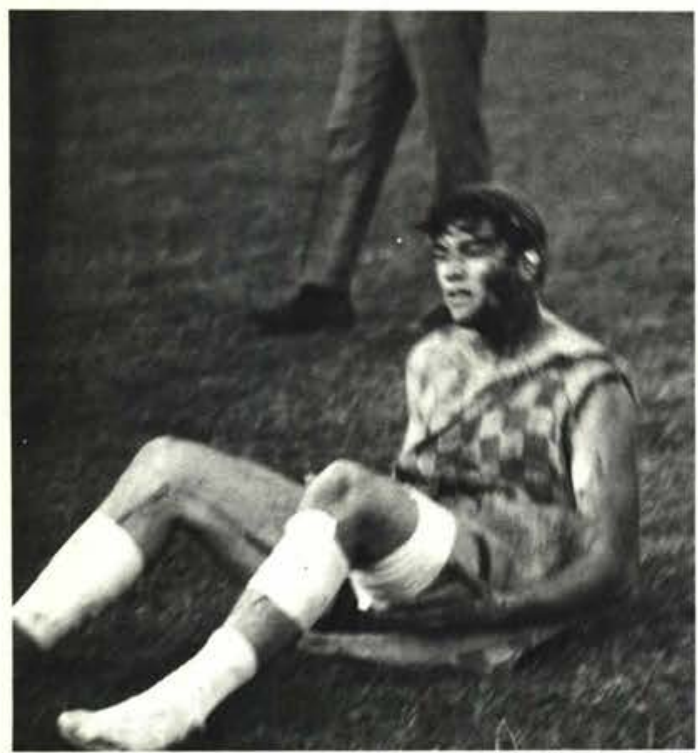

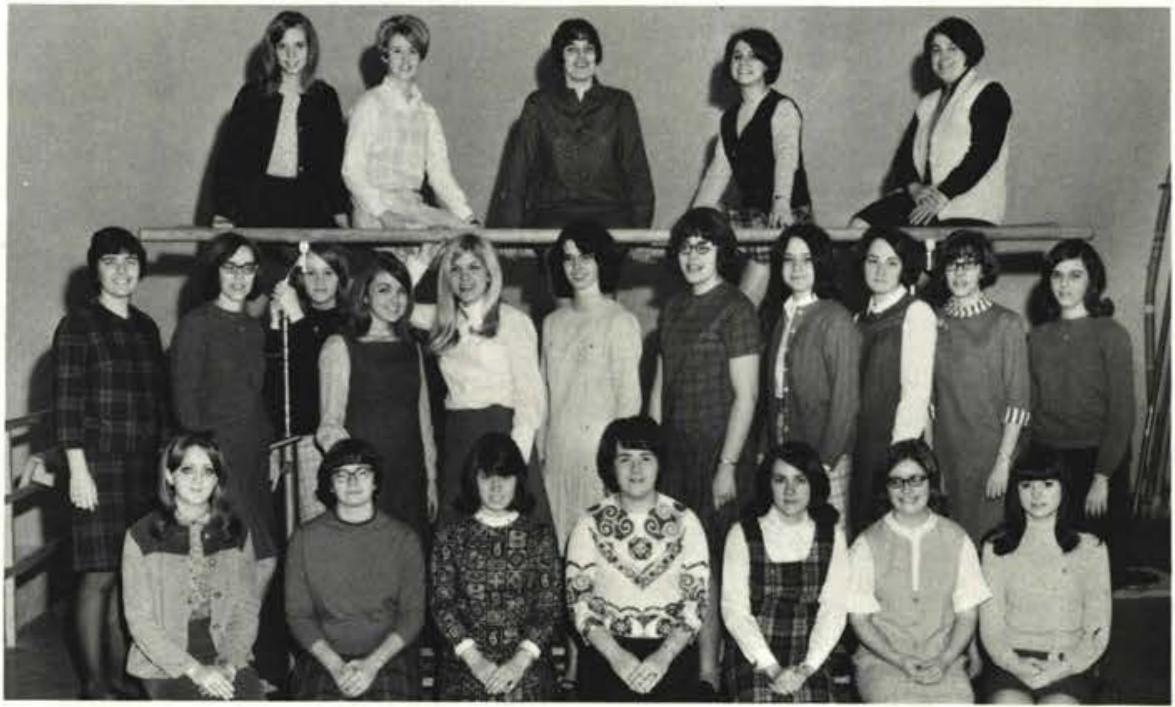

WRA-Row 1: D. Kahler, P. Branning, S. Estes, L. Brown, R. Bigley, M. Beitler, L. Grable. Row 2: Advisor: Miss Kearney, J. Strychalski, C. Walker, J. Brookhart, G. Sears, D. Kemp, S. Lathrop, K. Phenix, D. Baker, S. Lathrop, N. Bailey. Row 3: K. Peterson, P. Wissinger, C. Tompkins, B. Thomas, K. Spencer. 
JV Basketball

Walsh

Findlay

Wilmington

Malone

Twin Valley

Bluffton

Urbana

CSU

Market

Defiance

Rio Grande

Alumni

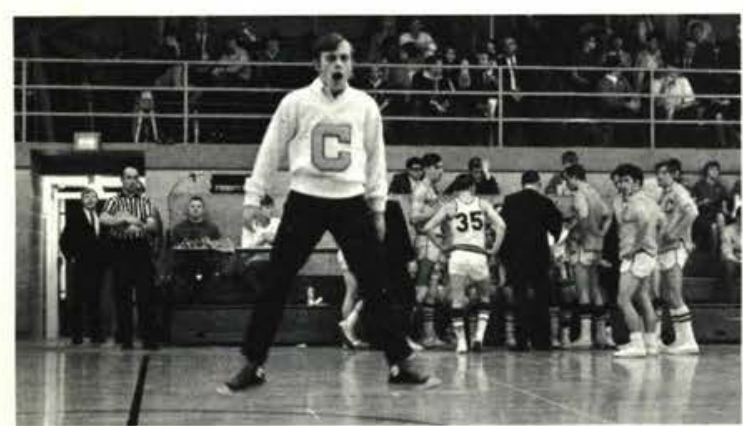

\section{The JV Team}

\section{Pushes}

\section{Its Hardest}

The JV Team pushes its hardest for victories, is often disappointed, but always eager for another chance. And so develops our future Varsity teamthrough defeat and battles.

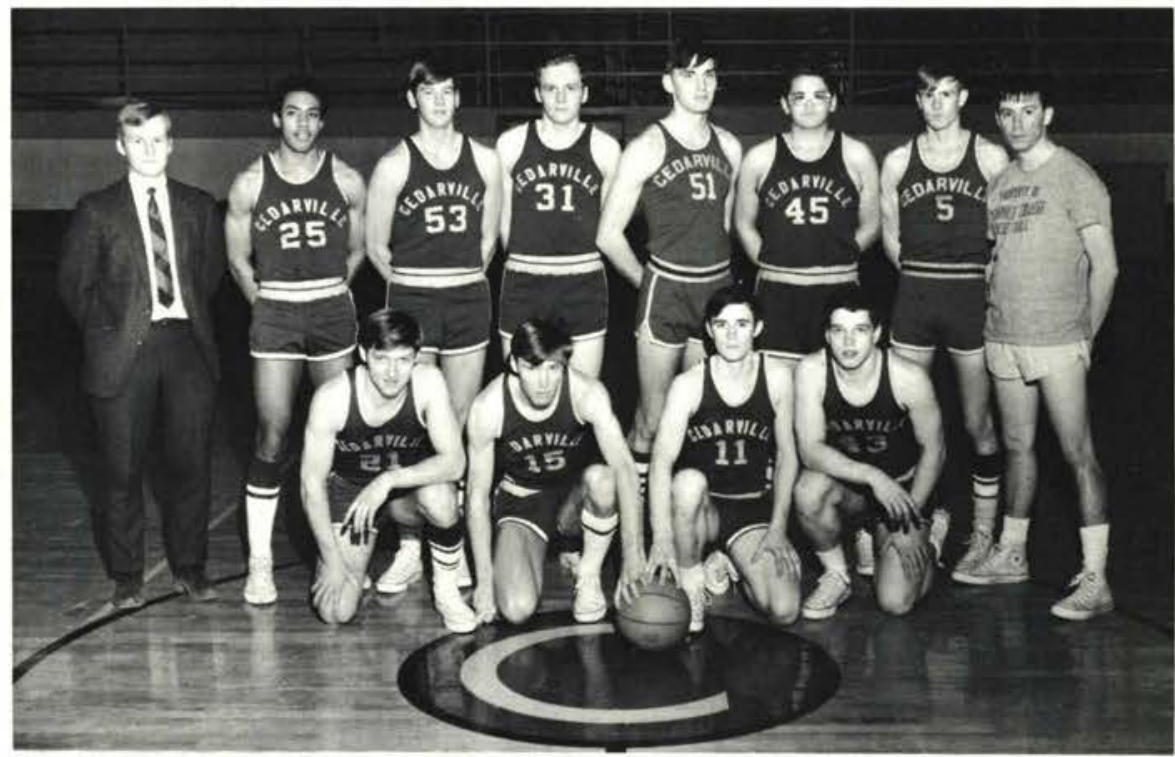

Pictured above is the JUNIOR VARSITY BASKETBALL TEAM-Row 1: Rich Lewis, Larry Holbrook, Dick Butler, Dan Williams. Row 2: Ken Heyer, Gary Hunter, Carl Bondorff, Charles Williams, Gary Holbrook, John Harrison, Bill Hoffman, and Coach Dick Pettit.
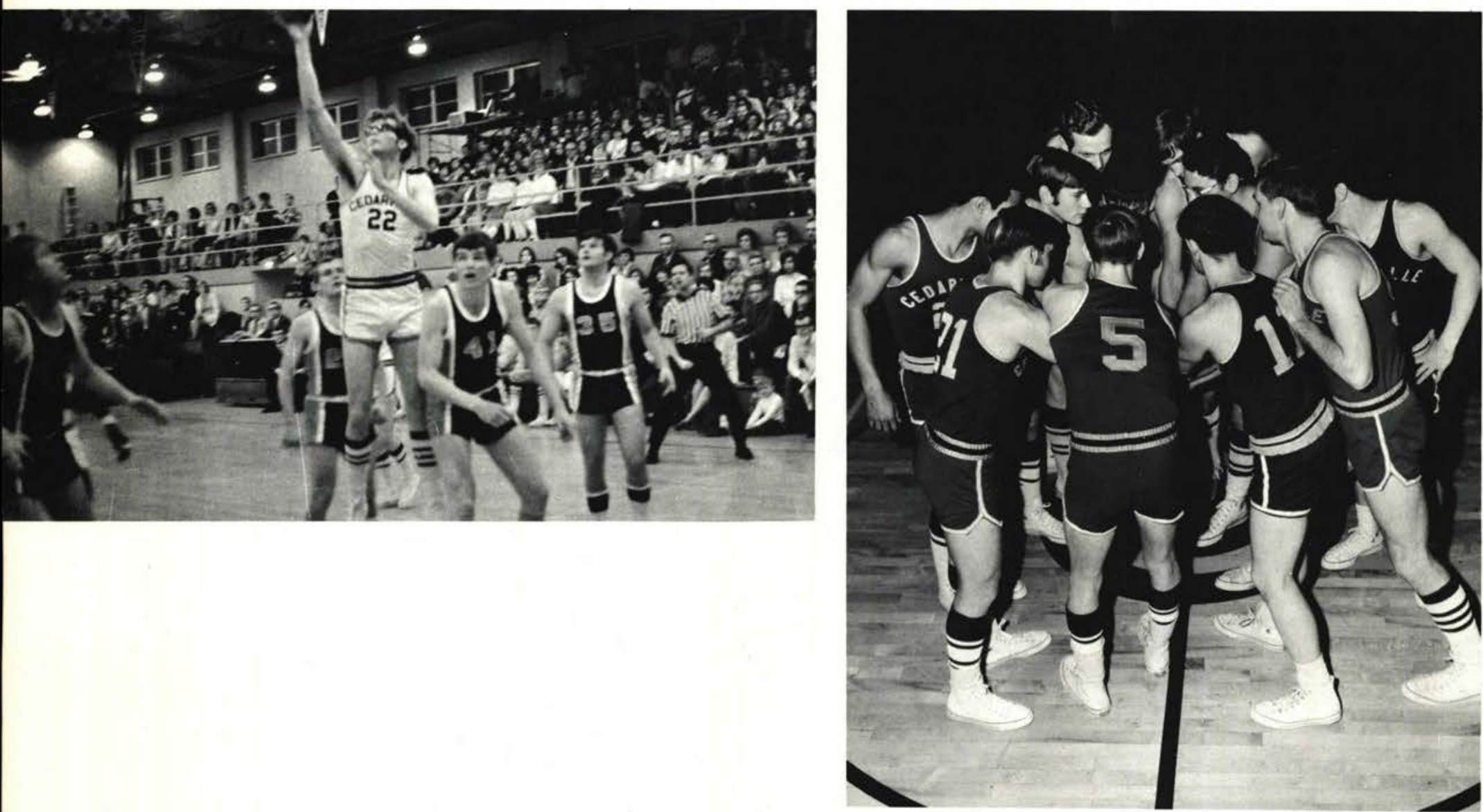


\section{Basketball Ties}

\section{For First}

What can you say about a championship team? Congratulations, Great job, or how about, That's our team? Nothing could rightly describe the tense moments of the Defiance game or the crowds as they carried the team away. The credit goes to the team's work and will, and the crowd's intense spirit.

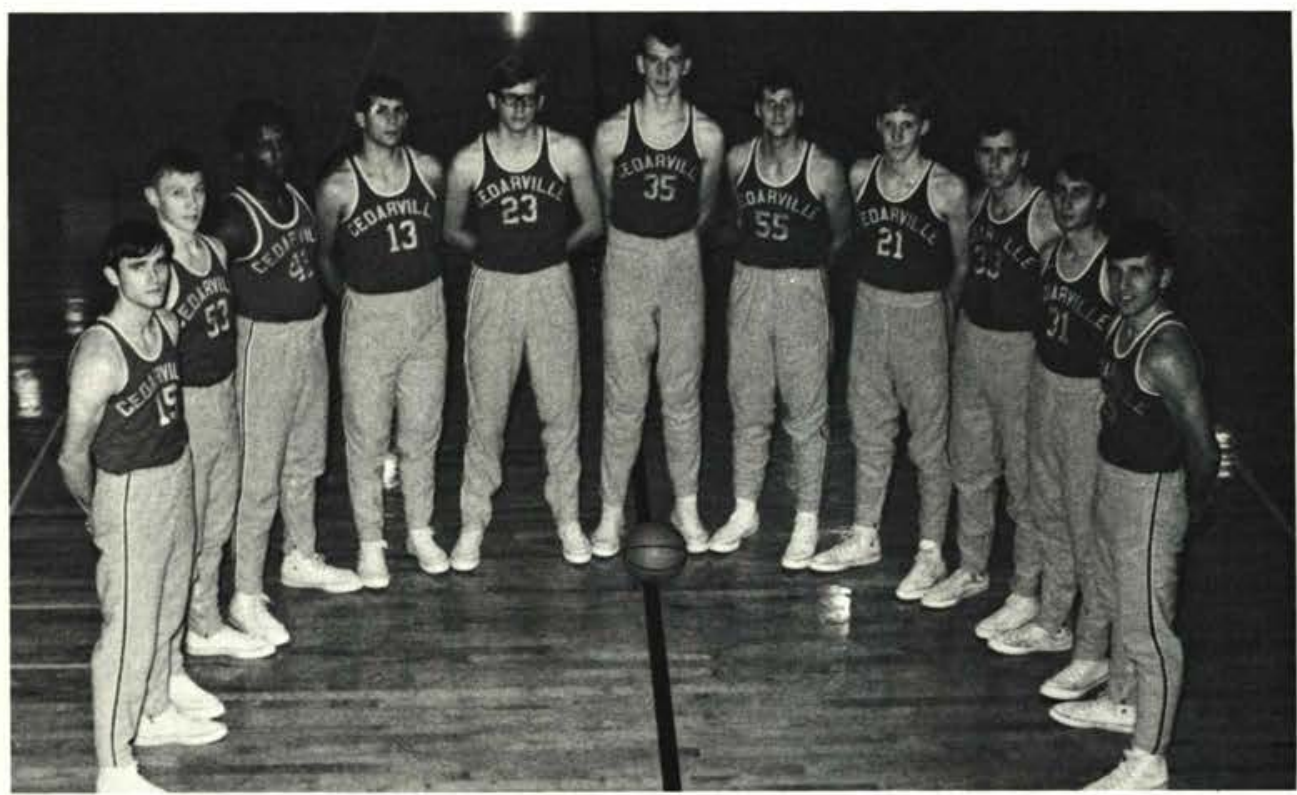

Pictured above is the VARSITY BASKETBALL TEAM: Darwin Boertje, Dave Southwell, Bob Warren, Bill Trefzger, Gary McDowell, Don Atherton, Dave Gaffner, Gary Darrow, Loren Reno, Mike Zazvrskey, and Bruce McDonald.
CC Basketball

Grace College Invitational

$\mathrm{CC}$

Olivet

92100

Messiah

Tri-State

Walsh

Findlay

Grace

Northwood

Urbana

Wilmington

Malone

Calvary

Bluffton

Kentucky S.

$\begin{array}{ll}60 & 58\end{array}$

$\begin{array}{ll}70 & 91\end{array}$

$\begin{array}{ll}92 & 94\end{array}$

$\begin{array}{ll}87 & 88\end{array}$

$\begin{array}{ll}92 & 81\end{array}$

$\begin{array}{ll}90 & 88\end{array}$

$109 \quad 101$

$\begin{array}{ll}70 & 74\end{array}$

6966

$94 \quad 118$

$77 \quad 90$

$76 \quad 77$

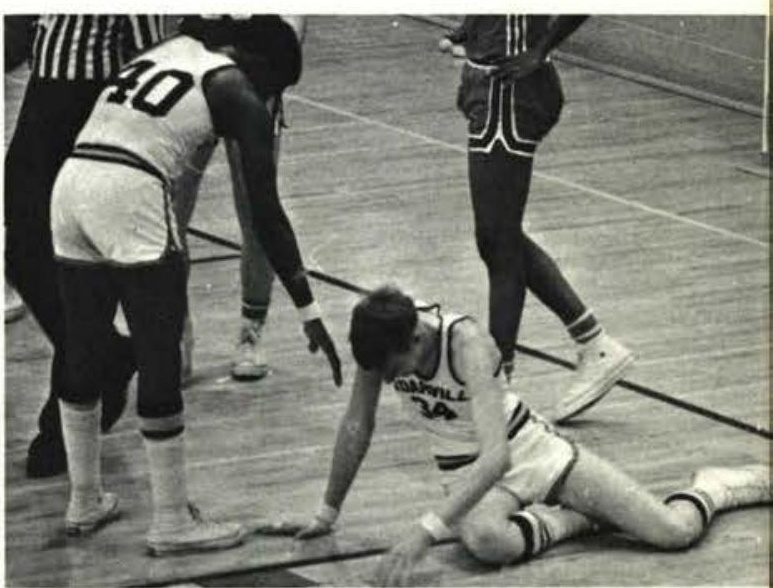

The team was honored by being Mid-Ohio co-champs. Bruce McDonald was All-Conference and Hon. Mention All American, 2nd leading scorer in CC's history. Don Atherton was leading rebounder and made All-Conference with Bob Warren.
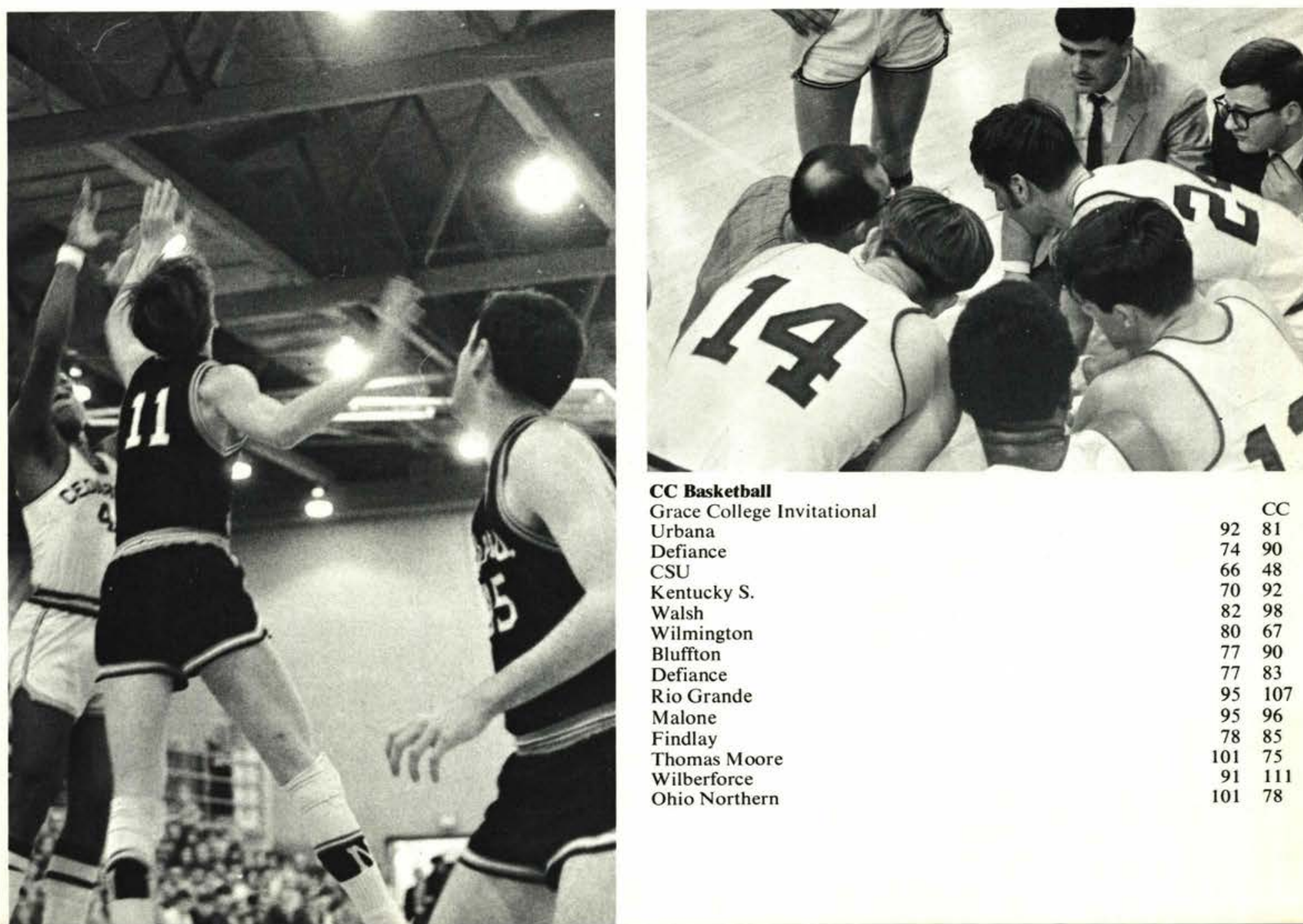
Pictured below is the CROSS COUNTRY: Bill Hoffman, Charles Williams, Mike Pasquerello, Dave Jewell, Ken Evans, and Dan Smith.
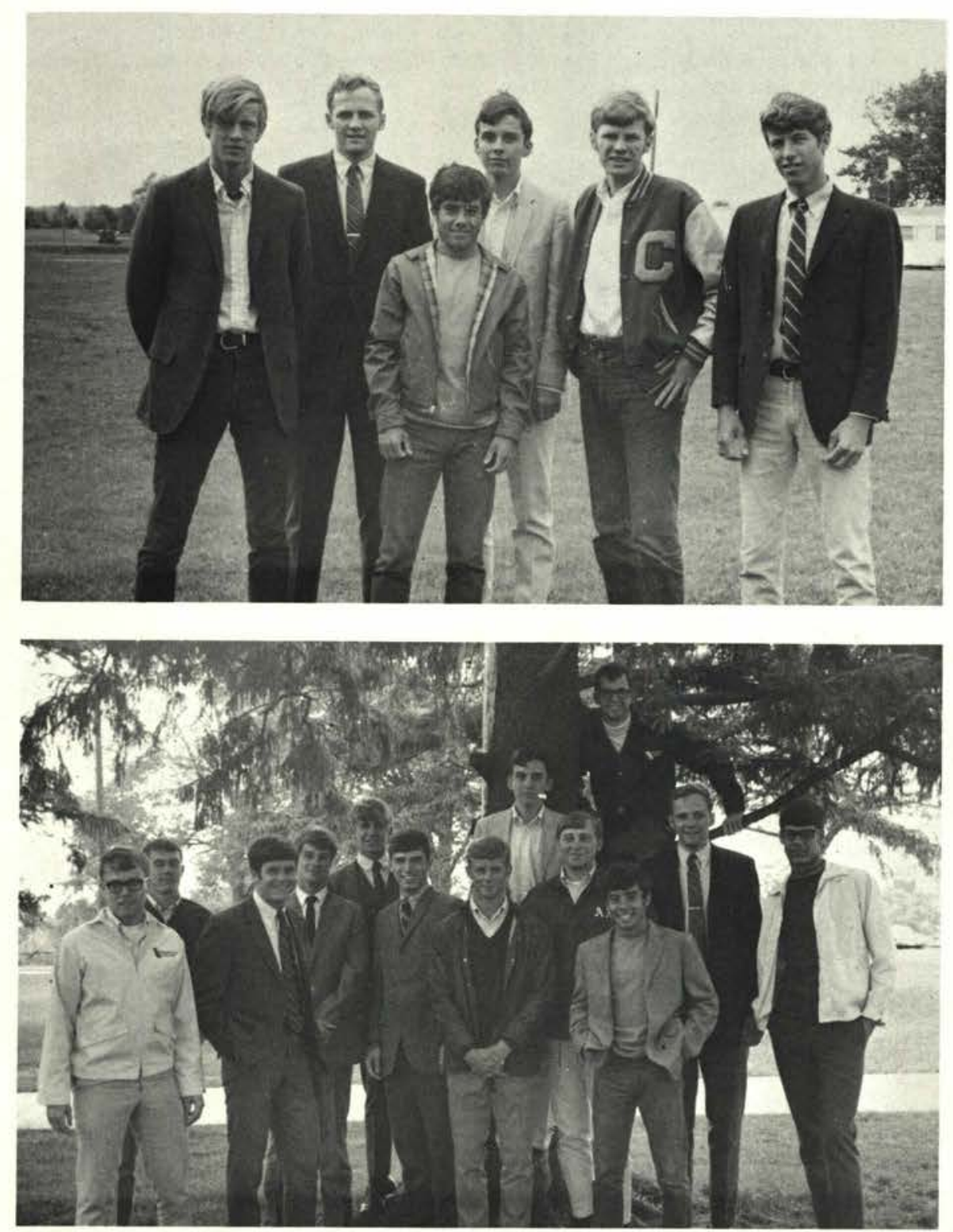

Pictured above is the FIELD TEAM: Doug Ambroza, John McGrillvray, Coach Randy Ross, Dave Argos, Bob Senseney, Ken Booth, Bruce Rogers, Dave Jewell, Denny Huddleston, Mike Pasquerello, Jim Hostetler, Charles Williams, and Dave Wright.

\section{Cross Country}

\section{And}

\section{Field}

\section{Too Often}

\section{Ignored}

Two CC teams spend much time at practice, play, and often receive little recognition. It's the cross country track and field teams that most foster exceptional skill, endurance, and strength. And with the new athletic fields these teams will be able to show their ability best on their home track.

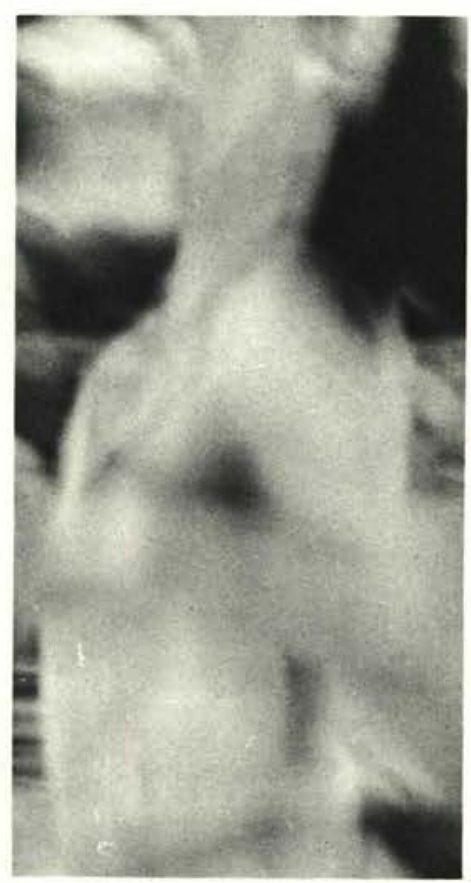




\section{Women's Intervarsity: Hockey, Basketball, and Volleyball Teams.}

WOMEN'S FIELD HOCKEY TEAM-Row 1, Sitting: Barb Kensil, Karen Rau, Judy Stamatis. Pat Wissinger, Billie Thomas, Nancy Bailey, Darlene Mann. Row 2, Standing: Advisor Miss Kearney, Mary Lynn Grable, Darlene Rouch, Connie Tompkins, Linda Wyssel, Joan Dautel, Kathy Spencer, Sandy Lathrop.
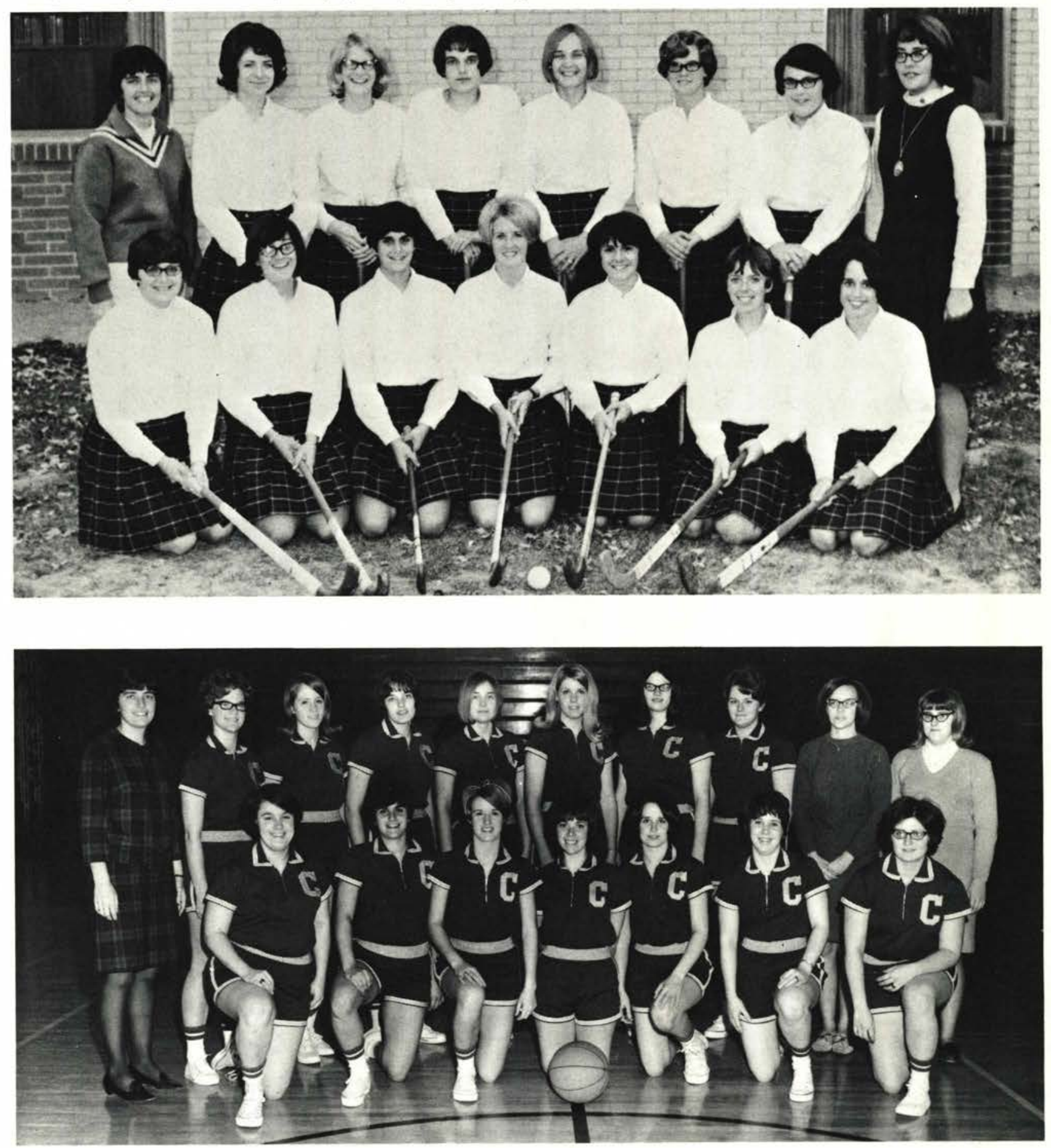

WOMEN'S INTERVARSITY BASKETBALL TEAM - Row 1, Kneeling: Kathy Spencer, Judy Stamatis, Pat Wissinger, Nancy Brown, Darlene Mann, Pam Betts, Barb Kensil. Row 2, Standing: Advisor Miss Kearney, Joan Dautel, Connie Walker, Connie Tompkins, Linda Wyssel, Karol Taylor, Darlene Fulcomer, Bev Moore, JoAnn Strychalski, Lela Tanner. 

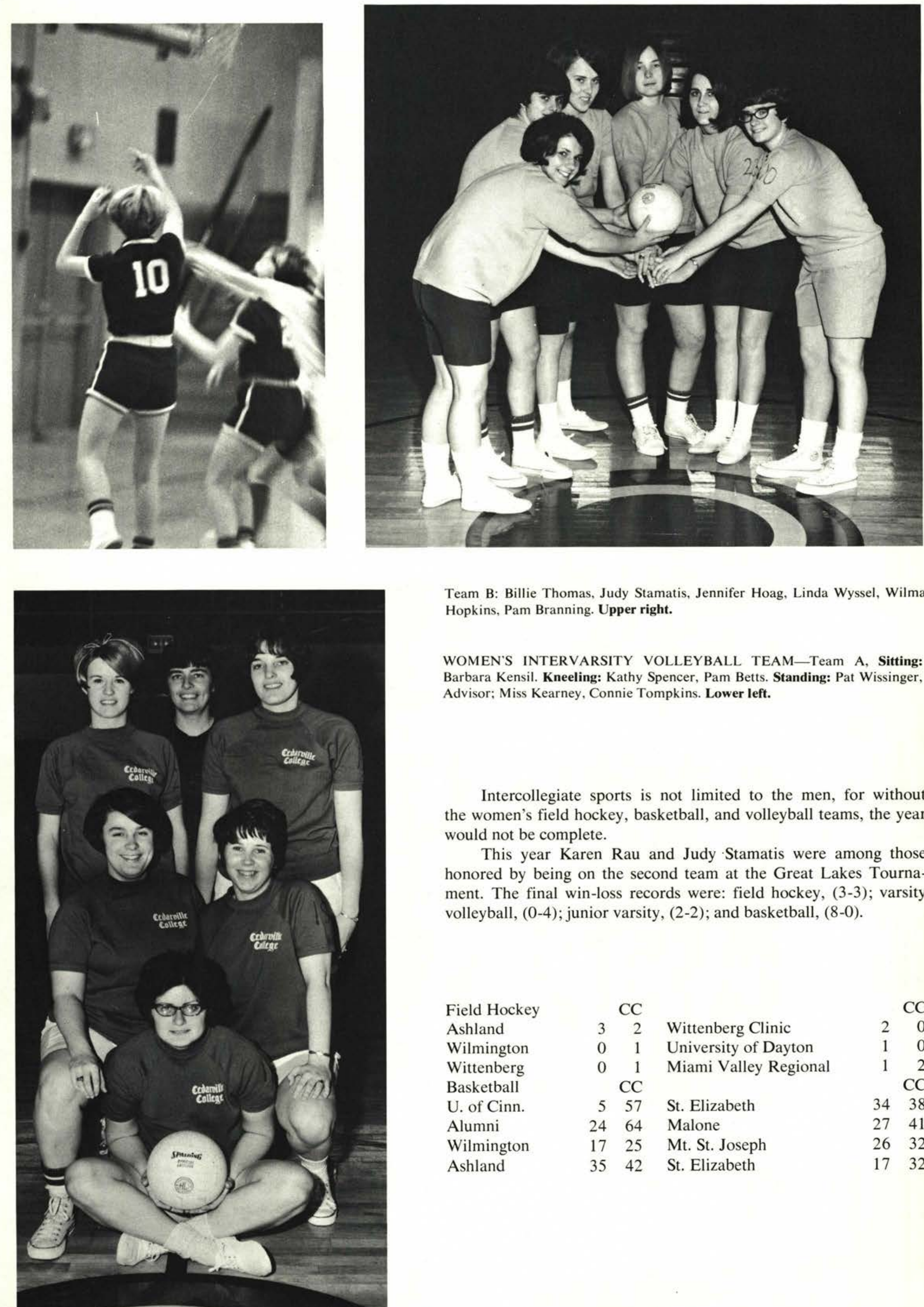

Team B: Billie Thomas, Judy Stamatis, Jennifer Hoag, Linda Wyssel, Wilma Hopkins, Pam Branning. Upper right.

WOMEN'S INTERVARSITY VOLLEYBALL TEAM-Team A, Sitting: Barbara Kensil. Kneeling: Kathy Spencer, Pam Betts. Standing: Pat Wissinger, Advisor; Miss Kearney, Connie Tompkins. Lower left.

Intercollegiate sports is not limited to the men, for without the women's field hockey, basketball, and volleyball teams, the year would not be complete.

This year Karen Rau and Judy Stamatis were among those honored by being on the second team at the Great Lakes Tournament. The final win-loss records were: field hockey, (3-3); varsity volleyball, (0-4); junior varsity, (2-2); and basketball, (8-0).

Field Hockey

Ashland

Wilmington

Wittenberg

Basketball

U. of Cinn.

Alumni

Wilmington

Ashland

\section{$\mathrm{CC}$}

32

$\begin{array}{ll}0 & 1\end{array}$

$0 \quad 1$

$$
\mathrm{CC}
$$

$\begin{array}{ll}5 & 57\end{array}$

$24 \quad 64$

$17 \quad 25$

$35 \quad 42$
Wittenberg Clinic

University of Dayton

Miami Valley Regional

\section{St. Elizabeth}

Malone

Mt. St. Joseph

St. Elizabeth
$\mathrm{CC}$

20

10

12

$\mathrm{CC}$

$34 \quad 38$

$27 \quad 41$

$26 \quad 32$

$17 \quad 32$ 


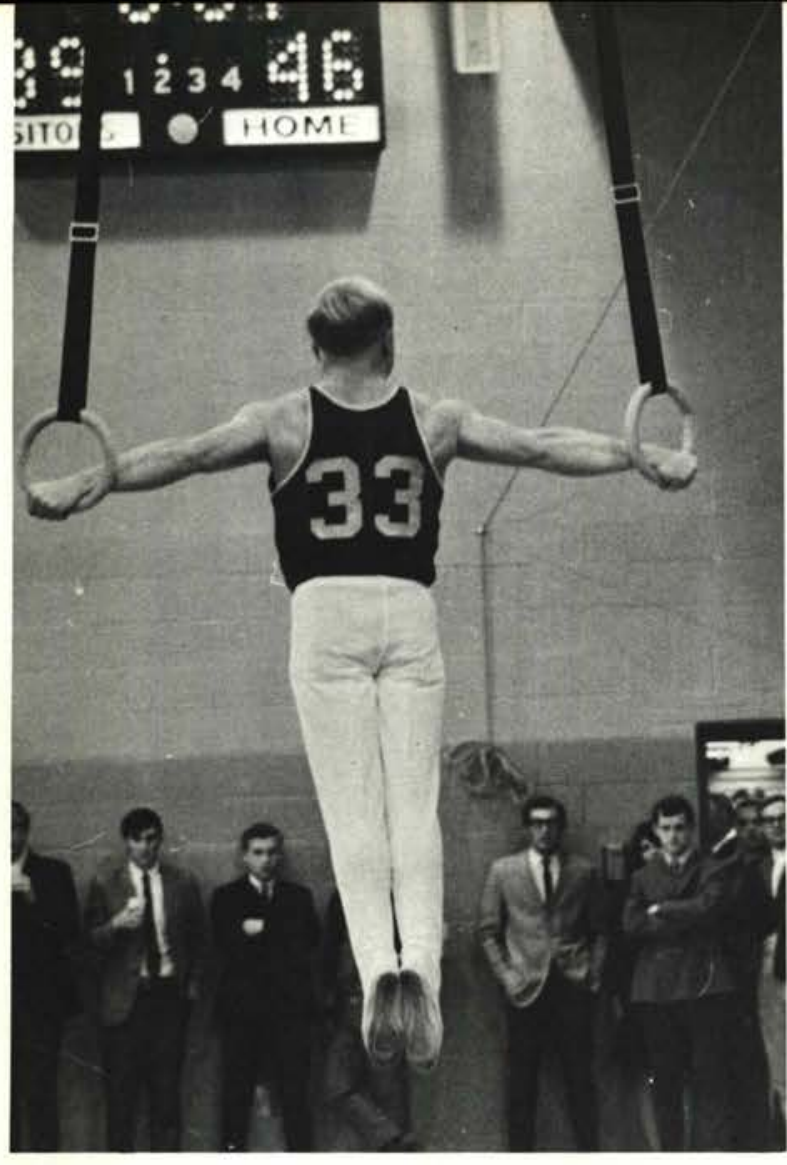

Monkey bars, horses, and rings bring the gymnastics team into action. With a scant but energetic beginning, the team has found its audiences enthused at basketball half times.

In the spring a man's fancy turns to baseball. And CC's team is no exception. The excitement of a game brings shrill cheers, easy breaks, strike outs, close runs, and even rain.

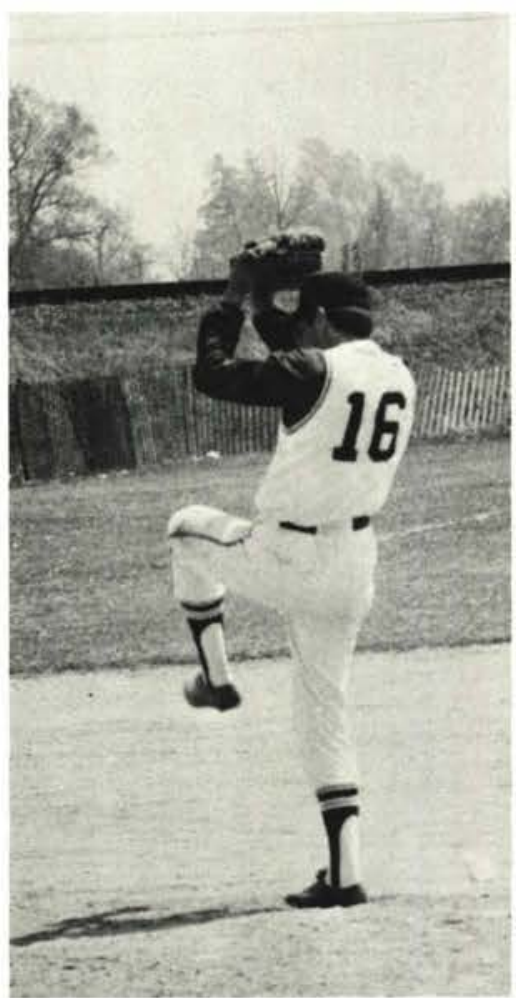

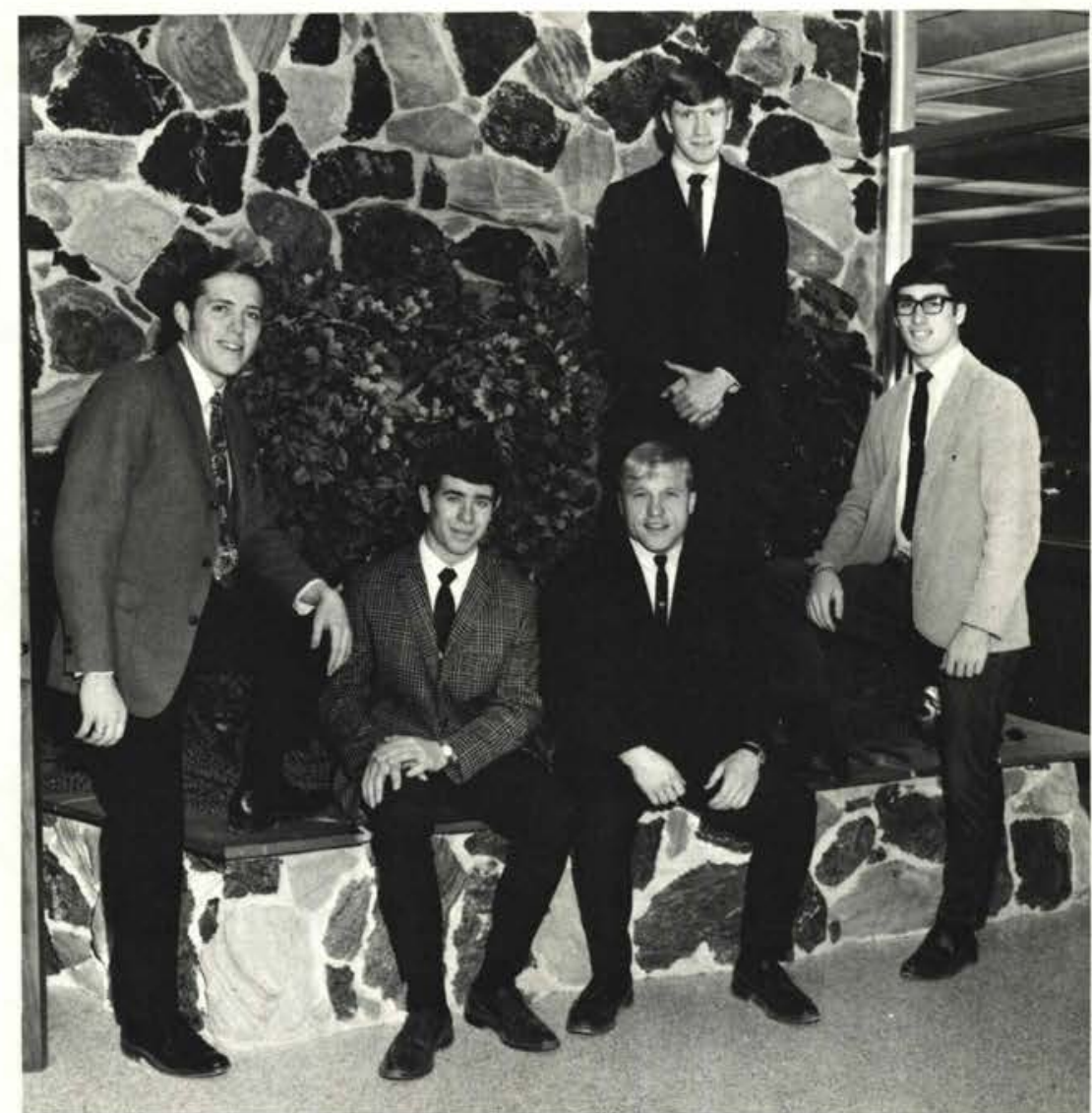

Pictured above is the GYMNASTICS TEAM: Chip McDaniel, Ralph Perkins, Terry Phipps, Jon Frye, and Roger McCrum.

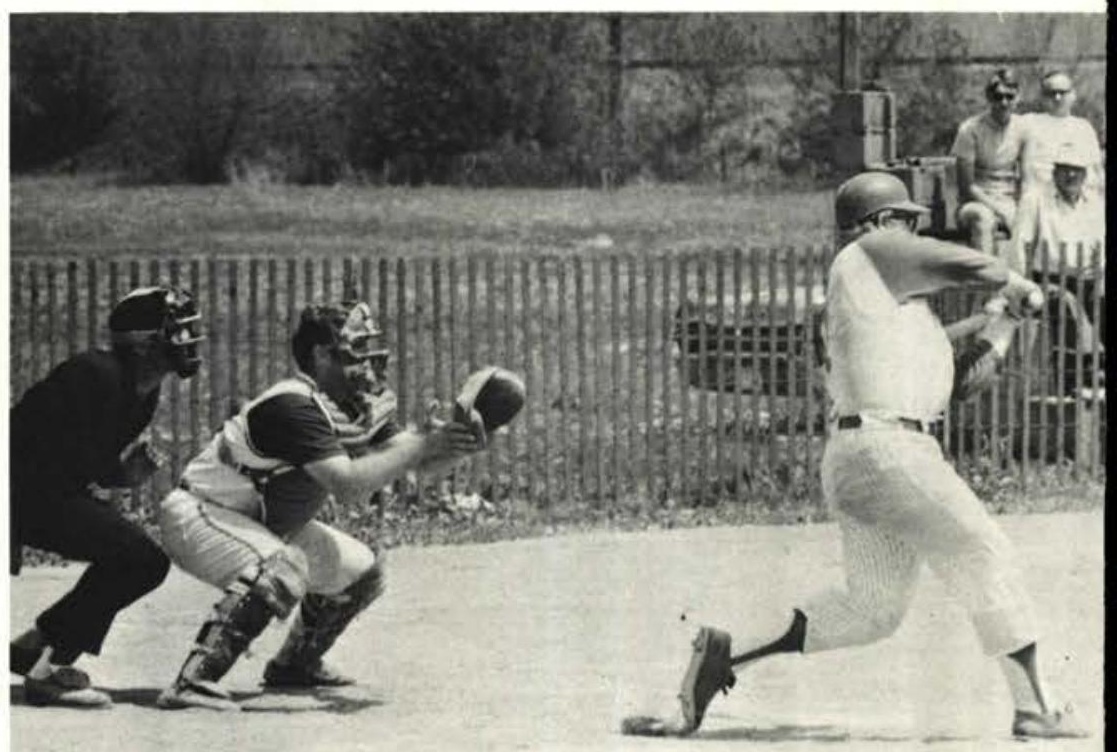



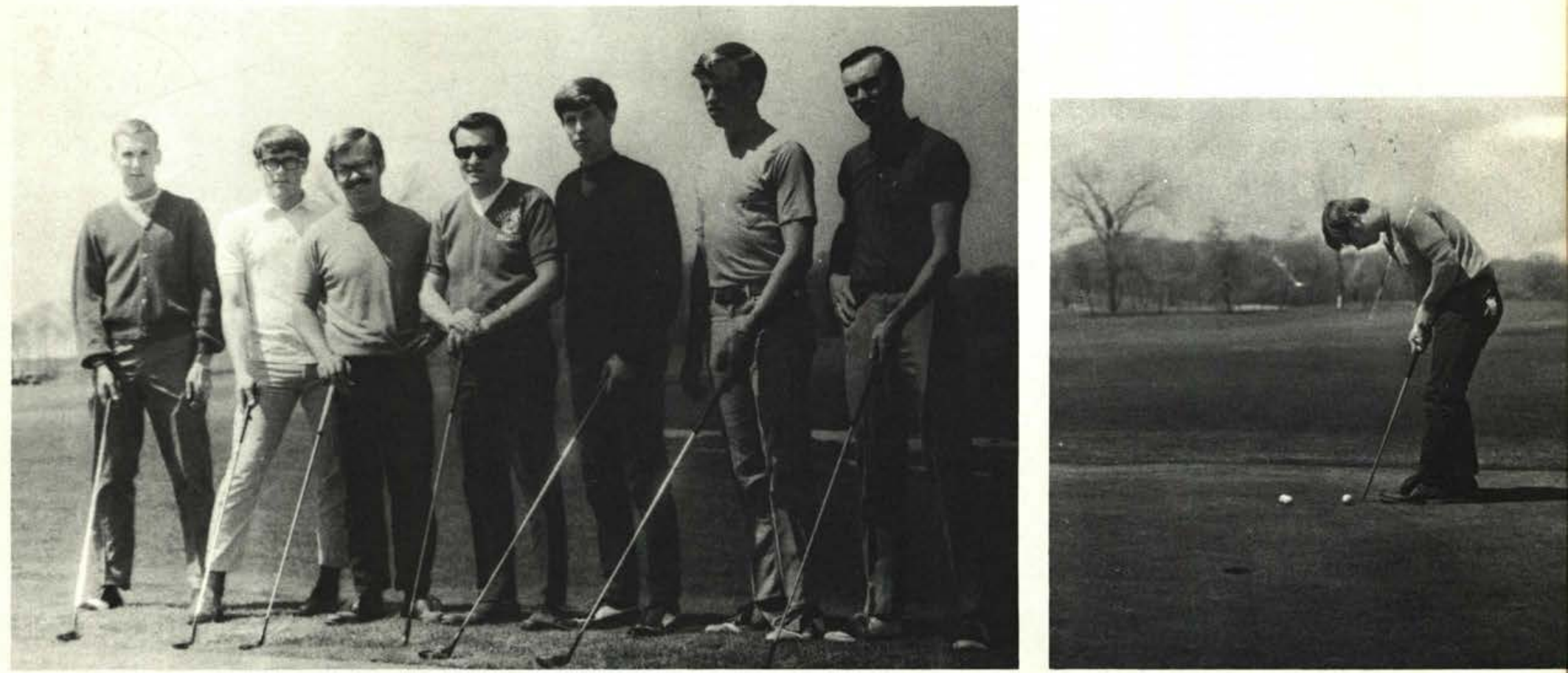

GOLF TEAM: Tom Andrews, Jim Spaulding, Bob Schultz, Dr. Gromacki, Dan Smith, Randy Berry,

Sam Kelley.
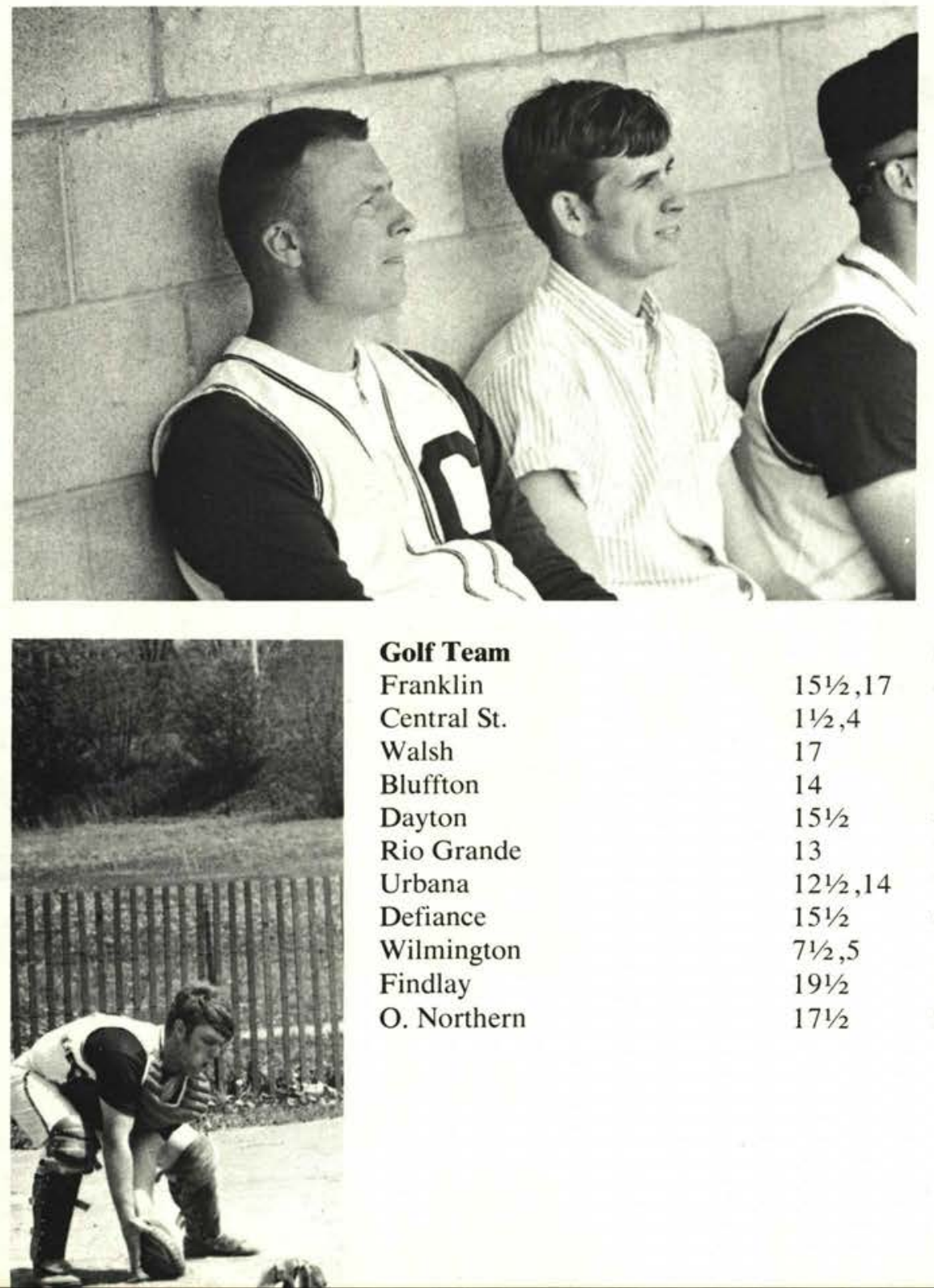

Golf Team

Franklin

Central St.

Walsh

Bluffton

Dayton

Rio Grande

Urbana

Defiance

Wilmington

Findlay

O. Northern

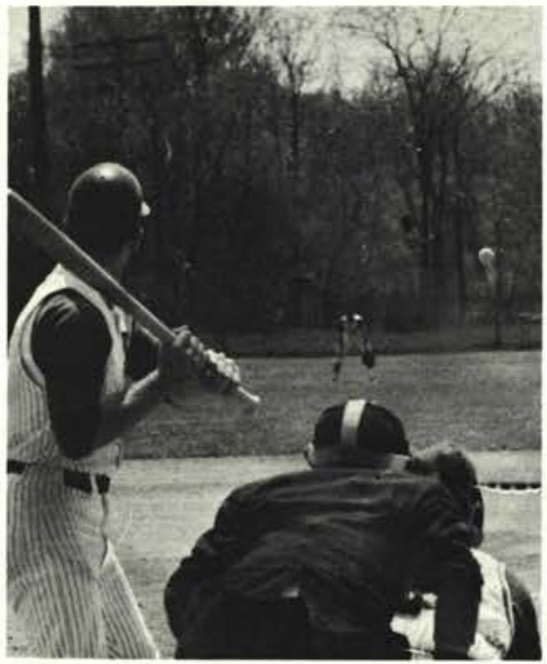

$\mathrm{CC}$

$15 \frac{1}{1 / 2,17} 41 \frac{1}{2,3}$

$11 / 2,4 \quad 181 / 2,16$

$17 \quad 3$

146

$151 / 2 \quad 41 / 2$

$13 \quad 7$

$12 \frac{1 / 2,14 \quad 71 / 2,6}{}$

$151 / 2 \quad 41 / 2$

$71 / 2,5 \quad 12 \frac{1}{2}, 5$

$191 / 2 \quad 1 / 2$

$171 / 2 \quad 21 / 2$
Putting, teeing off, the eighteenth hole, these are all terms for the fastest growing sport-golf. And even at Cedarville, the sport is catching on fast and mustering many team members. Averages were: R. Berry, 83.4; B. Schultz, 84.8; D. Smith, 88.0; T. Andrews, 96.0; S. Kelley, 96.3; J. Spaulding, 100.0. 


\section{MOC Tennis Champs Repeat}

Last year, Cedarville pulled a first ever for the MOC when it won all divisions of the conference tennis tournament. This year they did it again. With only one tennis court (?), CC finished the tournament by sweeping the maximum of nine first places. Their victory won them honors for the trip to Kansas City for the second consecutive year. Through practice and pep, strong will backed by action, the Jackets Tennis Team put Cedarville on the map.

$\begin{array}{llllrr}\text { Tennis } & & \text { CC } & & & \text { CC } \\ \text { Thomas More } & 0 & 9 & \text { Findlay } & 0 & 9 \\ \text { Georgetown } & 0 & 9 & \text { Bluffton } & 0 & 9 \\ \text { Transylvania } & 5 & 4 & \text { Malone } & 0 & 9 \\ \text { Central State } & 0 & 9 & \text { Cleveland State } & 6 & 3 \\ \text { Ohio Northern } & 0 & 9 & \text { MOC Tournament } & & 45 \\ \text { Spring Arbor } & 0 & 9 & \text { Defiance } & 12 & \\ \text { Detroit } & 0 & 9 & \text { Bluffton } & 6 & \\ \text { Hillsdale } & 3 & 6 & \text { Malone } & 3 & \\ \text { Pikeville } & 0 & 9 & \text { Findlay } & 3 & \\ \text { Defiance } & 0 & 9 & \text { Wilmington } & 0 & \end{array}$
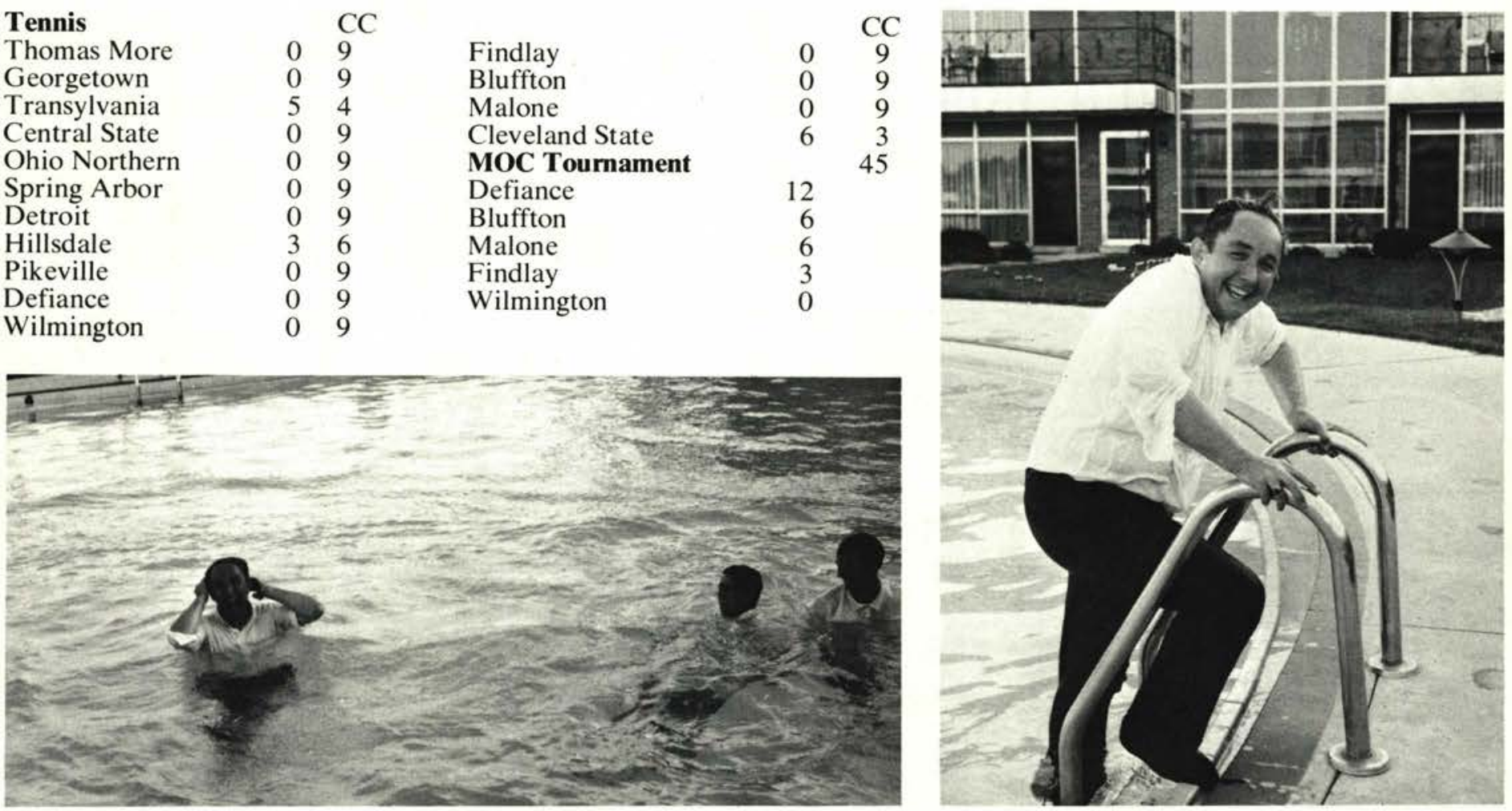

Pictured below are the NO. 1 CHAMPS: Dan Martin, Dave Durham, Dan Ruffin, Dave Beck, Warren Pettit, Paul Entner, Ron Baker, and Coach Murray Murdoch.

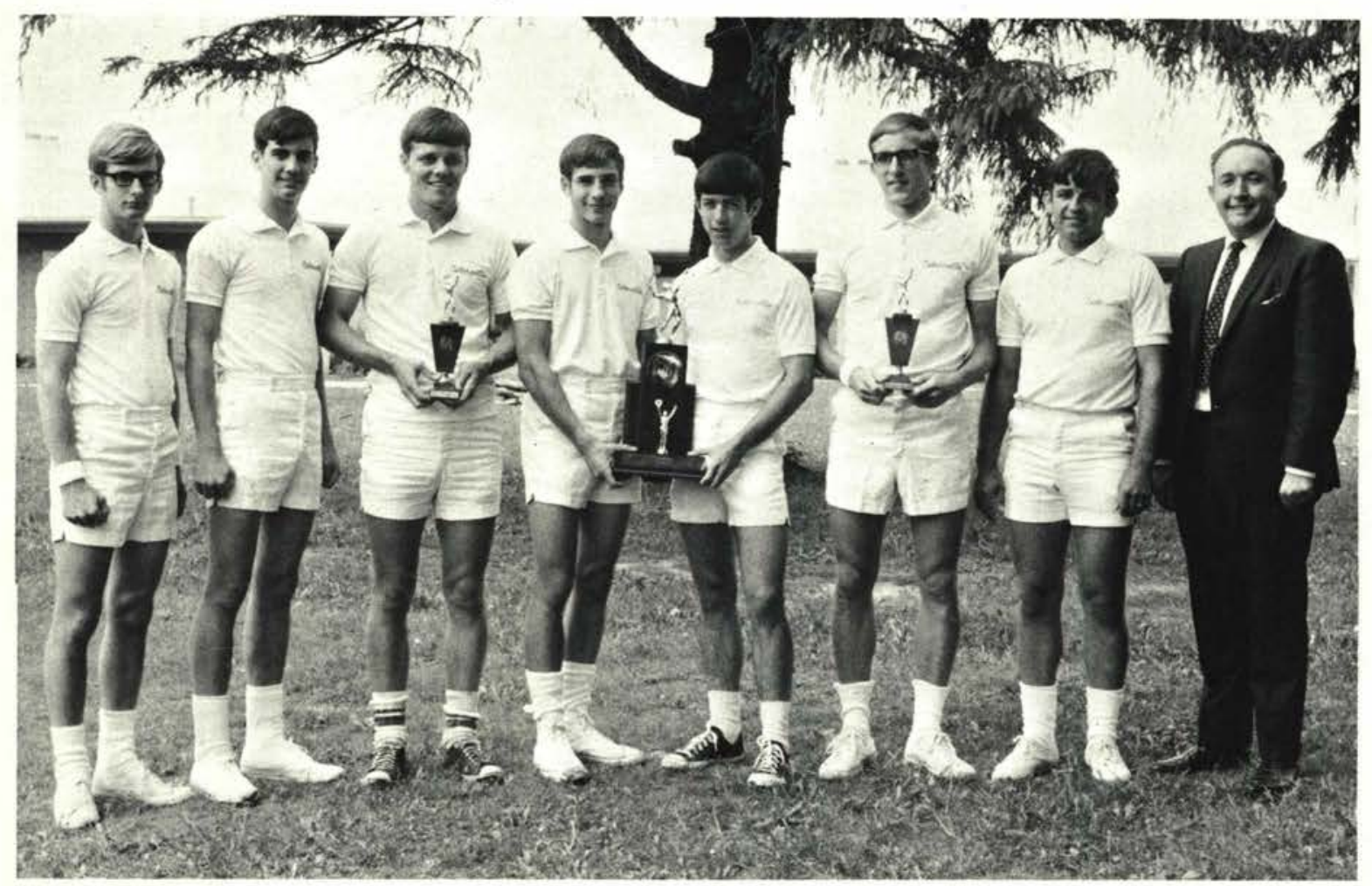




\section{The Finale of the Cheers, Pep, Push, Spirit}

The finale of the cheers, pep, push, and spirit is the spring athletic banquet with its presentation of trophies and awards. Well-deserved letters are given as all feast on the Smiths' delicious banquet food. The season may have begun with a whimper, but it certainly concluded with a bang.
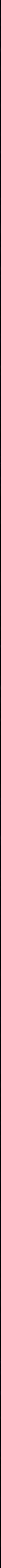


\section{ACTION . . .}

the pinching of pennies. the rivalry of clubs, leaving Student Council at 9:00 P.M. the burning of midnight oil. the excitement of belonging . . this is our action. 


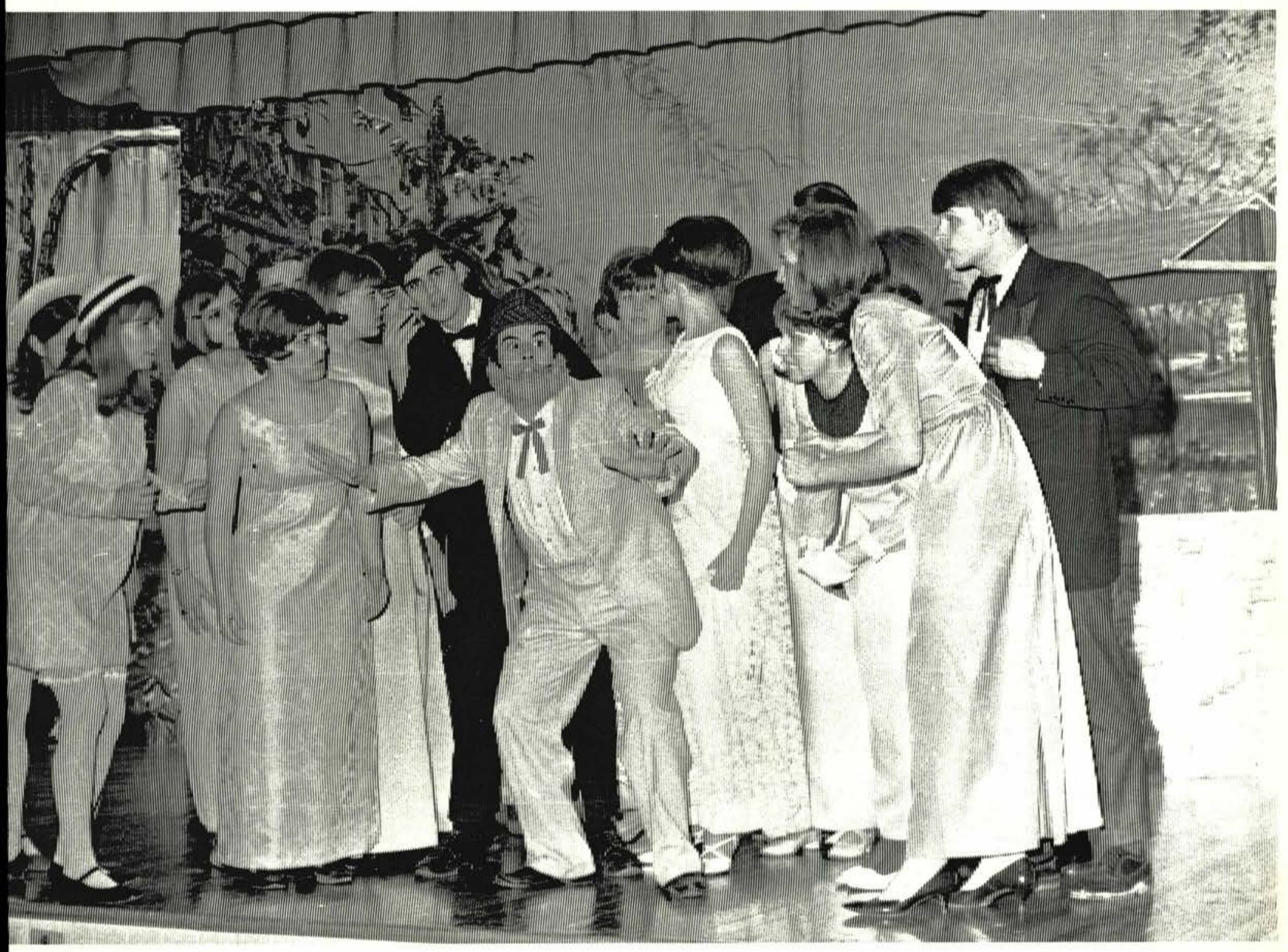



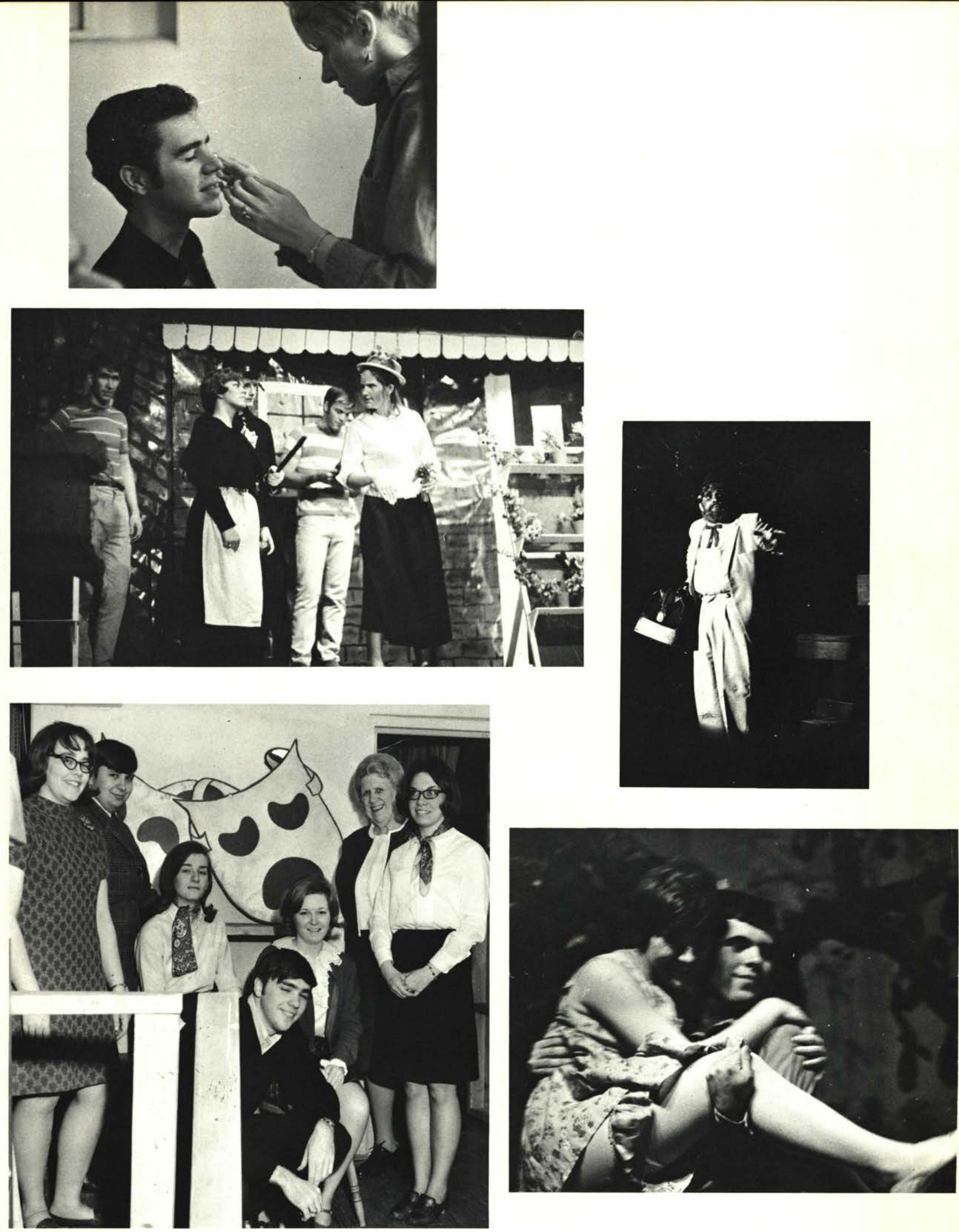


\section{Whispering Cedars}

"The presses are rolling." The Whispering Cedars is more than a few words crammed onto a page. It demands literary skill, layout ability, and advertising salesmanship. But the most significant factor is the value of a newspaper to serve as representative of the college. The Cedarville College newspaper has successfully been a "middleman" of communication between faculty and students, as well as a spokesman for the campus. Credit can be given to editor, David Haffey; assistant editors, Rich Mitchell and Dawn Myers; business manager, Gary Darrow; art editor, Connie Averitt; and photographers, Dale Braun and Art Shuter.

Pictured below is the Whispering Cedars Staff: Carol DeBoer, Becky Sharp, Jerry Greyson, Janet Phenix, Dawn Myers, Rich Mitchell, Judy Leach, Pat Lawhead, Gail Sears, Pat Wissinger, Ellen Young, Bonnie Smith, Dave Haffey, and and Patti France.
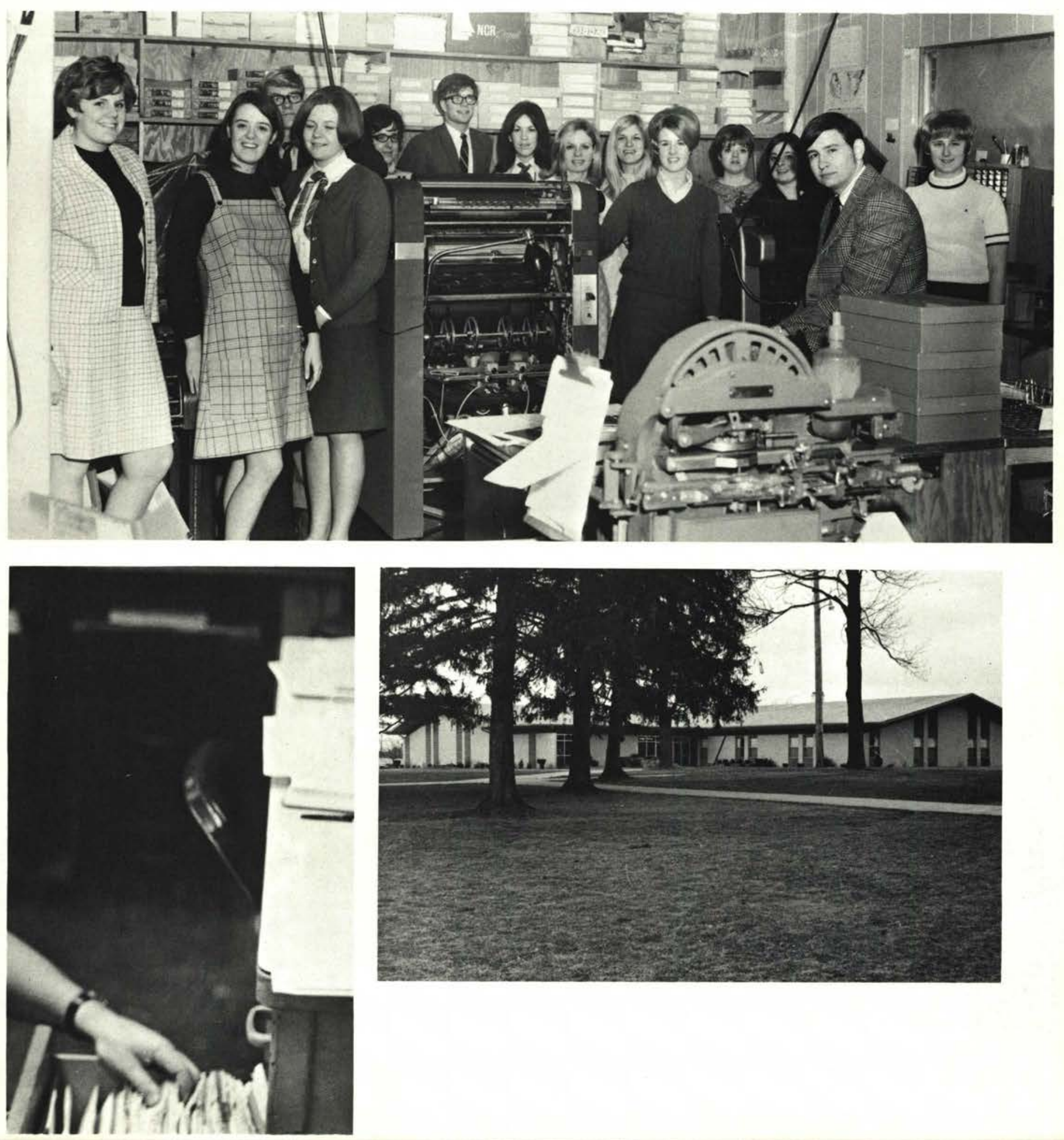


\section{Alpha Chi}

Alpha Chi is a Christian men's organization serving the Lord, Cedarville College, and themselves. This year some of their services included the "Cedar What" fall banquet, the annual talent night, the crowning of the Alpha Chi Sweetheart, and the Cedar Day festivities. Besides these areas of service, they did provide entertaining activities for themselves, including socials and gym parties.

The officers this year are: Ron Coriell, Pres.; Randy Patten, V.Pres.; Roger Leach, Sec.; Max McCullough, Treas.; Ron Meyers, St. Council Rep.; Jerry Motter, Rescue Squad Chief; Tim Bosworth, Membership coordinator.

Pictured at right is Alpha Chi Sweetheart, Gail Sears; at bottom left, Alpha Chi plebs participate in initiation; and at bottom right, the members enjoy an ice cream social.
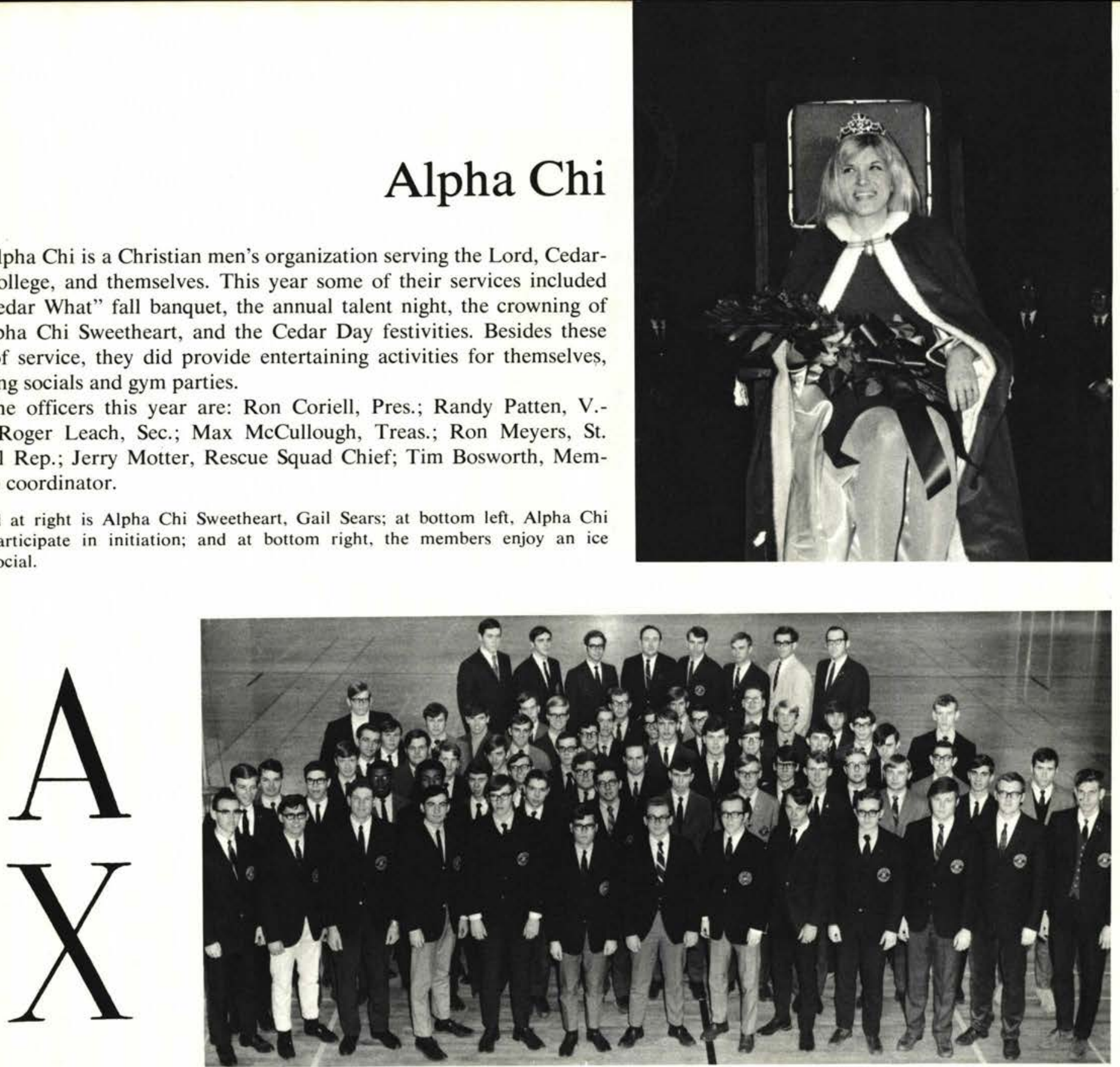

ALPHA CHI-Row 1: A. Shuter, G. Creviston, L. Eichelburger, C. Rowe, C. Dutton, R. Jezowski, D. Acker, J. Holliday, G. Dawson, R. Coombs, M. Sattler, B. Schill, B. Lapp. Row 2: D. Braun, D. Stevens, D. Long, K. Hammonds, B. Hunter, R. Perkins, K. Holdin, R. Hamilton, D. Mays, D. Rohm, P. Large, D. Huddleston, D. Durham, L. Reno. Row 3: J. Frye, D. Seigneur, C. Roberts, B. Rehkopf, S. McMillan, D. Dieringer, B. Amstutz, M. Wilhite, S. Olsen, G. Parcher, P. Senseney, R. Curtis. Row 4: R. Baker, J. Colyer, L. Anderson, G. Muska, M. Coffman, D. Manross, J. Rumley. Row 5: G. McDowell, W. Jenkins, K. Boothe, K. Cole, J. Seeley, D. Nelson, L. Davis, D. Hull, D. Martin, B. Carmean, B. King, C. Jensen, H. Moore, C. Strychalski, D. Atherton. Row 6: J. Motter, R. Meyers, R. Coriell, Advisor; Mr. Murdoch, R. Patten, M. McCullough, T. Bosworth, R. Leach.
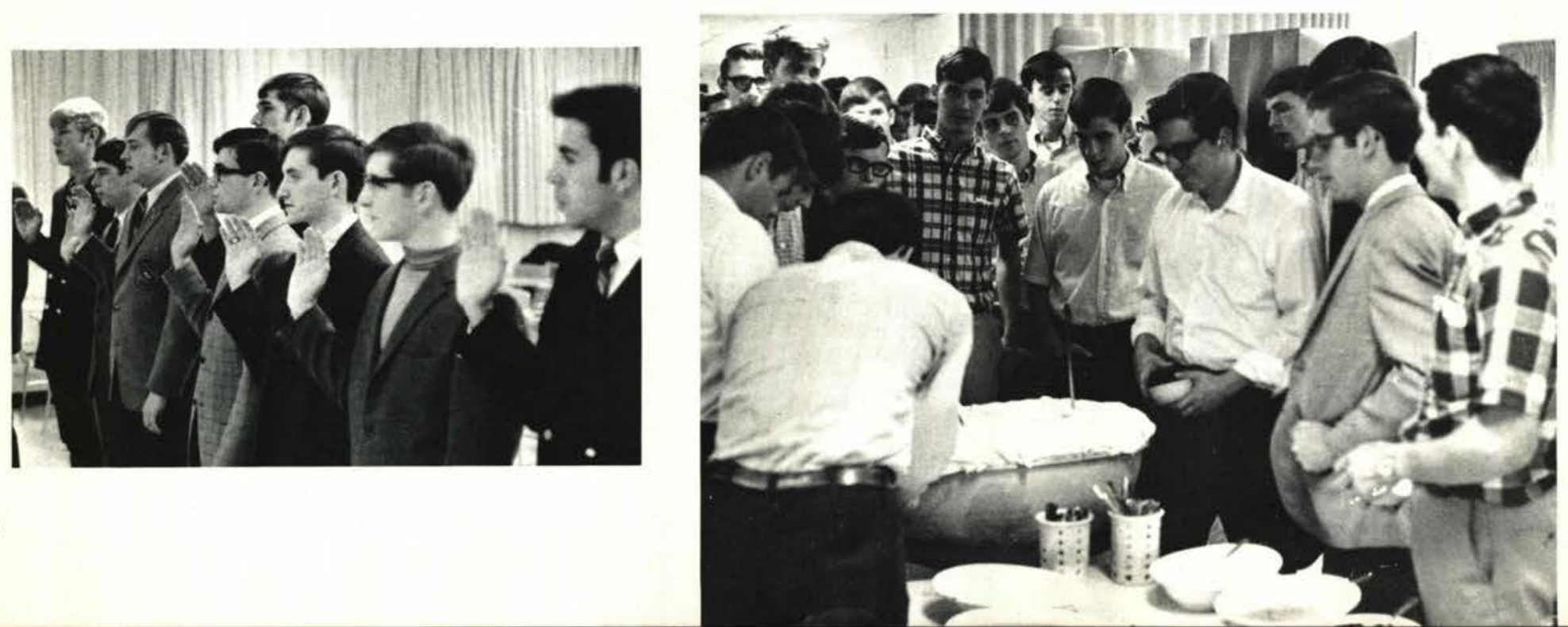


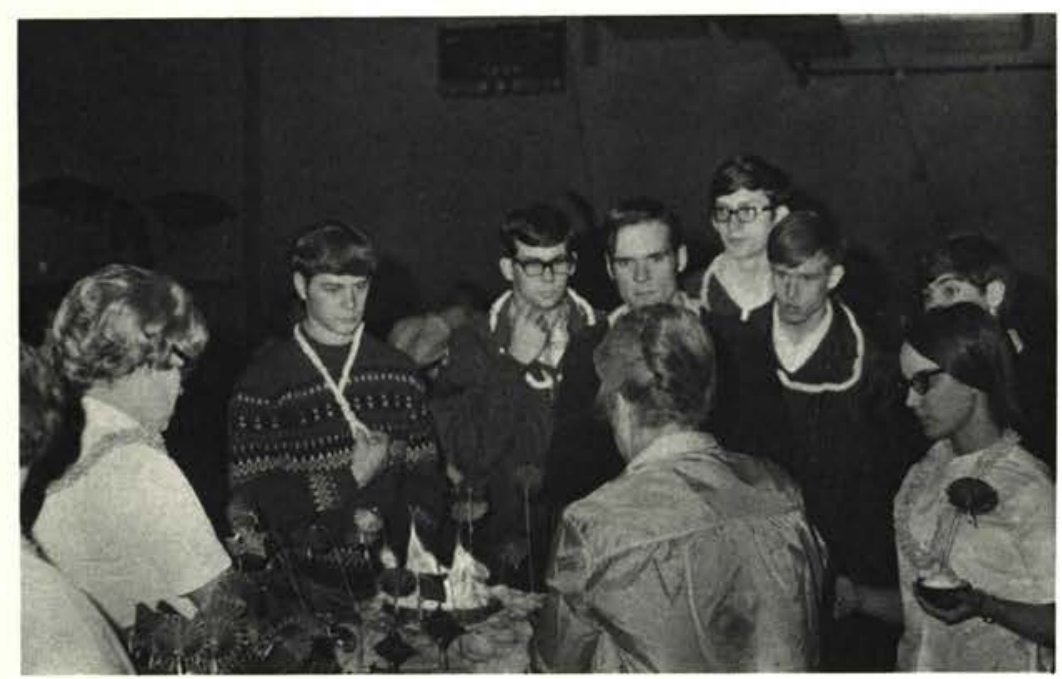

\section{Pi Sigma Nu}

$\mathrm{Pi}$ Sigma $\mathrm{Nu}$ is a men's organization which stands for the spirit, mind, and body of the total man. $\mathrm{Pi}$ Sigma $\mathrm{Nu}$ endeavors to develop maturity in all aspects of college life and to prepare men to face life after graduation.

Pi Sigma Nu presented their annual school banquet on February 14 and sponsored a variety show starring their own members.

The officers for this year are: Ken Muck, Pres.; Warren Pettit, V.-Pres.; Loren Hamill, Sec.; Ken Curcio, Treas.; Richard Adams, St. Council Rep.; Bob Schultz, Chaplain; and Mr. Brad Moore, Advisor.

Pictured at the left and the bottom is Pi Sigma Nu's all school luau.

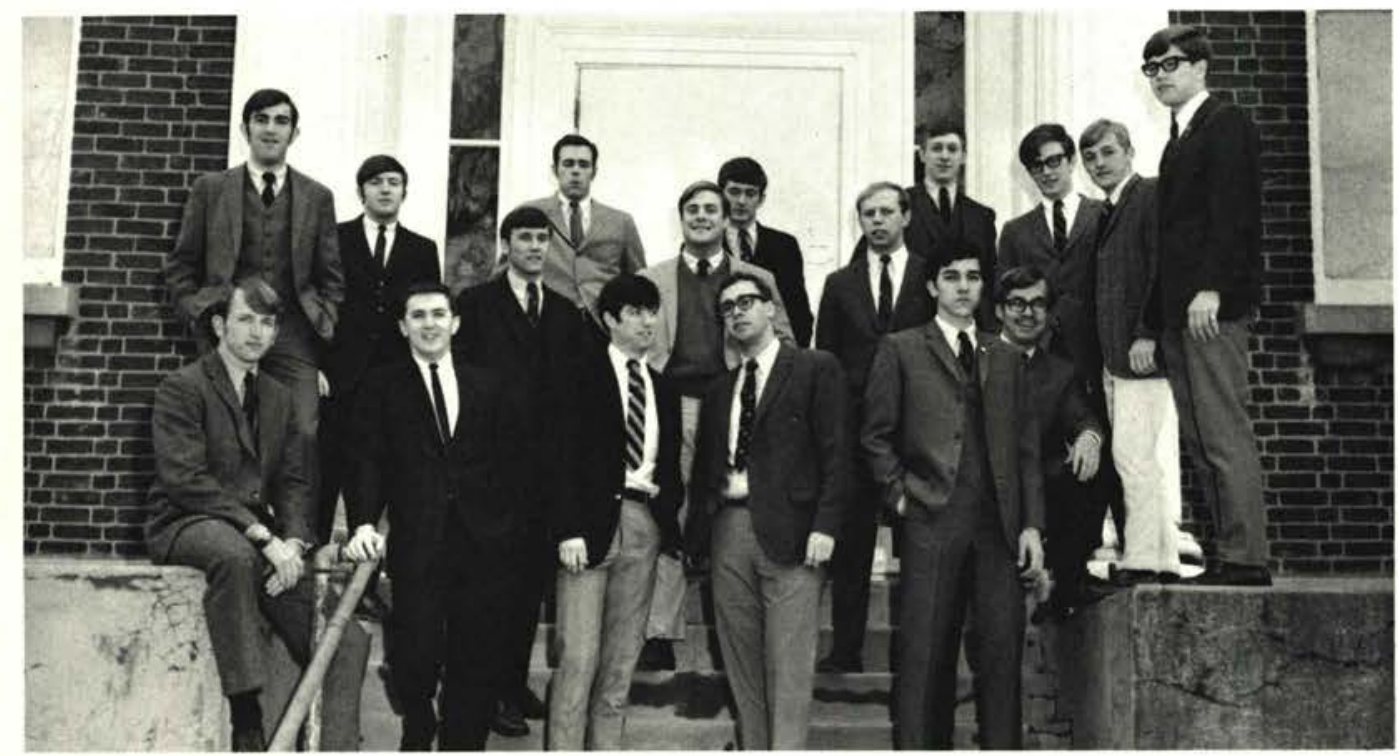

PI SIGMA NU_-Row 1: Bob Lunney, Advisor; Mr. Moore, Warren Pettitt, Ken Muck, Ken Curcio. Row 2: Bob Whattoff, Dennis Bunting, Dennis Stora, Bob Shultz. Row 3: Dave Gregory, Jim Williams, Dave Draxler, Jim Jeremiah, David Southwell, Tim Hales, Rock Adams, Andy Gathany.
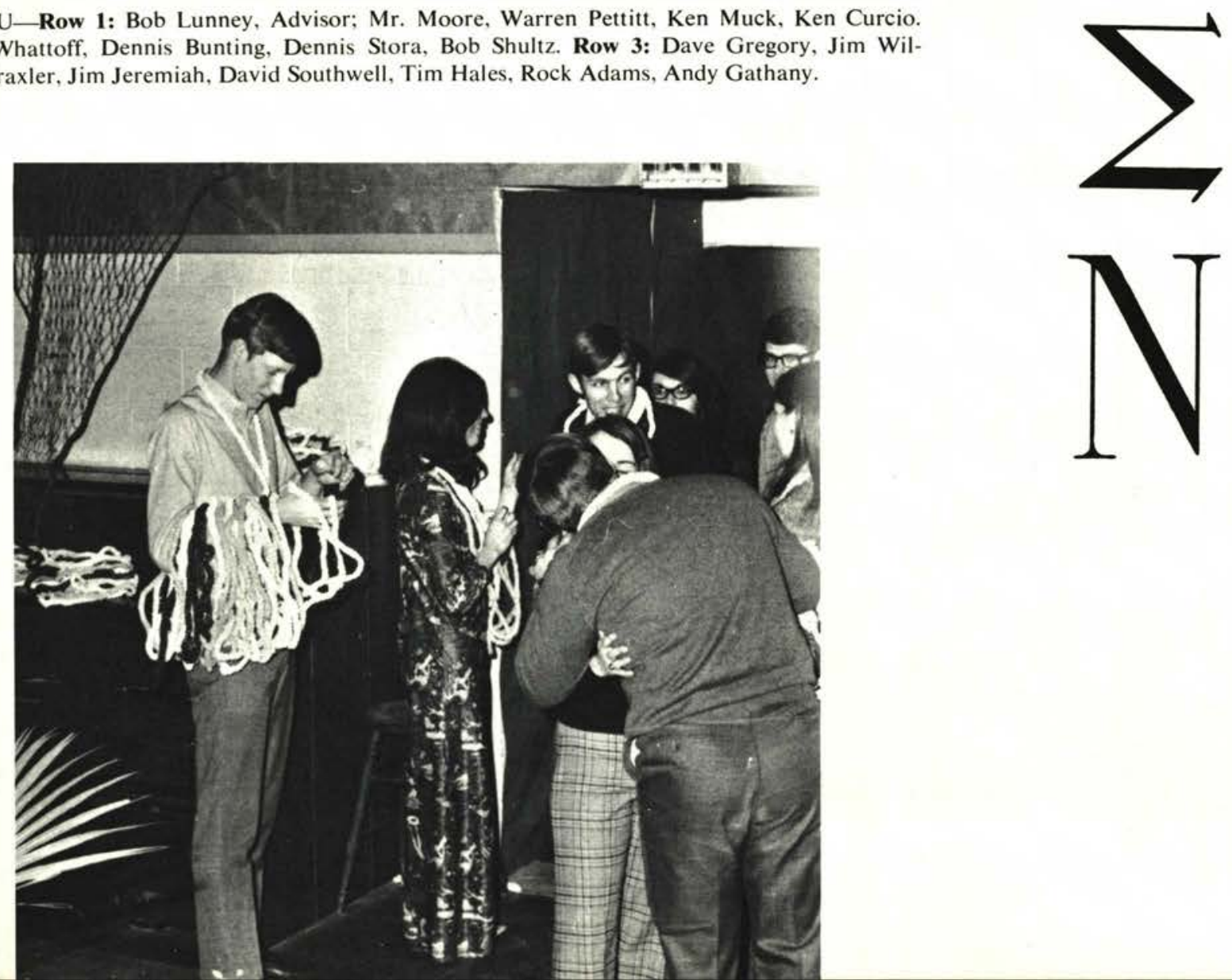


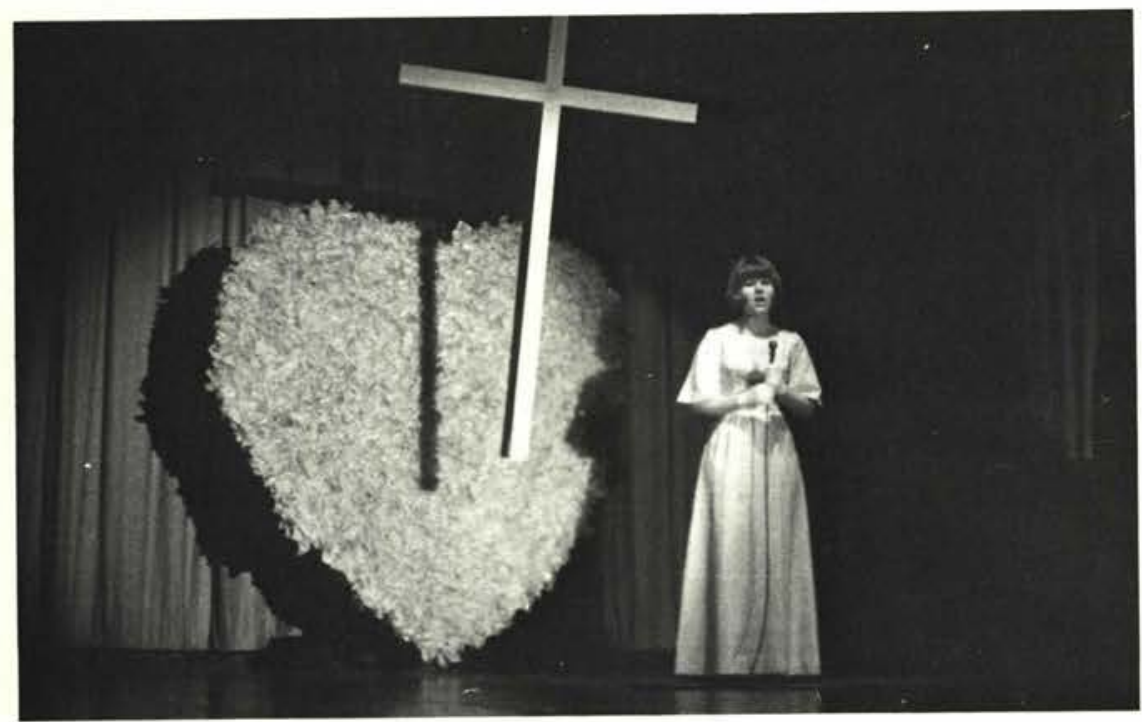

\section{Kappa Delta Chi}

Kappa Delta Chi is the Greek form of "Gracious ladies, servants of the Lord." Through vespers, missionary projects, attending a musical, and going canoeing, the organization stimulated interest in gracious living in a manner pleasing to God.

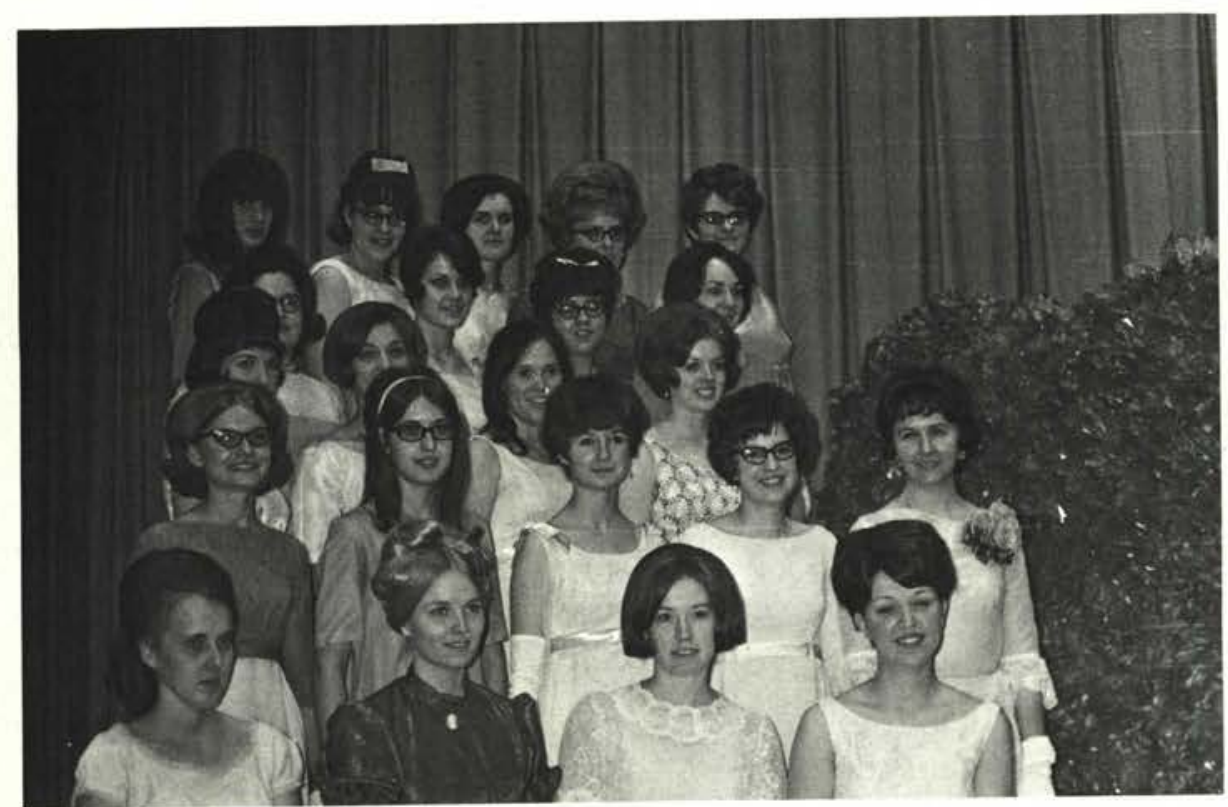

KAPPA DELTA CHI-Row 1: Jennie Hoag, Carol Beerer, Joan Corbin, Roxanne Butler. Row 2: Marty Gutow, Jan Kever, Betsy Bodenmiller, Karen Hamilton, Mrs. McPheeters. Row 3: Tanis McDaniel, Mary Beitler, Retta Nutter, Gail Gatliff. Row 4: Pat Sturdevant, Karen Donaldson, Dottie Abrams, Donita Baker. Row 5: Ruth Rogers, Sandy Lathrop, Judy Winston, Darylne Wuest, and Bev Moore.
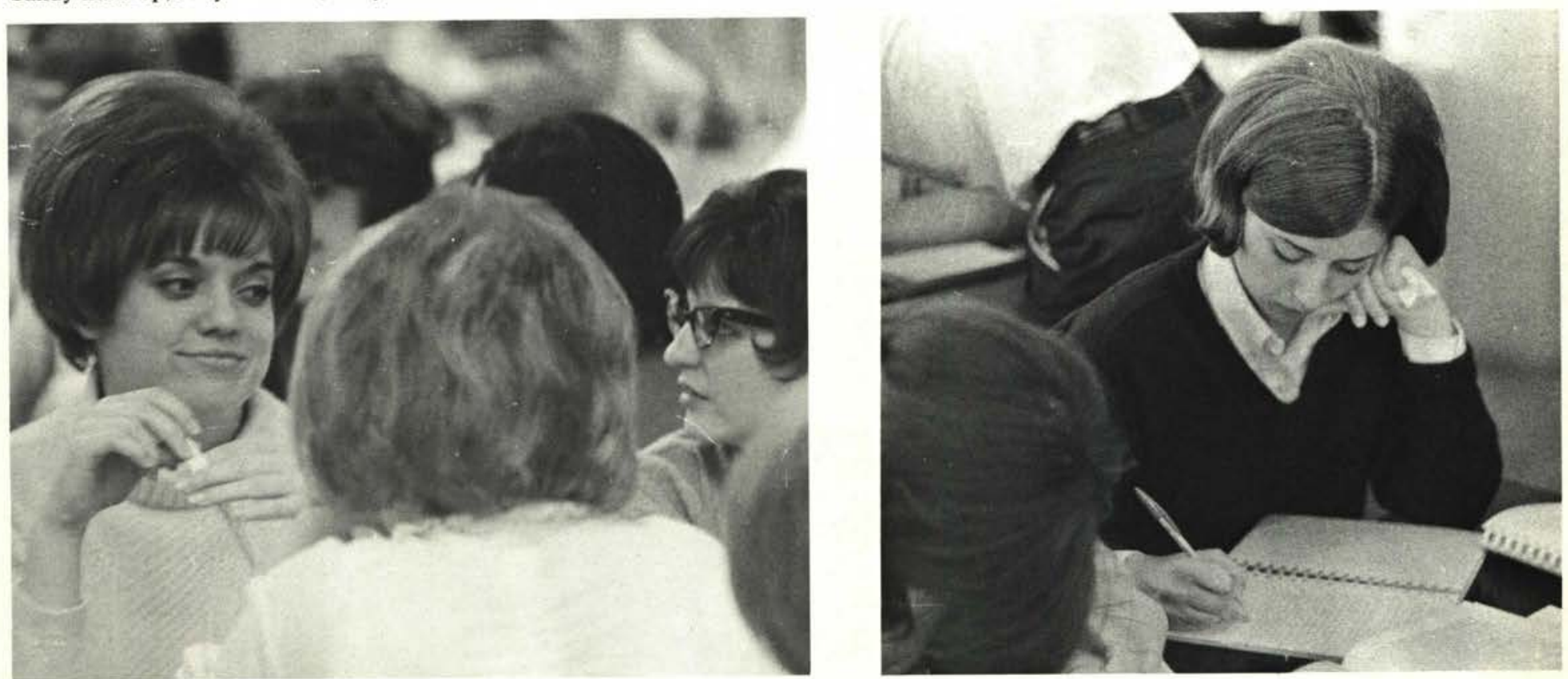


\section{SEAC}

The Student Education Association of Cedarville accepts as members those interested in teaching as a profession. This year through lectures, discussions, workshops, and publications, SEAC encouraged knowledge of and participation in the teaching field. Because of its association with similar state and national clubs, SEAC paves the way for future membership in professional organizations. But SEAC's greatest asset is its continuous push for dedicated, Christ-centered educators.

The officers this year are: Doug Yoder, Pres.; Bob Pereira, V.-Pres.; Carol Hare, Sec.; Lela Tanner, Treas.; and Joanna Barcus, St. Council Representative.

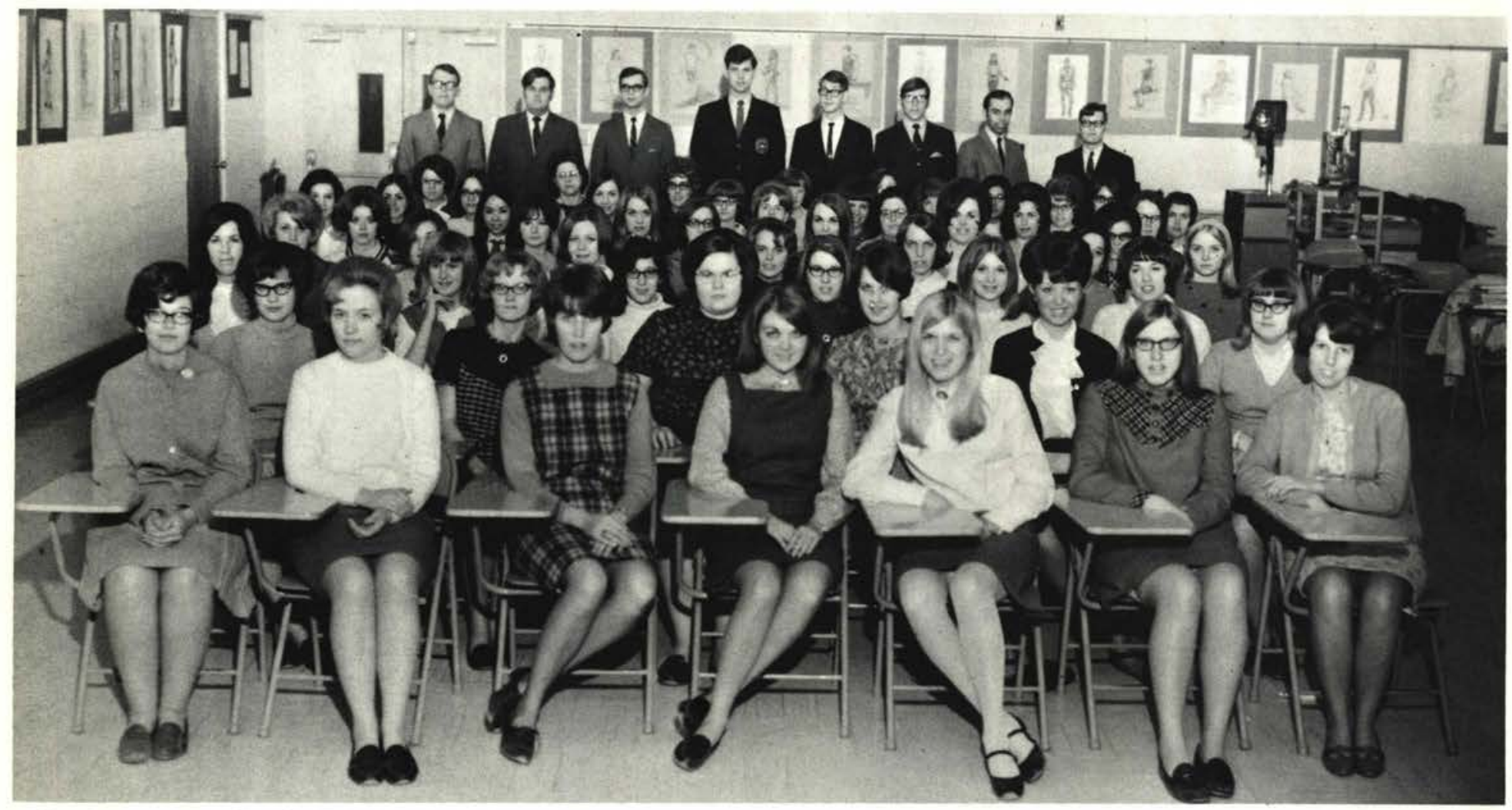

SEAC-Row 1: J. Chapin, E. Whipple, M. Bair, J. Brookhart, G. Sears, B. Harman, C. Hare. Row 2: K. Hamilton, R. Vincent, D. Bratka, K. Donaldson, R. Butler, L. Tanner. Row 3: J. Leach, C. Averitt, C. Zwiesler, B. Hostetler, N. Schwarm, T. McDaniel. Row 4: V. Meyer, B. Lepine, J. Phenix, C. Romine, J. Barcus, B. Smith, C. Beerer. Row 5: G. Gatliff, B. Bodenmiller, B. O'Keefe, J. Saemanes, M. Crunk, P. Black. Row 6: K. Borger, G. Furushima, F. Krikke, D. Preston, P. Sturdevant, S. Pape, C. Trumbull, N. Leapline, B. Biddison, V. Tobias, B. Hunter, E. Eldridge, J. Brock, K. Albright. Row 7: J. Boyd, A. Carlson, A. Moorman, J. Austin, B. Rudig, J. Martin, M. Ishuin, J. Kever. Row 8: P. Oehmcke, D. Seigneur, F. Stickle, S. Olsen, R. Farrar, D. Manross, B. Pereira, R. Jezowski. 


\section{The Inauguration of a New President \\ 1969}

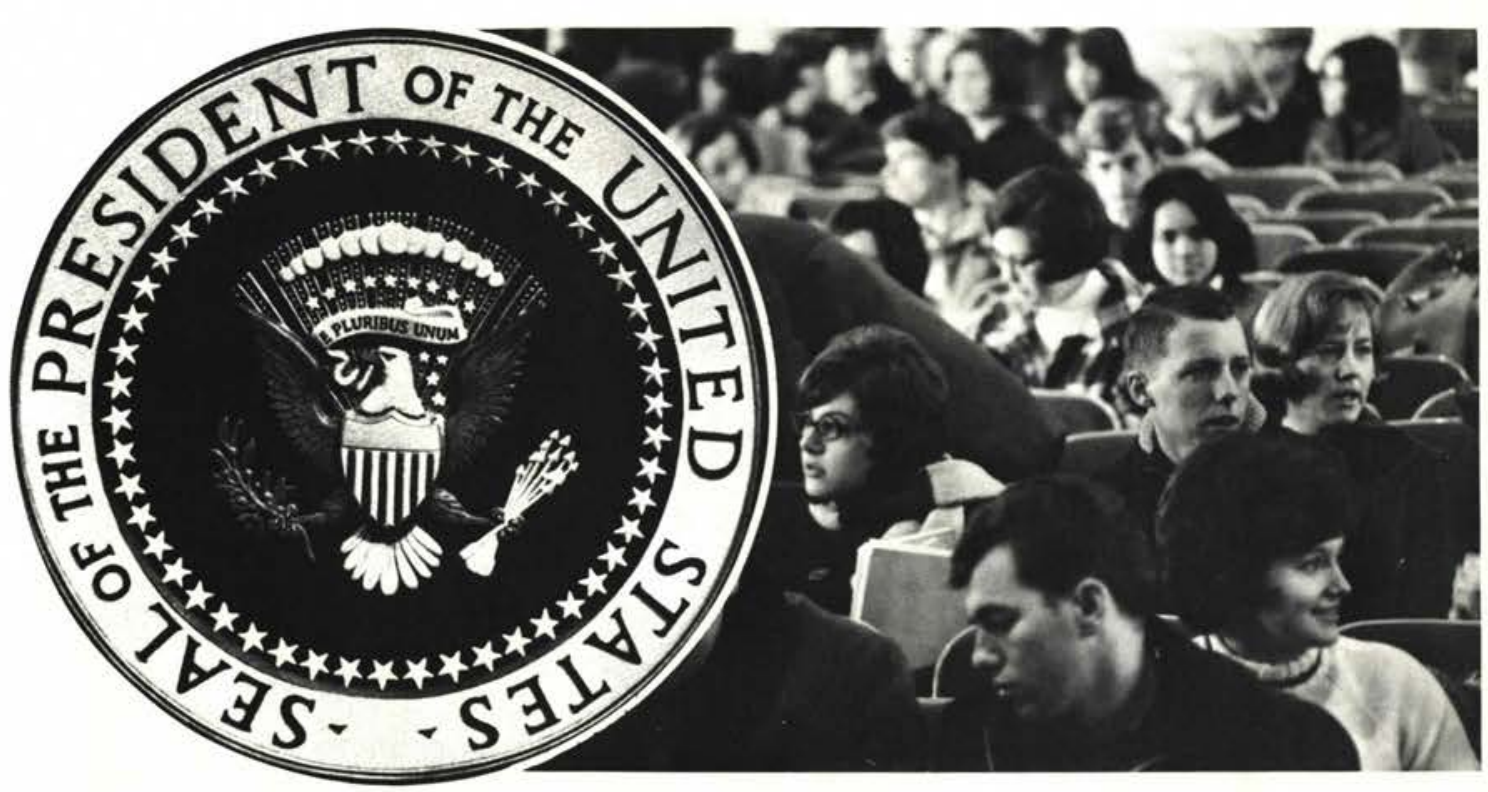

The flying banners, campaign buttons, snappy slogans, and election excitement permeated the campus on the eve of the 1969 presidential election results. Students milled around the WCDR Studio, engulfed the dormitory television sets, and read their textbooks to the sound of radio announcers. They were eager to learn the results - to learn of the new President of the United States of America.

The day after, eyes were heavy and banners useless but the nation had just elected a new president.

Pictured in the center are Dale Mills and Dave Draxler preparing for their Washington, D.C., trip to cover the election. Pictured below the WCDR Studio carries the latest results.
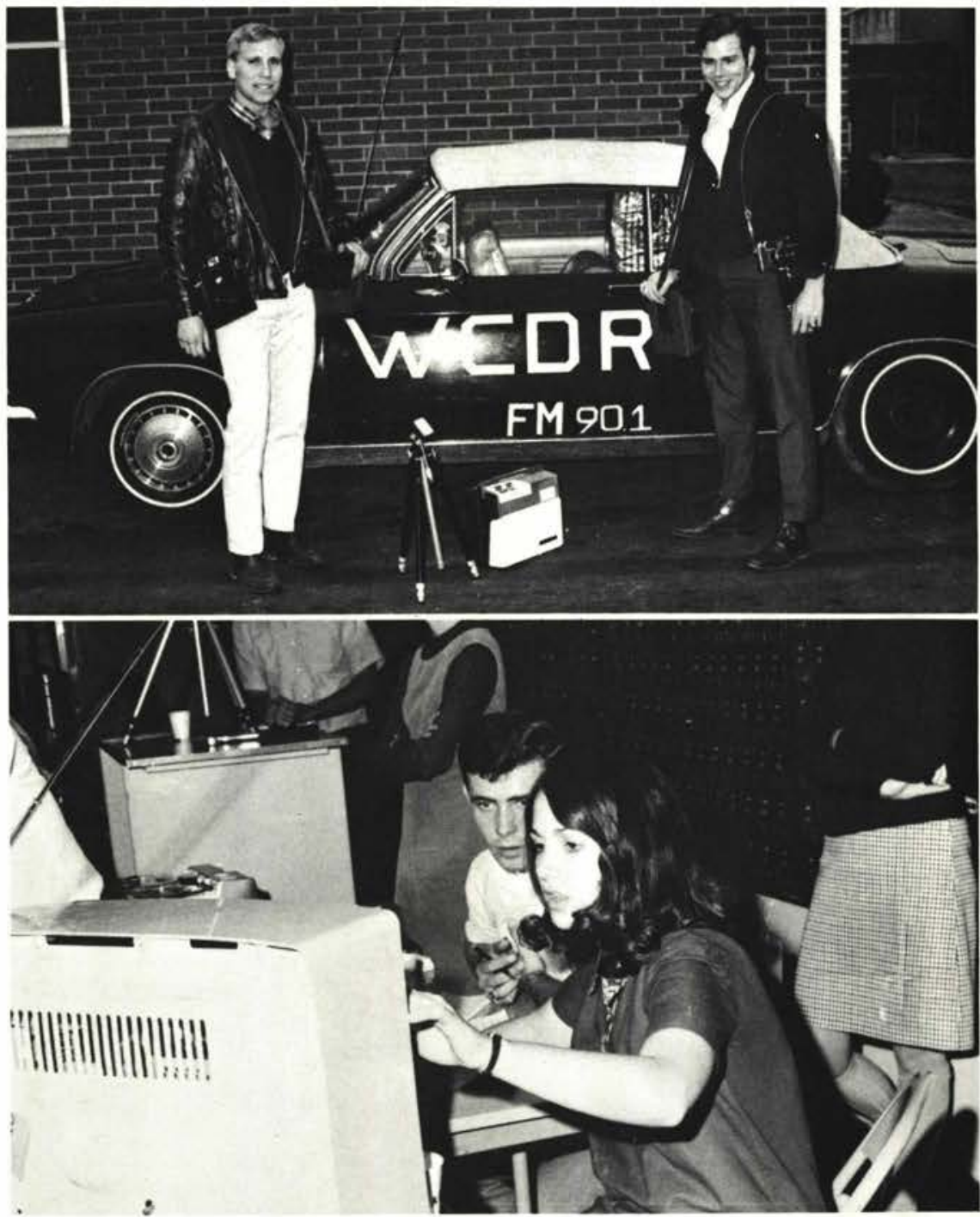


\section{Richard M. Nixon}

\section{The President of the United States}

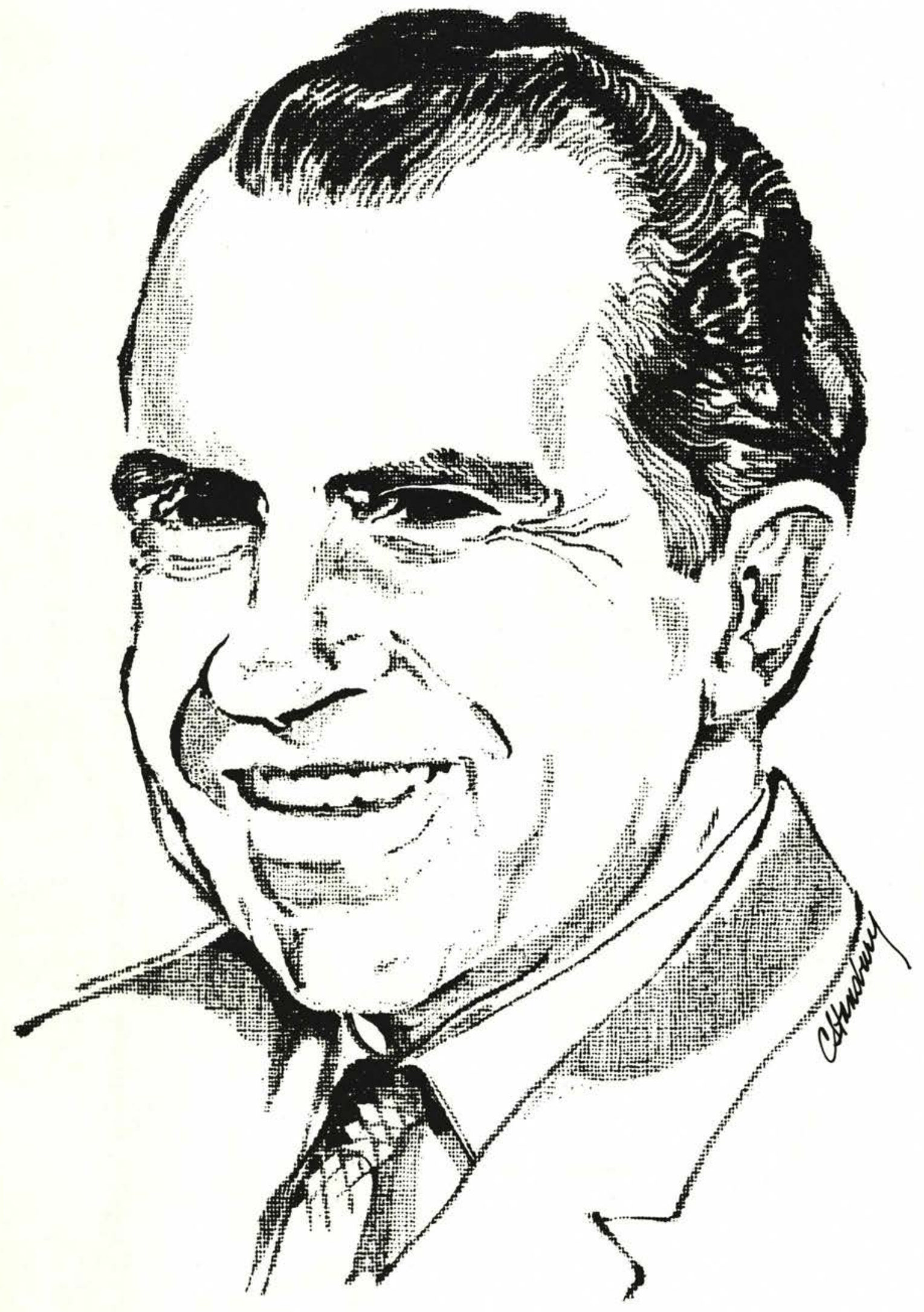




\section{WCDR Staff Station Student Operated}

Proclaiming Christ to the community while radioing the "world's most beautiful music"- that is the claim of the WCDR Station. Operated by students, the station provides practice and experience for future jobs as well as an opportunity for channeling the gospel to homes in the area.

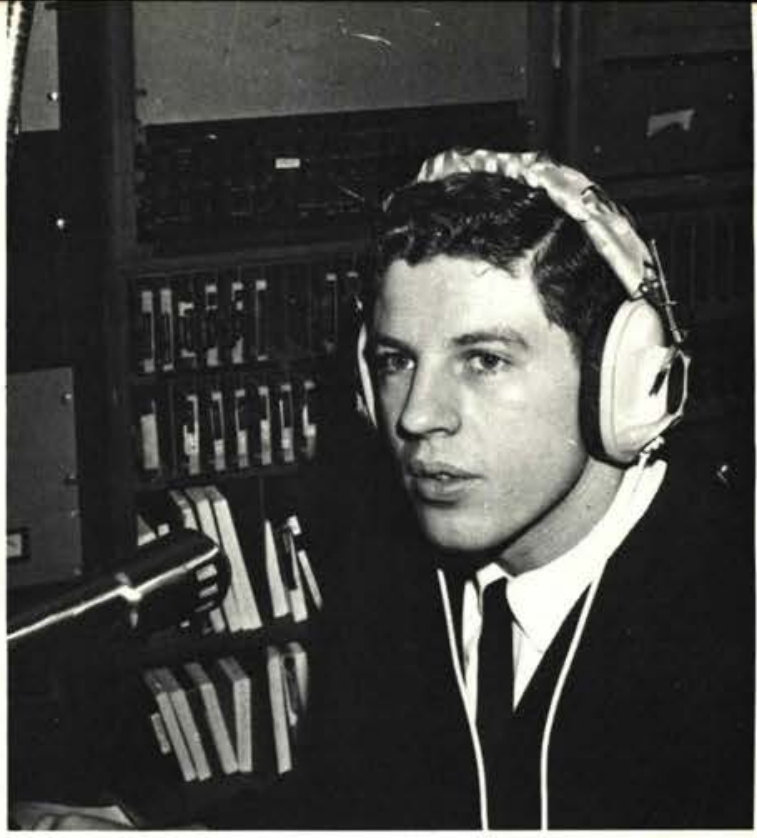

WCDR STAFF-Row 1: Rod McComber, Dale Mills, Lee Eichelberger, Don Meade, Dane Rohm, Dave Kearney, Bob Bixel, Dave Peters. Row 2: Judy Rehn, Melinda McNiece, Bev Maidment, Joyce Saemenes, Connie Busho, Penny Nichols, Marsha Edwards, Dawn Myers, and Mr. Gathany.
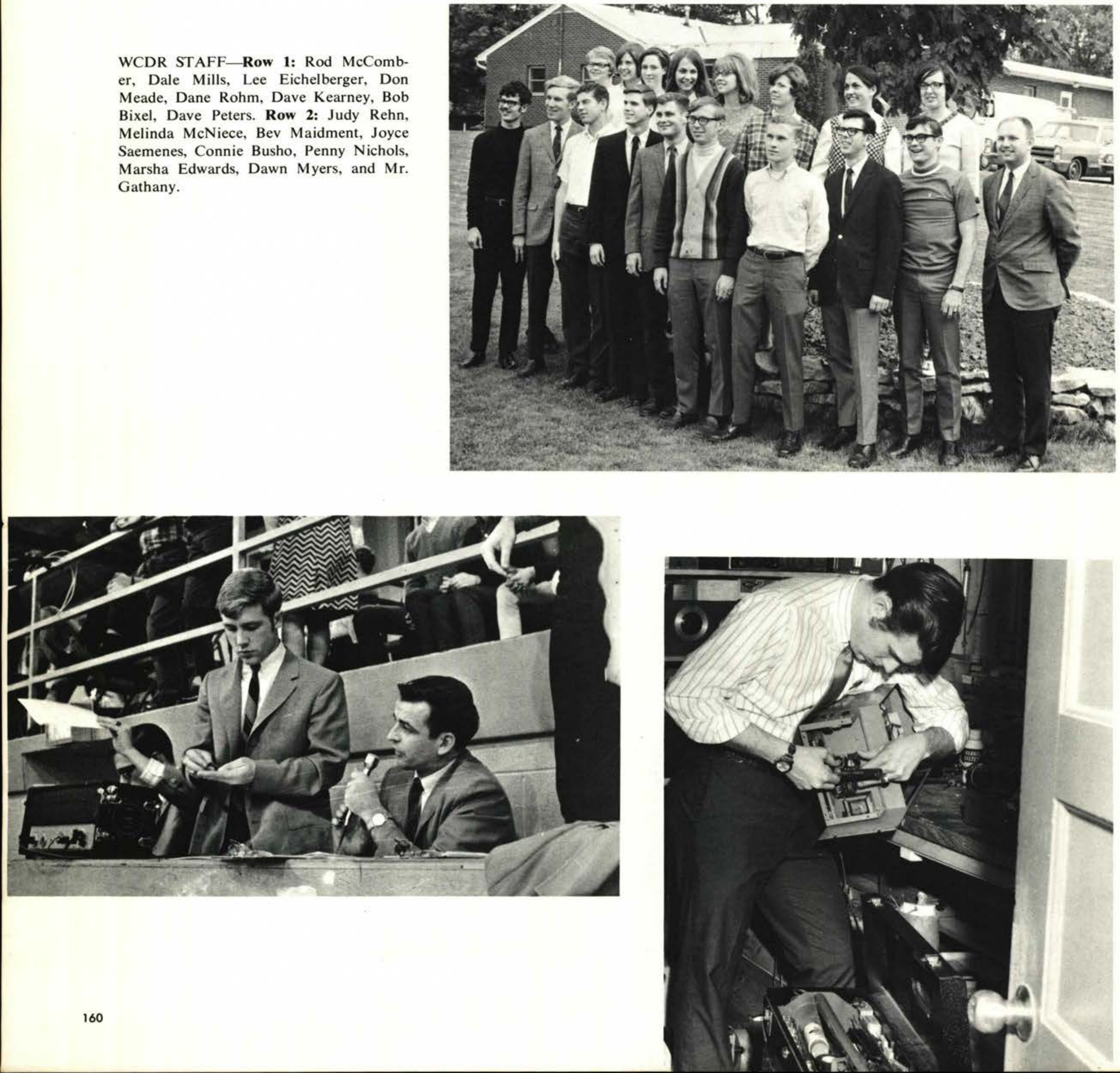


\section{College Fire Department}

The Cedarville College Fire Department, set up in 1967 , was active this year fighting local fires and clearing tornado wreckage. Called to Dayton to help after a tornado demolished homes, the members slaved all night long and returned to the campus exhausted. And yet, even considering this activity, the college remembers most the shrill siren, the false alarms, the 2:00 A.M. fire drills, and the firefighters' willing spirit.

COLLEGE FIRE DEPARTMENT—Jerry Motter, Art Shuter, Bob Hunter, Ron Myers, Gary Dawson, Charles Rowe, Ron Coombs, Roger Leach, Jeff Seeley, Melbourne Sattler.
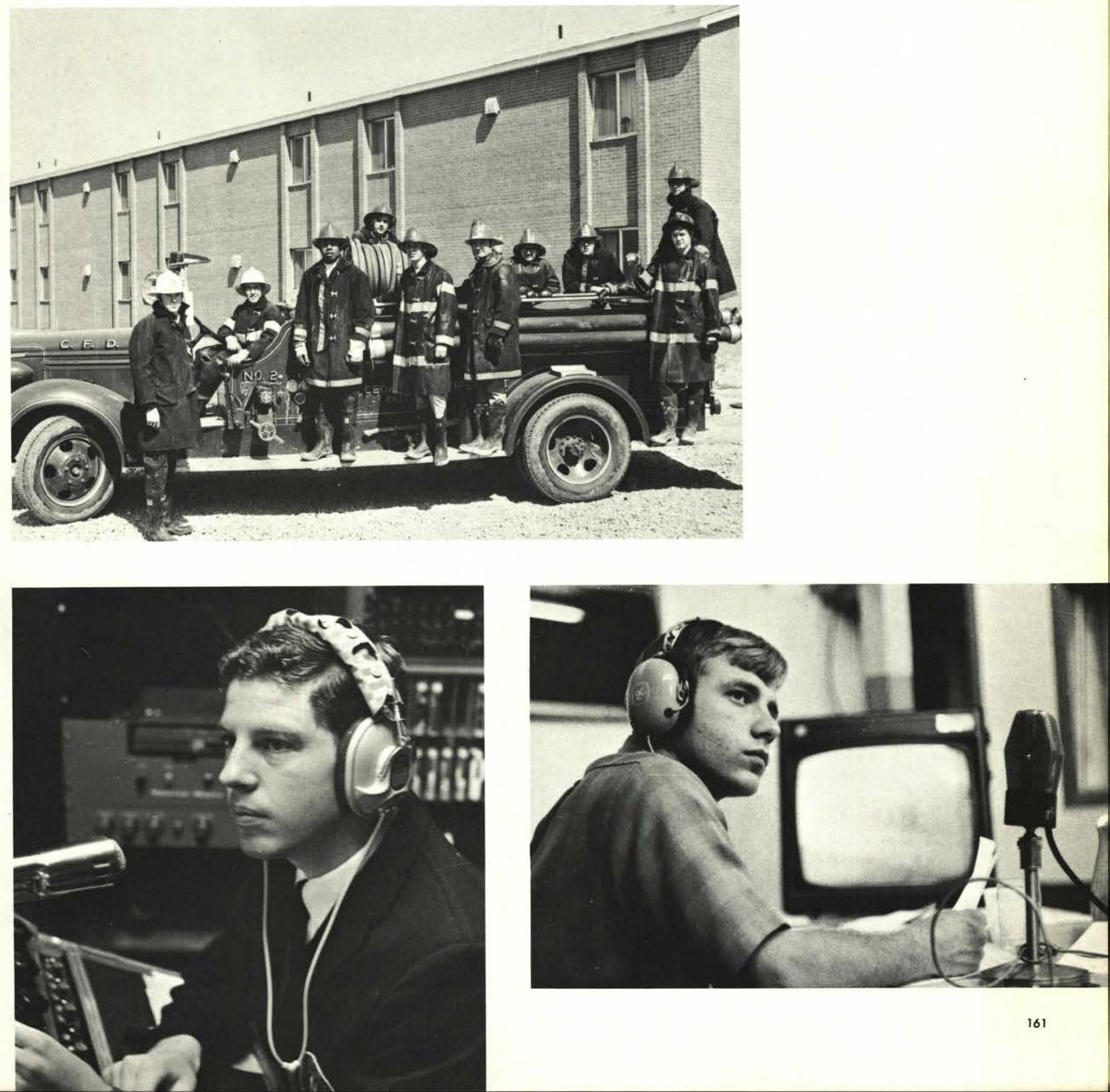


\section{FWM \& Married Students}

Fellowship for World Missions honors God's command to "pray ye the Lord of the harvest that He would send forth laborers." Their meetings not only provide an opportunity for prayer, but also for learning the needs of missionaries all over the world.

To strengthen the spiritual emphasis of the campus and to introduce missionaries as real people, FWM presented this year's missionary conference, centered around the theme, "A Light That Shines."

This year's officers are: Dave Handyside, Pres.; Paul
Jones, V.-Pres.; Janis Martin, Sec.; Margaret Muirhead, Treas.; Mary Ann Beitler, St. Council Rep.; Mary Grable, Prayer Letter Coor.

The campus would not be complete without the addition of the married students. As a representative group, these few pictured symbolize the energy, ambition, and determination of all the married students. The night shifts, late hours, and crammed lessons emphasize their desire for an education- $\mathrm{a}$ desire which is often unnoticed.

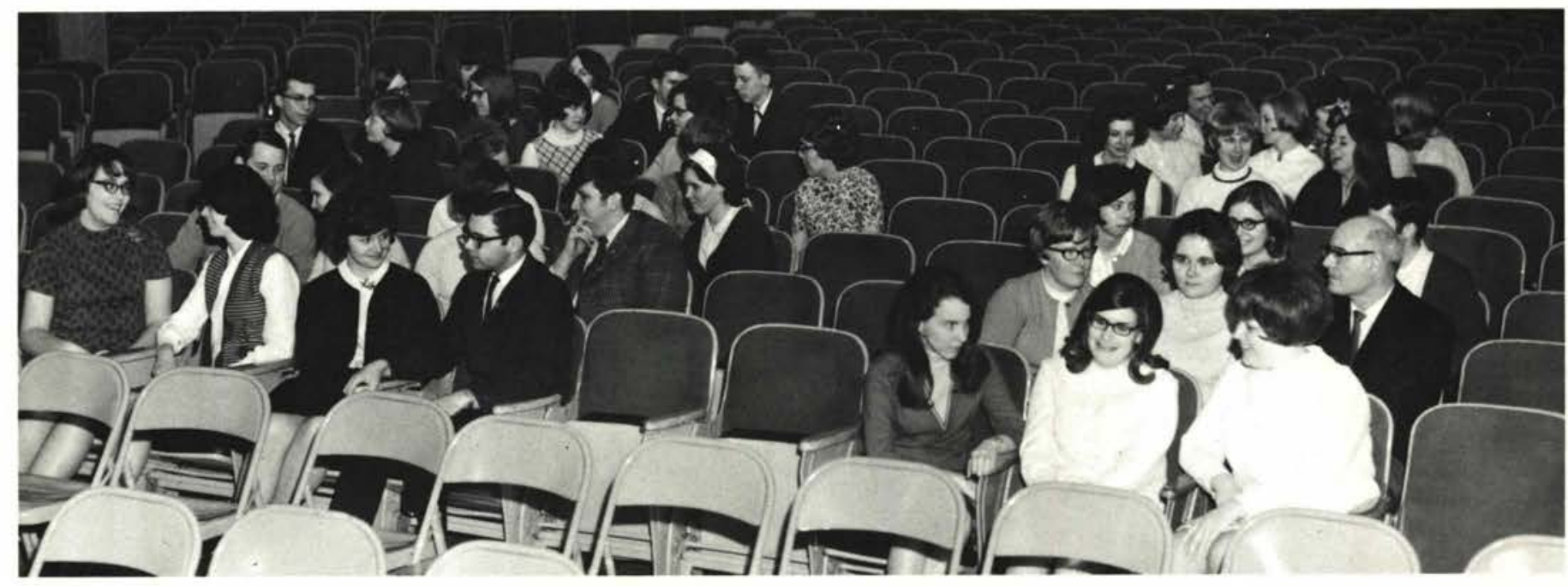

FWM-Row 1: S. Lathrop, D. Kemp, L. Shaffer, P. Jones, J. Hirschy, M. Anderson, K. Cartner. Row 2: R. Edwards, D. Kishpaugh, C. Zickefoose, D. Liechty, C. Morrow, B. Mix, Advisor, Dr. McDonald. Row 3: M. Bartlett, S. Lixey, J. Miller, M. Beitler, A. Call. Row 4: B. Kilko, J. Austin, E. Young, A. Moorman. Row 5: M. Vaderpughl, B. Hostetler, M. Beitz, C. Lambert, L. Olsen, P. France, B. Smith. Row 6: R. Rodgers, D. Baker, B. Brown, L. Radcliffe, T. McDaniel, J. Martin, B. Rudig. Row 7: B. Smith, D. Good, S. Loomis.

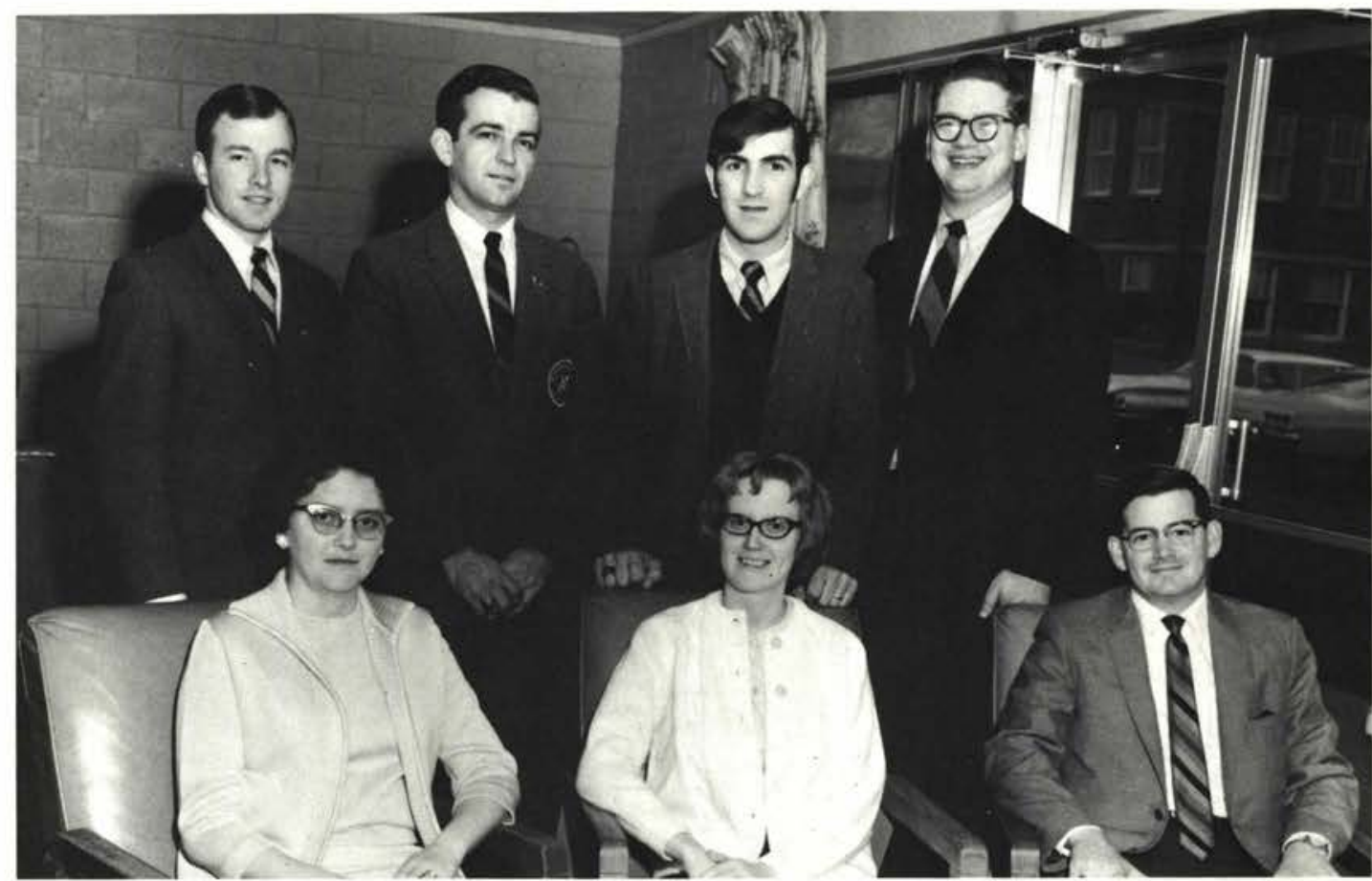

MARRIED STUDENTS - Row 1, Sitting: Beverly Foulkrod, Ruth Vincent, Thomas Foulkrod. Row 2, Standing: David Rockwell, Ronald Baker, David Gregory, Bob King. 
Sigma Delta Kappa \& Foreign Students' Club
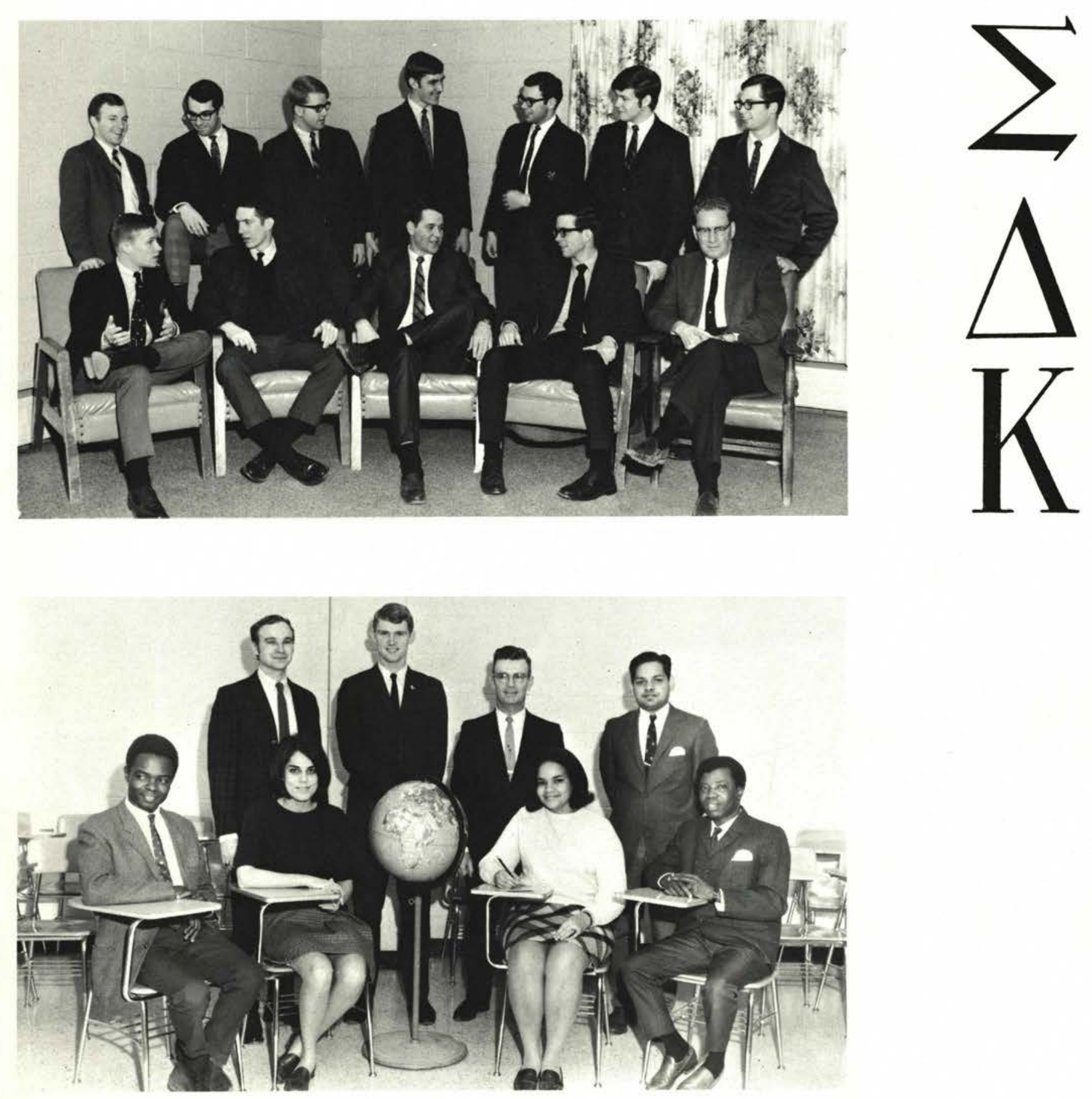


\section{Excellence}

\section{in \\ Music}

The blare of the trumpets, the beat of the drums, and the strum of the violins combine to form the sounds of the college concert band.

In addition to its peppy songs at basketball games, the band presented an excellent combined spring concert with the choir and choralaires, and visited the Lebanon correctional institution. The continuing progress of the band guarantees more participation next year.

THE COLLEGE BAND includes - Row 1: Mike Pasquerella, Dottie Abrams, Sarah Hicken, Sue Roloff, Linda Brown. Row 2: Tim Kline, Bev Nelson, Ron Artrip, Vicki Tobias, Becky Bittner, Dr. Warren Webber, Joyce Motts, Pat Riley, Art Shuter, Nancy Haffey, Dan Smith. Row 3: Don Long, Carolyn Lambert, Carol Herriman, Kathy Albright, Ron Meyers, Glenda Dalton, Judy Grover, Phil Senseney, Bob Senseney, Cliff Jensen, Dave Nelson, Daryl Prindle, Bob Snyder. Row 4: Ken Hammonds, Roger Curtis, Carolyn Webber, Curtis Rexroth, Jeff Seeley, and John Colyer.

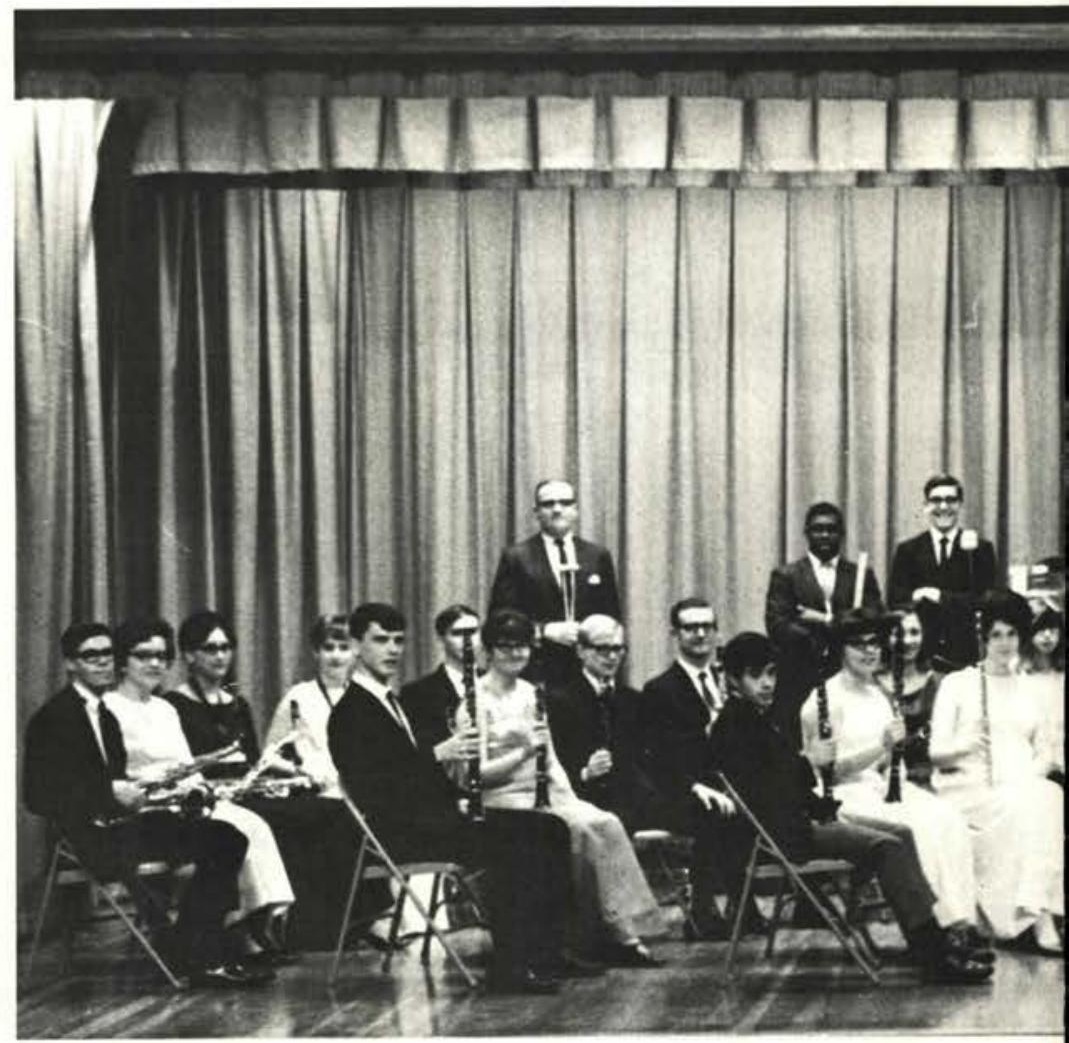

The Concert Band
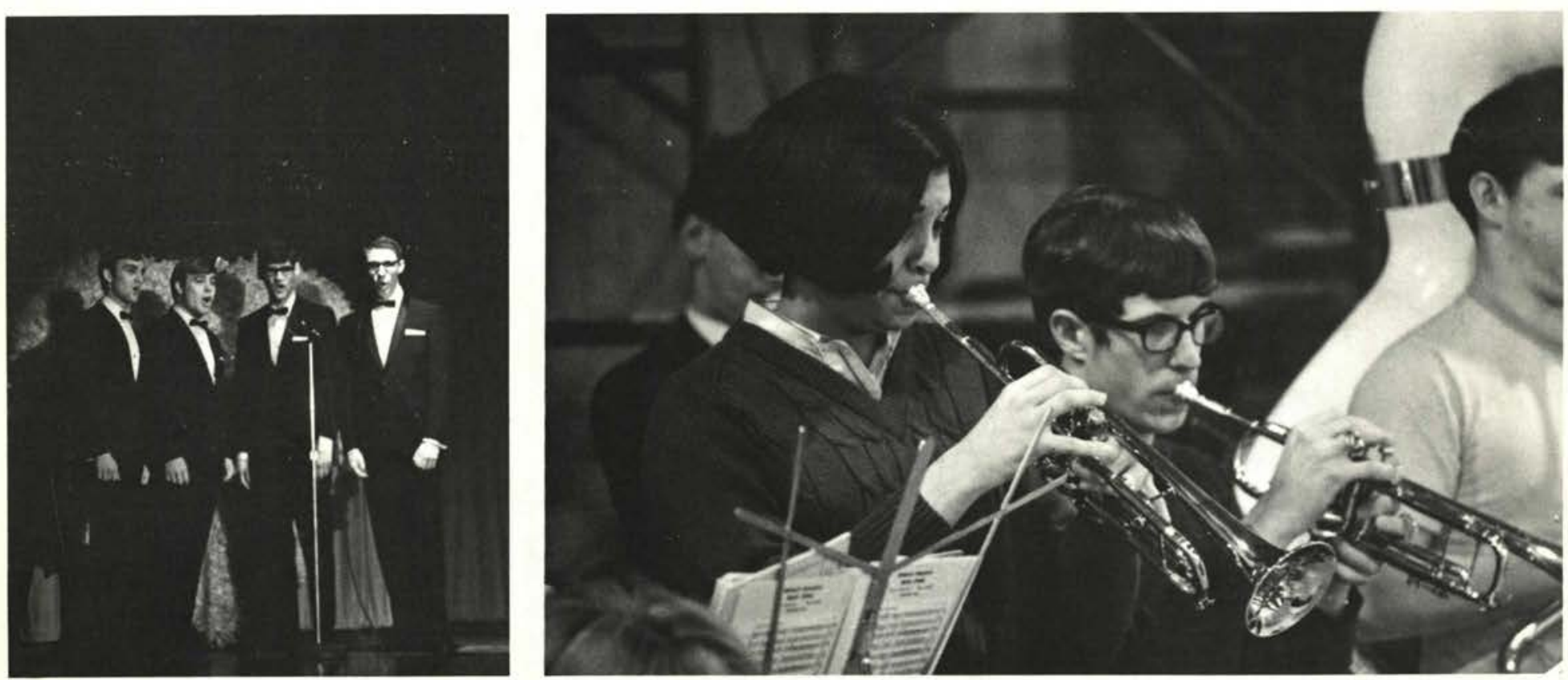
Student Council, as the students' representative voice in the college, is composed of two representatives from each class and one from each organization on campus. Through its weekly meetings, the council recommends desired action and improvement to establish an efficient school atmosphere.

The officers for this year are: Dan Stevens, Pres.; Loren

Reno, Vice-Pres.; Gayle Furushima, Sec.; Jim Jeremiah, Treas.; Paul Entner, Chaplain; and Ken Cole and Dave Southwell, SMP Co-Chairmen.

Student Court, as a newly formed organization, upholds the regulations of the college in cases of students accused of violation of these regulations. The eight members, elected by the faculty, students, and student council, help to instill respect for campus rules through peer pressure and involvement.

\section{Student Council and \\ Student Court}

STUDENT COUNCIL-Row 1, Sitting: G. Furushima, D. Myers, J. Beesley, B. Rudig, D. Wuest, M. Beitler, G. Gatliff, D. Walters, J. Young, D. Fitch, S. Gift. Row 2, Standing: R. Meyers, L. Anderson, S. Walker, K. Cole, R. Mitchell, Advisor: Mr. McIntosh, P. Entner, D. Kearney, D. Dieringer, D. Stevens.

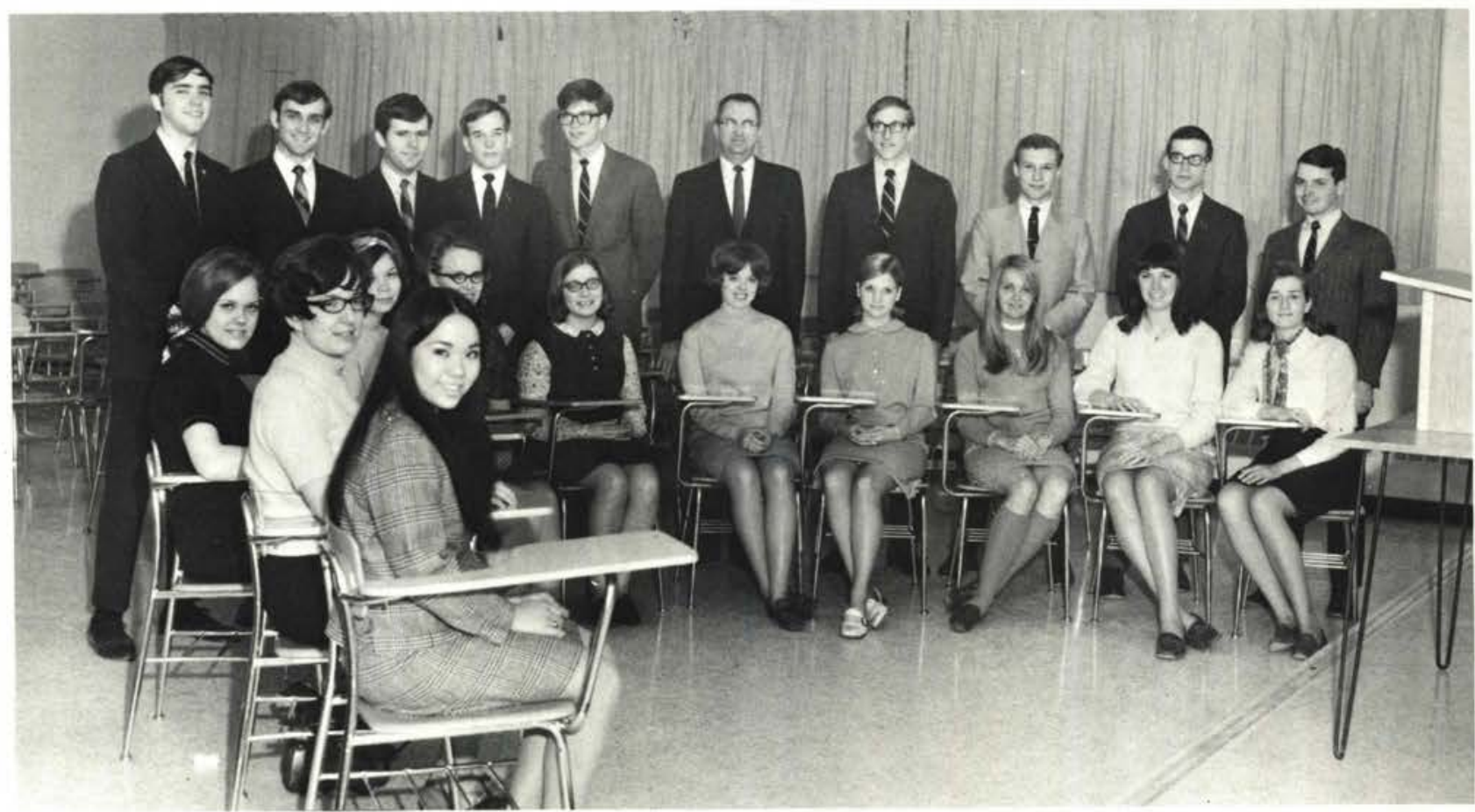

STUDENT COURT—Lyle Anderson, Dave Kearney, Dave Haffey, Bob Hunter.

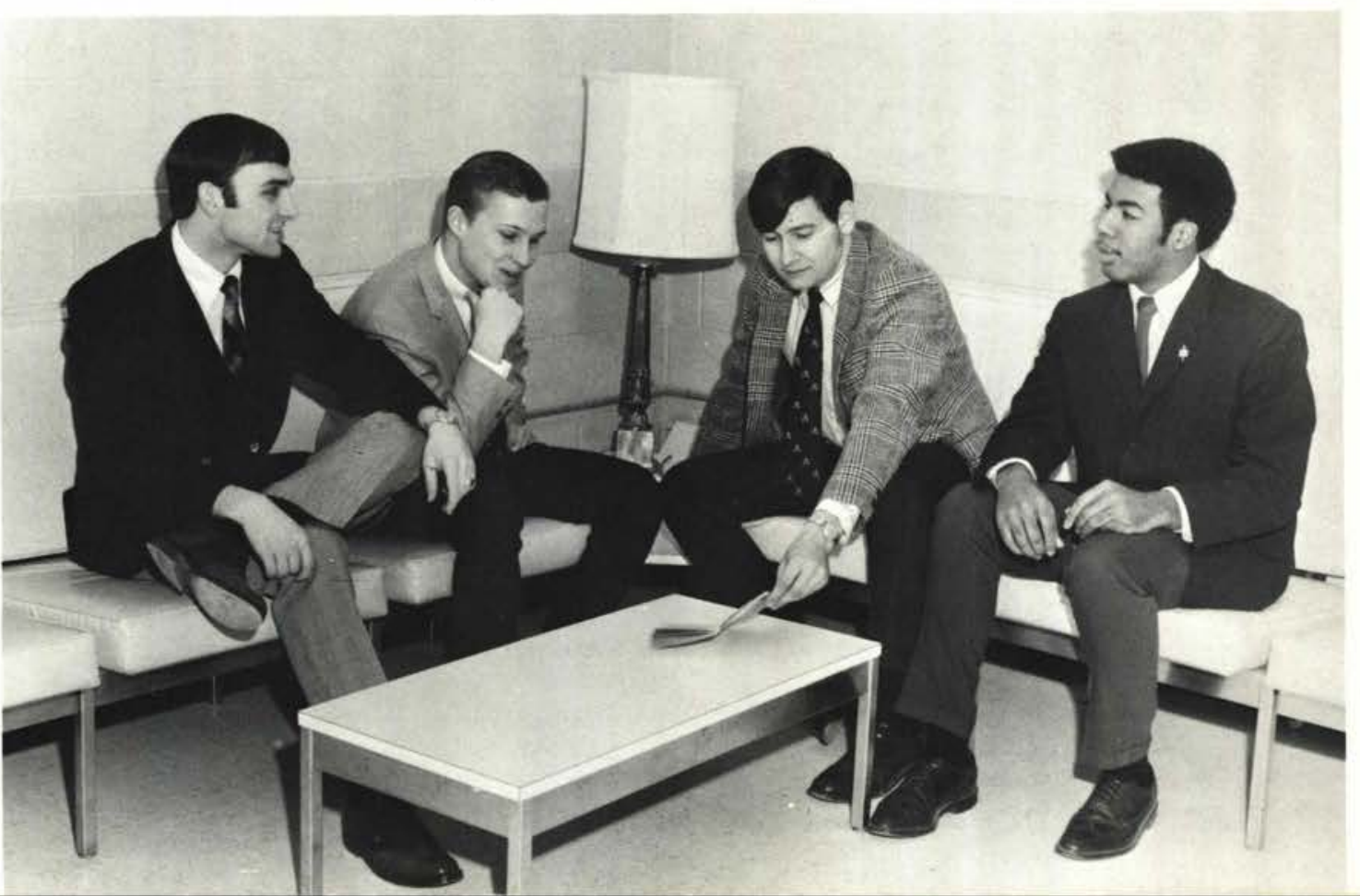




\section{Dorm}

\section{Counselors}

Demerits, room fines, failures to sign in, late permissions, and complaints are often credited to the dormitory counselors.

Too often their conferences, dorm prayer meetings, encouragement, friendship, and spiritual emphasis are forgotten. And yet without these counselors-the question answerers, the criticism accepters, the guidance givers, and the discipline seekers, the college could not operate easily nor efficiently.
MEN DORM COUNSELORS - Row 1, Sitting: Dan Stevens, Ron Jezowski, Lyle Anderson, Ron Edwards, Bill Smith, Ken Cole, Jim Berry. Row 2, Standing: Dave Kearney, Dean Seigneur, Andy Gaffney, Ron Meyers, Gary McDowell, Stanley Brown, Phil Mohler, Kirk Heldreth, Dave Southwell.

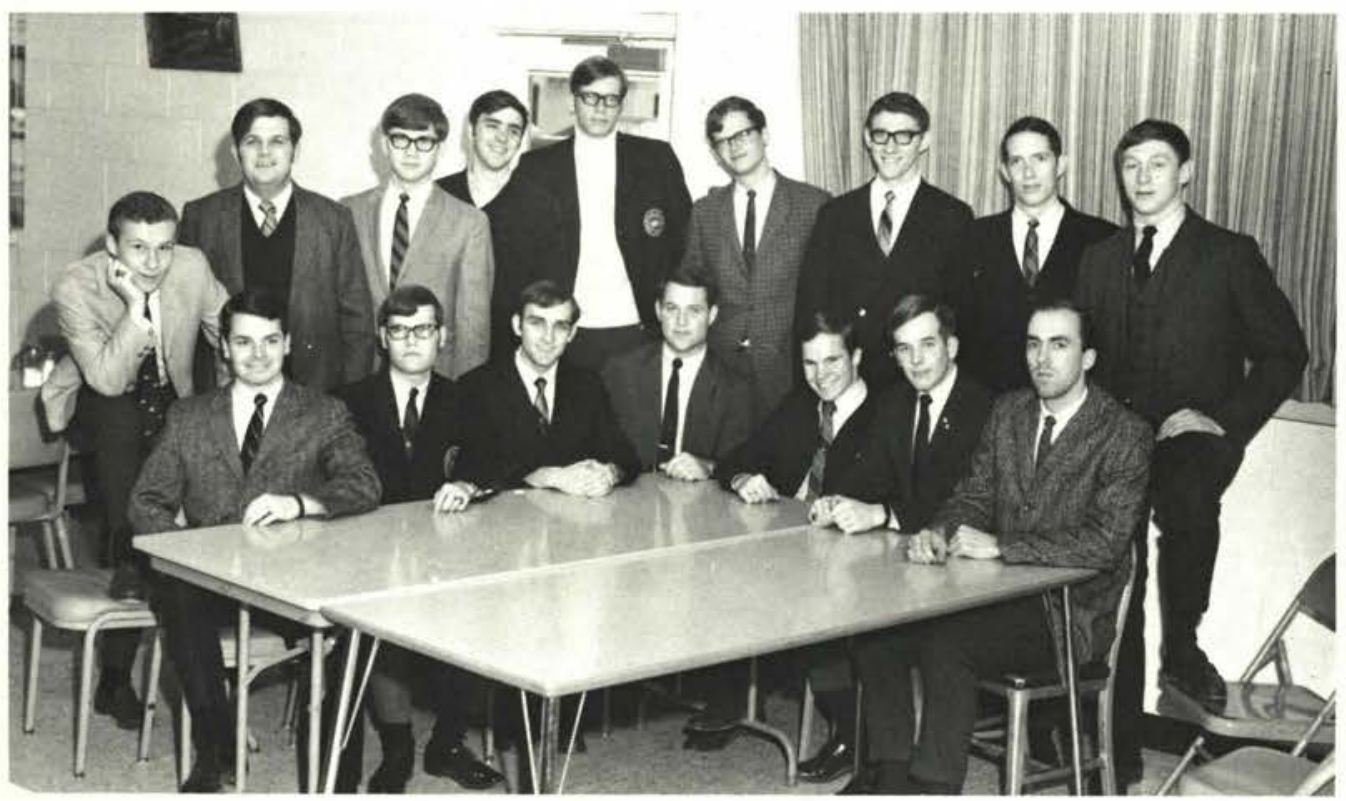

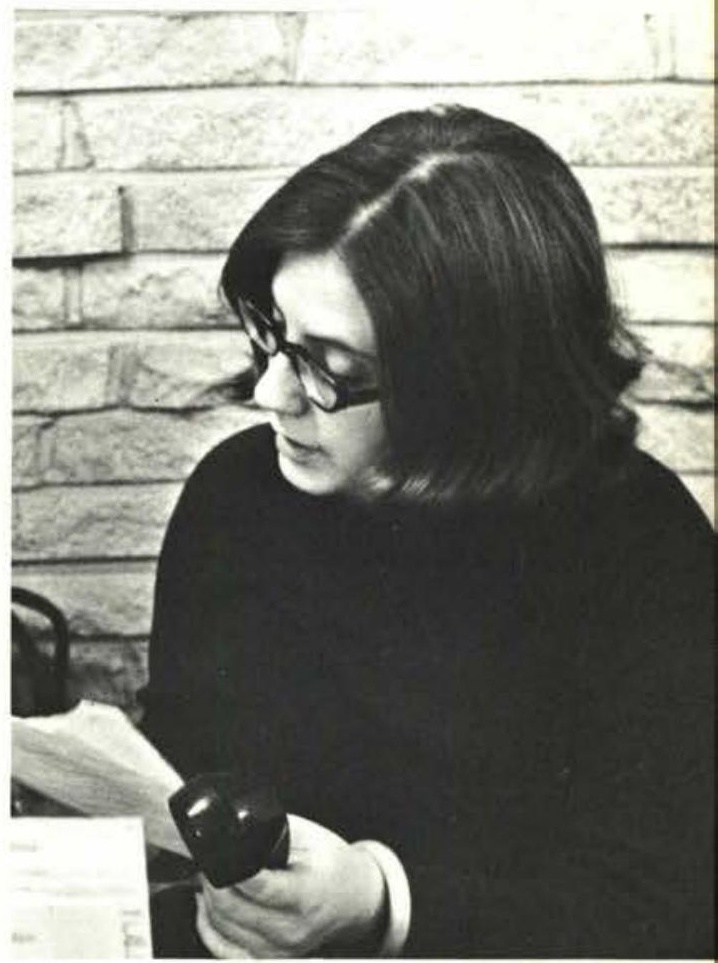

WOMEN DORM COUNSElORS - Row 1, Sitting: S. Pape, J. Beesley, K. Borger, B. O'Keefe, C. Zwiesler, D. Abrams, J. Winston, F Krikke, F. Johnson, B. Biddison, C. Shafer, T. McDaniel, M. Bair, M. Beitler, M. Beitler, R. Hardy, B. Mix. Row 2, Standing: G. Sears, J. Phenix, J. Hoag, M. Trumphour, D. Fitch, C. Busho, S. Webb, B. Maidment, J. Lewis, P. France, A. Kusumoto, A. Miller.

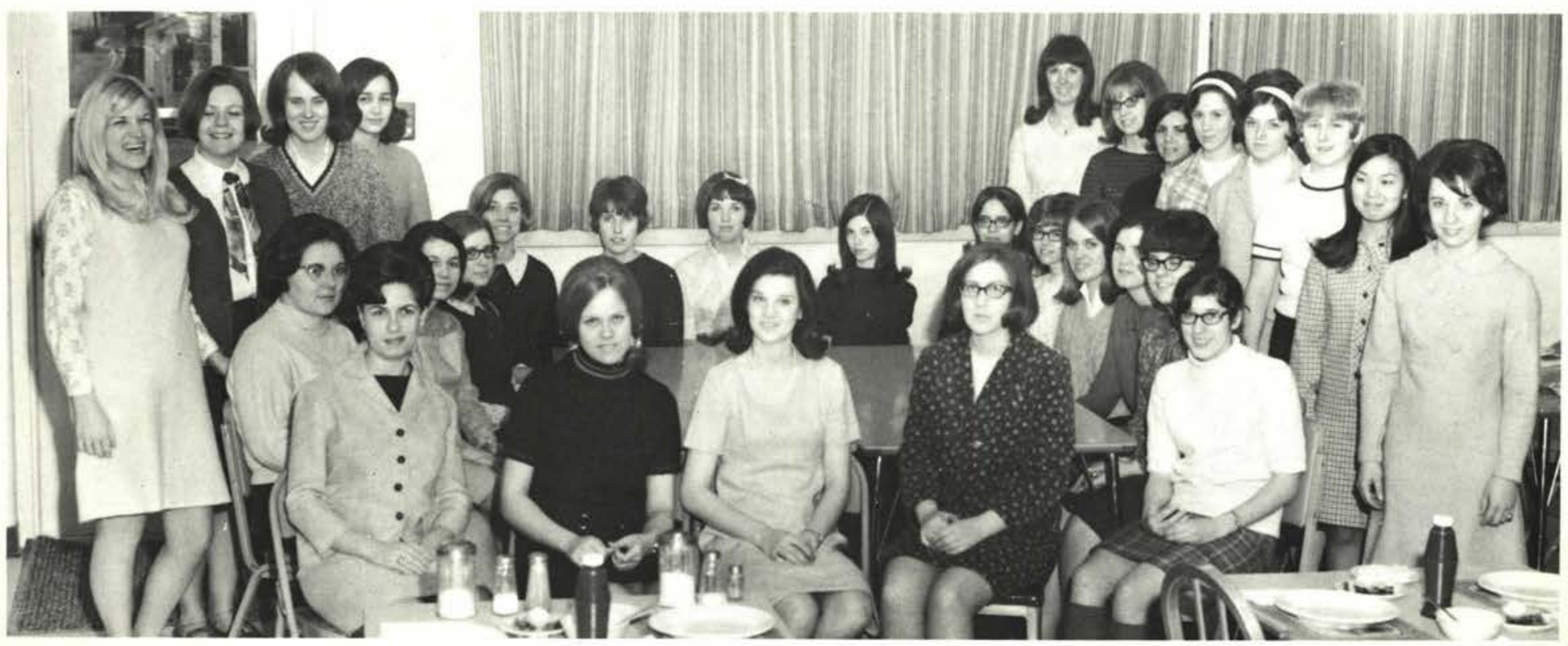




\section{VISION . .}
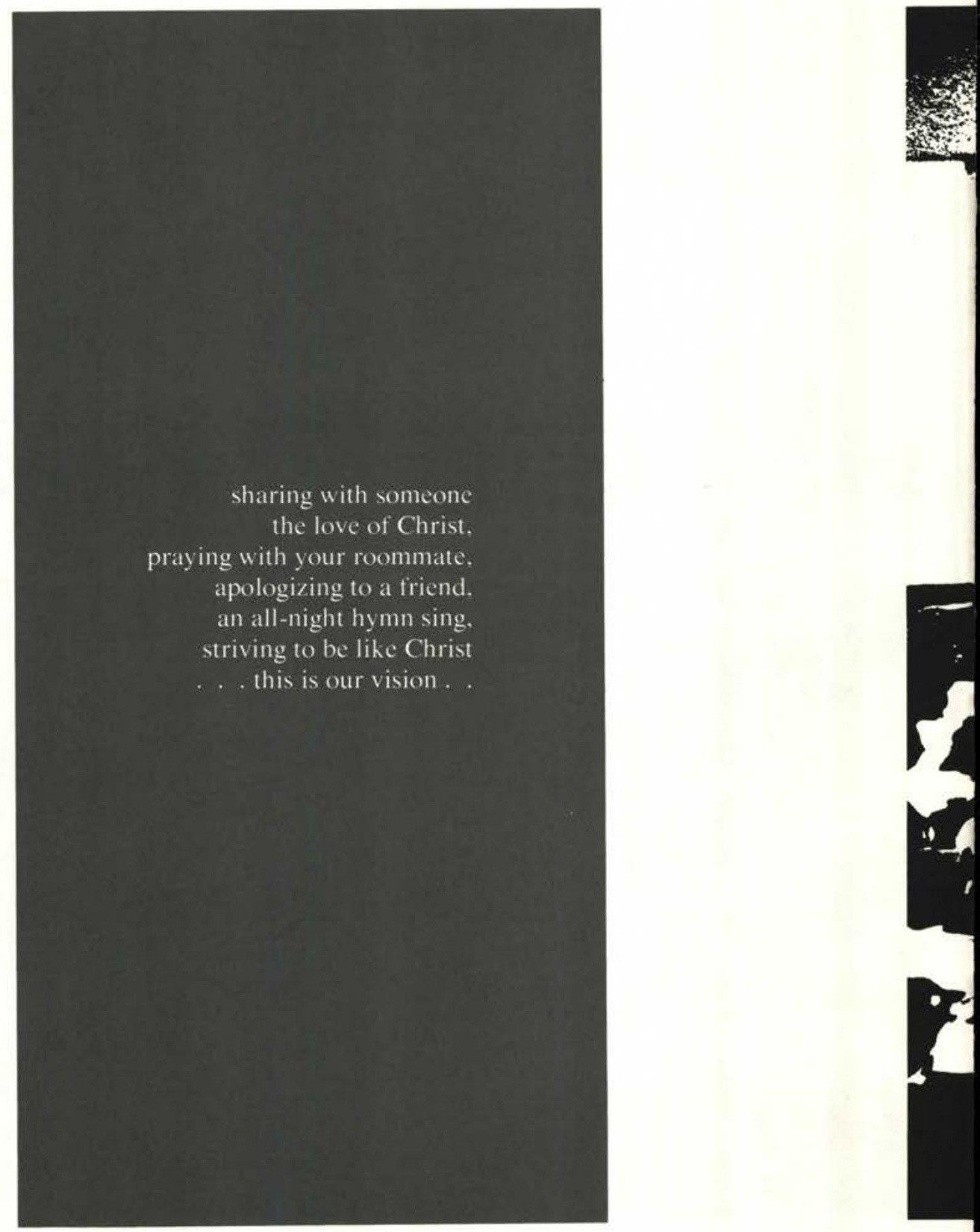


\section{. . . As Dedicated "Real" People}

The 1968-69 fall Bible conference and the spring missionary conference overlooked emotionalism and "once a year" decisions to present Biblical truths for daily use. This was the year of seeing pastors and missionaries as dedicated "real" people and as close friends.

Pictured below are the MISSIONARY SPEAKERS: Mr. Donaldson, Mr. Ajaj, Miss Malmstrom, Mr. Nieschev, and Mr. Stoner.
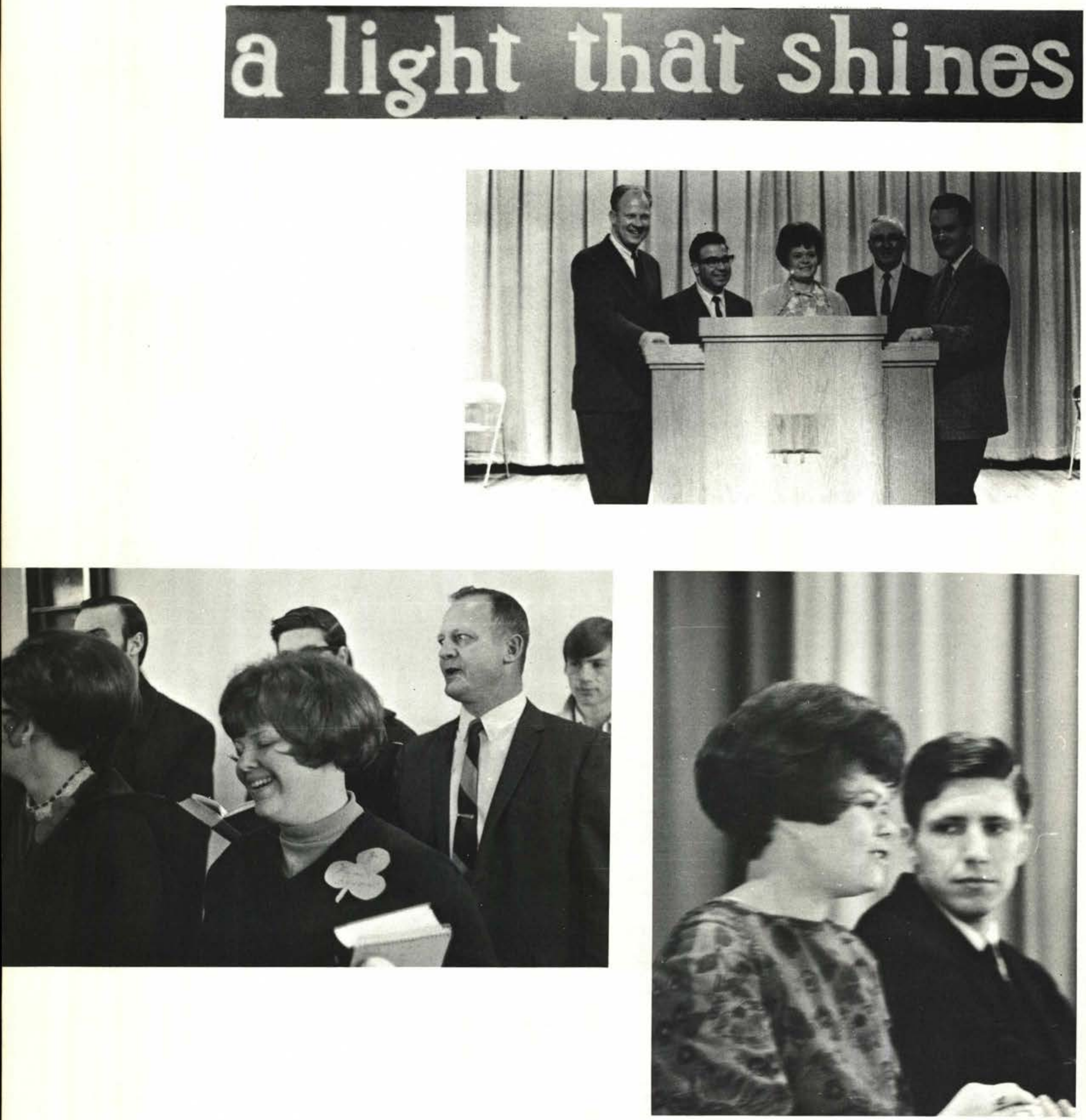

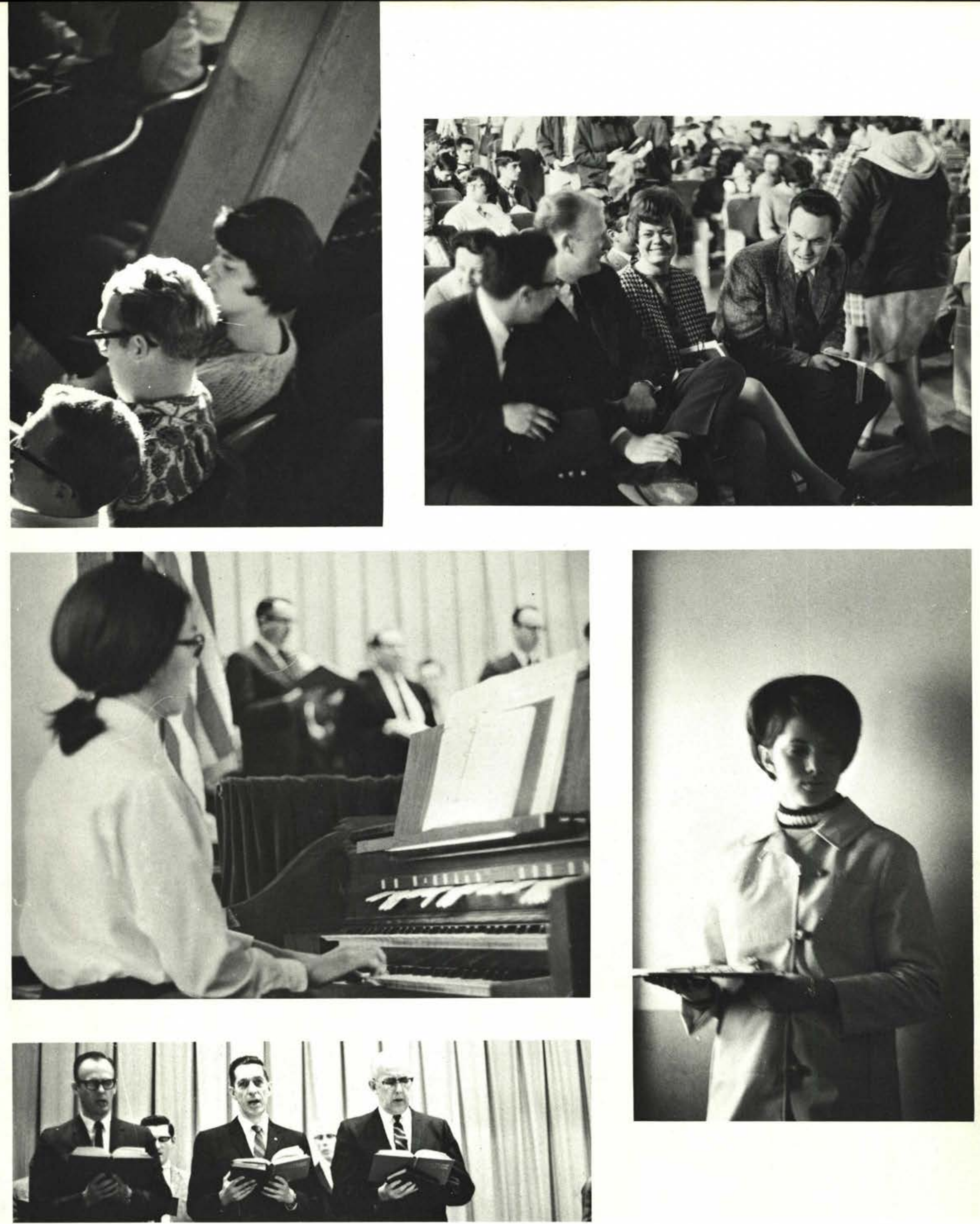


\section{A Goal Attained}

The saving of over a thousand dollars for medical equipment for Dr. and Mrs. Entner, medical missionaries to the Philippine Islands, was the missionary project voted on by the student body.

Pennies saved by pinching students clanked into the pop cans. The bank's label of surgical masks reminded students of the needed surgical equipment. But the proudest moment came as the Student Body Chaplain, Paul Entner, presented the hardearned check to Dr. James T. Jeremiah, the college president.
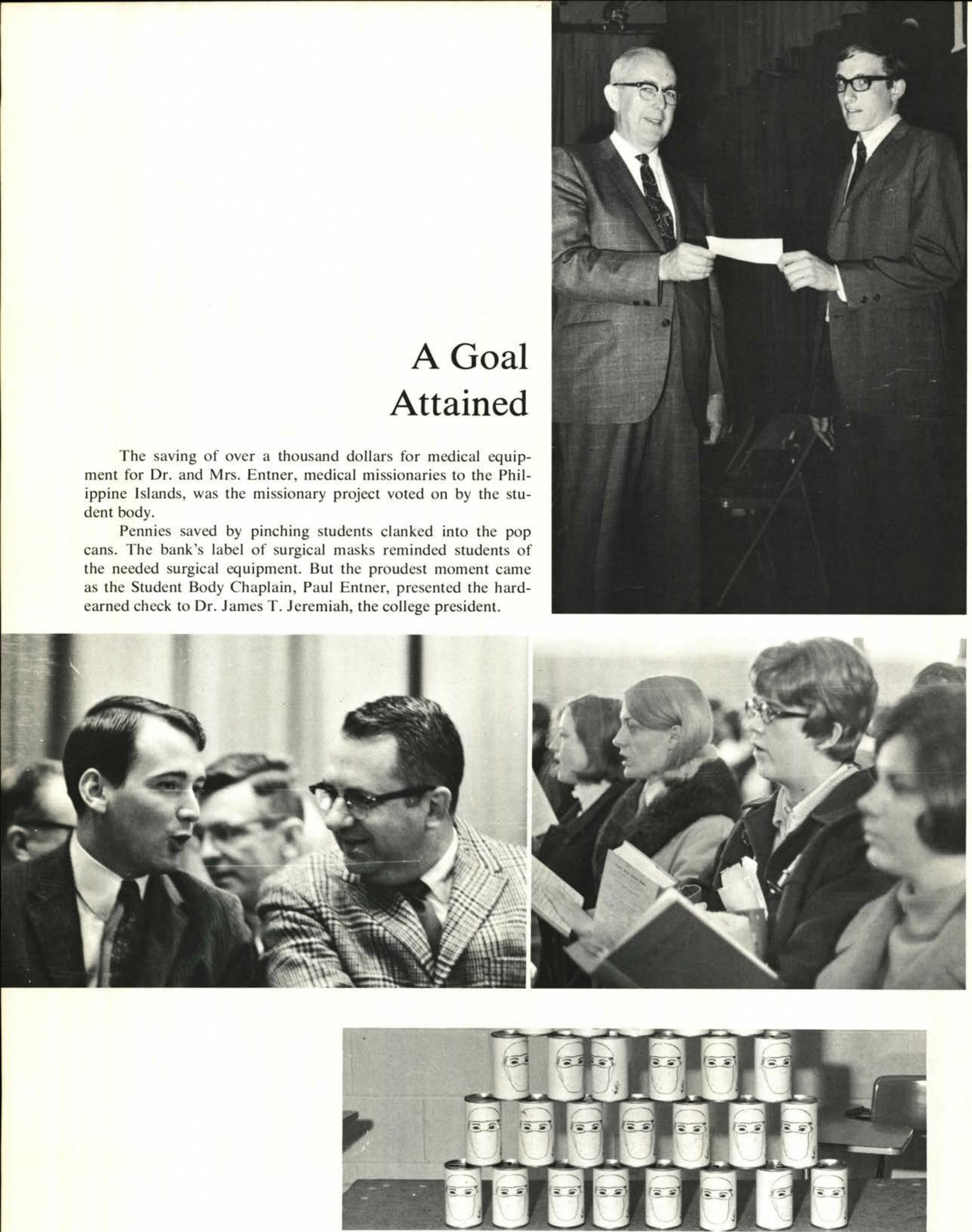


\section{Swordbearers and Detention Home}

SWORDBEARERS - Linda Olson, Carole Kies, Jean Stafford, Donita Baker, Linda Campshell, Mary Bartlett, Ken Boothe, Larry Radcliff, David Grant, David Peters, Merle Slabaugh, Bob Brown, Bill Smith, Paul Radcliff, Ralph Perkins, Bonnie Smith, Dianne Kemp, Ted Northey, Larry Rumfield.
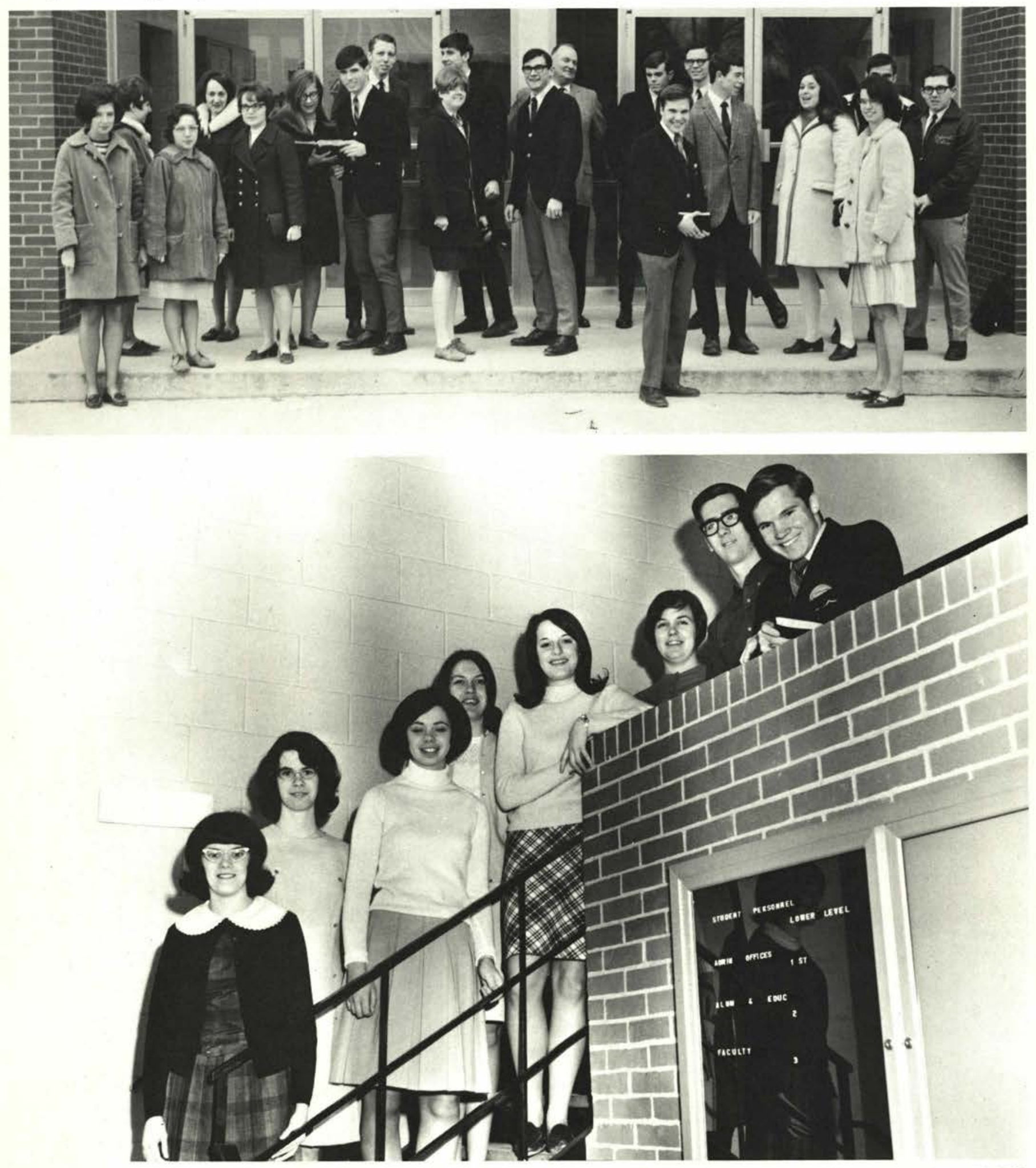

DETENTION HOME—Nora Irwin, Dianne Kemp, Joyce Miller, Nancy Snider, Julie Hoerath, Kathy Albright, David Hull, Bill Smith. 


\section{Bible Club and Campus Life}

BIBLE CLUB - Dan Manross, Gloria Shriver, Barb Work, Becky Rudig, Janice Martin, Darlene Rouch, Marsha Bair, Barb Hart, Linda LeFever, Sarah Hickam, Carolyn Stubrich, Carol DeBoer, Joyce Brookhart, Lynn Grandy, Nancy Paugh, Gail Sears, Anne Beitler, Cherrie Gosset, Ken Hammonds.
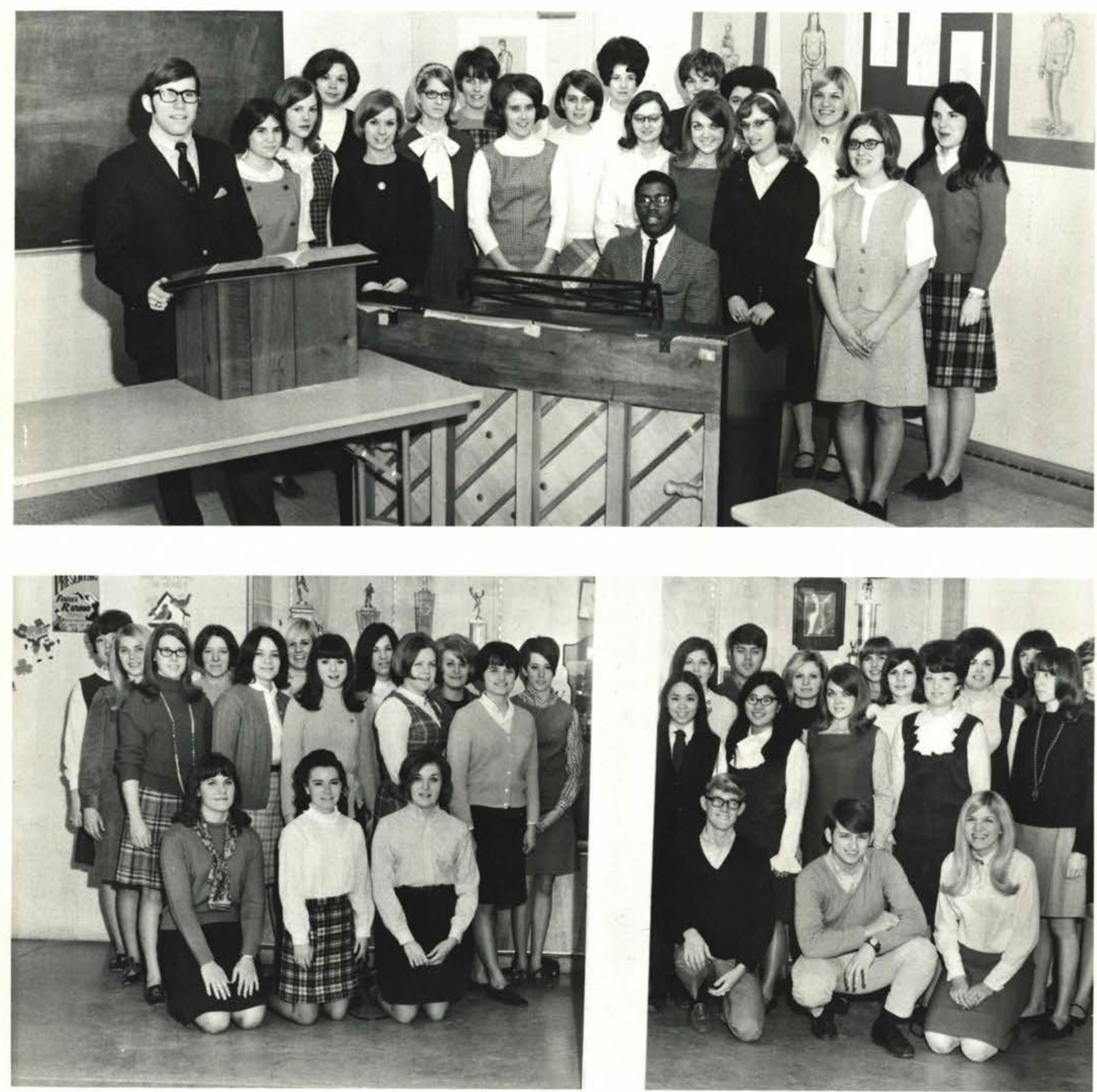

CAMPUS LIFE—Kneeling: Andrea Houchin, Beth Bennett, Barb Lepine, Jerry Grayson, Dale Schilling, Gail Sears. Row 1: Bonnie Holstetler, Kay Phenix, Laurea Lee Grable, Janet Phenix, Carol Morrell, Gayle Furushima, Mitsu Ishuin, Joyce Brookhart, Roxanne Butler, Judy Hubbard. Row 2: Janet Epps, Lynda Fowler, Cathi Marlowe, Dorena Johnson, Judy Leach, Viann Meyer, Nancy Addleman, Hannah Stowell, Phil Johnson, Pat Lawhead, Laura Hansmann, Janice Vlug, Maureen Crunk, Darlene Fitch, Carol DeBoer. 


\section{Vietnam Prayer, SS and Junior Church}

SUNDAY SCHOOL AND JUNIOR CHURCH—Row 1, Sitting: Carolyn Stubrich, Kay Phenix, Tammy Porter, Becky Harman, Joyce Saemenes, Susan Pauling, Sharon Graham. Row 2, Sitting: Cecilia Romine, Faye Johnson, Melba Smith, Pat Jenkin, Beth Bennett, Tanis McDaniel, Billie Thomas, Norma Schwarm. Row 3, Standing: Ron Jezowski, Carolyn O'Keefe, Barbara Biddison, Regina Bigley, Patricia Lear, Linda Nelson, Karen Borger, Janet Phenix, Viann Meyer, Hannah Stowell, Marsha Osman. Row 4, Standing: Barb Fiest, Peggy Robbins, Darlene Lewis, Carol Spencer, Pat Black, Vicki Tobias, Jane Cunningham, Dave Draxler, Ron Meyers, Larry Modrall, Mike Wilhite.
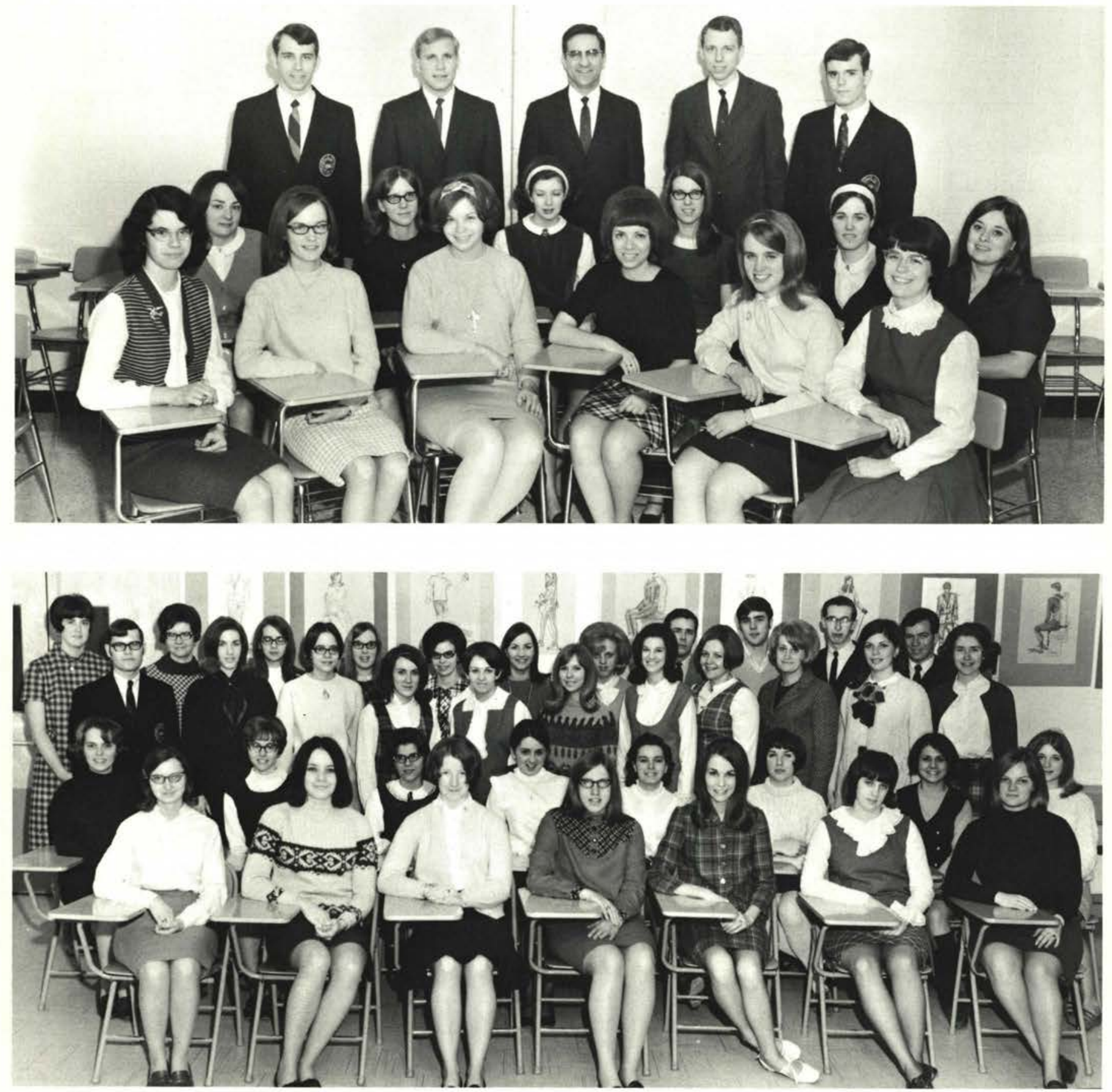

VIETNAM PRAYER-Row 1: Diane Kemp, Diana Radcliffe, Becky Rudig, Elaine Eldridge, Joan Hovingh, Edith Phillips. Row 2: Donita Baker, Mary Vanderpuhl, Linda Olsen, Bonnie Hostetler, Sharon Lixey, Bonnie Smith. Row 3: Randy Patten, Dale Mills, Dr. John Reed, Larry Radcliff, Bob Brown. 


\section{O.S.S.O. and Jail Group}

O.S.S.O.-Row 1: Viann Meyer, Barb Lepine, Ann Kusumoto, Joan Hovingh, Debbie Good, Gayle Furishima. Row 2: Patti France, Bev Maidment, Pat Sturdevant, Kathy Spencer, Mitsu Ishuin, Cheryl Shafer. Row 3: Roger Miller, Paul Large, Judy Lewis, Andy Gathany, Ken Muck, Joan Miller, Connie Walker, Dorena Johnson, Margarie Brown, Maureen Crunk, Margarita Lima. Row 4: Denny Stora, Ron Meyers, Dave Wood, Renee Silverthorn.
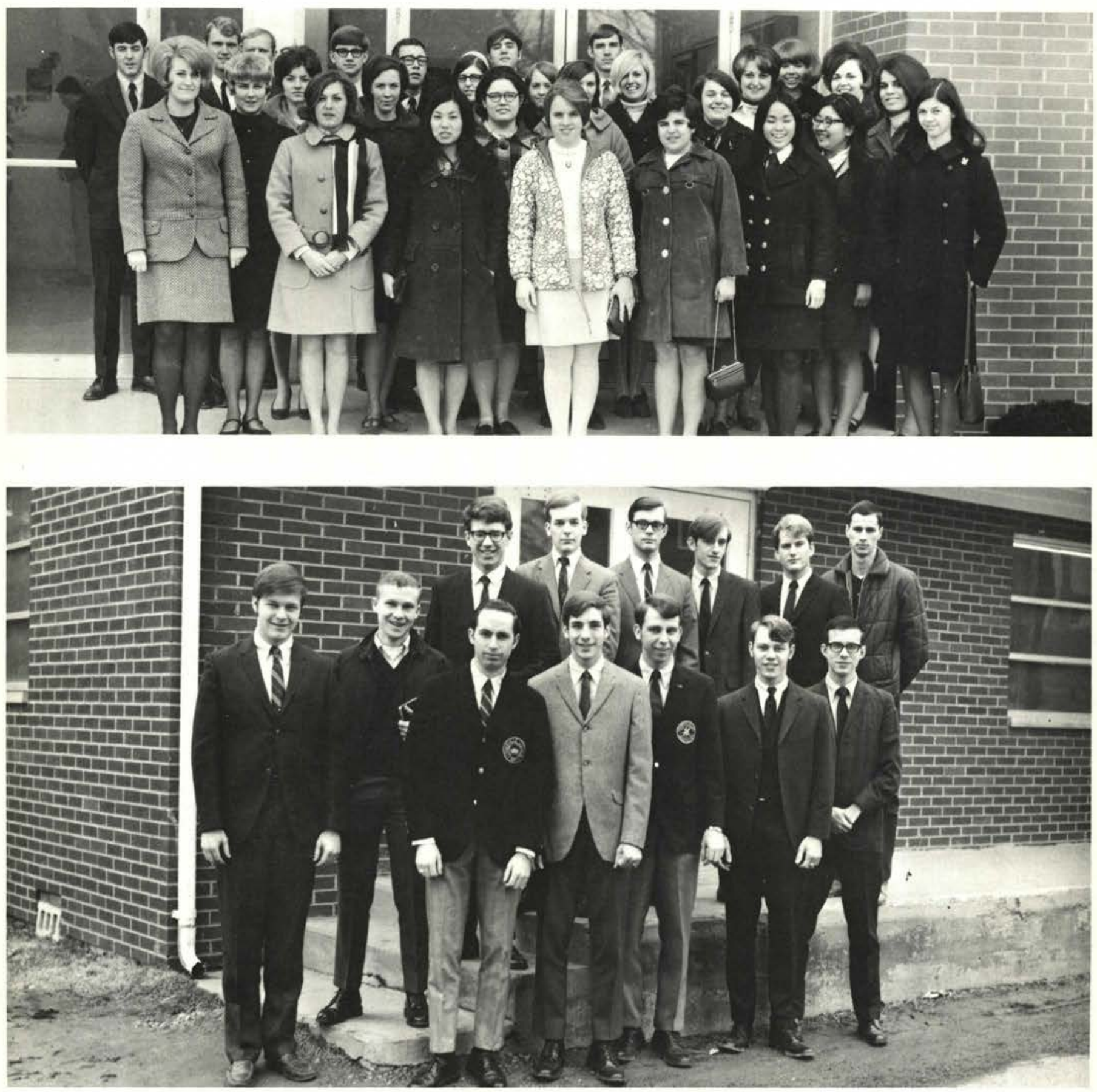

XENIA AND SPRINGFIELD JAIL GROUPS—Row 1: Mel Sattler, Dave Kearney, Mark Wilhite, Dave Beck, Randy Patten, Gary Dawson, Denny Dieringer. Row 2: Gary Stutzman, Ken Cole, Fred Stickle, Bob Rehkopf, Craig Roberts, Ernest Music. 


\section{Happy Timers and Old Folks}

HAPPY TIMERS -Alice Moorman, Mary McMurtry, Jim Powell, Judi Winston, Jane Cunningham, Carol Engle, Elaine Eldridge, Mark Wilhite, Dan Inghram, Chuck Dutton, Ken Cole, Rick Inghram.
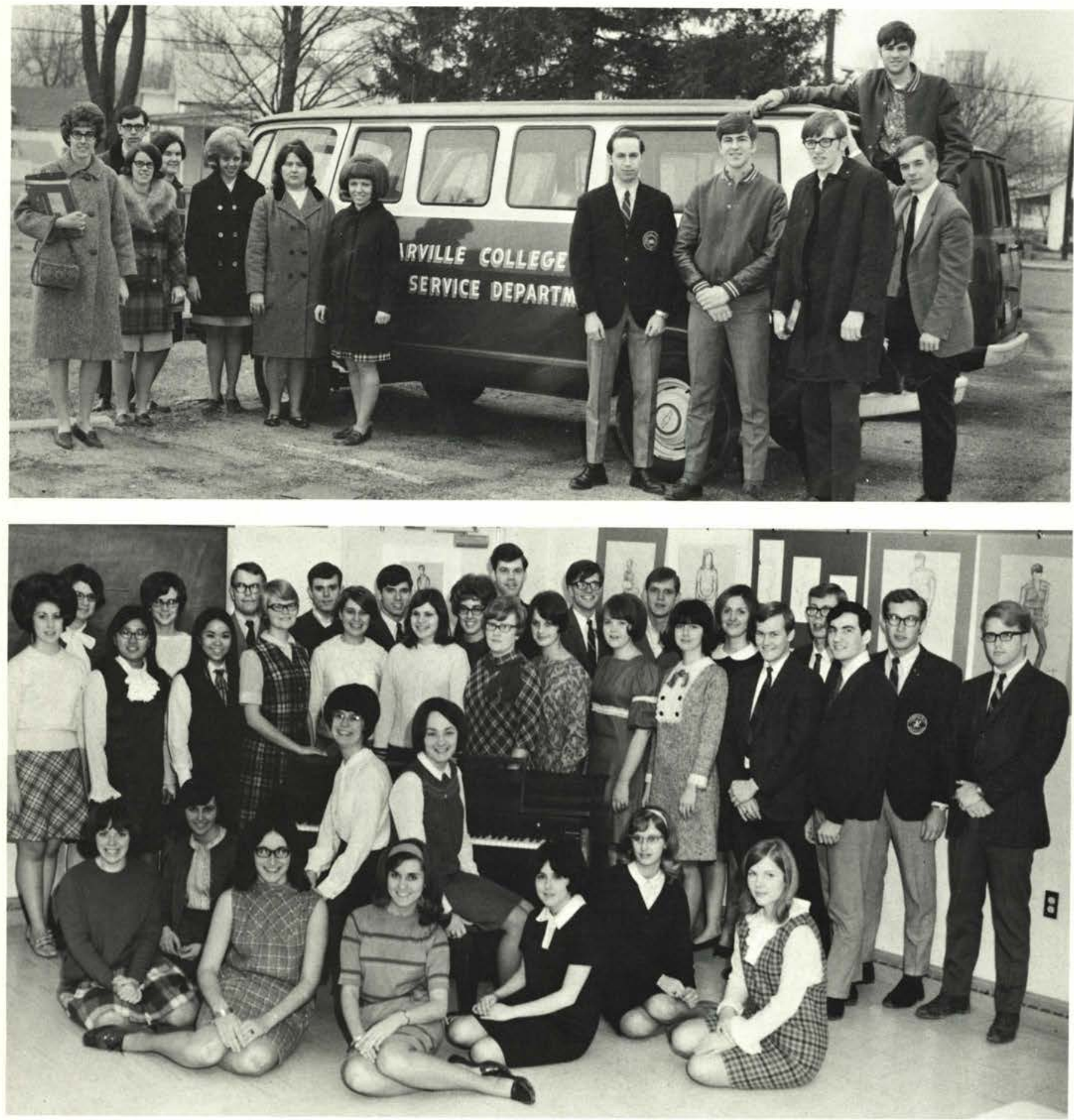

OLD FOLKS - Seated: Nancy Brown, Diane Williamson, Carol Herriman, Edith Phillips, Becky Decker, Donita Baker, Joyce Motts, Nancy Paugh, Barb Work. Row 1: Ruth Hollowood, Gayle Furushima, Mitsu Ishuin, Judy Rehn, Linda LeFever, Janice Vlug, Alice Moorman, Coletta Morrow, Karen Donaldson, Janet Epps, Kathy Clark, Ken Heyer, Chuck Rowe. Row 2: Joan Boyd, Janet Yardley, Peter Oehmeke, Bob Brown, Ken Booth, Sam Olsen, Rich Mitchell, Louis Tewis, Marikay Schneider, Tom Greenwood, Larry Davis, Dave Turner. 


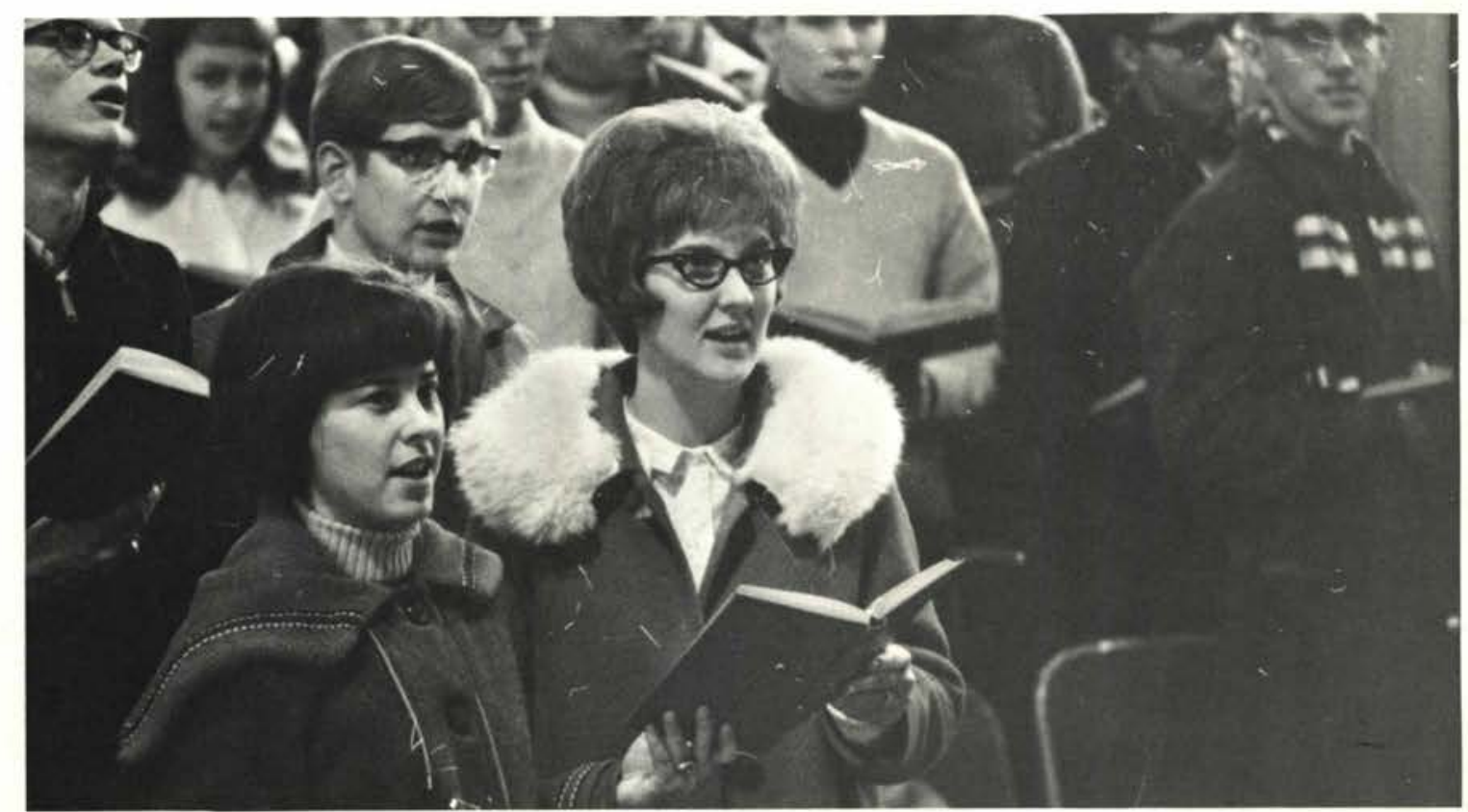

"I didn't think there were still kids like this around."

"They seemed so natural, so intelligent; not 'holier than thou,' yet so dedicated to Christ."

"I wish those young people had been at the Chicago Democratic Convention."

These were the audience's comments as Cedarville students appeared on the Phil Donahue Show, the number one television program in the Dayton area. The interview, in an extraordinary way, portrays the vision of our students - dedicated to Christ, teaching Bible Club, directing a choir, voicing a chorus, and singing a chapel solo.
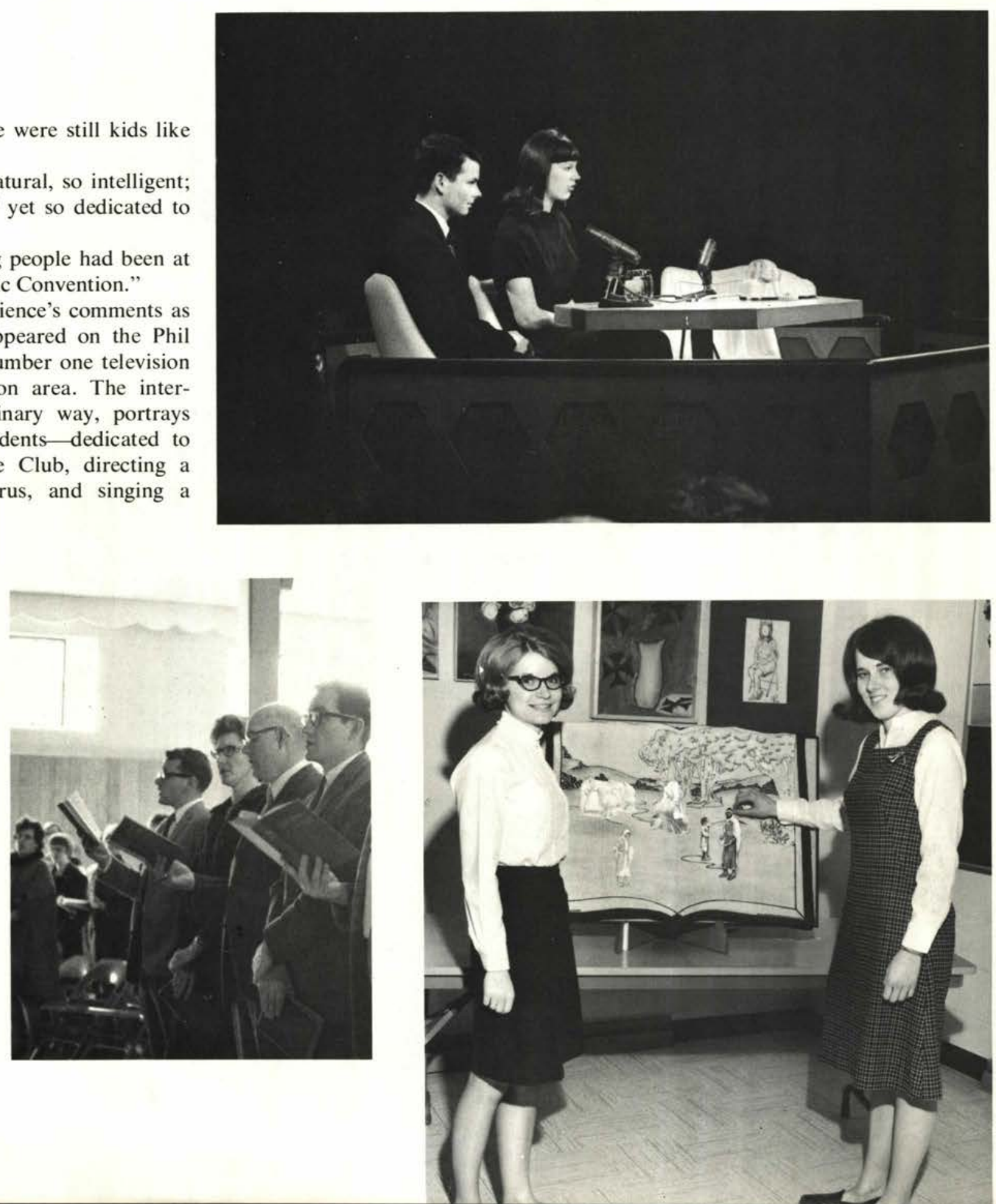

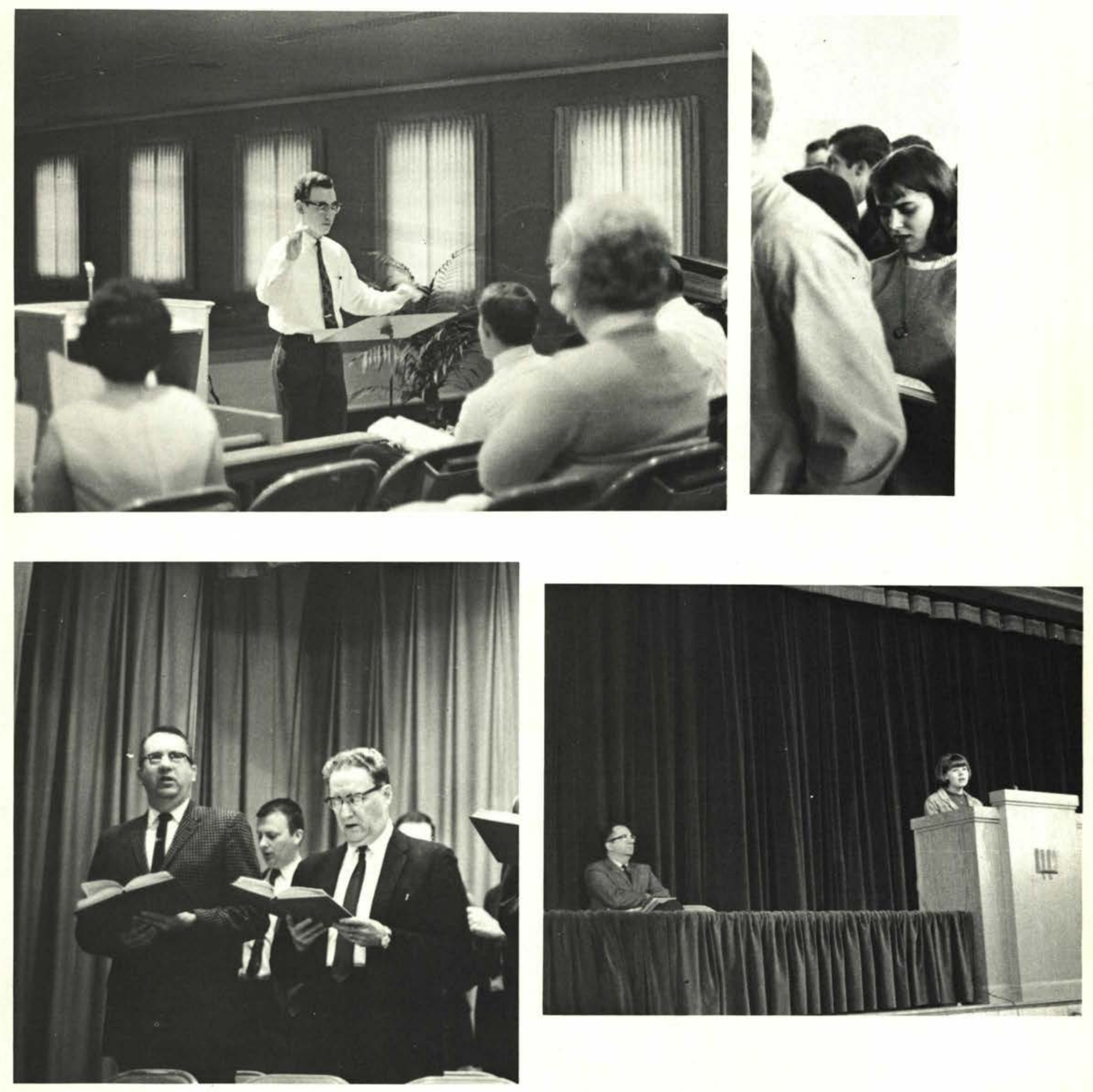


\section{Musical Ensembles}

GUARDSMEN-Philip Mohler, Phil Senseney, Dennis Bunting, Lyle Anderson, and Ron Spieth.

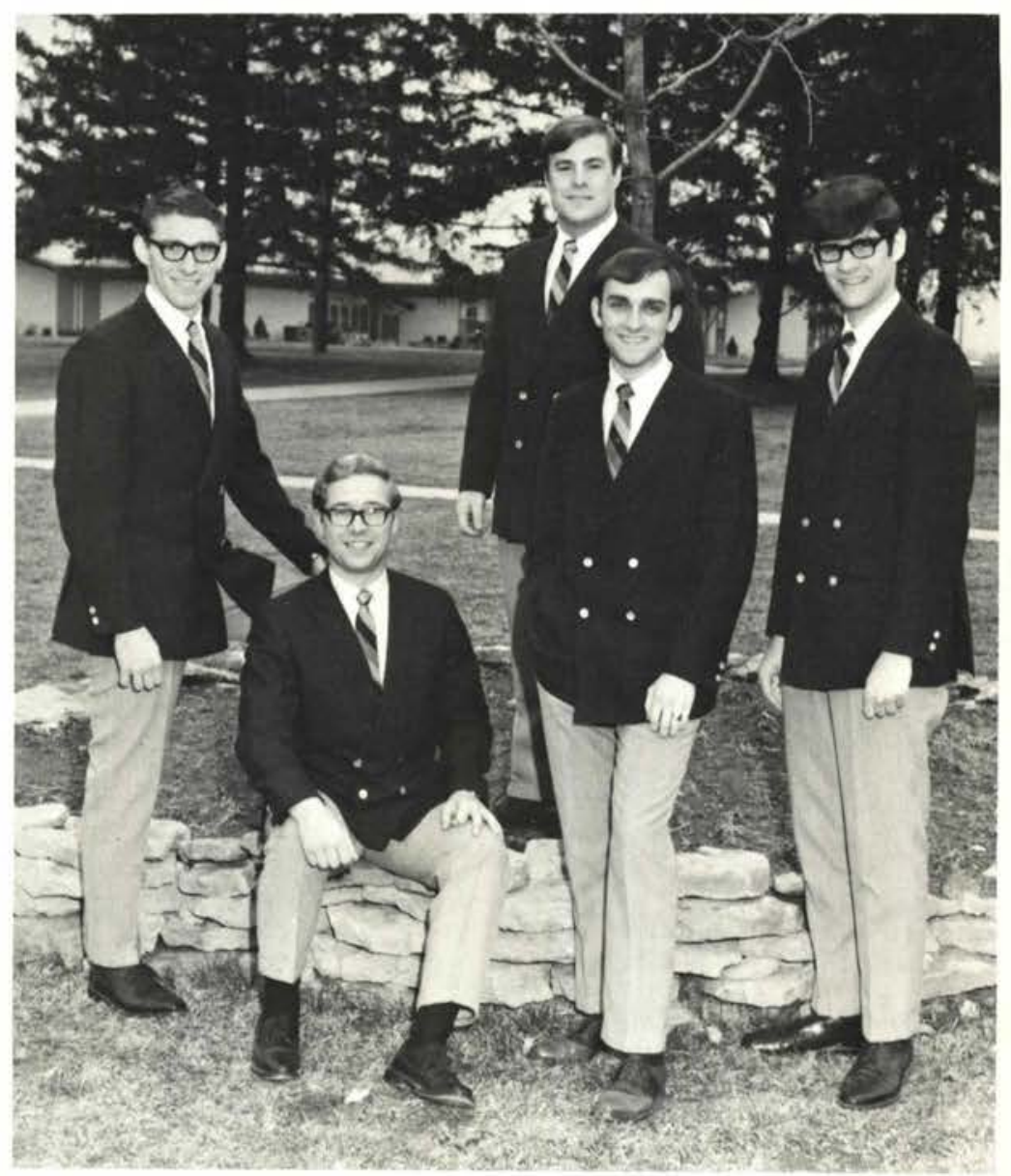

VICTORS-Margaret Anderson, Esther Greenwood, Darlene Fitch, and Cathy Cartner.

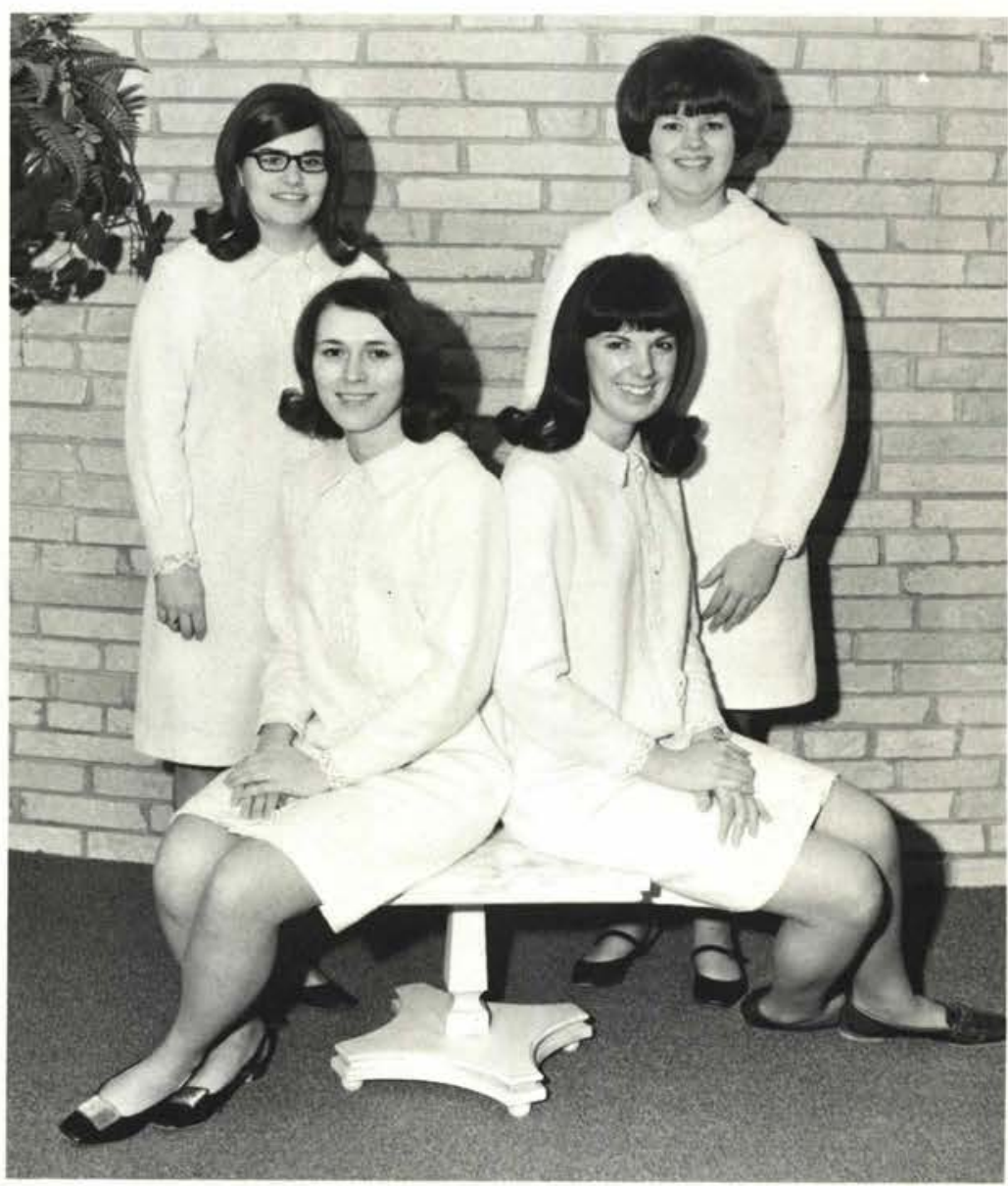




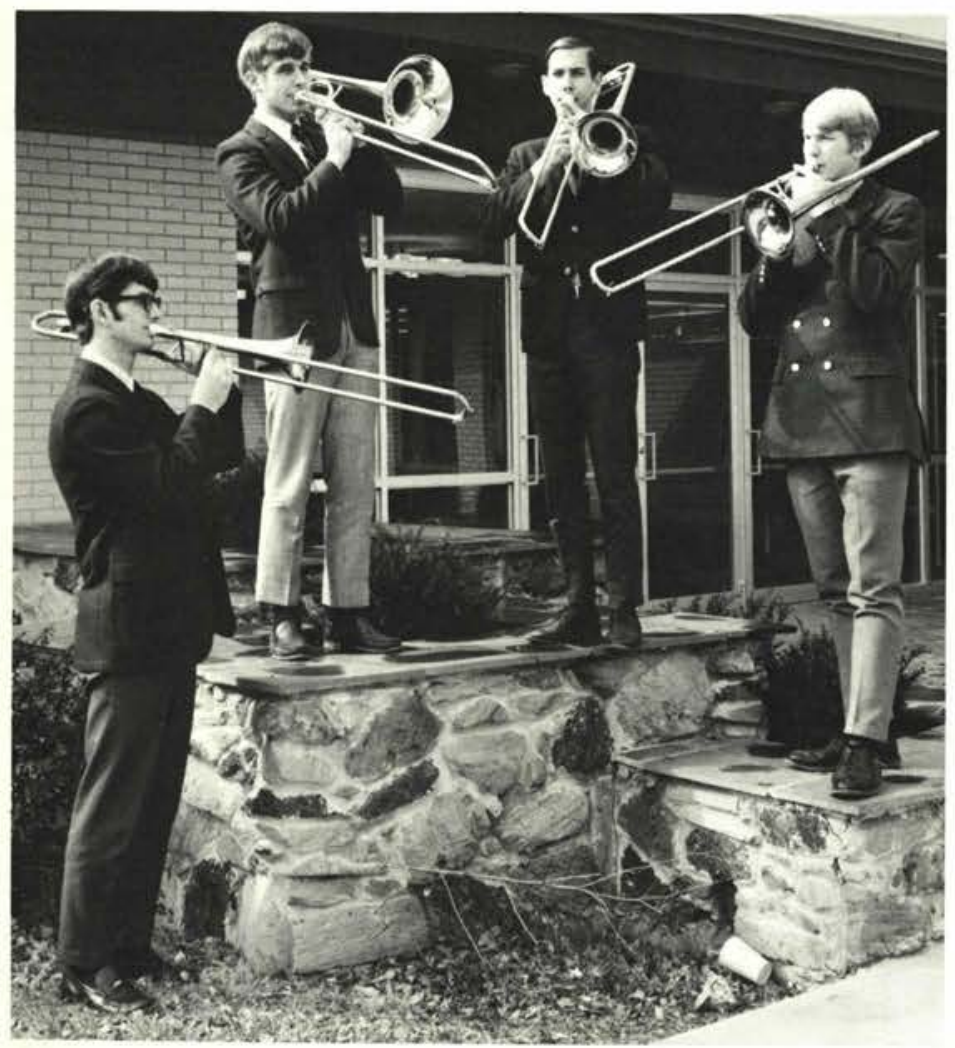

KINGSMEN-Daryl Prindle, Bob Senseney, David Nelson, and Cliff Jensen.

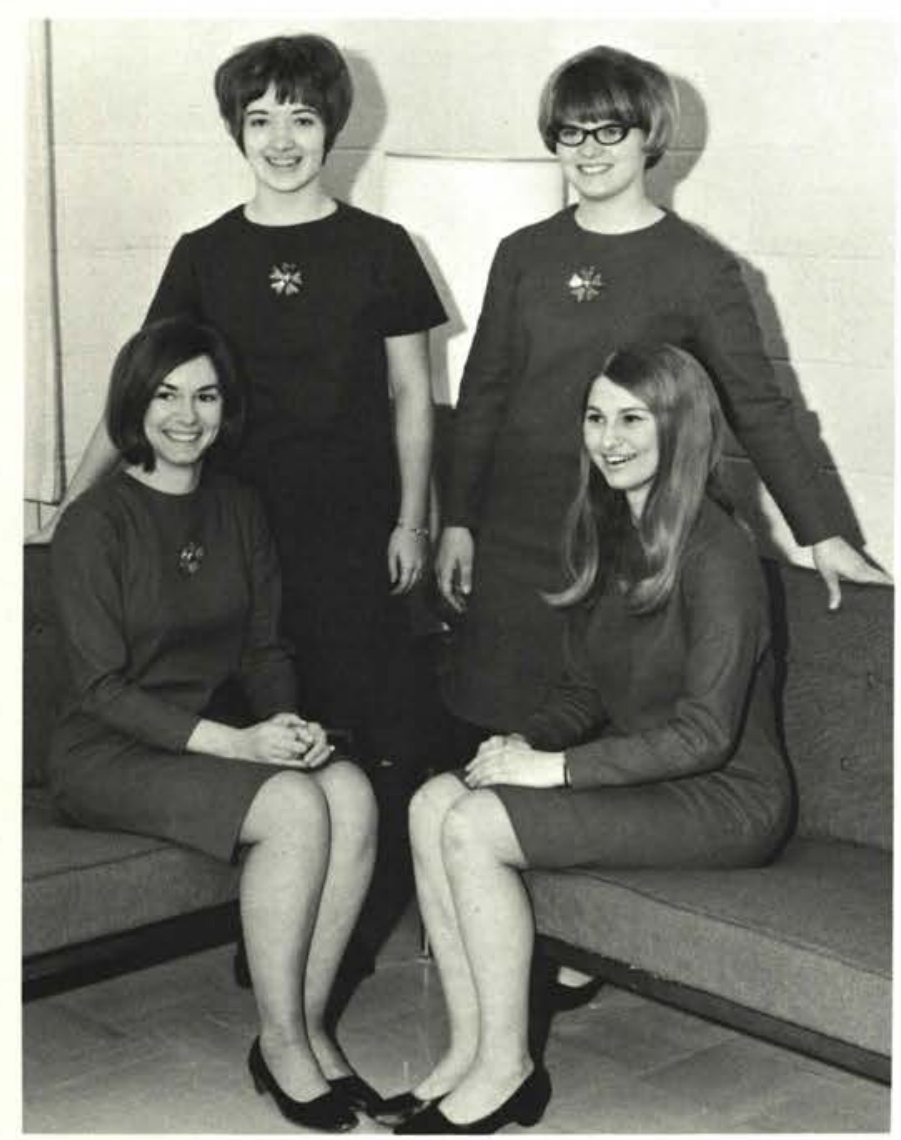

CONQUERETTES - Gail Carsey, Annette Clark, Linda Betts, and Sue Scott.
DIADEMS—Sitting: Karen Borger, Pat Black, and Cecilia Romine. Standing: Pat Riley.

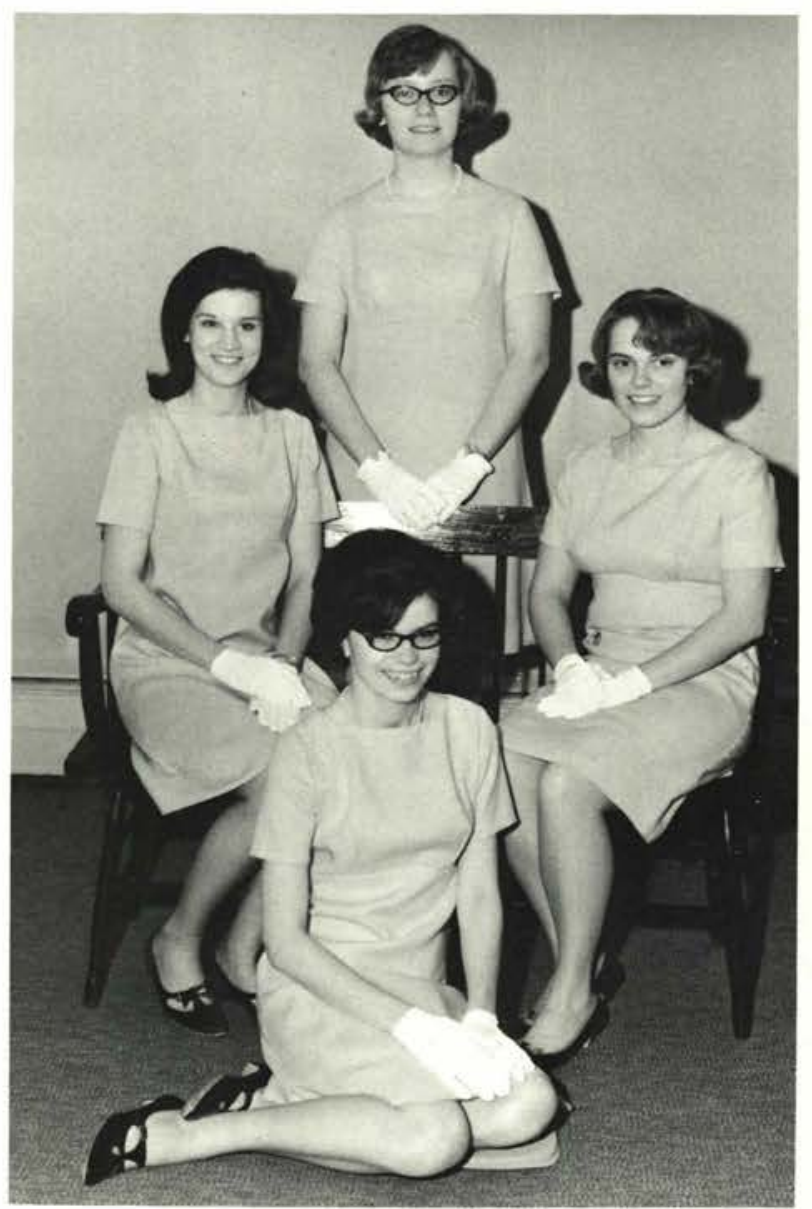

THE NEW IMAGE-Judy Grover, Janice Timpe, Becky Hull, and Cyd Schaechterle.

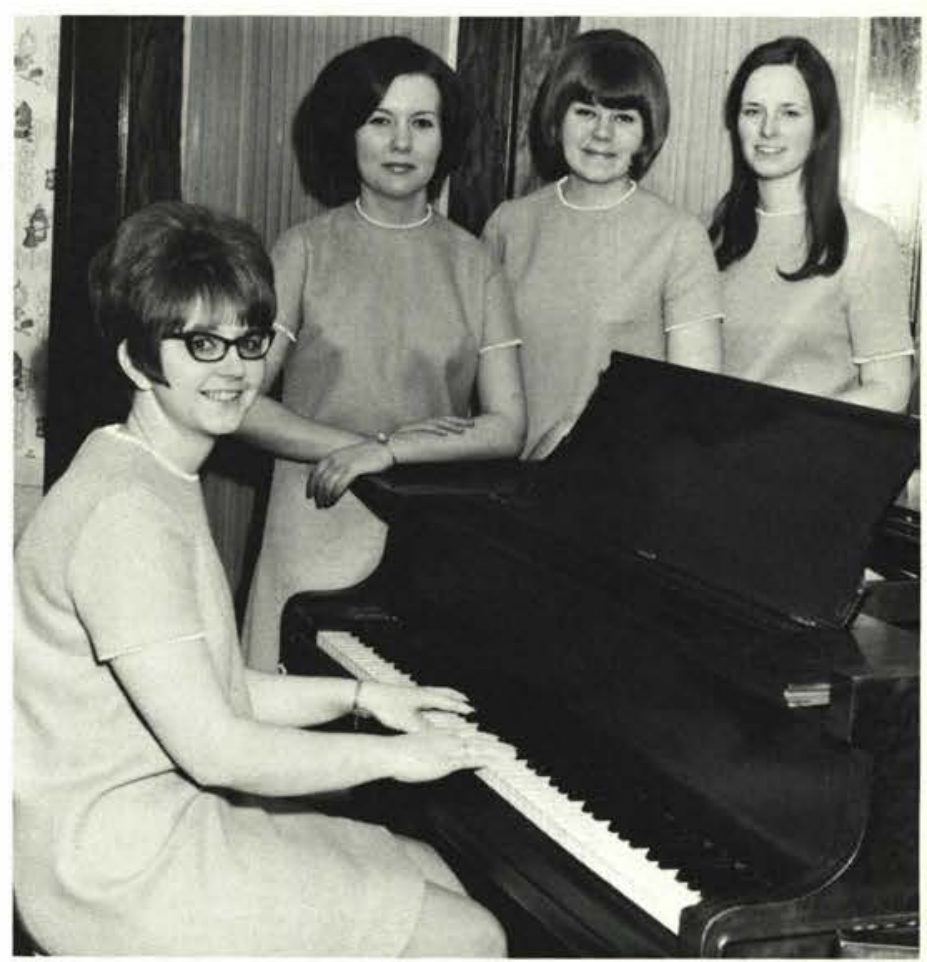



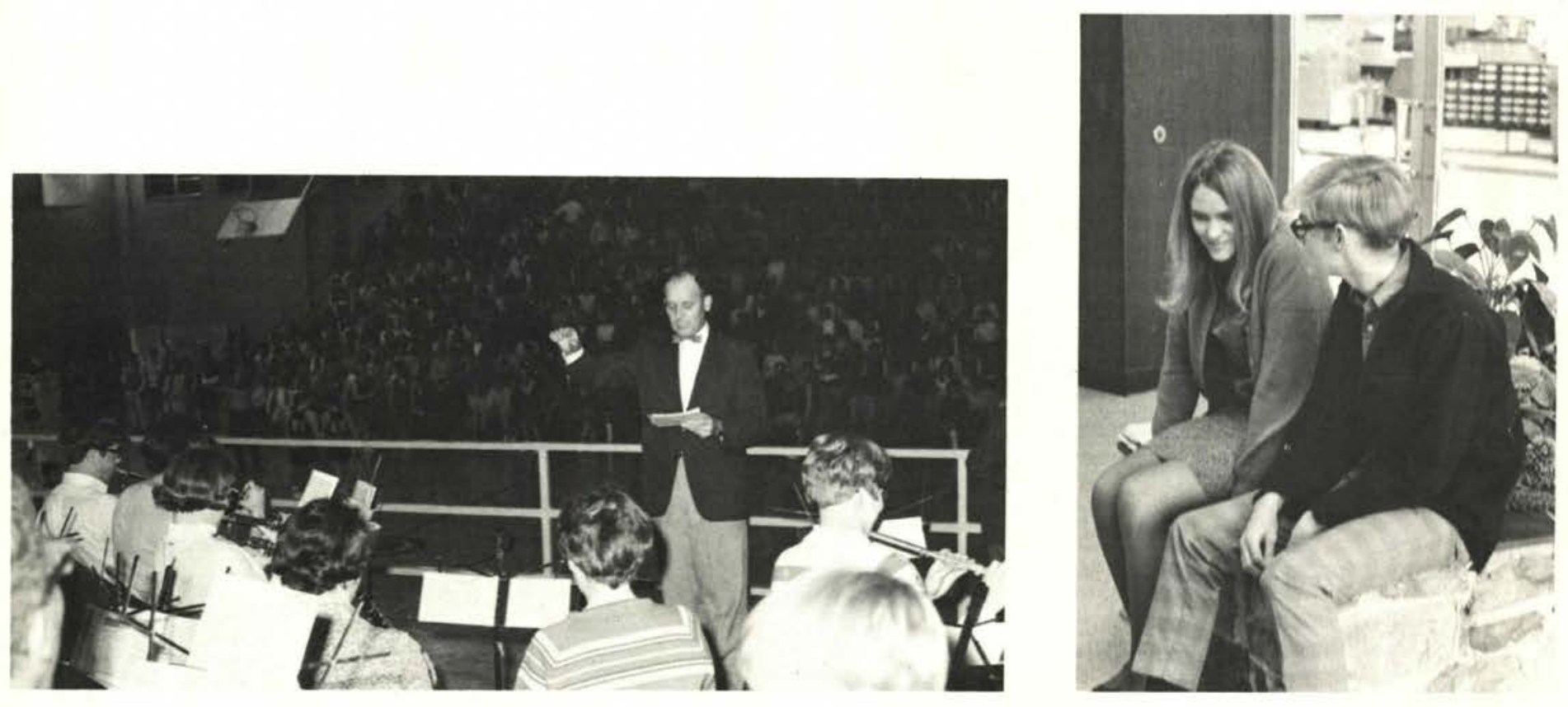

\section{The 24-Hour}

The spiritual side of man-his vision for the present and future-is not limited to Sunday church and Wednesday prayer meeting.

No. You might say, "living for Christ" is a 24 hour, 7 day a week job. That's why Cedarville pictures people at their best in whatever they doplaying in the band, dating, studying, going out for sports, teaching, partying, attending classes, or just thinking. "Whatever you do, do all to the glory of God." I Corinthians 10:31.
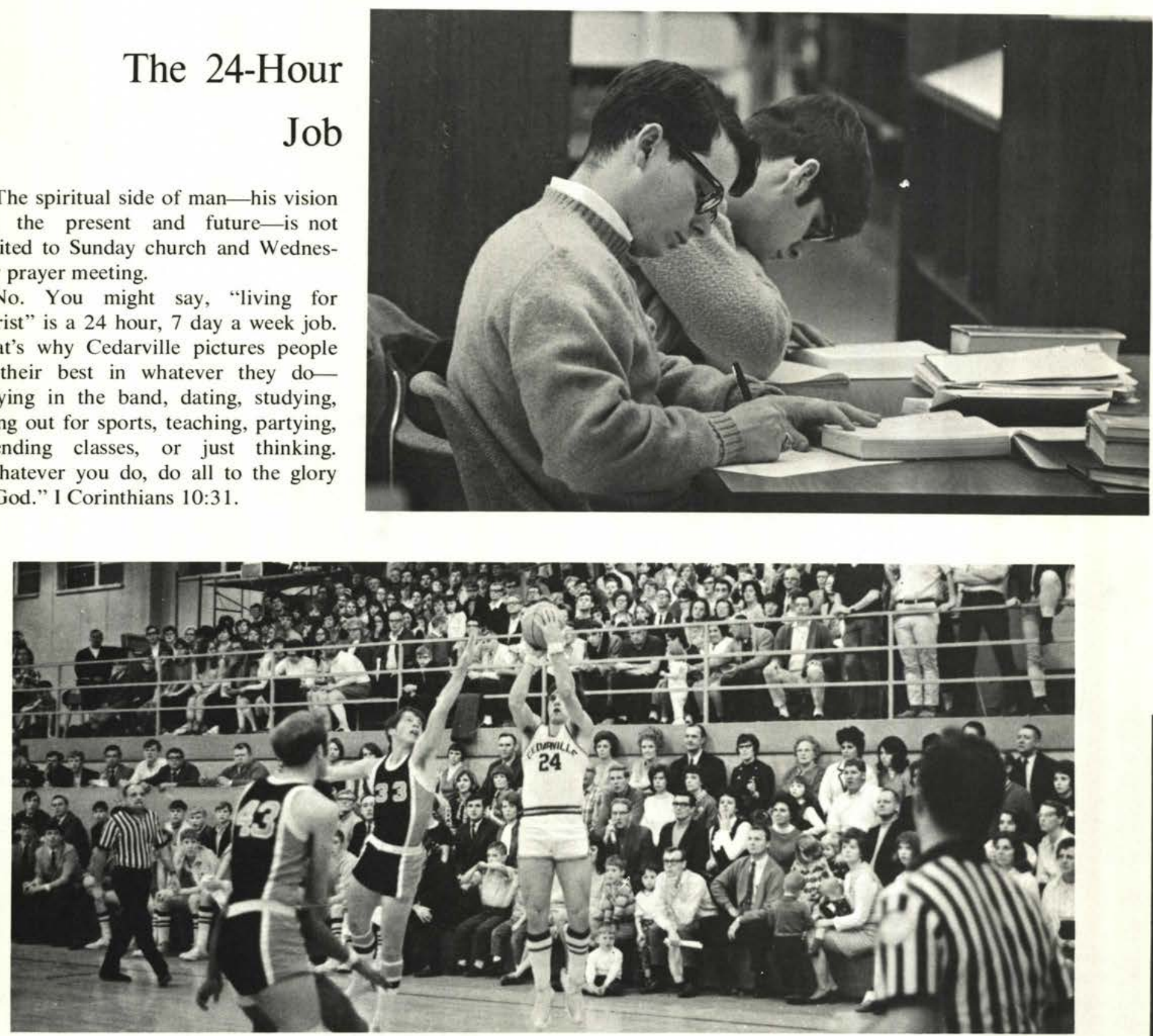

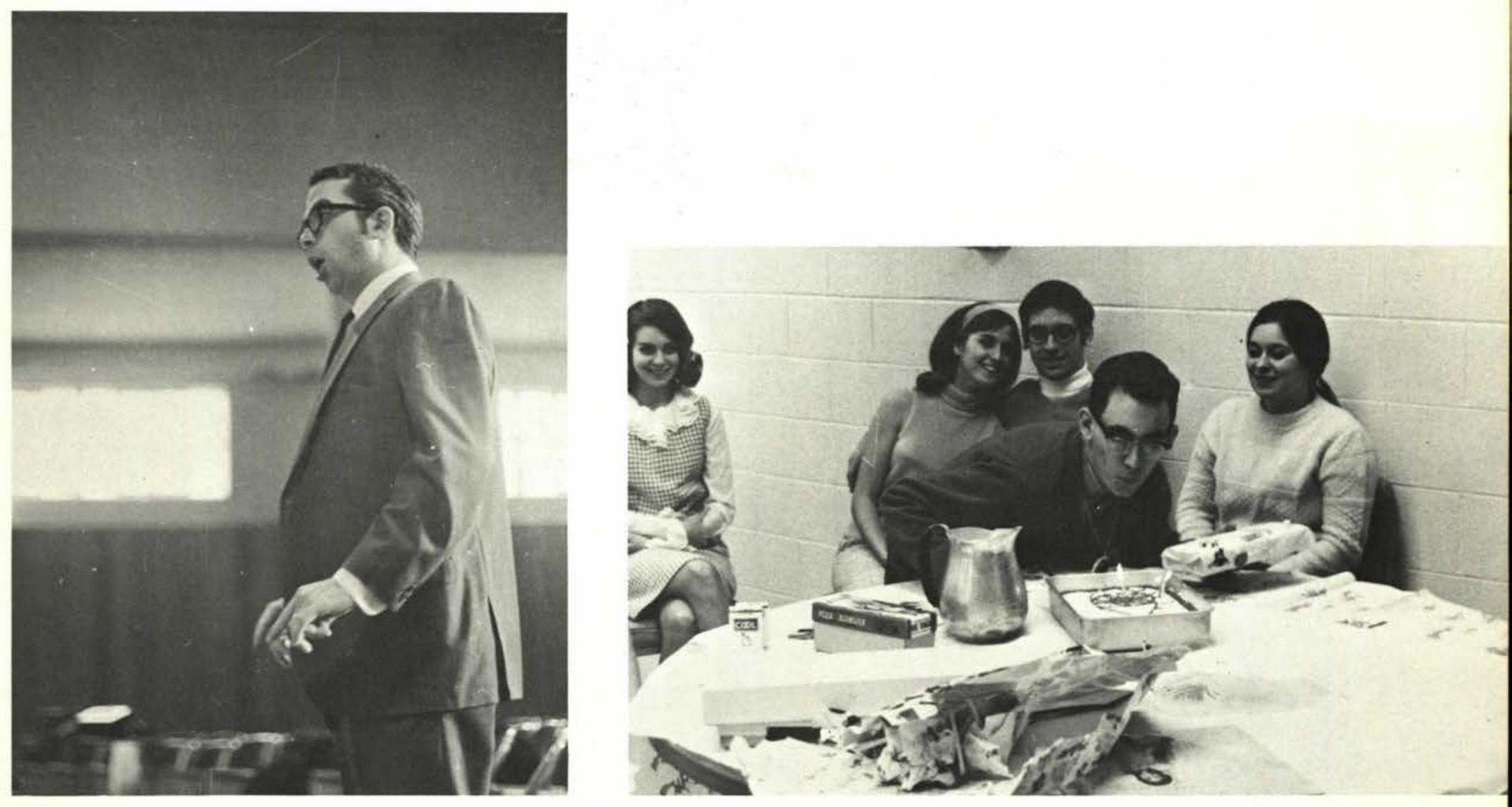

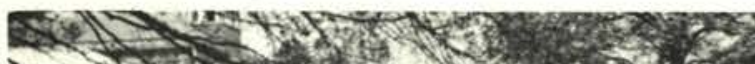
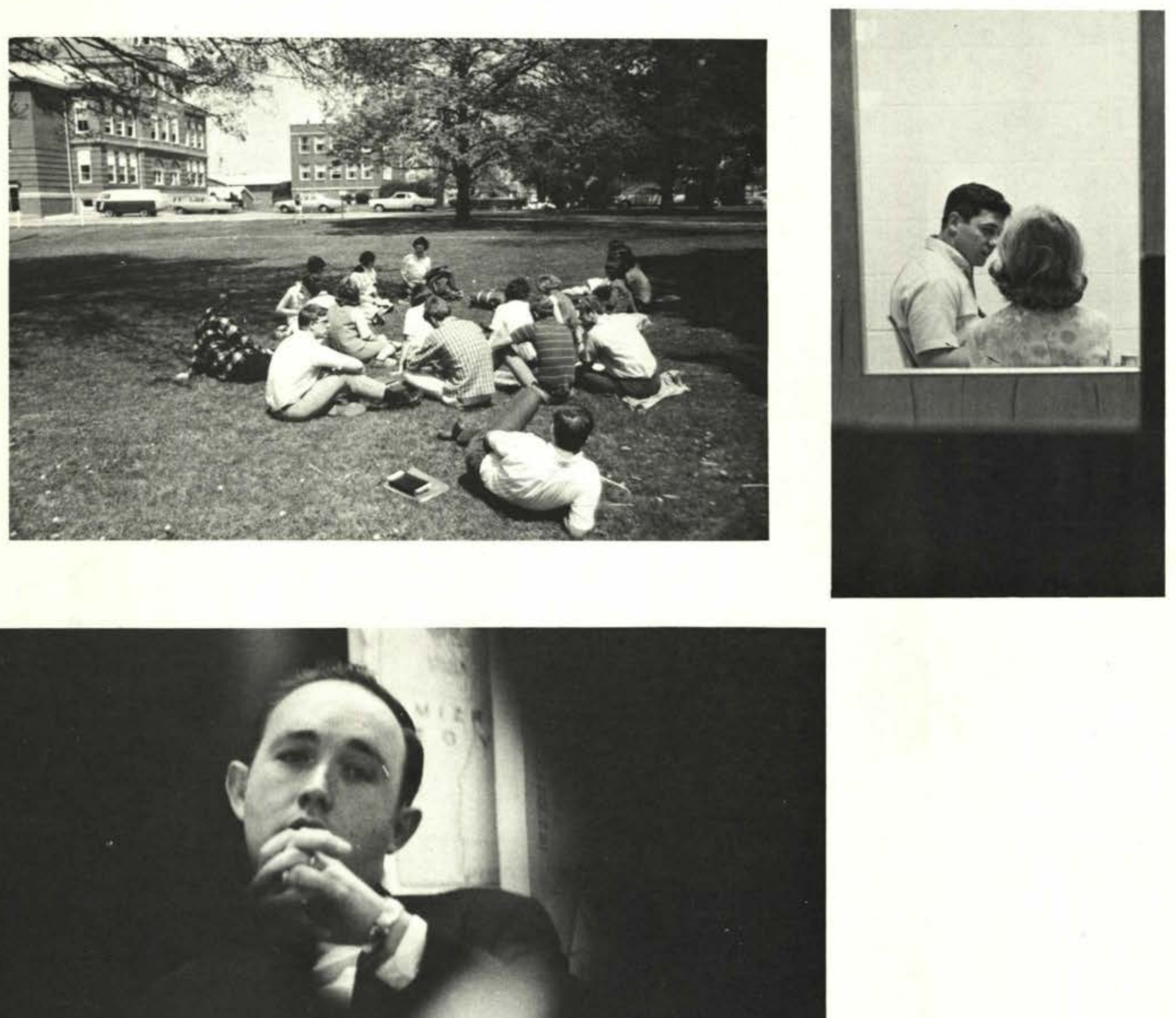


\section{Cedarville College Choir}

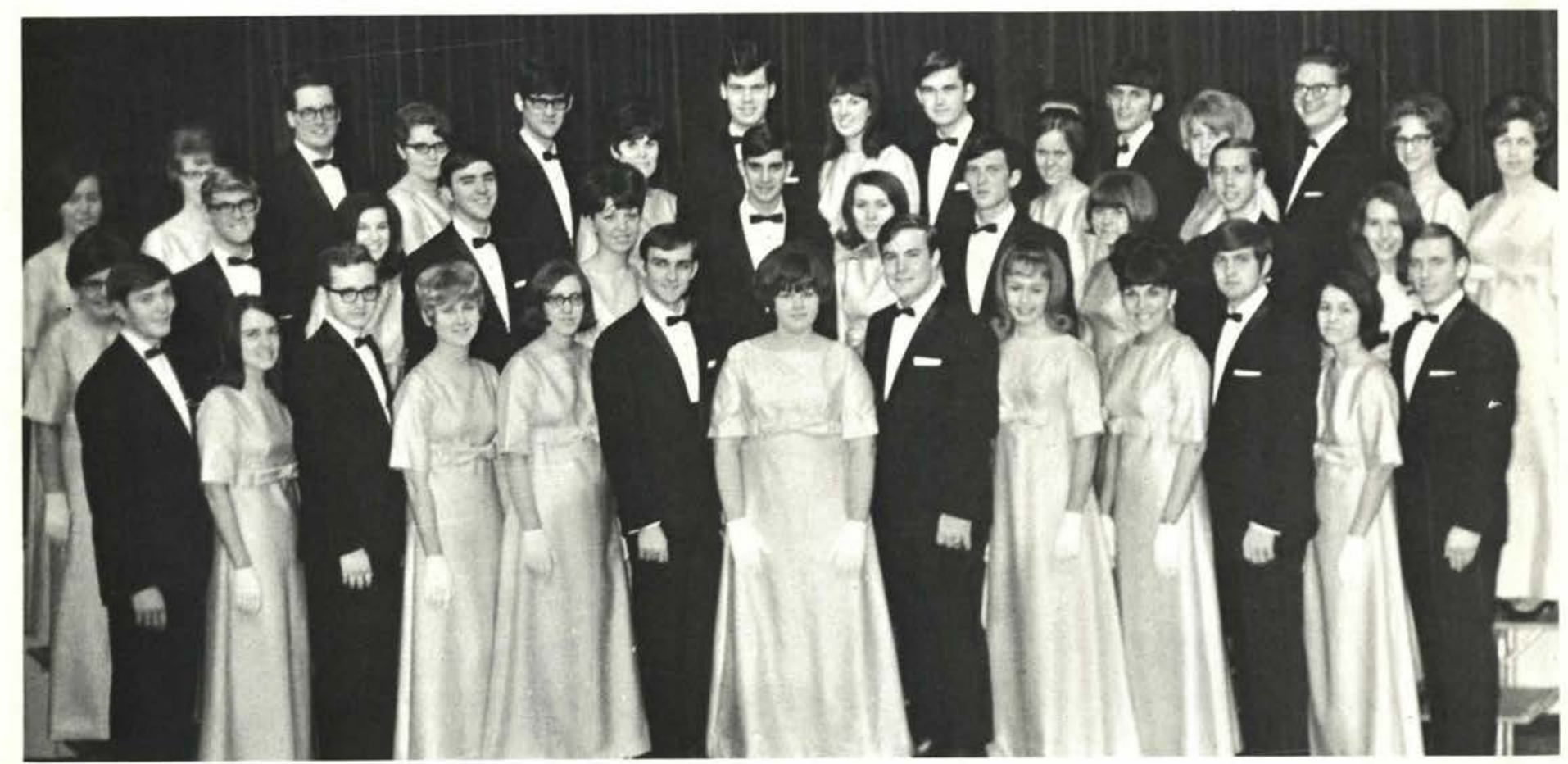

COLLEGE CHOIR - Row 1: S. Hancock, R. McIntyre, R. Coombs, P. France, B. O'Keefe, L. Anderson, K. Cartner, D. Bunting, J. Gabriel, D. Daab, H. Moore, R. Hardy, D. Railsback. Row 2: M. Anderson, J. Grayson, K. Borger, R. Meyers, R. Butler, D. Durham, E. Greenwood, L. Rodman, B. Hull, D. Nelson, J. Hirschy. Row 3: J. Timpe, J. Brock, G. Taylor, B. Moore, R. Spieth, C. Steenberg, S. Olsen, D. Fitch, V. Lakes, J. Beesley, J. Schneider, V. Myer, B. King, J. Hess, S. Pape.

The 1968-1969 College Choir, under the direction of Mr. David Matson, is an ensemble of forty-five selected voices emphasizing the a cappela tradition. The Choir annually makes a spring tour of many of the supporting churches for the purpose of performing significant sacred choral literature of various periods and styles "for the . . . testimony of Jesus Christ." In addition, several concerts are presented on the campus and in surrounding communities.

During this school year, the Choir has presented concerts in Illinois, Indiana, Kentucky, Michigan, Minnesota, Ohio, and Wisconsin. Together with these concerts, the Choir has appeared as guest choir at conferences, colleges, and prisons, and has performed on radio and television in addition to recording its latest album.

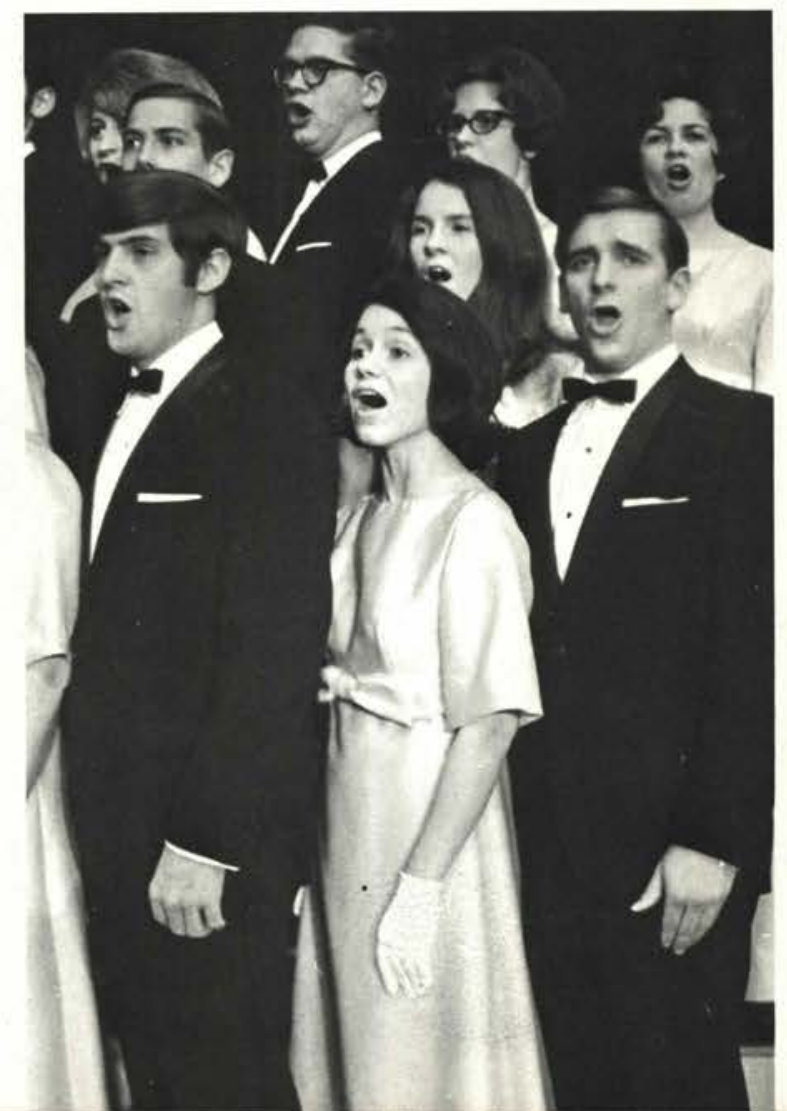




\section{Choralaires and}

\section{Oratorio}

Choralaires is an ensemble of approximately thirty selected voices with an emphasis on significant secular works of various styles. This group has appeared in churches, schools, prisons, before civic organizations, and in campus concerts.

It is the purpose of this ensemble to provide an avenue of tasteful expression in the realm of secular repertoire which will be not only a means of providing an optimum of wholesome entertainment, but also will further prepare those who, upon graduation, will be assuming roles as music educators.

The oratoria, a choral reading group, assisted the Choralaires in their concert this year.

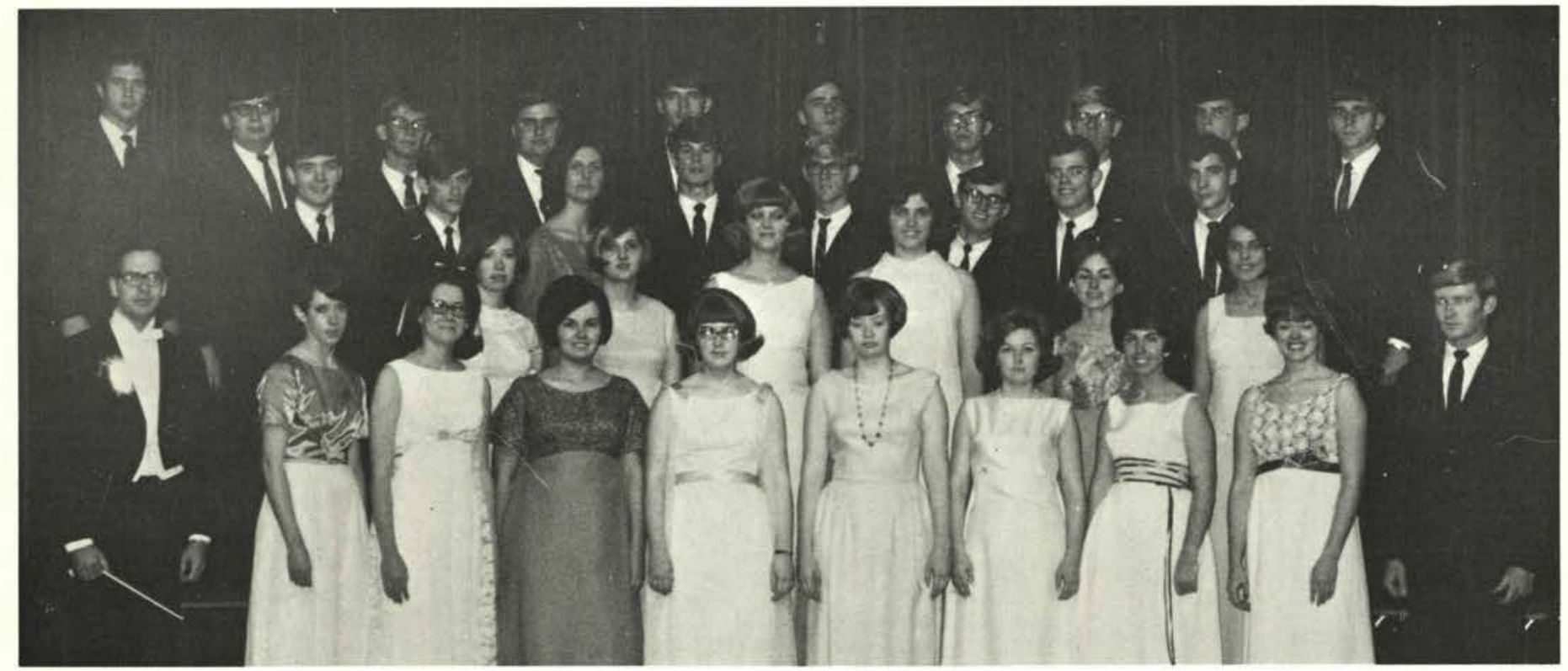

CHORAlaires - Row 1: Advisor: Mr. Paul Vanderkoy, N. Addelman, C. Cartner, L. Hirschy, J. Austin, L. Browning, C. Morse, G. Gatliff, C. Laynor. Row 2: J. Colby, J. Risko, J. Love, R. McDowell, N. Lepline, M. Lima. Row 3: S. Hancock, B. Rehkopf, M. Schneider, D. Argo, J. Grayson, S. McMillan, B. Brown, D. Beck. Row 4: D. Bathel, D. Liechty, J. Greening, M. Coffman, R. Meyers, T. Greenwood, T. Sidler, T. Kline, B. Senseney.

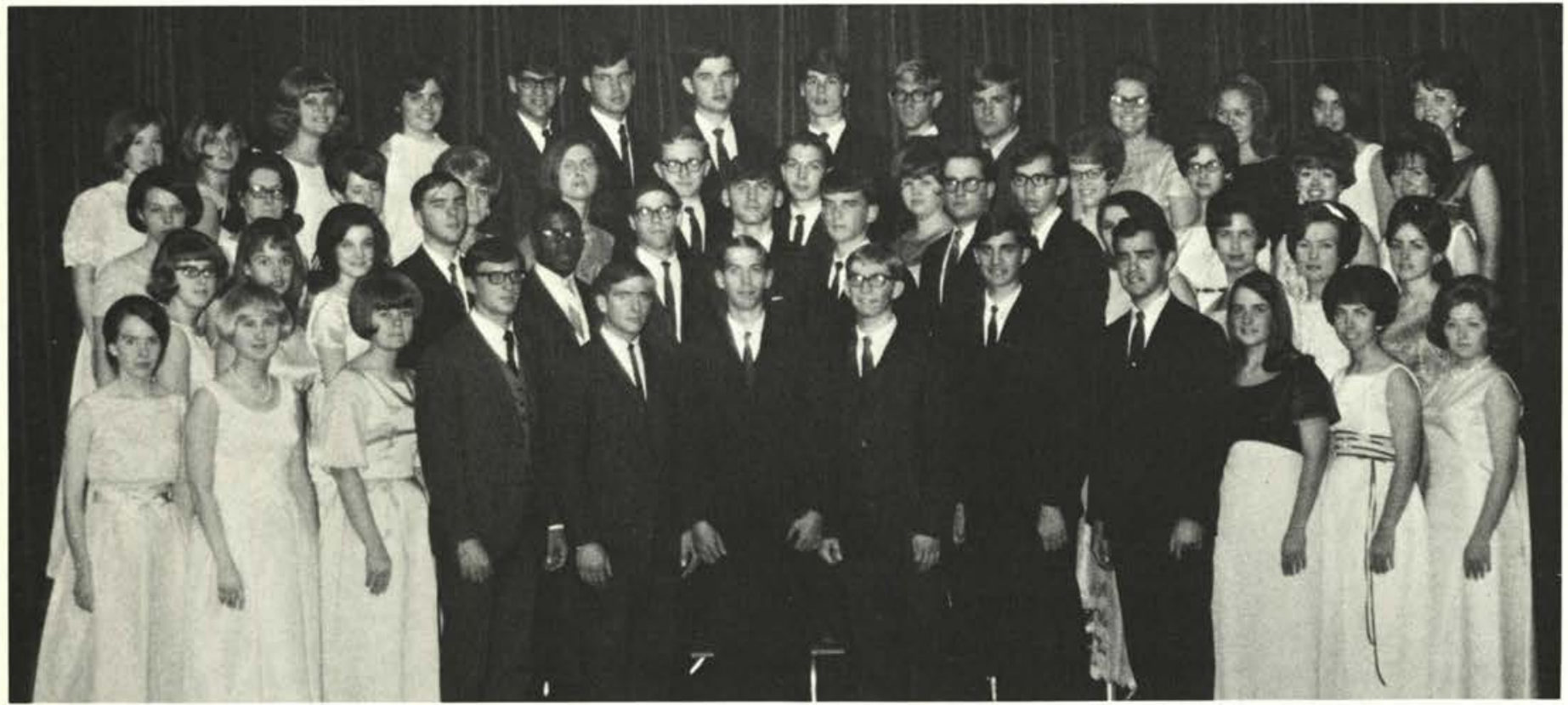

ORATORIO CHORUS - Row 1: J. Hirschy, P. France, B. Hull, L. Rodman, D. Railsback, D. Nelson, J. Greening, D. Durham, C. Rexroth, R. McIntyre, C. Morse, L. Browning. Row 2: L. Hirschy, J. Gabriel, K. Borger, R. Meyers, K. Hammonds, D. Long, J. Schneider, T. Kline, G. Taylor, J. Powell, E. Greenwood, S. Pape, J. Timpe, N. Lepline. Row 3: P. Emerson, C. Cartner, N. Addleman, V. Meyer, M. Schneider, R. Coombs, K. Holden, K. Cartner, J. Brock, J. Hess, G. Gatliff, B. Bodenmiller. Row 4: J. Colby, J. Risko, J. Love, R. McDowell, R. Spieth, S. Olsen, V. Lakes, D. Argo, J. Grayson, D. Bunting, B. Moore, J. Beesley, M. Lima, R. Butler. 
A

Abernathy, Betty 75

Abrams, Dorothy 75,155,164,167

Acker, Donald 85,152

Acton, Daniel 61

Adams, JoAnna 43

Adams, Richard 85,130,153

Addleman, Nancy $43,174,185$

Afolabi, John 61,163

Albright, Kathryn 75,164,173

Aldrich, Kathy 43

Allen, Robert 75

Ambroza, Douglas 85,137

Amstutz, William 61,152

Anderson, Lyle $75,125,152,165,166$, $167,180,184$

Anderson, Margaret 85,162,165,180, 184

Anderson, Olivia 85,148

Andrews, Thomas 85,141

Argo, David 43,137,185

Artrip, Ronald 75,164

Ashley, Janet 75

Atherton, Donald $61,135,152$

Augsburger, Maxine 85

Augspurger, Ruth 85

Aumack, Kathy 43

Austin, Jane $75,152,185$

Austin, Kathleen 75

Austin, Robert 43,163

Averitt, Constance 61

\section{B}

Bailey, Nancy 75

Bair, Marsha $61,167,174$

Baker, Carol 85

Baker, Donita $75,155,162,173,175,177$

Baker, Judith 43

Baker, Rodney 43

Baker, Ronald 85,125,143,152

Balyo, Michael 43

Barcus, Joanna 85,156

Barnhart, Karen 85

Bartlett, Mary 61,162,173

Bates, Basil 43

Bathel, D. 185

Beck, David 61,143,176,185

Beck, Margaret 43

Beckley, Phyllis 43,185

Beerer, Carol 86,155

Beesley, Janet $61,154,165,166,167$, 184,185

Beitler, Mareanne $61,155,162,166$, 167,174

Beitler, Marilyn 86,167

Beitz, Mary 43,154,162

Bell, Ken 61

Beltle, Allen 75

Bennett, Beth 74,75,148,174,175

Berger, Karen 181

Berkheiser, Bill 61

Bernath, Karen 43

Berry, James 86,167

Berry, Randy 141

Betts, Linda 43,181

Betts, Pamela 43

Biddison, Barbara 61,167,175

Bigley, Regina 61,175

Bittner, Rebecca 43,164

Bixel, Robert 86,160

Black, Patricia 86,175,181

Black, Richard 43

Blake, Diane 86

Blum, Linda 43

Bodden, David 75
Bodenmiller, Betsy $86,155,185$

Bodenmiller, Thayne 44,130

Boertje, Darwin 75,135

Bolen, Paula 86

Bondorff, Carl 44,134

Booghier, Stephen 86

Boothe, Kenneth 44,137,173,177,152

Boothroyd, Hilda 61

Borger, Karen 75,184,167,185

Bosh, Donald 44

Bosworth, Timothey 61,152

Bowersox, Bernice 75

Boyce, Michael 61

Boyd, Joan 61,177

Bradford, David 44

Branning, Pamela 44

Braswell, Sylvia 61

Bratka, Donna 75

Braun, Dale 75,150,152

Brock, Janice 75,180,184,185

Brooker, Martha 44

Brookhart, Joyce 61,174

Brown, Beverly 44

Brown, Kirby 62

Brown, Linda 44,164

Brown, Marjorie 44,176

Brown, Nancy 62,177

Brown, Robert 62,162,173,175,177, 185

Brown, Stanley 86,167

Browning, Linda $62,148,154,185$

Bunting, Dennis 60,62,153,180,184

Burroughs, Carol 86

Busho, Connie 62,160,167

Butcher, Preston 76

Butler, Janet 44

Butler, Richard 62,134

Butler, Roxanne 86,155,174,184,185

Butler, Thomas 62

Butler, Valerie 76

Buzzard, James 62

Byer, Beverly 44

Call, Alan 76

C

Calvin, Roy 44

Campshell, Linda 173

Caraway, Daniel 84,86

Carity, Marcia 62

Carlson, Annie 86

Carmean, Robert 76,152,163

Carpenter, Timothy 87

Carroll, Donald 62

Carsey, Gail 44,181

Carter, Helen 44

Cartner, Cynthia 76,162,180,185

Cartner, Kathleen $87,165,184,185$

Catteau, John 62

Causey, Mark 76

Cavey, James 45,130

Chaffe, Diane 87

Chaney, Ervin 45

Chapin, Janet 87

Christiansen, Linda 45

Chumbler, David 87

Clark, Annette 181

Clark, Carolyn 76

Clark, Cathy 63,177

Clark, Connie 45,165

Clark, Susan 63

Clay, Joan 63

Clay, Roger 45

Cleckner, Barbara 87

Closson, Pamela 45

Cockerill, Diane 63

Coffman, Michael 63,152,185
Colby, J. 185

Cole, Ken 76,123,125,152,166,167, 176,177

Collins, Cherrill 87

Collison, Kenneth 63

Colyer, James 63

Colyer, John 45,152,164

Conant, John 45

Conant, Joy 87

Conant, Virginia 87

Cooley, Mark 63

Cooley, Janice 76,154

Coombs, Ronald 63,152,184,185

Corbin, Joan $87,121,155$

Coriell, Ronald 87,152

Cussins, Martin 63

Cox, Martha 76

Crabtree, James 45

Crampton, Roger 87

Creviston, Gary 63,152

Crunk, Maureen 63,174,176

Cunningham, Cynthia 64

Cunningham, Jane 175,177

Cunningham, Mark 45

Curcio, Charles 76,153

Curtis, Roger 45,152,164

Cypher, Richard 87

Daab, Donna 87,154,165,184

Dalton, Edith 45,164

Darrow, Gary 88,135

Darst, Anne 145

Dautel, Joan 76

Davis, Jeffrey 45

Davis, Larry 88,152,177

Davis, Marilyn 64

Dawley, Bruce 46

Dawson, Gary 64,152,176

DeBoer, Carol 64,151,154,174

Decker, Rebekah 76,154,177,185

Dersham, Michael 46,150

Devor, Elizabeth 46

Dewalk, Richard 76

Dewar, Barbara 88

Dieringer, Dennis 64,152,163,166,176

Dillard, Joseph 88

Dillard, Rose 88

Dixon, Elaine 46

Doctor, Silas 46

Donaldson, Karen 88,155,177

Donley, John 88

Douglass, Sandra 64

Draxler, David 76,103,130,153,158, 175

DuBois, Leonnard 88

Duell, Brenda 46

Duell, Regina 64

Dunkin, Mary 46

Durham, David 64,143,152,184,185

Dutton, Charles $64,152,177$

Earnhart, Pamela 46

Eberhart, Michael 88

Eckart, Cynthia 77

Edelbrute, Meda 46

Edwards, Marsha 46,160

Edwards, Ronald 77,162,163,167

Eichelberger, Clinton 46

Eichelberger, Leland 77,152,160

Eldridge, Elaine 77,154,175,177

Elsner, James 46

Emerson, Patricia 46,185

Emerson, Richard 46

Empet, Sara 88 
Endicott, Connie 77

Engle, Carol 64,177

Entner, Paul 88,125,143,166,172

Epps, Janet 64,154,174,177

Erickson, Randall 64

Estes, Sharon 46

Evans, Kenneth 64,137

Evans, Thomas 88

Eveland, Jean 64

Falci, Brenda 46

Falknor, Thomas 46

Fallo, Beverly 46

Farrar, Robert 64

Fidler, Dave 88

Fiest, Barbara 46,174

Fissel, Roger 46

Fitch, Darlene $88,154,166,167,174$, 180,184

Flanagan, Devon 47

Flynn, Elizabeth 64

Folkmann, Walter 64

Foster, Donna 47

Foster, Glenda 88

Foulkrod, Beverly 89,162

Foulkrod, Tom 89,162

Fowler, Lynda 47,174

Fowler, Steven 64,130

Fraley, Tomecia 65

France, Patricia 77,125,151,154,162, $167,184,185$

Francisco, Paul 77

Freehauf, Heidi 65

Freeman, Nancy 89

Frenchko, Stephanie 47

Frields, Mark 65

Frye, Jonathan $60,65,140,152$

Fulcomer, Darlene 47

Furushima, Gayle 65,154,166,174,176, 177

\section{G}

Gabriel, Janet $69,65,184,185$

Gaffner, David 89,135

Gardner, Stephen 47

Gardner, Steve 47

Garlock, Linda 84,89

Gathany, Andrew 77,155,167,176

Gatliff, Gail 89,155,165,166,185

Gavitt, E. Leroy 89

Gelo, Thomas 77

Gerber, Lonnie 65

Getz, Phylis 65

Gibson, Stephen 47

Gift, Susan $77,148,154,166$

Gillenwater, Glenda 77,148,154

Gilmore, Sharon 47

Golliher, Carolyn 47

Good, Deborah 48,162,176

Goodman, John 89

Gordey, Sonya 89

Gossett, Sherry 48,174

Gowman, Sandra 65

Grable, Laura 48,174

Grable, Mary 89

Graham, Sharon 77,175

Grandy, Lynn 65,174

Grant, David 48,173

Graves, Christine 48

Grayson, Jerry 48,151,174,184,185

Greening, James 48,185

Greenwood, Esther 65,180,184,185

Greenwood, Tom $89,177,185$

Gregory, David 89,130,153,162

Griswold, Karen 65,154
Grover, Judy $65,164,165,181$

Gutow, Martha 89,155

\section{$\mathrm{H}$}

Haffey, David 89,151,166

Haffey, Nancy $65,164,165$

Hahnlen, Lee 89

Hales, Timothy 65,153

Hamill, Loren 65,153

Hamilton, Karen 90,155

Hamilton, Randall 152

Hammond, Faith 77

Hammonds, Kenneth 74,164,174,185, 152

Hancock, Sam 90,184,185

Handyside, David 84,90

Hansmann, Laura 174

Hanthorn, Rebecca 48,150

Hardy, Ruth 90,125,165,167,184

Hare, Beverly 48

Hare, Carol 90,156

Hare, Evelyn 77

Harman, Rebecca 78,150,154,175

Harold, Susan 48

Harrison, John 48,134

Hart, Barb 174,48

Healey, Barbara 49

Heldreth, Kirk 74,78,163,167

Hendrickson, Rose 90

Henry, William 49

Hergenrather, Connie 90

Herrin, Sue 90

Herriman, Carol 49,164,177

Herwig, John 90

Hesler, Sherrill 78

Hesler, Susan 49

Hess, Jane 90,125,165,184,185

Hetrick, Sally 90

Heyer, Kent $65,134,177$

Hickam, Sarah 78,164,174

Hill, Alan 49

Hirschy, Judith 90,125,162,165,184

Hirschy, Linda 65,185

Hitchman, David 49

Hoag, Jennifer 90,155,167

Hoerath, Julie 66,173

Hoffman, Robert J. 78

Hoffman, William 49,134,137

Holbrook, Gary 134

Holbrook, Larry 134

Holden, Kevin 49,152,185

Holderby, Teresa 49

Holliday, Jack 77,152

Holloway, Linda 90

Hollowood, Ruth 66,177

Hon, Sharon 49

Hopkins, Carla 49

Hopkins, Donna 78

Hopkins, Wilma 49

Hostetler, Bonita 49,162,174,175

Hostetler, James 66,137,163

Houchin, Andrea 49,174

Hovingh, Joan 49,162,175,176

Howdyshell, William 49

Hoyer, Barbara 78

Hubbard, Judy 66,174

Huddleston, Dennis 78,137,152

Huebner, June 66

Hughes, William 90

Hull, Becky 165

Hull, David 78,152,173

Hull, Rebecca 49,181,184,185

Hunter, Gary 49,134

Hunter, Rebecca 49

Hunter, Robert 91,152,166

Hussey, Patricia 49
Hutchison, Dianna 79,150,214

Inghram, Dan 50,177

Inghram, Richard 66,177

Irwin, Nora 66,173

Irwin, Patti Jo 66

Ishuin, Geraldine $66,154,174,176,177$

Ison, Robie 148

Ivins, Julene 91

Jacoby, Elaine 67

Jefferies, Barbara 91

Jefferies, Linda 79

Jefferies, William 91

Jenkin, Patricia 67,133,154,175

Jenkins, Warren 50,152

Jensen, Clifton 50,164,152,181

Jensen, Val 91

Jeremiah, James 79,153,166

Jewell, David 50,137

Jezowski, Ronald 91,152,167,174

Johnson, Dorena 67,174,176

Johnson, Elaine 91

Johnson, Faye $67,167,175$

Johnson, Francis 91

Johnson, Philip 79,174

Jones, Laura 50

Jones, Paul 74,79,162,163

Jordan, Barbara 91

Journell, Stephen 50

Kahler, Donna 50

Kaufman, Joan 67

Kearney, David 79,160,163,166,167, 176

Kelley, Samuel 91,141

Kemp, Dianne 42,50,162,173,175

Kendrick, Pamela 50

Kensil, Barbara 91

Kever, Janet 91,155

Kies, Carol 67,173

Kilko, B. 162

Kincannon, Donna 92

King, Jean 67,185

King, Maureen 92

King, Robert 79,152,162,165,184

Kinniburgh, Daniel 92

Kinniburgh, Sherian 50

Kintz, Michael 92

Kinvig, Paul 92

Kirby, Helen 92

Kircher, Ruth 51

Kirchner, David 92

Kishpaugh, Deanna 79,162

Kishpaugh, JoAnne 79

Klamm, Harvey 67

Klein, George 79

Kleymeer, Joy 92

Kleymeer, Julie 51

Kline, Tim 42,51,164,185

Klomparens, Ruth 92

Koehn, Darlene 133

Koehn, Deborah 67,133

Krikke, Florence 67,167

Kukasky, Thomas 67

Kusumoto, Ann 67,167,176

Lake, Harry 92

\section{L}

Lakes, Victor 51,184,185

Lambert, Carolyn 51,150,154,162,164

Lantz, Dawn 51

Lapp, Robert $67,148,152$ 
Large, Paul 67,152,163,176

Larson, Curtis 51

Lathrop, Sandra 79,148

Lathrop, Susan 51,155,162

Lavender, Larry 92

Lawhead, Pat 79,151,174

Layner, Clifford 92,165,185

Leach, Judith $67,151,154,174$

Leach, Roger 92,148,152

Leapline, Nancy 79

Lear, Patricia 67,175

LeFever, Linda $51,174,177$

Liechty, Dan 185,74,79,148,162

Leonard, Susanne 51

Lepine, Barbara 79,174,176

Lepline, Nancy 185

Leslie, Frank 51

Lewis, Darlene 67,175

Lewis, Judy $67,167,176$

Lewis, Rich 134

Lewright, Barbara 68

Lima, Iris 68

Lima, Margarita $150,163,176,185$

Linger, Linda 51

Lixey, Sharon 51,162

Long, Donald 68,152,164,165,185

Loomis, Sharon 51,150

Love, Joyce 51,185

Lovins, Larry 52

Lunney, Robert 68,153

M

Maidment, Beverly $68,154,160,167$, 176

Mann, Darlene 68

Manross, Daniel $69,68,152,174$

Marlowe, Catherine 52,174

Marsh, Lynnette 92

Martin, Daniel 52,152,162

Martin, Janis 80,174

Mason, Beverlee 68,133

Mays, Dee 68,152

Mays, Michael 52

McCann, Judy 80,133

McComber, Rodney 68,160

McCrum, Roger 52,140

McCulloch, James 68

McCullough, Max 80,152

McCullough, Michael 92

McDaniel, Ferris 42,52,140

McDaniel, Tanis $69,155,162,167,175$

McDonald, Bruce 84,125,135

McDonald, Rebecca 69

McDowell, Gary 80,135,152,167

McDowell, Rita 52

McDowell, R. 185

McFarlane, Winifred 93

McGhee, Kenneth 93

McGehee, Tom 69

McGillivray, John 137

McIntyre, Ruth 93,184,185

McMillen, Samuel 69,152,185,130

McMurtry, Mary 52,177

McNiece, Melinda 69,123,154,160

Mead, Daniel 52,123,160

Meadows, Donald 93

Mellish, Ron 93,163

Meyer, Judith 52,150

Meyer, Viann $80,154,165,174,175$, $176,184,185$

Meyers, Ronald $69,148,152,164,166$, $167,175,176,184,185$

Miller, Alice 80,167

Miller, Darryl 69,165

Miller, Joan 69,176,185

Miller, Joyce $80,162,173$
Miller, Priscilla 93

Miller, Roger 52,176

Miller, Timothy 53

Mills, Dale 69,158,160,175

Mitchell, Richard 74,80,151,166,177

Mix, Beverly 69,162

Modrall, Larry 175

Mogle, Claire 93

Mohler, David 69

Mohler, Philip 69,167,180

Mohr, Rebecca 53

Moon, Philip 53

Mooney, Jerry 69

Moore, Beverly 53,155,184,185

Moore, Harold 152,165,184

Moorman, Alice 80,162,177

Morrell, Carol 80,162,174

Morrow, Coletta 69,177

Morse, Carole 69,154,165,185

Mossman, Janice 69

Mott, Shirley 80

Motter, Jerome 80,152

Motts, Joyce 69,154,164,165,177

Moulder, Steven 69

Muck, Kenneth 93,153,176

Muirhead, Margaret 81

Mulford, Arlan 93

Mummery, Sharon 53

Murdoch, David 53

Music, Ernest 176

Muska, Gary 53,152

Muzzy, Cheryl 53

Myers, Dawn 69,151,160,166

Myers, Linda 69

Nelson, Beverly 53,164

Nelson, Brenda 70

Nelson, David 53,152,164,181,184, 185

Nelson, Linda 70,154

Nelthropp, Sherie 53,163,175

Nichols, Penny 81,160

Northey, Ted 53,173

Northey, Timothy 60,70

Norton, Daniel 70

Norton, Nancy 93,125

Norton, William 81

Nutter, Loretta 93,155

Odewale, Kola 163

Oehmeke, Peter 81,177

O'Keefe, Carolyn 70,175

O'Keefe, Elizabeth 81,123,167,154, 184

O'Keefe, James 81

Olsen, Linda 53,173,175

Olsen, Samuel 81,152,162,177,184, 185

O'Shell, Constance 93

Osman, Marsha 70,175

Overholt, Kenneth 93

Owen, Judy 53

Packard, Calvin 93

Paige, Lynn 70

Palmer, Milton 70

Palmer, Vicki 70

Pape, Sue 94,167,184,185

Parcher, George 70,152

Pasquarello, Michael 53,137,164

Patten, Randall 70,123,152,175,176

Paugh, Nancy 70,174,177

Pauling, Susan 81,175
Pears, Carol 71

Peek, Jeanette 53

Pereira, John 53

Pereira, Robert 94,156

Perkins, Ralph 42,53,140,152,173

Perry, Bertha 53

Perry, Bruce 53

Perryman, Susan 54

Persing, Cheryl 54

Peters, David 54,160,173

Peterson, Karyn 54

Pettit, Warren 81,143,153

Phelps, Linda 54

Phelps, Ronald 94

Phenix, Janet 81,151,154,167,174,175

Phenix, Kathryn 54,174,175

Phillips, Edith 81,123,175,177

Phipps, Patricia 81

Phipps, Terry 81,140

Plate, Alberta 81

Porter, Tamara 54,175

Porterfield, Peggy 71,154

Powell, James 54,177,185

Prather, Sandra 71

Preston, Donna 94

Pribble, Sharon 54

Price, Connie 71

Price, Judith 71

Prindle, Daryl 54,164,181

Pruden, John 54,150

\section{$\mathrm{R}$}

Radcliff, Larry $81,162,173,175$

Radcliff, Paul 54,173

Radcliffe, Diana $81,154,175$

Railsback, David 54,184,185

Rakes, David 94

Ransbottom, Ruth 54

Rau, Karen 94,139

Ravas, Mary 54

Ray, Susan 81

Reagan, Wilborn 94

Reams, Donald 81

Reed, Barbara 71

Reed, Deborah 55

Reed, Dennis 55

Reed, Gary 55

Reeder, Thomas 55

neese, Betty 81

Rehkopf, Robert 81,152,176,185

Rehn, Judith $94,123,125,160,177$

Reno, Lee 71

Reno, Loren 82,135,152,166

Rexroth, Curtis $50,164,165,185$

Richardson, Gerald 94

Riley, Patricia 55,150,164,181

Risko, Jeanne 94,185

Robbins, Peggy 55,175

Roberts, Craig 71,152,176

Robinette, Lawrence 55

Rochelle, Rebekah 82

Rocher, Shirley 55,150

Rockwell, David 94,162,163

Rodgers, R. 162

Rodman, Lyle 55,184,185

Rodriguez, Ruth 82

Rogers, Bruce 55,137

Rogers, Ruth 94,155

Rohm, Dane 71,152,160

Roloff, Susan 55,164,165

Romine, Cecilia 94,175,181

Rooke, John 94

Rothwell, Susan 94

Rouch, Darlene 55,174

Rouch, Deborah 95

Rowe, Charles 71,152,177 
Rudig, Rebecca $82,154,162,166,174$, 175

Ruffin, Danny 82,143

Rumage, Lois 82

Rumfield, Larry 55,173

Rumley, John 95,152

Russell, Saundra 82

\section{$\mathrm{S}$}

Saemenes, Joyce $82,154,160,175$

St. Clair, Linda 55,154

Sattler, Melbourne 71,152,163,176

Saulter, Suzanne 56

Sawdey, Carmen 95

Schaechterle, Cynthia 56,181

Schill, Martha 95

Schill, William 95,152

Schilling, Dale 71,123,150,174

Schisler, Roy 95

Schneider, John 82,184,185

Schneider, Marikay 71,177,185

Schultz, Robert 95,141,153

Schwanbeck, Dale 56

Schwarm, Norma 71,175

Schwenk, Marian 95

Scott, Susan 56,181

Sears, Gail 82,151,154,167,174

Seeley, Jeffrey $71,152,164$

Seidler, Thomas 56

Seigneur, Dean 95,125,152,167

Senseney, Philip 82,152,164,165,180

Senseney, Robert 56,137,164,181,185

Shafer, Cheryl 71,167,176

Shafer, Lona 56,162

Shamblin, Rebecca 95

Sharp, Rebecca 82,151

Shaw, Cathy 56

Shelley, Melanie 56

Sherrill, Patricia 71

Shreve, Arthur 71

Shriver, Gloria 56,174

Shuter, Arthur 82,150,152,164,165

Sickels, Charlene 56

Sidler, T. 185

Silverthorn, Renee 71,154,176

Simmons, James 71

Skelton, Linda 56

Slabaugh, Merle 173

Slater, Suzanne 57,145

Slates, Linda 72

Slavens, Deborah 57

Smelser, Edward 95

Smith, Bonnie $72,150,151,154,162$, 173,175

Smith, Dan 82,137,141,164,165

Smith, Donna 57

Smith, Melba 72,175

Smith, Nancy 57

Smith, William $82,162,167,173$

Snider, Nancy 72,173

Snyder, Robert 57,164

Snyder, Stephen 95
Sommerfield, Philip 82

Sopher, William 57

Soule, David 57

Southwell, David 82,133,153,166,167

Spaulding, James 72,141

Spencer, Carol 57,175

Spencer, Kathryn 95,176

Sperry, Thomas 57

Spieth, Ronald $72,165,180,184,185$

Spinks, Linda 95

Sprunger, Marcia 95

Stafford, Jean 173

Stamatis, Judith 82,139

Steenburg, Cheryl 82,180,184

Stephens, Linda 71

Stevens, Daniel 96,125,152,166,167

Stewart, Robert 57

Stickle, Fred 96,176

Stillwell, Dennis 96

Stock, Cheryl 57

Stoner, Beth 57

Stora, Dennis $82,153,1 ; 6$

Storey, Mary 72

Stowell, Hannah 72,154,174,175

Strong, Tom 57

Strychalski, Charles 57,152

Talbot, Dorly 83

Tallmon, Verna 72

Tanner, Lela 96,156

Taylor, Karol 57

Taylor, Gary 96,184,185

Taylor, Linda 96

Taylor, Richard 83

Taylor, Steve 72

Tennant, Mercy 72

Tewis, Louis 57,177

Thase, Barbara 96

Thomas, Billie 72,175

Thomas, George 96

Thomas, Neil 73

Thorne, Susan 96

Timpe, Janice $57,181,184,185$

Tobias, Vicki $57,164,175$

Tompkins, Connie 57

Towle, Nancy 84,97

Treat, Kenneth 83

Trefzger, William 135

Trumbull, Cheryl 97

Trumphour, Mary 83,167

Turner, David 73,163,177

$\mathrm{V}$

VanderMeer, Anton 58

Vanderpuhl, Mary 162,175

Vincent, Ruth 97,162

Vlug, Janice 174,177

\section{W}

Waggoner, Patricia 58
Wagner, Karolyn 83

Walborn, Daniel 97

Waldron, Corinne 58

Walker, Connie 58,176

Walker, Thomas 73,166

Wallis, Nelson 97

Wallner, Carol 58

Walters, Denise 42,58,166

Warburton, Art 58

Warren, John 135

Warren, Timothy 97,130

Watson, Nola 83

Weaver, Jeanette 59

Weaver, Judith 59

Webb, Jeffrey 59

Webb, Susan 73,167

Welch, Glenda 73,154

Whatoff, Robert 97,153

Wheatley, Ronald 59

Whipple, Ellen 97

Whitaker, Patricia 73

Whitney, Leah 97

Wilhite, Mark 73

Wilhite, Mike 42,59,152,175,176,177

Wilkes, Deborah 73,154

Williams, Charles 59,134,137

Williams, Dan 134

Williams, James 153

Williams, Joseph 73

Williamson, Diane 59,177

Willis, Charlotte 59,145

Wilson, Herbert 73

Wilson, Irene 97,121

Winston, Judith $83,155,167,177$

Winters, Thomas 73

Wissinger, Patricia 83,151

Wolford, Michael 83

Wood, David 59,163,176

Woodcock, Jeffrey 59

Work, Barbara 59,174,177

Work, Dale 97

Work, Wendy 73

Wright, David 137

Wright, Rebecca 59

Wuest, Darlyne 73,155,166,185

Yaple, David 73

Yardlay, Janet 73,177

Yeater, Sharon 97

Yoder, Charlotte 97

Yoder, Douglas 97,156

Young, Ellen 59,151,162

Young, Jeff 97,130

Young, Joyce 74,83,166

Z

Zazurskey, Michael 135

Zickefoose, Cynthia 162

Zimmerman, Monica 59

Zwiesler, Catherine 73,167 


\section{FIRST BAPTIST}

Butler, Pennsylvania

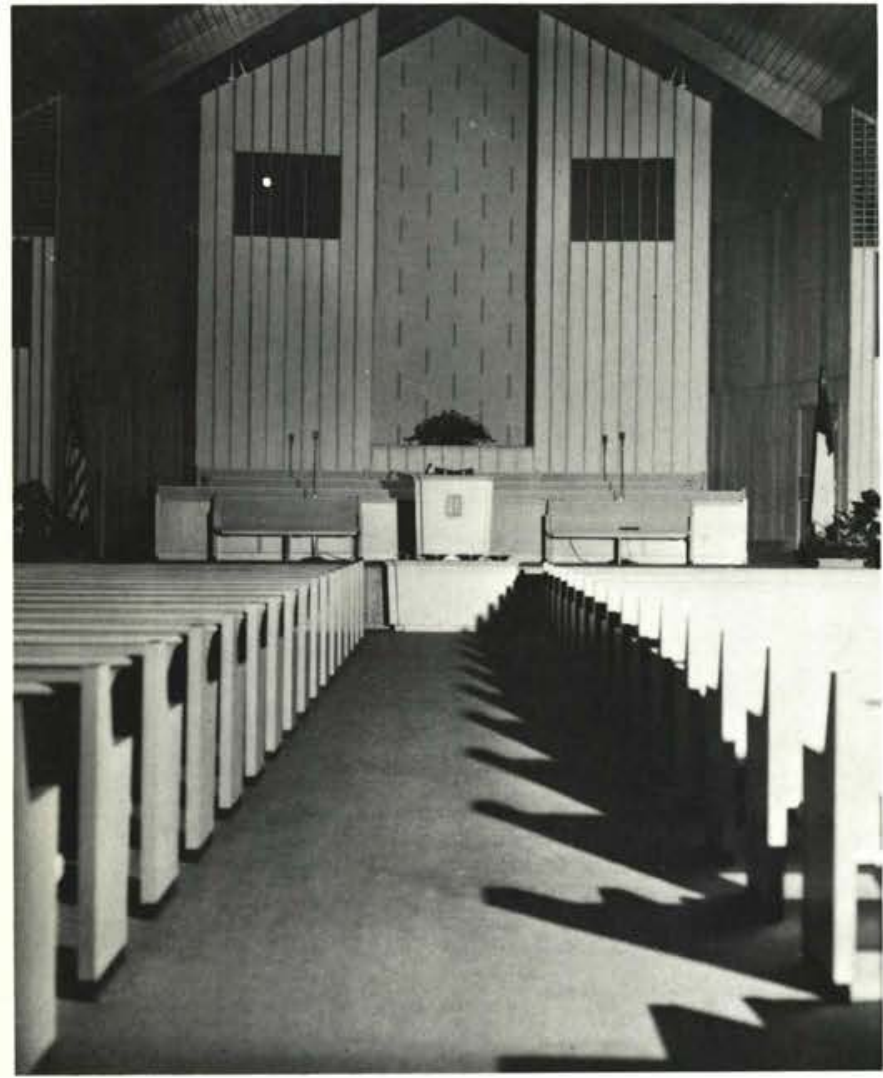

\section{CALVARY BAPTIST}

Buffalo, New York

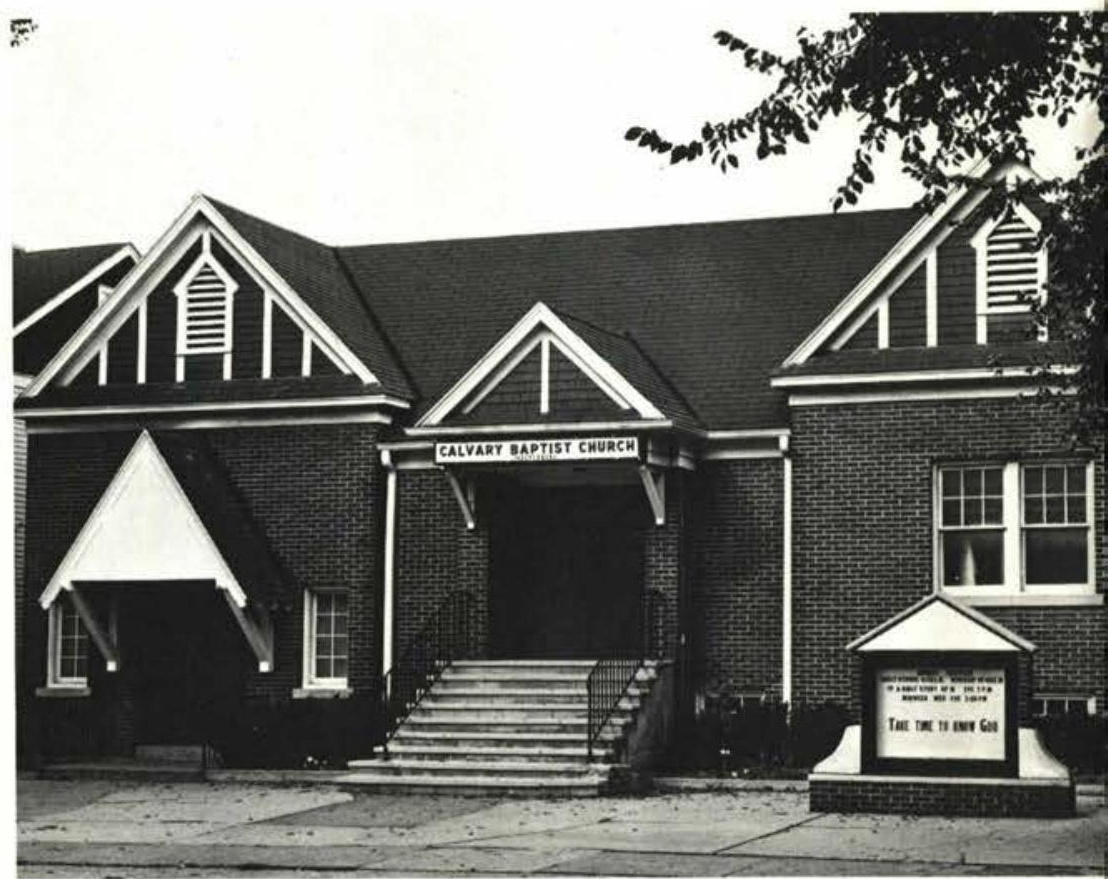

\section{CALVARY BAPTIST}

Covington, Kentucky

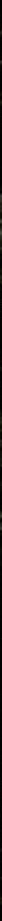

$\Rightarrow$

$\mathrm{x}=\mathrm{P}$

$\longrightarrow$ 


\section{HADDON HEIGHTS BAPTIST CHURCH}

\author{
Third and Station Avenues \\ Haddon Heights, New Jersey 08035
}

Dr. K. W. Mastellor, Pastor

Rev. F. D. Henzler, Asst. Pastor

Rev. D. P. Jeremiah, Minister of Christian Education
Ralph O. Burns is pastor of the First Baptist Church, 221 New Castle Street, Butler, Pennsylvania. At First Baptist, a member of GARBC, they are "holding forth the Word of Life, holding fast the faithful Word."

Calvary Baptist Church in Buffalo, New York, is found at 1264 Kensington Avenue. The pastor is Timothy R. Barrett.

Calvary Baptist, the church with a heart in the heart of Latonia, is located at West Southern and Tibbatts, in Covington, Kentucky, and is pastored by Warren W. Wiersbe.

James F. Dersham, the pastor, along with the Emmanuel Baptist Church at 5046 Broadway, Lorain, Ohio, wishes to extend its congratulations to the graduating class of 1969. Best wishes, seniors!

\section{EMMANUEL BAPTIST}

Lorain, Ohio

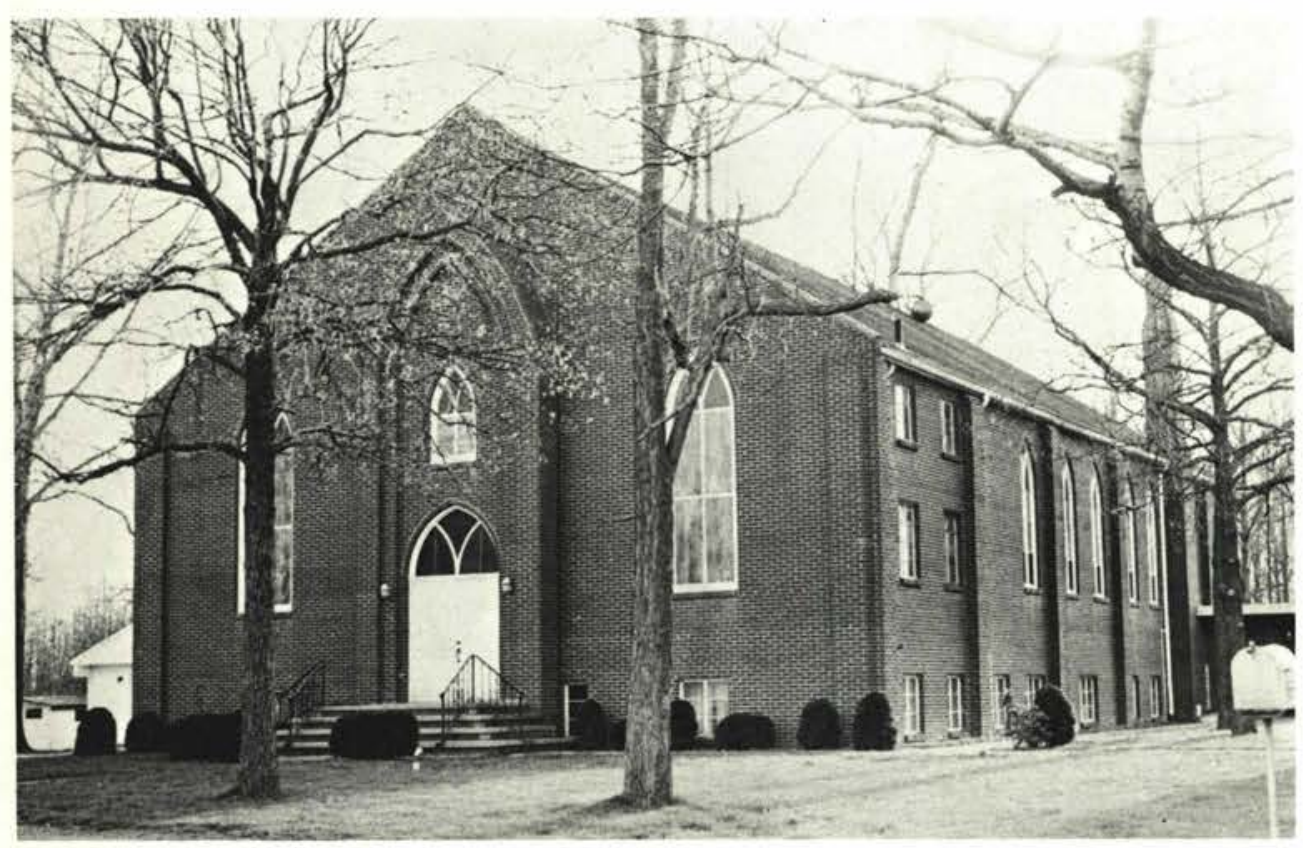


The home of Calvary Baptist Church, Painesville, Ohio, is 727 Mentor Avenue with John M. Strong pastoring. Calvary has Bible School on Sundays at 9:45 A.M. and evening service at 7:00 P.M., and Thursday night prayer service.

In Xenia, Ohio, at North Detroit and West Church Streets, is the First Reformed Church, Edward E. Smith, pastor. First Reformed, which provides bus service for its Sunday Services, believes that the gospel is the most contemporary message of our time.

\section{Calvary Baptist}

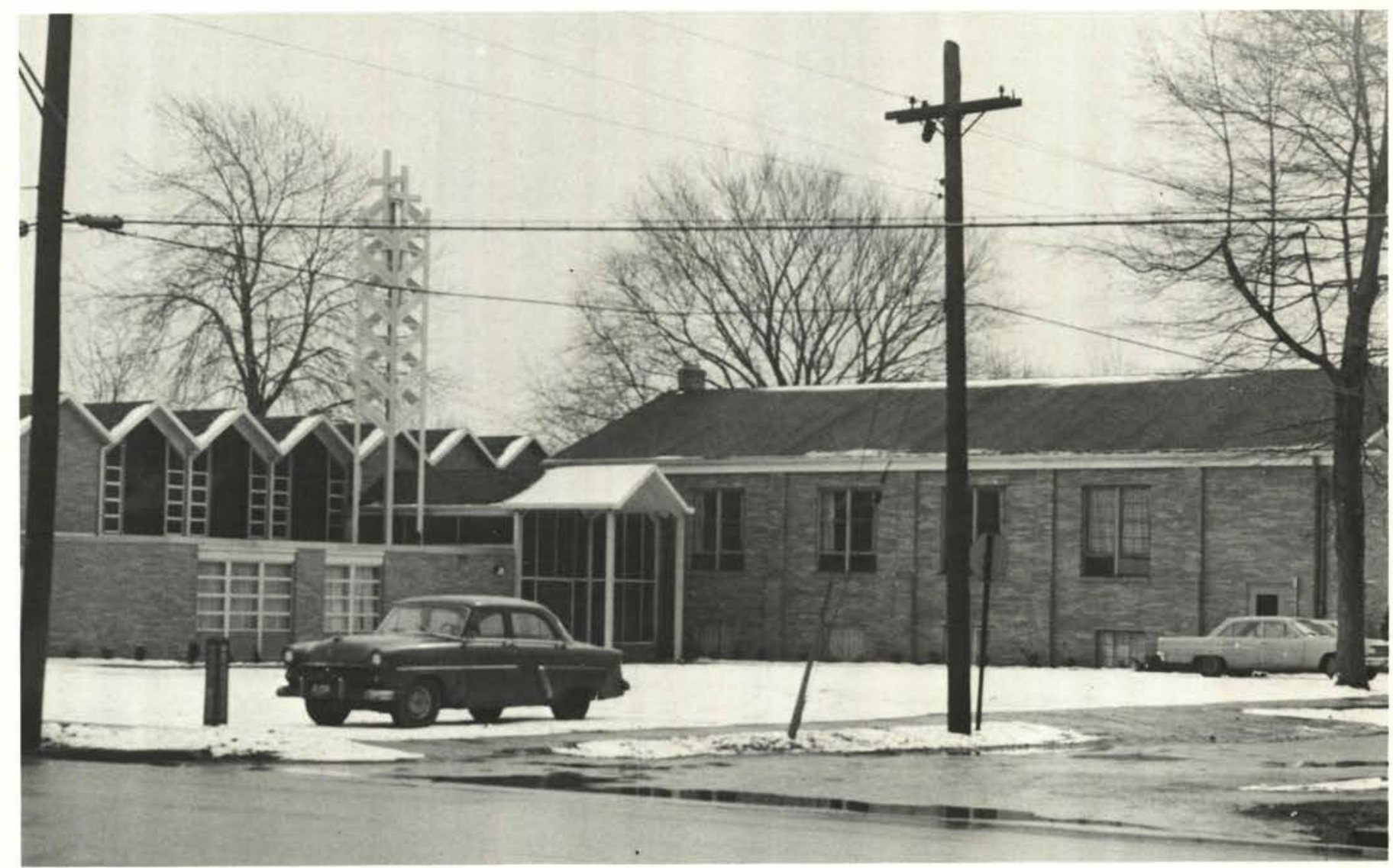

\section{First Reformed} Xenia, Ohio

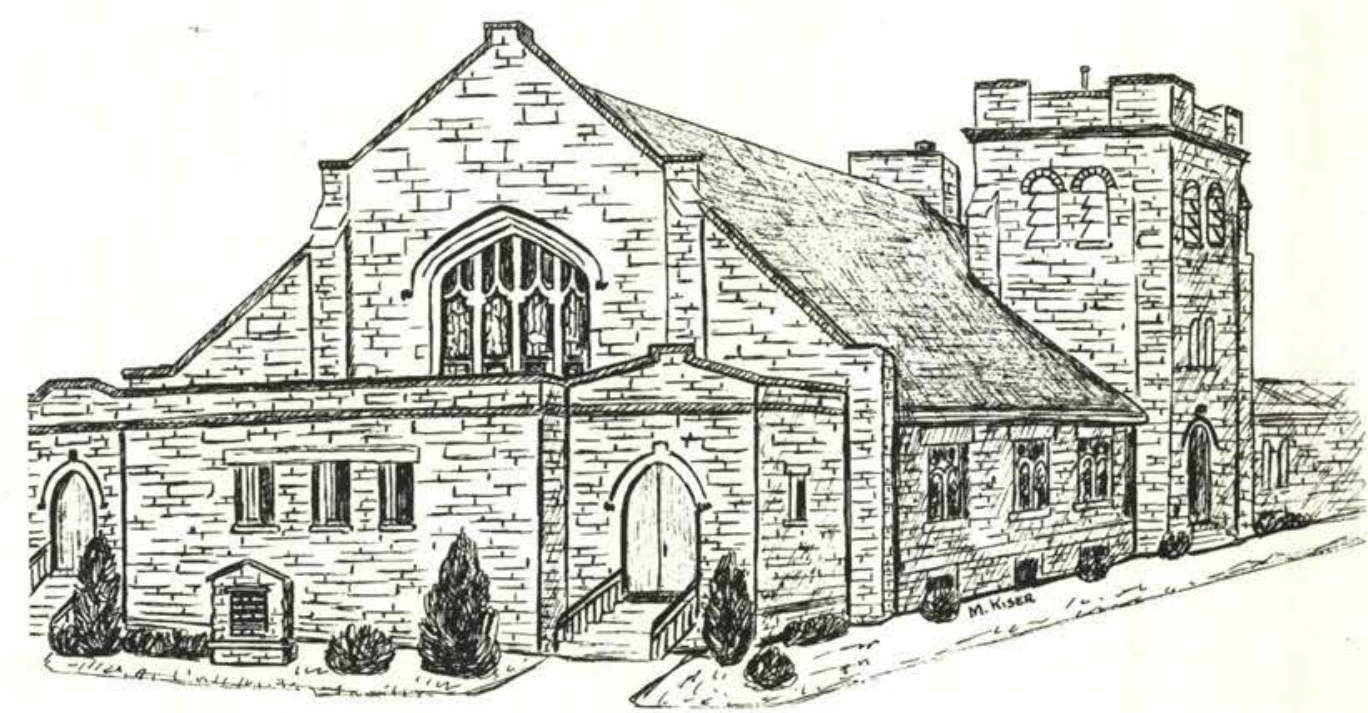




\section{Pastor Smelser}

First Baptist

Medina, Ohio

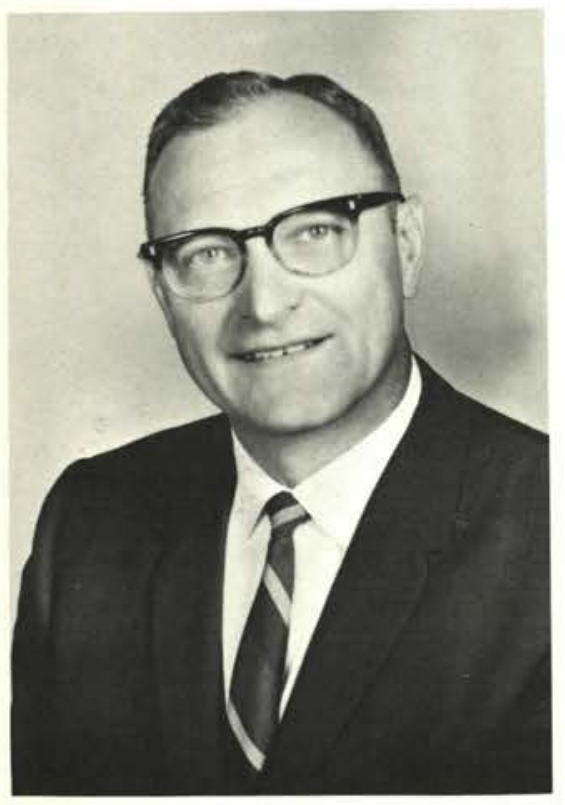

"In the heart of Medina with Medina on its heart is the First Baptist Church of Medina, Ohio. The church, found at 123 West Liberty Street, is taught by R. Kenneth Smelser, the pastor, and "Bud" Couts, the assistant pastor.

"A friendly gospel church in a friendly growing community." This describes the Wheelersburg Baptist Church in Wheelersburg, Ohio. Donald Grollimund is the pastor.

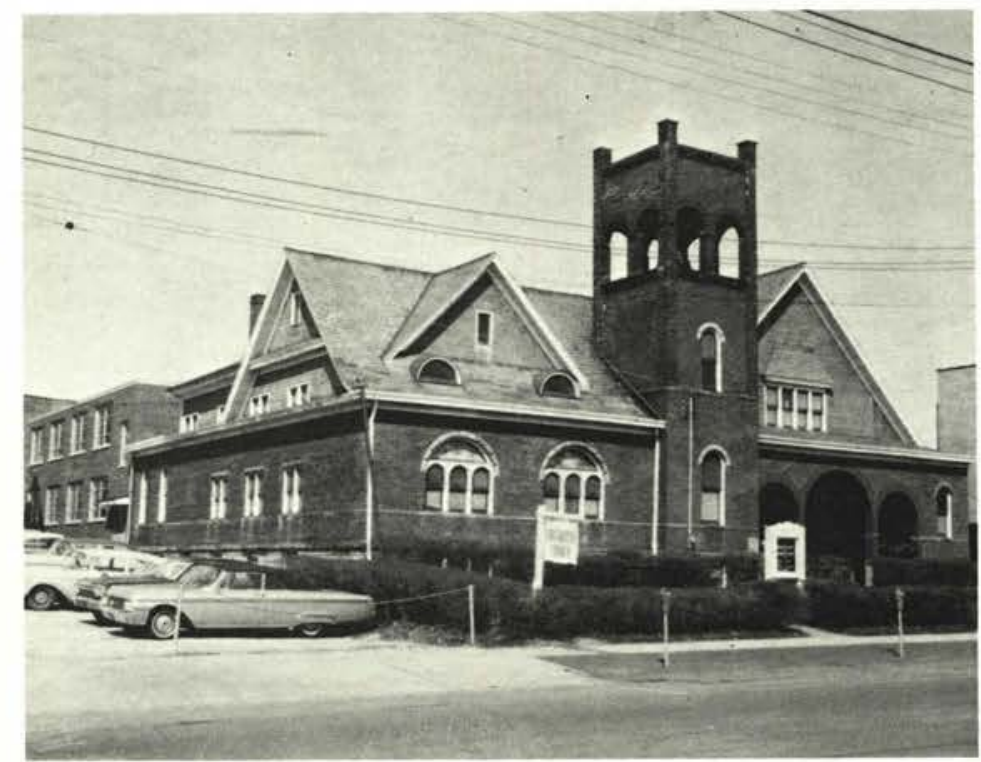

\section{Wheelersburg Baptist}

Wheelersburg, Ohio

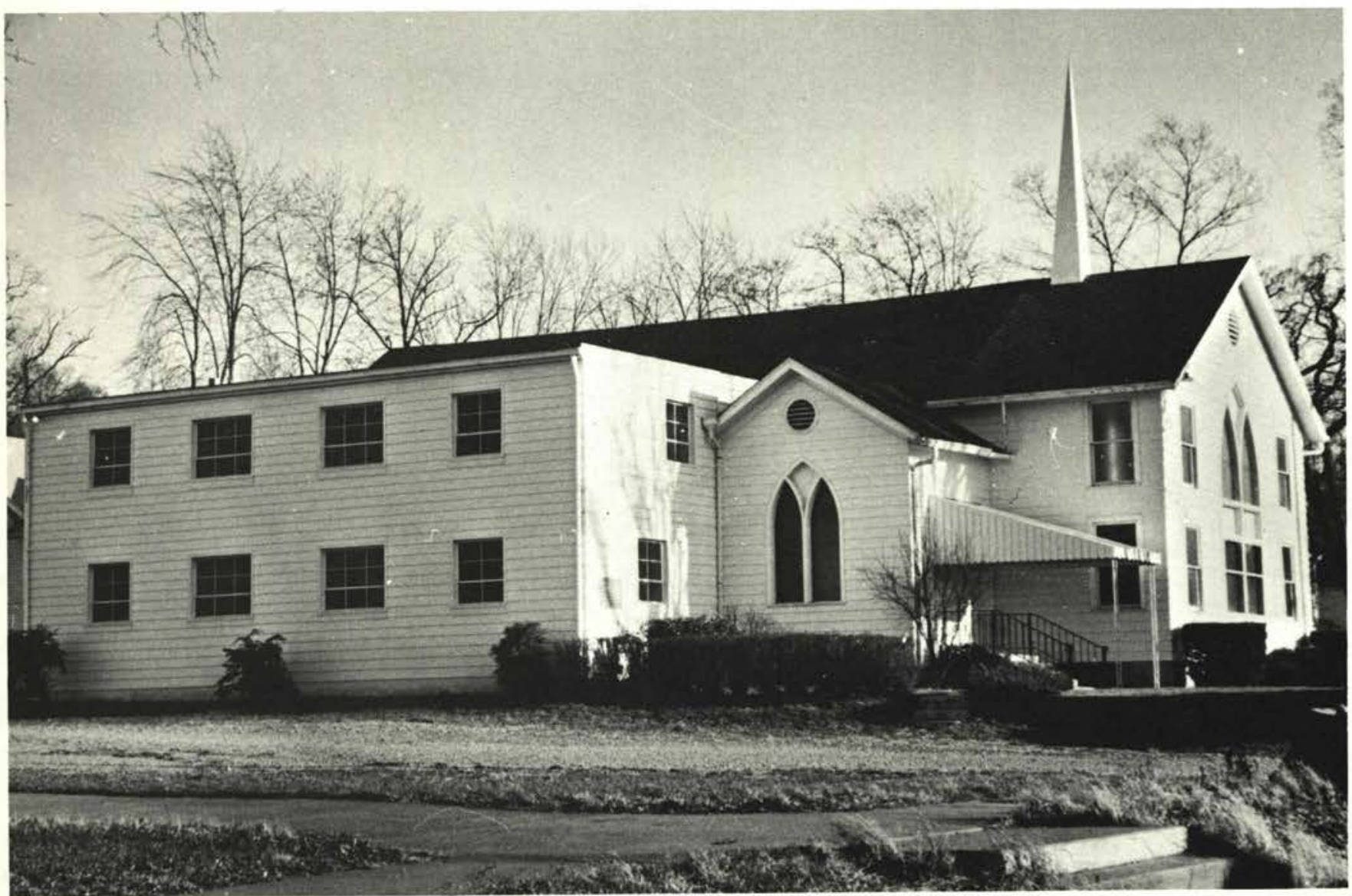




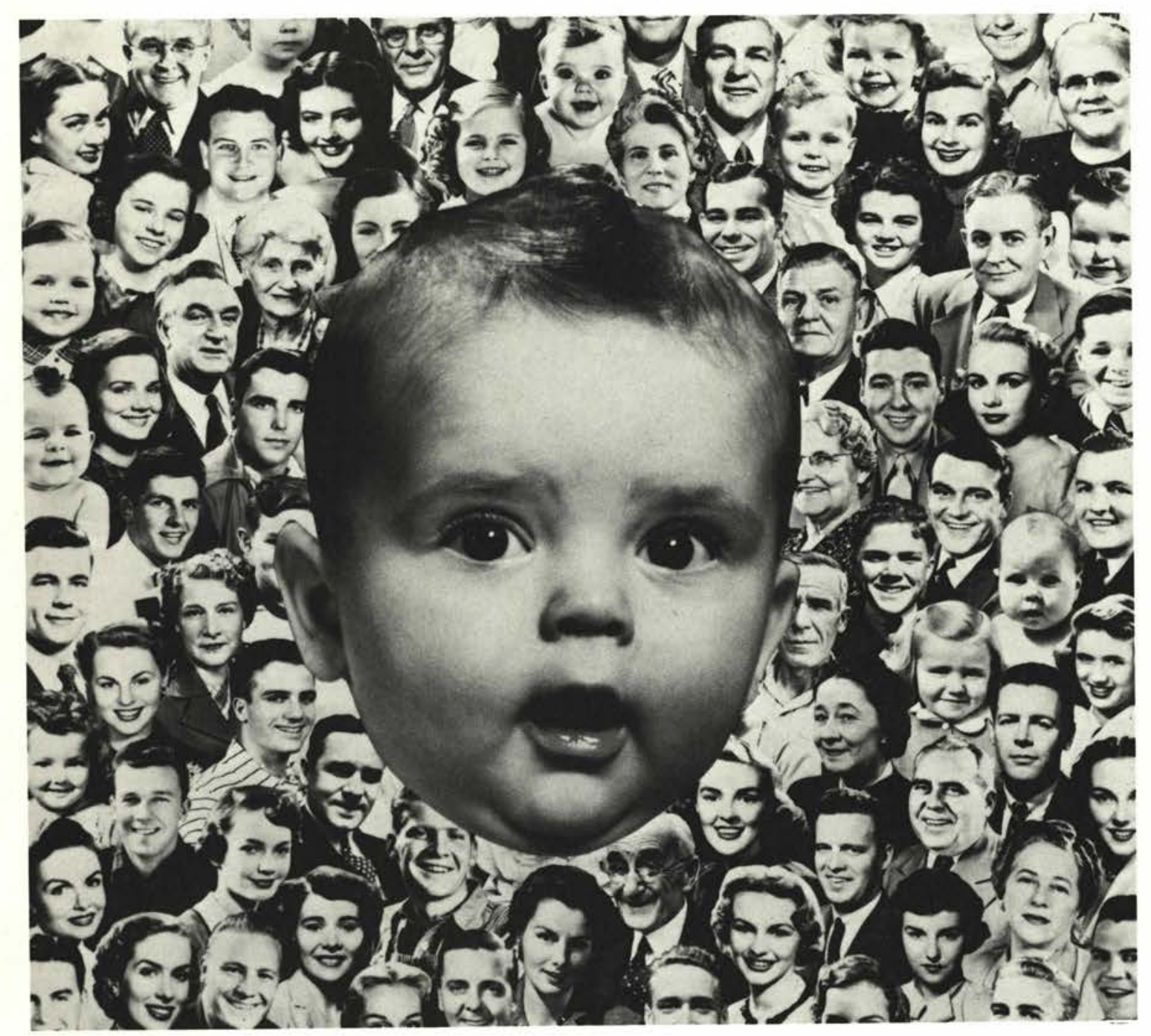

"The Family Church"

\title{
FIRST
}

\section{BAPTIST CHURCH}

\author{
602 Illinois Avenue \\ McDonald, Ohio
}

\author{
9:30 A.M.-Sunday School \\ 10:30 A.M.-Morning Worship \\ 6:30 P.M.-Family Study Hour \\ 7:30 P.M.-Evening Service
}

Midweek Service, Wednesday 7:30

J. E. Beckley, Jr., Pastor 444 Indiana Ave.

The First Baptist Church in Mishawaka, Indiana, found at Main and Lawrence, has youth groups, a radio broadcast, telephone ministry, and a missionary program. With Roy G. Hamman as pastor, they are "looking for that Blessed Hope."

You are invited to attend Berea Baptist Church, Berea, Ohio, with Earl V. Willets, pastor. Located at 250 West Street, the church has Bible School at 9:30, worship service at 10:45, and evening service at 7:00 P.M. on Sundays.

In Valparaiso, Indiana, the Baptist Children's Home, which serves nationally and is GARBC approved, is found at 65 South Franklin Street. Ministries include a child care home, with children from 8 states; foster home care; adoption, which crosses state lines; Bethesda Home for unwed mothers; and counseling. Rev. Donald E. Worch acts as the executive director. 
Sincere Christian Wishes

to the

Graduating Class of 1969

\section{HUNTSBURG BAPTIST CHURCH}

Huntsburg, Ohio

Ben H. Garlich, Pastor

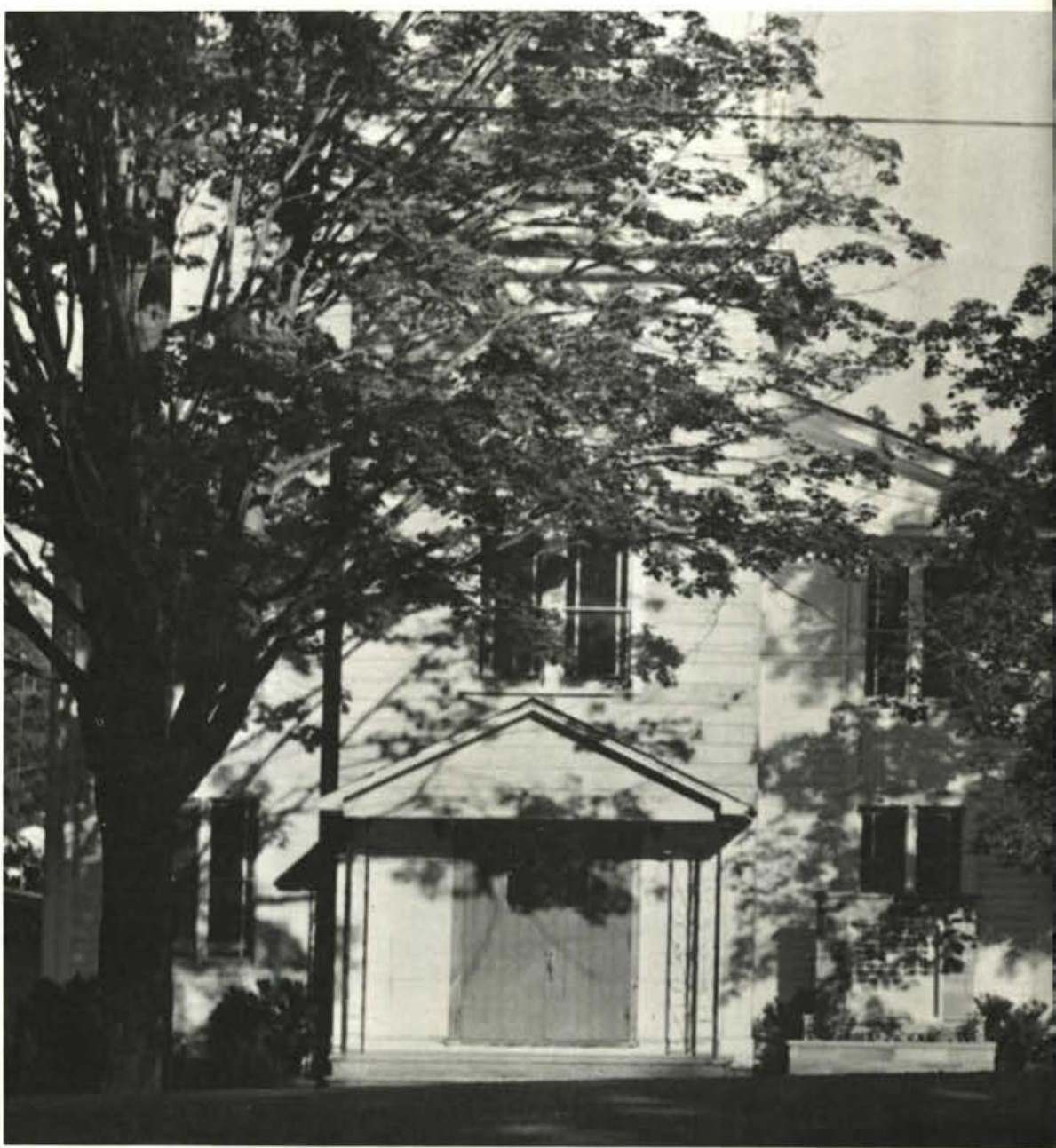

\section{FIRST BAPTIST CHURCH}

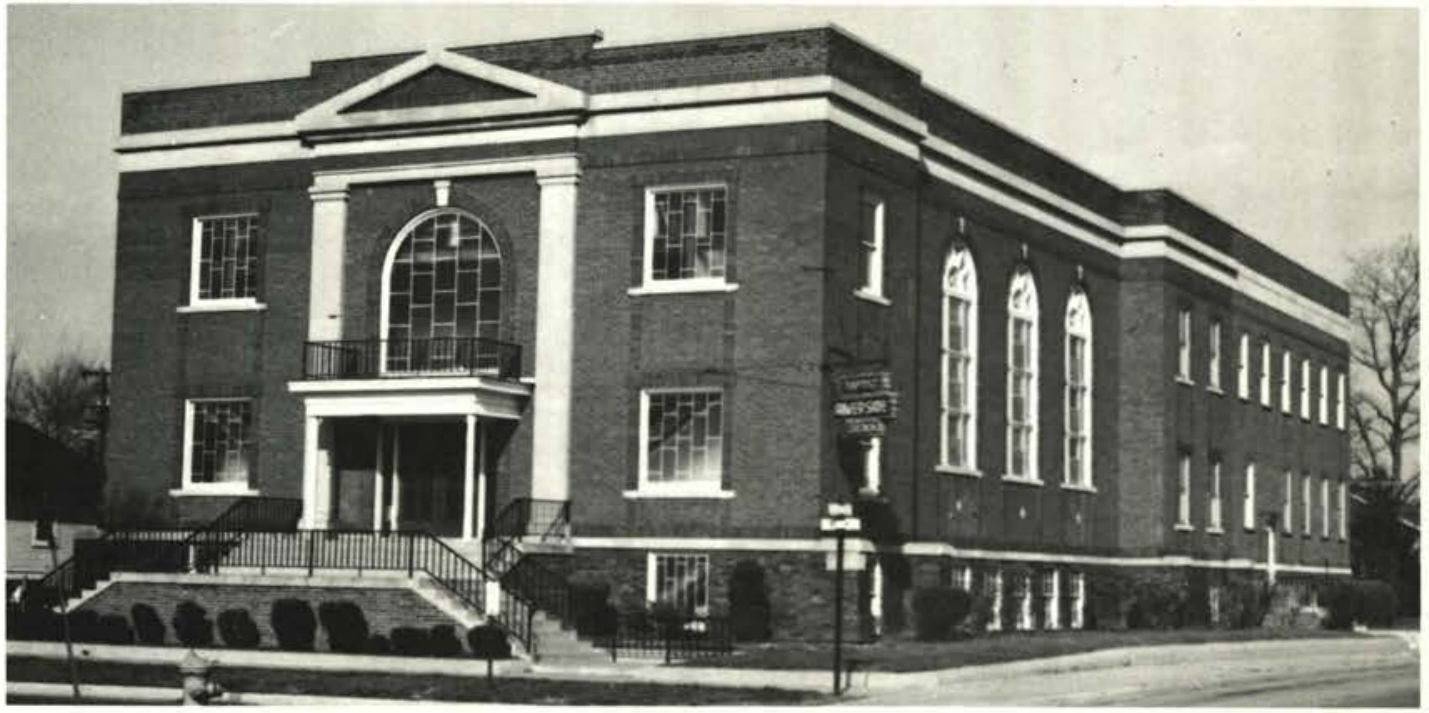

\section{RIVERSIDE BAPTIST CHURCH}

Decatur, Illinois 


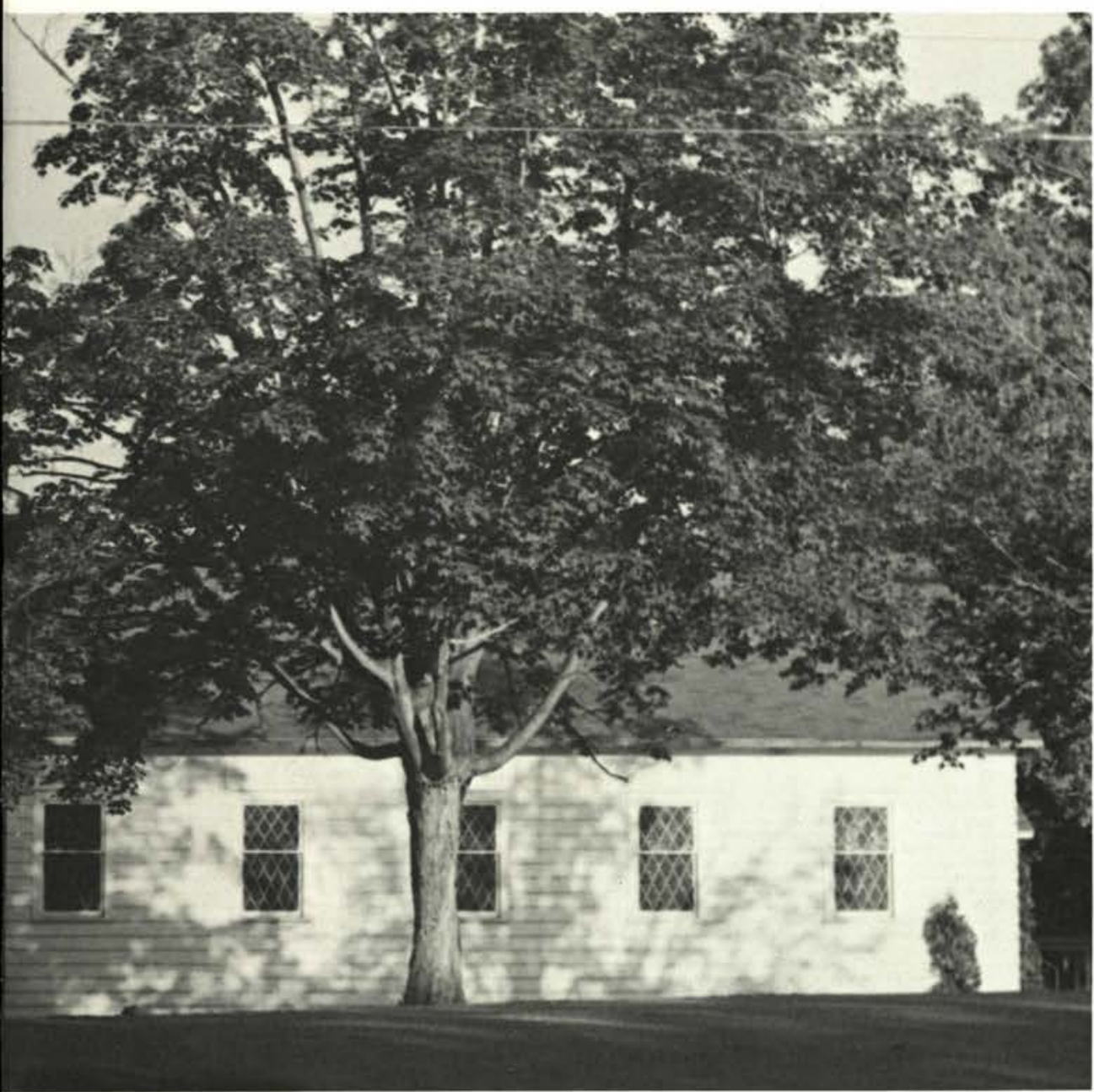

Rev. Robb, as the Pastor of First Baptist Church at Sherman, New York, exemplifies the feeling of many when he says, "(we) are very interested in Cedarville, and several students from the church have gone there, and some are there now with others planning on attending the school in the future."

Pastoring the Riverside Baptist Church of Decatur, Illinois, is Reese A. Johnson. Along with Thomas D. Streeter, the Christian Education Director, they seek God's direction in the weekly services.

Rev. John G. Balyo and the Cedar Hill Baptist Church at 12601 Cedar Road, Cleveland Heights, Ohio, support the college through advertising, attending students, prayer, and chapel speaking. For churches such as this, we are most thankful.

Sherman, New York

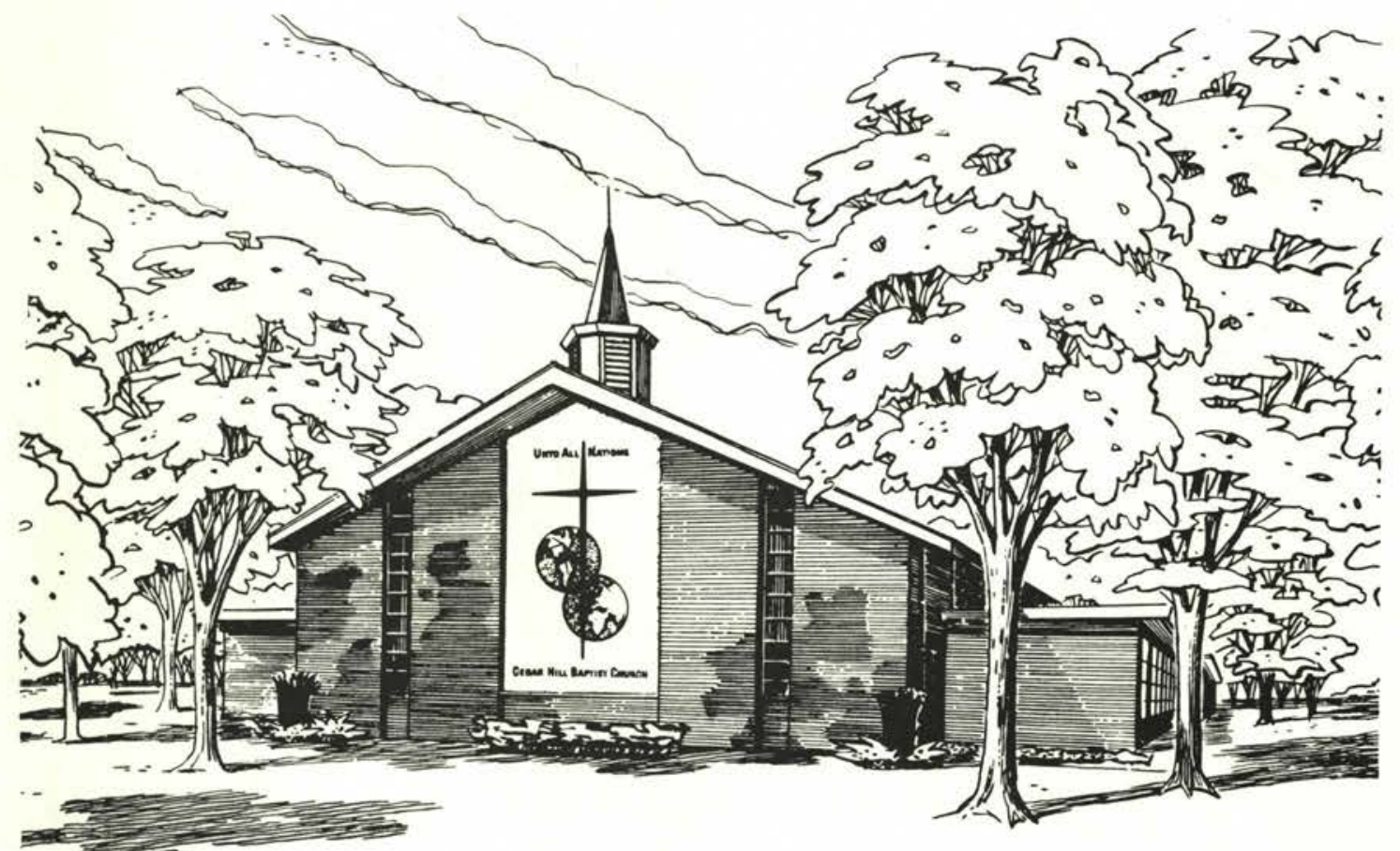

\section{CEDAR HILL BAPTIST CHURCH}

Cleveland Heights, Ohio 


\title{
UNIVERSITY HEIGHTS BAPTIST CHURCH
}

\author{
Indianapolis, Indiana
}

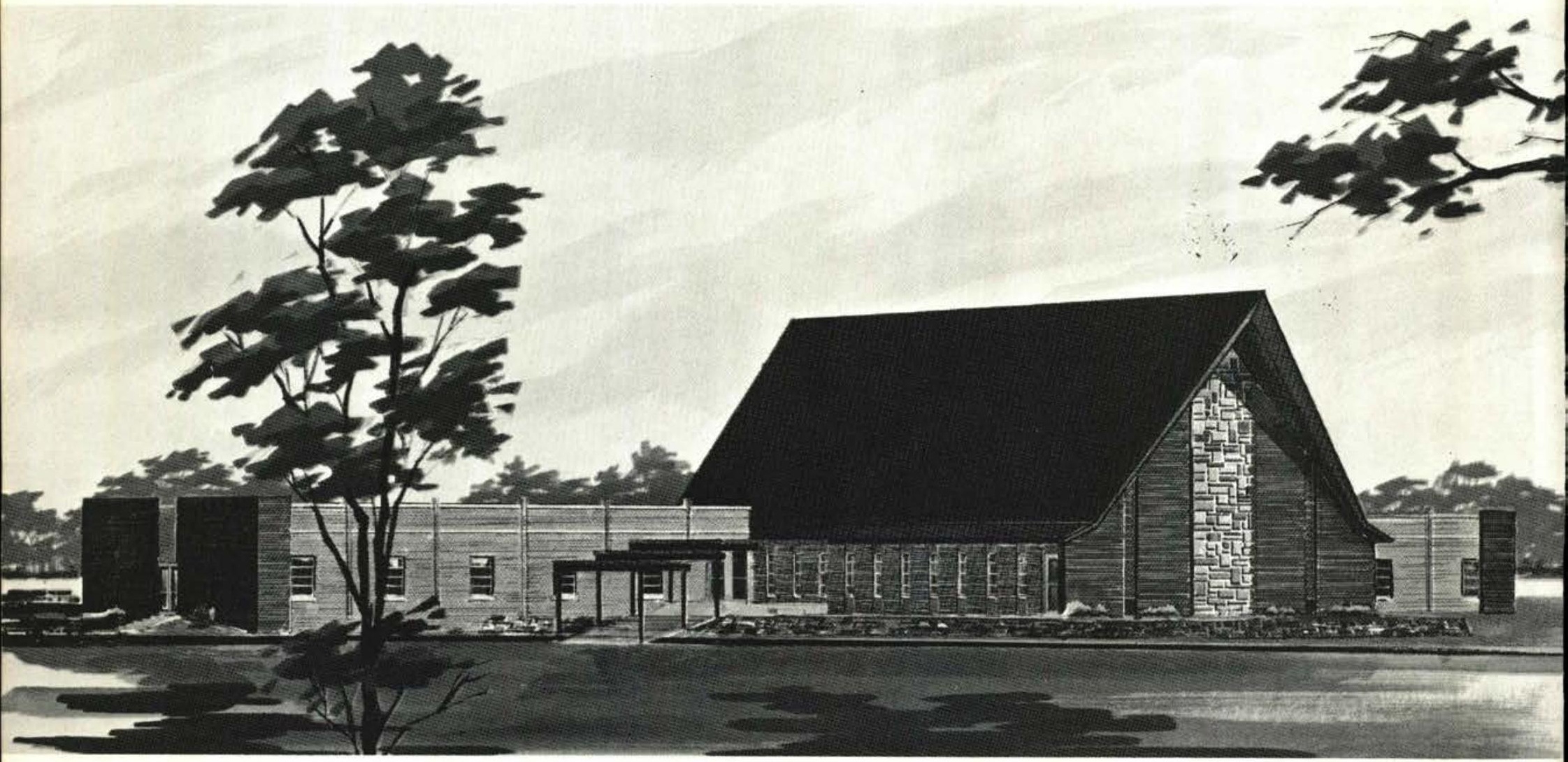

\section{The Galilean Baptist Mission}

Grand Rapids, Michigan

"My little children, let us not love in word, neither in tongue; but in deed and truth." I John 3:18 


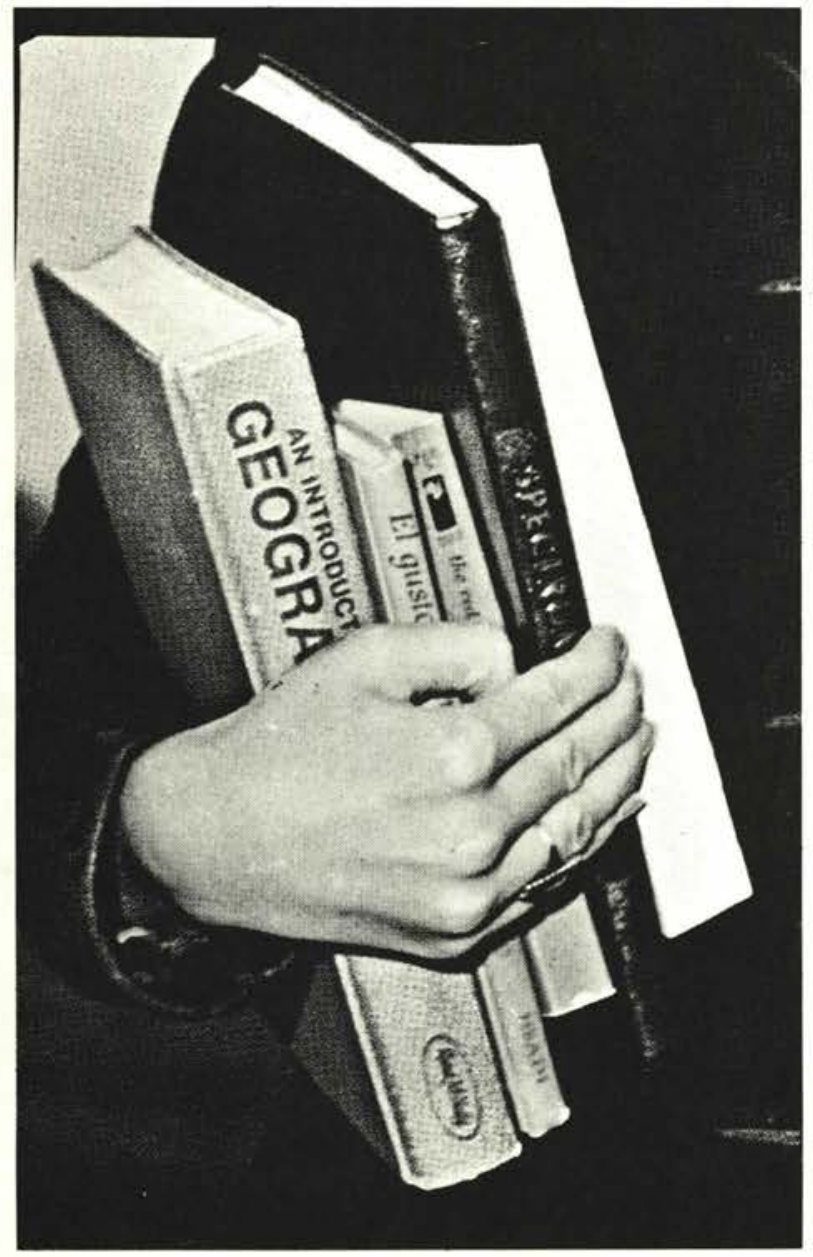

"Holding fast the faithful Word" Titus 1:9. The University Heights Baptist Church welcomes visitors and new members at 2200 East Hanna Avenue. Pastor E. Wilson Wahl preaches the Biblical truths to the congregation at Indianapolis, Indiana.

The College Bookstore, managed by Bernice Mick, supplies students and faculty with hundreds of books, references, tests, and paperbacks. The sales and discounts cater to the collegianne's finances, and initiate the students' library collection.

As the books stack up, the finals pass and the seniors soon finish. Pastor Wm. Broughton and Grace Baptist Church congratulate the many seniors who chose to worship with them. The proposed addition can more effectively serve Cedarville, the College, the community, and the countryside.

\section{THE CEDARVILLE COLLEGE BOOKSTORE}

Textbooks

Supplies

Souvenirs

Drugs

Paperbacks

Devotionals

\section{GRACE BAPTIST CHURCH}

\section{Cedarville, Ohio}

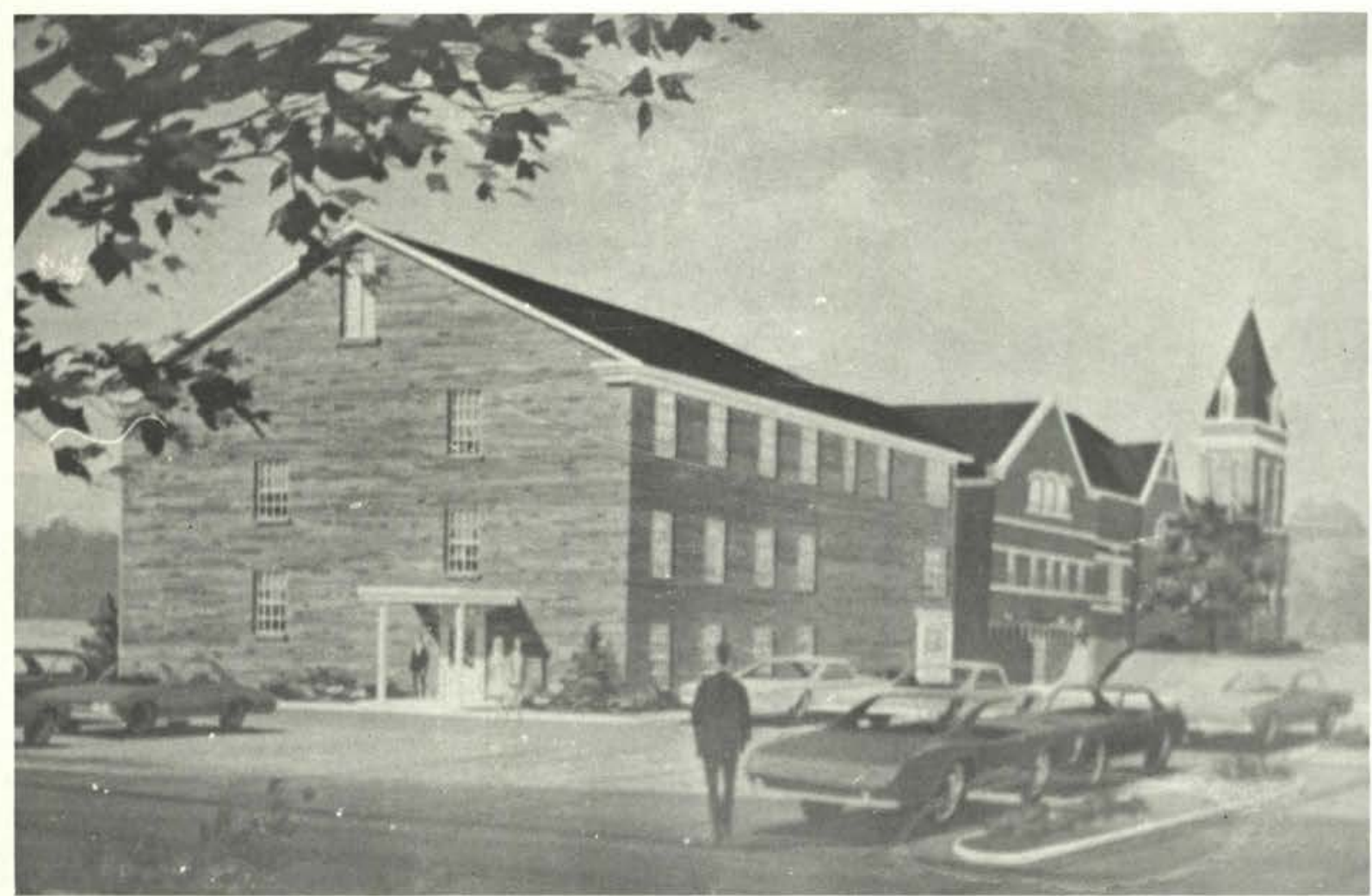


The Cedarville College Snack Shop, not only prepares delicious pizzas and grill orders, but also delivers them. And generally the delivery boy is greeted with hungry smiles. Orders can be taken at 766-2251, Cedarville, Ohio.

The students' attempts at baking donuts and warming soup in popcorn poppers would not be successful without the groceries of the Cedarville Super Valu. Their meats, produce, and groceries supply the college with the "extra" boost needed after the evening meal.

To charm that special girl, the men buy candy and flowers, and keep themselves well-groomed. But this job can best be done with the assistance of Chick, the local barber.

To quench that dry throat at the outset of finals, Pepsi is there to "pour it on" with the "taste that beats the others cold." Bottled under Pepsico, Inc. by Pepsi-Cola Bottling Co., Pepsi is delivered and serviced here from the Springfield plant.

\section{CEDARVILLE SNACK SHOP}

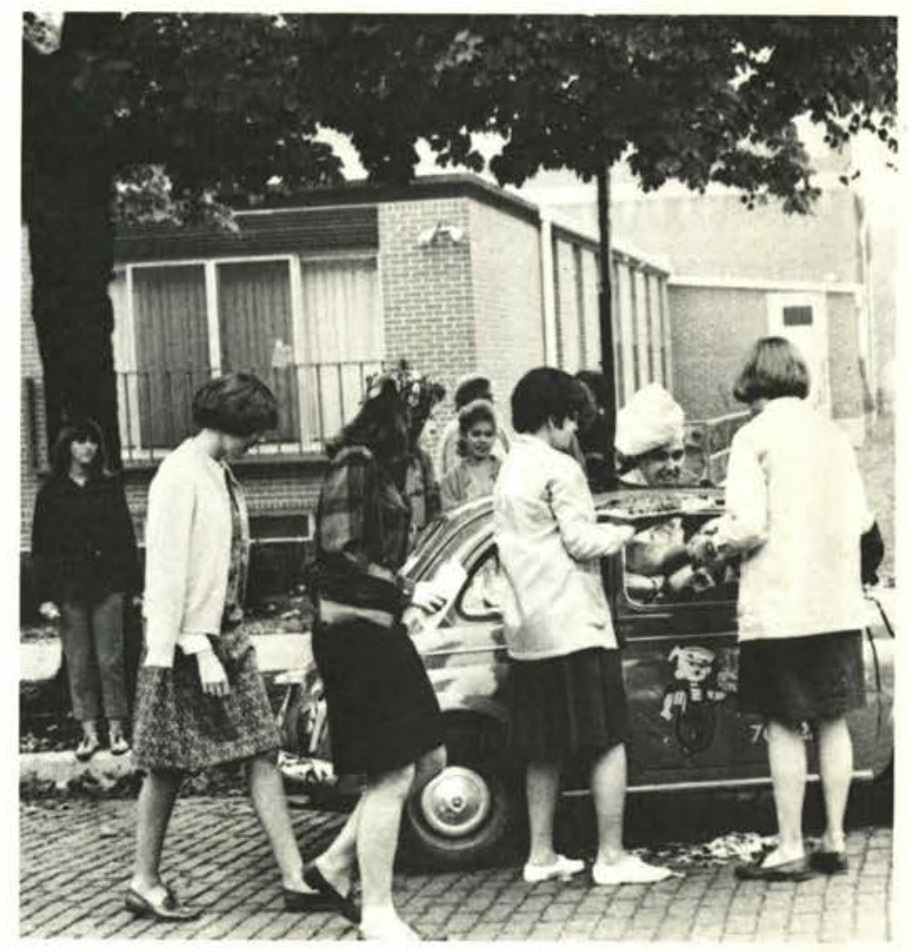

\section{CHICK'S BARBER SHOP}

\section{SUPER VALUE}

\author{
Cedarville \\ Super Valu
}

Produce Meats Groceries

Phone 766-1201

Cedarville

Ohio

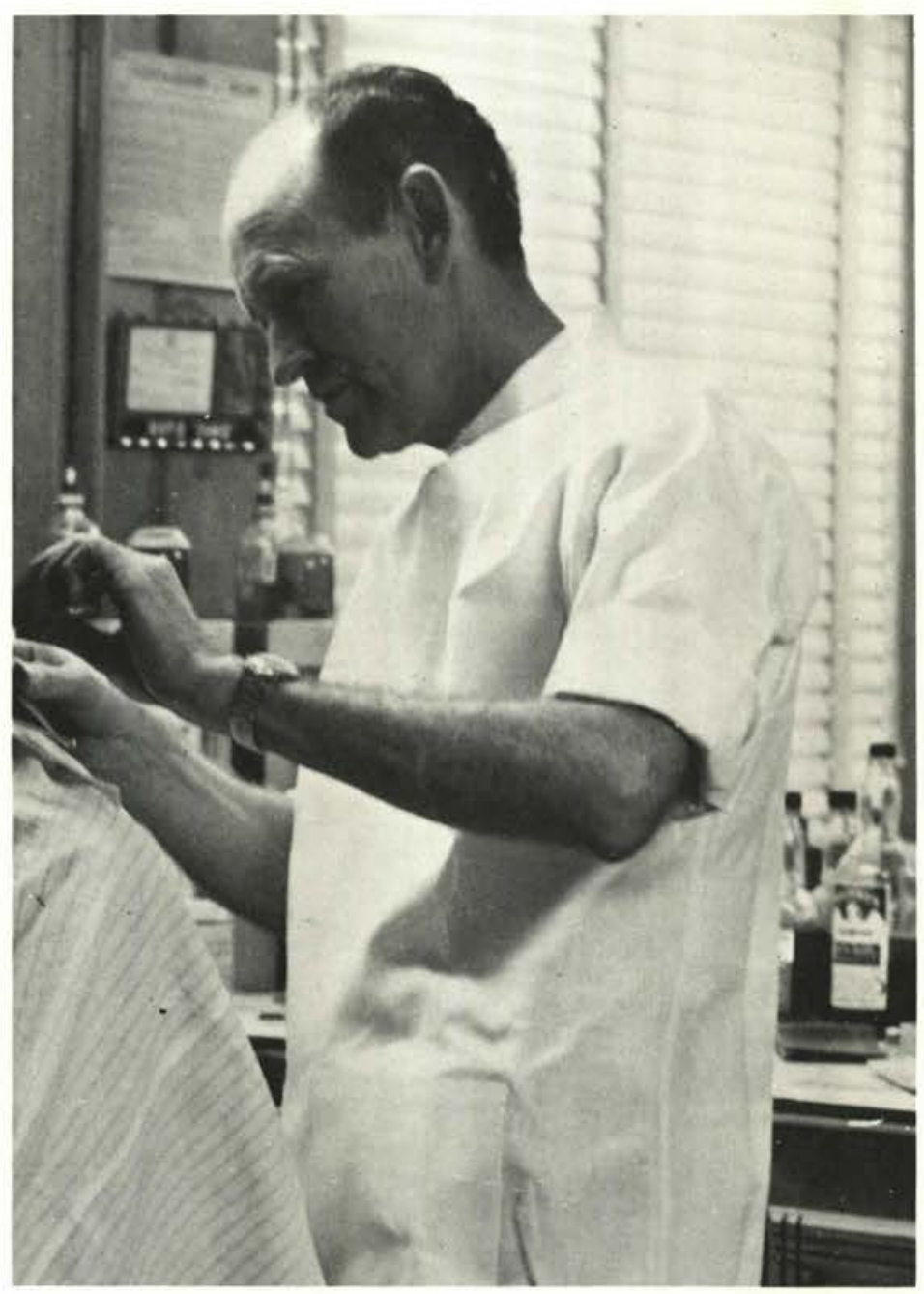




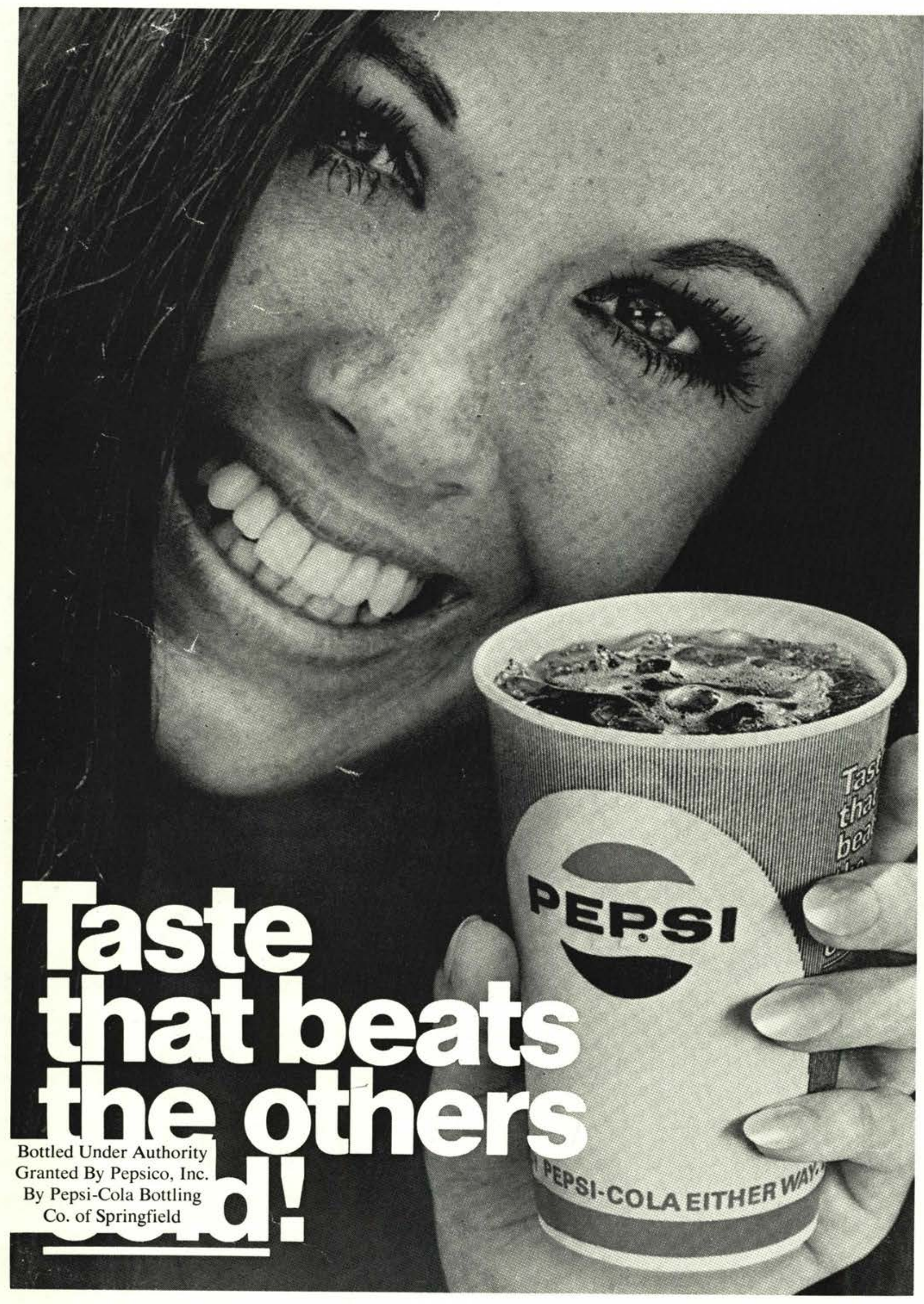




\section{JOHN DONLEY GAS \& OIL DISCOUNT}

\section{South Main Street}

"First Quality Products Only"

"Lowest Gas Prices in Town"

To eat out at a convenient place and in an appetizing way, the students and community seat themselves at the Village Restaurant in Cedarville, Ohio.

The "progressive hardware service," the Cedarville Hardware store, serves the community by providing the "Best deal in electrical appliances." A quick call to 766-1941 will bring immediate service.

The neighborhood drugstore, Stephens' Rexall at $42 \mathrm{~N}$. Main, is equipped for the people's demands. Phone 766-1771.

For discount on first grade petroleum products, Donley Gas Discount is the place to see with its offices in Cedarville, Jamestown, Xenia, and Wilmington.

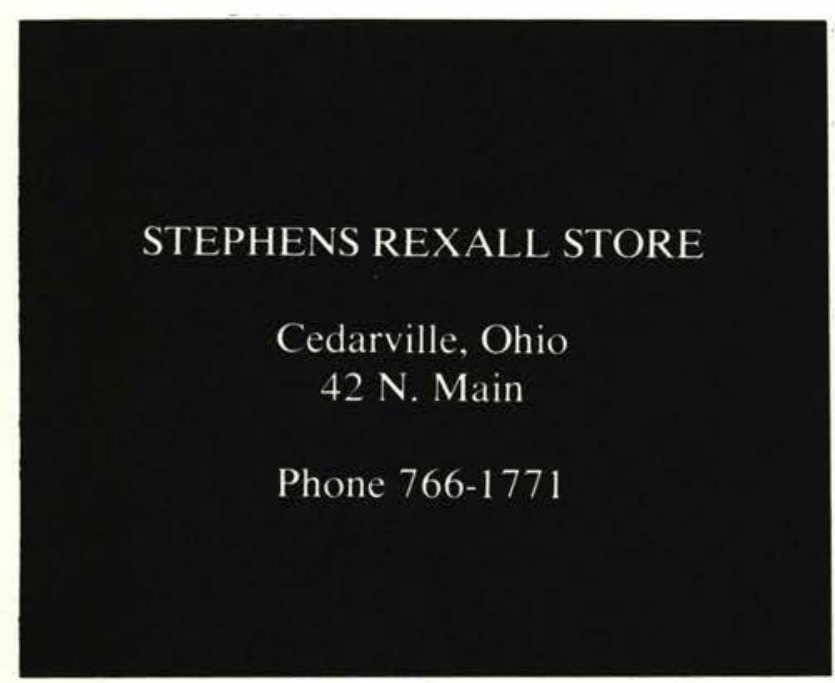

\section{CEDARVILLE HARDWARE}

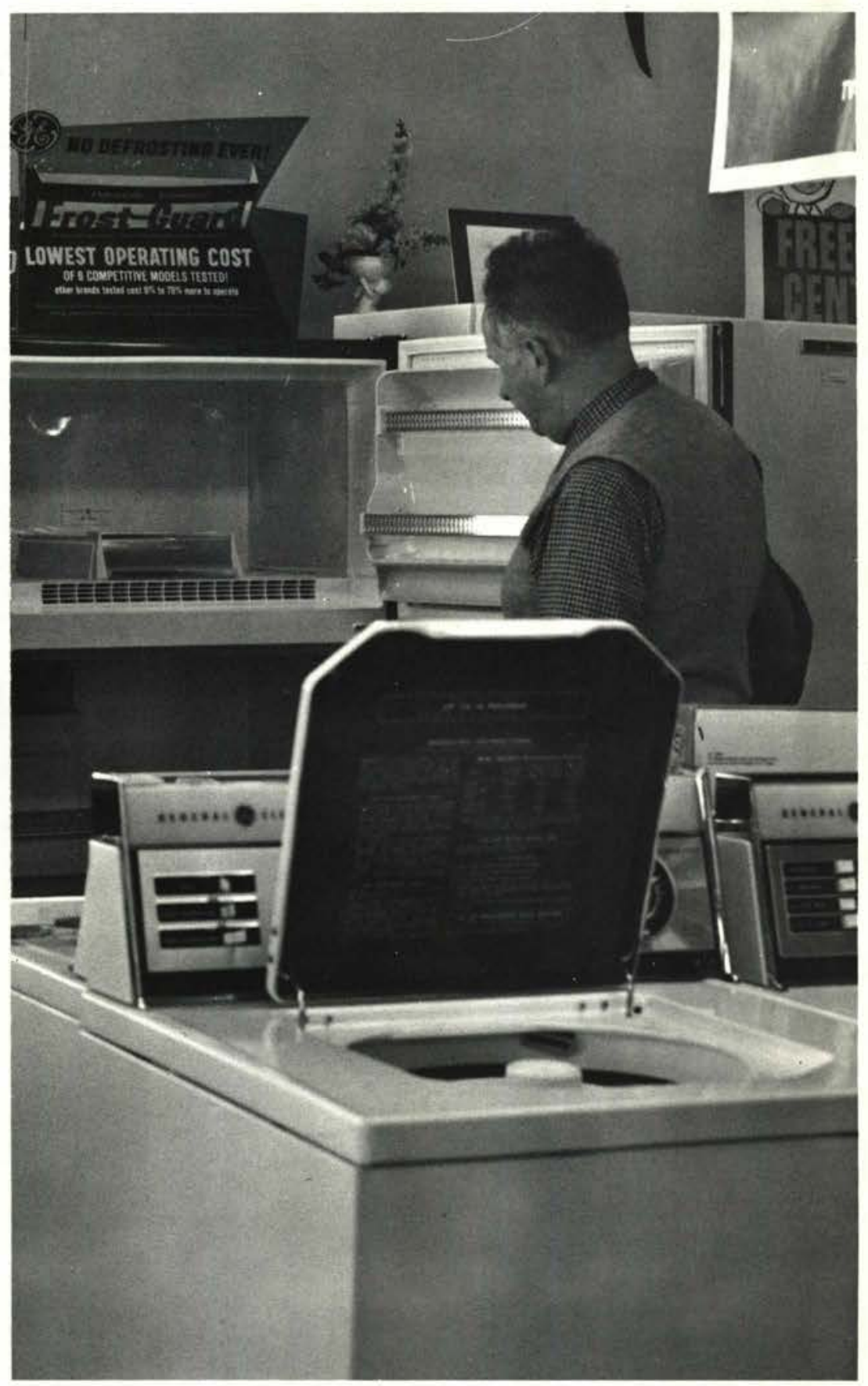

\section{VILLAGE RESTAURANT}

"In the Heart of Cedarville"

Complete Food Service

$766-5318$ 


\section{MORRIS}

Morris Bean and Company, producers of high quality aluminum and ductile iron castings, has plants in Yellow Springs and Cedarville, Ohio. The plant pictured, located in Cedarville, is one of the world's most important sources of tire mold castings used by all the major rubber companies.

To supply groceries and drugs, College Hill IGA is conveniently located across from the girls' dormitory, Maddox Hall.

COLLEGE HILL IGA

Serving Cedarville

Monday thru Saturday

Route 72, Main St.

Cedarville, Ohio

\section{SWANDER'S \\ SOHIO SERVICE}

Xenia Ave., Cedarville, Ohio

766-5511

\section{Hour \\ Wrecker \\ Service}

We have service for Minor Tune-up Tire Repair Ignition Systems Exhaust Systems Tires-Brakes Oil Change Lubrication

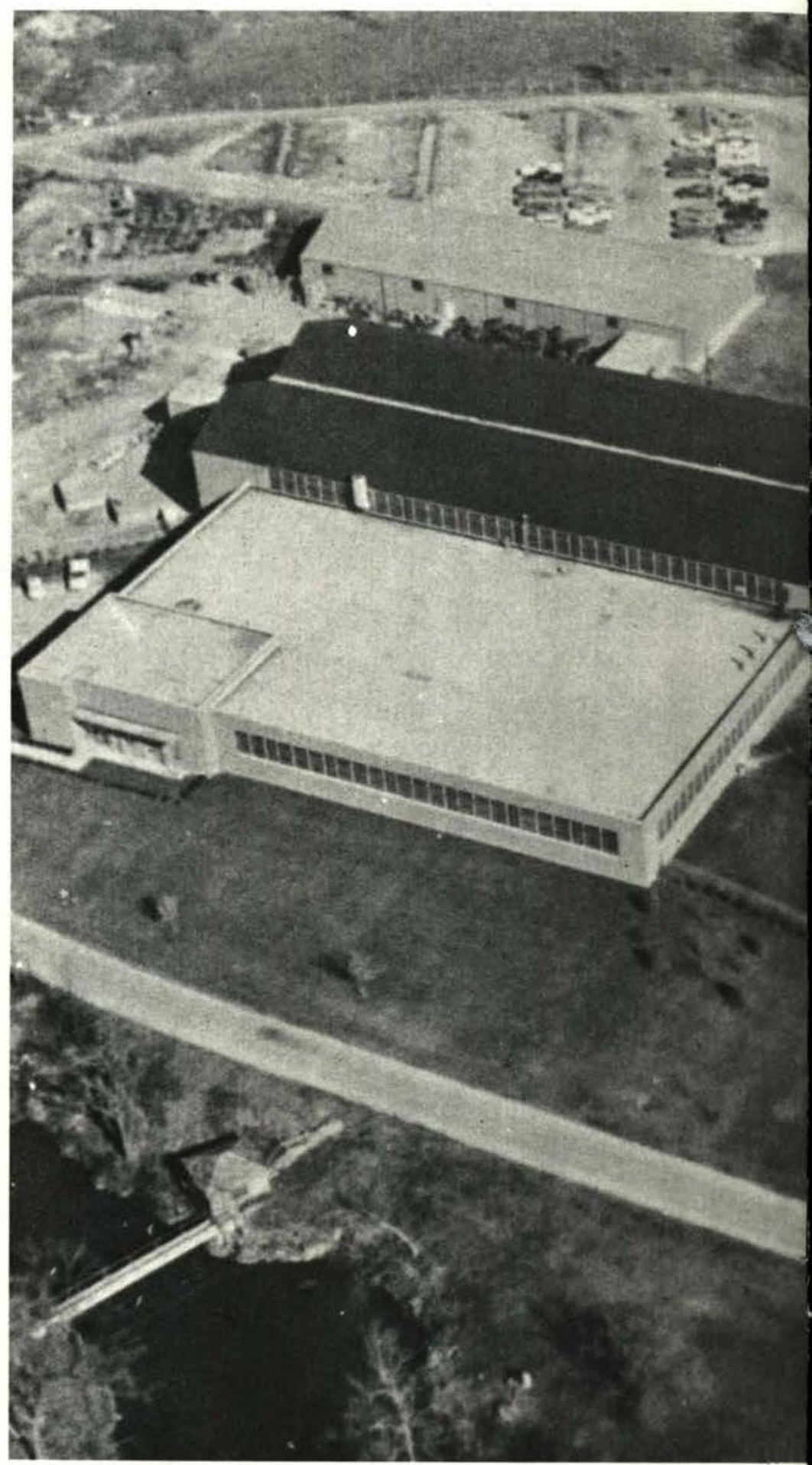




\section{PATRONS}

BAND BOX MUSIC STORE

57 West Main Street

Xenia-Fairborn

CEDARVILLE VARIETY STORE

N. Main St., Cedarville, Ohio

"Clothes and Gifts for the Family"

MC DORMAN'S MEN'S CLOTHING

53 West Main Street

ROGER'S JEWELERS

37 East Main Street

Xenia, Ohio 372-7681

FAMOUS AUTO SUPPLY

64 E. Main 372-4071

Sporting Goods

CARRIAGE HOUSE RESTAURANT

37 West Main Street

Xenia, Ohio

CEDAR CLIFF BEAUTY SALON

Xenia Avenue

Cedarville, Ohio 766-4864

RICH JEWELERS

Main and Detroit

Xenia, Ohio

SHERWIN WILLIAMS

47 West Main

Xenia 372-6083

CHERRY'S FURNISHINGS

56 W. Main Street

Xenia-372-3579

NILSON-BONE FLORISTS

Lucille's Beauty and Gifts

Xenia, Ohio $372-2171,372-4211$

THE CARD SHOP

Hallmark Cards and Gifts

17 East Main Street

I-T PIZZA

130 E. Main Street

372-3587

XENIA 1 HR. MARTINIZING

168 West Main Street

Xenia, Ohio

TIFFANY JEWELRY STORE

20 South Detroit Street

Xenia, 372-3161

HURLEY'S FLORIST

544 W. Main Street

"Flowers Speak for Themselves"

BEREAN CHURCH SUPPLIES

$53 \mathrm{~S}$. Detroit

Xenia-372-8711

BLACK'S FURNITURE

"For Furniture New"

Xenia, Ohio 372-4191

BRAUN'S JEWELERS

714 East Main Street

Xenia - 372-5071

XENIA DAILY GAZETTE

"Growing with All Greene County"

37 S. Detroit—Xenia

\section{OLAN MILLS-}

The Official Photographers

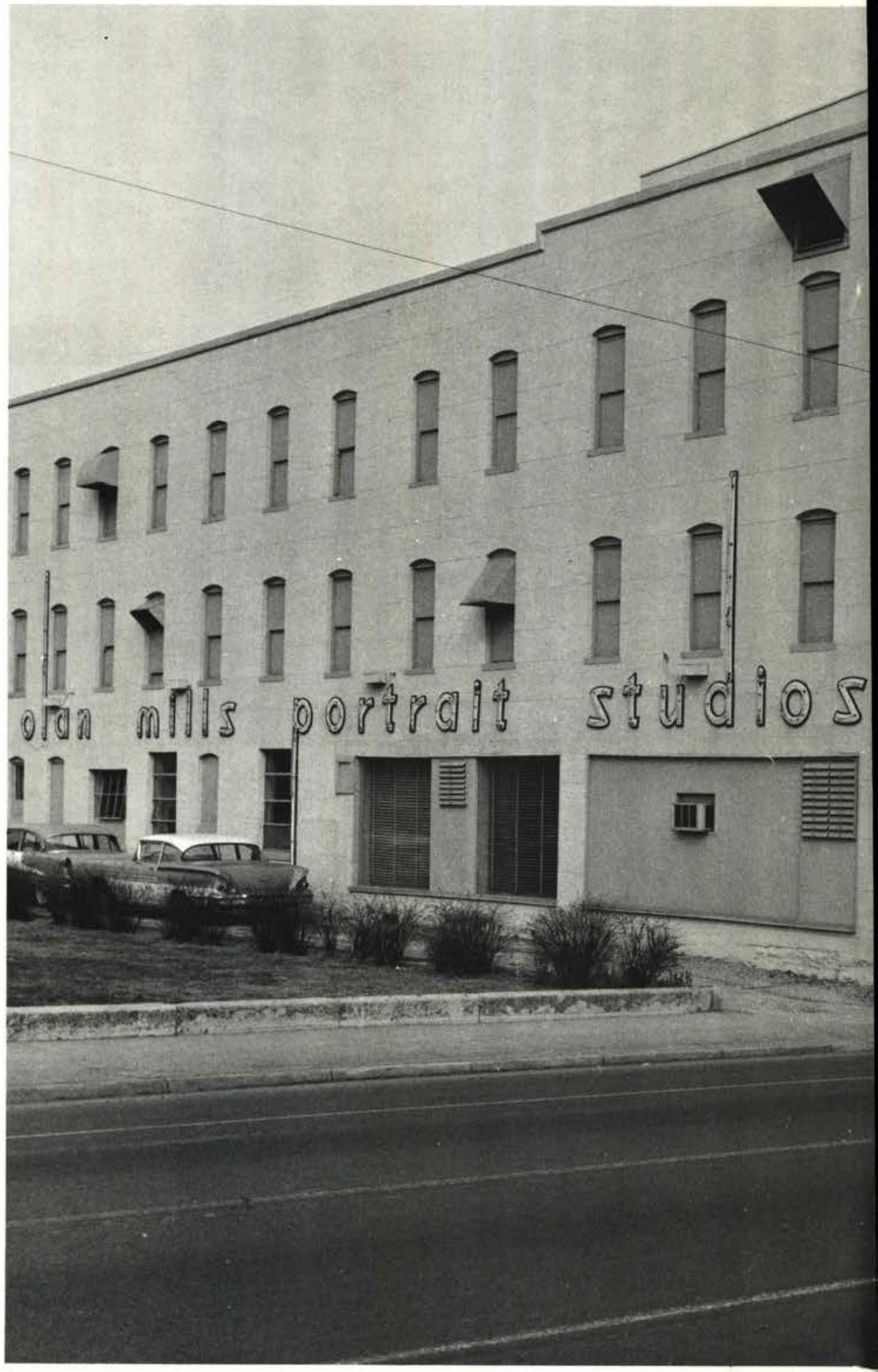


The completion of the yearbook could not have been a reality without the photography of the Olan Mills Studio. Their individual shots and group pictures enhanced the Miracle as well as the staff's satisfaction for the studio's job well-done.

\section{FOR THE MIRACLE}

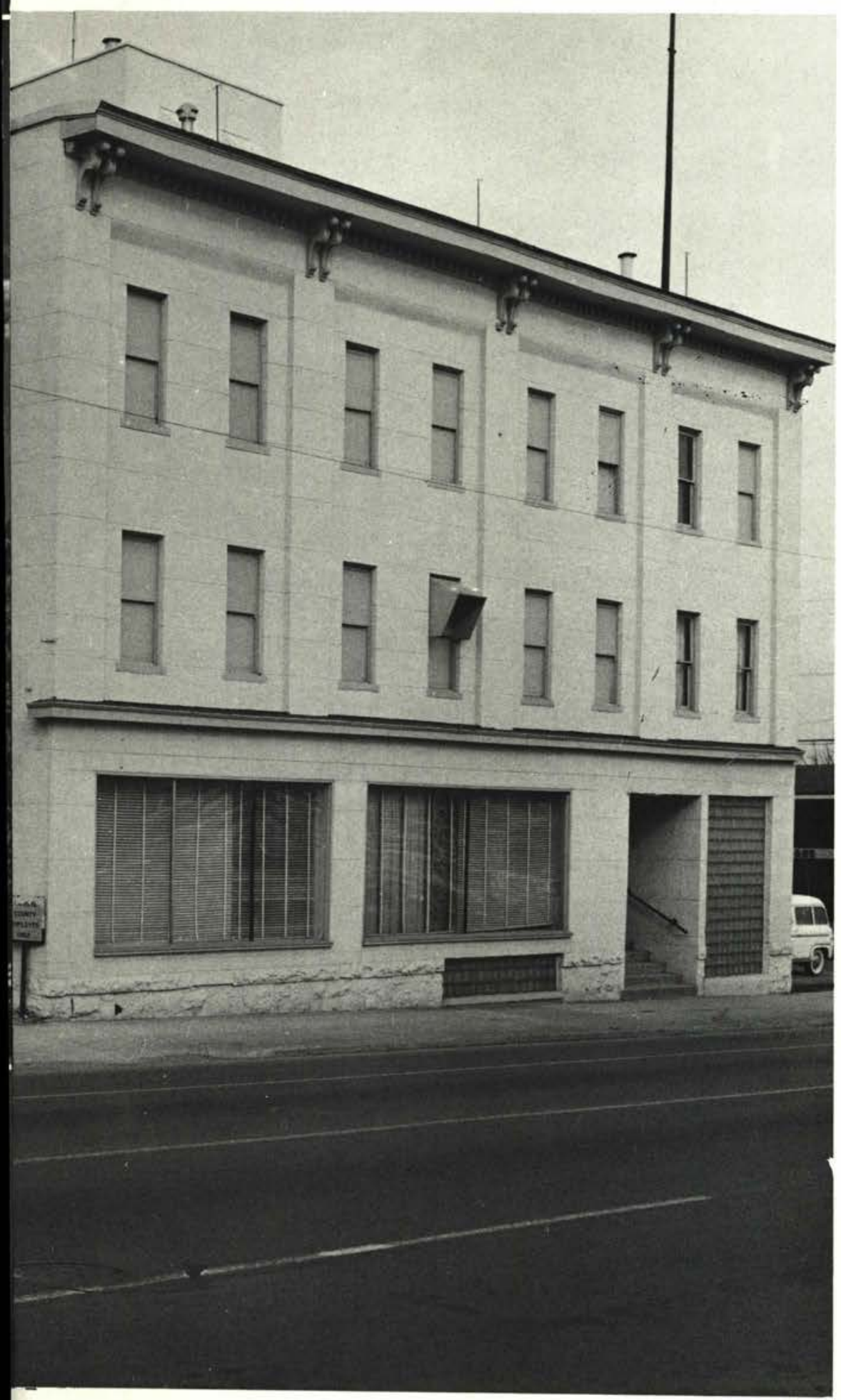

"Depend on the CAMERA SHOP" for Personalized Service

161 E. Main St.-82 N. Allison Ave. Xenia, Ohio

Member Federal Deposit Insurance Corporation 
"Finally, brethren, farewell. Be perfect, be of good comfort, be of one mind, live in peace; and the God of love and peace shall be with you."

CEDARVILLE

FEDERAL SAVINGS

\& LOAN

Serving Cedarville

and the

Community

Congratulates

The Class of '69
ICorinthians 13:11

THE 1969 GRADUATING CLASS

CEDARVILLE

FEED \& GRAIN

Grain, Feed, Seed, Coal, Salt

Wool, Fertilizer

Builders' Supplies and Fencing

Cedarville, Ohio

Congratulations

Class

Phone 766-2021

of

\section{THE CRITERION}

Xenia, Ohio

Men's Clothing and

Furnishings

Varsity Town-Arrow

MacGregor-Stetson

Palm Beach

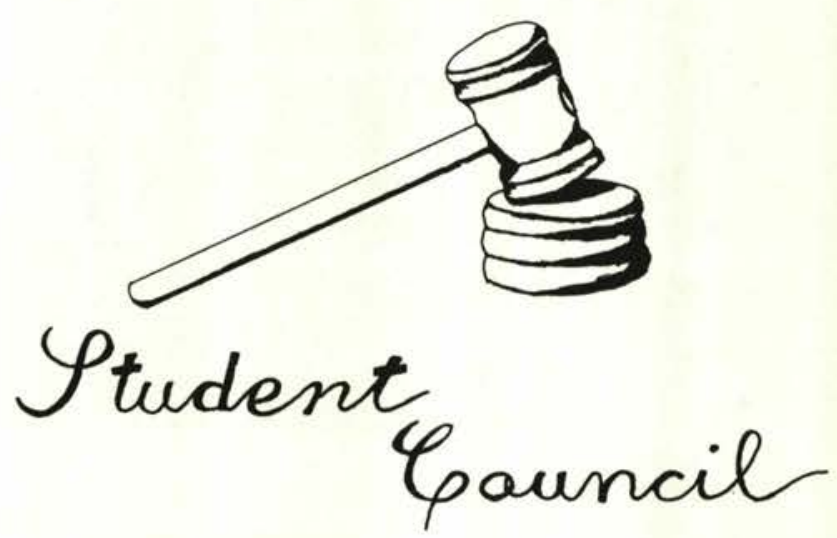




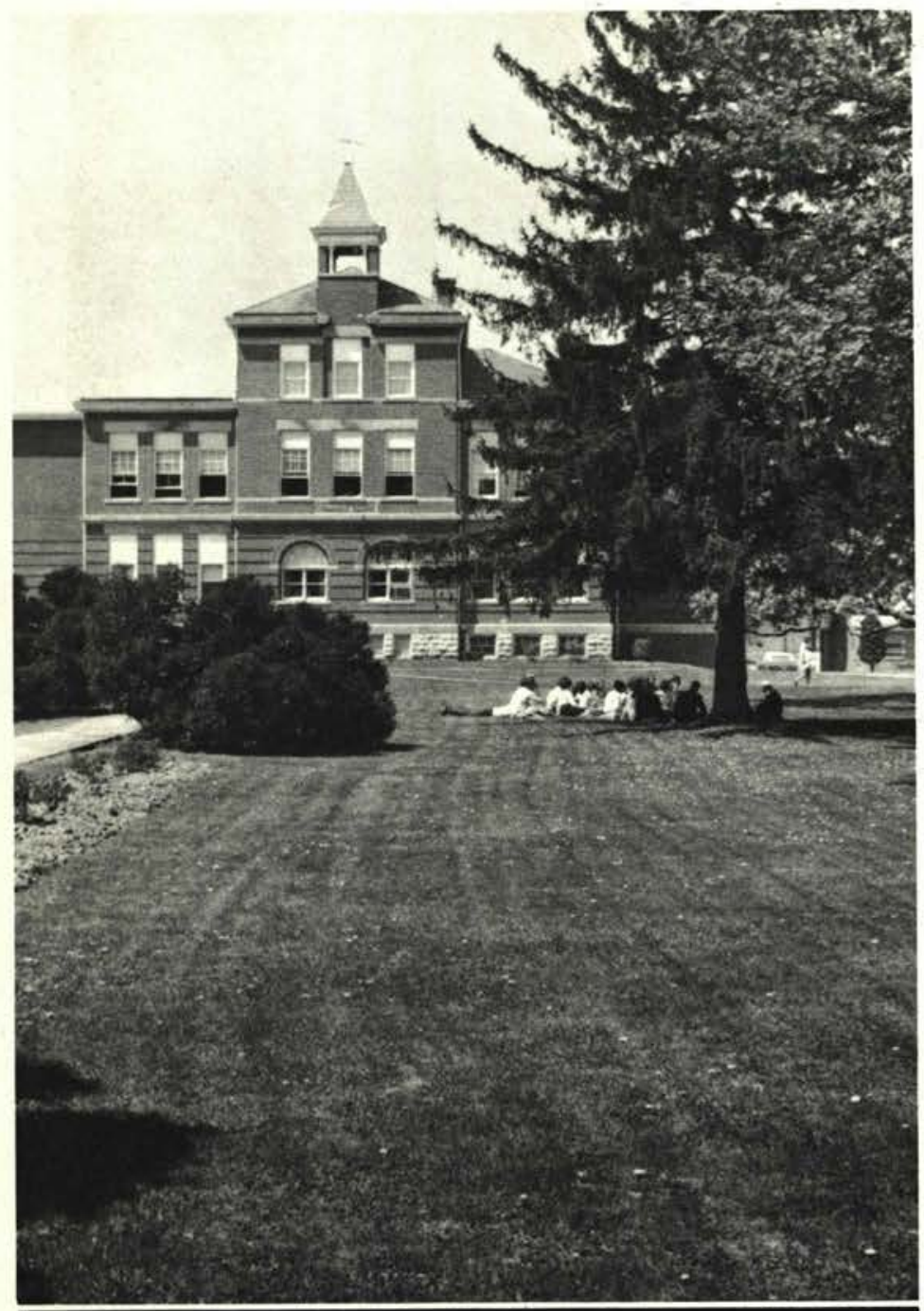

CHAPLIN CLEANERS

LAUNDRY SER VICE

Cleaning

Shoe Repair

Phone 766-3781

Cedarville, Ohio

\section{LEACH QUICK WASH}

24-Hour Self-Service

Cedarville, Ohio

E. Xenia Street Behind Firehouse

Phone 766-5186

\section{CONGRATULATIONS SENIORS}

\author{
Dianna Hutchison \\ Becky Hanthorn \\ and \\ the Miracle Staff
}

"It seems like only yesterday . . ." For the graduating seniors, the four years have flown by and as the graduates leave, they learn that Cedarville has exchanged their service for lasting memories.

Those lasting memories commemorate their graduation as the community patrons ask God's blessing on their future. Sincere congratulations, class of 1969 ! 


\section{In Memoriam}

He had just been here earlier in the year, and now, although everyone had prayed that he might live to further his ministry, God saw fit to bring him home. Now he is rejoicing in the presence of the Lord in whom he trusted.

Dr. Paul Jackson was a man with a vision of Christ—a man of thought, action, and spirit. For this, we honor the National Representative of the General Association of Regular Baptist Churches, in memoriam:

I'm not alone when the dawn light is breaking And westward the last mist-hung shadow has flown;

When from sweet slumber my soul is awaking

Thou, God, art with me, I'm not alone.

When through the gray dawn I send my thoughts winging, Questing through prayer-laden space to the throne,

Stars of the morning are joyously singing

Thou, God, art with me, I'm not alone.

I'm not alone with the darkness around me

Though the night curtains a pillow of stone;

A ladder of light to heaven has bound me,

Thou, God, art with me, I'm not alone.

Myra Brooks Welch 


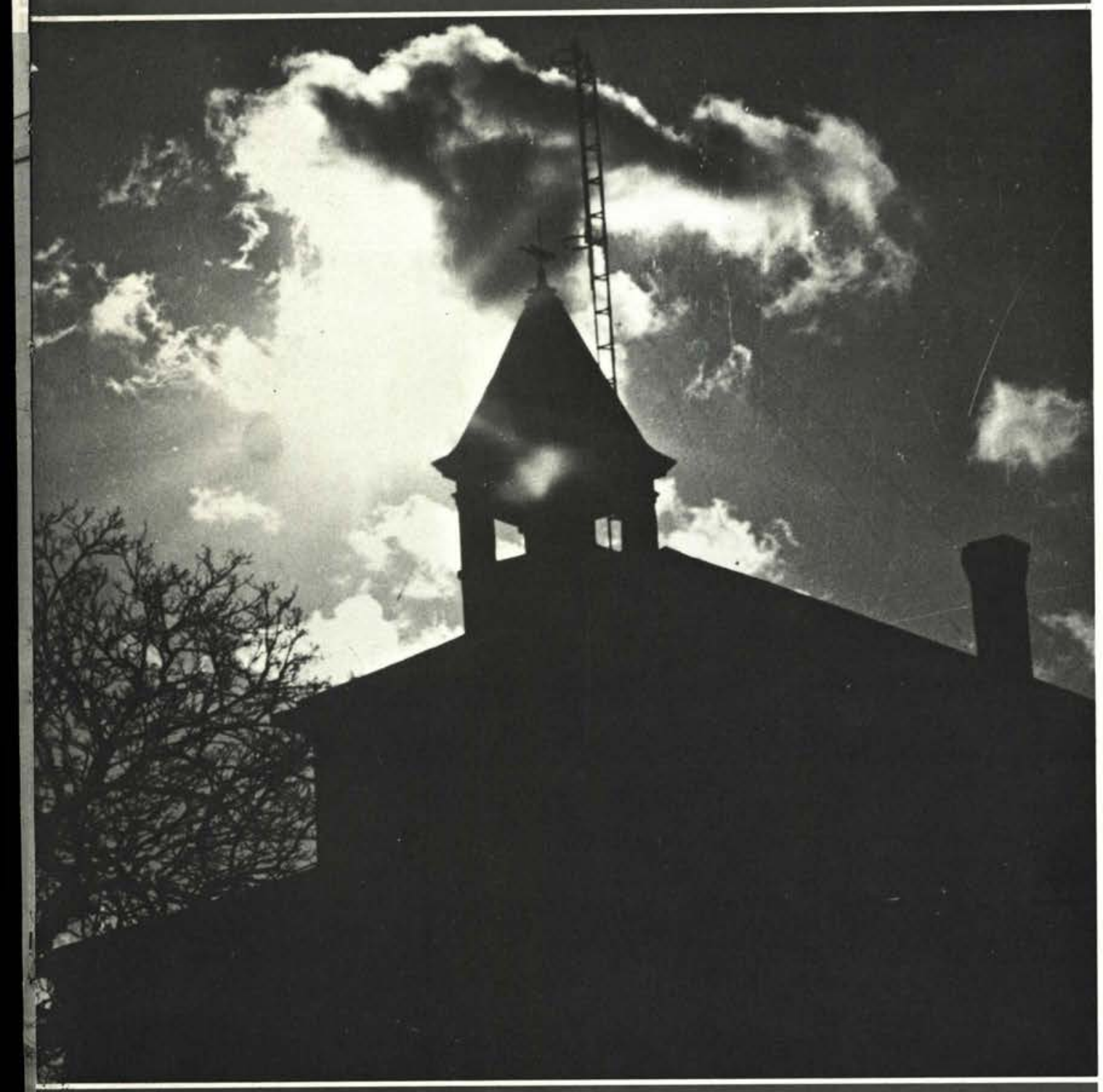


$\frac{x}{x}+x$ Get lowe ard the mitiator of happiness $x$ lt binds pexple through thisughts. fectings and dreans: ind tistegards alce color and class.

In this vearbook i have tiled to share the people of Cedarille College their mosis thoughts acterin-spint and wisien - with the werded thave tide to shate the mumies of al few stuterits with all the students

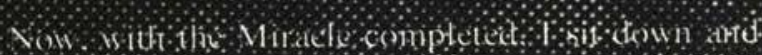

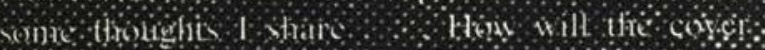

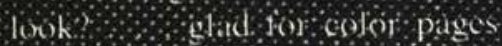

Siciny ringut

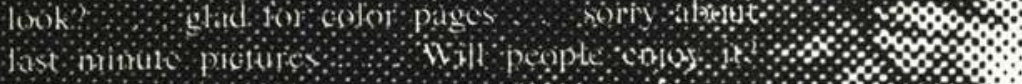

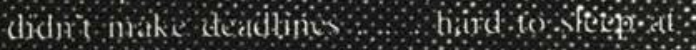

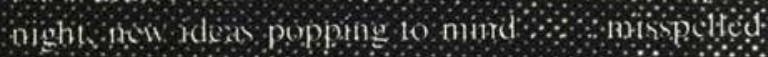
nanes to litly

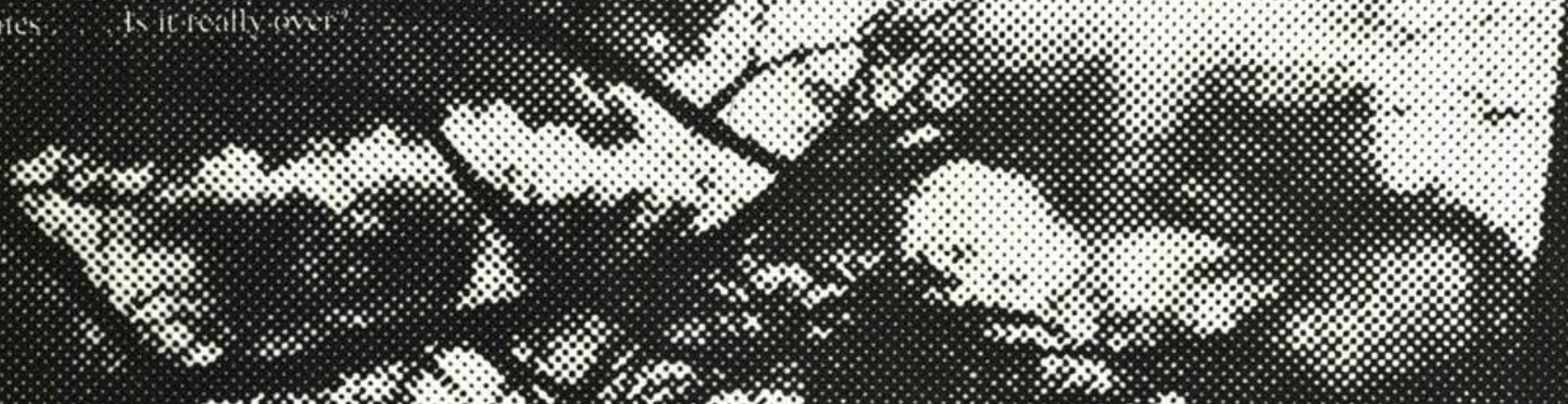
\%

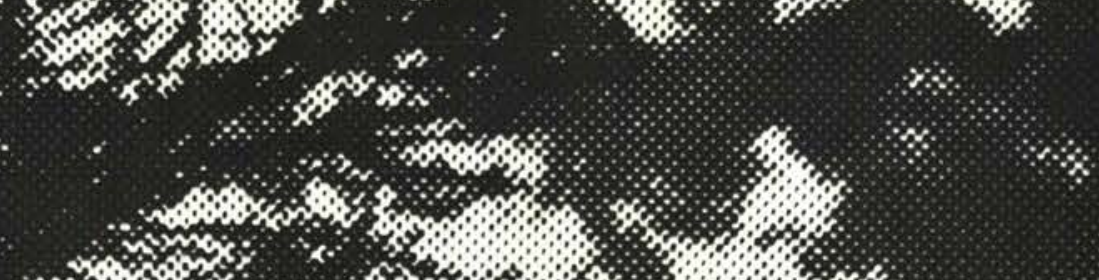

$\%$
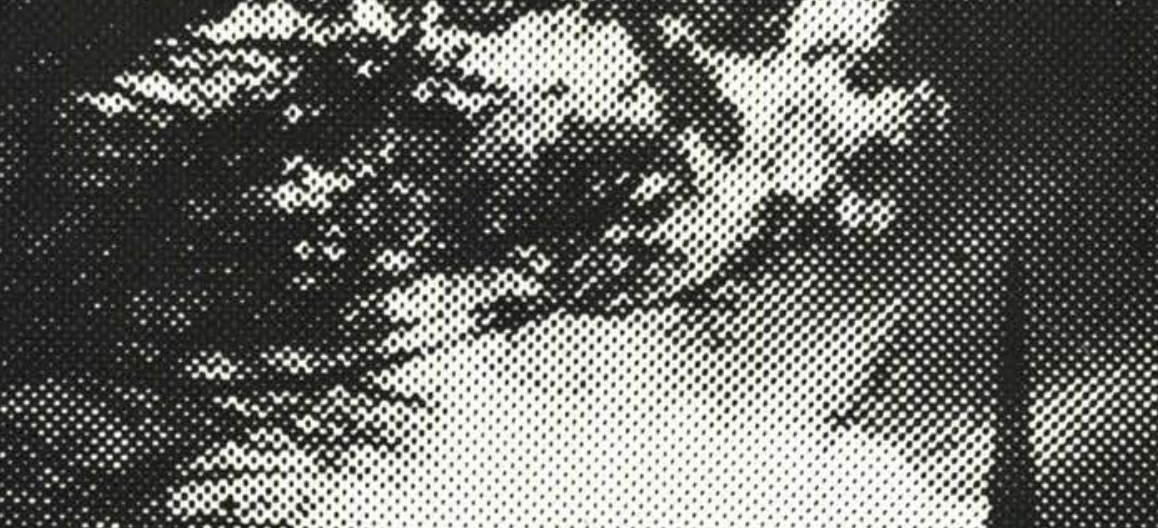
(2)

$+8$

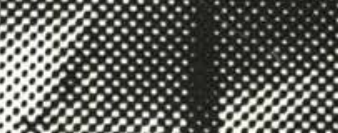

\%

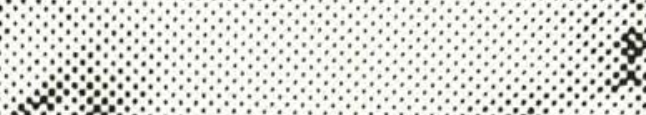

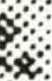
on

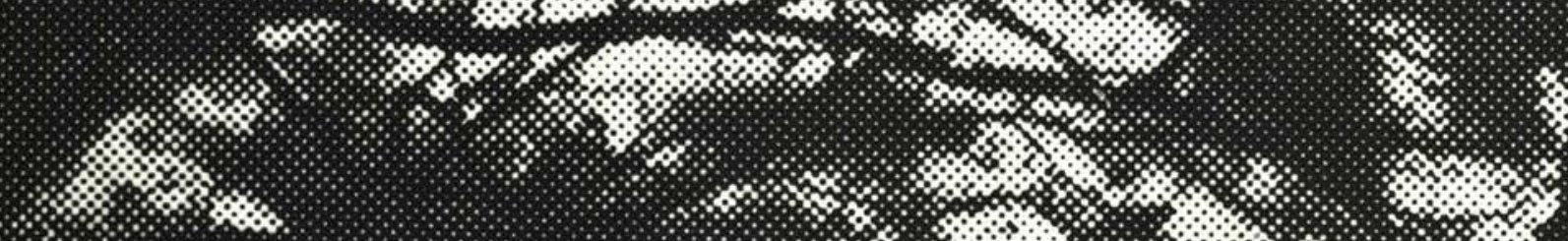

$\alpha \alpha \beta \alpha$
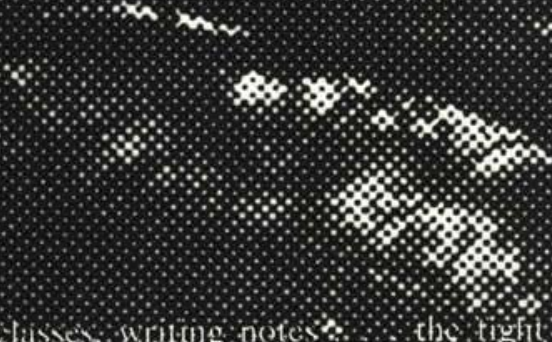

cuthin whise writing notes

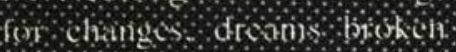

and Chatie

iiv the esilfoge

$506-\mathrm{M}$ ur king

$\alpha_{\alpha} \alpha_{\alpha} \alpha$

\%

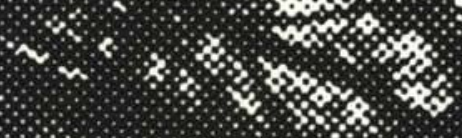
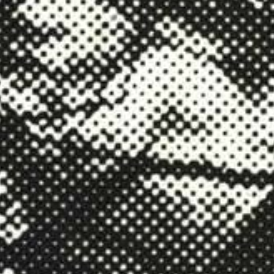

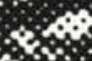

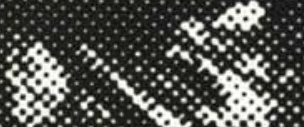

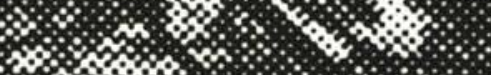

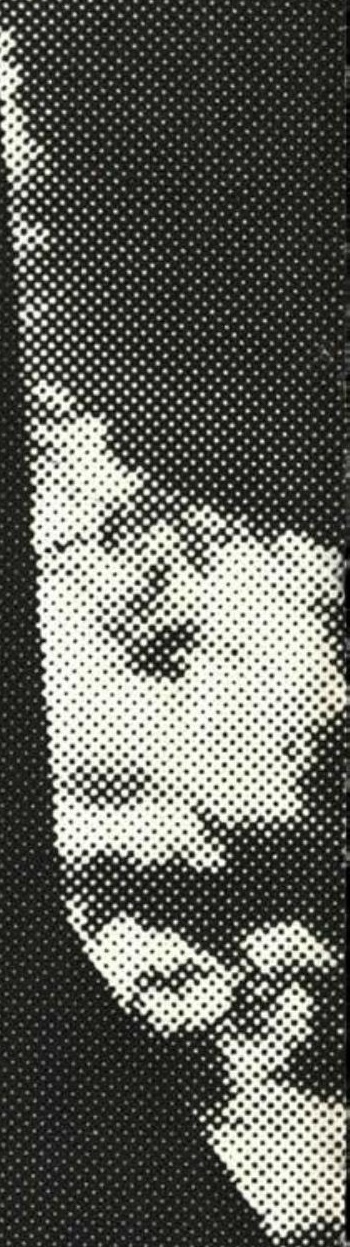

$\alpha+\infty \alpha$

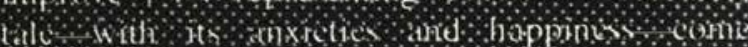

1ric

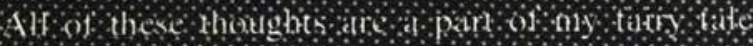

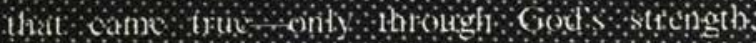

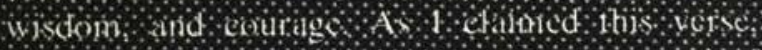

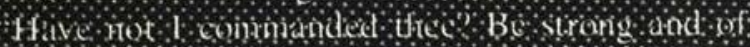

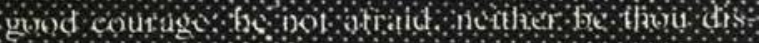

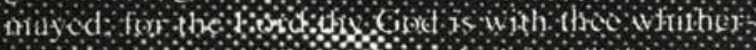

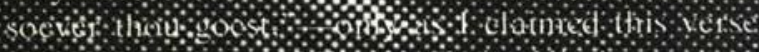

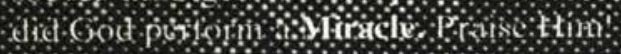

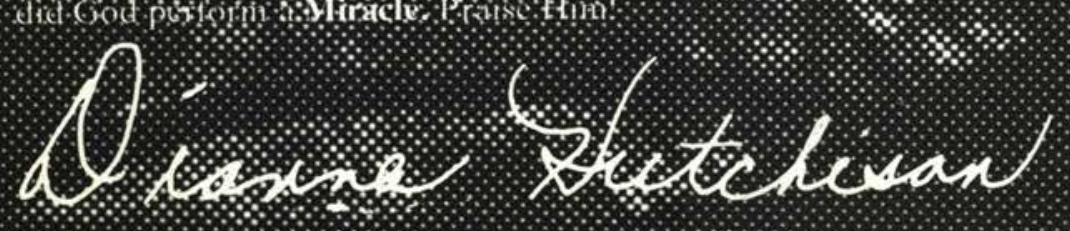






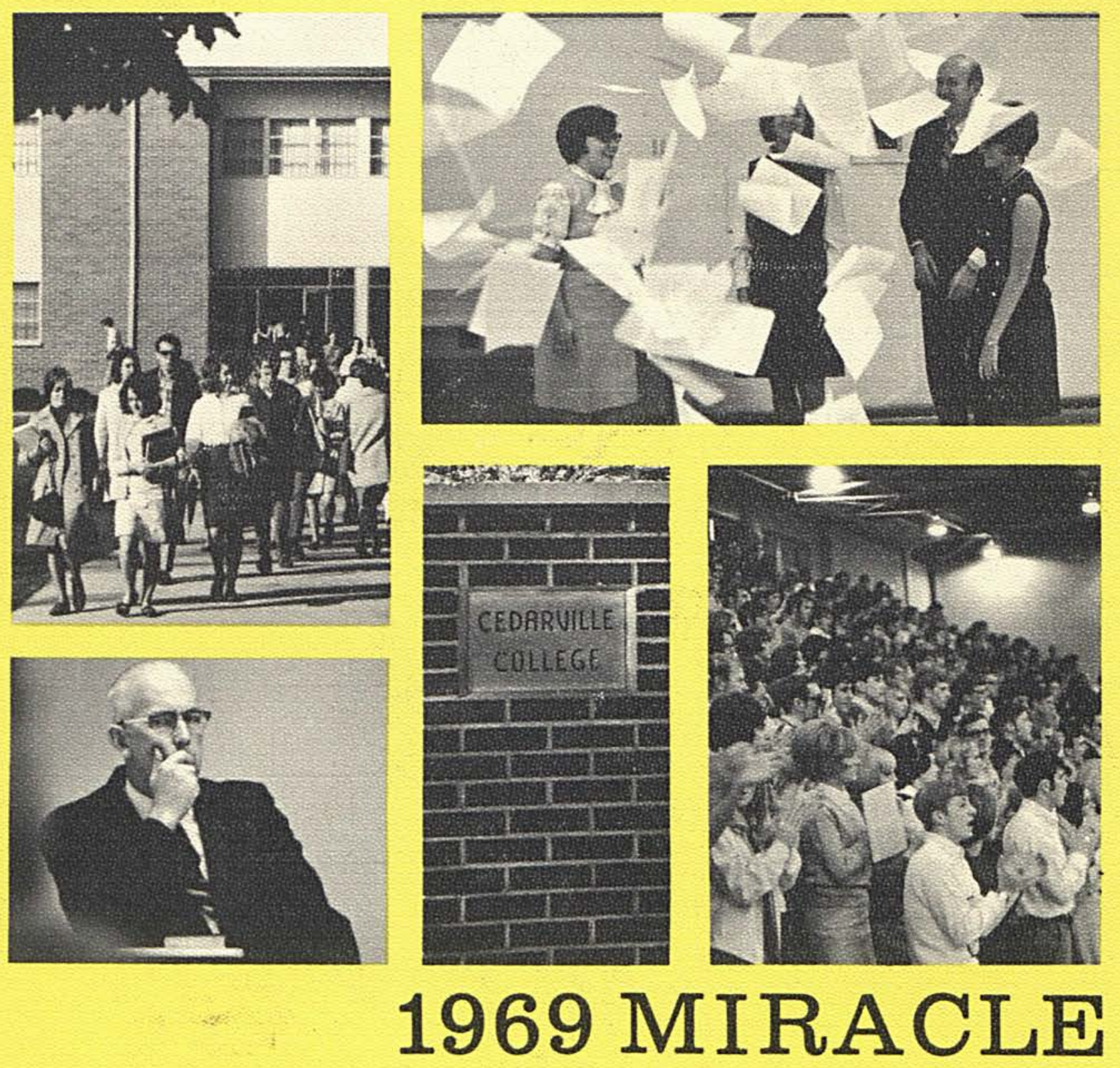

